


DEPARTMENT OF THE INTERIOR

UNITED STATES GEOLOGICAL SURVEY

GEORGE OTIS SMITH, DIRECTOR

Professional Paper 80

\section{GEOLOGY AND ORE DEPOSITS}

OF THE

\section{SAN FRANCISCO AND ADJACENT DISTRICTS}

\section{U'TA H}

BY

B. S. BUTLER

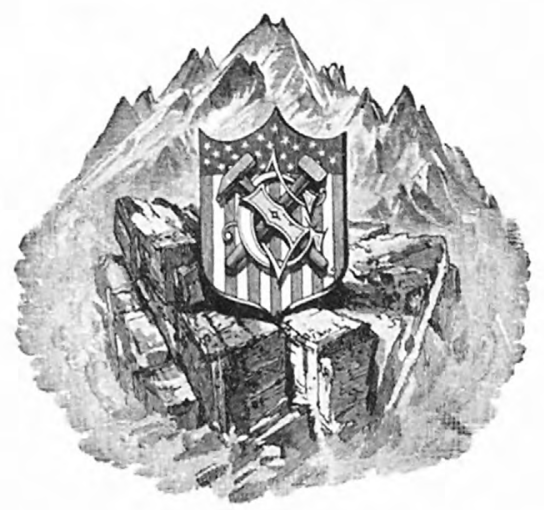

WASHINGTON

GOVERNMENT PRINTING OFFICE 1913 


$\left[\begin{array}{c}\text { US.GEOL.SURVEY } \\ \text { OCT UII IS:3 } \\ \text { LERARY }\end{array}\right.$




\section{CONTENTS.}

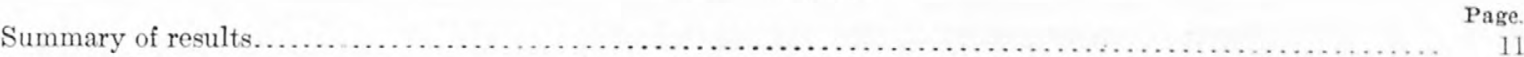

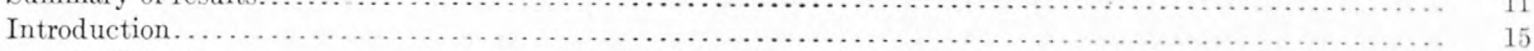

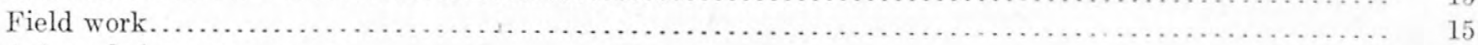

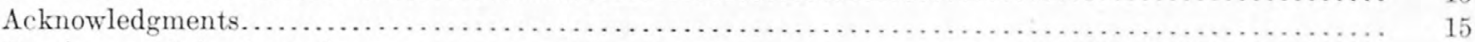

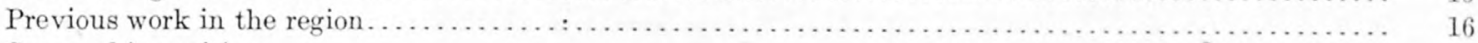

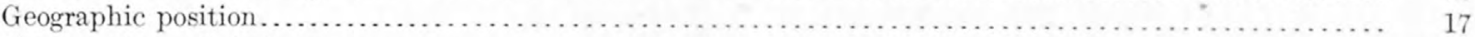

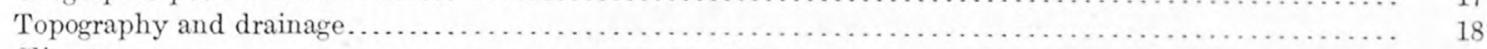

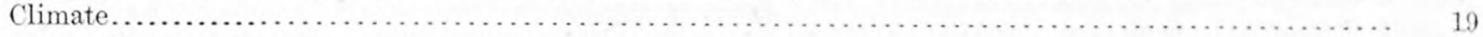

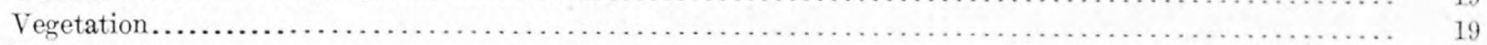

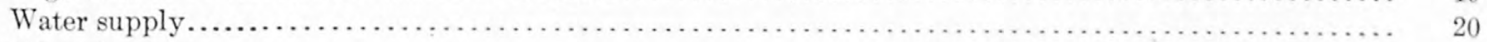

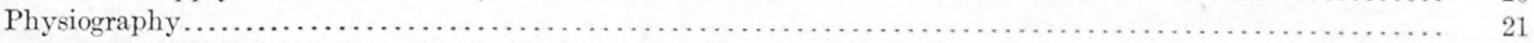

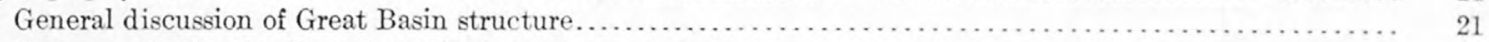

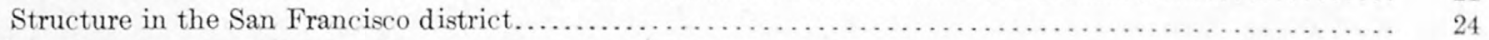

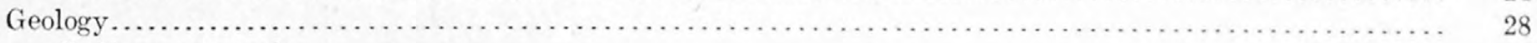

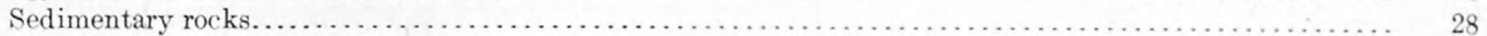

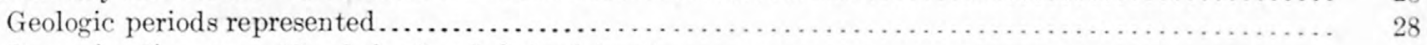

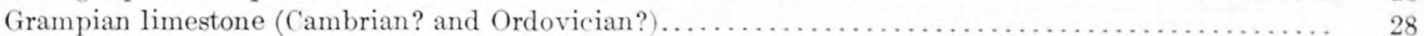

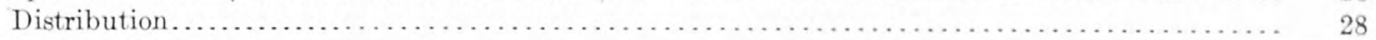

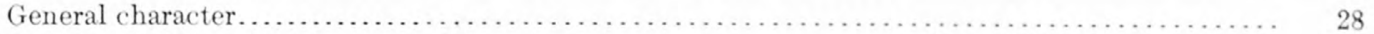

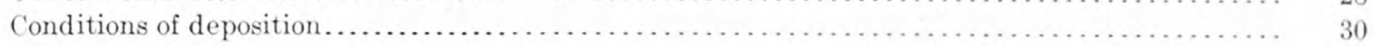

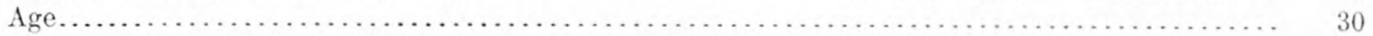

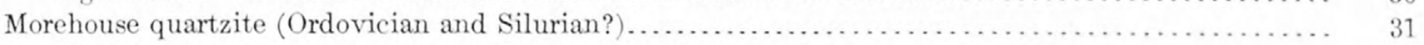

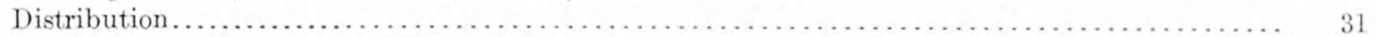

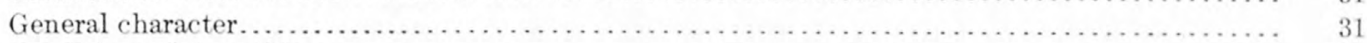

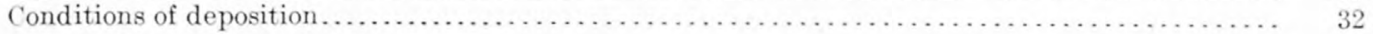

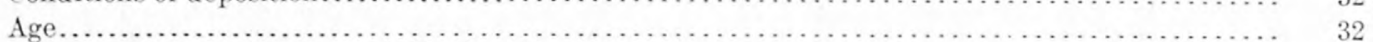

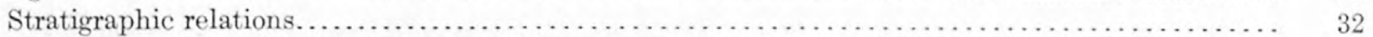

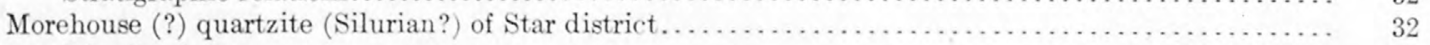

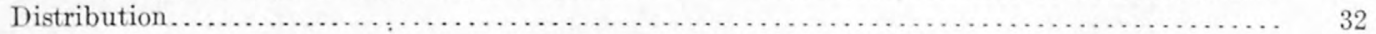

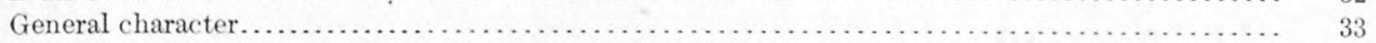

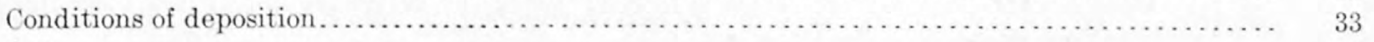

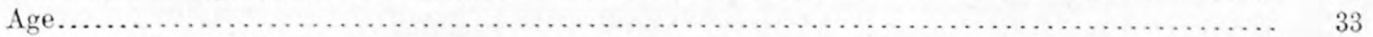

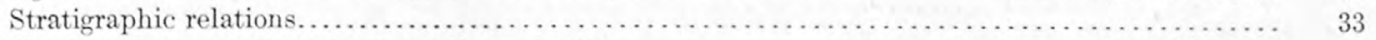

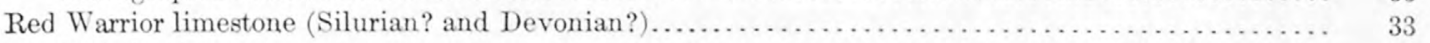

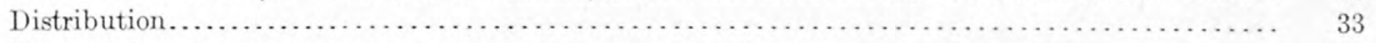

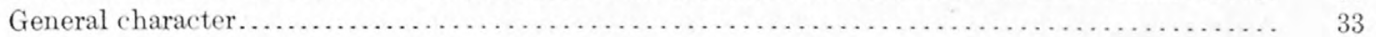

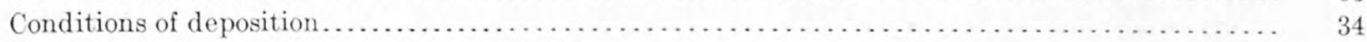

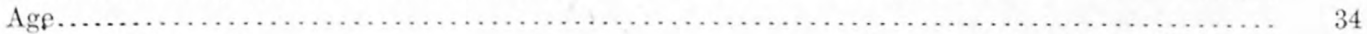

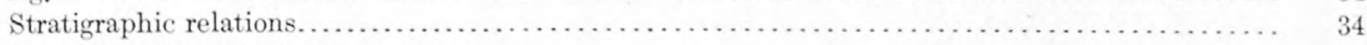

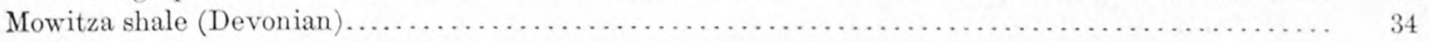

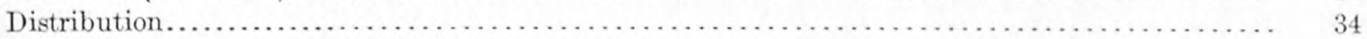

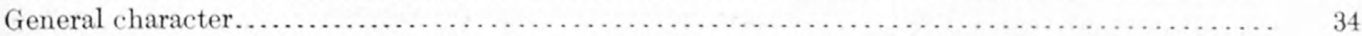

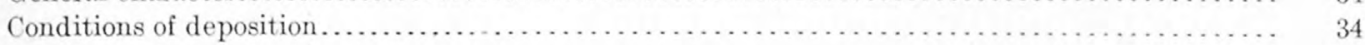

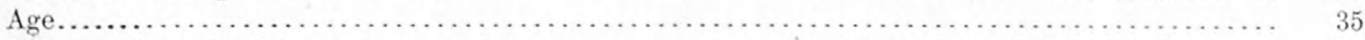

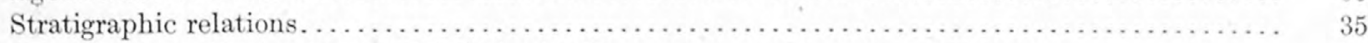

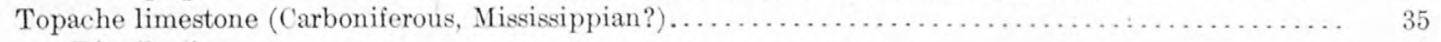

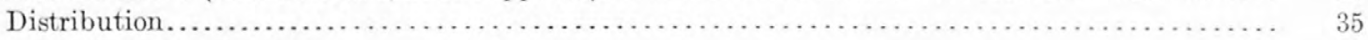

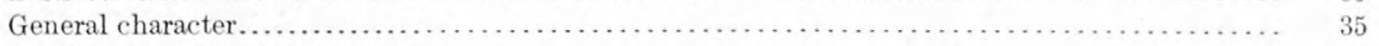

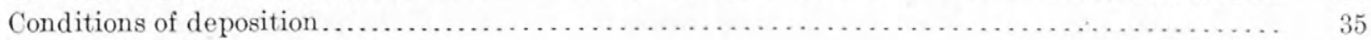

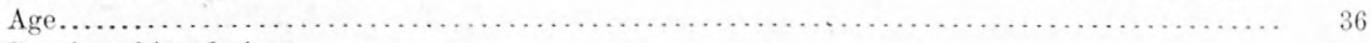

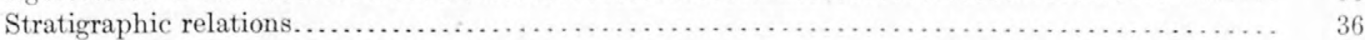

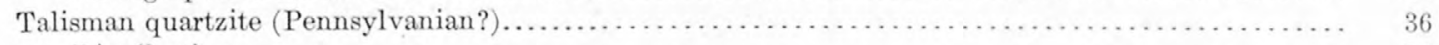

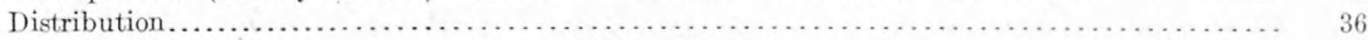

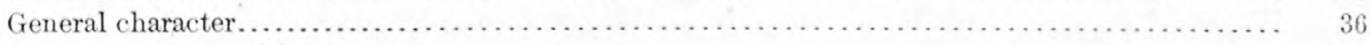

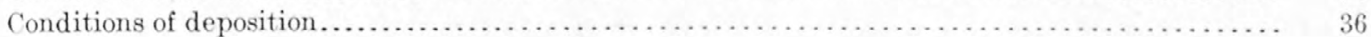

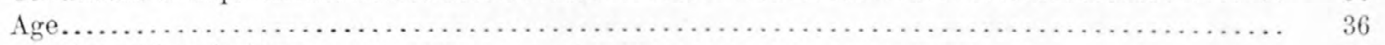

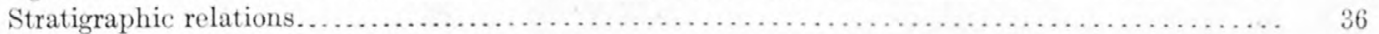


Geology-Continued.

Sedimentary rocks-Continued.

Elephant limestone (Pennsylvanian?)

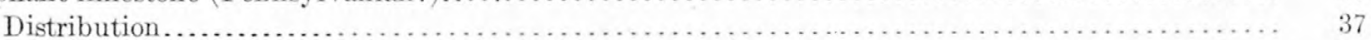

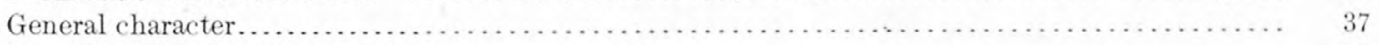

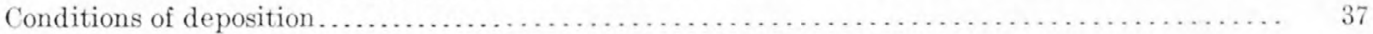

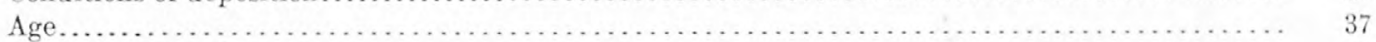

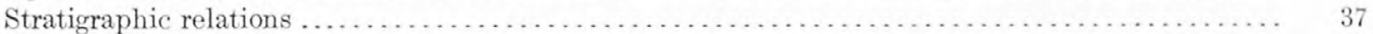

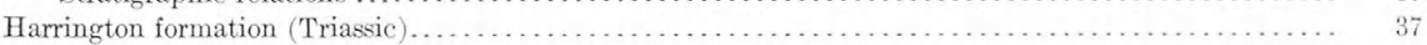

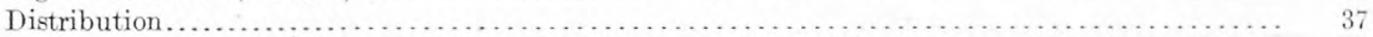

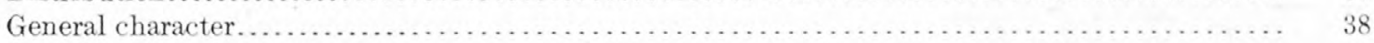

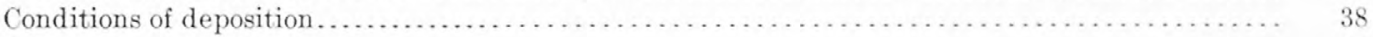

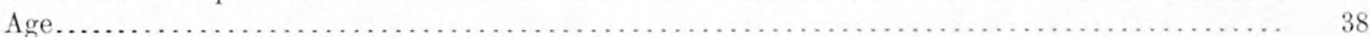

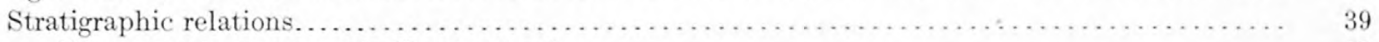

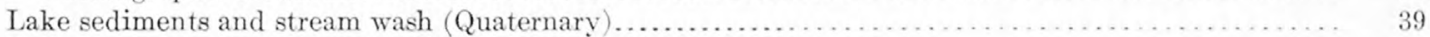

Comparison of the San Francisco section with other sections........................ 40

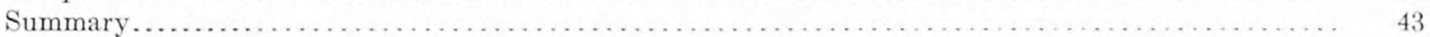

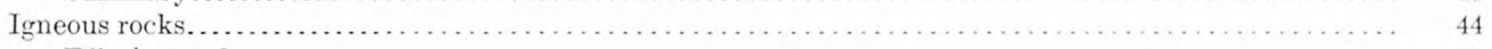

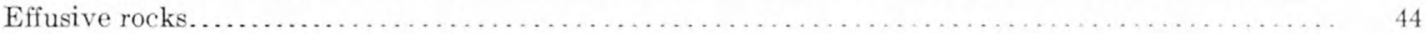

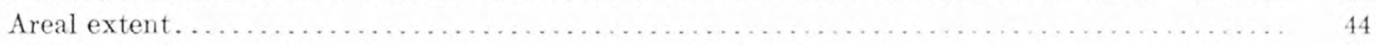

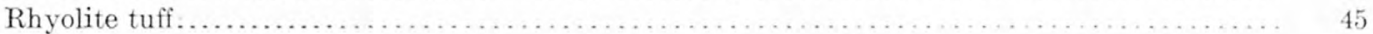

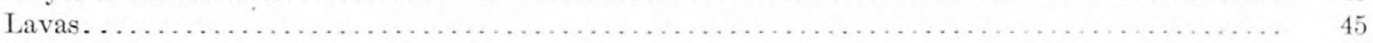

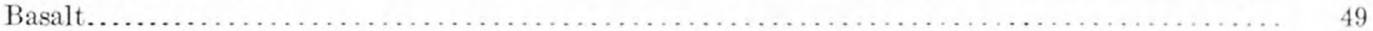

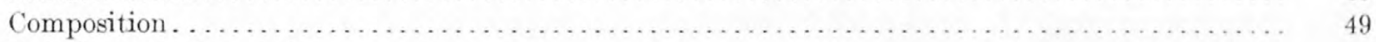

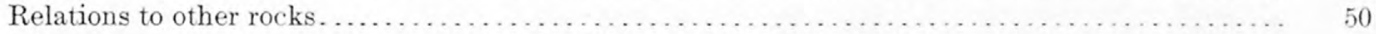

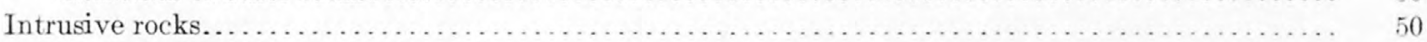

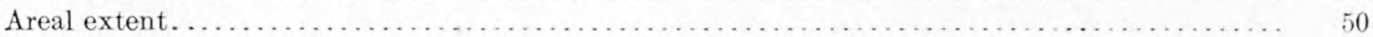

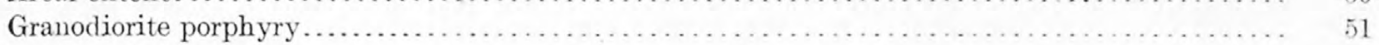

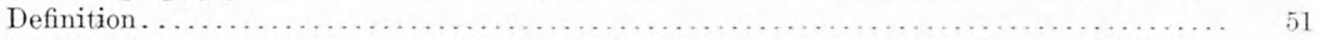

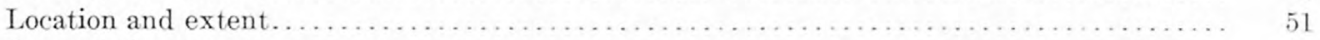

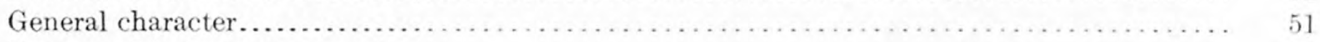

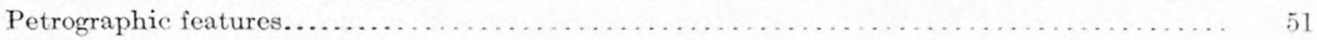

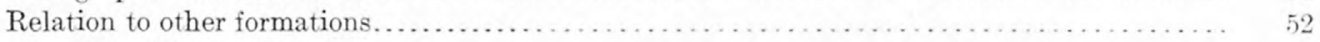

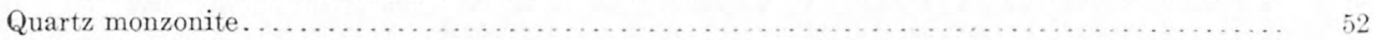

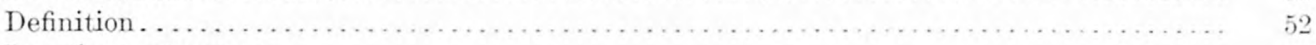

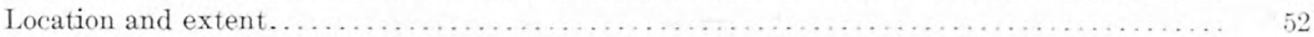

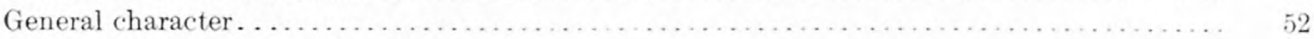

Quartz monzonite of the Cactus area ................................. 52

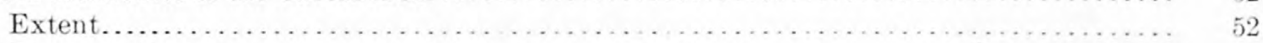

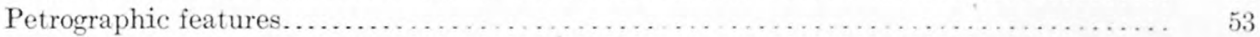

Microscopic features............................................

Composition. . . . . . . . . . . . . .

Quartz monzonite of the Beaver Lake area . . . . . . . . . . . . . $56 \ldots \ldots \ldots \ldots \ldots \ldots$

Areal extent. . . . . . . . . . . . . .

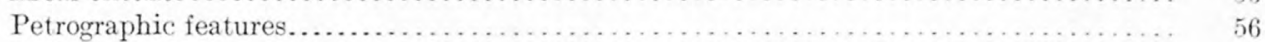

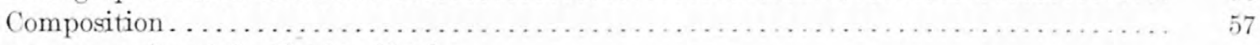

Quartz monzonite of the Rocky district............................... 57

Quartz monzonite of the Star district. . . . . . . . . . . . . . . . 57

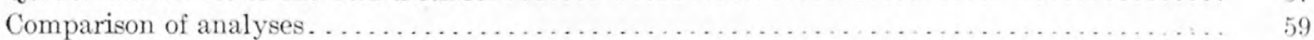

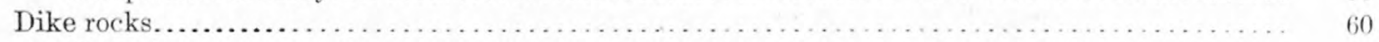

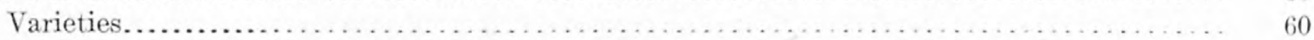

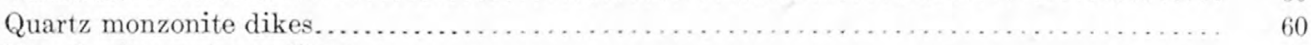

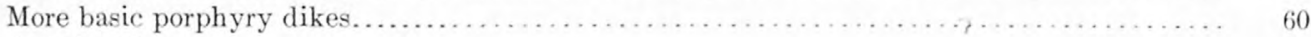

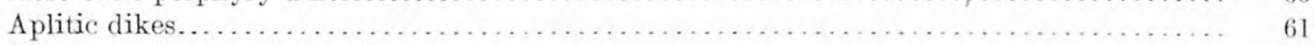

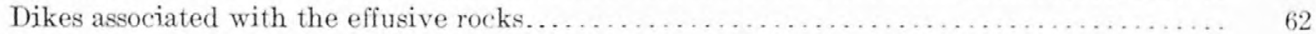

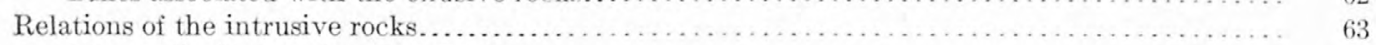

Quartz diorite porphyry stocks................................... 63

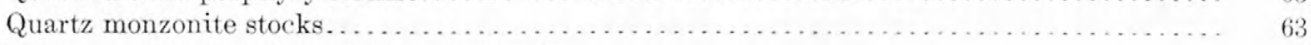

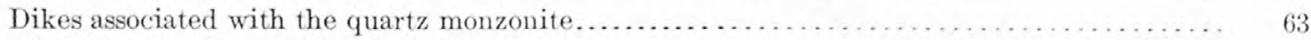

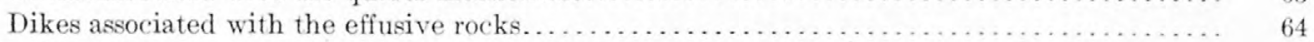

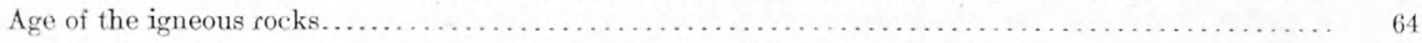

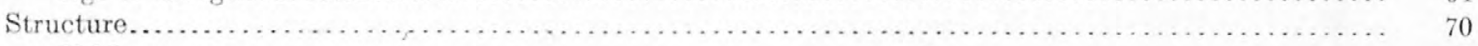

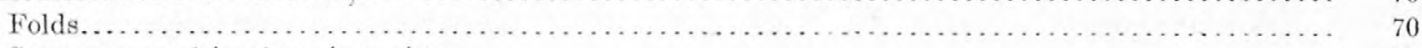

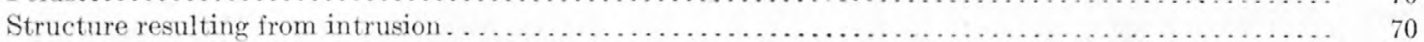


Geology-Continued.

Structure - Continued.

Faults.

Page.

Normal faults

Lateral faults

Other faults.

Age of faulting

rissures.

Metasomatic alteration of the rocks by hot solutions.

Conditions and character of the changes.

Alteration of quartz monzonite.

Alteration of lavas.

Differences in the character of alteration in the lavas and quartz monzonite...................

Alteration of the sedimentary rocks.

Local variations in character. .

Metamorphism in the several districts.

San Francisco district.

Beaver Lake district.

Rocky district.

Star district. . .

Comparison of contact alteration in the San $\mathrm{k}$ ranciseo region with that in other districis.

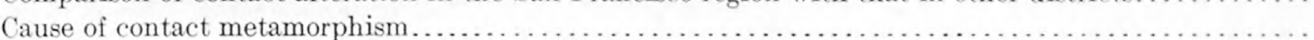

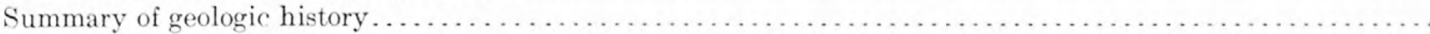

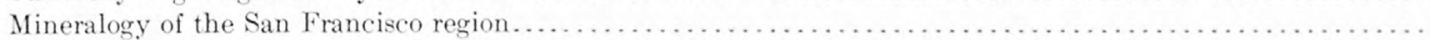

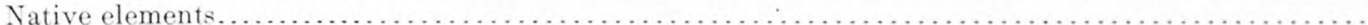

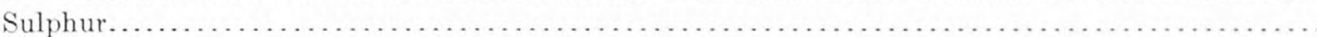

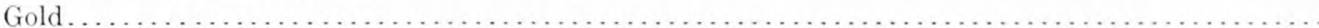

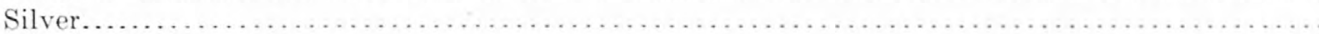

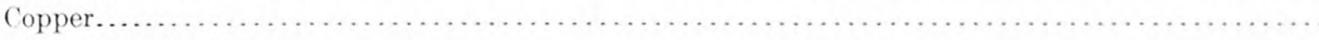

Sulphides. . .

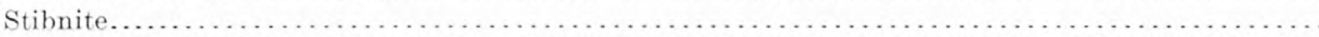

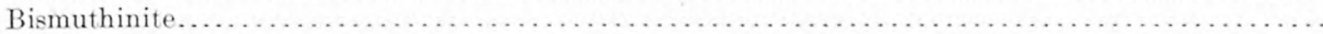

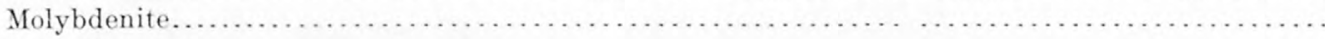

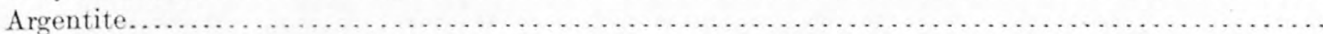

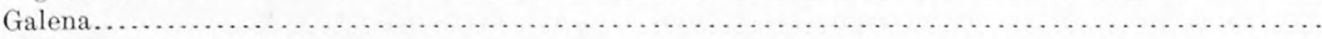

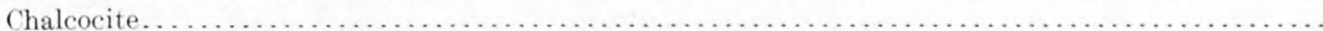

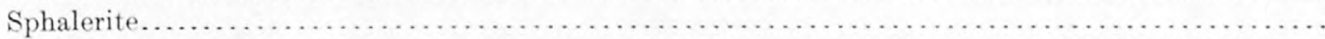

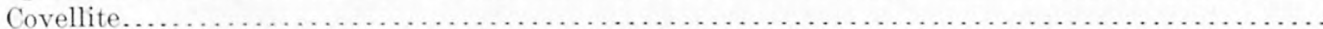

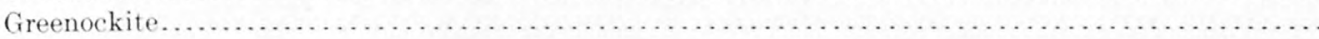

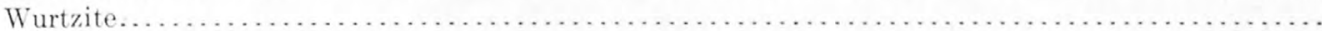

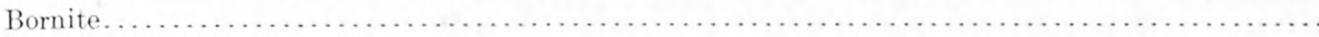

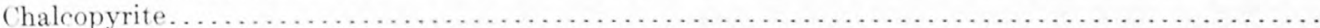

Pyrite.

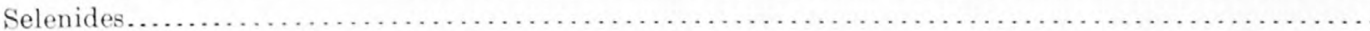

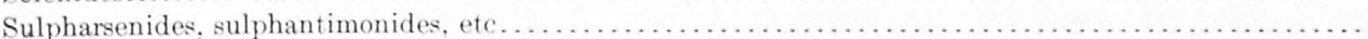

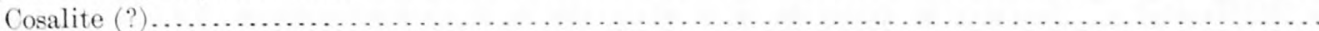

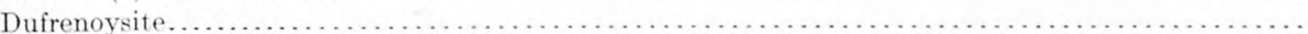

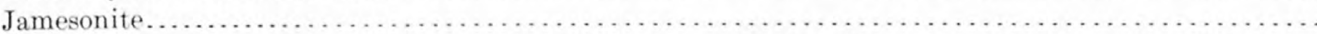

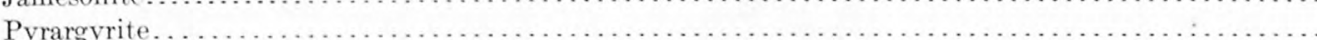

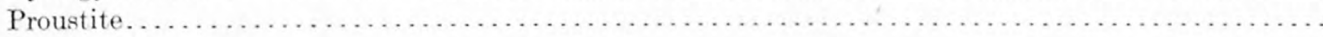

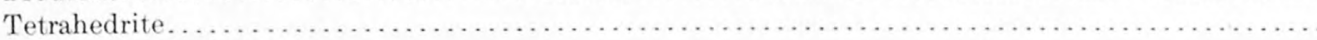

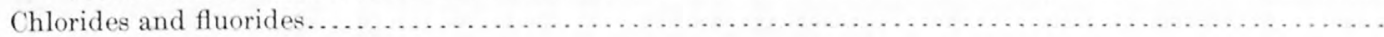

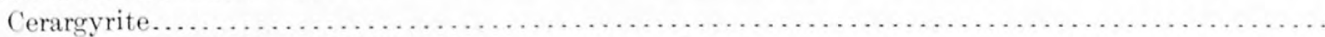

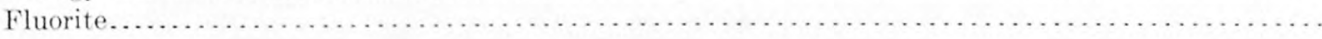

Oxides. ...

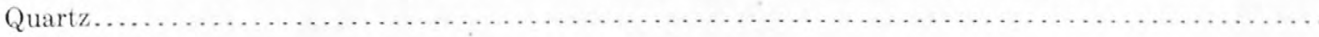

Opal.

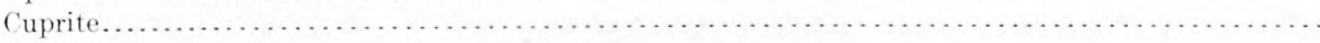

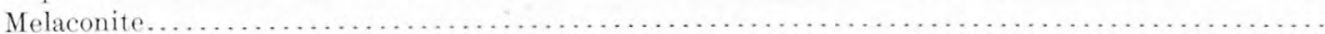

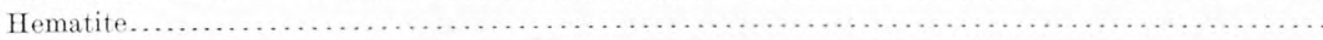

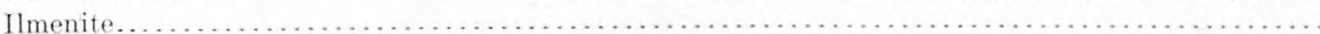

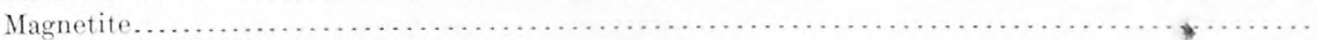

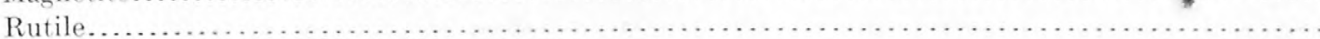

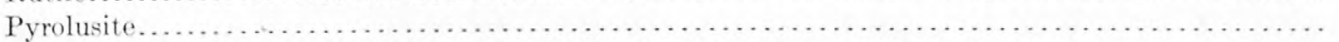


Mineralogy of the San Francisco region-Contiuned.

Page.

Hydrous oxides.

Diaspore.

Goethite.

Manganite

Limonite......

Copper pitch.

Carbonates.

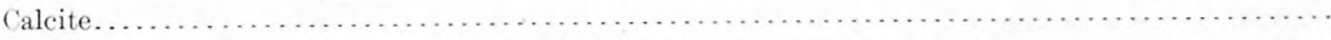

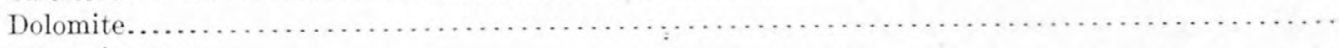

Magnesite......................

Siderite.......

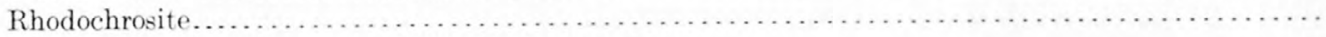

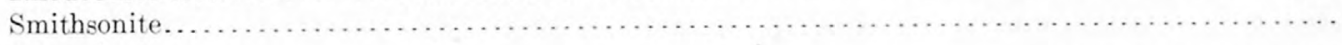

Aragonite. ....

Cerusite.

Hydrous carbonates . . . . . . . . . . . . . . . . . .

Malachite.

Azurite. . .

Silicates.

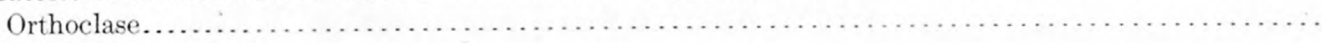

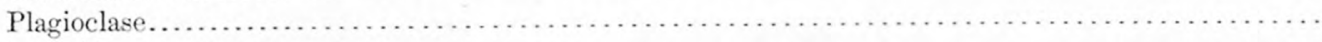

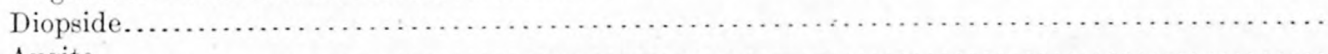

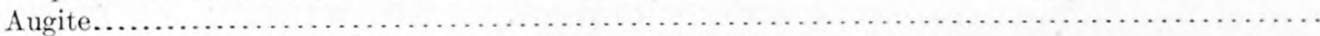

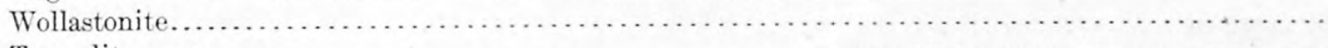

Tremolite. . .

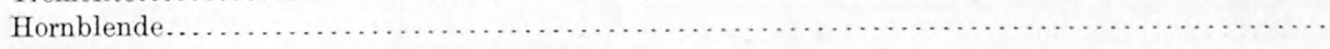

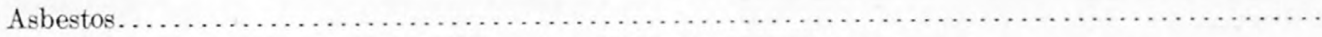

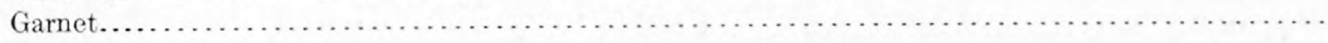

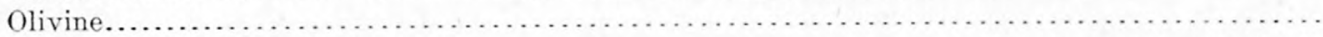

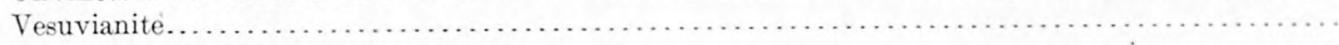

Zircon $\ldots \ldots$
Andalusite $\ldots \ldots$
An

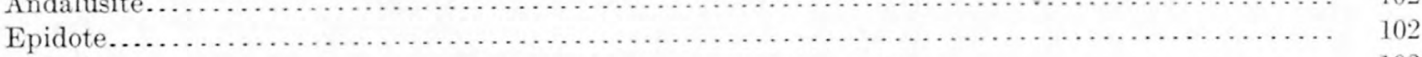

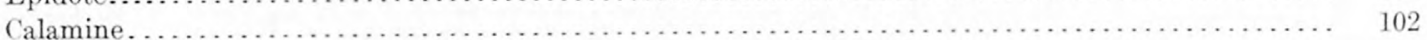

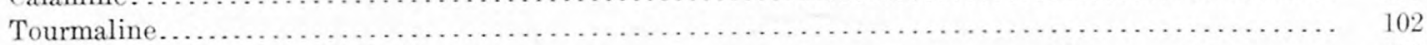

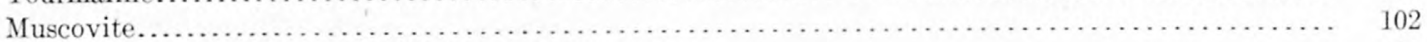

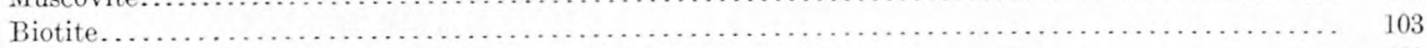

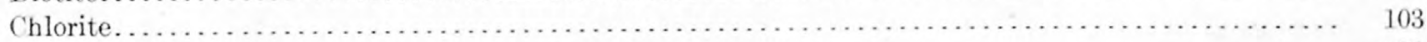

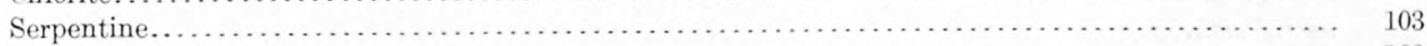

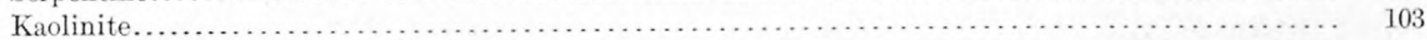

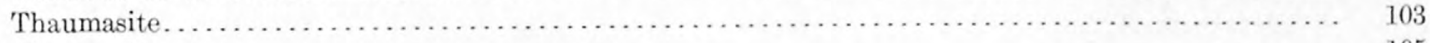

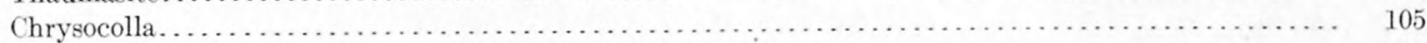

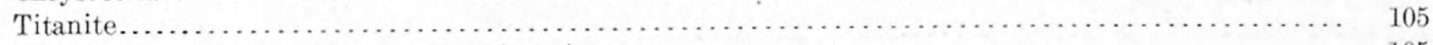

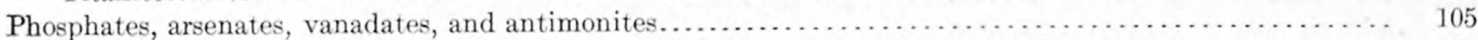

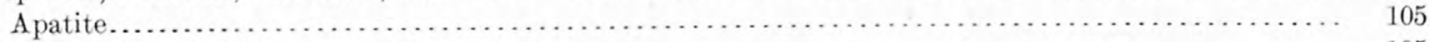

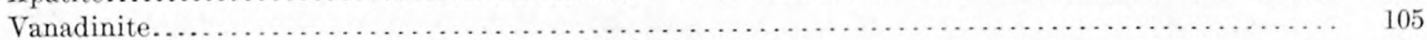

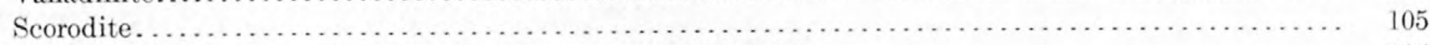

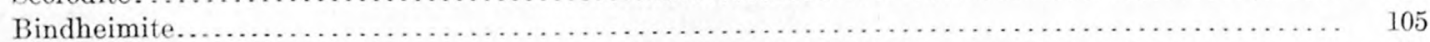

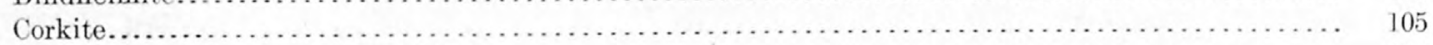

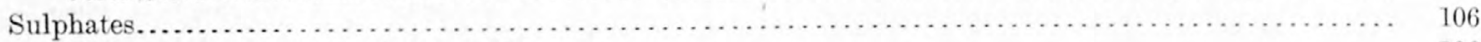

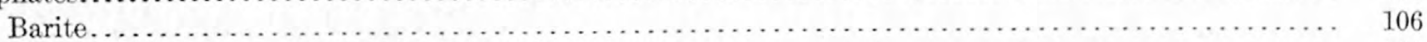

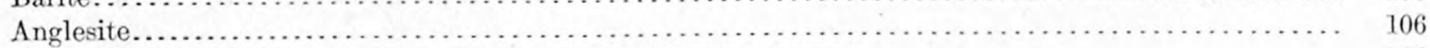

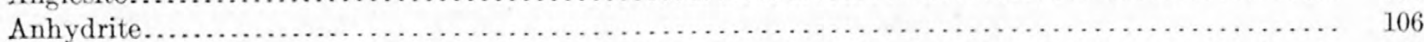

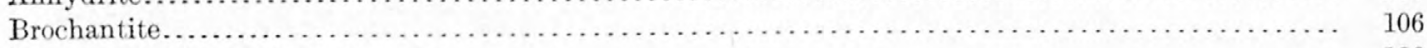

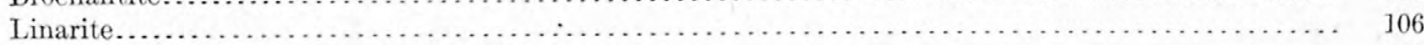

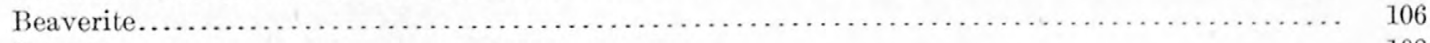

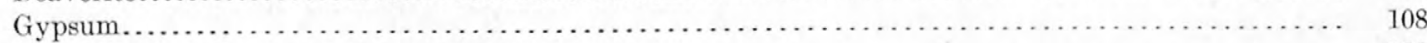

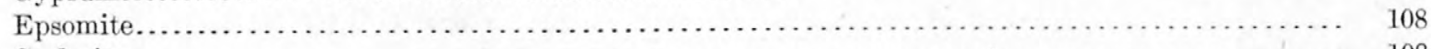

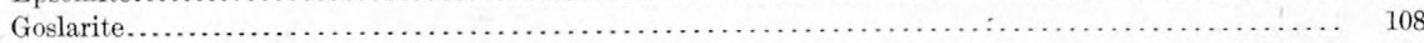

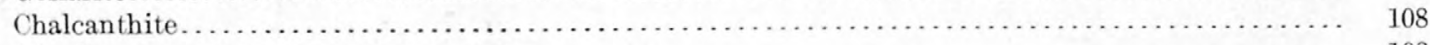

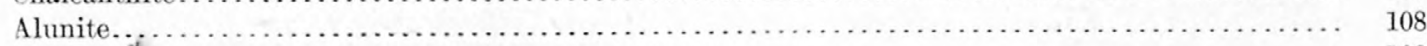

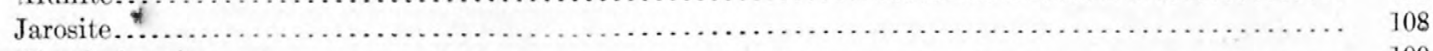

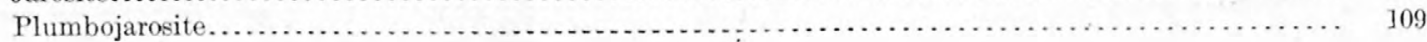


Mineralogy of the San Francisco region-Continued.

Molybdates.

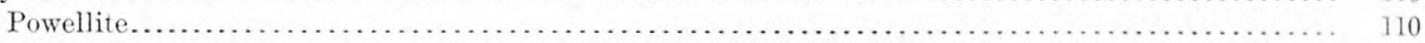

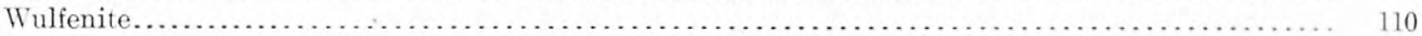

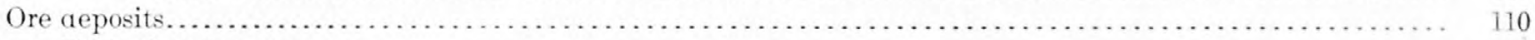

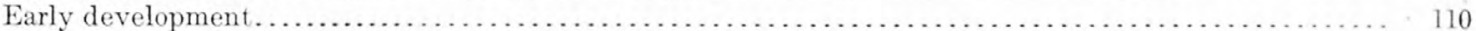

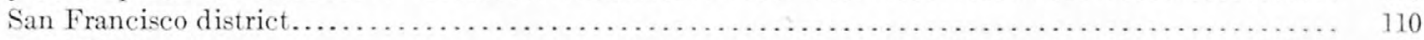

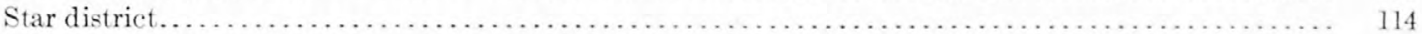

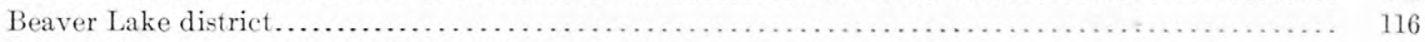

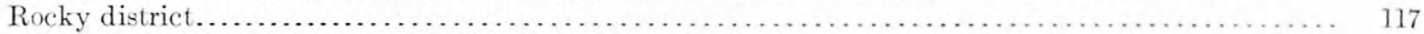

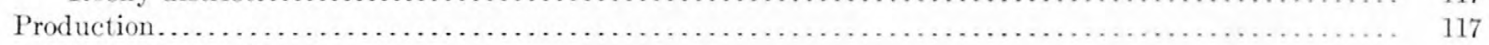

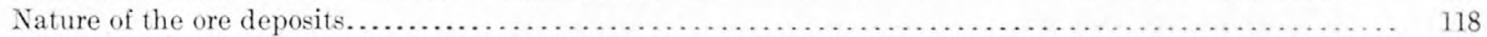

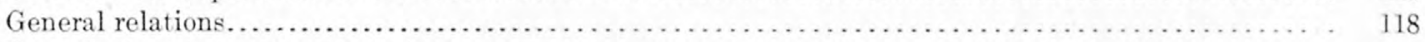

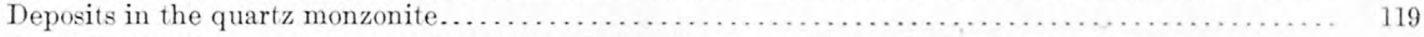

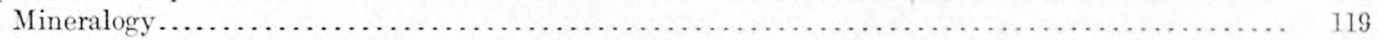

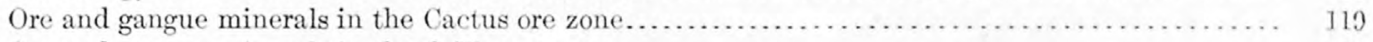

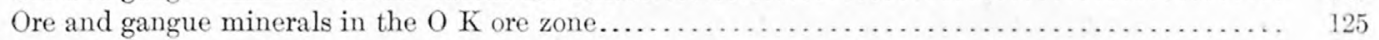

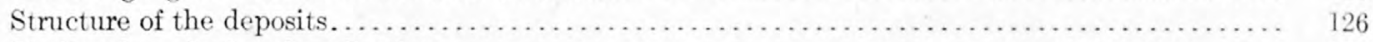

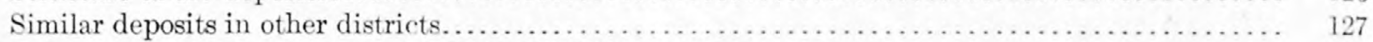

Deposits formed by the replacement of sedimentary rocks . . . . . . . . . . . . . . . . . 129

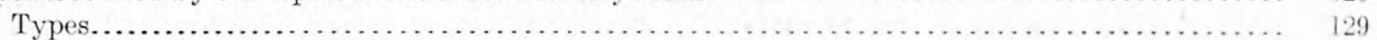

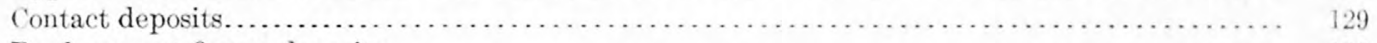

Replacement fissure deposits........................................... 130

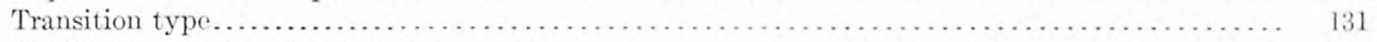

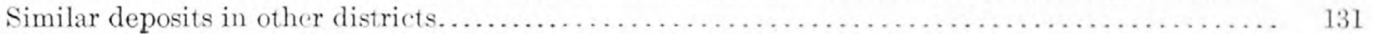

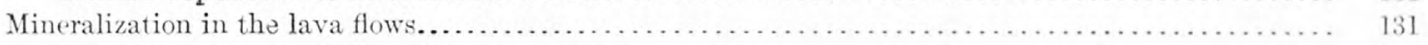

Location and general character......................................... 131

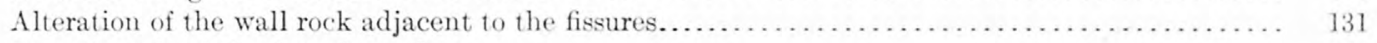

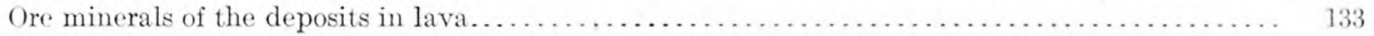

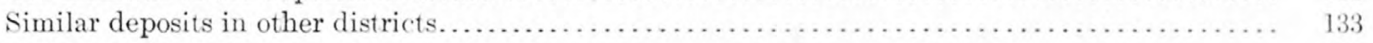

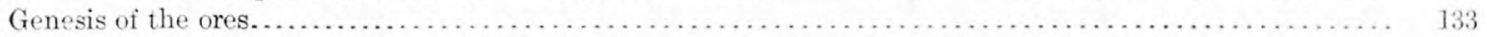

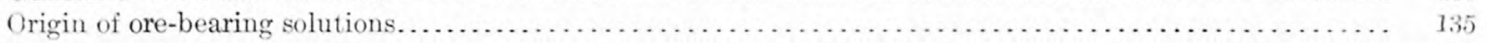

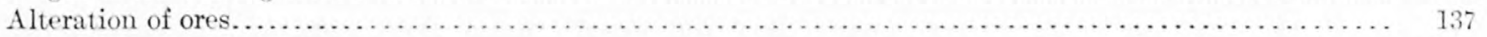

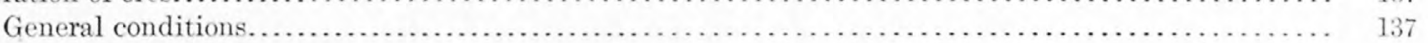

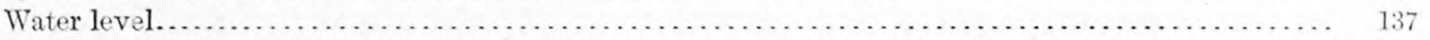

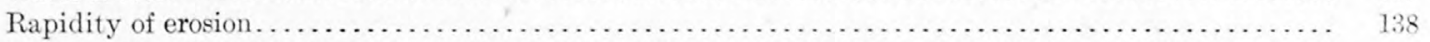

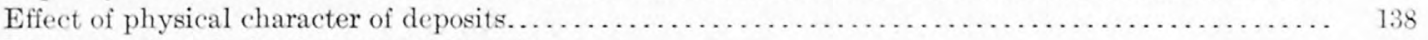

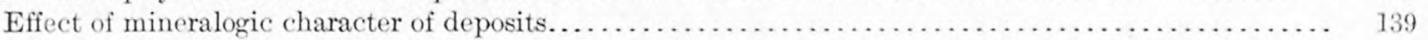

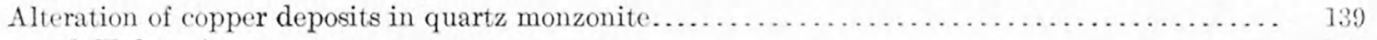

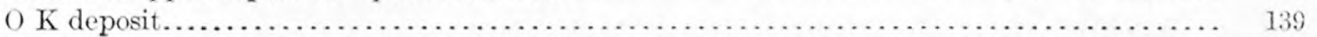

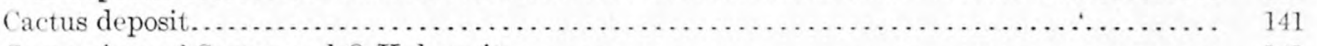

Comparison of Cactus and $\mathrm{O} \mathrm{K}$ deposits........................................ 141

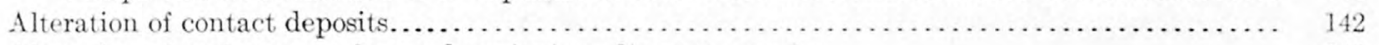

Alteration of replacement fissure deposits in scdimentary rocks........................ 143

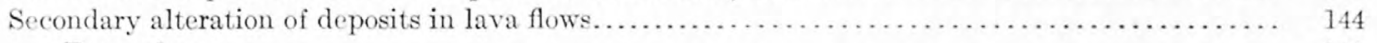

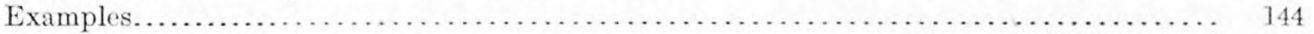

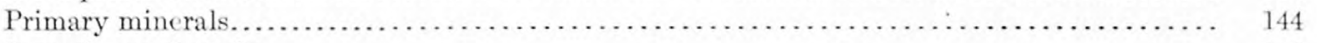

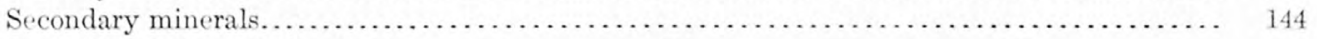

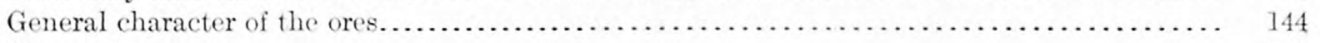

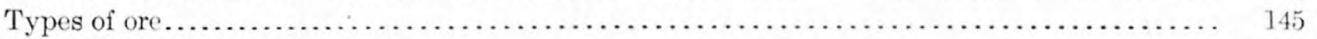

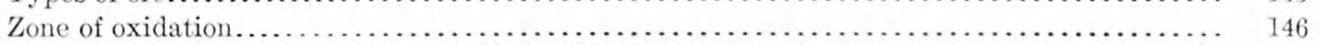

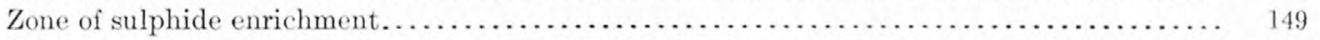

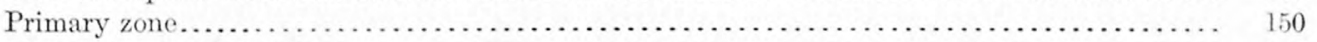

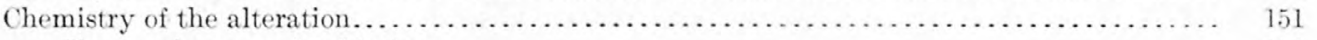

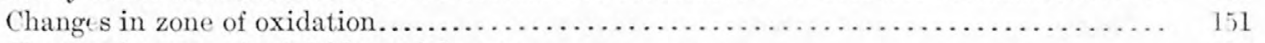

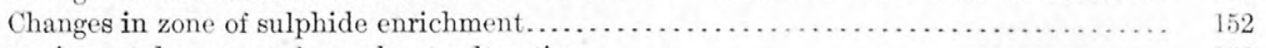

Change in metal content of ores due to alteration................................ 158

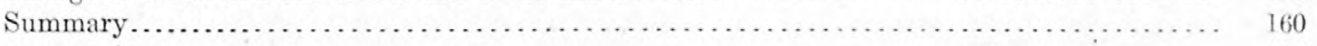

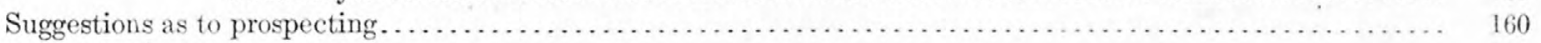

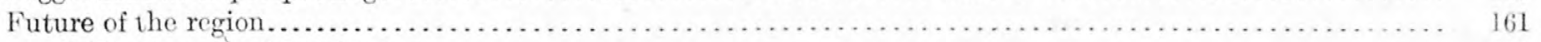

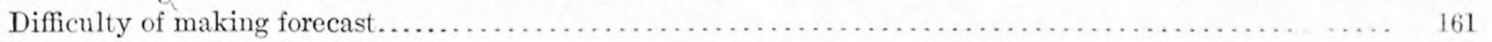

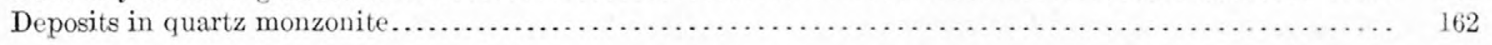


Future of the region-Continued. Page.

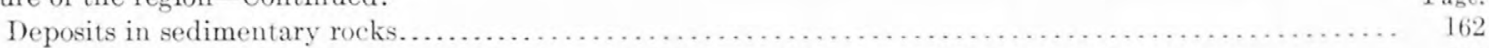

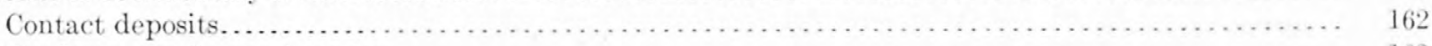

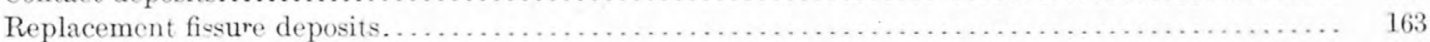

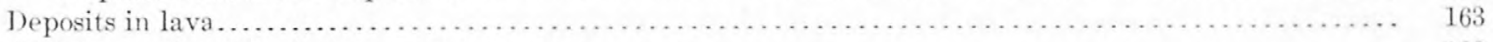

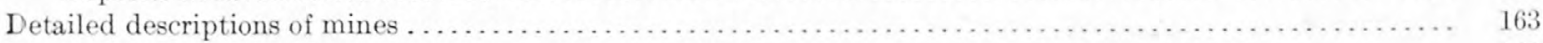

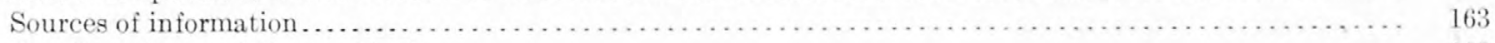

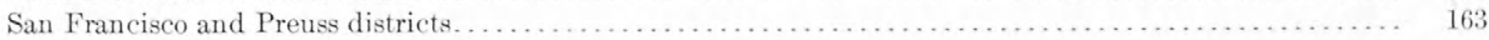

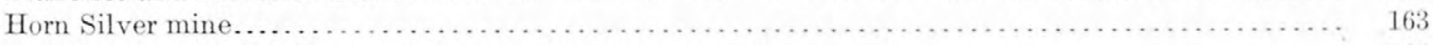

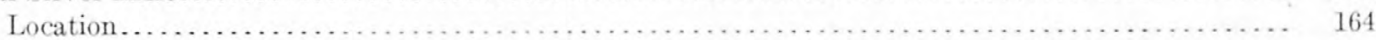

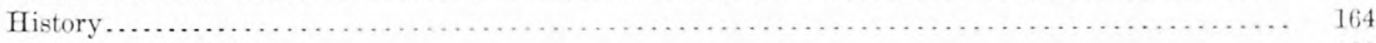

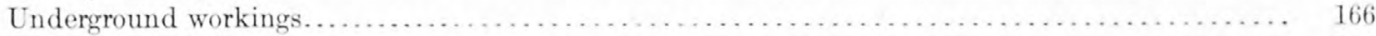

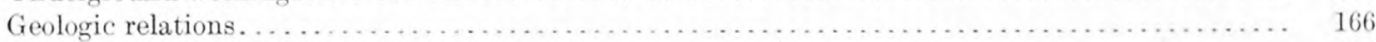

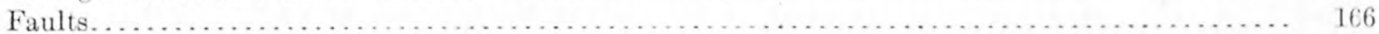

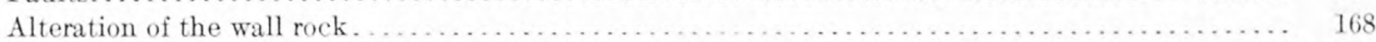

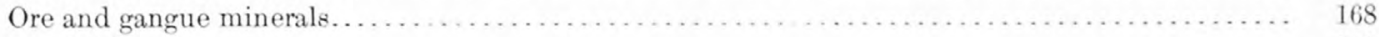

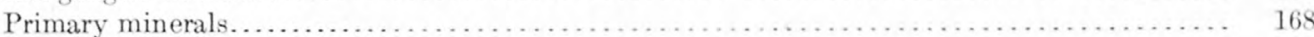

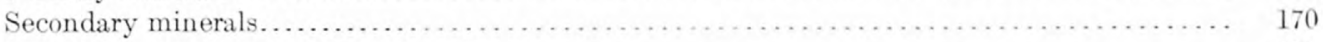

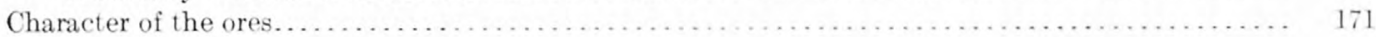

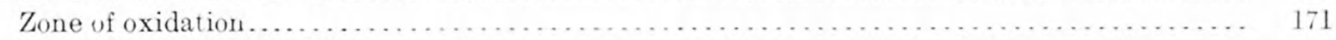

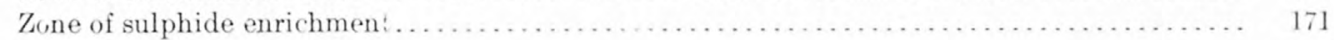

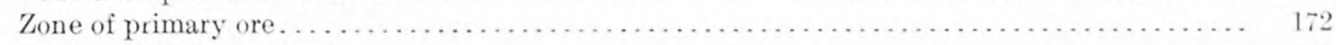

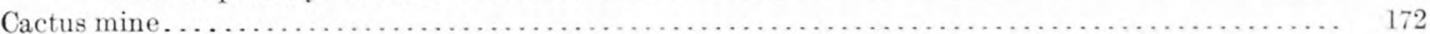

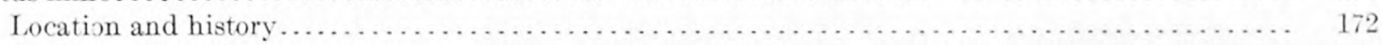

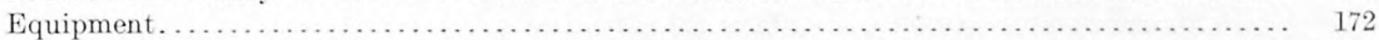

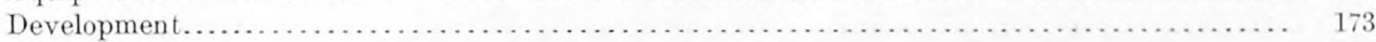

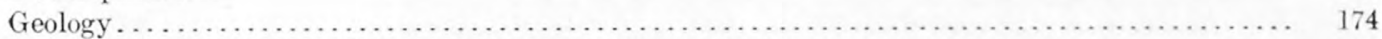

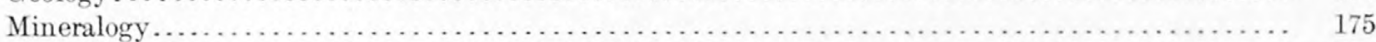

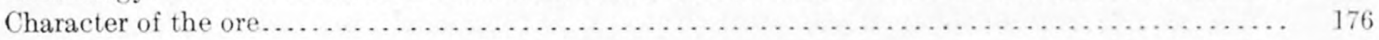

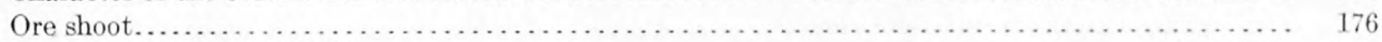

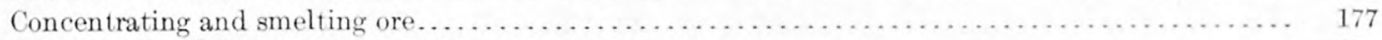

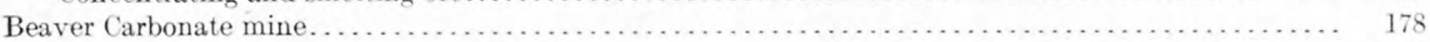

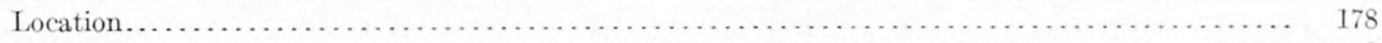

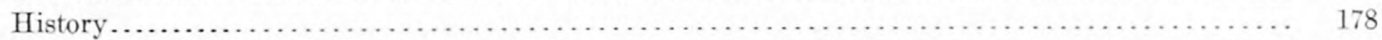

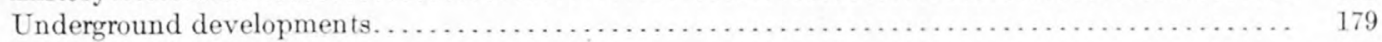

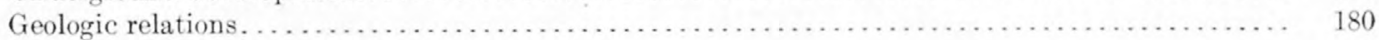

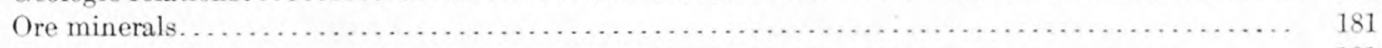

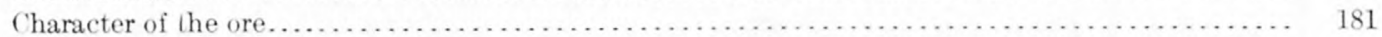

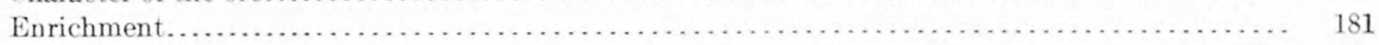

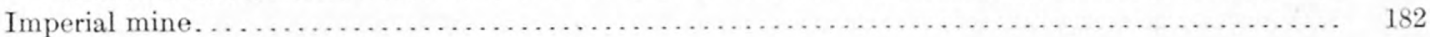

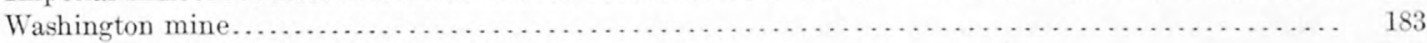

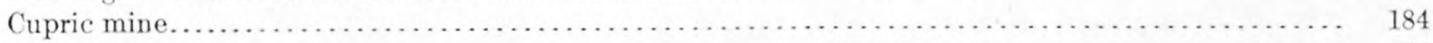

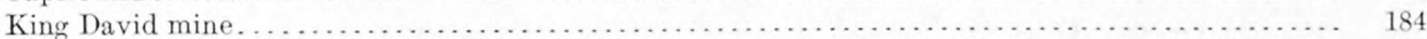

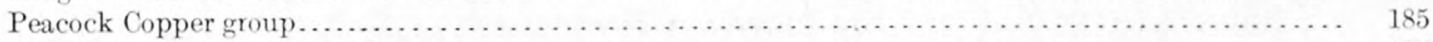

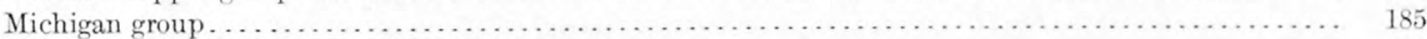

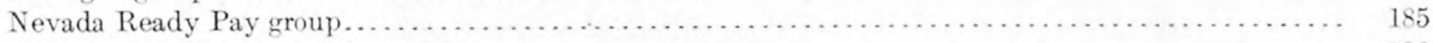

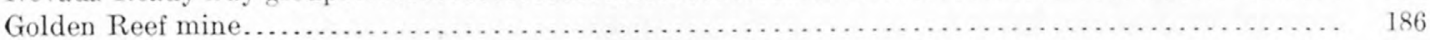

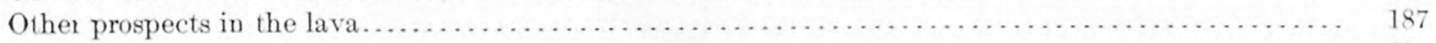

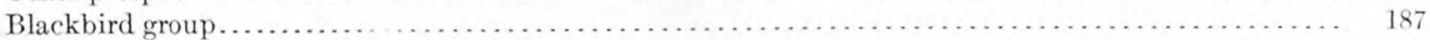

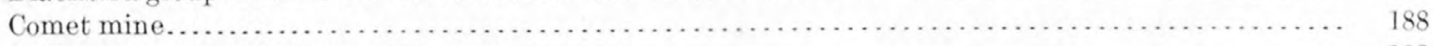

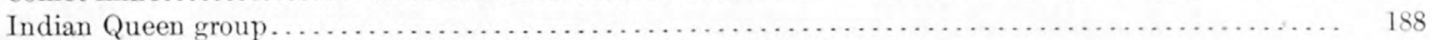

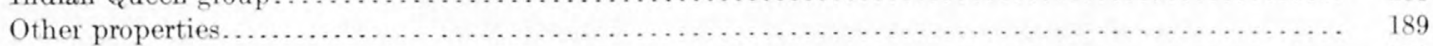

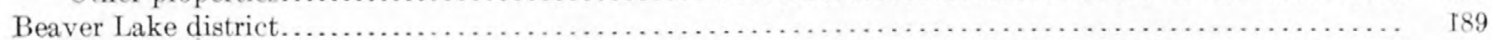

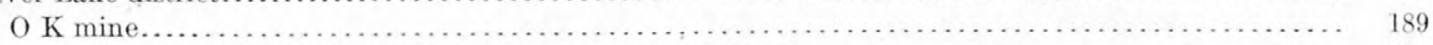

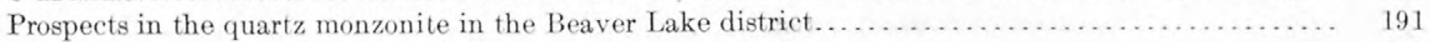

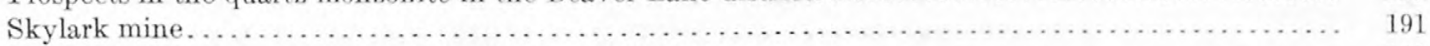

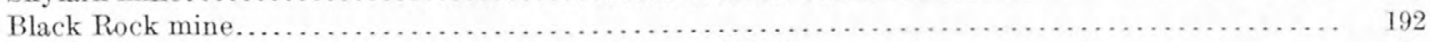

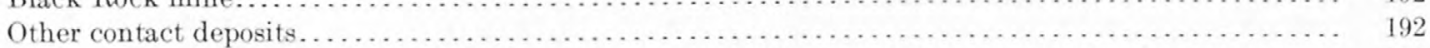

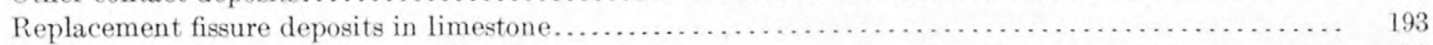

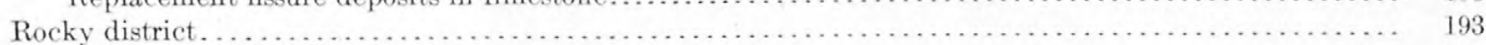

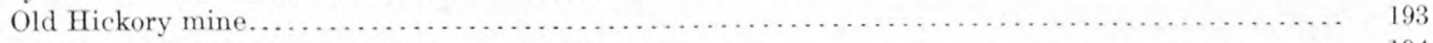

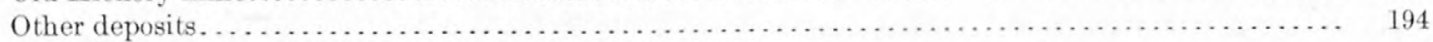


Detailed decsriptions of mines-Continued

Star district .

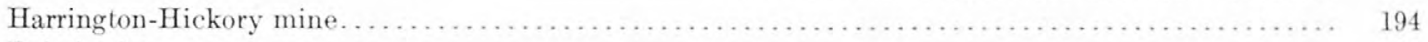

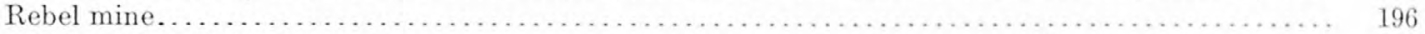

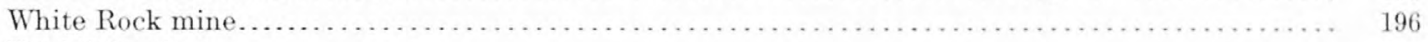

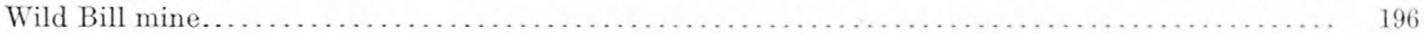

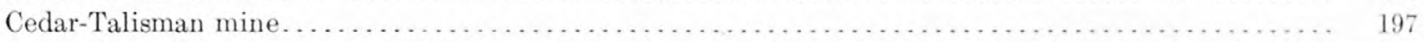

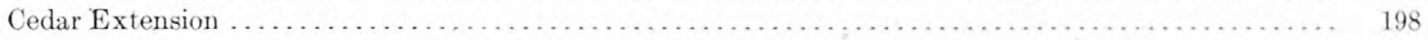

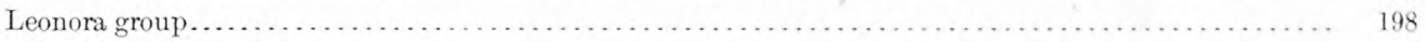

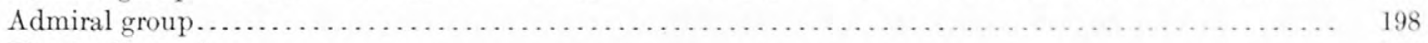

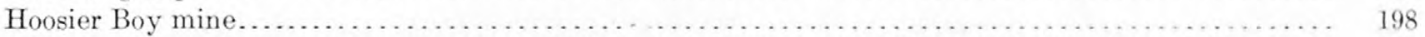

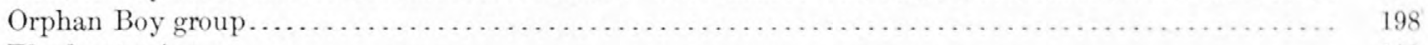

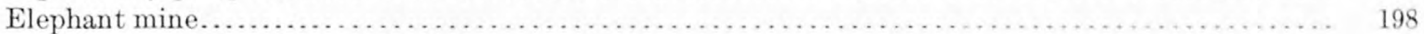

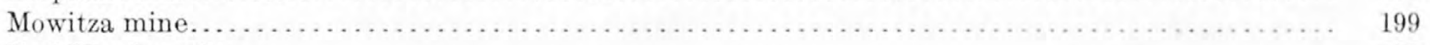

Red Warrior mine ............................................................ 199

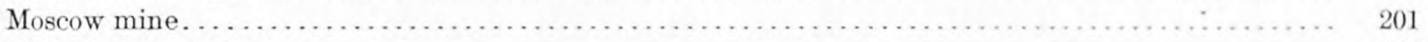

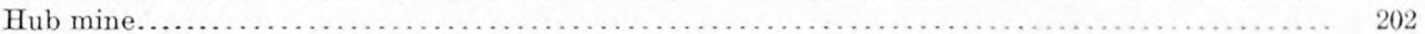

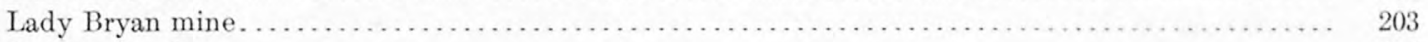

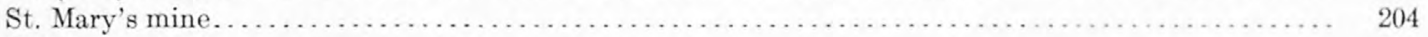

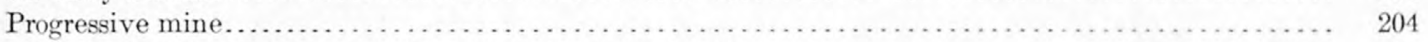

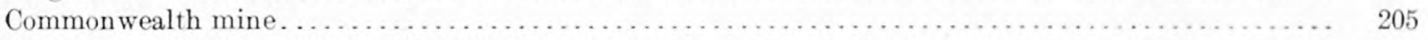

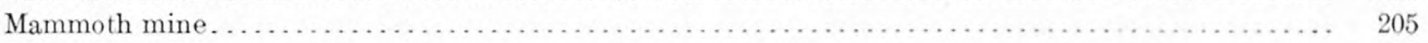

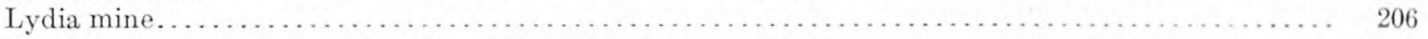

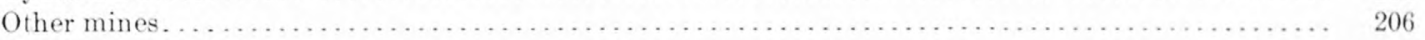

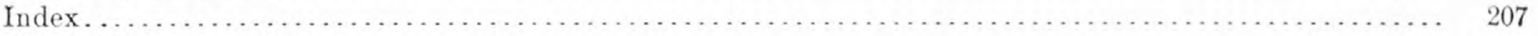

\section{ILLUSTRATIONS.}

Plate I. Geologic map and sections of the mining districts of the San Francisco region, Utah.......... In pocket.

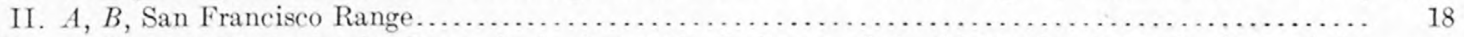

III. A, The Big Wash, Rocky Range in background; $B$, Beaver Lake Mountains from the base of the San Francisco Range, Rocky and Mineral ranges in the background $\ldots \ldots \ldots \ldots \ldots \ldots \ldots \ldots \ldots \ldots \ldots$

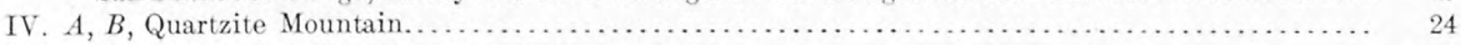

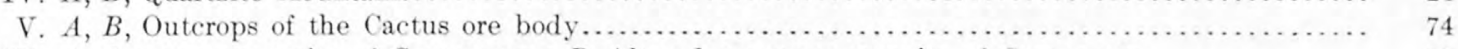

VI. A, Quartz monzonite of Cactus area; $B$, Altered quartz monzonite of Cactus area.............. 75

VII. A, Indian Grave Peak, silicified "reef," near view; $B$, Silicified "reef" south of Carbonate mine... 78

VIII. A, O K mine, Beaver Lake district; $B$, Contact-altered limestone, Loeber Gulch............... 82

IX. $A$, Tremolite, Washington mine; $B$, Garnetized limestone, Loeber Gulch; $C$, Banded limestone,

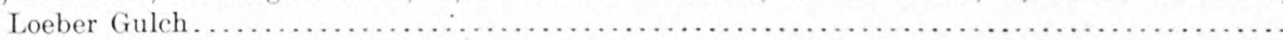

X. $A, B$, Contact of quartz monzonite and altered limestone, Imperial mine . . . . . . . . . . . . . . .

XI. $A$, Quartz crystals, Cactus mine; $B$, Tourmaline in quartz, Cactus mine; $C$, Tetrahedral erystals

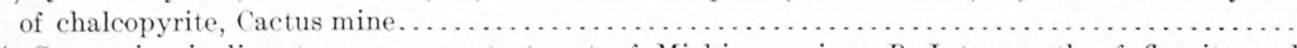

XII. $A$, Serpentine in limestone, near contact east of Michigan mine; $B$, Intergrowth of fluorite and

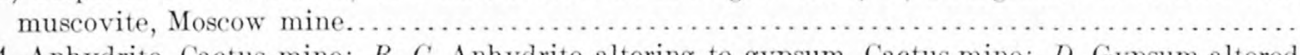

XIII. $A$, Anhydrite, Cactus mine; $B, C$, Anhydrite altering to gypsum, Cactus mine; $D$, Gypsum altered

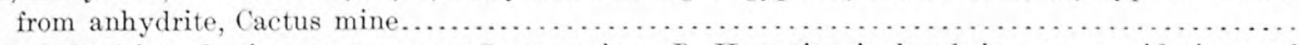

XIV. A, Anhydrite altering to gypsum, Cactus mine; $B$, Hematite inclosed in quartz, siderite, and

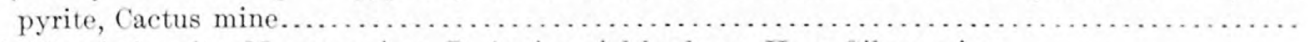

XV. A, Plumbojarosite, Moscow mine; $B$, Antimonial lead ore, Horn Silver mine................ 108

XVI. $A, B$, Coarse pegmatitic quartz with interstitial chalcopyrite, $\mathrm{O} \mathrm{K}$ mine; $C, D$, Molybdenite veins

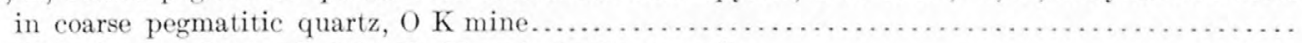

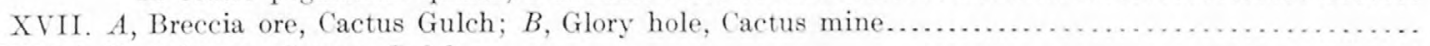

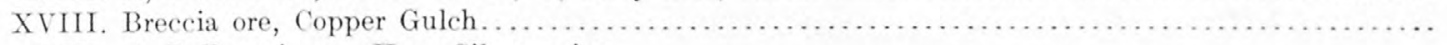

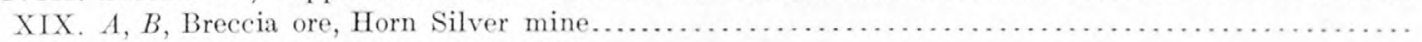

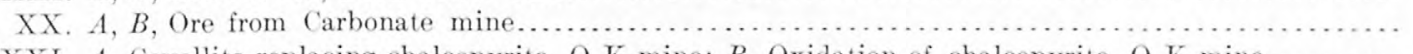

XXI. $A$, Covellite replacing chalcopyrite, $\mathrm{O} \mathrm{K}$ mine; $B$, Oxidation of chalcopyrite, $\mathrm{O} \mathrm{K}$ mine.........

XXII. $A, B$, Covellite replacing chalcopyrite, O $\mathrm{K}$ mine; $C$, Spheroidal "crystals" of wurtzite, Horn Silver mine; $D$, Galena partly replaced by covellite and sulphates. Horn Silver mine...........

\section{3}

84

96

97

106

107 
Plate XXIII. A, Pyrite in gangue of quartz and barite, Horn Silver mine; $B$, Covellite replacing pyrite,

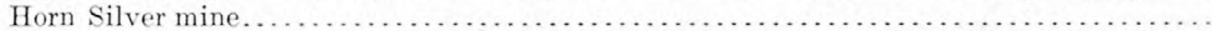

XXIV. A, Smithsonite pseudomorphs after calcite crystals, seventh level, Horn Silver mine; $B$,

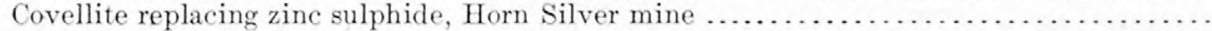

XXV. $A, B$, Dark-gray zine sulphides, sphalerite and wurtzite, Horn Silver mine; $C, D$, Crystals

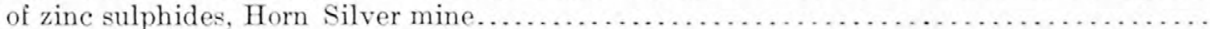

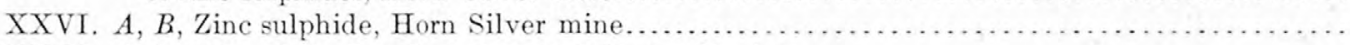

XXVII. Claim map of the San Francisco and Preuss districts . . . . . . . . . . . . . . . . . . . . . .

XXVIII. $A$, Horn Silver mine and village of Frisco; $B$, Red Warrior mine, Star district . . . . . . . . . .

XXIX. Map of levels of the Horn Silver ore body . . . . . . . . . . . . . . . . . . . . . . . . .

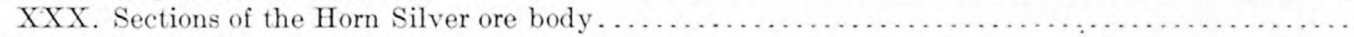

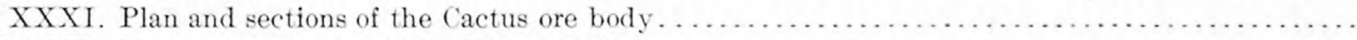

XXXII. Transverse section of the Cactus ore body .

XXXIII. A, Vein of magnetite in pyrite, Peacock copper mine; $B$, Veins of iron oxides and sulphides in crushed garnetized limestone, Imperial mine; $C$, Chalcepyrite and pyrite inclosed in iron oxide, Cupric mine.

XXXIV. A, Galena, garnet, and muscovite replacing limestone, Washington mine; $B$, Galena, garnet, and tremolite replacing limestone, Washington mine; $C$, Intergrowth of tremolite and galena, Washington mine.....

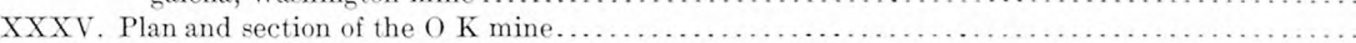

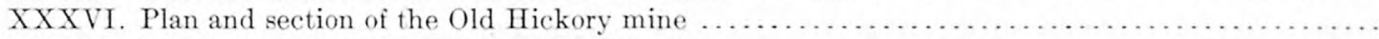

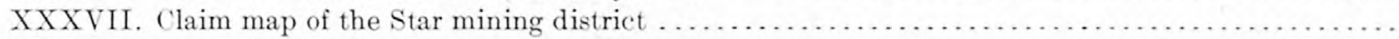

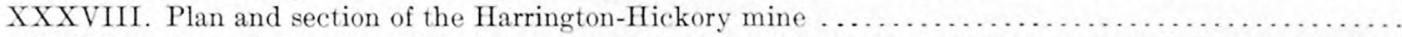

XXXIX. Plan of the Wild Bill mine

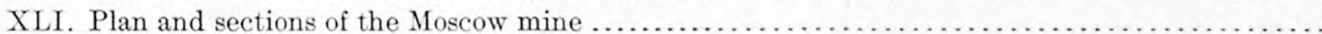

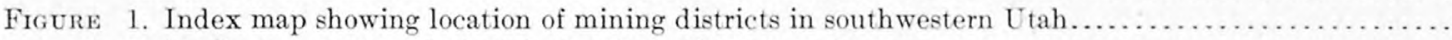

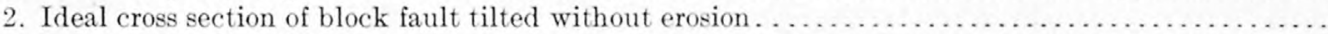

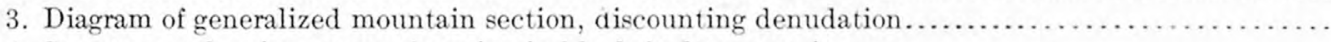

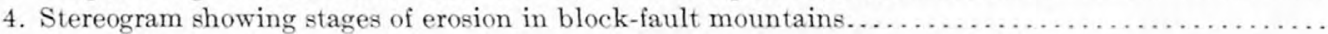

5. Generalized section across Mineral, Beaver Lake, San Francisco, and Wa Wa ranges...........

6. Generalized section of the sedimentary series in the San Francisco and adjacent districts........

7. Diagrammatic cross section of intrusive stock, showing surrounding areas of contact metamorphism.

8. Generalized stereogram representing the relations of the formations in part of the San Francisco Range north of Squaw Springs Pass.

9. Magnetite surrounding chalcopyrite; generalized drawing from microphotograph...............

10. Diagram showing the relative period of formation of the principal ore and gangue minerals in the Cactus ore zone.

11. Curve showing the solubility of anhydrite at varying temperature.

12. Generalized stereogram showing relation of pegmatitic quartz and altered and mineralized quartz monzonite in the $\mathrm{O} \mathrm{K}$ mine.

13. Sketch near the end of a small quartz-sulphide vein, O K mine, showing relation of chalcopyrite

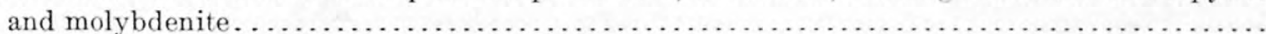

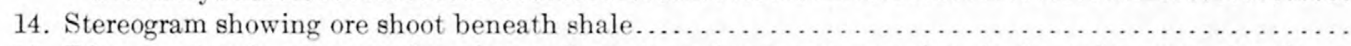

15. Diagram showing the relation of secondary alteration to outcrop of ore body and to water level....

16. Plan of workings of Beaver Carbonate mine. 


\section{SUMMARY OF RESULTS.}

\section{GENERAL GEOLOGY OF THE DISTRICT.}

The rocks of the San Francisco and adjacent districts consist of sedimentary formations, lava, flows, and intrusives.

SEDIMENTARY ROCKS.

The stratified rocks have resulted from a long period of sedimentation, extending from Cambrian to Triassic time. The fossils indicate the presence of Ordovician, Devonian, Carboniferous, and Triassic sediments. Fossils of Silurian age were not found, but no evidence was obtained to show that sedimentation was not in progress during the Silurian period. No sediments younger than Triassic crop out in the district, with the exception of the Lake Bonneville beds and alluvial deposits.

At some time after the deposition of the Triassic the region was elevated and subsequently reduced to a mature erosion surface.

IGNEOUS ROCKS.

Both extrusive and intrusive rocks are extensive and important in the district.

Effusive rocks.-Probably from early to middle Tertiary time there was an extensive outpouring of lavas that nearly or quite buried the old erosion surface of the sedimentary rocks. This body of lava was made up of many flows of varying physical character and somewhat diverse composition. The composition of the great bulk of the extrusive rocks, however, is that of a quartz latite, though there are small bodies of these rocks that may be classed as rhyolite and others that are andesite and dacite. The latest flows are basalts and were probably poured out at a considerably later period than the main body of the effusive rocks.

Intrusive rocks.-The extrusion of the main body of the lavas was followed by extensive intrusion of quartz monzonite and closely allied rocks that formed irregular stocks in the sedimentary rocks and lavas. These in turn were followed by intrusives of more siliceous and basic types, forming small aplitic and basic dikes. Neither of these later types is of any considerable areal extent.

\section{STRUCTURE.}

Folding is not an important feature of the structure of the district. On the west side of the San Francisco Mountains there is an anticline, the western limb of which has been eroded except in the lower beds exposed. Other folds that may have been present have been masked or obliterated by the intrusive rocks.

Faulting has played a far more important part in determining the structure of the region than folding. The larger faults trend in a general north-south direction and have determined the outline of the San Francisco Range, which has resulted from the relative uplift and tilting of a block between two faults. Similar faults have determined the outline of the Mineral Range to the east, and the Wa Wa Range to the west. There are smaller east-west faults, the principal ones within the region being the one that has determined the position of Squaw Springs Pass through the San Francisco Mountains and the Elephant Canyon fault, in the Star district. Still smaller faults and fissures that have had an important influence on the formation of the ore deposits are present in all the districts. 


\section{METAMORPHISM.}

Locally the rocks of the region have undergone extensive changes, due to the action of heated liquids or gases carrying mineral matter in solution.

Alterations in quartz monzonite.-In the quartz monzonite the alteration has been confined to the vicinity of fissures along which heated liquids and gases have passed. The characteristic alteration is that to a quartz-sericite rock containing minor amounts of other constituents, including sulphides of iron and copper, oxide of iron, and in some places carbonate of iron, magnesium, and manganese.

Alterations in lava flows.-Locally the lavas have suffered extensive alteration from heated solutions. In some places this change has been confined to the vicinity of fissures, but in other places extensive areas have been affected. These areas are usually in close proximity to the quartz monzonite, and the alteration has probably resulted from the intrusion of that rock. The most usual change is that to a rock composed essentially of quartz and sericite, but where the alteration has been most intense the resulting rock is composed of quartz, sericite, and andalusite, with minor amounts of other minerals.

Alteration of sedimentary rocks. - The limestone has undergone far more extensive alteration than the other sedimentary rocks, though both shale and quartzite have been affected to a minor extent.

The alteration of the limestone may be described as of two types, though they grade into one another. The limestone adjacent to the quartz monzonite bodies has nearly everywhere been recrystallized to form a white crystalline limestone or marble, though there may have been no marked change in composition during this process. Locally the limestones have undergone extensive chemical change with important additions of silica, iron, a little alumina, and minor amounts of other constituents, and carbonic acid has been almost entirely removed. Mineralogically this change is shown by the presence of garnet, tremolite, vesuvianite, epidote, and other contact silicates, together with magnetite, specularite, and sulphides of iron and copper in varying amounts. It is believed that the alteration is the result of the intrusion of the quartz monzonite - that the heat given off by this mass has resulted in a recrystallization of the adjacent limestone wherever it is in contact and probably in slight additions to the limestone of elements coming from the intrusive rock. Where there have been important additions to the limestone they have probably entered as gaseous or aqueous solutions that have been excluded from the crystallizing quartz monzonite magma. The localization of these areas of highly altered rocks is due to the facts that the upper and outer portion of the intrusive body solidified first and that the materials excluded from the deeper-seated sources escaped through fissures in the already solidified portion and thus were collected in certain channels, their effects being localized where these channels entered the limestone or passed along the contact at the line of least resistance.

Relation of the different types of alteration.-The additions that have taken place in the alteration of the quartz monzonite and the limestone are in general very similar, and it is believed that both have been derived from the same source, namely, the solution escaping from the quartz monzonite magma crystallizing at considerable depth. The alteration of the lavas is of somewhat different type, and in the more extensive areas, like that in the Beaver Lake Mountains, may have resulted largely from a circulation of surface waters that were heated by the intrusion of the quartz monzonite.

\section{ORE DEPOSITS.}

CLASSIFICATION.

All the ore deposits of the San Francisco and adjacent districts are believed to be of essentially the same age, the deposition of the ores closely following the intrusion of the quartz monzonite. The marked difference in the character of the different deposits is probably due to several causes, among the more important of which are differences in the character of the rock in which the deposits occur; in the distance from the intrusive body, resulting in differences of tem- 
perature, pressure, etc., and in the time in the general period of mineralization in which the deposits were formed. Classified on the basis of the character of the rock in which the deposits occur they may be divided into three groups, each including deposits of similar character. These groups may be designated deposits in quartz monzonite, deposits in sedimentary rocks, and deposits in lavas.

DEPOSITS IN QUARTZ MONZONITE.

The deposits in quartz monzonite are characteristically copper deposits of the replacementvein type. The typical alteration of the quartz monzonite adjacent to the veins is a marked sericitization. The most abundant vein mineral aside from the altered quartz monzonite is quartz, which in the $\mathrm{O} \mathrm{K}$ deposit is pegmatitic in character. The metallic minerals are principally pyrite and chalcopyrite, with minor amounts of molybdenite, galena, tetrahedrite, and the iron oxides magnetite and specularite, which are in some places relatively abundant. In the Cactus mine tourmaline, anhydrite, barite, and carbonate are rather abundant primary gangue minerals.

In the Cactus mine the minerals show a rather definite order of formation, beginning with sericitization, followed by the deposition of tourmaline and quartz, next of hematite, and last of anhydrite, barite, and carbonate. Sulphides were being deposited through the entire period of mineralization.

In addition to the copper deposits there are some deposits of lead ore in the quartz monzonite, but up to the present time these have not been shown to be of much commercial importance.

DEPOSITS IN SEDIMENTARY ROCKS.

The deposits in the sedimentary rocks may be divided into two types, contact deposits and replacement fissure deposits.

Contact deposits.-The contact deposits have resulted from the replacement of limestone close to the quartz monzonite. They are typically copper deposits carrying some precious metals. The gangue minerals are contact silicates, together with oxides of iron, the latter in some places forming the principal gangue.

Replacement fissure deposits.-The replacement fissure deposits have resulted from the replacement of sediments, commonly limestone, along fissures, usually at some distance from the quartz monzonite. The deposits of this character thus far worked have their principal value in lead and silver, though zinc and copper are present in varying and, in some deposits, important amounts. The primary minerals consist of pyrite, galena, sphalerite, and chalcopyrite in a gangue of unreplaced limestone, quartz, and in places some contact silicates and iron oxides.

The region contains every gradation between the typical contact deposit and the typical replacement fissure deposit.

DEPOSITS IN VOLCANIC ROCKS.

The deposits in the volcanic rocks are replacement fissure deposits. The rock adjacent to them has been sericitized and where alteration has been most intense silicification has been pronounced. In some localities chlorite and kaolinite have been important products of alteration. The chief value of deposits of this type has been their lead and silver content, though they carry notable amounts of zinc and copper. The principal primary minerals are galena, pyrite, sphalerite, and chalcopyrite, with minor amounts of sulphantimonides and sulpharsenides, in a gangue consisting largely of altered wall rock, together with cherty quartz and barite and, in the Carbonate mine, calcite.

GENESIS OF THE ORES.

The genesis of the ores has already been indicated in the discussion of metamorphism. There seems little doubt that the deposits replacing the sedimentary rocks and those in the quartz monzonite are of essentially the same origin - that is, they have been deposited from heated solutions given off by the quartz monzonite magma on crystallization. This theory for 
the origin of the deposits in quartz monzonite is supported by the facts that aplitic dikes in the quartz monzonite that represent a differentiation of the magma contain sulphides as original minerals and that in the $\mathrm{O} \mathrm{K}$ deposit sulphides are present in a coarse pegmatitic quartz that is believed to represent a further differentiation of the magma.

The contact deposits contain the minerals typical of such deposits and indicative of having formed at high temperatures. At the immediate contact there is in some places a blending of the minerals characteristic of the quartz monzonite and of the altered limestone, showing a gradual transition from one to the other. The gradation from typical contact deposits to replacement-fissure deposits is so complete that there can be no doubt that the two are of common origin.

The evidence bearing on the genesis of the deposits in the lava flows is less conclusive, but the general relations suggest strongly that they have a common origin with the other deposits of the district, namely, that they have been deposited from solutions given off by the quartz monzonite magma.

ENRICHMENT OF THE DEPOSITS.

Enrichment has been an important though very variable factor in producing the ore deposits as they are found.

Enrichment of deposits in quartz monzonite.-In the copper deposits in the quartz monzonite sulphide enrichment, or the leaching of the copper from the upper part of the ore zone and its reprecipitation on the sulphides lower down as chalcocite or covellite, has been important in the $\mathrm{O} \mathrm{K}$ mine, but in the Cactus deposit such enrichment is practically absent. This difference is due, it is believed, to the presence in the Cactus deposit of abundant carbonate, which prevented the migration of the copper and retained it in the oxidized zone as carbonates instead of permitting it to pass to greater depth and be precipitated as sulphide.

Enrichment of contact deposits.- Secondary alteration in the typical contact deposits has been confined to a zone comparatively near the surface, owing to the dense nature of these deposits and the relatively inert character of the silicates composing the gangue. The ore that has been extracted from deposits of this type, however, has resulted from concentration in the relatively shallow zone of oxidation.

The replacement fissure deposits have undergone extensive secondary alteration. In most places oxidation has extended to the depth to which mining operations have gone. The secondary ores consist mainly of cerusite carrying silver and minor amounts of copper and zine carbonates in a gangue of limonite. During the process of alteration the zine content has probably decreased, whereas the relative content of other metals may have been slightly increased through the removal of sulphur and other constituents.

Enrichment of deposits in lavas.-In the deposits in lavas secondary alteration has been highly variable on account of the differences in the water level due to local conditions. In the Carbonate deposit there has been little secondary alteration owing to the fact that the local water level is very near the surface, but in the Horn Silver deposit the water level is deep and secondary alteration has been extensive. In the Horn Silver deposit oxidation has been very complete to a depth of more than 500 feet and in some parts of the deposit to much greater depths.

In the upper levels zinc and copper have been practically removed and the galena has been largely altered to anglesite, with minor amounts of cerusite and the more complex sulphates plumbojarosite and beaverite. In the deeper oxidized zone, where the rich secondary sulphide copper ores have been attacked, brochantite is relatively abundant and carbonates and silicate of copper are present. Zinc has been largely removed from the oxidized ores, though it is present to some extent as smithsonite and calamine. Silver has in general remained in the oxidized ores, in part, at least, as horn silver.

In the zone of sulphide enrichment the ores have been enriched in copper and zinc. The copper has replaced the other sulphides, forming rich ores consisting mainly of covellite and chalcocite. The zinc has been deposited in areas of highly brecciated ore as the rare sulphide wurtzite, 


\title{
GEOLOGY AND ORE DEPOSITS OF THE SAN FRANCISCO AND ADJACENT DISTRICTS, UTAH.
}

\author{
By B. S. Butler. \\ INTRODUCTION. \\ FIELD WORK.
}

The San Francisco district was of recognized importance in the early days of mining in Utah, but its output soon declined and thereafter it attracted little attention until about 1903, when the development of the Cactus mine was undertaken.

In August, 1904, S. F. Emmons, then in charge of the division of metalliferous deposits of the Geological Survey, visited the district and determined the area to be covered by a projected topographic map. In 1904 and 1905 Fred McLaughlin completed a topographic map covering the San Francisco and Preuss districts and parts of the Beaver Lake, Rocky, and Star districts, an area of about 175 square miles.

In the spring of 1908 Waldemar Lindgren, in charge of the division of metalliferous deposits, visited the San Francisco district and decided that the Survey should make a study of its geology. The writer was assigned to the work of mapping the surface geology and was occupied in this work during part of July, the whole of August, and part of September, 1908.

Before the geologic work was completed the renewed activity in the Star district made it desirable that all that district should be included in the geologic study and therefore, in the summer of 1909, W. M. Beaman extended the topographic work to include the more active parts of the Star, Rocky, and Beaver Lake districts that were not included in the previous map. The total area mapped is about 200 square miles.

In 1909 the writer was assigned to the study of the ore deposits and spent the greater part of July, the whole of August, and part of September in the district. In 1910 he spent about 10 days in the district and in 1910 and 1911 was engaged in studying other districts in southwestern Utah. Office work on the present report has been in progress since the fall of 1908 .

\section{ACKNOWLEDGMENTS.}

It is a pleasure to acknowledge the hearty cooperation of the mining men in the district, who furnished to the writer everything at their command to further the study. These mining men will recognize in the conclusions stated in this report some ideas that they have imparted. The final product, however, is composite, consisting of ideas derived from many sources, and it is, as a rule, impossible to assign definite credit for any idea or conclusion, though the writer has attempted to give credit when possible.

The writer is indebted to Messrs. E. O. Ulrich, E. M. Kindle, and G. H. Girty for the determination of fossils, and to Messrs. Chase Palmer, R. C. Wells, George Steiger, and W. T. Schaller for chemical and mineralogic determinations. He desires also to acknowledge the aid rendered by his associates in the Geological Survey, who have freely given him the benefit of their suggestions and criticisms.

Mr. Waldemar Lindgren, under whose supervision this work was done, was in the field with the writer for several days in 1908 and 1909, and his helpful suggestions, both in the field and in the office, are gratefully acknowledged. 
PREVIOUS WORK IN THE REGION.

Considering the importance and the interesting character of the ore deposits of this portion of Utah and its ready accessibility in recent years, little investigation has been made of its geology and ore deposits. One of the earliest reports containing important geologic data concerning this region is that by Gilbert, ${ }^{1}$ who made a reconnaissance through the region in 1871 . In this report he gives a summary of the results of his geologic investigations and describes briefly the mining activities then just beginning in the region.

Gilbert discusses the gaology of the region more fully in a later report ${ }^{2}$ and gives the age of the formations on the map of the region in the accompanying atlas. In his history of Lake Bonneville ${ }^{3}$ Gilbert also describes certain physiographic features, especially the alluvial cones and lake beaches.

In 1879 the Engineering and Mining Journal ${ }^{4}$ published a series of articles describing the geology and mineralogy of the Horn Silver mine and the method of extracting and treating the ores. This description was based very largely on reports made to the Horn Silver Mining Co. by W. E. Hooker and Henry Cummings.

Newberry ${ }^{5}$ makes brief mention of the Carbonate mine in an article on ore deposits published in 1880 .

O. T. Hollister ${ }^{6}$ published a brief description of the mines and mining operations in Beaver County in 1887.

Emmons ${ }^{7}$ in 1901 published a brief description of the Horn Silver deposits and the geology in the immediate vicinity. Emmons later ${ }^{8}$ described the ore deposit of the Cactus mine and the general geology of the San Francisco Range in the vicinity of the deposit.

In 1908 Joseph Jensen, R. C. Tower, Ralph R. Wooley, Ernest S. Bowman, H. E. Havenor, and V.B. Herbert made a study of the general geology, petrography, and ore deposits of the San Francisco Mountains, giving special attention to the west side of the range. The results of this study were presented as a thesis to the University of Utah.

Lee ${ }^{9}$ has described the geology of the Beaver Valley and Mineral Range and the recent sediments of the Milford Valley.

Lindgren ${ }^{10}$ has described the occurrence of anhydrite in the Cactus mine and in connection with this the general character of the ore deposit.

Palmer ${ }^{11}$ has described the Cactus ore deposit and the methods of extraction and treatment of the ores.

The Survey's annual report "Mineral resources of the United States" has yearly contained descriptions of the activities in the region and statistics of the production.

The report of the Tenth Census ${ }^{12}$ of the United States contains an account of the mining operations in the region previous to 1880 and an estimate of production.

In addition to the publications above mentioned the mining magazines have from time to time published reviews of mining in the districts here discussed.

Numerous private reports on individual properties have been made by engineers, but so far as the writer is aware none has been published. The writer has had the privilege of seeing several of these reports and has referred to them in the text of this paper.

1 Gilbert, G. K., U. S. Geog. Surveys W. 100th Mer., 1872, pp. 18-24.

2 Idem, vol. 3, 1875, pp. 27-29.

3 Gilbert, G. K., Lake Bonneville: Mon. U. S. Geol. Survey, vol. 1, 1890.

4 Eng. and Min. Jour., vol. 28, 1879, pp. 335, 352, 376, 392, 411

5 Newberry, J. S., The origin and classification of ore deposits: School of Mines Quart., vol. 1, 1880, p. 102.

${ }^{6}$ Hollister, O. T., Gold and silver mining in Utah: Trans. Am. Inst. Min. Eng., vol. 16, 1888, pp. 7-9.

7 Emmons, S. F., The Delamar and Horn Silver mines-two types of ore deposits in the deserts of Nevada and Utah: Tans. Am. Inst. Min.

Eng., vol. 31, 1902, pp. 658-683; Notes on two desert mines in southern Utah and Nevada (abstract): Science, new ser., vol. 13, 1901 , pp. $426-427$.

${ }^{8}$ Emmons, S. F., The Cactus copper mine, Utah: Bull. U. S. Geol. Survey No. 260, 1903, pp. 242-248.

${ }^{2}$ Lee, W. T., Water resources of Beaver Valley, Utah: Water-Supply Paper U. S. Geol. Survey No. 217, 1908

10 Lindgren, Waldemar, Anhydrite as a gangue mineral: Econ. Geology, vol. 5, 1910, p. 522; Science, new ser., vol. 28, 1908, p. 933.

it Palmer, Leroy, The South Utah mine and mill: Mines and Minerals, May, 1911, p. 592.

12 Huntley, D. B., Tenth Census U. S., vol. 3, 1880, pp. 464-475. 
GEOGRAPHIC POSITION.

The San Francisco mining district is in the north-central part of Beaver County, Utah (see fig. 1, and Pl. I, in pocket), the area covered by the accompanying geologic map lying between latitude $38^{\circ} 19^{\prime}$ and $38^{\circ} 33^{\prime}$ north, and longitude $113^{\circ} 4^{\prime}$ and $113^{\circ} 21^{\prime}$ west, covering

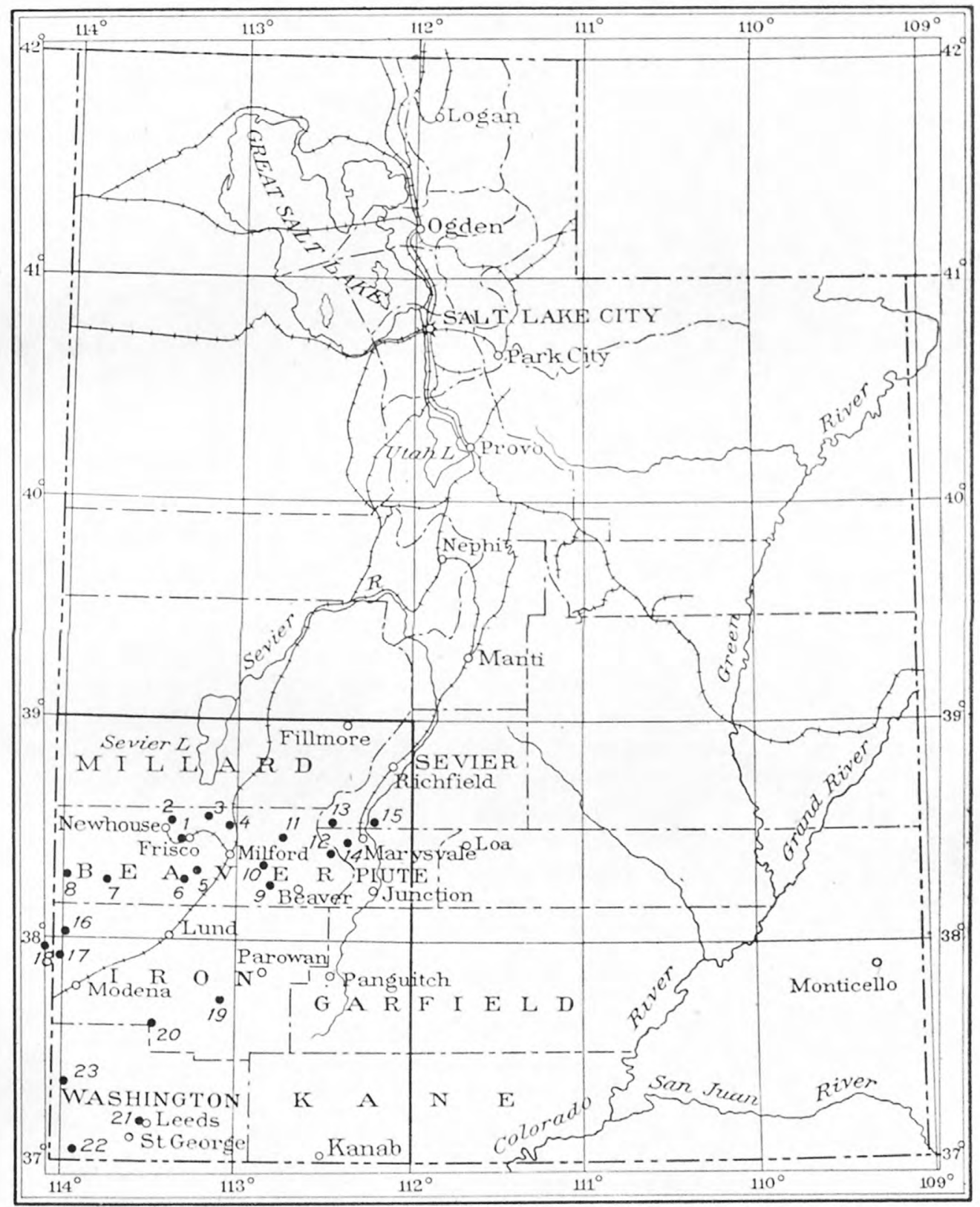

Figure 1.-Index map showing location of mining districts in southwestern Utah.

about 200 square miles. The district is about 180 miles a little west of south of Salt Lake City. Milford, a few miles east of the district, on the San Pedro, Los Angeles \& Salt Lake Railroad, is the railroad center for the region. A branch of this road extends from Milford to Frisco and Newhouse. Solus, a station on this branch, is the shipping point for the Beaver Lake district, and a short branch extending to the Old Hickory mine furnishes shipping facilities for the $73363^{\circ}-$ No. $80-13-2$ 
Rocky district. A siding south of Shauntie is the nearest shipping point for the Star district. The North Star district finds Milford its most convenient shipping point.

Only two towns of importance are located within the district. Frisco, the oldest mining town of the region, is situated just east of the San Francisco Mountains. The town was built to serve the needs of the Horn Silver mine, and its prosperity has always been largely dependent on this one mine. In the "boom" days of this famous mine Frisco was a prosperous camp. The decadence of the mine is, however, painfully reflected in the decay of the town.

Newhouse, on the west side of the San Francisco Range, was recently built to serve the needs of the Cactus mine and mill, the construction work being done very largely by the company. It contains two boarding houses capable of caring for 125 men, and 86 dwelling houses for the accommodation of families. The company also built a club house for the use of the employees and the Cactus Club has built an opera house and café. All the buildings are substantial and comfortable, and the camp is, in many ways, superior to the average mining camp. If sufficient water for irrigation could be obtained, it might easily be made beautiful.

Among the older camps in the eastern part of the region are the Harrington-Hickory, of the North Star district; the Old Hickory, of the Rocky district; and the O $\mathrm{K}$ and Blueacre, of the Beaver Lake district. Shauntie, in the southwestern part of the Star district, is located near the largest spring in the district. More recent camps in the Star district are the Red Warrior, Moscow, and other smaller settlements.

\section{TOPOGRAPHY AND DRAINAGE.}

The surface features of the San Francisco and adjacent districts are typical of the Great Basin, consisting of broad desert valleys or plains from which the mountain ridges rise abruptly. (See Pl. II.) The plain rises gradually from an elevation of 5,250 feet in the eastern part of the region to 6,500 feet at the town of Frisco. West of the San Francisco Range, in Preuss Valley, the plain scarcely reaches an elevation of 5,000 feet.

The San Francisco Mountains, the most prominent range of the region, extend across its western part in a nearly north-south direction. Ten miles to the north the axis turns slightly to the east and the range is continued in the Beaver River Mountains, on the east side of Sevier Lake. From Grampian Hill northward the range is strongly developed and continuous. South of this point it breaks into short ridges and irregular hills. A series of these low hills connects with the higher mountains of the Star district, to the east. The western face of the range rises abruptly to a maximum elevation at Quartzite Hill of 9,725 feet, or over 4,000 feet above the level of the plain. The eastern slope is much less precipitous and is flanked by a series of low hills extending for 2 miles toward the plain. The range is broken just south of Grampian Hill by a low pass, through which the railroad extends to Newhouse and the Cactus mine. The streams have cut many canyons or gulches in the mountains, those tributary to the Preuss Valley being the most pronounced. Marble Gulch, Loeber Gulch, and Copper Gulch extend to the heart of the range. To the east the canyons are less deep, though Morehouse and Sawmill canyons extend well into the range.

The Beaver Lake Mountains, from a distance, have the appearance of a low irregular dome rising from the desert plain. (See Pl. III, B.) On closer approach they are seen to be composed of ridges and rounded hills rising toward the center of the mountain mass. The northern part of the range, composed of dolomitic limestone, is more rugged. A series of low hills extending southeastward from the Beaver Lake Mountains connects them with the Rocky Range, which, except for the southern point, is a rugged range of granitic rocks rising abruptly from the plain. The southern part contains some limestone but is scarcely less rugged than the granite area to the north.

The Star Range has a general north-south trend, but instead of the prominent western scarp characteristic of the San Francisco Range it is connected with that range by a series of low hills. Elephant Canyon cuts the range from west to east and forms the boundary between the old North Star and Star mining districts. The direct road from Milford to the camps of the district follows this canyon. An interesting feature in this part of the district consists of the 


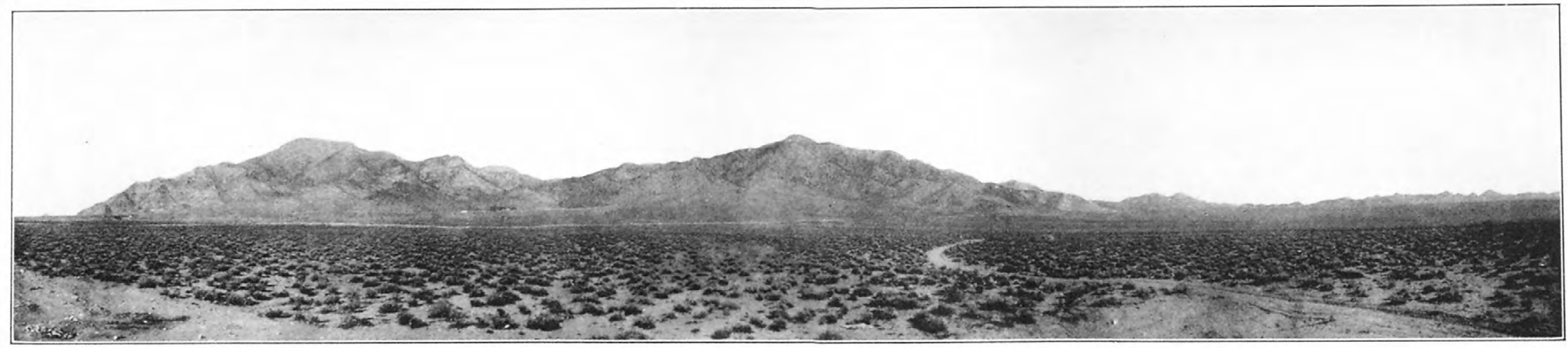

A. SAN FRANCISCO RANGE FROM THE WEST.

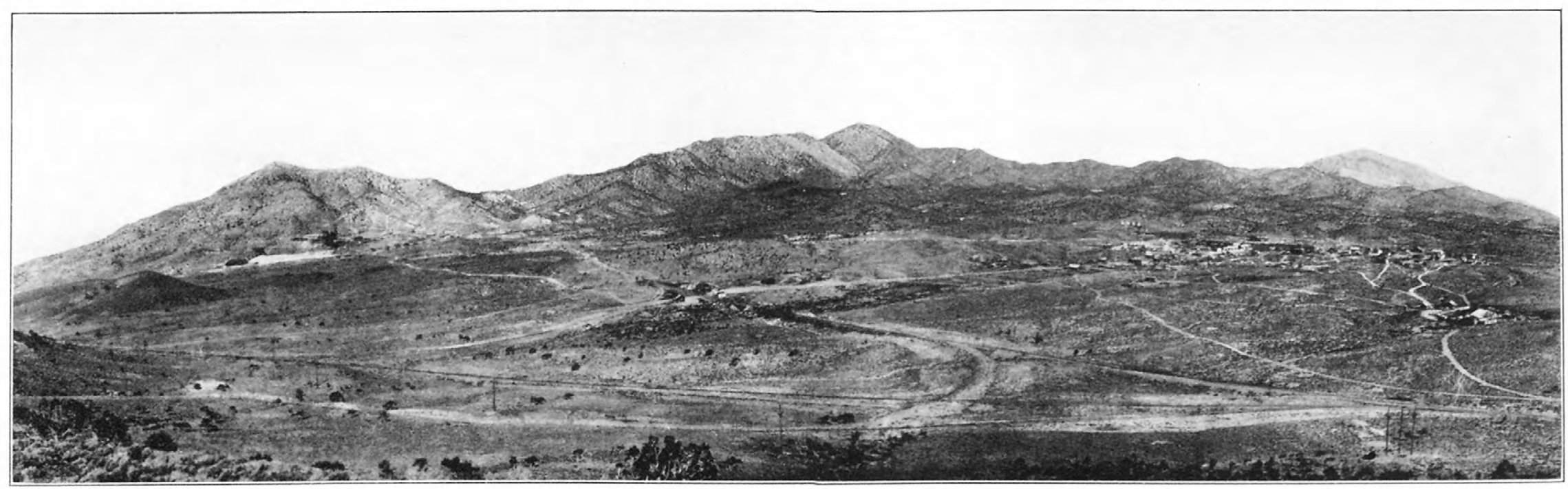

B. SAN FRANCISCO RANGE FROM THE EAST. 


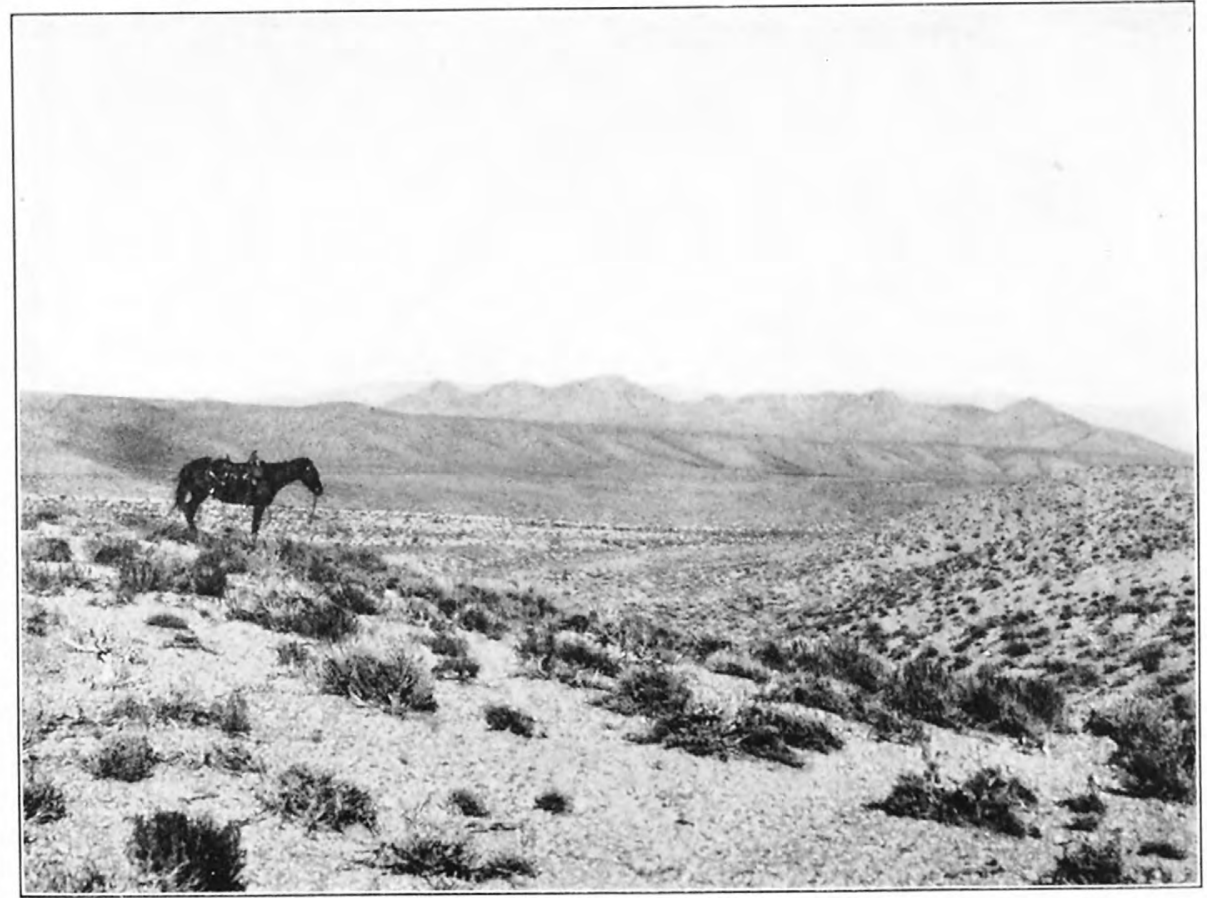

1. THE BIG WASH.

Typical of recent stream cutting. Rocky Range in background.

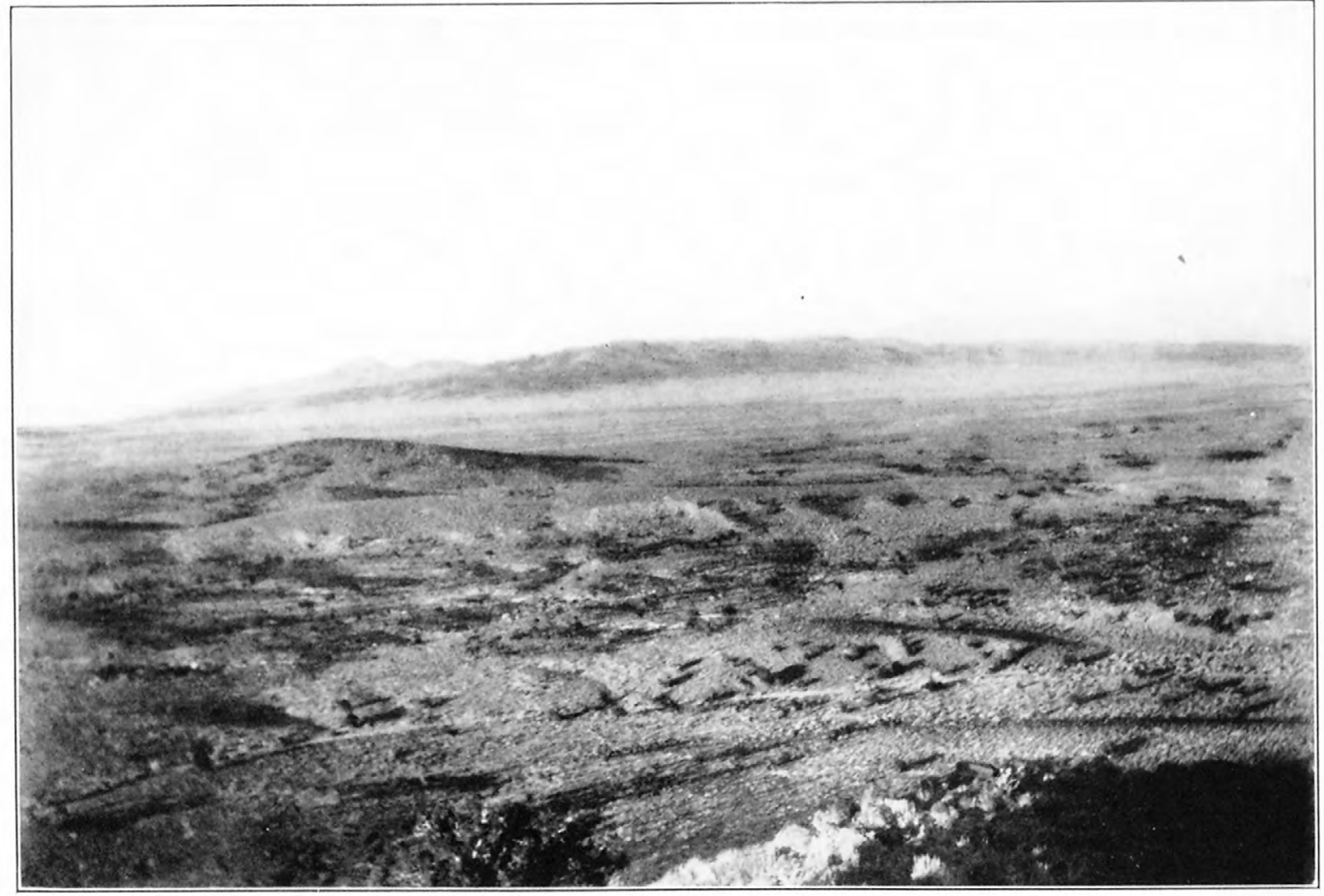

13. BEAVER LAKE MOUNTAINS FROM THE BASE OF THE SAN FRANCISCO RANGE. 
small "stacks" or "cones" of granitic rock rising abruptly from the plain and completely separated from the main mass of the mountains. Such a cone is seen on the Frisco road near its junction with the Hickory road.

There are no perennial streams in this region, and for the most part the valleys or washes leading across the desert plains from the mountains are entirely dry. (See Pl. III, A.) Occasionally, however, when a cloudburst occurs at the headwaters of one of these valleys, it will be converted into a muddy torrent, flooding the lowlands at its mouth.

Nearly all the area east of the San Francisco Range drains into Beaver Creek, which, except in the wet season, sinks into the plain a few miles north of Milford. The area west of the range and a small area near Squaw Springs Pass east of the range drain into the Preuss Valley, where small playas are formed in wet seasons.

CLIMATE.

The climate of southwestern Utah is temperate, not being subject to extremes of either heat or cold. Like all desert and arid lands, the region has pronounced differences in temperature between night and day. The summer days, except in the low valleys, are not excessively warm, and the nights are nearly always delightfully cool.

The precipitation does not usually exceed 12 inches annually, a large part of this occurring in early spring and late summer. During the latter period severe thunderstorms or cloudbursts are of frequent occurrence. The water that falls during these storms quickly runs off, at times causing local floods in the lowlands.

The nearest United States Weather Bureau station is at Modena, Utah, about 60 miles southwest of Frisco, 5,479 feet above sea level. The conditions at this station are very similar to those in the San Francisco district.

The following table shows the meteorologic conditions at Modena for 1904 and 1905:

Precipitation and temperature at Modena, Wtah, 1904 and 1905.

\begin{tabular}{|c|c|c|c|c|c|c|}
\hline \multirow{2}{*}{ Year. } & \multicolumn{2}{|c|}{$\begin{array}{l}\text { Precipitation } \\
\text { (inches). }\end{array}$} & \multicolumn{4}{|c|}{ Temperature $\left({ }^{\circ} \mathrm{F}.\right)$. } \\
\hline & Annual. & $\begin{array}{l}\text { Snow- } \\
\text { fall. }\end{array}$ & $\begin{array}{c}\text { Mean } \\
\text { annual. }\end{array}$ & $\begin{array}{c}\text { Mean } \\
\text { monthly. }\end{array}$ & $\begin{array}{l}\text { Maximum } \\
\text { for year. }\end{array}$ & $\begin{array}{l}\text { Minimum } \\
\text { for year. }\end{array}$ \\
\hline $1904 \ldots$ & 9.83 & 23.0 & 49.2 & $\left\{\begin{array}{l}\text { Aug. } 70.6 \\
\text { Jan. 24.4 }\end{array}\right.$ & 95 & \\
\hline $1905 \ldots$ & 12.39 & 30.1 & 48.2 & $\left\{\begin{array}{l}\text { July } 71.0 \\
\text { Dee. 26.4 }\end{array}\right.$ & 97 & \\
\hline
\end{tabular}

The following table shows the precipitation at Frisco as given by Lee: ${ }^{1}$

Precipitation at Frisco, Wtah, 189\%-1906.

\begin{tabular}{|c|c|c|c|c|c|c|c|c|c|c|c|c|c|}
\hline Year. & Jan. & Feb. & Mar. & Apr. & May. & June. & July. & Aug. & Sept. & Oet. & Nov. & Dec. & Total. \\
\hline 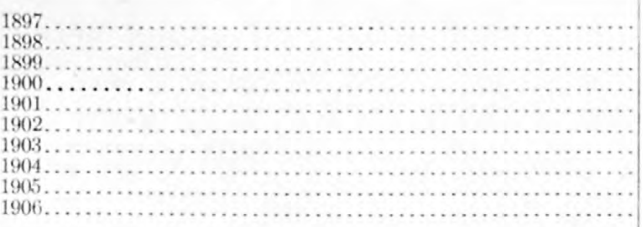 & $\begin{array}{l}0.42 \\
.10 \\
.11 \\
.35 \\
.95 \\
.75 \\
.50 \\
.66 \\
.10\end{array}$ & $\begin{array}{r}0.30 \\
.10 \\
.65 \\
.04 \\
2.36 \\
.02 \\
1.66 \\
.64 \\
1.44 \\
.56\end{array}$ & $\begin{array}{r}0.44 \\
.12 \\
2.56 \\
.03 \\
.28 \\
.72 \\
.68 \\
.97 \\
1.71\end{array}$ & \begin{tabular}{|c|} 
Tr. \\
0.41 \\
1.01 \\
1.73 \\
.86 \\
.10 \\
1.49 \\
.10 \\
.58
\end{tabular} & \begin{tabular}{r}
0.20 \\
2.59 \\
.08 \\
\hdashline 1.42 \\
Tr. \\
1.88 \\
2.49 \\
1.44
\end{tabular} & \begin{tabular}{c|}
0.11 \\
.11 \\
.36 \\
.04 \\
.97 \\
Tr. \\
.66 \\
.11 \\
.02
\end{tabular} & $\begin{array}{c}0.16 \\
.97 \\
.81 \\
\text { Tr. } \\
1.76 \\
.74 \\
.72 \\
.86 \\
.58\end{array}$ & $\begin{array}{r}0.19 \\
1.46 \\
.18 \\
.05 \\
.64 \\
.82 \\
1.12 \\
.83 \\
1.04\end{array}$ & $\begin{array}{c}1.21 \\
.00 \\
\mathrm{Tr} . \\
1.41 \\
\mathrm{Tr} . \\
.47 \\
.82 \\
.45 \\
2.32\end{array}$ & $\begin{array}{r}1.50 \\
.31 \\
.51 \\
.77 \\
.68 \\
.15 \\
.85 \\
.41 \\
.89\end{array}$ & $\begin{array}{c}0.45 \\
.15 \\
.28 \\
.55 \\
\mathrm{Tr} . \\
1.22 \\
.02 \\
.00 \\
.83 \\
.98\end{array}$ & $\begin{array}{l}1.00 \\
.24 \\
\mathrm{Tr} . \\
.05 \\
.75 \\
.39 \\
.07 \\
.22 \\
.30 \\
.95\end{array}$ & $\begin{array}{r}6.88 \\
6.54 \\
10.07 \\
5.58 \\
10.79 \\
7.58 \\
11.81\end{array}$ \\
\hline
\end{tabular}

VEGETATION

The San Francisco district has the scanty vegetation characteristic of arid regions. On the higher parts of the San Francisco Range, however, tree-covered slopes may be seen. On these high slopes pines (Pinus monophylla) grow to considerable size, trees 2 feet or more in diameter not being uncommon. Cedar trees of good size are also numerous. Most of the tim- 
ber has been removed, a part being used as timbers for the Horn Silver mine and a considerable quantity converted into charcoal for the smelting of the local ores. The lower slopes bear a scanty covering of scrub pines and cedar. Where soil conditions are favorable these may form rather dense thickets, as in the lava hills in the southern part of the district. Sagebrush (Artemisia) is the prevailing vegetation of the lower valleys, though in some localities white sage (Eurotia lanata) is plentiful. In the lowest and most arid parts of the district the sagebrush gives way in part to spiny desert plants. Several varieties of cactus occur in the district, but these are nowhere abundant.

Bunch grass is found in most parts of the district, except in the very low and arid parts of the valleys. This, together with the sagebrush and the grasses that grow rather abundantly on the débris fans and talus slopes at the base of the mountains, furnish grazing for a few head of horses and cattle and the flocks of sheep that are annually driven through the district.

\section{WATER SUPPLY.}

Water is scarce in the region, and much of it is of inferior quality. For water for drinking and household use most of the eastern part of the region is dependent on Milford, where an abundant supply of excellent water is obtained from artesian wells.

The supply for Newhouse and the Cactus mill is obtained from the Wa Wa Springs, on the opposite side of the Preuss Valley. This group of springs has a flow of about 1,200 gallons a minute and is the largest water supply in the region. The flow from sixteen springs is gathered into a collecting reservoir, from which it is conveyed through a pipe 44,000 feet long to a reservoir situated above the mill and town of Newhouse.

From the heavy beds of quartzite capping the San Francisco Mountains issue several springs, furnishing a small amount of excellent water. One of these springs supplies the Indian Queen mine, and another was formerly connected by pipe with the Blackbird mine. In the fall of 1908 the Morehouse Spring, 5 miles north of Frisco, was connected with the King David mine by a pipe line, and this also supplies the town of Frisco, which formerly obtained its water for drinking and household use from Milford. Springs from the same formation occur in Barrel Spring ('anyon and the canyon north of it, but at present the water is not utilized.

The springs in the other formations in the western part of the region furnish water of inferior quality, which is, however, available for stock and for other purposes. The Squaw Springs, 1 mile southwest of the Horn Silver mine, Coyote Springs, three-fourths of a mile north of the Carbonate mine, and Horn Silver Spring, in the town of Frisco, are the largest of this type in the western part of the region. The Horn Silver Spring was developed to supply water for smelting and later for concentration of the Horn Silver ores, but no large flow was obtained. A meager supply has been obtained from several wells about Frisco, and during the summer of 1908 water was being pumped from the old shaft of the Beaver-Carbonate mine to supply two concentrating tables. Water is also present in the lower workings of the Horn Silver mine. All the springs mentioned in this paragraph issue from the volcanic rocks, and their water is too impure for household use.

The West Spring, Fairview Springs, and a spring developed in driving a tunnel in Butch Canyon supply the northern part of the Beaver Lake district. These springs issue from the monzonite and furnish water of better quality than that from the volcanic rocks.

The South Beaver Lake, Rocky, and Star districts are dependent upon Milford for their drinking water. The springs issuing from the volcanic rocks at Shauntie furnish water for use in gasoline engines in the southwestern part of the Star district. Water, said to be of good quality, has been encountered on the 500-foot level of the Harrington-Hickory mine, and water is also present in the shaft of the $\mathrm{O} \mathrm{K}$ mine at a depth of about 490 feet.

The depth at which water is found varies considerably in different parts of the district. Around Frisco water is obtained in wells 15 to 25 feet below the surface, and some shafts west of the Carbonate mine have encountered water at even less depth. The water from these wells and shafts is not fit for drinking. The Horn Silver mine, however, contains very little water above the 1,200-foot level. The Cactus mine in 1909 was nearly dry at the 900 -foot level, 
though some water was later encountered on the 700 -foot level. The Carbonate mine has but little water on the 700-foot level of its new shaft. Most of the mines in the eastern part of the region are dry, though, as already stated, water occurs in the Harrington-Hickory and $\mathrm{O} \mathrm{K}$ mines.

The Milford supply of water is derived from artesian sources and is of very good quality. The following data concerning wells at Milford are taken from the paper by Lee ${ }^{1}$ already cited.

The Milford town well is 425 feet deep, and the water has a pressure of 6 pounds to the square inch at the surface, flows 30 gallons a minute, and has a temperature of $72^{\circ} \mathrm{F}$. The natural flow being insufficient to supply the town, the water is pumped, the ordinary discharge of $156 \mathrm{gallons}$ a minute being readily supplied.

The Lewis well has a 4 -inch pipe to a depth of 450 feet, from which there is a flow of 37 gallons a minute. Within this is a 2-inch pipe extending to a depth of 750 feet, from which there is a flow of 2 gallons a minute.

The Winberg well at the steam laundry in Milford is 326 feet deep and penetrates water strata at depths of $260,285,310$, and 326 feet. The pressure at the mouth of the well is 6 pounds to the square inch and the flow 9 gallons a minute.

The San Pedro, Los Angeles \& Salt Lake Railroad has three wells in Milford; two are 2-inch wells with a depth of about 400 feet and furnish about 18 gallons a minute each. The third is a 12-inch well extending to a depth of 310 feet. This has a surface pressure of 6 pounds to the square inch and a flow of 30 gallons a minute. In this well ground water was reached at a depth of 8 feet, and artesian flows were encountered at depths of 170 and 310 feet. By pumping, this well supplies 270 gallons a minute.

The Majestic Copper Mining \& Smelting Co. has four wells at its smelter south of Milford. These have depths of $95,340,465$, and 470 feet. The natural flow is slight, owing probably to the location of the wells on the bench above the valley bottom.

The records of some of the Milford wells are given on page 40.

These records do not seem to indicate the presence of a thick stratum of sand or gravel that would form a large artesian reservoir underlying the valley, but rather a number of small reservoirs, probably representing more or less lenticular deposits of sand and gravel inclosed in clay. It therefore appears as yet uncertain whether a large flow of artesian water could be developed, though it is probable that by sinking several wells that would draw from different strata considerable water might be obtained.

During the summer and fall of 1910 several wells were driven in the valley south of Milford and the water was pumped from them to supply some of the mines of the Star district.

Beaver Creek extends several miles north of Milford before completely sinking beneath the surface. During the season of high water there is a considerable flow in the stream at Milford, but during the season of low water, when there is a heavy demand for water for irrigation, the flow is slight.

\section{PHYSIOGRAPHY.}

\section{GENERAL DISCUSSION OF GREAT BASIN STRUCTURE.}

The physiography of the San Francisco and adjoining districts is similar to that of other parts of the Great Basin region, the north-south mountain ranges rising abruptly from the broad, flat desert valleys. As the basin ranges have received the attention of geologists since the early days of exploration, and investigators differ somewhat as to the causes that have exerted the major influence in producing this type of topography, it will not be out of place to review briefly some of the theories that have been advanced to account for it before taking up in detail the discussion of the districts with which this paper deals.

One of the earliest theories formulated was that of Clarence King, who had become familiar with the geology of the Great Basin in his work in the exploration of the fortieth parallel. He proposed ${ }^{2}$ the following simple explanation: "These low mountain chains which lie traced across the desert with a north and south trend are ordinarily the tops of folds whose deep synclinal valleys are filled with Tertiary and Quaternary detritus."

\footnotetext{
I Lee, W. T., Water-Supply Paper U. S. Geol. Survey No. 217, 1908. 2 U. S. Geol. Expl, 40th Par., vol. 3, 1870, p. 451.
} 
In 1871 and 1872 G. K. Gilbert made an extended reconnaissance in the Great Basin, and from the data gathered came to the conclusion that folding had played a far less prominent part in the formation of the mountains than King had attributed to it. He advanced the theory of block faulting, which supposed that the region had been broken into numerous blocks, and that the earth forces acting on these had tilted them to positions that varied but maintained a general north-south strike. Such a block would have its simplest form if the strat a were horizontal before the faulting took place. After the faulting it would present a steep face on the relatively uplifted side, and a gentle back slope on the relatively depressed side, as suggested in figure 2, though of course no such ideal result as that shown in the figure would be attained. The uplift was gradual, and as soon as the ridge rose above the general level weathering and

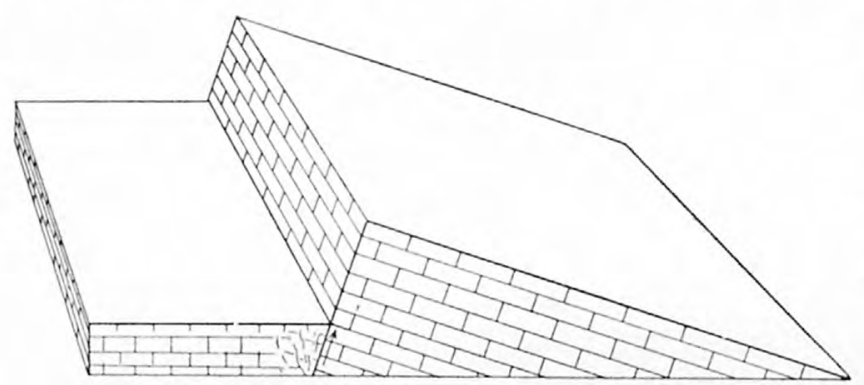

FIGURE 2,-Ideal cross section of block fault tilted without erosion. erosional agencies began the process of tearing down and thus greatly modified the appearance of the block.

Gilbert ${ }^{1}$ gives a general section (fig. 3) and the following brief summary of his conclusions on the structure of the ranges:

Our routes in 1871 and 1872 were of such nature as to enable us to accumulate a great number of cross sections of mountain ridges of the Cordilleras in parts of Nevada, Arizona, California, and Utah. The study of these led to some speculations in regard to the origin of mountain ridges, very nearly identical with the views recently advanced by Prof. Joseph Le Conte. ${ }^{2}$ Without entering upon these, or attempting to present the material upon which they depend, I will briefly note a single conclusion in regard to the structure of the Cordilleras of the West that seems pertinent to the discussions of general orology now in progress.

The sections accumulated by our geological observers admit of the following classifications:

1. Faulted monoclinals occur, in which the strata on one side of the fault have been lifted, while those on the opposite side either do not appear $(a)$ or (less frequently) have been elevated a less amount (b). Two-thirds of the mountain ridges can be referred to this class.

2. Other ridges are uplifts limited by parallel faults $(c)$, and to these may be assigned a few instances of isolated synclinals $(d)$ occurring under circumstances that preclude the idea that they are remnants omitted by denudation.

3. True anticlinals (e) are very rare except as local, subsidiary features, but many ranges are built of faulted and dislocated rock masses $(f)$, with an imperfect anticlinal arrangement.

Not only is it impossible to formulate these features, by the aid of any hypothetical denudation, in such a system of undulations and foldings as the Messrs. Rogers have so thoroughly demonstrated in Pennsylvania and Virginia, but the structure of the western Cordillera system stands in strong contrast to that of the Appalachians. In the latter corrugation has been produced commonly by folding, exceptionally by faulting; in the former, commonly by faulting, exceptionally by flex-

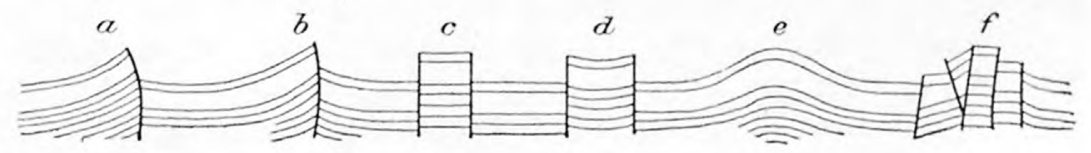

FigUre 3,-Diagram of generalized mountain section, discounting denudation. After Gilbert. (See text for explanation of lettering.)

ure. In the latter few eruptive rocks occur; in the former volcanic phenomena abound and are intimately associated with ridges of upheaval. The regular alternations of curved anticlinals and synclinals of the Appalachians demand the assumption of great horizontal diminution of the space covered by the disturbed strata and suggest lateral pressure as the immediate force concerned; while in the Cordilleras the displacement of comparatively rigid bodies of strata by vertical or nearly vertical faults involves little horizontal diminution and suggests the application of vertical pressure from below. For these reasons and others that will be adduced in the final report I regard the forces that have upheaved the Cordilleras as distinctively deep-seated, producing, in a portion of the earth's crust below the immediate surface, inequalities, perhaps undulations, in adjusting to which, under gravity, the upper portion of the crust has assumed the forms we see.

In 1873 Gilbert made a reconnaissance through southwestern Utah and published a more detailed account ${ }^{3}$ of his observations of the basin ranges, in which he reaches essentially the same conclusions as those already quoted.

\footnotetext{
1 Gilbert, G. K., Progress Rept. U. S. Geog. Surveys W. 100th Mer. for 1872, 1874, p. 50.

2 Am. Jour. Sci., 3 d ser., vol. 4, November and December, 1872.

3 U. S. Geog. Surveys W. 100th Mer., vol. 3, 1875, p. 26.
} 
In $1876 \mathrm{~J}$. W. Powell ${ }^{1}$ expressed a belief in the faulting hypothesis to explain the basin ranges, summing up in the following words: "The basin province is characterized by northsouth ranges that are monoclinal ridges of upheaval, and these monoclinal ridges are separated by stretches of subaerial gravels that mask the structure of the areas of subsidence. But while this is the prevailing structure, other types are found."

In $1878 \mathrm{King}^{2}$ appears to have greatly modified his earlier views and recognizes the dominant influence of faulting in late geologic time. He writes as follows:

These remarkable quasi-parallel mountain bodies separated from each other by mountain valleys, which are occupied by fresh-water Tertiary and Quaternary beds, are a series of mountain islands lifted above the desert plains. They have given rise to considerable discussion, and there is already considerable difference of opinion between Powell and Gilbert on the one hand and myself on the other. * * * Powell and Gilbert have called attention to the abundant evidence of local vertical faults and the resultant dislocation into blocks. One of the most common features of the basin ranges is a mountain body composed of a steeply or a gently dipping monoclinal mass, edged on both sides by the horizontal desert formations, the back of the monoclinal mass consisting of inclined planes of strata, while the other face of the mountain body consists of an abrupt cliff, evidently the result of a vertical fault, which has been more or less modified by comparatively recent erosion. The frequency of these monoclinal detached blocks gives abundant warrant for the assertions of Powell and Gilbert that the region is one prominently characterized by vertical action; yet when we come to examine with greater detail the structure of the individual mountain ranges it is seen that their vertical dislocation took place after the whole area was compressed into a great region of anticlinals with intermediate synclinals. In other words, it was a region of enormous and complicated folds, riven in later times by a vast series of vertical displacements, which have partly cleft the anticlines down through their geological axes, and partly cut the old folds diagonally or perpendicularly to their axes.

During the next 10 years parts of the Great Basin were studied and described by Dutton and Russell. The conclusions reached by both are strikingly similar to King's later views, namely, that there was an earlier period of extensive folding, but that the latest disturbance has been a breaking into blocks along fault lines and a tilting of these blocks.

Later detailed studies have shown faulting to be of minor importance in individual ranges, ${ }^{3}$ but it was not until 1900 that this theory for the origin of the basin ranges in general was challenged. In that year J. E. Spurr ${ }^{4}$ published the conclusions he had arrived at from observations made during an extensive reconnaissance in Nevada and California and a study of the works of earlier investigators. He concludes that faults have had little effect on the present topography, the main features being the result of extensive erosion, and briefly summarizes the evidence against the fault theory as follows:

1. The faults actually observed in this region are comparatively few. Actually ascertained heavy faults along the main fronts of ranges are exceedingly rare.

2. The transverse faults which run across the general trend of these basin ranges are, as far as observed, equally or more numerous than the north-south ones, and they display more openly their relations. In general they have either no effect on the topography or have induced the formation of gulches. Occasionally they are accompanied by cliffis which are usually of trifling height as compared with the displacement. These can often be proved to be erosion fault scarps, not infrequently reversed. Finally there are rare faults, generally of relatively small displacement, which have a direct effect on the topography and have produced simple fault scarps.

In 1903 W. M. Davis ${ }^{5}$ published the results of a study of the basin ranges from the standpoint of systematic physiography. He shows that many of the ranges, such as the Wasatch, which are characterized by a steep scarp on one side and a gentle slope on the other, can be sa tisfactorily explained only by assuming profound faulting of recent age, and that with progressive stages of erosion the origin by faulting becomes more obscured but still retains certain characteristic features. The diagrams in figure 4, reproduced from the paper by Davis, show the change in form from a recently tilted block to one that has suffered profound erosion.

As it is recognized by all geologists who have worked in the Great Basin that faulting has been in progress in that region through a long period of geologic time extending to the present,

1 Geology of the eastern portion of the Uinta Mountains, U. S. Geol. and Geog. Survey Terr., 2d div., 1876, p. 29.

${ }^{2}$ King, Clarence, U. S. Geol. Expl. 40th Par., vol. 1, 1878, p. 735.

3 Tower, G. W., jr., and Smith, G. O., Geology and mining industry of the Tintic district, Utah: Nineteenth Ann. Rept. U. S. Geol. Survey, pt. 3,1899, p. 617 .

4 Bull. Geol. Soc America, vol. 12,1901, p. 217.

5 Bull. Mus. Comp. Zool. Harvari Coll., vol. 42, 1903, pp. 129-177. 
it would be expected that mountain blocks in different stages of destructional development would be found, and Davis shows that this is the case.

The best-known and perhaps the best example of a block that is known to be in the process of uplift at the present time is the Wasatch Range. In his study of the Lake Bonneville deposits Gilbert ${ }^{1}$ found in the gravels along the front of the range escarpments that could be explained only on the assumption that there has been faulting of the underlying rocks since the deposit of the Lake Bonneville beds. So convinced was he that movement along the front of this range is still in progress that he sounded a warning note to the inhabitants of this district as follows: ${ }^{2}$

It is legitimate to infer that the belt of fertile valleys that follows the western base of the great mountain range of Utah is an earthquake district, and this despite the fact that since the first settlement in 1850 no important tremors have been recorded. It is a matter of geologic history that the Wasatch Range is gradually rising and that this rise is not uniform in time and place but is accompanied by small and sudden displacements, more or less localized, with intervals of rest. Of the length of these intervals we have no means of judging, and no one can predict the date of the

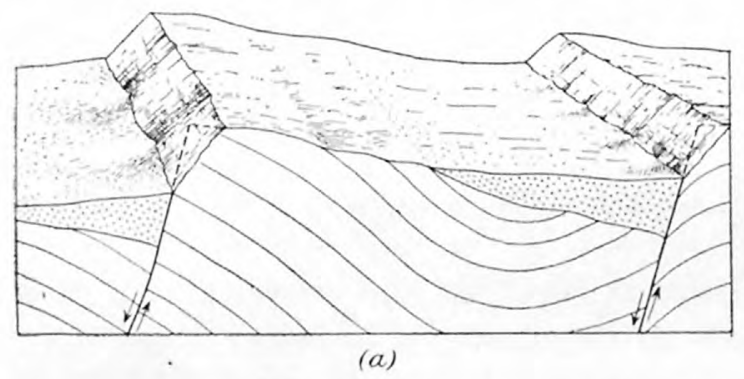
next movement, but it is beyond question that such movement will take place and that when it occurs the adjoining valleys will experience an earthquake.

The steep wall-like front of this range and the narrow gorges which the streams occupy but which weathering agencies have not yet had time to transform into open valleys testify to the recent period at which the mountains have been uplifted. With the progress of time weathering agencies will broaden the valleys

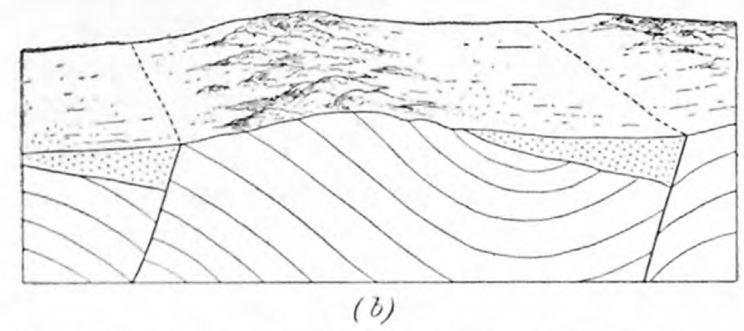

FIGURE 4.-Stereogram showing stages of erosion in block-fault mountains, $a$, Young stage; $b$, rnature stage. After W. M. Davis. and etch back the steep front, and as old age is approached the former front will be cut into long spurs separated by broad flat-bottomed valleys. During this process the steep front slope will be worn back faster than the gentle back slope, and when it reaches the stage of maturity the two may show very slight difference (see fig. 4), though the attitude of the beds may indicate the portion that was relatively uplifted by the ancient displacement.

In 1904 Louderback $^{3}$ published a description of the Humboldt region of Nevada, in which he shows that the mountains are due to block faulting which took place after the latest volcanic activity, namely, in late Tertiary and post-Tertiary time.

\section{STRUCTURE IN THE SAN FRANCISCO DISTRICT.}

The eastern boundary of the Great Basin, which is formed by the Wasatch Range in the vicinity of Great Salt Lake, turns westward a little south of Utah Lake and in the latitude of the San Francisco district is formed by the range of mountains east of Beaver. Mineral or East Range is the easternmost of the typical basin ranges. It is separated from the Beaver Lake and Star ranges by the broad Milford Valley, and these in turn are separated from the San Francisco Mountains by a lava-filled valley. The broad Preuss, or Wa Wa Valley, lies between the San Francisco Mountains and the Wa Wa Range next to the west.

All these ranges are composite as regards the rocks of which they are formed. The Mineral Range ${ }^{4}$ consists of a central mass of granitic rock, with beds of limestone, sandstone, and shale, having an easterly dip, forming the southern portion, and limestone and sandstone the northern portion. The extension of the range south of Beaver Canyon pass is composed of

${ }^{1}$ Mon. U. S. Geol. Survey, vol. 1, 1890.

${ }^{2}$ Idem, p. 361.

3 Louderback, G. D., Basin-range structure of the Humboldt region: Bull. Geol. Soc. America, vol. 15, $1904, \mathrm{pp} .289-346$.

4 Lee, W. T., Water resources of Beaver Valley, Utah: Water-Supply Paper U. S. Geol. Survey No. 217, 1908 , p. 14. 


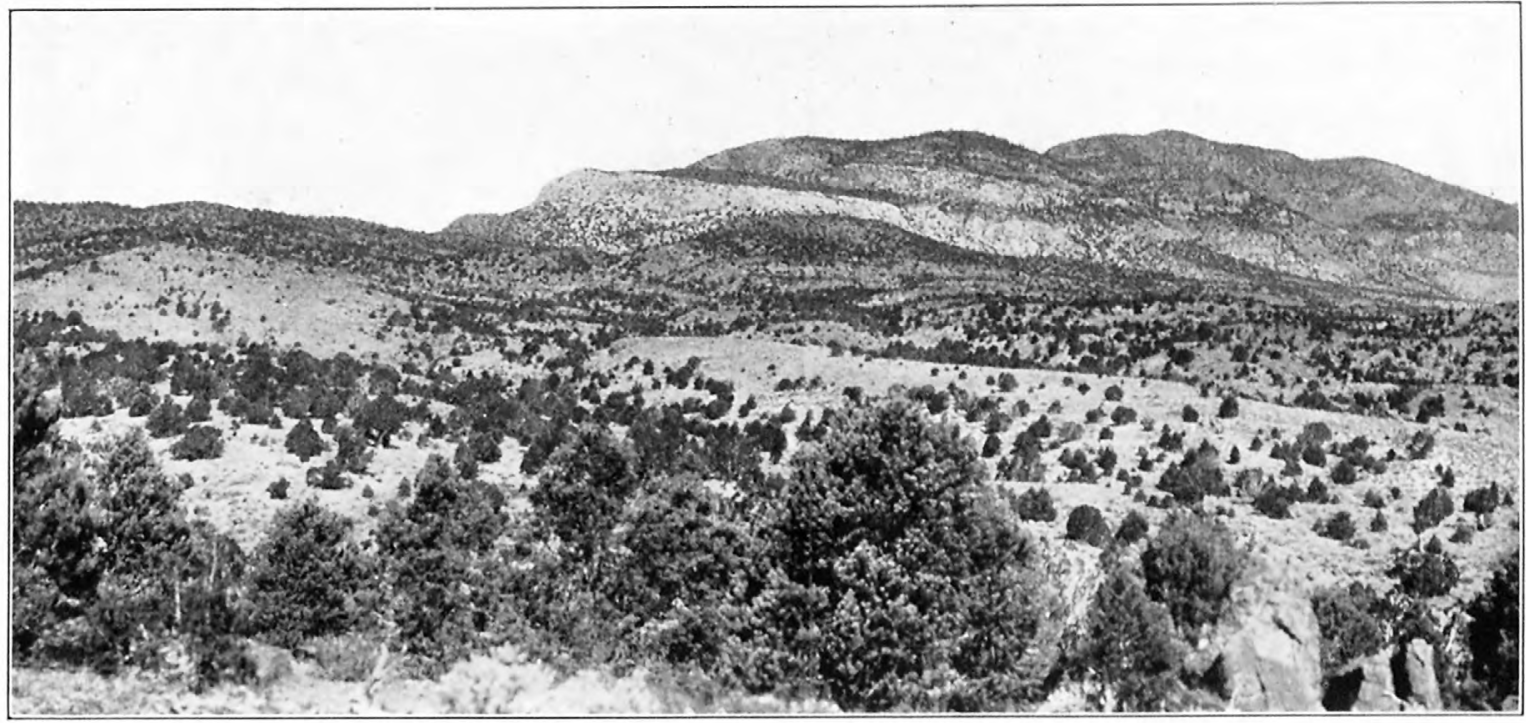

A. QUARTZITE MOUNTAIN FROM THE EAST.

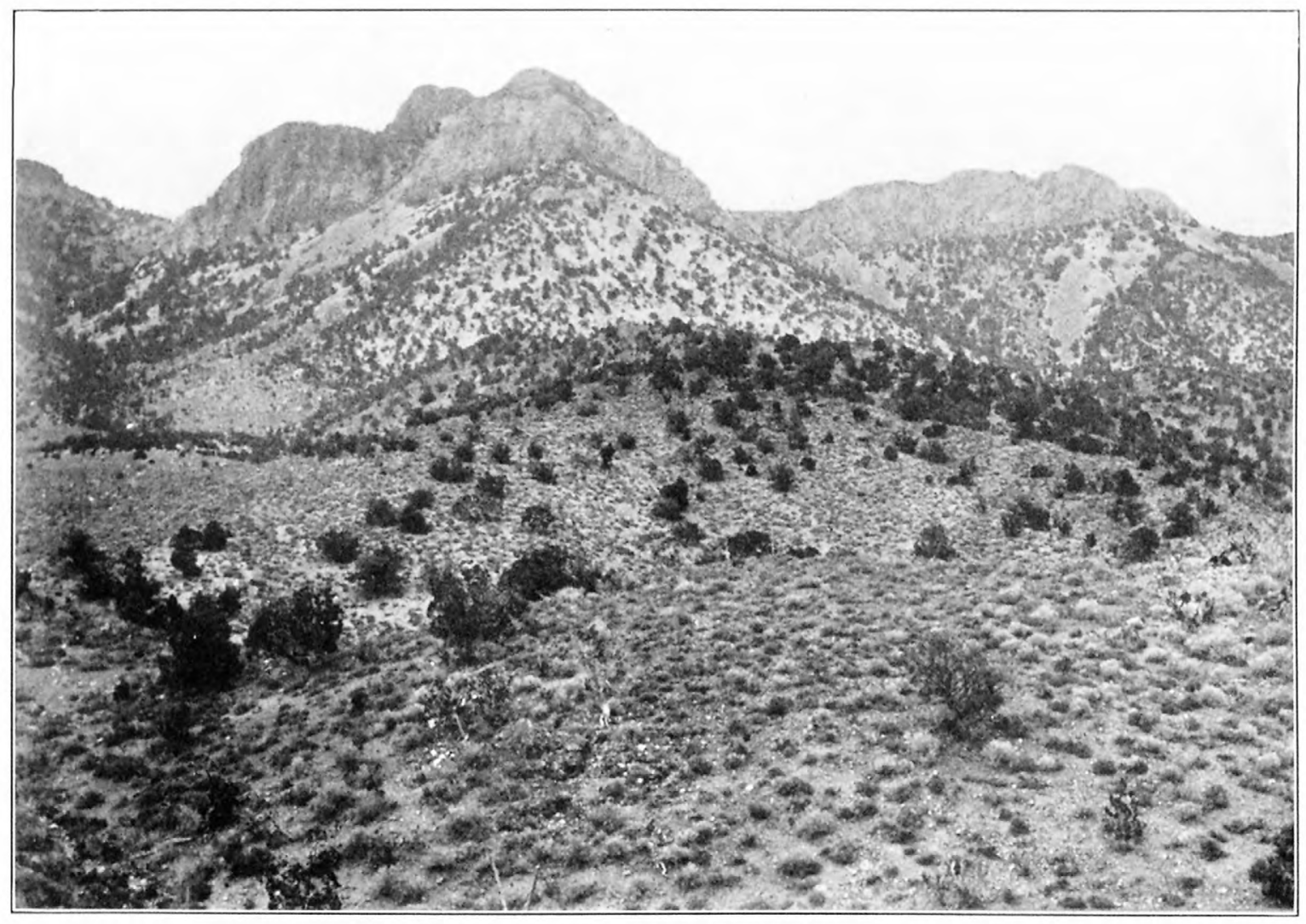

B. QUARTZITE MOUNTAIN FROM THE WEST. 

volcanic rocks. Underlying the Beaver Valley to the east and extending for some distance up the eastern flank of the range is a series of volcanic flows and tuffs. The Carboniferous limestone strata are represented by Lee as abutting against Tertiary clastic rocks in the valley to the west. The front or western face of the range forms a very nearly straight line, although, as already stated, the range is composed of different rocks, and these have a varying resistance to the attacks of weathering. The front of the range was not examined in detail by the writer, but so far as could be learned the lara flows are not exposed west of the front, and if present they are buried by recent deposits and are at a much lower level than those east of the range.

The Beaver Lake and Star ranges are also composite, being made up of shales, limestones, quartzite, granitic intrusives, and volcanic rocks. The Beaver Lake Mountains consist of a maturely dissected range of limestone, monzonitic intrusive rocks, and lava flows. Though the range is in part rather rugged, it shows few steep escarpments that can be attributed to faulting, but the steep face west of Fairview Springs may represent a fault.

The Star Range is likewise composed of sediments, monzonitic intrusive rocks, and lava flows, the lavas being confined largely to the western portion, as shown on the geologic map (Pl. I, in pocket). If the lava once covered the entire range, as seems probable from the fact of its extension well around to the east, just north and south of the range, it has been removed from the summit and eastern part. The range shows a mature erosional topography, the only steep faces being due to the rapid erosion of the soft shales in the eastern part, the resistant limestone and quartzite being left standing as steep slopes. The precipitous slope on the east side of the point extending northward from the Harrington-Hickory mine is suggestive of faulting, though evidence other than that of the topography was not obtained. Several broad open valleys extending toward this scarp from the west appear to have their upper portions cut off by the scarp, a condition which it is difficult to account for on any theory other than faulting.

The San Francisco Range, like the others, is composite. The portion south of Squaw Springs Pass consists principally of lava flow; the portion north of the pass is made up of limestone and quartzite, with intruded monzonite; and the eastern flank of the northern portion is composed of lava and tuff. The deep Squaw Springs Pass follows a fault that separates the sediments from the lava flows to the south. The attitude of the sediments in the northern part of the range is apparently the result of at least two movements. The intrusion of the monzonite has caused a slight doming of the sediments, so that in general they dip away from the intrusive mass, and a later vertical uplift has given them a gentle eastward dip where they were least affected by the earlier movement. The volcanic rocks to the south of Squaw Springs Pass also have an easterly dip. The east side of the range shows a comparatively gentle slope, but the west face is precipitous. (See Pl. IV.) The west face, like that of the Mineral Range, forms a nearly straight line, and no volcanic rocks are to be found beyond the front. Erosion has, however, made much more rapid progress in the soft volcanic rocks forming the southern part of the range than in the more resistant rocks to the north.

Across the Wa Wa Valley volcanic rocks are again encountered on the eastern flank of the Wa Wa Range. These extend nearly to the summit of the low divide west of the Wa Wa Springs. Observations on this range were confined to those made in crossing it at Pine Grove and Wa Wa Pass, but these were sufficient to show that the range is composed principally of limestone at Wa Wa Pass and of limestone underlain by shale and quartzite farther south, the sediments all having an easterly dip. Volcanic rocks extend well up on the east side. The west face rises abruptly from the desert valley, and no volcanic rocks were seen west of the western base of the range nor, in fact, west of the summit, except south of the Pine Grove road, where the volcanic rocks rise to a higher elevation than they attain farther north.

Figure 5 (p. 26) is a generalized section across the ranges just described.

From the above descriptions it will be seen that the three most prominent ranges have several characteristics in common. (1) All have a rather gentle eastern slope and an abrupt western face, and the formations dip to the east. (2) The western bases form, in general, straight lines, regardless of the varying resistances of the component rocks. (3) The eastern flanks of 
all the ranges are made up of volcanic material. (4) The volcanic rocks are cut off at the western faces along essentially the same lines as the other formations. The Beaver Lake and Star ranges, however, have none of these characteristics.

In accounting for the origin of the basin ranges, three hypotheses have been advanced, as already stated - (1) that they are the summits of anticlines; (2) that they are the result of the tilting of the block faults; (3) that the present forms are due primarily to the erosion of a folded and faulted area.

The evidence indicating anticlines with north-south axes in the ranges under discussion is not pronounced. At the west face of the San Francisco Mountains, near the northern border of the area mapped, the lower beds show an anticlinal structure, the western limb of the anticline being entirely removed in the upper beds and only a small portion of it remaining in the lower beds. The $\mathrm{Wa} \mathrm{Wa}$ Range from a distance appears to contain a broad anticline transverse to the

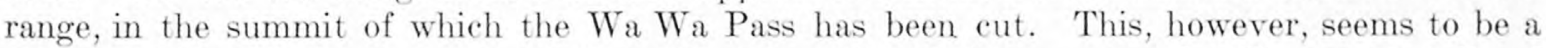
doming of the sediments due to an intrusion that is just being uncovered. The general dip of the formations is to the east.

Assuming for the moment that the ridges are the summits of anticlines, we must date the folding subsequent to the formation of the volcanic series, for these rocks form the southern parts of the San Francisco and Mineral ranges. After the folding practically the entire western limbs of the folds were eroded and, although the ranges are composed of formations varying distinctly in their resistance to erosion, the fronts of the ranges have preserved nearly straight lines. It seems hardly possible that the front of a ronge composed of several types of rocks varying materially in resistance could recede at so uniform a rate. This is also a point difficult to explain if the forms of the ranges are considered as due mainly to erosion without regard to the original

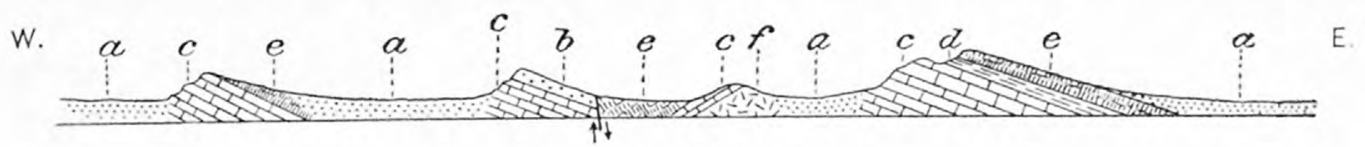

Figure 5.-Generalized section across Mineral, Beaver Lake, San Francisco, and Wa Wa ranges, $a$, Recent sediments; $b$, quartzite; $c$, limestone; $d$, shale; $e$, lava; $f$, granite rock.

cause of elevation. It is evident that erosion has been dominant in producing the details of the present forms. For example, the valleys in the volcanic rocks in the southern portion of the San Francisco Range are much more mature than those in the limestone and quartzite to the north. This, however, only emphasizes the fact that were the main features of the range due to erosion, the differences due to varying resistance of the several formations would be still more prominent. In the Beaver Lake and Star ranges, however, the erosion appears to have been the dominant factor in producing the present forms. The prevalent easterly dip of the beds in the Star Range might be interpreted as representing either tilting or the eastern limb of an anticline. In the Beaver Lake Mountains the position of the sedimentary beds has been so far influenced by intrusions that there is no way of determining the original cause of uplift. A comparison of the photograph reproduced in Plate III, $B$ (p. 19), with the ideal condition of a tilted block in old age, as shown by Davis (fig. 4, p. 24), indicates that it is not impossible to consider that origin, though the carving from other structures would fit the observed conditions equally well.

The fault-block hypothesis comes the nearest of those suggested to meeting all the observed facts in the district here discussed. On this hypothesis, with eastward-dipping beds a gentle slope on the east and an abrupt slope on the west are what would be expected. The western base being determined by the fault, formations of differing resistance would terminate at the same line until weathering and erosion had modified the front. If the region was largely covered by volcanic rocks before the faulting, the relative lowering of the areas in front of the western scarps would carry the lava to a low level, where it would be quickly buried beneath the wash. On the other hand, the lava on the eastern flanks would remain exposed, that on the higher portions of the ranges being rapidly removed by erosion. In the two ranges that do not show evidence 
of prominent north-south faulting, namely, the Star and Beaver Lake ranges, the volcanic formations extend well up toward the summits, being especially prominent on the west side, the rocks to the east, adjoining the Milford Valley, being more rapidly removed.

In the San Francisco Range the east as well as the west side of the northern portion of the range is bounded by a fault, as is well shown in the Horn Silver mine. The throw of the eastern fault was doubtless much less than that of the western and it does not extend south of the Squaw Springs Pass. Its presence is not shown in the topographic development.

There has been some faulting transverse to the ranges, but this has not had a prominent effect in determining the major topographic features. The volcanic rock in the southern part of the San Francisco Range has been faulted down against the sediments. The fault has determined the position of the Squaw Springs Pass. Faults also cross the Star Range and have determined the general position of Elephant Canyon.

The evidence observed seems to indicate that previous to the igneous activity the region had been reduced to one of moderate relief. This surface was very largely if not completely buried by volcanic rocks and the area was invaded by intrusives. After and perhaps in part contemporaneous with the igneous activity the country was broken into blocks along northsouth faults, and these blocks were tilted, forming the three prominent ranges. Erosion followed the tilting, removed the lava from the summits of the ranges, and filled the low valleys between. It has also removed the volcanic rocks from areas that did not suffer pronounced tilting, as the Beaver Lake Mountains, and exposed portions of the old erosion forms.

The exact manner in which the fault-block structure was brought about in this region has not been fully demonstrated. It is difficult to understand how a series of horizontal sediments could be broken by simple normal faulting and tilted to form the parallel ranges, necessitating, as normal faulting does, an increase in the horizontal space occupied by the series. A possible explanation is that the region underwent a broad doming and that, the support being withdrawn from underneath this dome, it broke into a series of blocks. In such an event the eastward tilting of the strata might be due to the original dip of the dome structure intensified by the relative sinking of the eastern portions of the individual blocks. A cause for the doming and also for the collapse of the dome may be found in the volcanic activity. In its early stages there may have been strong pressure from beneath which caused the bowing up of the overlying strata, and when the vast amount of lava had poured out on the surface the release of pressure from beneath combined with the added weight above would tend to cause the collapse of the dome.

Lindgren ${ }^{1}$ has suggested for the Sierra Nevada an origin similar to that discussed above, as shown by the following quotation:

In many publications the greatly increased grade of the Tertiary rivers and of the surface of the range as a whole is ascribed to an uplift of the range along the eastern break, accompanied by a tilting of this lifted block. An inspection of the profiles across the range shown in Plate IX will easily convince the observer that such an explanation is wholly untenable. East of Lake Tahoe the total displacement by the faulting which occurred in late Tertiary time just before the andesitic eruptions amounted to only 2,200 feet. Such an uplift would be utterly insufficient to change the grade of the western Tertiary rivers from say 20 feet to the mile to 90 or 100 feet to the mile. All this strengthens the belief that we have here to deal with a composite movement, the upward element affecting a large area and the downward element consisting in the local sinking of moats (graben).

The nature of the uplift preceding the one that has produced the dominant forms of the present topography is not known, though it is possible that folding played a part in it.

Since the uplift described above the streams have carved deep valleys in the ridges, varying from canyon-likeforms in the harder formations to mature valleys in the softer rocks. The wash from these streams has been built into immense alluvial cones which border the bases of the mountains. Within the area mapped these cones are best shown on the west side of the San Francisco Range. (See Pl. II, A, p. 18.) As shown by Gilbert, ${ }^{2}$ the cones were built before the Lake Bonneville beds were laid down, the shore deposits of that lake being built upon these

\footnotetext{
1 Lindgren, Waldemar, The Tertiary gravels of the Sierra Nevada of California: Prof. Paper U. S. Geol. Survey No. 73, 1911 , p. 41.

2 Mon. U. S. Geol. Survey, vol. 1, 1890, p. 92.
} 
forms. The shore deposits are not prominent in the area mapped, the only conspicuous deposit of this type being the gravel bar that lies just on the margin of the area mapped, half a mile northwest of Newhouse. A little north of this area, on the west side of the San Francisco Range, the shore lines of the old lake are strongly developed.

After the Lake Bonneville waters had receded, the streams began cutting in the old deposits and at present the main valleys have troughlike canyons in their bottoms. This condition is well shown in The Big Wash where it is crossed by the Frisco road (see Pl. III, A, p. 19) and in Copper Gulch, where the stream has cut through the old alluvial deposits and for several feet into the underlying rocks. The alluvial fans west of the San Francisco Mountains have been so cut up by these shallow steep-sided valleys that riding across them transverse to the direction of the valley is slow and difficult.

The history of the geologic development of this region is further discussed on page 90.

\section{GEOLOGY.}

SEDIMENTARY ROCKS.

GEOLOGIC PERIODS REPRESENTED.

The consolidated sedimentary rocks exposed in the San Francisco and adjoining districts include limestones, quartzites, and shales ranging in age from Ordovician, or, probably, from Cambrian to Triassic. Probably all the formations laid down during these periods are exposed in the region and so far as has been positively determined sedimentation went on without a break throughout this time, during which probably 18,000 feet of sediments were deposited. Figure 6 gives a generalized section of these strata.

\section{GRAMPIAN LIMESTONE (CAMBRIAN? AND ORDOVICIAN).}

Distribution.-The lowest formation recognized in the region is the limestone of the San Francisco Range, which will be called the Grampian limestone, after Grampian Hill, which is composed of this formation. The formation is separated into a northern and a southern portion by the monzonite mass which forms the ridge for some distance north of Grampian Hill. The limestone extends westward from the summit of Grampian Hill to White Mountain. About 2 square miles of the formation are exposed in this mass.

From a point about half a mile north of the Cactus mine this limestone forms the western portion of the range to the northern margin of the area mapped, a distance of over 2 miles. About $3 \frac{1}{2}$ square miles of the formation have been mapped in this mass. A small body of limestone, which is possibly the same formation, is exposed south of Squaw Springs Pass, making a total areal extent of nearly 5 square miles of this formation in the range.

General character.-The best section of the Grampian limestone is on the steep westerly face of the range north of the Indian Queen mine, where about 4,000 feet is exposed, the upper boundary of the formation being determined by the overlying quartzite but the base being concealed. The unaltered rock, for the most part, is a heavy-bedded blue dolomitic limestone, showing a rather remarkable uniformity of character through the great thickness of the deposit. There are some beds of light-gray limestone which are plainly seen on the face of the mountain. At the Indian Queen tunnel, near the base of the formation as exposed, occur some thin alternating beds of siliceous and calcareous shales. The strata are of different colors and on weathering the varied coloration becomes more prominent. This has given the rock a pronounced banded appearance and has led to the local term zebra rock.

Locally the limestones are siliceous or cherty. This condition is well shown just above Marble Gulch. The silica here appears to have replaced organic material, forming nodulary masses of varying character. Many of these nodules are lenticular spongelike masses, varying in length from an inch to 18 or 20 inches, with the elongation parallel to the stratification. They may be so abundant in certain beds as to form almost a continuous cherty layer. In other localities the silica has replaced wormlike organic remains that extend continuously 
along the bedding for considerable distances. These silicified portions are distinctly more resistant than the inclosing rock and stand out on the weathered surface. Naterial from these beds was submitted for paleontologic identification but was found to be too poorly preserved to permit determination.

In the upper part the formation becomes more shaly, the top few hundred feet consisting of limy shales interbedded with some fine quartzites. These beds grade into interbedded shales

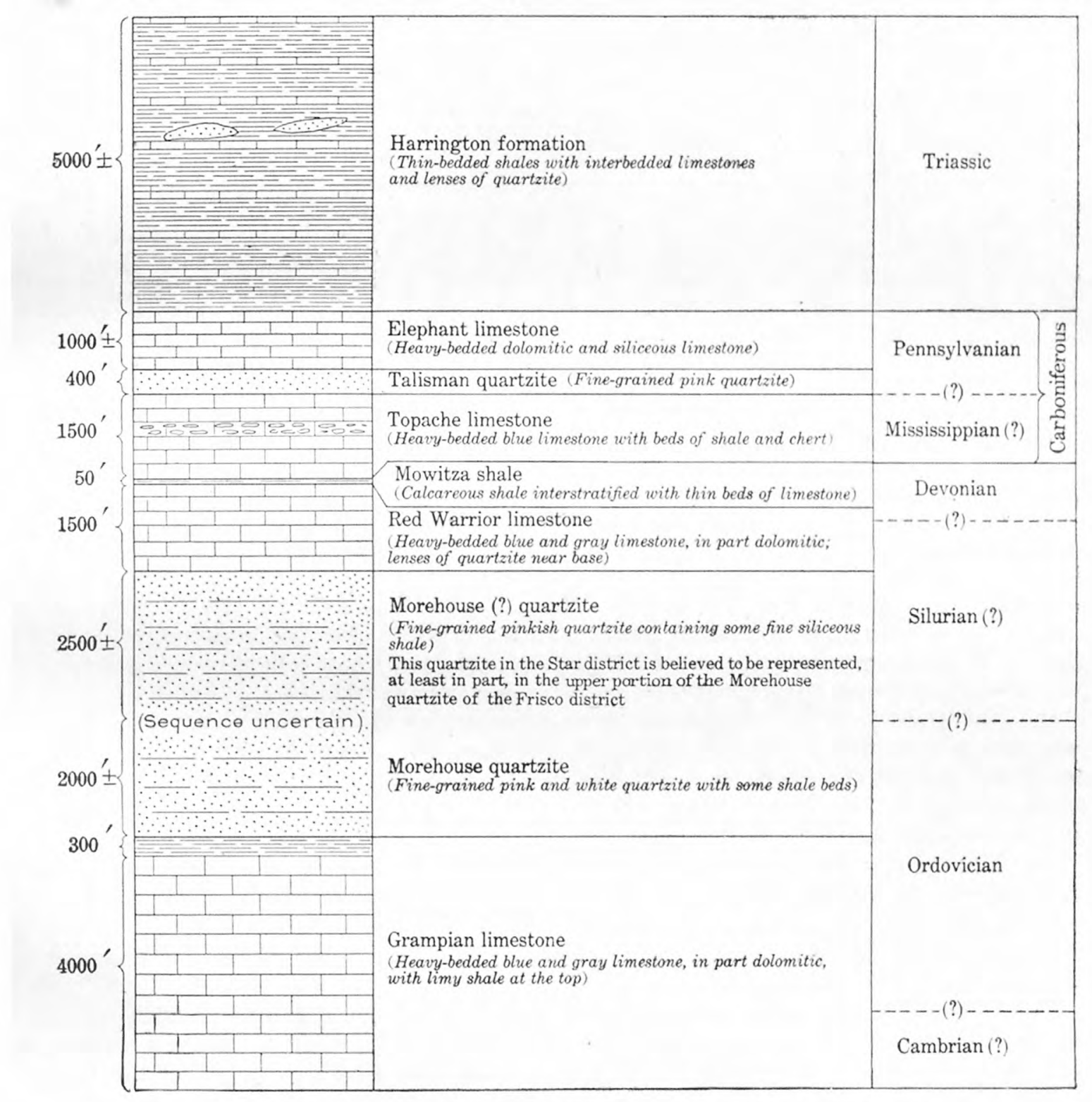

FiguRE 6.-Generalized section of the sedimentary series in the San Francisco and adjacent districts.

and quartzites, and finally into the heavy-bedded white quartzite of the overlying formation, the Morehouse quartzite. On the geologic map the shaly beds have been included with the Grampian limestone. Several of the limy shale beds carry poorly preserved fossils.

Near the monzonite contact the rock has suffered extensive alteration, varying considerably at different points. East of the Imperial mine it appears in the field to have been altered almost entirely to a reddish-brown garnet, though on microscopic examination other minerals are found to be present in considerable quantities. For a considerable distance west of the 
Imperial and Washington mines amphibole is an abundant alteration product, giving to the rock the fibrous and tough character well known to miners who have worked in it. Still farther west, in White Mountain, and for some distance to the east the rock has been recrystallized and marmarized, but neither garnet nor amphibole is abundant. Along the northern contact the rock is also marmarized but shows relatively slight contact mineralization. The contact alteration of the limestone is more fully treated on page 82.

Specimens of the limestone collected near the Reciprocity mine were analyzed by George Steiger and found to have the following composition:

Analyses of limestone near Reciprocity mine.

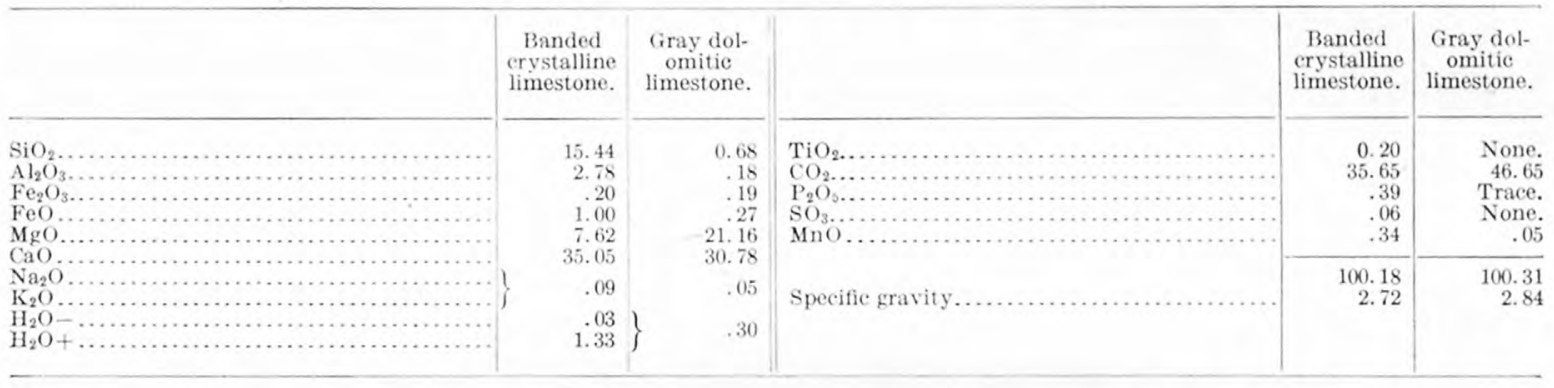

Conditions of deposition. - The great thickness and uniformity of the Grampian limestone indicate deposition in a large body of water, and the absence or scarcity of fossil remains except in the upper beds points to accumulation in deep water, probably at a distance from shore lines and under conditions not well suited to abundant marine life. The beds of fine shaly and siliceous limestones at the Indian Queen mine, near the base of the formation as exposed, indicate shallow-water and near-shore deposition with slight fluctuation. The gradation from limestone through shaly limestone and limy shales with interbedded lenses of quartzite to quartzite that is shown in the transition from the Grampian limestone to the Morehouse quartzite points to a change from deposition at a distance from shore to deposition close to the shore line, and the presence of marine fossils in the upper beds indicates shallow-water conditions compared with those prevailing during the deposition of the main body of the formation.

Age.-In the Grampian limestone the only horizon at which fossils that proved of any value in age determination were found was in the limy shale lying between the quartzite and lime. Fossils from these beds were collected in 1908 from Barrel Canyon, on the east side of the range, and near the limestone quartzite contact on the ridge east of the old Indian Queen workings, on the west side of the range. The following determinations were made by $\mathrm{E}$. $\mathrm{O}$. Ulrich from the material collected in the latter locality: "Gastropod, very poor, suggesting a Maclurea like M. oceana. Fragments of two orthoid shells and very imperfect pygidium of trilobite, all too poor to risk even generic determination." One-fourth of a mile south of the northern boundary of the area mapped, in the north-south valley, were found "ramulets suggesting Buthotrephis."

Of the collection from the mouth of Barrel Canyon, Mr. Ulrich makes the following statement: "This lot contains numerous fragments of orthoids and trilobites. They are not in condition to determine specifically, but enough is shown to establish the age of the rock as upper or middle Beekmantown."

Fossils were collected on the east side of the range at nearly the same horizon in 1908, and on these Mr. Ulrich makes the following report:

The collections evidently represent nearly the same stratigraphic horizon. It is widely distributed in Utah and Nevada. Unfortunately most of the species have never been described, but they are highly characteristic and the fauna is easily recognized. Essentially the same fauna is found in the lower part of the Simpson formation of Oklahoma. There it marks the basal part of the Ordovician as now recognized. In the East only the lower Chazy fauna is at all comparable. 
Lot 367 :

Eccyliopterus sp. nov. (near E. volutatus).

Leperditia sp. nov. (near L. fabulites).

Two small undetermined Ostracoda.

Lots 380 and 381 :

Nearly all the species are repeated in these two lots. Doubtless they represent the same bed.

Receptaculites mammilaris.

Orthis sp. nov.? (near O. tricenaria).

Orthis lonensis?

Orthis pogonipensis.

Hebertella ci. vulgaris.

Dinorthis sp. nov.? (cf. Streptorhynchus minor Walcott).

Protowarthia sp. undet.

Euomphalus? sp. undet.

Orthoceras sp. nov.

Amphion sp. undet.

Trilobite of uncertain affinities.

Leperditia bivia.

Leperditia sp. nov. (near L. fabulites).

Four or five small, undescribed Ostracoda.

Lot 381A:

Amphion nevadensis.

Amphion sp. undet.

Eccyliopterus sp. nov. Same in lot 367 .

It is apparent from the fossil evidence presented that the uppermost beds of the Grampian limestone are of Lower Ordovician age. No fossils were collected lower in the formation, but it seems probable that the lower part may be Cambrian. This view is held partly because it seems unlikely that 4,000 feet of limestone was deposited in Ordovician time previous to the deposition of the shales carrying Chazy or Beekmantown fossils and partly in view of the fact that there is a lithologic similarity between the lower part of the Grampian limestone and the upper part of the limestone exposed in the Wa Wa Range to the west, from which fossils of Upper Cambrian age were collected several thousand feet below the top of the formation.

\section{MOREHOUSE QUARTZITE (ORDOVICIAN AND SILURIAN?).}

Distribution.-The Morehouse quartzite, named from Morehouse Canyon, on the east side of the San Francisco Range, where it is well exposed, overlies the Grampian limestone and forms the summit of the range north of the monzonite mass. Like the underlying limestone, the quartzite has been separated by the intrusion of the monzonite and the subsequent erosion into two distinct bodies. The larger area extends from the monzonite mass, a little east of north of the Cactus mine, to the northern border of the area mapped and forms a large part of the range still farther north. The eastern boundary of this area is uncertain, as the contact between the quartzite and the lavas is deeply buried in quartzite float for a considerable part of the distance. Several outcrops of lava near the contact, together with outcrops of the underlying limestone in Barrel and Morehouse canyons, have, however, made it possible to indicate the probable limits of the formation to the east with considerable certainty. Within the area mapped this body of the formation occupies about 3 square miles. The second body is south of the monzonite and forms the capping of the ridge east of the Imperial mine. This body is but a fraction of a square mile in extent and a few hundred feet in thickness.

General character. - The best exposure of the quartzite, as of the limestone, is in the west face of the mountains. There has been considerable slumping of large blocks along this face, apparently due to sapping of the underlying limestone, which makes the determination of the thickness of t'ie beds uncertain; furthermore, the steepness of the cliff, which is practically inaccessible, renders a careful study of this face exceedingly difficult. As measured in the cross section of the range through Quartzite Hill, the formation has an apparent thickness of about 2.000 fset. 
On the east side of the range the base of the quartzite is exposed in Barrel and Morehouse canyons. Here the face of the mountain is much less precipitous, and as there has been no opportunity for the sapping of the underlying limestone the difficulty occasioned by slumping is not encountered. In Morehouse Canyon the section is as follows: At the base are heavy beds of fine-grained, dense white quartzite. On fresh fracture this rock is nearly pure white and has a sugary texture. It weathers to a dull gray, locally with a pinkish tinge. In some beds the grains are moderately coarse, but for the most part they are fine and rather uniform. The thickness exposed is 450 feet. Above the white quartzite, and separated from it rather sharply, is pink quartzite which extends to the summit a vertical distance of 1,450 feet. In the lower portion of the pink quartzite there are several beds of red and reddish-brown shale. These rocks show a fine stratification and an imperfect slaty cleavage parallel to it. They weather readily and by allowing the slumping down of the interbedded quartzite have caused the rapid broadening of the valley above the white quartzite, through which the stream flows in a canyon. The same beds of shale are well exposed on the flat top of the ridge above the Golden Reef mine. Near the top of the formation as exposed the material is coarser, a few beds of conglomerate composed of quartz pebbles being present near the summit of Quartzite Hill.

South of the monzonite mass only the lower portion of the formation, the white quartzite, is present. This rock, like that to the north, is uniform and fine grained. It appears to contain rather more iron than the northern beds at the same horizon, as on weathering it has a distinct pinkish color, well shown where the Imperial trail crosses the quartzite float.

Conditions of deposition.- The conditions of deposition during the period in which the great body of the Morehouse quartzite was laid down were essentially uniform, as is shown by the character of the deposits, the only variation from the fine-grained quartzite being a few lenses of shale and conglomerate. It is evident that the quartzite was deposited near the shore line of a land area of considerable relief.

Age.-The only fossils collected from the formation were a few indistinct forms from the shales near the base of the pink quartzite. These proved of no value for age determination. The only fossil evidence that bears distinctly on the age of the formation is that of the shale beds between the underlying limestone and the quartzite. These beds in the mapping have been included in the Grampian limestone and, as already shown, they are of Lower Ordovician age. It is probable that a part at least of the quartzite was deposited in Ordovician time, but there are no data on which to base a separation of the Ordovician and the supposed Silurian above.

Stratigraphic relations.-No unconformity was discovered between the limestone and the quartzite. On the contrary, there seems to have been a rather gradual change from the conditions favoring the deposition of limestone to those in which quartzite was laid down. In the upper part of the limestone formation beds of shale alternate with the limestone and these in turn give place to more siliceous rocks and finally to quartzite.

In the Grampian Hill area, south of the monzonite, the beds immediately underlying the quartzite have been so changed by contact alteration that correlation with those to the north on lithologic or paleontologic evidence is impossible. The white quartzite, however, shows little alteration, and its close resemblance to that of the northern area, together with the similarity in the limestone formation in the lower beds of the two areas, leaves little doubt that the two are parts of the same formation which have been separated by the intrusion of the monzonite.

Erosion has removed the upper portion of the quartzite in the San Fran isco Range, and its relation to the next higher formation can not be positively stated.

\section{MOREHOUSE (?) QUARTZITE (SILURIAN?) OF STAR DISTRICT.}

Distribution.--The lowest formation exposed in the Star Range, to the east is a quartzite that is believed to represent the upper part of the Morehouse quartzite. Inasmuch as the two quartzites are separated by an area entirely covered by lava and late sediments and no fossil 
evidence is available, a positive correlation can not be made. However, the age of the overlying limestone in the Star district indicates that the two are probably of the same age, and it is probable that they are parts of the same formation. The quartzite occupies about a square mile in the northwestern part of the Star district, west of the Shauntie road.

General character.-The rock is a fine-grained pinkish quartzite, rather massive in structure, though on weathered surfaces it shows a fine stratification with sandy beds from one-fourth to one-half inch in thickness, alternating with fine siliceous laminæ. The fine material is usually distinctly darker in color. The rock shows no tendency to split along these strata. In the upper part the beds are more shaly and some of them contain considerable lime. These beds pass rather gradually into the overlying series of heavy-bedded limestone, the lower part of which contains small lenses of quartzite.

The formation is nearly surrounded by lava and an accurate determination of the thickness exposed is difficult. The apparent thickness is about 2,500 feet, and the total may be even more.

Conditions of deposition.-The conditions under which this quartzite was laid down were similar to those prevailing when the Morehouse quartzite of the San Francisco Range was deposited. At the close of the period of sandstone deposition there was a return to conditions of deep-water sedimentation probably similar to those prevailing during the deposition of the earlier limestone.

Age.- No fossils were collected from the Morehouse (?) quartzite, and its age can therefore be determined only by its relation to the other formations. It is believed that at least the lower portion of the overlying limestone is Silurian and the quartzite is considered to be of the same age.

Stratigraphic relations.-As the base of the quartzite is not exposed its relation to the underlying formation can not be positively stated, but it is believed to be equivalent to the upper portion of the Morehouse quartzite. To what extent, if any, it duplicates the upper part of the quartzite as exposed in the San Francisco Range has not been determined. There is no recognized unconformity between the quartzite and the overlying limestone. The transition shows a gradation from quartzite through more or less shaly material to limestone with lenses of sandy material and finally to massive bedded lime.

RED WARRIOR LIMESTONE (SILURIAN? AND DEVONIAN?).

Distribution.-The Red Warrior limestone, named after the Red Warrior mine, located in the upper beds of this formation, is exposed in a belt averaging from one-half to three-fourths of a mile in width along the western border of the Star district. It is underlain by the Morehouse (?) quartzite, though the contact with the quartzite is covered by volcanic rocks throughout the greater part of its extent in the district. It is overlain by the Mowitza shale. The eastern boundary nearly coincides with the line formed by the group of mines extending in a nearly north-south direction through the Star district, including the Lady Bryan, Hub, Moscow, Red Warrior, Mowitza, and Elephant. North of Elephant Canyon the formations have been faulted to the west, the Red Warrior limestone appearing in a small area south of the Hoosier Boy mine. About 1 square mile in the district is covered by this formation. Owing to the poor exposure of the base of the Red Warrior limestone the thickness of the formation can not be determined accurately, but it is approximately 1,500 feet.

General character.- The Red Warrior limestone for the most part is a heavy-bedded blue dolomitic and in part rather siliceous limestone. In the lower portion lenses of quartzite are present and in the upper portion there are a few beds of gray limestone. The limestone has been intruded by the granitic rocks of the district and in part highly altered and recrystallized, though contact minerals have not formed abundantly. Locally the limestone has been silicified to a cherty material that resembles to some extent the fine quartzite lenses in the lower part of the formation, but if these silicified areas are examined closely it will be found that they do not conform to the limestone bedding, but may cut almost directly across it, as is well shown 
east of the Lady Bryan mine in the Topache limestone (Carboniferous), where the same action has taken place.

Conditions of deposition.-During the deposition of the lower portion of the Red Warrior limestone conditions of sedimentation were slowly changing from near-shore conditions favorable to the formation of sandy sediments to offshore and deep-water conditions favoring the deposition of heavy-bedded limestone. The latter conditions prevailed throughout the remainder of the Red Warrior epoch, until the slight changes occurred which resulted in the laying down of the overlying Mowitza shale.

Age.-Fossils were not found in the Red Warrior limestone and it is therefore impossible to determine its age on direct evidence. It is immediately overlain by the Mowitza shale, which carries Devonian fossils, and it is therefore Devonian or older. From comparison of the lithologic succession of the beds and those of northern Utah, as is shown later, it seems probable that at least the lower portion of the Red Warrior limestone is of Silurian age, and it is equally probable that the upper portion was laid down in Devonian time.

Stratigraphic relations. - So far as can be determined from the poorly exposed contact between the Red Warrior limestone and the Morehouse(?) quartzite no unconformity exists between the two, the change in sedimentation from sandy to limy material being rather gradual. The Mowitza shale lies conformably on the Red Warrior limestone, the change in conditions of sedimentation being slight.

MOWITZA SHALE (DEvoNiaN).

Distribution.-The Mowitza shale forms a narrow band extending north and south through the Star district and marks the line along which some of the most important mining developments of the district have taken place. The formation is so named from the fact that its most prominent outcrop is on the saddle just northeast of the Mowitza shaft. From this point it can be readily followed north to the east-west fault near the Elephant tunnel. North of the fault it is readily recognized just north of the Hoosier Boy mine and can be traced for a short distance to the point where it is covered by the lavas. Between the Elephant tunnel and the Hoosier Boy mine the rock has been much broken by faults and it is not possible to trace the different formations definitely.

South of the Mowitza mine the formation can be readily traced past the Red Warrior mine, where it is well exposed in the gulch southeast of the shaft, and thence to the Moscow mine, where the best exposure is near the assay office. South of this point the rocks are considerably altered, being in the vicinity of extensive intrusive masses, and the different beds are less easily recognized. The shale bed passes near the Lady Bryan mine. Here its lithologic character is not so apparent and fossils were not found in it, but fossils collected on the slope about halfway between the Lady Bryan shaft and the summit of the ridge to the south proved to be lower Carboniferous and thus to belong to the overlying Topache limestone, a fact which indicates that the shale is present lower down. This fact, together with the position of the bed as related to the cherty beds in the Topache limestone, leaves little doubt that the Mowitza shale extends through the southern part of the district near the Lady Bryan mine.

The distinctly shaly and fossiliferous beds do not exceed 50 feet in thickness.

General character.-The formation is composed of limy shale beds interstratified with thin beds of limestone, both limestone and shale carrying fossils. The rocks are dark grayish blue in color where not bleached by mineralizing solutions.

Immediately underlying the shales is a bed of light-gray limestone that can be traced with the shale from the Elephant mine to the Moscow mine. Above the shale are blue heavy-bedded limestones.

Conditions of deposition.-The conditions of deposition in the Mowitza epoch did not differ greatly from those immediately preceding and following. The formation was evidently laid down in waters sufficiently shallow to permit the existence of marine fossils in considerable abundance. 
Age.-Fossils were collected from the formation at numerous points in the district and submitted to E. M. Kindle, who makes the following report:

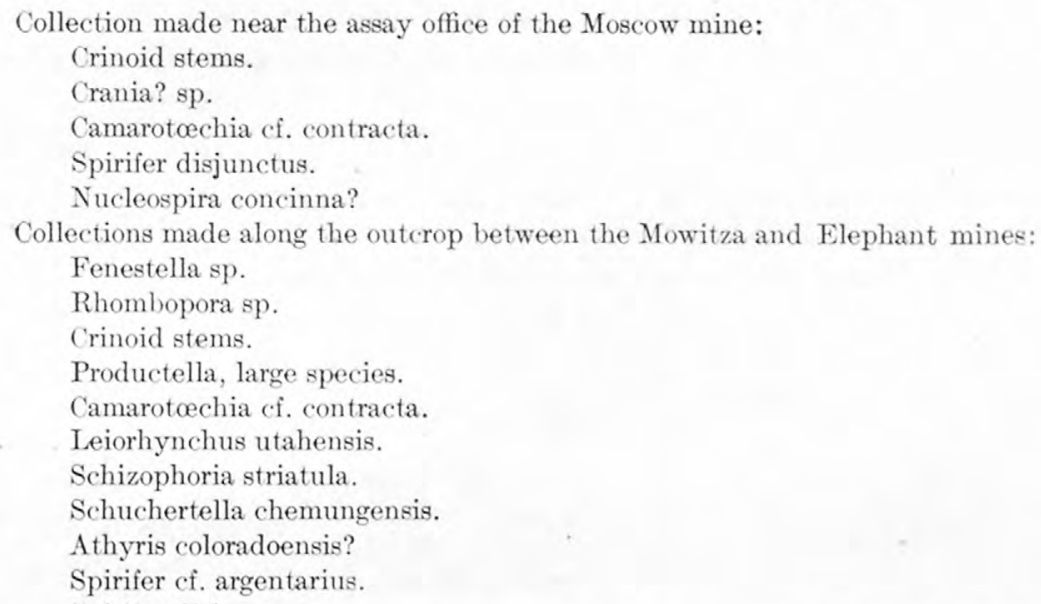

Spirifer disjunctus is the most abundant fossil in the fauna. These shells are of the broad mucronate type and appear to resemble the typical Spirifer disjunctus rather than the common western variety known as Spirifer whitneyi. The collection contains the first complete specimen of Leiorhynchus utahensis which has been collected. The horizon represented is Upper Devonian. The fauna appears to represent a facies corresponding to the upper part of the Jefferson limestone of northeastern Utah.

A collection from the beds east of the Hoosier Boy mine and north of the Elephant Canyon fault contained Spirifer disjunctus, indicating Devonian age, and this evidence and the lithologic character of the beds shows that they are the continuation of the Mowitza shale north of the fault.

Stratigraphic relations. - The Mowitza shale is conformable with the underlying Red Warrior limestone and the overlying Topache limestone, the epoch in which it was laid down representing but slight differences in conditions of sedimentation from those preceding and following.

TOPACHE LIMESTONE (CARBONIFEROUS, MISSISSIPPIAN?).

Distribution.-The Topache limestone, named from the prominent peak formed of it, overlies the Mowitza shale and is overlain by the Talisman quartzite. It forms a belt more than half a mile wide extending through the central part of the Star district and covers an area. of about $2 \frac{1}{2}$ square miles. Several of the ore deposits of the district are in this formation, including the Wild Bill, Cedar-Talisman, Mammoth, Commonwealth, Progressive, and St. Marys. The heavy-bedded dolomitic limestone in the northern part of the Beaver Lake district is possibly to be correlated with the Topache limestone, though evidence of its age was not obtained and it may be either younger or older.

General character.- The lower beds of the formation are heavy-bedded blue dolomitic limestones, which give place near the center to shaly limestones and these in turn to siliceous and cherty beds interstratified with limestone and shales. The cherty beds where the edges are exposed in the canyon have a pronounced banded appearance, the strata varying in thickness from a few inches to a foot or more. These beds are readily recognized throughout the district. Overlying the cherty beds are blue limestone and a few shaly beds, the limestone becoming distinctly siliceous as it approaches the Talisman quartzite. The formation has a thickness of about 1,500 feet.

Conditions of deposition.-There was no marked change in the conditions of deposition in Topache time from those prevailing in the preceding epoch. Slight variations permitted a. change in character of sediment from limestone to limy shales, and several hundred feet of shaly and siliceous beds at about the center of the section indicate a considerable period favorable to the deposition of clays and sands. 
Age.-North of Elephant Canyon fossils were collected from the shaly limestone beds underlying the cherty shales (lot 511) and from shaly beds in the blue limestone overlying the cherty beds (lot 512). Fossils were also collected from shaly beds in the blue limestone about halfway between the Lady Bryan shaft and the summit of the ridge to the east (lot 507).

On these fossils G. H. Girty made the following report:

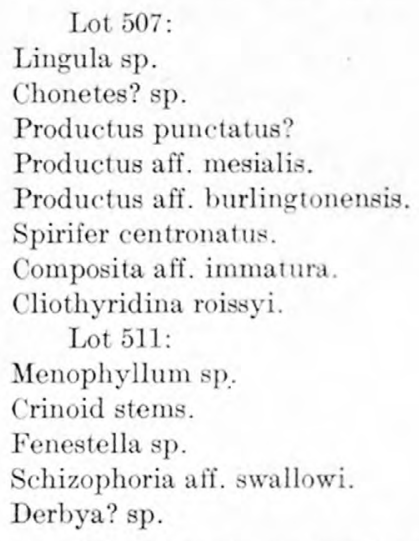

Lot 511 -Continued.

Productus aff. burlingtonensis,

Spirifer striatus var. madisonensis.

Reticularia cooperensis.

Spiriferina sp.

Composita? sp. Lot 512:

Zaphrentis? sp.

Derbya sp.

Productus pileiformis

Productus aff. semireticulatus.

Productus aff. adairensis.

Spirifer aff. keokuk

Cliothyridina aff. sublamellosa.

Cypricardinia sp.

It is difficult to determine the exact position of these faunas in the geologic column. They are clearly Carboniferous, and without much doub.t Mississippian. None of them has quite the characteristic facies of the Madison limestone, and $\mathrm{I}$ am disposed to think that they are somewhat younger. Lot 512 is rather suggestive of Upper Mississippian.

Stratigraphic relations.- The Topache limestone was deposited conformably on the Mowitza shale and is apparently overlain conformably by the Talisman quartzite.

TALISMAN QUARTZITE (PENNSYLVANIAN?).

Distribution.-The Talisman quartzite, named from the Talisman mine, near which it outcrops prominently, forms a band less than one-eighth of a mile in width extending entirely across the Star district, though broken by the Elephant Canyon fault and also by a fault about half a mile north of the Elephant Canyon road, so that it now has the appearance of a series of lenses in the limestone. In the portion just north of Elephant Canyon the fault zone is not readily determined and beds of limestone appear to lie between lenses of quartzite. The succession of overlying beds, however, leaves little doubt that the central block has been forced to the west.

General character.-The Talisman quartzite is throughout the district a rather fine grained pink rock composed of rounded quartz grains. It is not uniform in thickness, however, but in general is thinnest toward the south. To the north it becomes more shaly in character as it grades into the limestone. In the central portion of the belt it is about 400 feet thick.

Conditions of deposition.-At the close of the Topache limestone epoch there was a period of near-shore deposition during which the Talisman quartzite was laid down. To the south the transition appears to have been rather sudden, resulting in an abrupt change from the deposition of limy sediments to that of sand, and the return to the deposition of lime seems to have been equally abrupt. In the northern portion of the district the change was apparently more gradual and conditions favorable to the deposition of siliceous sediments persisted for a much longer time; in fact, the overlying beds in that part of the district are distinctly shaly.

Age.-No fossils were found in the Talisman quartzite and it is therefore impossible to state from direct evidence the age of the formation. From a comparison with formations in other parts of the State, as shown below, it is believed to be of Pennsylvanian age.

Stratigraphic relations.--The Talisman quartzite was apparently deposited conformably on the Topache limestone and no unconformity was detected between the quartzite and the overlying Elephant limestone. To the south the change to the limestone is rather abrupt, suggesting an unconformity, but to the north there is a gradual change from quartzite to shaly, siliceous, and limy beds. 


\section{ELEPHANT LIMESTONE (PENNSYLVANIAN?).}

Distribution.-The Elephant limestone, named from Elephant Canyon, which cuts across it, forms a band extending across the Star district immediately east of the Talisman quartzite. It has a width of one-fourth to one-half of a mile.

General character.-In the southern part of the district the Elephant limestone is a heavybedded blue dolomitic and in part rather siliceous limestone. In the northern part it is distinctly more siliceous, being made up of interbedded siliceous shales and limestones. The thickness of the formation where best developed is more than 1,000 feet.

Conditions of deposition.-During the deposition of the Elephant limestone the conditions were near the border line between those favorable to the deposition of shales and those that would produce fine quartzite and limestone. In the southern part of the district the limy sediments predominated; to the north the shaly and siliceous sediments were in excess.

Age.-Fossils were collected immediately above the quartzite north of Elephant Canyon and determined by G. H. Girty as follows:

Echinocrinus? sp.

Rhombopora? sp.

Lioclema? sp.

Productus semireticulatus.

A collection made near the top of the formation in the canyon west of the Silver Horn mine contained the following species:

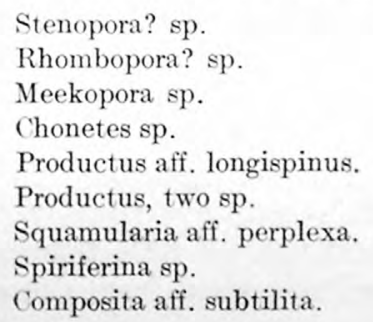

\section{Mr. Girty says:}

The Topache limestone in its lithologic and paleontologic features, is suggestive of the "Wasatch limestone" of the Wasatch Mountain section, which seems to represent both upper and lower Mississippian time. So also the Talisman quartzite and Elephant limestone are suggestive, lithologically, of the Weber quartzite and "Upper Coal Measures limestone" of the same section. The "Upper Coal Measures limestone," however, contains a highly characteristic assemblage of species having a decidedly different facies from the fauna of the Elephant limestone. It seems more probable, therefore, that the latter corresponds to part of the Weber which contains calcareous beds. If such is the case, the absence of the "Upper Coal Measures limestone" beneath the Triassic suggests an unconformity at this horizon of which there is evidence elsewhere.

Stratigraphic relations.- No unconformity was recognized between the Talisman quartzite and the Elephant limestone. In the northern part of the district especially the transition is rather gradual. Likewise in the field no unconformity was recognized between the limestone and the overlying Harrington formation, though there is a rather abrupt and marked change in the character of the sediments, and from the paleontologic evidence Mr. Girty has suggested the probability of an unconformity.

\section{HARRINGTON FORMATION (TRIASSIO).}

Distribution.-In the Harrington formation, named from the Harrington-Hickory mine, which is developed in it, is included the entire consolidated sedimentary series above the Elephant limestone. These rocks are not uniform in charâcter throughout, but the paleontologic evidence has given no basis for an age distinction and the lithologic character does not differ sufficiently to warrant a separation on that basis. The formation shows a thickness of about 5,000 feet. It occurs entirely in the eastern part of the Star district, occupying about $4 \frac{1}{2}$ square miles. 
General character.-At the base is a series of thin-bedded red and gray shales, showing ripple marks and fossil rain drops. These shales are friable and weather readily, giving rise to the low relief in this part of the district. In the northern part of the district the beds at the same horizon are more siliceous and this difference has resulted in a far more rugged topography. The shale has a thickness of about 1,000 feet. In the northern part of the district it is succeeded by a series of heavy beds of limestone over 200 feet thick, forming a north-south band, but in the southern part of the district these beds give place to thinner-bedded limestone and shale. This limestone is well shown in the hills in which the Horn Silver mine is developed. Above these beds the formation consists of interbedded limestone and shale, the shale, especially toward the north, being siliceous. In both the northern and southern parts of the district occur lenses of quartzite, that north of the Harrington-Hickory mine being a prominent example.

The sediments near the intrusives in the northern and southeastern parts of the district have been highly altered, those in the southeastern part being so much changed that it is difficult or quite impossible to correlate them with the equivalent less-altered strata. Their location and general composition, however, leave little doubt that they belong to the upper portion of the formation as exposed in the northern part of the district.

Conditions of deposition.- Throughout the time required to lay down the thick Harrington formation the conditions of sedimentation oscillated between those favorable to the deposition of shaly siliceous beds and those producing limy sediments with a few lenses of distinctly sandy material, the latter phase being especially predominant during the later part of the epoch.

Age.-The following fossils were collected from limestone strata in the shale a few hundred feet above the Elephant limestone south of Elephant Canyon:

Terebratula sp.

Aviculipecten n. sp.

Aviculipecten sp.

Myalina permiana.

Two collections from shaly limestone strata in the shale about half a mile north of the Elephant Canyon road and a little east of the road extending northeastward from the canyon road contained the following species:

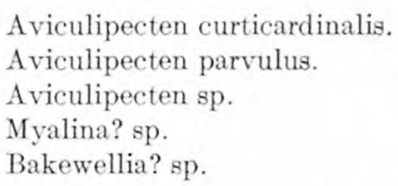

From a collection made near the top of the ridge extending southward from the prominent quartzite peak just east of the point where the Elephant Canyon road turns to the northeast, about one-fourth mile south of the peak, in a low saddle, the following forms were determined:

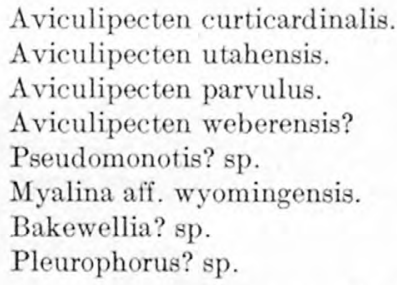

The highest horizon at which determinable fossils were collected is that of outcrops in the low hill rising above the general level about half a mile southeast of the point where the HarringtonHickory and Elephant Canyon road turns sharply to the west through the limestone hills. At this locality the following species were found:

Aviculipecten parvulus.

Aviculipecten curticardinalis.

Aviculipecten weberensis?

Pseudomonotis? sp.

Myalina permiana.

Pleurophorus? sp. 
All these species were identified by G. H. Girty, who states that they "represent the formation which was called 'Permo-Carboniferous' by the geologists of the Fortieth Parallel Survey and which is at the same horizon that Walcott referred to the Permian in his Kanab Canyon section. Recent data show that this formation includes the Lower Triassic ammonite fauna of Idaho, and it must therefore be referred to the Triassic."

Poorly preserved gastropods were collected in siliceous sediments near the summit of the hill just south of the Harrington-Hickory mine, but these proved to be too indistinct to be of value in age determination.

Stratigraphic relations.-No unconformity was determined between the Harrington formation and the underlying Elephant limestone, though the marked change in the character of the sediments and the paleontologic evidence suggest an unconformity. The beds overlying the shales have been removed within this district, and their character and relations have not been determined elsewhere.

LAKE SEDIMENTS AND STREAM WASH (QUATERNARY).

A large part of the region is buried beneath recent sediments. These vary greatly in depth, from a few feet over considerable areas near the base of the mountains to several hundred feet in the Milford and Preuss valleys. Near the mountains the character and composition of the Quaternary material is controlled by the nature of the rock of which the mountains are composed, as is well shown by the heavy deposit of quartzite float that buries the area east of the northern portion of the San Francisco Range, extending nearly to the Beaver Lake Mountains. The Quaternary deposit adjoining the voleanic hills to the south is largely fine volcanic material, and a similar relation between such deposits and the rocks of the adjacent mountains can be traced throughout the region. This intimate relation is due to the fact that the highest stage of Lake Bonneville, reaching an elevation of about 5,250 feet, did not cover the region here discussed, but barely touched the east and west sides; the lake-shore deposits occur just at the west edge of the area mapped, northwest of Newhouse. This freedom from a water body has allowed the migration of fragments from higher to lower ground to progress with slight mingling of material from sources widely separated. The absence of a body of water, together with the arid climate, has resulted in the building up of the immense alluvial fans at the mouths of valleys that are so characteristic of this and other parts of the Great Basin. Some of the fans have been deeply dissected and the underlying beds are seen to be consolidated. Such beds are to be seen in Copper Gulch below the outcrop of the Cactus ore body, where the stream has cut through the alluvial deposits to the underlying monzonite. The lower beds are here cemented into a conglomerate so resistant that the monzonite has weathered out from underneath, leaving the conglomerate beds overhanging for several feet. As in other places, the conglomerate is formed of pebbles of monzonite, limestone, and quartzite found in the mountains above, and the cementing material is largely lime with some silica.

In the lower portions of the valleys, outside of the area mapped, the sediments were, in part at least, deposited in lake waters and doubtless show a greater commingling of material from different sources. The following records of wells in the vicinity of Milford ${ }^{1}$ will give an idea of the nature of these deposits so far as it is known at present.

\footnotetext{
${ }^{1}$ Lee, W. T., Water resources of Beaver Valley, Utah: Water-Supply Paper U. S. Geol. Survey . o. 217, 1903, pp. $28,29$.
} 
Records of wells at Milford.

\begin{tabular}{|c|c|c|c|c|c|}
\hline & $\begin{array}{l}\text { Thick- } \\
\text { ness. }\end{array}$ & Depth. & & $\begin{array}{l}\text { Thick- } \\
\text { ness. }\end{array}$ & Depth. \\
\hline 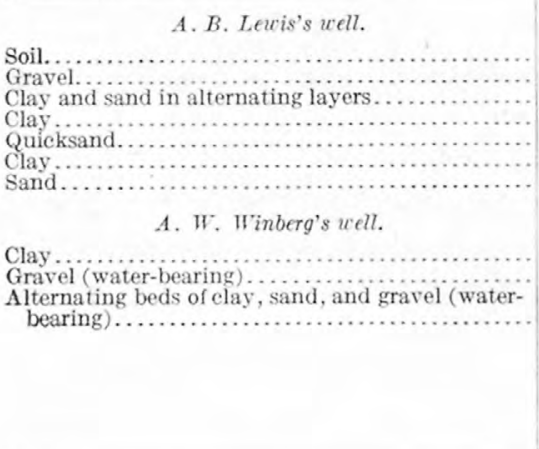 & $\begin{array}{r}F e c t . \\
12 \\
45 \\
390 \\
80 \\
5 \\
215 \\
\cdots \\
\\
\\
16 \\
44 \\
\\
266\end{array}$ & $\begin{array}{l}\text { Feet. } \\
12 \\
60 \\
450 \\
530 \\
535 \\
750 \\
(?) \\
\\
\\
\\
\\
16 \\
60 \\
\\
326\end{array}$ & 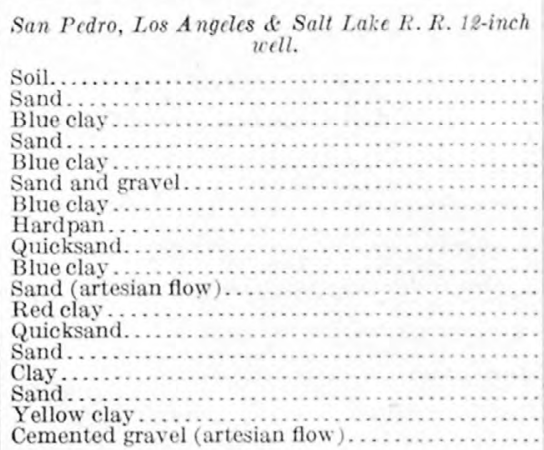 & $\begin{array}{r}\text { Feet. } \\
4 \\
6 \\
22 \\
33 \\
10 \\
15 \\
25 \\
4 \\
35 \\
15 \\
5 \\
81 \\
10 \\
5 \\
8 \\
10 \\
17 \\
5\end{array}$ & $\begin{array}{rr}\text { Fect. } \\
4 \\
10 \\
32 \\
65 \\
75 \\
90 \\
115 \\
119 \\
154 \\
169 \\
174 \\
255 \\
265 \\
270 \\
278 \\
288 \\
305 \\
310\end{array}$ \\
\hline
\end{tabular}

COMPARISON OF THE SAN FRANCISCO SECTION WITH OTHER SECTIONS.

From the foregoing descriptions it is apparent that the age of five formations is determined by fossil evidence, but the boundaries of these formations have not been located by evidence of this class. As an aid to determining the probable location of these boundaries it may be worth while to examine the formations as exposed in other sections in which more definite boundaries have been determined.

Boutwell ${ }^{1}$ gives the following section for the upper formations exposed in Big Cottonwoed Canyon:

Section in Big Cottonwood Canyon, Utah.

\begin{tabular}{|c|c|c|c|c|}
\hline $\begin{array}{l}\text { Sys- } \\
\text { tem. }\end{array}$ & Series. & Formation. & $\begin{array}{l}\text { Thick- } \\
\text { ness, } \\
\text { in feet. }\end{array}$ & Character. \\
\hline \multirow{2}{*}{ 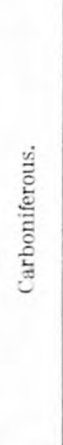 } & 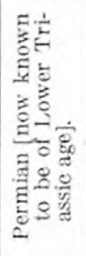 & $\begin{array}{l}\text { Ankareh shale......... } \\
\text { Thaynes limestone.... }\end{array}$ & $\begin{array}{l}1,500+ \\
1,190\end{array}$ & $\begin{array}{l}\text { Red shales, locally sandy, with interbedded coarse-gray sandstones. Carries in } \\
\text { lower portion Aviculipecten weberensis, A. curticardinalis, A. parvulus, My- } \\
\text { lina permiana. No economic importance. } \\
\text { Calcareous, with sandstones and shales; "Midred", shale separates more cal- } \\
\text { careous upper from more arenaceous lower portion. Carries large fauna, with } \\
\text { many new fossil species, chicfly pelecypods, including Pentacrinus sp. Mya- } \\
\text { lina permiana, M. aviculoides, A viculipecten curticardinalis, A. weberensis, A. } \\
\text { parvulus, A. occidaneus, Lingulas, Spirifers, Dentalia. Forms country rock } \\
\text { for replacement ore bodies and lodes. } \\
\text { Red shale, thinly bedded, fine grained, bears ripple marks, mud cracks, and } \\
\text { raindrop imprints. No direct economie importance. }\end{array}$ \\
\hline & 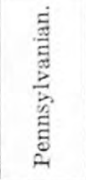 & $\begin{array}{l}\text { Park City limestone [now regarded as } \\
\text { probably Permian]. } \\
\text { Weber quartzite................... }\end{array}$ & $1,350+$ & $\begin{array}{l}\text { Calcareous, with interbedded quartzite, sandstones, and some shale. Carries } \\
\text { Lingulidiscina sp., Productus cora, Productus sp., Plagioglypta canna, Euphe- } \\
\text { mus subbapillosus, Bellerophon sp. Forms country rock for principal bonanza } \\
\text { replacement ore bodies. } \\
\text { Gray quartzite, massively bedded, homogeneous, dense. Carries, in Weber } \\
\text { Canyon, Lingula sp.,Productus subhorridus, Schizodus sp., Plagioglypta canna, } \\
\text { Euphemus subpapiliosus. Forms wall or walls of lead-silver lodes. }\end{array}$ \\
\hline
\end{tabular}

Blackwelder ${ }^{2}$ gives the following generalized section of the rocks in the Ogden region:

$$
\text { Generalized section of rocks in the Ogden region, Utah. }
$$

Quaternary: Lake Bonneville beds and alluvium...........

Unconformity.

Tertiary and Quaternary: High-level gravels...................

Unconformity.

Tertiary (lower Eocene): Wasatch formation (tuffaceous conglomerate, sandstone,

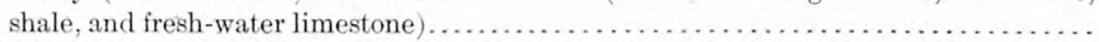

Unconformity (Cretaceous rocks occur just east of this district).

Jurassic and Triassic strata (not studied in connection with the work on the phosphate

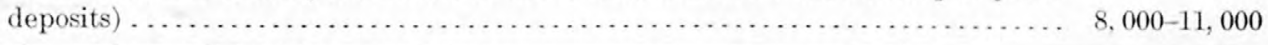

1 Boutwell, J. M., Jour. Geology, vol. 15, 1907, p. 437.

${ }^{2}$ Blackwelder, Eliot, Phosphate deposits east of Ogden, Utah: Bull. U. S. Geol. Survey No. 430, 1910, p. 538. 
Triassic or Carboniferous (Permian):

Feet.

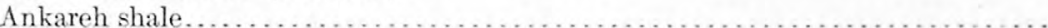

Thaynes limestone. . . . . . . . . . . . . . . . . . . . . . . . . . . . . . . .

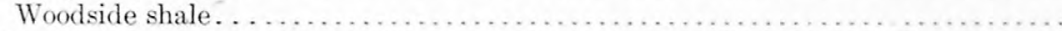

Carboniferous:

Pennsylvanian:

Park City formation (limestone, shale, and phosphate rock).............

Unconformity.

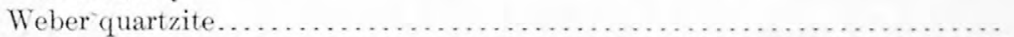

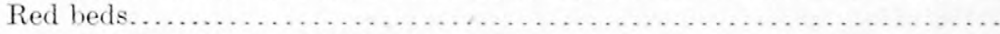

Unconformity.

Mississippian: "Wasatch limestone" of King in part (consists of upper fossiliferous black limestone, middle reddish and buff shale, and lower gray dolomites

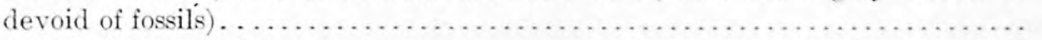

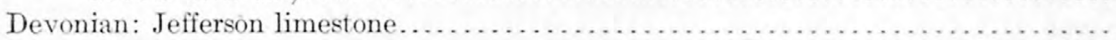

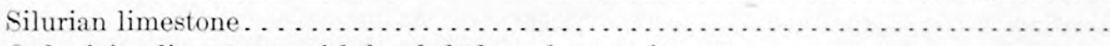

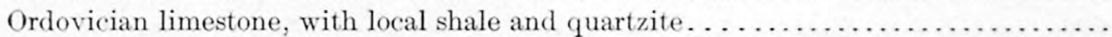

Cambrian, chiefly limestone, with beds of shale and a basal quartzite; divided by

Walcott into eight formations. . . . . . . . . . . . . . . . . . . . . . . . . . . . . .

$4,000-5,000$

$500-1,000$

$100-400$

$500-2,000$

$1,847-6,600$

Unconformity.

Algonkian (?): "Cambrian quartzite" of King (alternating quartzite, graywacke, and

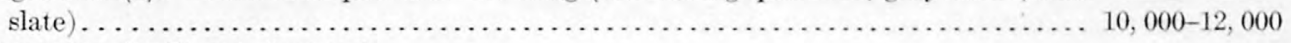

Unconformity(?) not observed.

Archean, complex of schist, gneiss, etc.

Blackwelder ${ }^{1}$ has also given the following generalized section of the formations in the northern Wasatch region, comparing the section of the Fortieth Parallel Survey with that established by later and more detailed work:

Formations in northern Wasatch region.

\begin{tabular}{|c|c|c|}
\hline $\begin{array}{l}\text { Hague and Emmons, } 1877 \text { [Fortieth } \\
\text { Parallel Survey]. }\end{array}$ & Boutwell, Kindle, Walcott, et al., 1880-1909. & Period. \\
\hline $\begin{array}{l}\text { Permo-Carboniferous shales and lime- } \\
\text { stone. }\end{array}$ & $\begin{array}{l}\text { Ankareh shale. } \\
\text { Thaynes formation. } \\
\text { Woodside shale. }\end{array}$ & Lower Triassic or Permian. \\
\hline Upper Coal Measure limestone. & Park City formation. & \\
\hline Weber quartzite. & $\begin{array}{l}\text { Weber quartzite. } \\
\text { Morgan formation. }\end{array}$ & . \\
\hline Wasatch limestone. & Mississippian limestone. & Mississippian. \\
\hline Ogden quartzite. $a$ & Jefferson limestone. & Devonian. \\
\hline \multirow{3}{*}{ Ute limestone. } & Paradise limestone. & Silurian. \\
\hline & $\begin{array}{l}\text { (Ogden quartzite). Shale and sandstone at Geneva.b } \\
\text { Box Elder limestone. }\end{array}$ & Ordovician. \\
\hline & \multirow{3}{*}{$\begin{array}{l}\text { St. Charles formation. } \\
\text { Nounan formation. } \\
\text { Bloomington formation. } \\
\text { Blacksmith formation. } \\
\text { Ute formation. [This is the Ute limestone as recognized by the United } \\
\text { States Geological Survey. } \\
\text { Pioche shale. } \text { \{ Spence shale. } \\
\text { Brigston limestone. } \\
\text { Brigham quartzite. }\end{array}$} & \multirow[t]{3}{*}{ Cambrian. } \\
\hline Primordial slates. & & \\
\hline \multirow{2}{*}{ Cambrian quartzites and slates. } & & \\
\hline & Algonkian quartzites and slates. & Algonkian. \\
\hline Archean. & Archean gneiss and schist. & Archean. \\
\hline
\end{tabular}

a Not correlated with Jefferson limestone, but supposed at first to be Devonian; later assigned to Ordovician. [But the quartzite that is

present in Ogden Canyon, the type locality, is the Cambrian quartzite brought up by faulting.]
$b$ Existence of Ogden quartzite disproved. Geneva formation occupies about the same horizon the Ogden was supposed to have.

$c$ La.agton and Spence members in Bear Lake district probably equivalent to the Pioche shale of Ogden region and southwestward.

1 Blackwelder, Eliot, New light on the geology of the Wasatch Mountains, Utah: Bull. Geol. Soc. America, vol. 21, 1910, p. 519. 
Lee ${ }^{1}$ gives the following section exposed in Beaver Canyon, in the Nineral Range:

Section of rocks exposed in Beaver Canyon, 4 miles east of Minersville, Utah.

1. Basalt, several hundred feet.

2. Rhyolitic flows, tuffs, and breccia, many hundred feet.

3. Andesitic flows, tuffs, and breccia, several hundred feet.

Feet.

4. Uncemented gravel and bowlders of limestone, quartzite, and andesite . . . . . . . . . 250

5 . Coarse consolidated conglomerate consisting of limestone, quartzite, and various crystalline rocks, the bowlders having a maximum diameter of 5 feet $\ldots \ldots \ldots \ldots \ldots \ldots \ldots \ldots . . \ldots \ldots$

Unconformity.

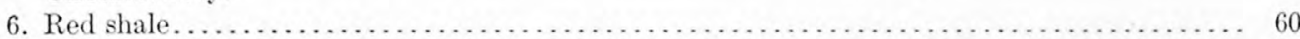

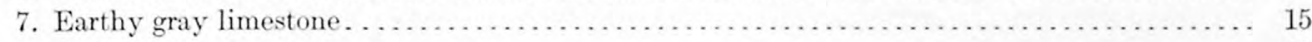

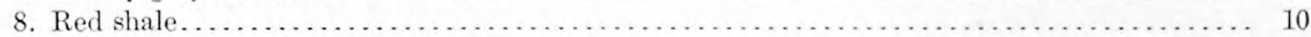

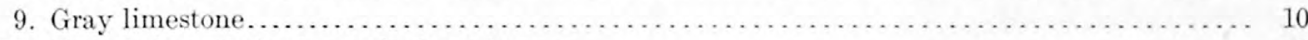

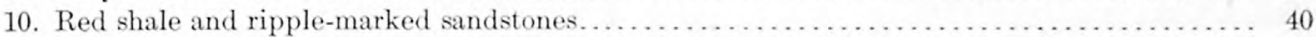

11. Blue limestone . . . . . . . . . . . . . . . . . . . 10

12. Red shale and ripple-marked sandstones................................. 120

13. Limestone containing Aviculipecten weberensis, Aviculipecten aff. occidentalis, Myalina aff. perattenuata, Bakewellia n. sp., Pleurophorus sp., Schizodus sp . . . . . . . . . . . . 15

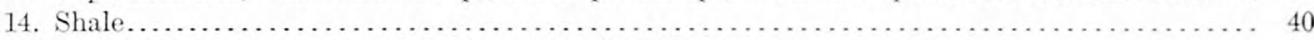

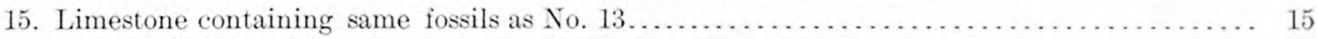

16. Buff shale with a subordinate amount of limestone . . . . . . . . . . . . . .

17. Shale and limestone containing Aviculipecten n. sp., Pleurotomaria? sp., Bakewellia n. sp., Naticopsis sp., Xenodiscus? sp., undetermined ammonoids . . . . . . . . . . . . . . . . . . 100

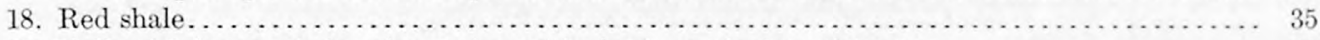

19. Yellowish-brown shales alternating with ripple-marked sandstones $\ldots \ldots \ldots \ldots \ldots \ldots \ldots .40$

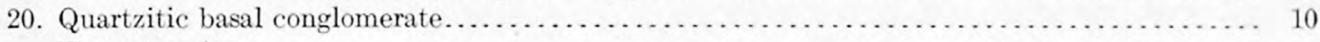

Unconformity.

21. Cherty limestone containing Zaphrentis? sp., Fistulipora sp., Septopora sp., Productus aff. subhorridus, Meekella? sp., Spirifer aff. cameratus, Squamularia aff. perplexa, Spiriferina aff. kentuckyensis, Spiriferina sp., Composita aff. subtilita, Hustedia aff. meekana, Pugnax aff. osagensis . . . . . . . . . . . . . . . . . . . . . . . . . . . . . . . 450

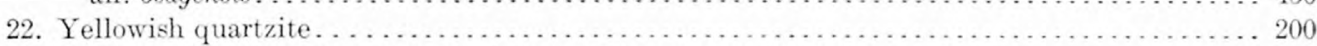

23. Cherty limestone containing Squamularia? sp. and Hustedia aff. meekana .............. 500 Base not exposed where section was measured.

Darton ${ }^{2}$ gives the following generalized section for northern Arizona:

Quaternary:

Generalized section of the rocks of northern Arizona.

Valley filling and lava flows.

Tertiary:

Cretaceous (Upper):

Sandstones and shales, local coal beds............................... 300

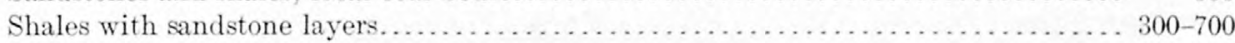

Sandstone . . . . . . . . . .

Unconformity.

Triassic (?):

"Painted Desert formation" (bright-colored, regularly stratified sandstone)....... 1,200

Triassic:

"Leroux formation" (calcareous clays, some sandstone) ................... 600-900

"Lithodendron formation" (sandstone and conglomerate, separated by light-colored

shales and "marls") .......................................... 300-800

Unconformity.

"Shinarump" conglomerate at base.

Permian:

"Moencopie formation" (reddish-brown saliferous and gypsiferous laminated shales,

with sandstones, limestones, and "marls")

Unconformity.

1 Lee, W. T., Water-Supply Paper U. S. Geol. Survey No. 217, 1908, p. 10.

2 Darton, N. H., A reconnaissance of parts of northwestern New Mexico and northern Arizona: Bull. U. S. Geol. Survey No. 435, 1910. pp. 12-13. 


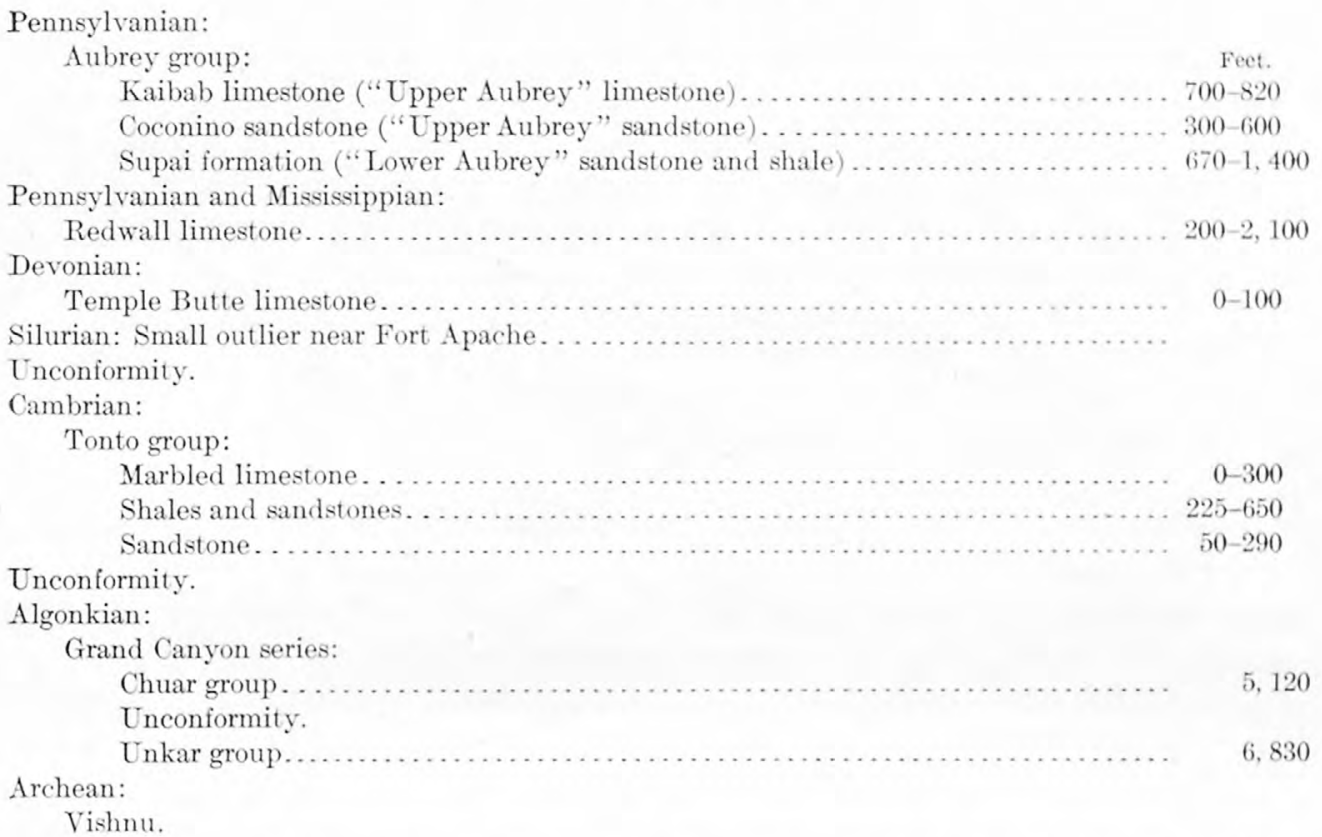

An examination of the preceding sections shows that on lithologic character there can be no very close correlation of the San Francisco section as a whole with the others studied.

The Harrington formation has a general lithologic resemblance to the Ankareh shale, Thaynes limestone, and Woodside shale of the Big Cottonwood section, and as they contain similar fossils there is good evidence for considering them as equivalent.

The Elephant limestone, immediately underlying the Harrington formation, corresponds in position to the Park City formation, but the fossil evidence indicates that it may be older and that it is separated from the Harrington formation by an unconformity.

The Talisman quartzite corresponds in stratigraphic position with the Weber quartzite in the northern part of the State, but has only a fraction of the thickness of that formation. It is possible, however, that the quartzite formation at this horizon thins toward the south and that the relatively thin Talisman quartzite of the San Francisco region corresponds with the much thicker Weber quartzite to the north.

The Topache limestone apparently corresponds with the Mississippian limestone to the north and the Mowitza shale with the Jefferson (Devonian) limestone.

Below the Nowitza the lithologic correlation seems less definite, as there appears to be at the north no quartzite that corresponds closely with the Morehouse quartzite. The Red Warrior limestone, Morehouse quartzite, and Grampian limestone are, however, probably the equivalent of the Silurian, Ordovician, and possibly part of the Cambrian sediments of the northern sections.

The section in Beaver Canyon given by Lee appears to correspond with the upper part of the section in the Star district.

SUMMARY.

In the San Francisco and adjacent districts sedimentation went on from Ordovician and possibly from Cambrian time to the Triassic. No conspicuous erosional unconformities have been recognized, but probably there were periods of nondeposition. The Ordovician rocks include most or all of the Grampian limestone and probably a part at least of the Morehouse quartzite, represented in the San Francisco and Star ranges. The presence of Silurian rocks has not been determined by fossil evidence, but if present they include part of the Red Warrior limestone and possibly part of the Morehouse quartzite. The Devonian is represented by the Mowitza shale and possibly by part of the underlying Red Warrior limestone. The Carboniferous rocks 
include the Topache limestone, the Talisman quartzite, and the Elephant limestone. Triassic sedimentation is represented by the Harrington formation.

The only consolidated beds younger than the Triassic exposed in the district are the conglomerate beds in Copper Gulch. These beds lie unconformably on the eroded surface of the monzonite and appear to be conformable with the overlying alluvial sediments. They are older than the Lake Bonneville beds, which were laid down upon the lower part of the alluvial deposits. Both the consolidated and unconsolidated portions of the pre-Lake Bonneville alluvial deposits are probably of Pleistocene age, as Gilbert ${ }^{1}$ considers the Lake Bonneville beds to be late Pleistocene, and these alluvial beds were doubtless deposited immediately before the Lake Bonneville beds. Lake Bonneville shore deposits are present in the Milford and Preuss valleys, but the only deposits within the area mapped are the gravel beds half a mile northwest of Newhouse.

Recent sediments are being deposited over the intermountain areas and cover a large portion of the area mapped.

\section{IGNEOUS ROCKS.}

EFFUSIVE ROCKS.

AREAL EXTENT

Effusive, extrusive, or volcanic rocks are formed from material that has reached the surface of the earth from deep-seated sources, as molten lava, and has either spread out as lava flows or been blown into small fragments by expanding gases and settled down on the surface of the earth as volcanic tuffs.

Effusive rocks are exposed over about 35 square miles of the area here discussed. Large areas that are represented on the geologic map as recent sediments are undoubtedly underlain at no great depth by voleanic rocks. In fact, there seems little doubt that the entire area lying between the San Francisco Range to the west and the Beaver Lake and Star ranges to the east is occupied by extrusive rocks. These rocks are exposed along the western border of this area, where an eastward dipping of the flows and erosion of the upturned portions have exposed the lower members of the volcanic series.

This series is composed of tuffs and flows, varying in texture from glassy obsidian to rocks that are so filled with phenocrysts that they have a holocrystalline appearance, and in composition from rhyolites to olivine basalt. The basalts, however, are probably considerably later in age than the main series. In general the more acidic rocks form the lower exposed portion of the lavas and the upper members are more basic. This is not entirely true, however, as dacite and andesite are found near the base of the series as exposed in the southwestern part of the area.

The several flows have the form of lenses of varying thickness from place to place, and each flow is not present in all parts of the area. The lower rhyolitic tuff is apparently more uniformly present-over the area than the higher members. The lowest member of the volcanic series exposed forms the hills in the extreme southwestern portion of the area mapped. This member consists of thick flows of coarse porphyritic dacite with some interbedded flows of andesite, the whole having a thickness of several hundred feet. Overlying these rocks are rhyolitic tuffs with interbedded rhyolitic flows. This member is made up of weak rock and its ready erosion has resulted in the area of low relief lying between the two northeast-southwest ridges in the southwestern part of the region. The rhyolite tuff is overlain by a succession of dacite and rhyolite flows having a total thickness of probably several thousand feet. The latest volcanic rock in the area is a thin sheet of basalt.

As the lower members of the volcanic series are usually exposed only on steep slopes, where the outcrops of the different members form bands so narrow that it is practically impossible to map them on the scale of 1 inch to the mile, and in other places extreme alteration has made differentiation uncertain or impossible, and as no definite association between the different members of the volcanic series and the ore deposits was discovered, it seemed inadvisable to

1 Gilbert, G. K., Mon. U. S. Geol. Survey, vol. 1, 1890, p. 397. 
attempt a separate mapping of the several closely similar divisions, and the entire volcanic series is shown on the map in one color. A description of the different members follows.

RHYOLITE TUFF.

The rhyolite tuff is most extensively exposed in the vicinity of Frisco, both east and west of the town, and has been employed to a considerable extent as a building stone, the Horn Silver offices and the Frisco Hotel being built of this rock. It is well exposed in Carbonate Gulch east of the Carbonate mine, and here and there in the gulches for 2 miles north of the Carbonate mine. Several outcrops of tuff in the hills south of Squaw Springs Pass, in the low areas between ridges, probably represent the same member. There are several other small areas of tuff in this part of the district similar to that about Frisco, but no bed was traced continuously and the several exposures appear to be at different horizons. One exposure occurs where the road leading southwestward from the Horn Silver mine crosses the low divide, and there is another small exposure southeast of this one, on the northwestern slope. Though these rocks closely resemble the tuff near Frisco, they are apparently at a higher horizon.

The tuff exposed about Frisco is a light-gray rock containing numerous fragments of dark lava and pumice. The matrix inclosing these fragments is glassy, with phenocrysts of feldspar, quartz, and biotite. The degree of induration varies greatly within short distances. In several localities the rock is sufficiently hard to be used as a building stone in this arid climate; in others it is so soft that it can be shoveled almost like sand. The mound of soft white material west of Frisco, in which numerous "dugouts" were excavated in the early days of the camp, is composed of tuff that has suffered alteration by heated solutions and later has undergone surface weathering. Under the microscope the rock (specimen 30) is seen to contain phenocrysts of orthoclase, quartz, and acidic plagioclase (oligoclase to andesine), with a few foils of strongly pleochroic biotite and some iron ore, in a groundmass of glass in places showing incipient crystallization. Phenocrysts form but a small percentage of the rock, and it is therefore impossible to state definitely the composition from the microscopic study, but it seems probable that this rock falls in the rhyolite family. Specimen 32, obtained east of the Carbonate mine, is similar to the one just described, except that it contains fewer fragments and less crystalline material. Specimen 53, obtained $1 \frac{1}{4}$ miles southeast of Frisco, is similar to the rock first mentioned, except that it contains numerous fragments of obsidian. An exposure in the southwest corner of the district is composed very largely of fragments of lava in a matrix that appears to be similar to those described above.

In the low hills one-fourth of a mile southeast of the Frisco railroad station are exposed beds of fine stratified tuff's of a dark-gray color interbedded with the lavas. These, however, are not present in other parts of the region and appear to be later in age than the tuffs deseribed in the preceding paragraph.

A series of lava flows overlies the tuffs and forms in a large part of the area the lowest exposed member of the volcanic rocks. These flows vary considerably in texture and thickness of beds. As exposed in the ridges east of Friseo, the thin-bedded lava is a dark reddish-brown rock containing scattered phenocrysts of quartz and feldspar. Small gas carities are rather abundant, but there are no large ones. A few thin beds have a black obsidian groundmass with scattering phenocrysts. All the thin-bedded lavas show pronounced flow structure.

Microscopically the fine lava (specimen 20) is seen to contain phenocrysts of orthoclase, plagioclase, and quartz, with a few foils of biotite, in a glassy groundmass. The plagioclase crystals have index $\beta$ about 1.54 and extinction in 010 of $-10^{\circ}$ to $-12^{\circ}$. Some crystals have index $\beta$ distinctly above 1.54. This indicates a feldspar about intermediate between albite and oligoclase, with some oligoclase. The small amygdaloidal cavities contain a mineral with low refraction and birefringence, probably chabazite. The rock is rhyolitic in character and probably similar to the tuff in composition, though weathering has produced in it abundant coloration with iron salts, little of which is seen in the weathered tuffs.

A partial analysis, by George Steiger, of a specimen of the thin-bedded lava taken from the hills east of Frisco gives the chemical composition shown on page 46. 
Partial analysis of thin-bedded lava from hills east of Frisco, Utah.

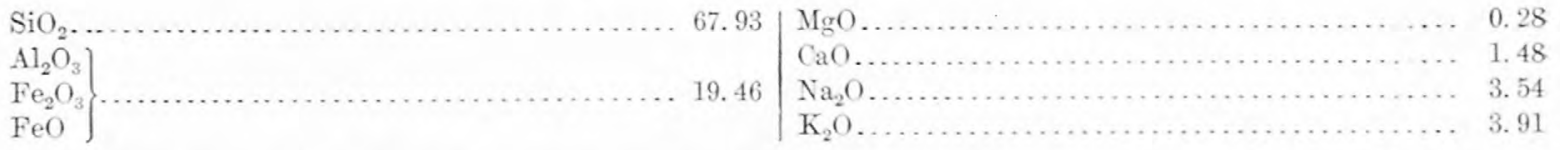

It is impossible to calculate accurately the mineral composition from this partial analysis, and as a large percentage of the rock is in the form of glass it can only be assumed what minerals would be present were it crystallized. The essential mineral constituents of a crystalline rock of this character would be in about the following proportions: Quartz, 31; orthoclase molecule, 22 ; albite molecule, 30; anorthite molecule, 7 ; biotite and hornblende, 3 . Potash is less abundant in this rock than in normal rhyolite, but the plagioclase feldspar is distinctly alkali and the rock may therefore be classed as rhyolite or soda rhyolite.

The thick-bedded lavas are similar to those just described in color, though this varies in both rocks with the amount of weathering and oxidation of iron-bearing minerals. Phenocrysts of feldspar are abundant, and there are a few crystals of biotite. Flow structure is much less pronounced than in the thin-bedded rocks, in places being detected only on rather careful examination. Lava of this type is well exposed in the ridge northwest of Coyote Springs, where it overlies the thin-bedded lavas.

The coarser lava (specimen 22) contains phenocrysts of andesine, orthoclase, and quartz, the andesine being the most abundant, with numerous pseudomorphs after biotite and hornblende and a few small crystals of pyroxene. The glassy groundmass is filled with microscopic feldspar laths.

A partial analysis of the rock (specimen 27), by George Steiger, gives the following chemicaI composition:

$$
\text { Partial analysis of dacite from San Francisco district, Utah. }
$$

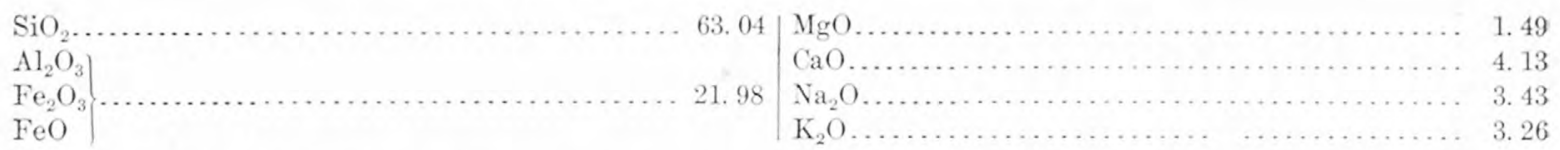

The probable ratio of the essential minerals in a crystalline rock of this composition may be calculated approximately as quartz, 21; orthoclase molecule, 18; albite molecule, 28; anorthite molecule, 16; hornblende and mica, 9. The rock is distinctly higher in lime than a normal rhyolite. On the assumption that all the soda and lime are present in the form of andesine, the ratio of plagioclase to orthoclase is 44 to 18 . The rock, therefore, has the composition of dacite.

The hills farthest to the west in the area south of Squaw Springs Pass contain several lenses of andesite distinctly more basic than the rhyolite and dacite inclosing them. These rocks are dark gray in color and contain prominent and abundant hornblende phenocrysts. The microscope shows them to be composed of phenocrysts of hornblende and acidic plagioclase, mostly andesine, in a glassy groundmass filled with microscopic feldspar laths. Iron ore is rather abundant. The higher and more western of these hills is composed of a coarsergrained heavy-bedded rock of dacitic composition, resembling that forming the high hills to the east described below. The lowest member exposed is rhyolitic tuff, which outcrops at the western base of the hills about $1 \frac{1}{2}$ miles north of the southern border of the area mapped.

The high hills southeast of Squaw Springs are composed of heavy beds of highly porphyritic rock. These beds have a northeasterly strike and form the outer series of low hills east of Frisco and north of the railroad. Some of the beds strongly suggest intrusive sheets, but for none of them has such an origin been definitely proved. The rock contains numerous phenocrysts of feldspar and a few of quartz, hornblende, and biotite in a fine crystalline groundmass. The microscope shows phenocrysts of orthoclase, plagioclase, quartz, hornblende, and biotite in a groundmass composed largely of untwinned feldspar and quartz. Feldspar phenocrysts are abundant, orthoclase and acidic plagioclase (andesine and oligoclase) being about equal in amount. Many of the crystals show intergrowths of orthoclase and plagioclase. 
Quartz phenocrysts are rare. Hornblende and biotite form but a small percentage, the former being the more abundant. In the groundmass feldspar is considerably more abundant than quartz. Most of the crystals are too small for definite determination but are orthoclase and plagioclase with index below balsam, albite, and acidic oligoclase. Apatite and iron ore are rather plentiful accessories. Alteration is slight except in the ferromagnesian minerals, which have undergone strong magmatic resorption. Both biotite and hornblende are surrounded by areas of augite and iron ore, and many of the smaller crystals have been entirely altered to these minerals or are represented by secondary iron ore. Only part of the beds have a holocrystalline groundmass. In the others the groundmass is composed in part of glass, though the abundance of phenocrysts gives the rock a holocrystalline appearance.

A partial analysis of the holocrystalline rock (specimen 49), by George Steiger, gives the following composition:

Partial analysis of quartz latite from San Francisco district, Utah.

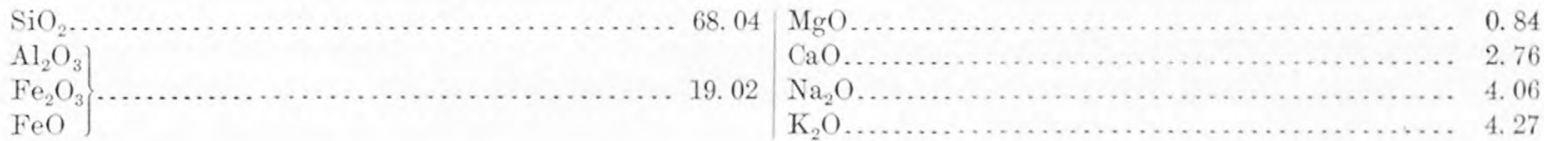

The essential minerals of a rock of this composition may be calculated approximately as follows: Quartz, 21; orthoclase molecule, 25; oligoclase, 44 (albite molecule, 34; anorthite molecule, 10); biotite and hornblende, 7 .

It is seen that in chemical composition and in the probable mineral composition of the crystalline rock this rock falls between the rhyolite and dacite already described and may be classed as quartz latite, latite being the name used to designate flow rocks intermediate in composition between andesite and trachyte, and quartz latite being used to designate flow rocks intermediate in composition between rhyolite and dacite.

Interbedded with these heary flows are a few beds of glassy rhyolitic lavas showing pronounced flow banding and also beds of rhyolitic tuff. The former are well exposed in the valley about $1 \frac{1}{2}$ miles a little east of south of the Horn Silver mine, and the tuffs are exposed in the road crossing the hills southeast of the Horn Silver mine. Neither is sufficiently crystalline to permit a determination of their composition from microscopic study, but both are rhyolitic in character and probably similar in composition to the massive beds, the difference in crystallization being due to the different conditions under which the rocks cooled. The massive beds, cooling slowly, were in some parts holocrystalline, but the thin beds and tuffs, which cooled rapidly, are composed largely of glass.

The eastern foot of the San Francisco Mountains is buried under flows of basaltic lava, but in the northwestern part of the Star district, in the low hills northwest of the Shauntie road and nearly due west of the Harrington-Hickory mine, the basalt has been removed by erosion, exposing a dense dark-gray to nearly black rock containing phenocrysts of hornblende and feldspar in a cryptocrystalline groundmass. The rock underlies the basalt and possibly forms the highest member of the earlier volcanic flows.

Microscopically this rock is seen to be porphyritic, containing crystals of plagioclase (andesine to labradorite), hornblende, and augite, in a fine groundmass of andesine laths and unstriated feldspar. Iron ore is abundant, and there are a few crystals of apatite. Some of the feldspar phenocrysts contain irregular crystals of augite. The hornblende crystals show strong resorption bands of iron ore; in the smaller crystals resorption has been complete. Chlorite, calcite, and epidote are present as secondary minerals.

A partial analysis of the rock (specimen 148), by R. C. Wells, gave the following composition:

Partial analysis of latite from San Francisco district, Utah.

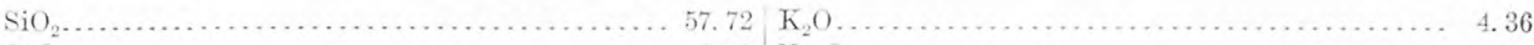

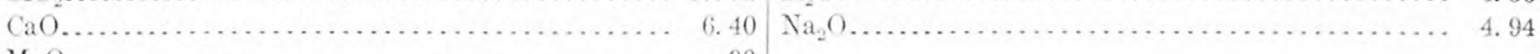

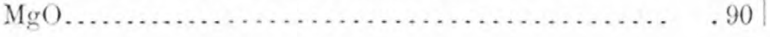


A part of the lime is present as calcite and some of the magnesia as chlorite. The probable mineral composition of the fresh rock may be estimated from the above analysis and microscopic study to be about as follows: Orthoclase molecule, 26; oligoclase-andesine, 62 (albite molecule, 42; anorthite molecule, 20) ; hornblende and augite, 6; iron ore, accessory minerals, and water, 6. Plagioclase with an average composition of acidic andesine is far in excess of orthoclase. Free silica is not present and the rock falls between typical andesite and latite.

The rocks exposed in the vicinity of Shauntie are rhyolites and dacites similar to those already described. A specimen taken at the base of the small conical hill one-fourth of a mile northeast of Shauntie is distinctly rhyolitic in character, containing abundant phenocrysts of quartz and orthoclase with a lesser number of acidic plagioclase in a cryptocrystalline groundmass of quartz and unstriated feldspar. Only a few small foils of biotite were present in the thin section examined. The higher beds to the north and west are more basic, some of them being distinctly andesitic in character, containing phenocrysts of andesine, augite, and hornblende or pseudomorphs after hornblende crystals in a fine groundmass of feldspar whose character could not be definitely determined.

The lavas forming the central portion of the Beaver Lake Mountains are of rather uniform character so far as can be judged from the areas of comparatively unaltered rock found in different portions of the district. A large part of these lavas have undergone so profound alteration that it is impossible to determine their original character, and in fact it is only by carefully following the gradation to less-altered portions that it is possible to determine whether the original rock was volcanic or sedimentary. In the ridge half a mile west of the $\mathrm{O} K$ mine and portions of the ridge next to the west, and to a less extent in other parts of the area, the rock has the appearance of an altered quartzite and was at first so considered. This lava can be traced northward on the ridge northwest of the $\mathrm{O} \mathrm{K}$ mine, where it becomes less altered and can be recognized as a tuffaceous rock. A similar gradation is found in other parts of the district. A more detailed account of this alteration will be found in the section on metamorphism (p. 78).

The freshest rock is a dark greenish-gray porphyry containing irregular feldspar crystals and pseudomorphs of ferromagnesian silicates. Under the microscope the phenocrysts (specimen 187, obtained near the prospect $1 \frac{1}{4}$ miles north of the $\mathrm{O} \mathrm{K}$ mine) are seen to be oligoclase and albite (most of the crystals tested have index $\beta$ below 1.54 , though a few were above and are acidic andesine), together with some orthoclase and pseudomorphs of ferromagnesian minerals, in a fine groundmass of plagioclase laths, orthoclase, and quartz. Plagioclase is the more abundant feldspar in the phenocrysts, but an accurate estimate of the relative abundance of the different feldspars in the groundmass is not possible. The ferromagnesian minerals are replaced by iron ore, quartz, and in some crystals muscovite. Some crystals have rims of iron ore and centers similar to the groundmass of the rock. Quartz is not abundant.

A partial analysis by R. C. Wells of specimen 187 gives the following composition:

Partial analysis of dacite from San Francisco district, Utah.

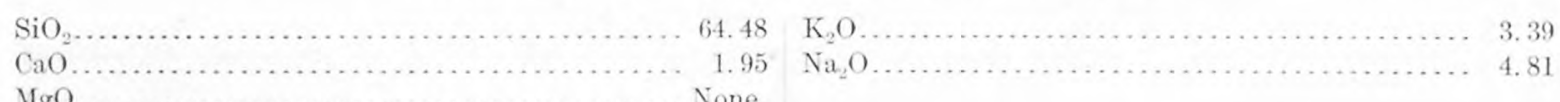

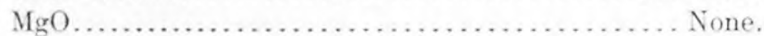

It is evident from the analysis and from microscopic study that the magnesium originally contained in the ferromagnesian minerals has been removed and that considerable alteration has taken place in the other minerals. It is therefore impossible to calculate the original composition of the rock, but the ratio of quartz and feldspar may be estimated approximately as quartz, 20; orthoclase molecule, 20; albite-oligoclase, 50 (albite molecule, 40; anorthite molecule, 10). It is evident from the chemical and mineral composition of this rock that it falls in the granodiorite family, and as it is a flow rock it is classed as dacite.

The main body of the lavas exposed in the western part of the Beaver Lake district is similar to the less-altered rock of the central mass. The ferromagnesian minerals have been entirely altered, but the feldspars are comparatively fresh. The composition is similar to that 
of the lavas in the central portion. In the extreme northwestern portion of the district are several outcrops of a fresh light-colored rhyolitic rock, apparently underlying the dacite and exposed by erosion. This rock contains rather abundant phenocrysts of feldspar, quartz, hornblende, and biotite, in a groundmass of glass that forms the larger part of the rock. Orthoclase and plagioclase are both present, but the latter is distinctly in excess. It has the optical properties of andesine.

No analysis was made of the rock, but so far as can be judged from the phenocrysts it is similar in composition to the other volcanic rocks of the district and is probably dacite or possibly basic rhyolite. A small area of tuff similar in composition to the flow rock is associated with one of the outcrops.

BASALT.

A thin sheet of basalt covers the area between the lava hills forming the eastern flank of the San Francisco Range and the Beaver Lake and Star ranges to the east. To the west it extends for a short distance up the slope of the tilted flows but is entirely removed from the higher portions, though some basaltic bowlders were found in the low valley south of Squaw Springs pass in the San Francisco Range. To the east it is largely covered by recent deposits, but scattered outcrops indicate that it is present over the area as stated.

The rock is a typical black basalt, in places so filled with gas cavities that it has a spongelike appearance, but at other points, probably lower in the flow, it is comparatively massive. The cavities are as a rule partly filled with a white carbonate. Phenocrysts of feldspar, augite, and olivine can be recognized in the hand specimen. Under the microscope the rock is seen to be composed of phenocrysts of plagioclase, augite, and olivine in a groundmass of the same minerals. Iron ore is abundant and small apatite crystals are numerous. A few zircon crystals were noted. The feldspar of the groundmass is a basic andesine; the phenocrysts are labradorite. Feldspar forms about 75 per cent of the rock. Augite and olivine probably form 20 per cent, olivine being about one-fourth as abundant as augite. Alteration is slight. The olivine crystals are clouded with iron oxide, but the fibrous serpentine characteristic of olivine alteration is not abundant.

\section{COMPOSITION.}

In order that the lavas of the district may be more readily compared, the chemical and probable mineral composition are shown in the following tables together with those of typical effusive rocks from other localities:

\section{Chemical analyses of lavas.}

\begin{tabular}{|c|c|c|c|c|c|c|c|}
\hline & 1 & 2 & 3 & 4 & 5 & 6 & 7 \\
\hline 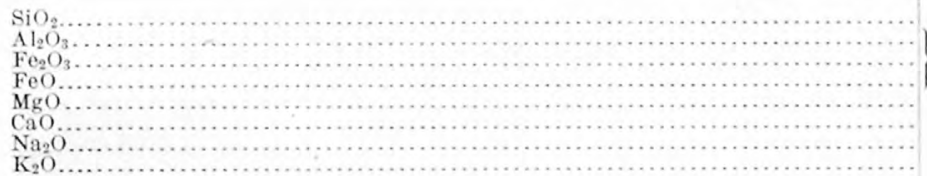 & $\begin{array}{r}68.04 \\
19.02 \\
\begin{array}{r}84 \\
2.76 \\
4.06 \\
4.27\end{array} \\
4\end{array}$ & $\begin{array}{r}67.93 \\
12.46 \\
.25 \\
1.42 \\
3.54 \\
3.91\end{array}$ & $\begin{array}{r}64.48 \\
\text { None. } \\
1.95 \\
4.81 \\
3.39\end{array}$ & \begin{tabular}{r|r}
63.04 \\
21.98 \\
1.49 \\
4.13 \\
3.43 \\
3.26
\end{tabular} & $\begin{array}{r}57.72 \\
.90 \\
6.40 \\
4.94 \\
4.36\end{array}$ & $\left\{\begin{array}{r}59.43 \\
16.68 \\
2.54 \\
3.45 \\
1.84 \\
4.09 \\
3.72 \\
5.04\end{array}\right.$ & $\begin{array}{r}66.46 \\
17.91 \\
2.42 \\
0.35 \\
0.49 \\
2.89 \\
4.79 \\
3.74\end{array}$ \\
\hline
\end{tabular}

Probable mineral composition of crystalline rock.

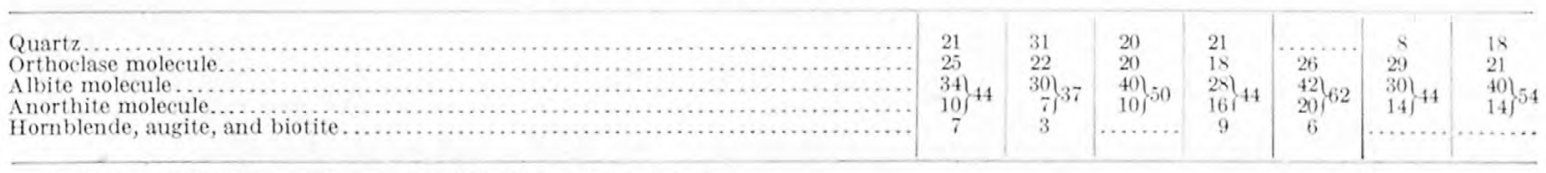

1. Heavy-bedded lava southeast of Squaw Springs (specimen 49).

3. Lava from prospect $1 \frac{1}{4}$ miles north of $\mathrm{O} \mathrm{K}$ mine (specimen 187).

4. Lava northwest of Carbonate mine (specimen 22).

5. Lava from northwestern part of Star district (specimen 148).

6. Augite latite, Dardanelle flow, Tuolumne County, Cal. Ransome, F. L., Am. Jour. Sci., 4th ser., vol. 5, 1898, p. 363

7. Dacite, Bald Mountain, Rosita, Colo. Cross, Whitman, Seventeenth Ann. Rept. U. S. Geol. Survey, pt. 2, 1896, p. 324.

A comparison of the analyses given in the table shows that the rocks are very similar in composition and, though the variation is sufficient to warrant different names they are believed $73363^{\circ}-$ No. $80-13-4$ 
to be of essentially the same age and might well be considered under a collective name. In composition they are intermediate between rhyolite and andesite, or the flow rock corresponding to granodiorite. The flow equivalent of granodiorite has, however, never been given a distinctive name and these rocks may be classed as quartz latite. Latites as defined by Ransome "are mineralogically closely related to ordinary andesites, but chemically they stand between the andesites and trachytes. They are higher in alkalies than the andesites. The potash is generally in excess of soda and, in the particular rocks described, is present chiefly in the unindividualized glass, where no biotite is present." If the rock contains considerable quartz, it is designated quartz latite.

The rocks of the San Francisco and adjacent districts are in general higher in silica than the type latite (analysis 6 ) and in general lower in magnesium, calcium, and potash. No. 5, however, is high in lime and may well be classed as a true latite, though it is on the boundary between latite and andesite.

RELATIONS TO OTHER ROCKS.

The volcanic rocks are plainly younger than the consolidated sedimentary rocks of the district, lying unconformably on them where the contact is not due to faulting.

The relation to the quartz monzonite is not everywhere apparent. It is most clearly shown in the Rocky Range, where numerous dikes of quartz monzonite can be traced directly from the main mass into the flow rocks and the granodiorite associated with them.

In the San Francisco district there are small areas of quartz monzonite porphyry, surrounded by volcanic rocks, that have the appearance of intrusive bodies, though on account of poor exposures of the contact positive evidence on this point was not procured. A careful search along the contact of the quartz monzonite and the lavas failed to discover any dikes that could be traced directly from the intrusive into the extrusive rock, but the porphyritic character of the monzonite on the point extending toward the Carbonate mine indicates a contact facies, as would be expected if it were intrusive into the lavas. The presence of rather abundant specularite at points along the contact is suggestive of contact alteration. Though the evidence of intrusion is not conclusive, the existing conditions are most readily explained by that assumption.

In the Beaver Lake district also the relation of the two types is not readily seen. In general the rock at the contact has the appearance of a lava that has flown over an erosional surface. The small bodies of quartz monzonite present all along the contact of the limestone and lavas in the western part of the district, however, suggest strongly that the quartz monzonite has been intruded along this contact, for it would be an unusual accident of erosion that would expose this relation. Moreover, as is shown in the section on alteration (p. 78), the nature of the alteration of the lavas indicates that it took place under conditions of considerable heat and pressure, which can be readily accounted for by considering the quartz monzonite as intrusive. The evidence as a whole indicates that the intrusive rocks are later than the extrusives. This is certainly true in the Rocky Range and there is no reason for believing that the lavas of that range are older than those of the neighboring range and although the evidence in other parts of the district is not conclusive it points to a similar relation. Nothing was noted that is inconsistent with this interpretation except the lack of dikes extending from the quartz monzonite into the overlying rocks, which certainly seems rather remarkable.

\section{INTRUSIVE ROCKS.}

AREAL EXTENT,

Intrusive rocks cover considerable areas in each of the districts here discussed, and they are of especial interest and importance, as it is within or closely associated with them that the ore deposits occur.

The large bodies of intrusive rocks occur as stocks breaking through the older formations and sending out dikes for short distances from their margins. Dike rocks of later age than the stocks have been intruded into them and other formations of the district. 
The intrusive stocks are of two ages. The earlier granodiorite porphyry is exposed principally between the Rocky Range and the eastern portion of the Beaver Lake Mountains; the later quartz monzonite stocks are present in each of the districts.

\section{GRANODIORITE PORPHYRY.}

Definition.-Granodiorite is a granular rock intermediate in composition between quartz diorite and quartz monzonite. Granodiorite porphyry is the porphyritic intrusive rock of the same composition. Lindgren ${ }^{1}$ defines granodiorite as follows:

Under the term granodiorite are included light-colored granular rocks composed of quartz, oligoclase or andesine, orthoclase, biotite or hornblende or both, titanite, magnetite, apatite, and zircon. * * * The truly characteristic feature of the granodiorites is that the soda-lime feldspar, which always is a calcareous oligoclase or an andesine, is at least equal to double the amount of the alkali feldspar. The latter may be taken to vary from 8 per cent to 20 per cent. Below the lower limit the rock becomes a quartz diorite; above the upper, a quartz monzonite.

Location and extent.-Granodiorite forms a smaller stock exposed in the low hills lying between the Rocky Range and the Beaver Lake Mountains. It possibly extends to the eastern part of the Beaver Lake Mountains, but owing to the intense alteration of the earlier rocks the granodiorite can not everywhere be differentiated from the lavas of this district. There are probably small masses in the lavas of the Rocky Range, but these are not readily recognized and accurate mapping is not possible.

General character.- The granodiorite porphyry is a dark, fine-grained porphyritic rock of dioritic appearance. It varies considerably from place to place, the porphyritic crystals being few at some points and abundant at others. It was possibly intruded in considerable amounts into the lavas of the Rocky Range, but the two rocks are so similar in character that a separation is practically impossible.

Petrographic features.-As already stated, the rock in different parts of the area differs considerably in appearance. Specimen 163, from the prospect north of Hickory, apparently belongs to this type and is a dark greenish-gray rock of fine texture in which only plagioclase laths and crystals of hornblende can be recognized with the unaided eye. Under the microscope the rock is seen to be composed of phenocrysts of plagioclase and hornblende in a fine groundmass of plagioclase, unstriated feldspar, biotite, augite, and a little quartz, with rather abundant iron ore and apatite. The plagioclase is andesine ranging from medium to basic. The dark silicates are abundant, forming fully 25 per cent of the rock. Plagioclase is distinctly more abundant than orthoclase. This specimen has essentially the composition of diorite.

Specimen 169, from the low hill just north of the road about midway between Hickory and the $\mathrm{O} \mathrm{K}$ mine, in general aspect is very similar to the rock just described though slightly lighter in color and less basic in appearance. The phenocrysts are plagioclase, ranging from oligoclase to acidic andesine; the groundmass consists of quartz, orthoclase, acidic plagioclase, biotite, homblende, and pyroxene. Iron ore is rather abundant and there are many very small crystals of apatite with a few large irregular masses. Quartz forms fully one-third of the rock and the dark silicates form fully 20 per cent, biotite being the most abundant. It is difficult to estimate the relative proportions of orthoclase and plagioclase, but the latter is probably considerably in excess. The composition of the rock is that of a granodiorite approaching quartz monzonite.

About one-fourth of a mile east of the Harrington-Hickory mine a small body of dark porphyritic rock outcrops as a low hill entirely surrounded by recent sediments. The main body of the hill is a gray porphyritic rock in which phenocrysts of feldspar and the dark silicates are abundant. Smaller masses apparently intrusive into the main body are greenish gray in color and of rather uniform fine grain. Rock of this type is exposed in the prospect pit on the southwest side of the hill. Under the microscope the specimens of the porphyritic rock examined were seen to be highly altered and its original mineral composition can not be definitely stated. The plagioclase crystals show rather low extinction and are probably oligoclase and acidic andesine, though on account of their altered condition definite determination is not possible.

${ }_{1}$ Lindgren, Waldemar, Am. Jour. Sci., 4 th ser., vol. 9, 1900, pp. 274-277. 
Pseudomorphs of secondary minerals after hornblende and biotite are plentiful, those after hornblende being the more abundant, and some pseudomorphs appear to be after pyroxene, though these are not so definitely recognized. The fine groundmass is made up of plagioclase, untwinned feldspar, and quartz, with alteration products from the dark silicates. Iron ore and apatite are plentiful. The fine-grained rock is rather similar to the porphyritic type in composition, though it shows a considerable decrease in the dark silicates. Remnants of hornblende and pyroxene crystals are present, but no unaltered biotite was seen in the section examined. The rock is more siliceous than the porphyritic type.

This rock is distinctly more acidic in character than the dikes observed in the Star district and in general character and composition is more closely allied to the granodiorite porphyry of the Rocky Range. Though it can not be stated positively to which period the rock belongs, its general character indicates that it is probably of the same age as the granodiorite.

Relation to other formations. - The main mass of the granodiorite contains intrusive bodies of the quartz monzonite and is plainly older than that rock. Nowhere was it positively identified cutting the sedimentary rocks, though a rock that is possibly connected with the granodiorite but may be a basic phase of the quartz monzonite has produced contact alteration where it cuts the limestone north of Hickory. What appear to be dikes of the granodiorite are present in the lavas of the Rocky Range, and it is believed to be younger than the flow rocks.

\section{QUARTZ MONZONITE.}

DEFINITION.

Monzonite is a granular plutonic rock intermediate in composition between syenite and diorite. Mineralogically it is composed of about equal amounts of orthoclase and plagioclase feldspar, together with one or more of the dark silicates hornblende, biotite, and pyroxene. With the addition of quartz it passes into quartz monzonite, intermediate between granite and granodiorite.

LOCATION AND EXTENT.

The quartz monzonite forms a large stock in the San Francisco Range, covering several square miles in extent. In the Beaver Lake Mountains two large bodies are exposed, separated by volcanic rocks at the surface, though probably united in depth. With the probable extension of these bodies under the recent sediments the areal extent is several square miles. A comparatively small body of this rock is exposed in the Rocky Range, but this also probably has a considerably greater extent than is evident at the surface, the lower portions being buried under the recent sediments.

In the Star district quartz monzonite forms several comparatively small stocks in the northern part of the district and a large body in the southern part, just south of the area included in the geologic map.

\section{GENERAL CHARACTER.}

As will be seen in the following descriptions, the rock mapped as quartz monzonite in this area varies from granodiorite or even quartz diorite to granite. These facies are not separated because it is impossible to make the distinctions in the field, where in individual stocks the transition is gradual and the appearance very similar. The different rocks are believed to have been derived from the same magma and to have been intruded at the same period. They are very similar in mineral and chemical composition and are therefore represented by the same color on the geologic map, though some specimens differ sufficiently in composition to warrant their classification under different rock names.

QUARTZ MONZONITE OF THE CACTUS AREA.

Extent.-The quartz monzonite of the Cactus area, in which the Cactus mine is located, is as exposed a roughly pear-shaped mass that has been intruded into the earlier rocks. Its greatest dimension is from east to west, the small end pointing east. It is a little over 3 miles in greatest length and a little less than 3 miles in width from north to south. An arm projects 
southward from the main mass between the limestone and lavas and in the limestone toward the Horn Silver mine. The total area exposed is about $6 \frac{1}{4}$ square miles.

Petrographic features.-The rock of the Cactus area differs considerably in texture in different parts of the mass, though the transition is usually readily traced and the general similarity in mineralogic composition makes it possible to connect the different types with certainty. The separation of the quartz monzonite and the lavas, however, is in places less certain. For example, along the contact between the quartz monzonite and the lavas extending northward from Indian Grave Peak both rocks have suffered considerable and in places intense alteration; both are characterized by phenocrysts of feldspar, and in the altered condition it is difficult and in some places impossible to locate the exact contact.

The typical rock of the central portion of the mass is well exposed east of Newhouse. Fresh specimens of this rock can be obtained from the dump of the working tunnel of the Cactus mine. It is a dark-gray medium-grained rock, in which the main mineral constituents ean be readily determined with the unaided eye. Both orthoclase and plagioclase can be recognized, though their relative amounts can not be determined in the hand specimen. Quartz is not conspicuous, but with the aid of a lens it can be recognized in small grains. Of the dark minerals hornblende and biotite are readily recognized. The former, in irregular green crystals, is by far the more abundant; the latter, in dark-brown to black flakes and nearly perfect crystals, is sparingly sprinkled through the rock. Yellowish-brown resinous grains of titanite are noticeable, and the rather abundant iron ore is readily detected in the powdered rock by the use of an ordinary hand magnet.

Toward the margins of the stock the quartz monzonite is usually finer grained and porphyritic. This fine texture, however, does not appear to be confined entirely to contact types, as the ridge west of Indian Grave Peak is composed of a fine uniform-textured rock, though too remote from the contact, it would seem, to have been greatly affected by the adjacent rocks. The porphyritic type is well shown in the point extending to the east, where all of the rock is fine grained and much of it is distinctly porphyritic. On the southern margin of the stock, however, there is very slight change of texture in the monzonite near the limestone contact.

In composition, as in texture, there is considerable variation toward the contact, though in many places no perceptible change occurs as the contact is approached. North of the Cactus mine the dark minerals are considerably more abundant near the contact and the rock has the appearance of a diorite. At the summit of the main ridge the rock also appears distinctly more basic near the contact, containing a larger percentage of mica. At this point alteration has been so great that no fresh material could be obtained for comparison. As the contact between quartz monzonite and lava is approached there appears to be no pronounced change in composition of the intrusive, and the same is true of the intrusive contact along the southern border of the mass, where the quartz monzonite retains its normal composition.

A type of rock which occurs in small bodies in Copper Gulch and other parts of the mass and which grades into the normal quartz monzonite is distinguished by a pinkish color, due to the presence of more abundant pink orthoclase feldspar, and a distinct decrease in the dark minerals. The mica occurs usually in very small erystals and is not readily detected unless the rock is closely examined. No definite boundary between this rock and the normal type was determined in the field, though the rock appears to be intermediate between the normal monzonite and the acidic aplitic dikes to be described later.

Microscopic features. - Specimen 109, from the Cactus tunnel, is a medium-grained granitic rock composed of plagioclase, orthoclase, hornblende, quartz, and pyroxene, with iron ore, titanite, and apatite as accessories. The plagioclase for the most part is an andesine of medium basicity, showing extinction on 010 of $-4^{\circ}$ to $-10^{\circ}$. Feldspar fragments immersed in liquid with an index of 1.549 showed that index $\beta$ of most of the plagioclase ranged slightly above and below 1.549, indicating an adesine with composition $\mathrm{Ab}_{2} A n_{1}$. A few crystals have the optical characters of acidic labradorite. Carlsbad twinning is common in the plagioclase and some crystals show zonal structure, though this is not usually very marked. A few crystals show a 
tendency toward microperthitic intergrowth of plagioclase and orthoclase. The feldspars form considerably more than 50 per cent of the rock.

Hornblende is the most abundant of the dark silicates. It is green, showing pleochroism, a pale green, $\mathfrak{h}$ apple-green, $\mathfrak{r}$ green-yellow, $c \wedge \mathfrak{r}=14^{\circ}-18^{\circ}$. It occurs usually in irregular areas presenting no crystal outline, though in a few places it has distinct crystal form with twinning on 100. Many of the crystals exhibit an alteration that evidently took place before the complete solidification of the rock. Certain of the hornblende crystals contain colorless irregular grains of augite and fine grains of magnetite which appear to have been formed from the hornblende as a result of magmatic conditions that rendered that mineral unstable. They are not confined to the margin of the crystals, however, as is common with resorption phenomena. Biotite occurs in small crystals and flakes showing pleochroism from straw-yellow to dark brown. It is considerably less abundant than the hornblende. Quartz, the latest mineral to crystallize, is interstitial and forms about 15 per cent of the rock. Fluid inclusions and negative crystals are abundant in the dark silicates. Apatite and titanite are both plentiful, the latter occurring in rather large irregular areas and only rarely in the characteristic wedgeshaped crystals. A few crystals of zircon were noted, but these are rare. Magnetite is rather abundant.

Specimen 5, the fine-grained type east of Indian Grave Peak, differs from that first described chiefly in containing more biotite and a very slight amount of hornblende. Augite does not differ greatly in amount, but is associated with biotite and appears to have resulted from the alteration of that mineral rather than from hornblende. Some of the augite crystals that are not associated with biotite may have crystallized direct from the magma. In this type the plagioclase ranges from acidic andesine to labradorite, the average being andesine with a composition approximately of $\mathrm{Ab}_{3} \mathrm{An}_{2}$, as determined by extinction angle. Quartz forms fully 20 per cent of this rock. In addition to the accessory minerals mentioned as occurring in the other rocks, there are a few crystals of rutile associated with some of the biotite crystals.

Specimen 134, obtained near the contact of the granodiorite and andesite about a mile west of Coyote Spring, shows a more basic composition than the normal rock. The essential minerals are plagioclase, orthoclase, pyroxene, iron ore, and biotite, with apatite and sphene as accessories. The ratio of plagioclase to orthoclase is considerably greater than in the normal rock. There is some irregular intergrowth of orthoclase and plagioclase and some microperthite is present. Pyroxene, the chief dark silicate, is a green variety showing distinct pleochroism. The margins are usually deeper green and extinguish at a slightly higher angle. In some crystals the centers are nearly colorless augite. The optical character is positive, with optical angle nearly $90^{\circ} ; b \wedge \mathbf{r}=36^{\circ}$. This indicates an augite approaching ægirite-augite. There are a few crystals of a mineral showing a rather strong pleochroism, a yellow, $\mathfrak{h}$ greenish yellow, $\mathfrak{r}$ chocolate-brown. This is optically positive, with small optical angle. The material did not permit a definite determination of this mineral. Biotite occurs as small crystals associated with magnetite in irregular areas. These appear to have resulted from the resorption of larger crystals. Hornblende was not recognized in the rock, and only a few small quartz crystals were noted.

Some of the contact types are even more basic than the one just described and are probably true diorite in composition. These, however, are usually rather highly altered, and their original composition was not definitely determined.

The pink facies of Cactus Gulch (specimen 104) contains the same minerals as the normal quartz monzonite, though the relative amounts differ considerably from those of the type already described. Orthoclase is more abundant and quartz forms a higher percentage of the rock, while the dark silicates are somewhat lower. These, as in the normal type, are hornblende, augite, and biotite. Augite is relatively more abundant. Some of the crystals are free from hornblende, but have the mottled appearance and included grains of iron ore characteristic of the augite which appears to have resulted from the alteration of hornblende. The later stages of crystallization of this magma appear to have been favorable to the formation of 
pyroxene; the formation of hornblende either ceased or some of that already formed changed to pyroxene. Biotite was less affected by the changing conditions of the magma.

Composition.-An analysis by George Steiger of specimen 109 from the Cactus tunnel gives the following composition:

Analysis of quartz monzonite from San Francisco district, Utah.

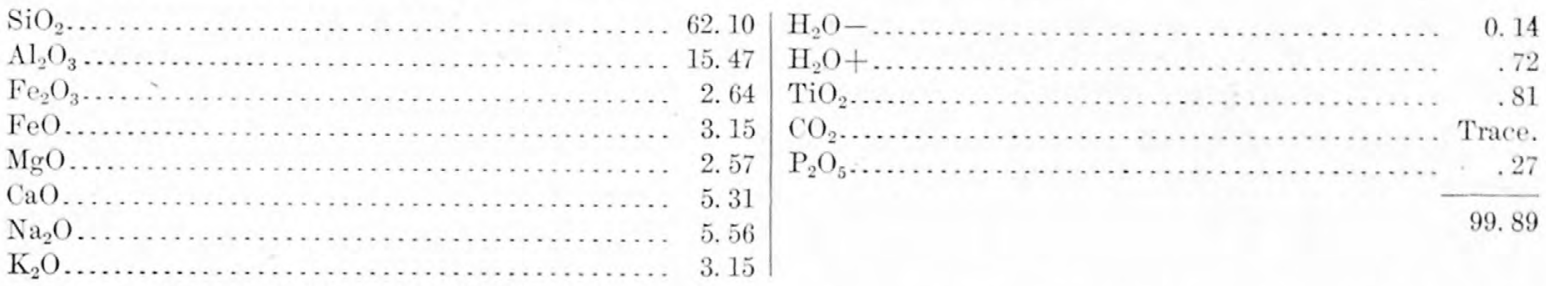

In calculating the mineral composition from the analysis, the averages of several analyses of biotite and hornblende from rocks of similar chemical composition were taken to represent these minerals in the rock. These averages are as follows:

Average compo ition of biotite and hornblende in quartz monzonites and quartz diorites.

\begin{tabular}{|c|c|c|c|c|}
\hline & \multicolumn{2}{|c|}{ Biotite. } & \multicolumn{2}{|c|}{ Hornblende. } \\
\hline & Per cent. & $\begin{array}{l}\text { Molecular } \\
\text { proportion. }\end{array}$ & Per cent. & $\begin{array}{l}\text { Molecular } \\
\text { proportion. }\end{array}$ \\
\hline 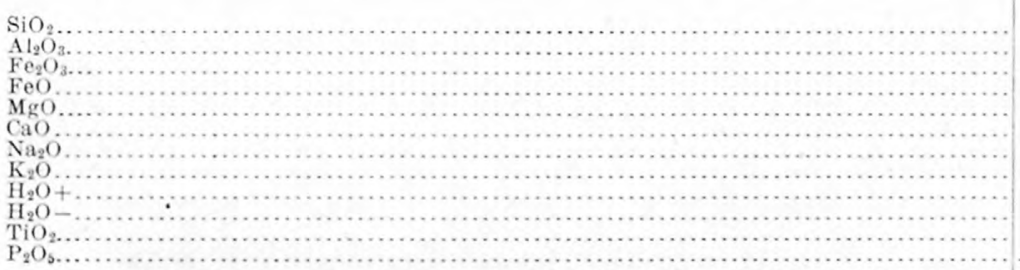 & $\begin{array}{r}35.72 \\
14.55 \\
4.55 \\
13.82 \\
12.40 \\
.39 \\
.36 \\
8.67 \\
3.88 \\
1.06 \\
3.09\end{array}$ & $\begin{array}{r}0.595 \\
.143 \\
.030 \\
.192 \\
.130 \\
.007 \\
.006 \\
.092 \\
.217 \\
.039\end{array}$ & $\begin{array}{r}46.61 \\
6.92 \\
4.91 \\
10.54 \\
12.69 \\
11.59 \\
.76 \\
.85 \\
2.07 \\
.36 \\
1.32 \\
.17\end{array}$ & $\begin{array}{l}0.777 \\
.068 \\
.031 \\
.146 \\
.317 \\
.207 \\
.012 \\
.009 \\
.111 \\
.015 \\
.001\end{array}$ \\
\hline
\end{tabular}

The biotite, as shown by the analyses, is very close to the molecule $2\left((\mathrm{~K}, \mathrm{H})_{2}(\mathrm{Al}, \mathrm{Fe})_{2} \mathrm{O}_{3}\right.$. $\left.2 \mathrm{SiO}_{2}\right)+3\left(2(\mathrm{Mg}, \mathrm{Fe}) \mathrm{O} \cdot \mathrm{SiO}_{2}\right)$, the ratios of the components being as follows: $\mathrm{K}: \mathrm{H}:: 1: 2.25$, $\mathrm{Al}: \mathrm{Fe}^{\prime \prime \prime}:: 4.76: 1, \mathrm{Mg}: \mathrm{Fe}^{\prime \prime}:: 1.61: 1$. The hornblende molecule is close to the composition $\mathrm{Ca}(\mathrm{Mg}, \mathrm{Fe})_{2}\left(\mathrm{SiO}_{3}\right)_{3}$, with $\mathrm{Na}_{2} \mathrm{Al}_{2}\left(\mathrm{SiO}_{3}\right)_{4}$ and $(\mathrm{Mg}, \mathrm{Fe})(\mathrm{Al}, \mathrm{Fe})_{2} \mathrm{SiO}_{6}$, the isomorphous molecules being in the ratio $9: 1: 3 \frac{2}{3}$.

From the section it was estimated that biotite formed about 5 per cent of the rock. By calculating about 5 per cent of biotite and the remainder of the magnesium as hornblende, both of the composition given above, the following mineral composition is obtained for the rock:

Wineral compo ition of quartz monzonite from San Francisco district, Utah.

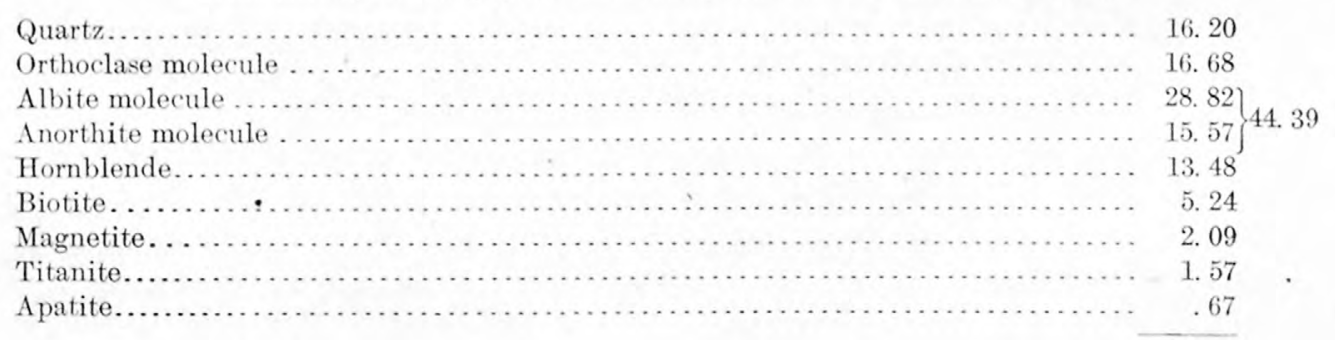

100. 00

This does not take into account the small amount of pyroxene present, but otherwise it is believed to approximate very closely the actual mineral composition and to be essentially that which would have resulted if changing physical conditions had not interfered with the final crystallization of hornblende and altered it, to a slight extent, to pyroxene and magnetite. 
The ratio of the orthoclase to the plagioclase molecule is about $16: 44$. The rock is about on the dividing line between quartz monzonite and granodiorite. Rocks of essentially the same composition as this have been placed in each of the above classes by different authors. In defining granodiorite Lindgren ${ }^{1}$ gives the following limits in mineral composition:

Granodiorite, a member of the great family of rocks with predominating soda-lime feldspars, is distinguished by a granular texture, grayish color, and a mineral composition of quartz, oligoclase or andesine, orthoclase or microcline, hornblende or biotite (usually both), the accessories being titanite, apatite, magnetite, and zircon. The quartz may average 23 per cent, the soda-lime feldspars 44 per cent, the orthoclase (with microcline and albite) 14 per cent, varying from 8 per cent to 20 per cent, the ferromagnesian silicates 14 per cent.

The rock would fall within these limits and might therefore properly be classed as granodiorite, but as it has already been called quartz monzonite and is in composition quite as near quartz monzonite as granodiorite, the writer prefers to retain the name already established for it.

QUARTZ MONZONITE OF THE BEAVER LAKE AREA.

Areal extent.- The quartz monzonite of the Beaver Lake district occurs chiefly in two stocks. The larger one of these lies in the northeastern part of the district, its southern boundary following Butch Canyon. To the east it is covered by recent wash but is doubtless connected with the quartz monzonite range in the northeast corner of the district. To the west a narrow strip of quartz monzonite is exposed between the limestone and the lavas. The northern boundary is formed by the limestone. This stock as exposed is about $2 \frac{1}{2}$ square miles in areal extent, but including the part buried beneath recent wash it is much larger. The second stock is in the southeast corner of the district. The area exposed is about $1 \frac{1}{2}$ square miles, but this stock also is known to be of much greater areal extent, its extension to the south being established by prospect shafts sunk through the débris which buries the flanks of this range. The extent of the buried portion is impossible to determine, but it is doubtless fully as great as the area exposed.

The northern mass is a medium-grained granitic rock, in which plagioclase, orthoclase, hornblende, biotite, and quartz are readily recognized in the hand specimen. Under the microscope, in addition to these, are seen iron ore, titanite, apatite, zircon, and rutile.

Petrographic features. - Specimen 182, obtained just north of the prospects in Butch Canyon, is considered to be typical of this mass. Orthoclase forms a larger percentage of this rock than of the typical quartz monzonite of the Cactus area. The plagioclase varies in composition from oligoclase to labradorite, though most of it falls within the limits of andesine. Hornblende is considerably more abundant than biotite, the two forming about 15 per cent of the rock. The hornblende is the green pleochroic variety already described as present in the quartz monzonite of the Cactus area. It contains inclusions of magnetite, together with a little biotite and unstriated feldspar. The biotite is also the same as that already described but contains numerous included crystals of zircon and some fine highly birefringent needles which are probably rutile. Quartz forms fully 15 per cent of the rock. Titanite and apatite are less abundant in this rock than in that of the Cactus area.

A specimen from the ridge in the northwestern part of the area is in every respect similar to the rock just described, except that the percentage of biotite is slightly higher. The monzonite of the southeastern part of the district is distinctly finer grained, though the essential minerals are readily recognized in the hand specimen. The mineral composition, as seen in a specimen taken from the Beaver-Harrison dump, is similar to that of the rock just described, except that the dark silicates are less abundant and quartz correspondingly increased. Hornblende is greatly in excess of biotite, the latter being represented only by scattered crystals.

A specimen taken from the $\mathrm{O} \mathrm{K}$ vertical shaft shows a distinct increase in the amount of quartz and a slight decrease in the relative amount of orthoclase. The rock, however, is similar to the others. There is little doubt that the two masses were derived from a common source.

1 Lindgren, Waldemar, Am. Jour. Sci., 4th ser., vol. 9, 1900, pp. 281-282. 
Composition.-Analyses, by R. C. Wells, of the rocks from the Beaver-Harrison dump and from the vertical shaft of the $\mathrm{O} \mathrm{K}$ mine give the following composition:

Analyses of quartz monzonite from Beaver Lake district, Utah.

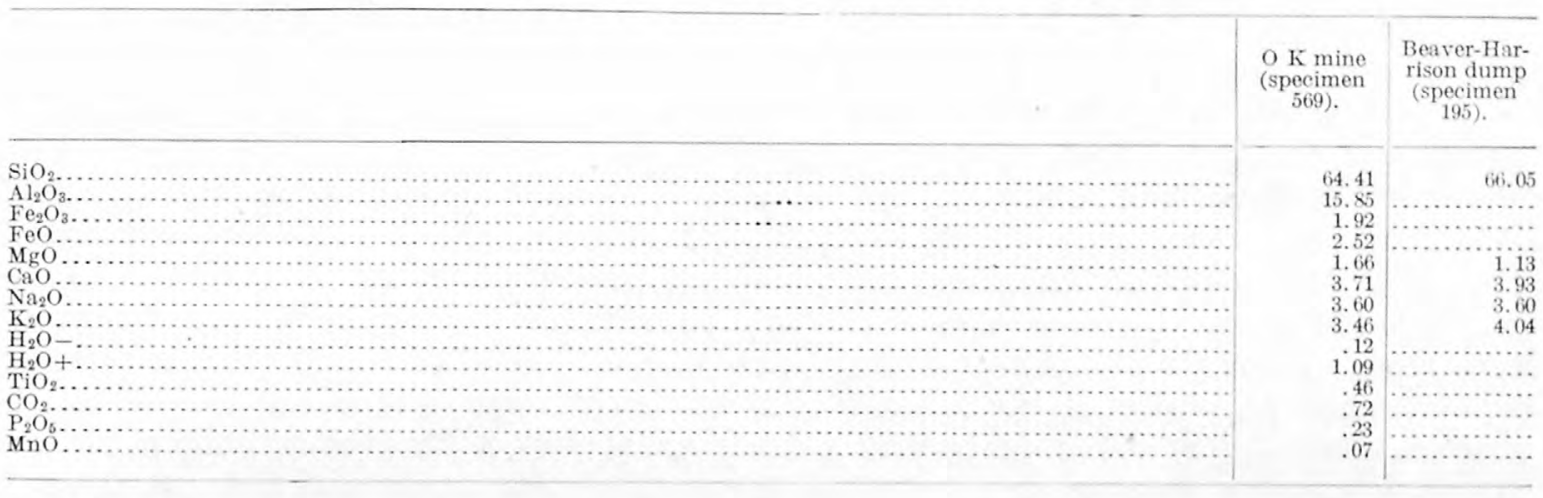

These analyses, calculated on the same basis as that employed for the quartz monzonite of the Cactus area (p. 55), give the following mineral composition:

Mineral composition of quartz monzonite from Beaver Lake district, Utah.

\begin{tabular}{|c|c|c|}
\hline 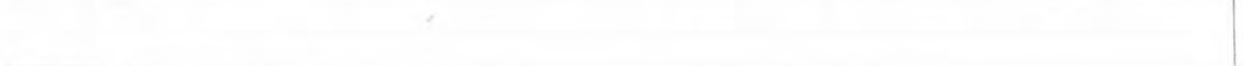 & O K. & $\begin{array}{l}\text { Beaver-Har- } \\
\text { rison. }\end{array}$ \\
\hline $\begin{array}{l}\text { Quartz } \\
\text { Orthociase molecule } \\
\text { Albite molecule } \\
\text { Anorthite molecule } \\
\text { Hornblende }\end{array}$ Bow & \begin{tabular}{r|r|}
23.16 \\
16.12 \\
29.87 \\
10.56 \\
4.70 \\
7.76 \\
2.87 \\
.59 \\
.34 \\
1.60 \\
1.59
\end{tabular} & 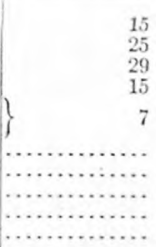 \\
\hline
\end{tabular}

These rocks are slightly less basic than the quartz monzonite of the Cactus area and are nearer in composition to the typical quartz monzonite.

QUARTZ MONZONITE OF THE ROCKY DISTRICT.

The quartz monzonite of the Rocky district forms the northern half of the Rocky Range and extends along the western portion to the southern end, where it is present in small stocks and dikes in the sedimentary rocks. The rock is similar in mineral composition to that of the southern part of the Beaver Lake district, though it is coarser and in general has suffered greater alteration. Dikes of the quartz monzonite cutting the earlier rocks show a decrease in the dark minerals and an increase in feldspar, quartz remaining about constant. In the sections examined titanite and apatite were both more abundant in the dikes than in the body of monzonite.

QUARTZ MONZONITE OF THE STAR DISTRICT.

The intrusive rocks in the Star district occur in three main areas and several smaller bodies. Of the three main masses, one forms the northern extension of the Star Range north of the Harrington-Hickory mine, another occupies the southeastern part of the district, and the third is in the southwestern part of the district.

In the northern area the base of the range is buried in recent sediments, separating it into several isolated hills at the north, but there is slight doubt of the continuity of the mass beneath the surface.

The rock in the main mass is a rather fine grained granitic rock, light gray on the exposed surfaces but usually having a pink tinge on fresh fracture, due to the unaltered pink orthoclase. 
Phenocrysts are not abundant within the mass, though scattering crystals of feldspar and augite are present. Toward the contact the rock becomes distinctly porphyritic, and in many places the phenocrysts form a large percentage of it. In the hand specimen feldspars, hornblende, and biotite are readily recognized; quartz is not conspicuous, but on close examination, especially with the aid of a pocket lens, it is seen to be rather plentiful. A few crystals of titanite can be detected with the naked eye.

A typical specimen (No. 151) from the main mass 1 mile north of the Harrington-Hickory mine is composed of orthoclase, plagioclase, quartz, augite, biotite, iron ore, and hornblende, with apatite, sphene, and rutile. Orthoclase appears to be nearly as abundant as plagioclase. Some of the few phenocrysts are andesine, and this also occurs in the groundmass. Several crystals have a center of plagioclase, acidic andesine, or oligoclase, surrounded by a zone of unstriated feldspar. Microperthitic intergrowths of orthoclase and plagioclase are of common occurrence. Interstitial quartz constitutes about 15 per cent of the rock. Ferromagnesian minerals form probably not more than 10 per cent, augite and biotite being about equal in amount, while only a few crystals of hornblende are present in the section examined. The augite is a nearly colorless variety, though some crystals are light green with faint pleochroism. Biotite shows the same characteristics as that in the other areas described. Iron ore is abundant, apatite and titanite are rather plentiful, and two crystals of rutile were noted.

Specimen 141, obtained close to the contact near the Rebel mine, contains large phenocrysts of feldspar in a fine groundmass. The percentage of plagioclase is somewhat higher than in the rock just described, and biotite is much more abundant than augite, only a few crystals of the latter being present in the section. Small crystals of zircon are plentiful. In brief, this phase differs from the body of the rock in having a pronounced porphyritic texture, being slightly more basic, having biotite as the principal dark silicate, and showing some decrease in the amount of iron ore.

The conical hill or knob near the intersection of the Frisco and Hickory roads is composed of a fine-grained aplitic rock consisting largely of feldspar and quartz. Under the microscope this rock is seen to be porphyritic, containing phenocrysts of feldspar and a few crystals of biotite and augite. Most of the feldspar phenocrysts are orthoclase, though there are a few of oligoclase and some microperthite. The groundmass is composed of a micropegmatitic intergrowth of quartz and orthoclase. Iron ore is rather plentiful. The accessory minerals are titanite, apatite, and zircon. The rock appears to have originated from the same source as the main mass to the south, as is shown by the close resemblance of the augite and biotite. It is, however, far more acidic, approaching an alaskite in composition, and rather closely resembles the aplitic dikes described on page 61.

In several places in this intrusive mass, notably on the east face of the ridge, about $1 \frac{1}{2}$ miles north of the Harrington-Hickory mine, there are dark lenticular masses inclosed in the gray quartz monzonite. These vary in greatest dimension from a few inches to fully 20 feet. On exposure they show a strong tendency to spheroidal weathering, in consequence of which the bowlders found in the float are usually round and readily peel off in concentric flakes. The rock is rather coarse in texture and dark gray in color. Feldspar and pyroxene are the only minerals readily detected in the hand specimen. Under the microscope (specimen 155) it is seen to be a porphyritic rock with rather fine groundmass. The phenocrysts are plagioclase, augite, and hornblende, with a few crystals of biotite. The groundmass is orthoclase, hornblende, augite, biotite, and quartz, with a little plagioclase. Iron ore is abundant throughout the rock, and apatite is plentiful, while there are but few crystals of titanite. The feldspar phenocrysts are labradorite for the most part, with a few of andesine; the feldspar of the groundmass is largely orthoclase. The two feldspars are about equal in amount and form approximately 60 per cent of the rock. The augite is nearly colorless, with a slight greenish tinge; some crystals have a margin of green pleochroic hornblende. In the groundmass the augite is in colorless microseopic crystals. Hornblende occurs in small grains in the groundmass. It is rather strongly pleochroic, a yellowish green, tr olive-green, $\mathfrak{r}$ dark green, $c \wedge \mathfrak{r}=13^{\circ}$ (average). Biotite is confined to the groundmass. It is the same strongly pleochroic variety that is present in most 
of the rocks described. Of the ferromagnesian silicates augite and hornblende are about equal in amount and biotite is much less abundant; together they form about 25 per cent of the rock. Quartz is interstitial and forms about 5 per cent of the rock. Iron ore is abundant. This rock has the same mineral components as the inclosing rock, with a higher percentage of ferromagnesian silicates and a slightly larger amount of plagioclase, which is considerably more basic. The mineral composition and the field relations suggest that these masses have resulted from a segregation of the basic elements in the magma. Similar masses of larger size are exposed in the intrusive mass west of the Old Hickory mine, in the Rocky Range.

A partial analysis of a specimen (No.151) from the central part of the mass, by R. C. Wells, gives the following composition:

Partial analysis of quartz monzonite from the Star district, Utah.

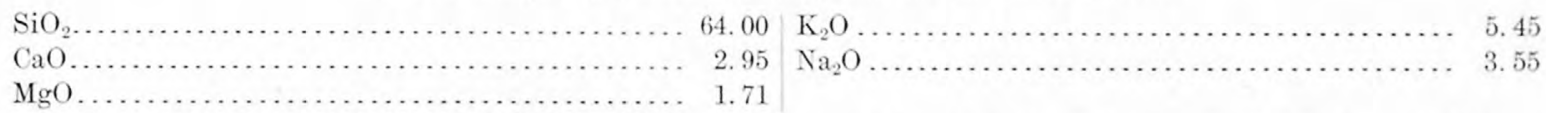

Calculated from the chemical analysis, the approximate mineral composition is as follows: Quartz, 14; orthoclase molecule, 31; albite molecule, 30; anorthite molecule, 10; biotite, augite, and hormblende, 11. In this rock orthoclase and plagioclase approach equality in amount; the rock is lower in quartz than the typical granite and is classed as quartz monzonite.

The rock in the southwestern part of the district is in every way similar to that already described, being distinctly granitic in character though varying somewhat in composition, that near the Hub mine being considerably more acidic than the rock farther to the south in the main body of the intrusive mass. Some of the specimens collected from the intrusive mass in the southeastern part of the district are more basic than those described above and contain distinctly more plagioclase feldspar than orthoclase. There is little doubt, however, that the rocks of the several masses are derived from the same parent magma, the differences noted being due to differentiation of this magma.

COMPARISON OF ANALYSES.

The following table groups the several analyses of quartz monzonites from the San Francisco and other districts. An average analysis of granodiorite and one of quartz monzonite are given for comparison:

Analyses of quartz monzonite from the San Francisco and adjacent districts, Utah.

\begin{tabular}{|c|c|c|c|c|c|c|}
\hline 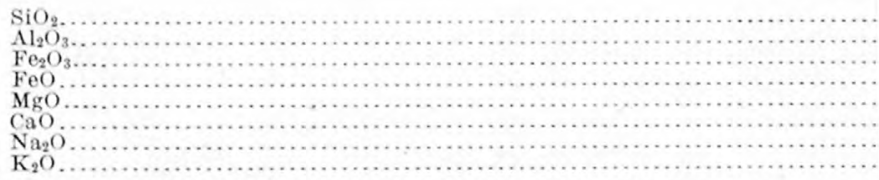 & $\begin{array}{r}62.10 \\
15.47 \\
2.64 \\
3.15 \\
2.57 \\
5.31 \\
3.56 \\
3.15\end{array}$ & $\begin{array}{l}66.00 \\
\cdots \cdots \\
\cdots \\
1.13 \\
3.93 \\
3.60 \\
4.04\end{array}$ & $\begin{array}{l}64.00 \\
\cdots \cdots \\
\cdots . . . \\
1.71 \\
2.95 \\
3.55 \\
5.45\end{array}$ & $\begin{array}{r}64.41 \\
15.85 \\
1.95 \\
2.52 \\
1.66 \\
3.71 \\
3.60 \\
3.46\end{array}$ & $\begin{array}{r}65.00 \\
16.00 \\
1.50 \\
3.00 \\
2.00 \\
5,00 \\
3.50 \\
2.25\end{array}$ & $\begin{array}{r}65.70 \\
15.31 \\
2.54 \\
1.62 \\
1.62 \\
2.56 \\
3.62 \\
4.62\end{array}$ \\
\hline
\end{tabular}

Approximate mineral composition.

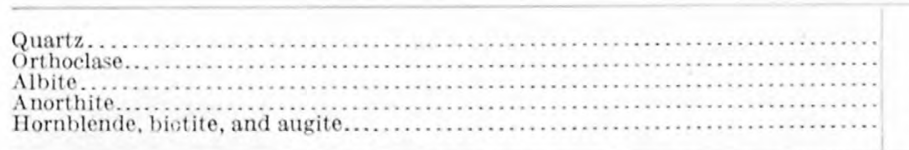

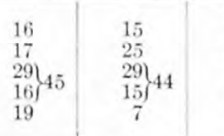

14
31
30
$10\}$
11

23
16
29
$10\}^{2}$
12 39

\begin{tabular}{l|l}
23 & 19 \\
14 & 27 \\
44 & 30 \\
14 & $12 j^{4}$ \\
14 & 8
\end{tabular}

1. Quartz monzonite of Cactus area, San Francisco district.

2. Quartz monzonite of Beaver Lake district.

3. Quartz monzonite of star district.

4. Quartz monzonite of $\mathrm{O} \mathrm{K}$ vertical shaft, Beaver Lake district.

5 verage composition of granodiorite, Lindgren, Waldemar, im. Jour Sci., 4th ser., vol. 9, 1900, p. 269.

6. Quartz monzonite, San Miguel Peak, Telluride, Colo. Cross, Whitman, Telluride folio (No. 57), Geol. Atlas U. S., U. S. Geol. Survey, 1899 , p. 6.

It is evident from the above table that the rocks are on the border line between granodiorite and quartz monzonite. The Cactus intrusive mass is within the limits assigned to granodiorite, the Beaver Lake mass is about on the border of granodiorite and quartz monzonite, and the Star mass is distinctly a quartz monzonite. 
DIKE ROCKS.

Varieties.-Dike rocks of at least two distinct ages are present in the district. Dikes of the quartz monzonite extend from the stocks into the adjacent rocks, and more basic dikes cut the quartz monzonite stocks and the other formations. Aplitic dikes are also present in the quartz monzonite.

Quartz monzonite dikes.-Quartz monzonite dikes are present in the rocks adjacent to all the stocks of quartz monzonite. Many of them can be actually traced from the quartz monzonite masses into the adjoining rocks, leaving no doubt that they are portions of the quartz monzonite material that was forced into fissures in the surrounding rocks at the time the stocks were intruded. These dikes vary considerably in texture, the larger ones resembling the porphyritic facies of the quartz monzonite. The smaller dikes are usually highly altered and their original composition is not always determinable, though some of them are more siliceous than the main body of the quartz monzonite.

One-fourth of a mile northwest of Frisco are several irregular outcrops of porphyritic quartz monzonite strongly resembling the porphyritic rock in the eastern part of the main mass. The rock is holocrystalline, with granitic texture in the groundmass, and is apparently intrusive. The essential minerals are plagioclase, orthoclase, quartz, and pyroxene, with a little biotite. The sections examined appear to contain rather more orthoclase than the main body of the quartz monzonite, but otherwise the two are very similar in composition. The general relations as seen in the field suggest that these rocks represent intrusions into the volcanic rocks, and although intrusive masses have not been traced directly from the quartz monzonite into the lavas it is believed that these masses are offshoots from that rock. The absence of dikes near the contact is, however, remarkable if the lava is earlier than the quartz monzonite.

More basic porphyritic dikes.-Small porphyritic dikes varying considerably in composition but distinctly more basic than the main eruptive masses are present in all the districts and cut both the sedimentary rocks and the intrusive stocks. They are especially abundant in the quartz monzonite of the Cactus area in the vicinity of Copper Gulch. Several of these dikes are exposed in the valley east of the tunnel portal and also in Copper Gulch. An especially prominent dike outcrops on the ridge on the north side of Copper Gulch about one-fourth of a mile north of the point where the roads branch at the entrance to the gulch. The dike is more resistant than the surrounding rock and stands out as a ridge. As will be seen from the following descriptions the dikes range from porphyritic dikes not differing greatly from the quartz monzonite in composition to dikes of the lamprophyre type, in which the dark silicates are very abundant. The dike one-eighth of a mile southeast of the portal of the Cactus tunnel (specimen 110) is a gray rock containing rather abundant phenocrysts of feldspar with a much less number of biotite and one of the other dark silicates. Under the microscope the phenocrysts are seen to be oligoclase-andesine, biotite, and pseudomorphs of serpentine and chlorite after hornblende, and possibly pyroxene, in a fine groundmass of plagioclase, orthoclase, and biotite, with chlorite and serpentine, which probably represents the alteration of hornblende and augite; a little quartz is also present. Iron ore is plentiful and small crystals of apatite are abundant. The character of the plagioclase of the groundmass could not be definitely determined.

The proportion of the feldspars in the groundmass is also uncertain, but the phenocrysts are plagioclase. No fresh augite or hormblende is present, but there are perfect pseudomorphs after hornblende and irregular ones that may represent augite. Biotite is the most abundant of the ferromagnesian silicates. This is strongly pleochroie, being similar to that of quartz monzonite.

A partial analysis of specimen 110 by R. C. Wells gives the following composition:

Partial analysis of porphyritic dike rock from San Francisco district, Utah.

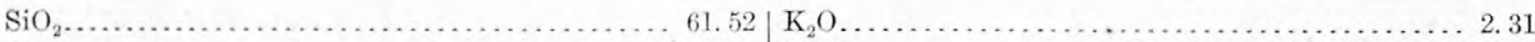

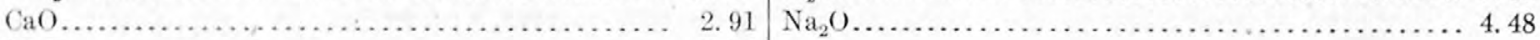

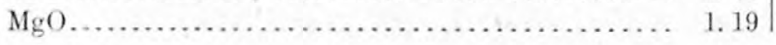


From this analysis the relative proportion of the principal minerals is calculated approximately as follows: Quartz, 19; orthoclase, 12; oligoclase, 51 (albite, 38; anorthite, 13); biotite and hornblende, 7 . The rock has the composition of granodiorite.

The prominent dike north of Copper Gulch has a composition similar to that given above.

Specimen 100 is from a small dike about one-fourth of a mile east of the limekilns on the Copper Gulch road. It is a dark-gray rock and shows pronounced basaltic jointing perpendicular to the dike walls. Very perfect crystals of augite are abundantly seattered through the rock. The hand lens shows a groundmass filled with crystals of biotite, but the other constituents can not be readily determined. Nicroscopically the rock is seen to contain phenocrysts of augite and biotite in a groundmass of andesine in radiating foils, orthoclase, biotite, augite, and a little hornblende, with abundant iron ore and fine needles that are probably apatite. The rock has the composition of kersantite.

A small dike just southeast of the mouth of the Cactus tumnel (specimen 113) is similar to the rock just described, though it is somewhat less basic, carrying free silica, and contains a notable amount of titanite as an accessory mineral.

Another small dike, similar in composition to those just mentioned, is exposed on the tunnel level of the Cactus mine, where it is seen to cut the ore body.

Small dikes are abundant in the quartz monzonite stocks of the Star district. In general they are dark greenish gray in color and vary considerably in texture, depending on the size. In the larger dikes feldspar phenocrysts are rather abundant and the feldspar and pyroxene crystals of the groundmass can be detected with the unaided eye. The smaller dikes, however, contain few phenocrysts and the minerals composing the rock can not be recognized in the hand specimen. One of the largest dikes observed (specimen 152) in the quartz monzonite cuts across the low hills just south of the Frisco road. The rock is dark grayish green and contains numerous irregular crystals of plagioclase. The groundmass is holocrystalline and feldspar crystals and one of the dark silicates can be readily detected. Under the microscope the phenocrysts are seen to be andesine and the groundmass to be composed of laths of andesine and augite, with abundant iron ore and a little apatite. Alteration is rather pronounced, sericite, carbonate, and epidote being present in the feldspar crystals and much of the augite being altered to serpentine and chlorite, with some epidote. The smaller dikes examined microscopically have a similar composition, though the alteration is more pronounced, the dark silicates being almost entirely changed to secondary minerals.

Dike rocks of a character similar to those just described are present in the sedimentary rocks of the San Francisco and Star ranges. In the San Francisco Range they are most abundant in the limestone to the south of the intrusive mass. They cut the limestone and shales in all parts of the Star district, but as they are small and usually greatly altered and more easily eroded than the limestone, they do not form prominent outcrops. All the dikes observed in the limestone are small and so altered that their original composition can not be determined.

In the dikes in Grampian Hill mineralization has followed along the same planes and so changed the dike rocks that in many places they can not be readily distinguished from the brecciated and altered limestone. In the fragments that have suffered least, however, porphyritic crystals having the outline of feldspar but entirely altered to a secondary mineral are seen. It is evident that correlation of material so highly altered with the other rocks of the district must be uncertain. The facts that small dikes of the quartz monzonite in the limestone near the contact and in Loeber Gulch are readily recognized and that no gradation of alteration to those above described was noted suggest that they are of different original composition and age. They are possibly of the same character as the dikes in the quartz monzonite but more highly altered.

Aplitic dikes. - Small aplitic dikes are numerous in the monzonite masses. Most of them are only a few feet in width at most and many are but a few inches, and they can be traced but a short distance along the strike. As seen in the hand specimens they are light-gray fine-grained rocks, apparently composed almost entirely of quartz and feldspar. Under the microscope they are seen to be composed essentially of orthoclase and quartz, with small amounts of acidic 
plagioclase and biotite. The accessory minerals are apatite, titanite, and rutile. The aplitic dike exposed in the bottom of the inclined shaft of the $\mathrm{O} K$ mine contains molybdenite and chalcopyrite. The molybdenite is in some places included in the feldspar crystals, and both sulphides appear to be original constituents of the rock. This relation is more fully discussed in the section on ore deposits (p. 136).

Dikes associated with the effusive rocks.-The belt immediately east of the San Francisco Range and north of Frisco, occupying the depression between the main range and the low volcanic hills to the east, is characterized by highly-altered lavas containing irregular masses of dark, slightly altered rock. Some of the less-altered masses are possibly portions of the lava that have been protected from the profound alteration which has affected the greater part of the lava in this belt, but several of them are distinctly coarser-grained than the lavas, and show a sharp boundary between the altered and fresh rock. These masses are of small areal extent and irregular in form, though usually roughly circular or elliptical. None of them was found to have an alignment that indicated the filling of a fissure; they rather have the appearance of small stocks or necks of intruded rock. The best examples of the larger bodies are seen in the low rounded hills three-fourths of a mile north of Frisco; smaller masses are numerous between the Carbonate and Frisco Contact mines and south of the latter.

The intrusive is dark, usually fine grained, containing phenocrysts of feldspar and, in the more coarsely crystalline types, of hornblende and biotite. A specimen (No. 11) from a mass one-fourth of a mile a little south of east of Indian Grave Peak is rather typical of the finegrained intrusive. It is a nearly black rock, containing numerous phenocrysts of feldspar and hornblende, with a few of biotite, in a fine groundmass in which the component minerals can not be recognized with the unaided eye. Under the microscope it is seen to contain phenocrysts of plagioclase (andesine to labradorite), hornblende, augite, and biotite. The groundmass is composed of laths of andesine and some small augite crystals. Fully one-half of the groundmass is too fine for definite determination. Hornblende is by far the most abundant of the dark silicates. It shows rather slight pleochroism from yellowish green to olive-green. Colorless augite and biotite are rather sparingly scattered through the rock, the biotite being strongly pleochroic from light yellow to dark brown. The hornblende and biotite show strong resorption bands of iron ore. Iron ore is also abundant as a primary mineral, making the rock rich in this constituent and strongly magnetic.

Specimen 15, from the dark hillock 1 mile due north of Frisco, near the wagon road, is a coarse type of the same rock. In it feldspar and hornblende phenocrysts are abundant, but the groundmass is still too fine for definite determination without the aid of the microscope. Under the microscope it is seen to have the same mineral composition as the rock just described. Biotite is less abundant, however, and the groundmass contains considerable unstriated feldspar.

Specimens from other parts of the belt are in general similar to those already described, although they vary somewhat in composition, some being more siliceous than those described.

A partial analysis by George Steiger of specimen 15, from the dark hillock 1 mile north of Frisco, gives the following composition:

Partial analysis of diorite intrusive in lavas north of Frisco, Utah.

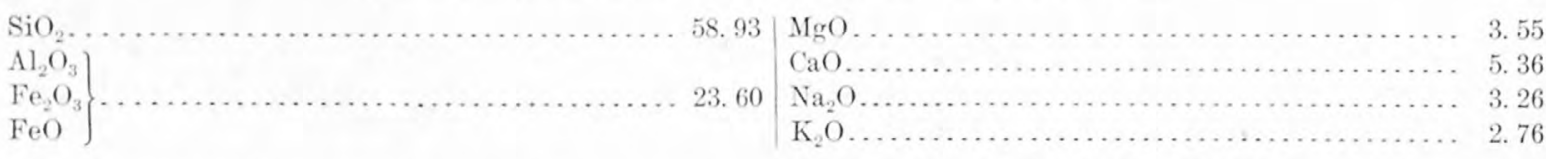

An accurate calculation of the mineral composition can not be made from this incomplete analysis, but from the microscopic examination and the analysis it can be determined that the rock has approximately the following composition: Orthoclase, 17; plagioclase, 43; hornblende, 25 ; and magnetite, 10 . This does not take into account small quantities of biotite and pyroxene and a little free silica that are present in the rock. The plagioclase is andesine, with the approximate ratio of $\mathrm{Ab}_{3} \mathrm{An}_{2}$. As indicated by this composition, the rock falls into the diorite family. Outcrops of a rather similar rock occur in the northern part of the area near Barrel Spring and 
Morehouse canyons and near the Golden Reef mine. The exposures are poor, and the relation to adjoining rocks was not determined. As seen in the field and under the microscope, the rock has more the appearance of lava than of an intrusive rock, though it can not be stated positively to which class it belongs.

RELATIONS OF THE INTRUSIVE ROCKS.

As already indicated, the intrusive rocks were formed at two distinct periods, and during one, and possibly both, of these periods material of different character was intruded at slightly different times. The relation of each type to the other rocks of the district is discussed below.

Quartz diorite porphyry stocks.-The quartz diorite porphyry stock between the Rocky Range and the Beaver Lake Mountains is probably the earliest intrusive rock of the district. As seen north of Hickory, it is intruded into the sedimentary rocks and has produced contactmetamorphic alteration of the limestone. It contains dikes of the quartz monzonite, and is therefore older than that rock. Its relation to the volcanic rocks was not positively determined, but what appear to be intrusions of this porphyry are present in the volcanic rocks of the Rocky Range, and it is therefore probably younger.

Quartz monzonite stocks. - The quartz monzonite stocks, like the quartz diorite, were intruded into the sedimentary rocks of the region, and have produced pronounced contact alteration in the limestones. Quartz monzonite was also intruded into the quartz diorite, as already noted, and consequently is later than that rock. Dikes of quartz monzonite are present in the lavas of the Rocky Range and can be traced directly from the main mass. Northwest of Frisco are dikes of quartz monzonite porphyry that are probably connected with the main intrusions. The point of quartz monzonite extending eastward into the lavas is porphyritic in character, suggestive of a contact facies, and specularite that has been developed locally in the lavas near the contact may be a contact alteration of the flow rocks. In the Beaver Lake Mountains no dikes of the quartz monzonite were found in the lavas, but the small bodies of this rock along the contact of the flows and sediments are suggestive of intrusion along this contact, and the presence of andalusite in the highly altered lavas suggests that this mineral is a product of contact alteration resulting from the intrusion of the magmas.

In many places where the two rocks were seen in contact they have the appearance of a flow or an erosion surface. In the Rocky district, however, the quartz monzonite is undoubtedly the younger rock, and it is believed that the same relation holds in the other districts, though the evidence is not as conclusive as could be desired.

Dikes associated with the quartz monzonite.-The basic and siliceous dikes in the quartz monzonite were, of course, later than that rock, but are believed to have been introduced very soon after its solidification. The two types of dikes were nowhere found together and it is therefore impossible to state from direct evidence which was the later intrusion. The ore deposits in the quartz monzonite, however, are believed to be closely associated with the acidic extreme of differentiation in the intrusion, and as the Cactus ore deposit is cut by a basic dike it seems likely that some, at least, of the basic dikes were later than the aplitic dikes.

The close chemical and mineralogic similarity of the earlier intrusive rocks leads to the belief that they were derived from a common source or magma. The first intrusion consisted of the material which solidified to form the quartz diorite. It was not an extensive intrusion, and the material, being forced into cool rocks, solidified as a rather fine grained porphyry. This was followed by much more extensive intrusions of material that, on account of the large masses, cooled slowly except near the margins and formed the granular quartz monzonite.

By a process that is not well understood, fluid rock material is believed to separate into basic and siliceous portions, and these may be separately forced into the overlying rocks, forming basic and siliceous dikes. Intrusions of this character at many localities have been described, and, in fact, an intrusion of basic and siliceous dikes following extensive intrusion of a rock of medium composition may be said to be the ordinary mode of occurrence. In some places it has been shown that the basic dikes preceded the siliceous; in others this order has been reversed. 
Such intrusions followed the solidification of the quartz monzonite in the San Francisco district. After the intrusion of the quartz monzonite materials that had differentiated into basic and siliceous portions were intruded, forming the more basic porphyritic dikes and the siliceous aplitic dikes.

The area of siliceous quartz monzonite near Copper Gulch may represent slightly differentiated material intruded into the quartz monzonite before that rock was entirely solidified and cooled, the consequence being a partial blending of the two, which resulted in a gradual gradation from one to the other rather than an abrupt contact. The presence in the vicinity of Copper Gulch of this siliceous rock, of numerous basic dikes, and of ore deposits indicates that for some reason this locality was a weak point in the quartz monzonite mass. On account of this weakness the fluid rock materials that were successively forced upward along the paths of least resistance were introduced more abundantly here than at any other point.

Dikes associated with the effusive rocks. - The basic dikes associated with the effusive rocks have a composition somewhat similar to the more basic dikes in the quartz monzonite, and it is possible that they were intruded at essentially the same time. As positive evidence was not obtained on this point it must be left an open question for the present.

AGE OF THE IGNEOUS ROCKS.

From direct evidence it is not possible to determine closely the age of the intrusive or extrusive rocks. The quartz diorite and quartz monzonite intrusives can only be said to be later than the Triassic sediments and the voleanic rocks which they cut. Similarly, the extrusive rocks can only be fixed as later than the Triassic sediments and earlier than the intrusive rocks that cut them and also earlier than the Lake Bonneville beds.

To arrive at a more definite idea of the period in which the igneous activities in this region occurred it is necessary to ascertain the time of igneous activity in neighboring districts where the presence of later sedimentary rocks has made age determination possible.

It is evident that western Utah lies between the Pacific coast province to the west and the Rocky Mountain province to the east. In the former the great intrusions of monzonitic and allied rocks took place in late Jurassic or early Cretaceous time. In the latter the main intrusive masses of monzonitic and allied rocks are of Tertiary age, in part early or middle Tertiary, and possibly in part late Tertiary. It thus becomes necessary to ascertain the age of the nearest intrusive rocks and see to which of them the rocks under discussion most nearly correspond.

The area nearest to the Frisco district in which the age of the intrusive rocks has been determined is the Iron Springs district of Iron County. For that district Leith and Harder ${ }^{1}$ give the following sequence of geologic events:

The principal features in the development of the present geological and physiographic features of the district have been in order as follows:

(1) Deposition of Carboniferous limestone, with thin fragmental base, on basement unknown in this district.

(2) A period of nondeposition, perhaps erosion, followed by deposition of Cretaceous and perhaps some Jurassic sandstone, with layers of shale, conglomerate, and limestone.

(3) An erosion interval, followed by deposition of Eocene limestone and conglomerate in an inclosed basin. The conditions are principally those of shallow water, strong currents, and rapid changes through both Cretaceous and Tertiary times.

(4) In early Miocene time intrusion of andesite laccoliths, principally into the Carboniferous limestone but also into the overlying Cretaceous, accompanied by tilting of all the formations away from the laccoliths, steeply near the laccoliths, less steeply farther away. Limestone and sandstone were metamorphosed near the contact.

(5) Fissuring and faulting caused by cooling of laccoliths.

(6) Immediate advent of ore-depositing solutions through fissures in the andesite, depositing iron ore in the andesite fissures and in the adjacent limestone and effecting other alterations.

(7) Erosion, exposing the laccoliths and rings of sediments and ores around them.

(8) Extrusion of late Miocene lavas over the entire area, except possibly some of the higher peaks of the exposed laccoliths, effecting a secondary concentration of the ores and further altering the underlying rocks.

(9) Further faulting.

(10) Vigorous erosion, reexhuming the andesite cores and developing the Pleistocene conglomerate and the Pleistocene and Recent mantle of stream, lake, and other alluvial deposits.

${ }^{1}$ Leith, C. K., and Harder, E. C., The iron ores of the Iron Springs district, southern Utah: Bull. U. S. Geol. Survey No. 338, 1908, p. 21. 
In the Henry Mountains, in southeastern Utah, the laccolithic masses have raised the Cretaceous sediments into broad domes, ${ }^{1}$ indicating that these intrusions were at least later than the deposition of the Cretaceous sediments. Farther east, in Colorado, numerous Tertiary intrusions are known to have occurred.

To the southwest, in the Clifton-Morenci district of Arizona, according to Lindgren, ${ }^{2}$ the following events occurred in the later geologic periods:

The time interval between the Carboniferous and the middle Cretaceous is not represented by any sediments; there is, on the contrary, evidence of an epoch of erosion, for the Cretaceous rests unconformably on the lower Carboniferous at Morenci, where the upper Carboniferous is not present.

The disturbance was, however, not great, and the later strata must have been deposited on the nearly horizontal though partly eroded Carboniferous. The last subsidence under the Cretaceous sea was of only moderate depth, the sediments consisting of coarser sandstones and carbonaceous shales, clearly not derived from the granite of this vicinity, but rather from somewhat distant land areas. The total thickness of Cretaceous is unknown; the larger part of the series may in fact have been removed by erosion.

This long era of deposition without far-reaching orogenic disturbances was followed by intense intrusive activity, beginning in the earliest Tertiary or in the latest Cretaceous. Masses of acidic porphyries, associated with diorite porphyries, invaded the lithosphere, filled great spaces made for them by gradual or violent dislocations, and congealed to stocks, sheets, dikes, and laccoliths in the disrupted granite and sediment. These intrusions form practically one connected mass from Eagle Creek to Copper King Mountain, which has been exposed only by subsequent erosion.

The porphyries in cooling produced far-reaching metamorphism of such of the adjacent sediments as were susceptible of this alteration, and the introduction of sulphides of various kinds accompanied the contact metamorphism. Shortly after the consolidation fissures broke open, following the general northeast direction of the stock and dikes, and were filled with cupriferous pyrite, zinc blende, and other minerals. Soon after the time of the intrusion an uplift must have taken place, raising the heavily sediment-laden crust to high elevations, throwing them, as well as the underlying partly plastic granite, into gentle dome-shaped swells or anticlines. Finally, the load proving too heavy, the risen area broke into fragments, which gradually settled down, forming monoclinąl blocks around the more resistant buttresses of Coronado and Copper King mountains, and fracturing still further as they settled.

The country was now a land area with rough topographic features, to which the faulting contributed important elements. An active erosion following the epoch of faulting has not been able to entirely efface this influence, and, though obscured by the Tertiary lava flows, these fault scarps are still dominant features visible in the granite bluffs of Coronado and Copper mountains and the downthrown valley between them.

During this epoch of erosion the principal valleys, like those of Chase Creek and San Francisco River, were carved. San Francisco Valley is, however, primarily of structural origin, being determined by the great Oroville fault.

Volcanic eruptions of great volume occupied the latter part of the Tertiary period and consisted chiefly of thricerepeated rhyolite and twice-repeated basalt flows, with subordinate masses of andesite. In places they are over 1,500 feet thick and almost entirely surrounded the old granitic buttresses.

Lindgren, Graton, and Gordon ${ }^{3}$ give the following summary of Tertiary and Quaternary events for New Mexico:

At the close of Cretaceous time the long-maintained condition of quiescence and scarcely broken periods of deposition ceased. Here, as elsewhere in the Rocky Mountain region, the deposition of the Cretaceous beds was followed by an epoch of igneous activity and of mountain building, during which the most important of the mineral deposits of the Territory were formed. Intrusions of large masses of monzonitic magmas seem to have constituted the first step; they were forced in underneath the pliable and tough mantle of Cretaceous sediments, bulging it in laccolithic fashion. Their distribution corresponds with the zone of orogenic disturbance and with the belt of mineral deposits extending across the Territory in a north-northeast and south-southwest direction. The marine conditions ceased, but during the Eocene lake basins were probably established in the northwestern part of New Mexico, possibly also elsewhere.

Mountain building accompanied and succeeded intrusion. While conditions still remained quiescent in eastern and northwestern New Mexico, tremendous forces were at work in the southward extension of the Rocky Mountain region. The old pre-Cambrian core in the north seems to have been forced upward by faulting, or by warping followed by faulting. Farther south the sediments were broken along north-south lines and the characteristic New Mexican monoclinal ranges were created, the prototype of the "Great Basin structure," which in fact is far more characteristically developed in this region than in the area from which it receives its name. Knowledge concerning the mechanics of this mountain building is somewhat uncertain, and the purposes of this report do not require their detailed discussion. It is sufficient to say that the Sandia, Oscura, San Andreas, Caballos, Organ, and other ranges, which lie in the southern continuation of the Rocky Mountain uplift, clearly show this combination of a fault scarp, facing east or west, with a monocline sloping gently in the opposite direction. Folding is absent or only slightly developed.

1 Gilbert, G. K., Geology of the Henry Mountains, U. S. Geog. and Geol. Survey Rocky Mtn. Region, 1877.

${ }^{2}$ Lindgren, Waldemar, The copper deposits of the Clifton-Morenci district, Arizona: Prof. Paper U. S. Geol. Survey No. 43, 1905, pp. 94-95.

sindgren, Waldemar, Graton, L. C., and Gordon, C. H., The ore deposits of New Mexico: Prof. Paper U. S. Geol. Survey No.68, 1910, pp. 32-34. $73363^{\circ}-$ No. $80-13-5$ 
During the same epoch the desert ranges of the southwestern part of New Mexico were outlined by intrusions and by faulting, though here the monoclines are far less conspicuous and erosion seems to have been the most active factor in producing the present mountain forms.

A general uplift of the plateau province, and to a less degree of the whole Territory, accompanied this orogenic disturbance, the major features of the present drainage system were outlined, and of course erosion at once began its work of exposing the deeper strata and the intrusive rocks.

A second epoch of igneous activity, distinctly separate from the first epoch of intrusion, began, probably in the middle Tertiary, and vast masses of andesitic and rhyolitic flows were extruded. The flows, which in places are 2,000 feet or more thick, rest on the old sedimentary rocks, beveled by erosion, on the earlier intrusive rocks, or on the preCambrian granites and gneisses. Naturally these piles of lava spreading as vast plateaus or gentle slopes from their foci of eruption were at once attacked by erosion, the work of which is well shown in the canyons of Gila and San Francisco rivers and in the consequent drainage of the Valles Mountains, north-northwest of Albuquerque. These mountains contain an important center of rhyolitic eruptions of middle Tertiary age. The San Mateo and probably other ranges in Socorro County have a similar history. There are several minor areas in the ranges of the extreme southwest, but the largest field of rhyolites, latites, and andesites is that extending from the vicinity of Socorro to the south end of the Mimbres Range and thence westward to Silver City, the Mogollon Mountains, and over into Arizona.

In the later Tertiary (Miocene epoch) a lake of large extent appears to have existed in the upper Rio Grande valley, and its deposits are known as the Santa Fe marl. Some of the deposits assigned to this age are probably subaerial, as held by D. W. Johnson, who examined them near Cerrillos, but there can be little doubt that lacustrine conditions prevailed at other places farther north.

Toward the close of the Tertiary there was a third outbreak of igneous activity. Basalts were erupted in large quantities and spread over vast areas, covering the Santa Fe marl, the eroded older sediments, or the intrusive rocks. Such basalt flows cover considerable areas in various parts of the Territory; for instance, at Raton, in the foothills east of the Mora uplift, along the northern course of the Rio Grande, and at many points farther south along the same river. There are also comparatively recent basalt flows along the Mexican boundary line between El Paso and Tres Hermanas and at a number of other places.

Basaltic eruptions continued during the Quaternary period and such eruptions of minor extent have taken place very recently. During the early part of the Quaternary there was a heavy accumulation of land deposits, forming masses of coarse gravels (known as the Palomas gravel), which filled many of the structural troughs to a depth of about 1,000 feet. Basalt flows were poured out again after the deposition of these gravels, and smaller flows of Recent age, possibly erupted only a few hundred years ago, are found in eastern Socorro and Otero counties and western Dona Ana and Valencia counties.

Since the main part of the basaltic outburst deep erosion has taken place. The whole upper canyon of the Rio Grande has been excavated, and in the central part of the Territory the streams have cut into the Palomas gravel to a depth of 800 feet. Their cutting was accompanied by the formation of gravel terraces, as well shown along the Rio Grande near Albuquerque.

To the north the Tintic district is the nearest area where careful study has been made. Tower and Smith ${ }^{1}$ consider both the intrusives and extrusives of this area to be of Tertiary age, though the evidence on which to base a determination of the age of the igneous rocks is scanty and not conclusive. The intrusives in the Tintic district are in part at least later than the extrusives. The age of the intrusive rocks at Bingham has not been determined, but the extrusives are believed to be of Tertiary age.

The evidence concerning the age of the intrusive rocks at Park City is more conclusive. Boutwell ${ }^{2}$ says:

The general anticlinal structure of the Paleozoic and Mesozoic beds which characterize the Wasatch as a whole is interrupted in this central portion by a transverse (east-west) ant cline or dome. Sediments ranging from Cambrian to Tertiary here dip northerly and southerly, quaquaversally from a series of laccolithic masses. These include, from west to east, the porphyritic granite of Lone Peak and Little Cottonwood Canyon, the granodiorite at the head of Little Cottonwood Canyon in the vicinity of Alta, the coarse and fine grained dioritic masses at the heads of Big and Little Cottonwood canyons, and the northeast extensions in the form of dikes. These several masses constitute a mammoth composite laccolith. It is noteworthy that these intrusions have taken place along a zone coinciding in location and course with the extension of the Uinta axis across the Wasatch. This fact, together with the influence of these masses in doming the structure athwart the general course of the Wasatch, naturally raises a query as to a similar influence in the formation of the Uintas. This transverse Wasatch dome and the Uinta dome are separated topographically, though not structurally, by a north-south trough. Into this, and thus blanketing the surface connection of these structures, extensive and thick masses of andesite have flowed.

From this statement it may be concluded that the intrusion forming the Park City laccolith occurred after the deposition of the Cretaceous sediments.

1 Tower, G. W., jr., and Smith, G. O., Nineteenth Ann. Rept. U. S. Geol. Survey, pt. 3, 1899, p. 672.

${ }^{2}$ Boutwell, J. M., Stratigraphy and strueture of the Park City mining district, U tah: Jour, Geology, vol. 15, 1907, pp. 455-456. 
Concerning the age of the great batholithic masses in western Montana which contain the Butte ore deposits, Weed ${ }^{1}$ makes the following statement:

The granites are of Tertiary age, for at the borders of the batholith late Cretaceous strata are cut by the intrusion, and, moreover, included fragments of the early Tertiary andesites occur in the granite. The rock is cut by rhyolite dikes, and as rhyolite ash showers form lake beds containing Miocene vertebrate remains, the granite and the veins are of earlier age, probably Eocene or early Tertiary. West of the district the lake beds appear, formed in a great Tertiary lake that filled a long and relatively narrow valley extending from south of Dillon in southern Montana to Garrison, a valley which was warped by later earth movements that drained it and carried the Continental Divide across its floor.

The intrusives of southwestern Idaho are considered by Lindgren and Drake ${ }^{2}$ to be of post-Carboniferous and most probably post-Triassic age. These authors state that "from analogy with other similar granite areas in Montana and California, this intrusion may very likely be assigned to a Cretaceous age."

Louderback ${ }^{3}$ gives the following summary of the geologic events in the Humboldt region, western Nevada:

Anyone familiar with the geological history of the Sierra Nevada must have been struck by its remarkable similarity to that of the Humboldt Mountains and vicinity. A brief chronology of each is given here for comparison. Some events have to be stated in a general way to bring out the analogy.

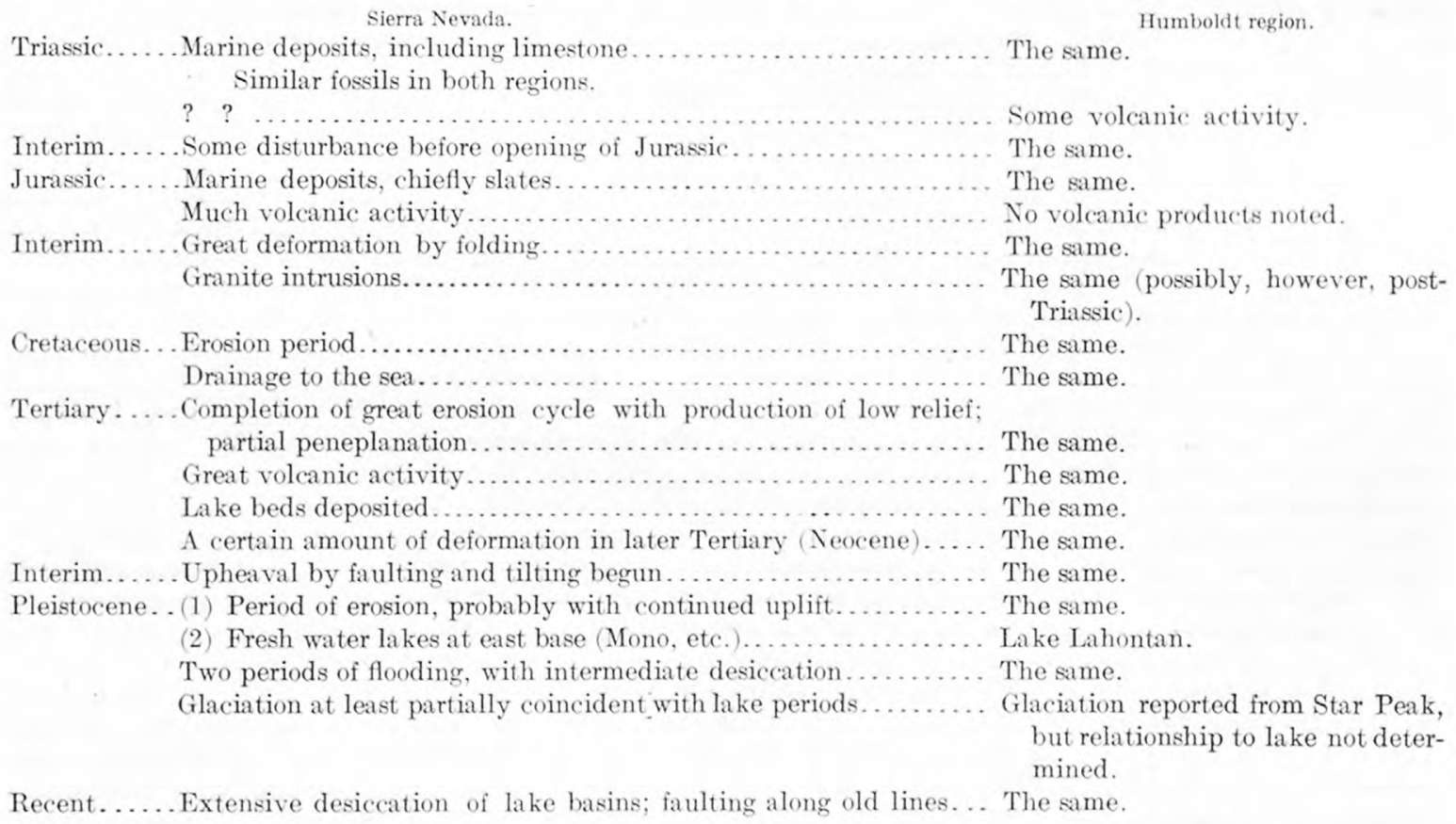

From this summary it appears that the main intrusive rocks of the Humboldt region are considered to be of pre-Cretaceous age and the effusive rocks of Tertiary age.

From an extensive reconnaissance in southwestern Nevada and southeastern California, Ball ${ }^{4}$ reaches the following conclusions concerning the events of later geologic periods:

After the deposition of this limestone (Pennsylvanian) the area was probably lifted above the sea and never sank beneath it again. The period of Paleozoic sedimentation thus concluded was unattended by volcanism, with the possible exception of that which produced the metamorphosed basic igneous rocks of the Amargosa Range.

King believed that contemporaneously with the emergence of this portion of the Great Basin above the sea the old land mass to the west subsided and that upon it were deposited Triassic and Jurassic rocks. He further believed that the ranges of western Nevada were formed at the same time as the Sierra Nevada, or at the close of the Jurassic. This seems very probable from the general parallelism of the Nevada ranges with the Sierra Nevada crest line, particularly since some of the ranges west of the area surveyed are composed of folded Triassic and Jurassic rocks. At this time the

1 Weed, W. H., Ore deposits of Butte, Mont.: Bull. U. S. Geol. Survey No. 213, 1903, p. 174.

${ }^{2}$ Lindgren, Waldemar, and Drake, N. F., Nampa folio (No. 103), Geol. A tlas U. S., U. S. Geol. Survey, 1904.

${ }^{3}$ Louderback, G. D., Basin-range structure of the Humboldt region: Bull. Geol. Soc. America, vol. 15, 1904, p. 340.

1 Ball, S. H., A geologic reconnaissance in southwestern Nevada and eastern California: Bull. U. S. Geol. Survey No. 308, 1907, pp. 39-42. 
Paleozoic rocks were complexly folded, the larger proportion of the flexures striking west of north. The folding in some places is close and in others open, being particularly intense in the ranges nearer the Sierra, such as the Panamint and Amargosa ranges. It was accompanied by reverse faulting. These post-Jurassic structural lines have ever since their formation proved to be lines of weakness, of which advantage has been taken by later deformation.

After considerable folding had taken place, and probably before the end of the deformation, granitoid rocks were intruded into the Paleozoic strata. That the granite intrusion was a late event in the deformation is indicated by the massive character of that rock. The intrusion was accompanied by local buckling of strata, by contact metamorphism, and somewhat less directly by ore deposition. It was followed by the intrusion of a quartz monzonite porphyry and later of diorite porphyry and diorite.

A long period of erosion, extending at least to Eocene time, followed the post-Jurassic folding and consequent mountain building. This period was probably one of heavy rainfall and large rivers. No estimate can be formed of the amount of erosion, but it was sufficient to remove from the granite the covering beneath which it solidified. Notwithstanding the length of this erosion period no peneplain was formed, from which it is inferred that the area was subjected to successive uplifts while being eroded. Where exposed beneath the oldest Tertiary formation the Paleozoic rocks appear to have been eroded into mountain ranges, many of which have a north-south extension. Some of these mountains of Paleozoic rocks-for example, the Kawich Range-were fully as high and rugged as the present ranges.

The Eocene inaugurated the Tertiary period of volcanism and lake-sedimentation processes, accompanied by important deformation, erosion, and ore deposition. The Tertiary igneous rocks, being largely in flows, in contradistinction to the intrusive post-Jurassic rocks, produced but little contact metamorphism. The permanency of the structural lines, initiated probably in early Cretaceous time, has already been mentioned. Along these lines the Tertiary deformation occurred, while many of the main lava extrusions burst from north-south vents along pre-Tertiary mountain ridges. The first lava to outflow was a rhyolite, which was followed by monzonites and acidic andesites, in part intrusive bodies. Next there was an important and probably long erosional interval, followed by a mighty extrusion of rhyolite, which equals or exceeds in bulk the basalt outflow of late Pliocene and early Pleistocene time. The rhyolite in turn was followed by andesites and dacites, and these by unimportant rhyolites, immediately preceding the deposition of the Siebert lake beds in the Pahute Lake. It was probably during this general period that the most important ore deposits in the Tertiary rocks were formed, presumably by waters heated in the still hot magmas. Between the outflow of the rhyolite and the formation of the Pahute Lake erosion was probably continuous, partially accounting for the formation of the lake basin, which in the main, however, originated through orogenic sinking that was possibly, in part, consequent on adjustments due to the extrusion of immense masses of lava, a hypothesis suggested by Spurr. The Pahute Lake covered practically the whole area surveyed, although the presence of coarse conglomerates in the Kawich and Amargosa ranges and the Bullfrog Hills indicates that rugged islands rose above the surface of the lake. Wherever the former shores of the lake are now seen it is evident that the surface of the older rocks was uneven and that each island was surrounded by islets. The climate must have been moist and the presence of fossilized wood in the lake beds shows that trees flourished near its shores. While the lake was thus for the most part fresh, periods of aridity alternated with those of comparative humidity, and the lake or portions of it were partially desiccated, permitting the local precipitation of limestone, gypsum, and boron minerals. Volcanic flows and explosive eruptions of rhyolitic material occurred at various times during the existence of the lake. The Pahute Lake was destroyed in part by the increasing aridity of the climate and in part by deformation, which was accompanied and immediately followed by the extrusion of rhyolite. By this deformation the whole area was uplifted with attendant southward tilting, which accounts for the relatively low altitudes occupied by the Siebert lake beds in the southern portion of southwestern Nevada. Furthermore, the deformation, by differential uplift, blocked out the mountain ranges as they now appear and formed many of the inclosed valleys by broad folding or warping. Death Valley was at this time first outlined, though it was depressed later, probably in the late Pliocene or early Pleistocene time, by block faulting.

Extensive erosion followed and before the end of Pliocene time it had reduced the surface to mature and comparatively gentle topography. In restricted areas the Pliocene-Pleistocene basalt appears to have flowed upon a local peneplain. In late Pliocene time the climate was moist and a shallow lake probably covered a considerable area in the vicinity of Goldfield. The older alluvium, a formation widely distributed over the area, may be considered as deposits of the waning stages of this lake period in the inclosed valleys. Toward the end of this period the basalt extrusion reached its climax. Uplift accompanied by normal faulting and folding followed the deposition of the older alluvium, and at this time erosion appears to have been very active.

In Recent time the erosion characteristic of arid lands has partially filled the inclosed valleys with bowlders, gravels, and sands - débris from the wasting mountains-and the process is still going on.

This description and the general section from Ball's report show that the main granitic and monzonitic intrusions in the Amargosa region occurred at the close of Jurassic time, though minor intrusions of monzonitic magmas occurred in the early Tertiary, after the eruption of the first rhyolite.

Of the age of the intrusive rocks in southeastern Nevada little is known. Ransome ${ }^{1}$ says concerning the Searchlight district:

The quartz monzonite, like the gneiss and schist, is supposed to be a part of the old crystalline floor through which the Tertiary eruptions broke. Definite proof of this, however, was not obtained in the course of the present reconnaissance, and the possibility of its being a Tertiary intrusive mass is still open to consideration.

1 Ransome, F. L., Preliminary account of Goldfield, Bullfrog, and other mining districts in southern Nevada: Bull, U. S. Geol. Survey No. 303 , 1907 , p. 66. 
Concerning the age of the intrusive rocks of northwestern Arizona, Schrader ${ }^{1}$ makes the following statement:

The pre-Cambrian gneisses and schists are in places intruded by igneous masses and dikes which are considerably older than the Tertiary volcanic rocks * * but whose exact age is unknown. Very likely they are of late Jurassic or early Cretaceous age and of the same period of intrusion as the batholiths of California and western Nevada.

The extrusive rocks of this region are of Tertiary age.

Spurr ${ }^{2}$ gives the following sequence of events for the Meadow Valley region southwest of Pioche, Nev.:

Out of the complicated conditions observed at so many points in the valley of Meadow Creek, the following rough sequence of events may be provisionally laid down:

1. Deposition of the Paleozoic series of quartzites and limestones.

2. Elevation of this series to a land mass and the erosion of the rocks to produce a system of mountains and valleys. This was attended by little or no folding.

3. Pouring out of great masses of white biotite rhyolite (early Tertiary).

4. The formation of a series of water-laid rhyolitic sandstones and tuffs, interbedded with thin sheets of rhyolite and rhyolite breccias. This whole series is roughly estimated at 4,000 feet thick and at the top contains relatively more tuffs, while at the bottom there are relatively more lavas. Several slight unconformities and many slight erosion gaps occur in the series.

5. Folding to a considerable degree of the whole crust.

6. Explosive eruptions of pyroxene andesites and latites of moderate extent.

7. The formation of a series of water-laid brown volcanic tuffs or sandstones and breccias, with interbedded quartzbearing volcanics, chiefly dacites and reddish rhyolites. The sandstones were relatively thick at the bottom of the series, the volcanics at the top. The entire thickness of the series is estimated at 3,500 feet: There are some petty erosion intervals.

8. General folding, comparatively gentle.

9. Deposition of at least 2,000 feet of brown or red conglomerates and soft sandstones, which are accompanied by very few volcanic flows and so are distinct from the preceding formations. They have remained nearly horizonta and are probably, in large part at least, lake beds. They have been referred to the Pliocene.

10. Drainage of the Pliocene lake, erosion and slight local folding in the Pleistocene.

11. Outpouring of thin sheets of rhyolite, tordrillite, and pyroxene-olivine basalt.

12. The formation of a small amount of high stream gravels.

13. Cutting down of the canyon bed to its present position.

The thickness of the basal rhyolite is not known. A very roughly estimated section of the overlying formations is as follows:

$$
\text { Section in Meadow Valley Canyon. }
$$

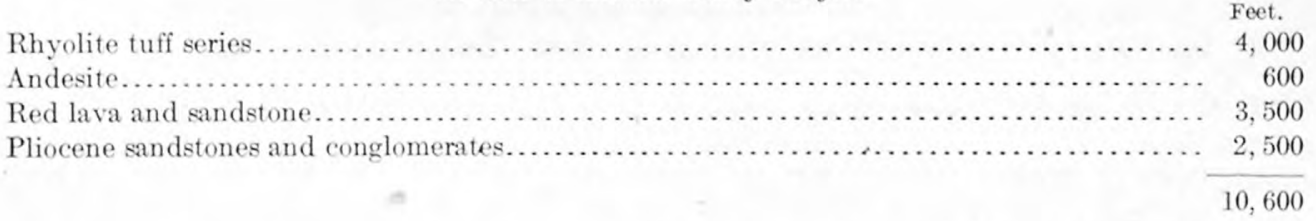

The succession of lavas, so far as can be made out in this confused section, is as follows: Biotite rhyolite, pyroxene andesite, biotite-hornblende-quartz latite, biotite-hornblende dacite, quartz latite or red rhyolite and tordrillite, pyroxene-olivine basalt, glassy rhyolite or tordrillite.

The San Francisco and neighboring districts lie on the western margin of the Rocky Mountain province, which extends from southwestern Arizona and Mexico on the south to western Montana on the north, and in which, as shown by the descriptions above quoted, the main masses of granite and monzonitic intrusive rocks whose age has been determined are Tertiary. The Iron Springs district, 40 miles south of the San Francisco district, is about the same distance west from the main axis of the Rocky Mountain belt, and the Park City district, to the north, is also nearly as far west of this main zone of Tertiary intrusives. It is a notable fact, moreover, that west of the San Francisco region, so far as can be judged from published descriptions, there is a broad belt including eastern and central Nevada in which intrusive rocks play a very small part. This belt is bordered on the west by one in which intrusives become of

${ }^{1}$ Schrader, F. C., Mineral deposits of the Cerbat Range, Black Mountains, and Grand Wash Cliffs, Mohave County, Ariz.: Bull. U. S. Geol. Survey No. 397,1909, p. 30.

${ }^{2}$ Spurr, J. E., Descriptive geology of Nevada south of the fortieth parallel and adjacent portions of California: Bull. U. S. Geol. Survey No. 208, 1903, p. 147. 
increasing importance from east to west till in eastern California the late Jurassic or early Cretaceous intrusives are the dominant formations.

The natural conclusion to be arrived at from these iacts, in the absence of definite evidence, is that the igneous rocks of the San Francisco region are of Tertiary age. The exact portion of the Tertiary in which the volcanic activity took place is uncertain, but it probably extended over a considerable period and may have continued into late Tertiary time. As shown by the above quotations, in most of the districts the intrusive rocks were earlier than the extrusives, the two being separated by an epoch of erosion. The extrusive rocks are of medium composition over large areas in Utah, and it is not surprising to find that bodies of similar rock have been intruded into the flows forming the monzonitic bodies. Such is the case in the Tintic and Marysvale districts as well as in the San Francisco district.

To the northeast of this district Gilbert ${ }^{1}$ found that the latest basaltic flows were postglacial, and it is possible that the olivine basalt that forms the latest flow in the San Francisco region is much later in age than the main body of volcanic rocks. The relation of this basalt to the other flows is not clearly shown owing to its burial under recent sediments.

\section{STRUCTURE.}

The main structural features of the region have resulted from the intrusion of the monzonitic stocks and the subsequent breaking of the region into blocks and the tilting of the blocks to form the present mountain ranges. Folding is of minor importance as a structural feature.

FOLDS.

The only point within the region where folding of the formations was observed was in the Grampian limestone area. In the canyons north of the Indian Queen mine the lower beds of this limestone are folded into a broad anticline pitching gently to the north. In the upper beds of the limestone the western limb of the fold has been entirely removed and the beds present the appearance of a purely monoclinal structure. In the Beaver Lake Mountains and the Rocky Range the dominant structure of the earlier beds is that resulting from the intrusion of the sediments by the quartz monzonite, and if folding was present in the beds previous to that event it has been entirely masked. In the Star Range folds were not observed.

Concerning the period in which the folding occurred, the district presents little evidence. It can only be stated that the folding was earlier than the intrusion of the quartz monzonite.

STRUCTURE RESULTING FROM INTRUSION.

Although the intrusive stocks have in general broken through the sedimentary beds rather than spread out in laccolithic form between the strata, yet the large stocks, like that of the quartz monzonite of the Cactus area, have distinctly domed the sedimentary rocks. The sedimentary formations dip away from this stock in all directions, and it is probable that the sediments and lavas at higher horizons, now removed, were domed completely over parts of the intrusive body. This relation is less apparent in other parts of the district where the intrusive masses are smaller and in some places, as in the Rocky Range, contain only detached blocks of the sedimentary rocks. Figure 7 gives a generalized cross section of an intrusive stock.

What becomes of the sedimentary material that formerly occupied the space taken up by the intrusive rocks is a question that has been much discussed but as yet without a general agreement. The San Francisco region was not favorable to a study of this important question, and it will therefore be passed over with little discussion.

In general, two theories have been advanced to account for the provision of the space now occupied by the igneous rock. (1) The molten rock has found room by dissolving or absorbing the sedimentary rocks. This process is commonly known as stoping. (2) The igneous material has pushed aside the rocks that previously occupied the space. In different places, and possibly in individual stocks, both of these processes may have been active. There

1 Gilbert, G. K., Lake Bonneville: Mon. U. S. Geol. Survey, vol. 1, 1890, p. 319. 
seems no doubt that the laccolithic bodies like those of eastern Utah have made space by raising or doming the sediments. Boutwell ${ }^{1}$ has shown that in the Park City district, Utah, the intrusive mass forced the sedimentary rocks bodily before it.

In the Star district a block of the sedimentary formations west of the intrusive body in the eastern part of the district has been forced to the west (see map, Pl. I, in pocket), and the relations suggest that the movement of this block was due to the intrusion of the quartz monzonite, the space for which was provided in that manner. In other parts of the region such evidence is not so well shown, as the sediments are not exposed completely around the stocks. However, the writer has not observed evidence of important "stoping" action by the invading magma and is inclined to believe that the intrusions found space very largely, if not entirely, by forcing aside the earlier rocks.

\section{FAULTS.}

The most important structural features of the region are the result of faulting, which of the faults whose relations have been worked out can be classified under two types-normal faults and lateral faults

Normal faults.-Normal faults are those in which the hanging wall is the downthrown side, and they are generally interpreted as indicating that the region has been subjected to a force tending to draw it apart. This type of fault is contrasted with reverse or thrust faults, in which the hanging wall is the upthrown side and which are generally interpreted as indicating that the region has been subjected to a force tending to compress it.

The normal fault is the type usually associated with the formation of the basin ranges of the Great Basin and similar block-fault mountains in other localities. The San Francisco Mountains are believed to be of the basin-range type, being a tilted block bounded on the west and in part on the east by faults. Since the formation of these mountains erosion has been active and the western face exposed above the recent sediments has doubtless been worn back to some extent, so that at present it is not possible to locate the exact position of the fault plane that determines the western front of the range. It is believed, however, that a line connecting the ends of the most westerly of the spurs extending toward the Wa Wa Valley will very closely mark the outcrop of this fault. The eastern or Horn Silver fault, named from the mine in which it is best exposed, can be traced from Squaw Springs Pass northward for about $1 \frac{1}{2}$ miles to a point where its identity is lost in the volcanic rocks. To the north a strong fault is encountered in the shaft of the Golden Reef mine near Sawmill Canyon, and what is apparently the southward extension of this fault can be seen in Barrel Spring and Morehouse canyons. Between these points and to the south of Morehouse Canyon the base of the range is deeply buried under quartzite float, rendering the tracing of the fault impossible.

No definite evidence of a connection between the northern exposure of the Horn Silver fault and the southern exposure of the Golden Reef fault was seen. The general relations indicate chat a fault existed before the intrusion of the quartz monzonite and that the intrusive body cut across it. There has been movement along the fault since the intrusion, however, and this later movement may have extended through the monzonite, though, being in rocks of a single type, it is not readily recognized. At both localities where the fault has been exposed below the surface by mine exploration it has a steep easterly dip, the eastern or hanging wall being the downthrown side. At the Horn Silver mine the limestone footwall is massive and

1 Boutwell, J. M., Stratigraphy and structure of the Park City mining district, Utah: Jour. Geology, vol. 15, 1907, p. 458. 
shows little parallel faulting or brecciation, except such as is associated with east-west faulting. The volcanic rocks, however, are brecciated through a broad zone, and gouges indicate some movement along planes essentially parallel to the main fault plane. The throw of the Horn Silver fault has not been determined. A throw of at least 1,600 feet is shown in the workings of the Horn Silver mine, and the actual displacement is doubtless much greater.

The Golden Reef fault has been but slightly explored in the workings of the Golden Reef mine. The shaft is near the contact of quartzite and the volcanic rocks. Both have suffered rather profound brecciation. To the east the area is buried under quartzite float, and its condition is unknown, but to the west the quartzite shows several parallel faults that are accompanied by brecciation. What appear to be the downward extensions of some of these faults are encountered in the tunnel of the Golden Reef mine. Where these planes pass through the shale strata underlying the quartzite, they show but slight displacement, some of them being represented by a monoclinal fold in the shale. This indicates that the fault breccia zones in the quartzite are the result of movements that have brecciated this brittle rock with slight displacement of the strata. So far as can be judged from the evidence obtained, the main displacement has

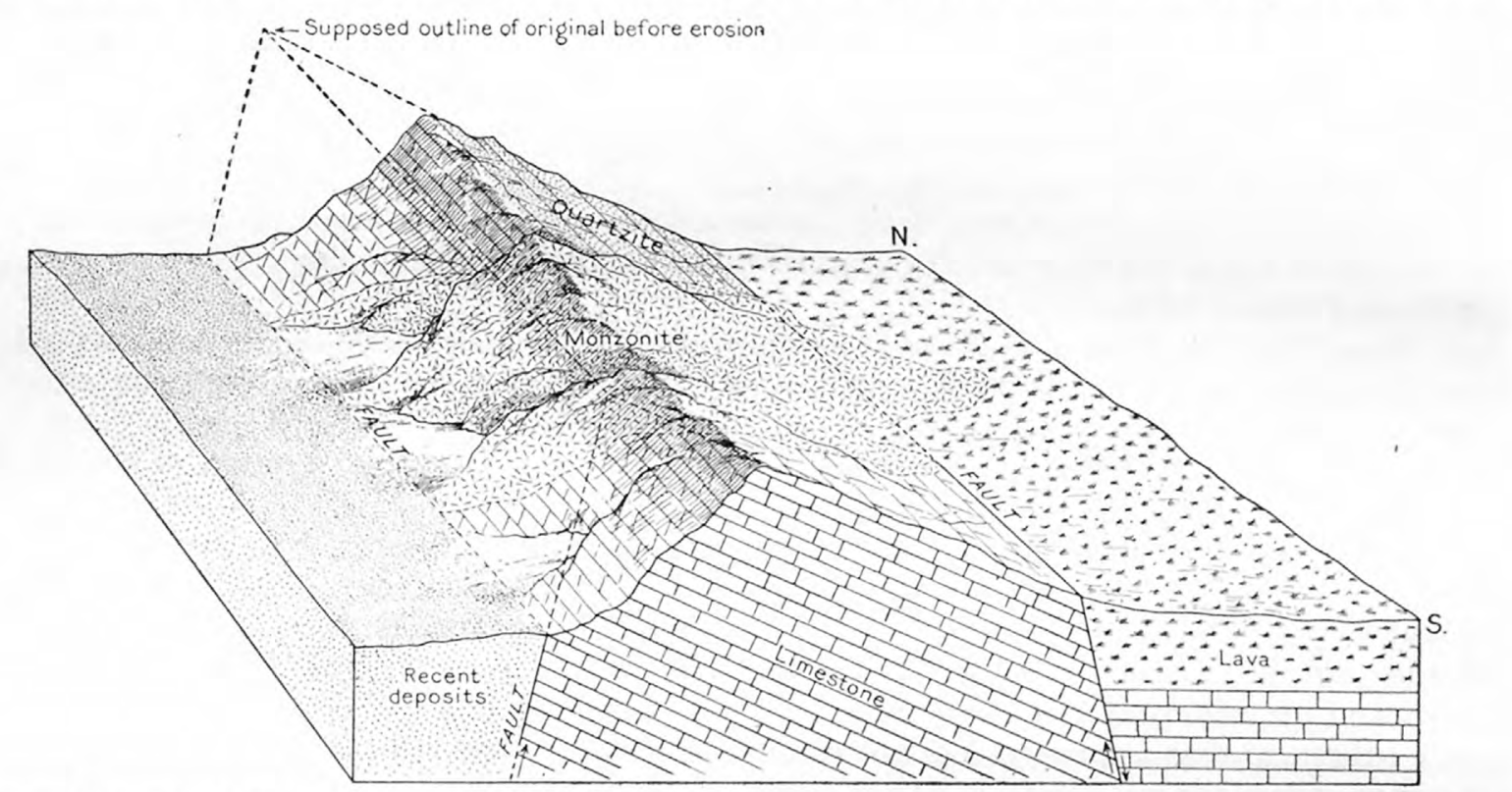

Figure 8.-Generalized stereogram representing the relations of the formations in part of the San Francisco Range north o ISquaw Springs Pass.

been confined to the principal fault rather than distributed among several parallel faults, as might be judged from the presence of parallel fault-breccia zones in the quartzite.

The Squaw Springs fault has dropped the lavas of the southern portion of the range down against the limestone. The general position of this fault is indicated by the low Squaw Springs Pass. Its exact location, however, has not been determined. The throw of this fault is not known but must be at least several thousand feet.

The Horn Silver and Squaw Springs faults form the eastern and southern boundaries of the portion of the San Francisco Range in which the sedimentary and intrusive rocks are exposed and which has remained several thousand feet higher stratigraphically than the area to the east and south. Figure 8 is a conventionalized representation of the range north of Squaw Springs Pass.

Besides the main faults in the San Francisco Range, already mentioned, there are numerous east-west faults with comparatively slight throw, and these are usually not readily detected unless they have been exposed by mining operations. Several such faults are exposed in the workings of the Horn Silver and Lulu mines, where they appear to have been formed at the time the block was uplifted, the movement along them being probably in part contemporaneous 
with that along the Horn Silver fault. This minor east-west movement along the main northsouth fault while movement along that fault was still in progress resulted in a pronounced brecciation of the rock in the vicinity of the junction of the two systems and thus rendered the rock in these positions especially favorable to the action of mineralizing solutions when these found their way along the fault planes.

As already indicated, there has probably been movement along many of the mineralized fissures in the San Francisco Range, but the movement has been slight, and it is rarely that a displacement is apparent in the heary-bedded sediments.

In several other places in the region the topographic development can best be explained on the supposition that there has been recent normal faulting. Such faults are seen in the north-south escarpment 1 mile northeast of the Harrington-Hickory mine, which cuts off the upper parts of mature valleys, and west of Fairview Springs, in the Beaver Lake Mountains.

Lateral faults. - Some displacements are due to lateral movement unaccompanied by important changes in the vertical position of the formations on opposite sides of the fault. In a region of folded or inclined strata it is not always readily apparent whether the present position of the strata is due to vertical movement previous to the folding or tilting or to a lateral movement occurring after the strata had been folded or tilted. In the San Francisco region, however, the relation of the formations in certain localities is most readily explained by supposing that they were displaced by a nearly lateral movement after they had assumed essentially their present position.

The most important displacement of this character has resulted in forcing to the west the wedge-shaped block between the North and South Elephant Canyon faults. This displacement appears to have resulted from the intrusion of the quartz monzonite mass to the east, which provided space for itself by forcing the block of sediments bodily before it. Between the main east-west faults bounding this block there has been much minor faulting and movement, so that the structure of the block itself is not readily deciphered and is entirely too complex to represent on the scale of the accompanying map.

The intrusion of the quartz monzonite of the Cactus area probably resulted in similar movement, but as the sediments both to the east and west of this mass are buried it is not apparent.

Other faults. - In the Star district especially there has been movement along planes having a nearly horizontal position but with irregularities resembling a warped surface. The rocks are highly polished and grooved in places along these planes, but it was not demonstrated that there had been extensive movement. Faults of this type were observed in several of the mines of the Star district, but in the present stage of development of the mines the character and amount of the movement could not be determined.

Age of faulting.-Faulting has probably been in progress in the area over a long period. Important faults had doubtless formed before the intrusion of the quartz monzonite, and there has certainly been faulting since the intrusion.

Dutton considered that the faulting in the high plateau region of southeastern Utah began in the later part of the Pliocene and extended down to relatively recent time. It is possible that some of the faulting in the San Francisco region is of the same age, and, although it seems probable that the movement was largely completed by late Pliocene time, it is by no means improbable that movement has occurred in very recent time and may yet be in progress.

\section{FISSURES.}

Fissures are important in this area, for they have furnished channels for the passage of ore-bearing solutions. In the Star district the important fissures strike nearly east and west and are vertical or dip very steeply. In the San Francisco district the fissures can not be said to have a predominant direction. There are numerous east-west fissures, but north-south and intermediate fissures are also abundant.

The fissures in the limestone were probably formed for the most part at the time of the monzonitic intrusion and were caused by the stresses in the limestone resulting from the injection of the igneous material. - To a slight extent, especially near the contact, there was fissuring 
after the first contact alteration of the limestone; this may be attributed to the stresses caused by the shrinkage of the cooling mass. Probably the same cause has resulted in the fissuring of the monzonite.

The fissures in the lavas, which are of considerable importance in the region about Frisco, were probably also produced by the quartz monzonite intrusion. To what extent the silicified and mineralized zones in this region are true fissures rather than faults has not, however, been determined. In the Carbonate zone there has certainly been considerable movement, as is indicated by the strong gouges, and it seems probable that similar movements have occurred along the silicified zones that have the surface appearance of fissures.

\section{METASOMATIC ALTERATION OF THE ROCKS BY HOT SOLUTIONS. CONDITIONS AND CHARACTER OF THE CHANGES.}

Changes that occur in rocks, principally as a result of the replacement of a whole or part of the elements composing them by others and thus very greatly modifying their character, may take place under very different conditions, and they have done so in the San Francisco region. If the temperature is very high where the alteration is taking place the substances entering the rock will be in the form of gases rather than in liquid solutions and the process is then known as pneumatolytic alteration. Such conditions are believed to have prevailed in this region when the contact zones were formed and doubtless in the earlier part of the alteration of the quartz monzonite.

Where the temperature is lower the alteration is produced by heated watery solutions instead of gases and is known as hydrothermal alteration. This condition is present along fissures at some distance from the intrusive bodies. It is obvious that there can be no sharp line between these two types of alteration, for gaseous solutions may gradually merge into liquid solutions and the effects of the two will show a similar gradation. Moreover, it is to be expected that changing conditions will cause a superposition of one of these types of alteration upon the other.

A third type of alteration is that produced by watery solutions at ordinary temperatures. This is the alteration that is everywhere taking place at the surface and is commonly known as weathering. It is, of course, superimposed on all other types of alteration. As a general geologic process it is the most important type, and it is also of great importance in its effect upon ore bodies. The effect of weathering on the rocks of the San Francisco region has not been the subject of special study, but its effect on the ore is discussed in considerable detail on page 137 .

The alteration of the different types of rock will be taken up separately below.

\section{ALTERATION OF QUARTZ MONZONITE.}

In general, the quartz monzonite has suffered very slight alteration. Except along fissures, the rock is hard and compact, and the feldspar and ferromagnesian minerals show bright cleavage faces. Along zones of fracture, however, there has been a marked alteration in the rock. During this process the rock is bleached to a varying degree, the most highly altered rock as exposed at the surface being nearly white where free from iron stains. In the less-altered rock the dark silicates can still be recognized, but the bright luster has gone and the feldspars have a dull chalklike appearance. The highly altered and somewhat weathered rock is nearly white, of dull chalky appearance and fine granular structure, and some of it rather closely resembles altered limestone, for which it has sometimes been mistaken. This phase is well shown near the Cactus and $\mathrm{O} \mathrm{K}$ mines but is even better shown in the less extensive zones where sulphides have been but sparingly deposited, and consequently the exposures are comparatively free from iron stains. Such zones are of common occurrence in the monzonite north and northwest of the Frisco Contact mine and also near the summit of the range just north of the trail from Frisco to the Cactus mine and at many other localities in the monzonite masses. (See Pl. V.)

Where the altered rock has been exposed underground free from the influence of surface alteration, it is of a pale-greenish color and has a silky luster due to the presence of fine crystals of sericite. 


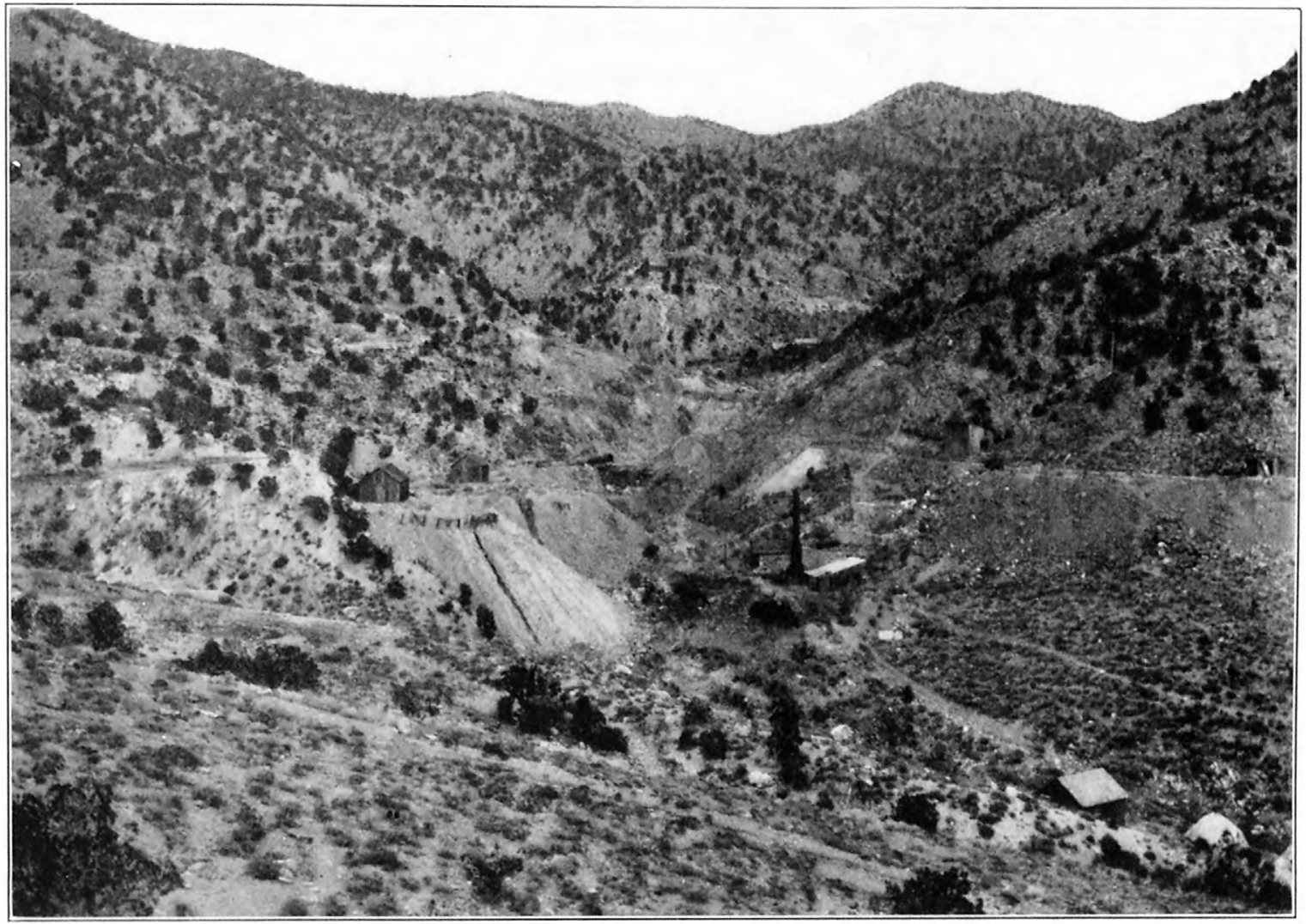

4. VIEW LOOKING EAST FROM NEW YEAR'S SHAFT.

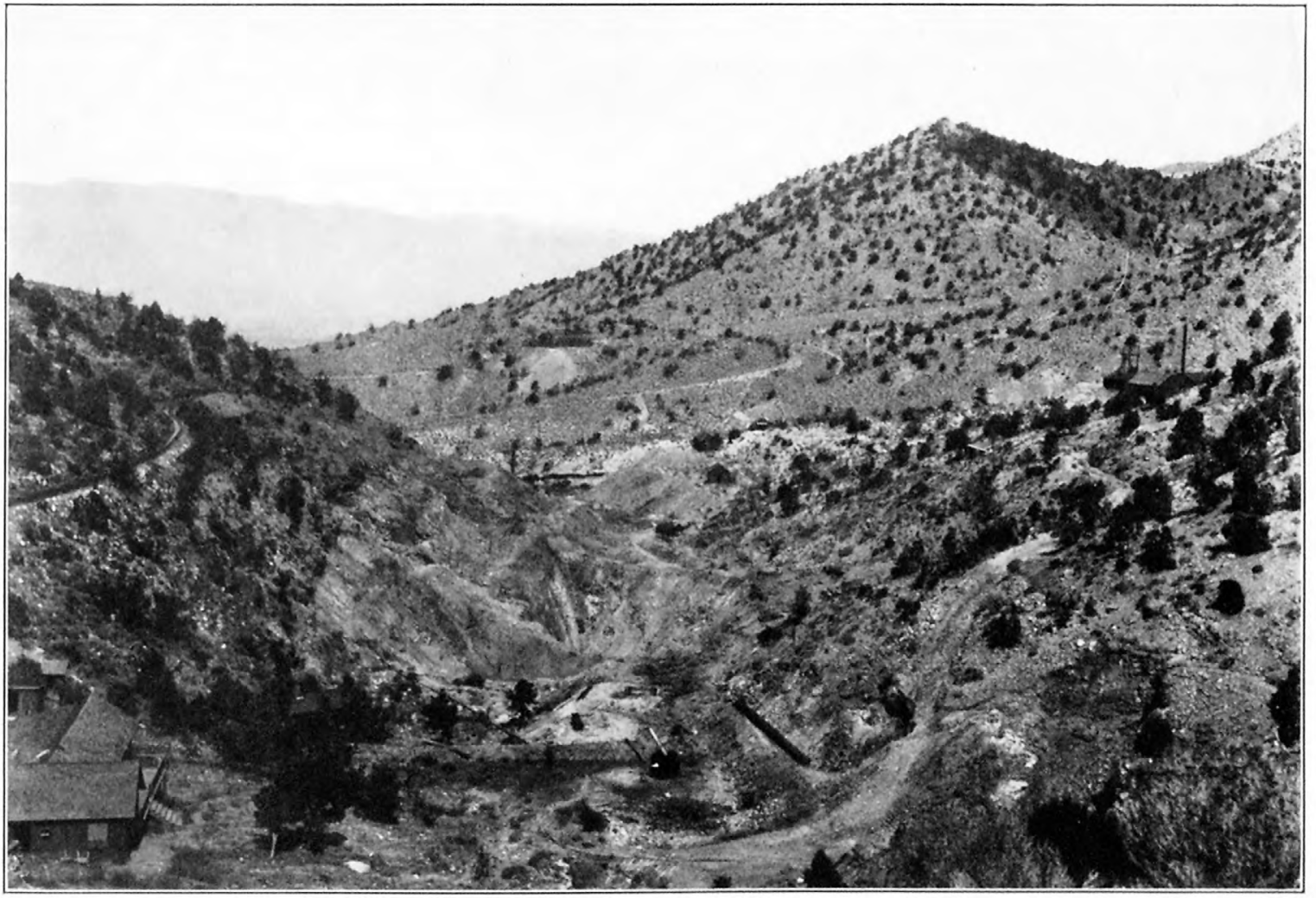

B. VIEW LOOKING WEST FROM A POINT NEAR COMET MINE. OUTCROPS OF CACTUS ORE BODY. 


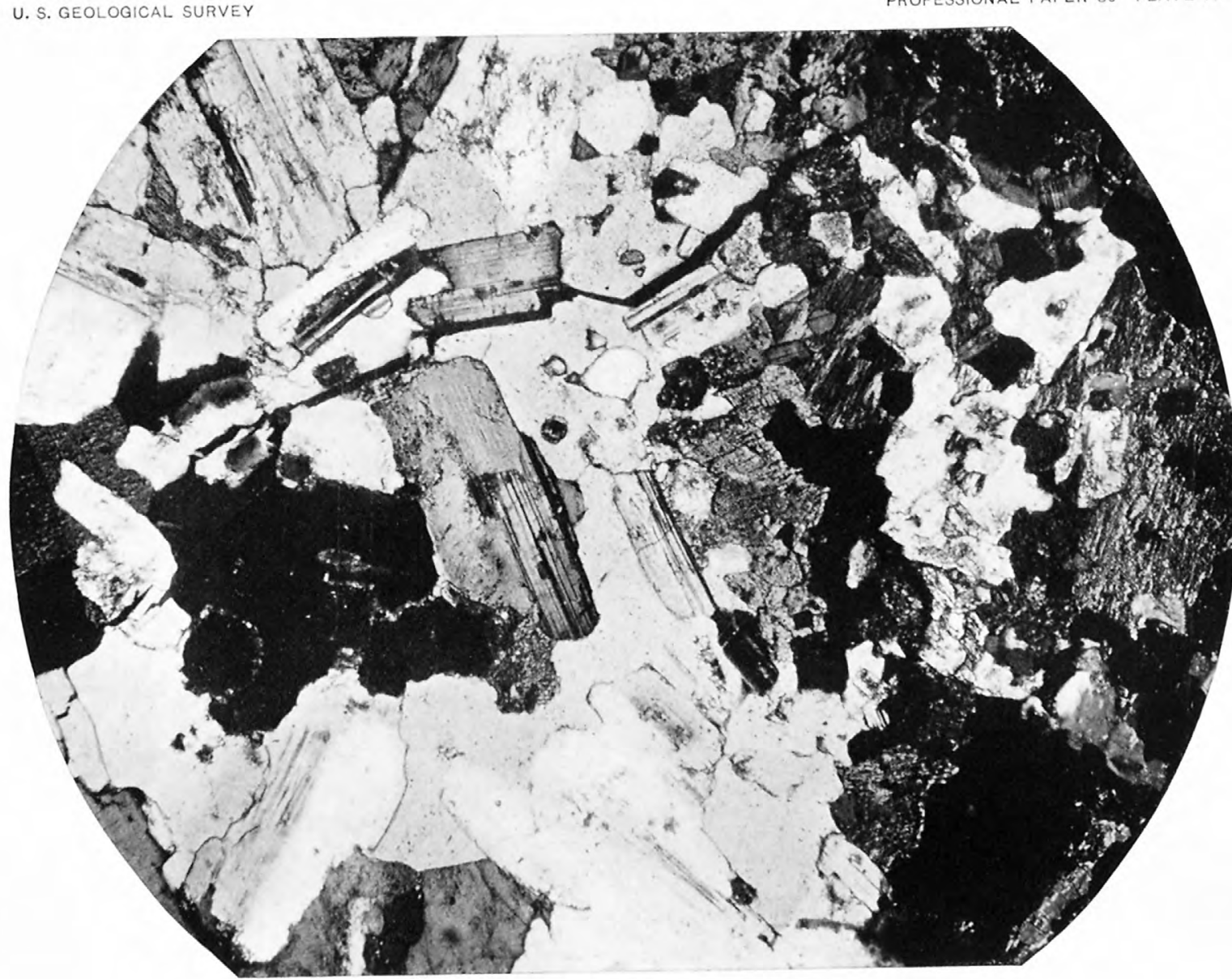

4. QUARTZ MONZONITE OF CACTUS AREA.

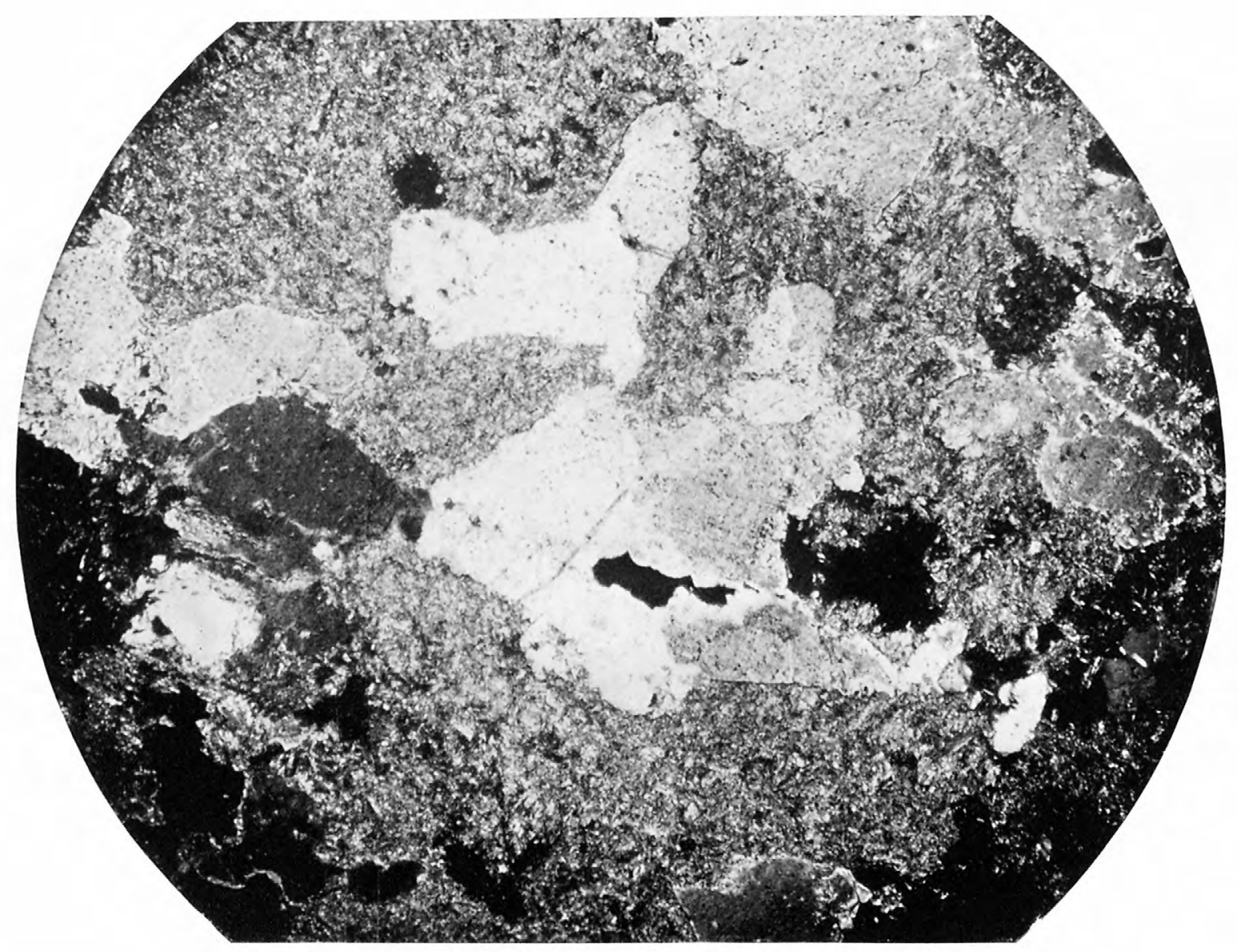

B. ALTERED QUARTZ MONZONITE OF CACTUS AREA.

Felted areas sericite, clear areas quartz. Enlarged 30 diameters. 
On microscopic examination it is seen that the alteration of the minerals has been essentially as follows:

The ferromagnesian minerals, biotite and hornblende, are among the first to be attacked. Some of the brown biotite alters along cleavage cracks to a green, highly pleochroic mica which in turn alters to chlorite. In many specimens the secondary mica was not present, and the biotite appears to have altered directly to chlorite. Calcite and quartz are present as lenses in many of the altered crystals, although there is great variation in the amount of these minerals. The chlorite areas contain a clouded mineral, usually without definite crystal outline but with high refraction and double refraction, which is believed to be rutile. Where more highly altered these clouded areas are composed of minute crystals of rutile. Whether the titanium in the mica resulted directly in the formation of rutile on the alteration of the mica or passed through an intermediate stage, possibly titanite, has not been positively determined. The hornblende passes to chlorite and carbonate. In rock showing the advanced stage of alteration it is usually impossible to tell from which of the dark minerals the alteration products have resulted, and in much of the highly altered rock the areas occupied by the dark silicates can not be recognized, as sericite has entered these areas as well as feldspar and quartz. In the most altered rock the magnesium is present as serpentine scattered in small fibrous masses through the minerals.

The feldspars show alteration nearly as soon as the dark silicates. The lime-soda feldspars alter more readily than the orthoclase. The latter is slightly clouded by some extremely fine secondary mineral even before the plagioclase shows marked alteration, but aside from this appears to be much more stable than the plagioclase. Alteration in the feldspars begins by the replacement of the mineral along cleavage cracks by flakes of sericite (muscovite) and this spreads till the whole crystal is changed to a felted mass of sericite. Calcite may be present in the first stages of alteration in the feldspar crystals, but in the advanced stages of sericitization it has not been noted.

Quartz is one of the latest minerals to be affected. Where alteration has been profound foils of sericite develop in the quartz crystals along cracks, and in the most highly altered rock the quartz crystals have been broken up, the space being filled with granular quartz and sericite. Usually, however, the quartz crystals retain the form and outline they have in the unaltered rock. (See Pl. VI.) A few of these apparently original crystals contain the cleavage line and shreds of biotite, indicating that quartz has replaced that mineral.

Of the accessory minerals, magnetite is usually among the first to be altered, probably in part at least forming the sulphides and in the Cactus vein possibly in part forming carbonate and secondary magnetite and hematite. Titanite is much more resistant and remnants of titanite crystals are present in some of the highly altered rock. In every occurrence observed rutile is the final alteration product of titanite. Crystals of rutile are always present in the titanite where the alteration of the rock has been pronounced. Apatite is present in all stages of alteration of the rock and apparently has suffered little change. In the altered rock adjoining the Cactus vein siderite is rather abundant, but in the $\mathrm{OK}$ and other alteration zones it was not noted in the highly altered rock, though carbonate, largely calcite, formed in the earlier stages of alteration. Magnetite also appears to be variable in its occurrence. In the Cactus zone it is present in considerable amount, apparently formed after the alteration of the magnetite of the original rock and as a rule closely associated with carbonate. Its usual mode of occurrence is in small grains, apparently resulting from the alteration of lath-shaped crystals. Some of these laths are still in part composed of a reddish mineral, doubtless hematite. and apparently the original mineral deposited was hematite. In the $\mathrm{O} \mathrm{K}$ zone neither magnetite nor hematite was recognized in the highly altered rock. In the Cactus zone tourmaline is present in some of the altered wall rock, though it has usually formed in open spaces rather than in the rock. A very few microscopic crystals of tourmaline were also noted in specimens from the O K mine. Sulphides of iron and copper are present in varying amounts. Molybdenite is present in the $\mathrm{O} \mathrm{K}$ zone, and a few microscopic crystals were noted in specimens from the Cactus mine. 
In a few places, as about due north of the Cactus mine, there is a slight alteration along joints in the quartz monzonite near the limestone contact. The minerals that have formed along these joints are principally wollastonite and epidote, with some colorless amphibole and considerable calcite. Sulphides are present in small amounts. The minerals are similar io those ordinarily formed at the contact of limestone and monzonite and the mineralization is doubtless influenced by the proximity of the limestone.

The following chemical analyses show the composition of the fresh and altered rock in the Cactus and $\mathrm{O} \mathrm{K}$ zones, with analyses of similar rocks from two other districts for comparison:

Analyses of fresh and altered monzonite.

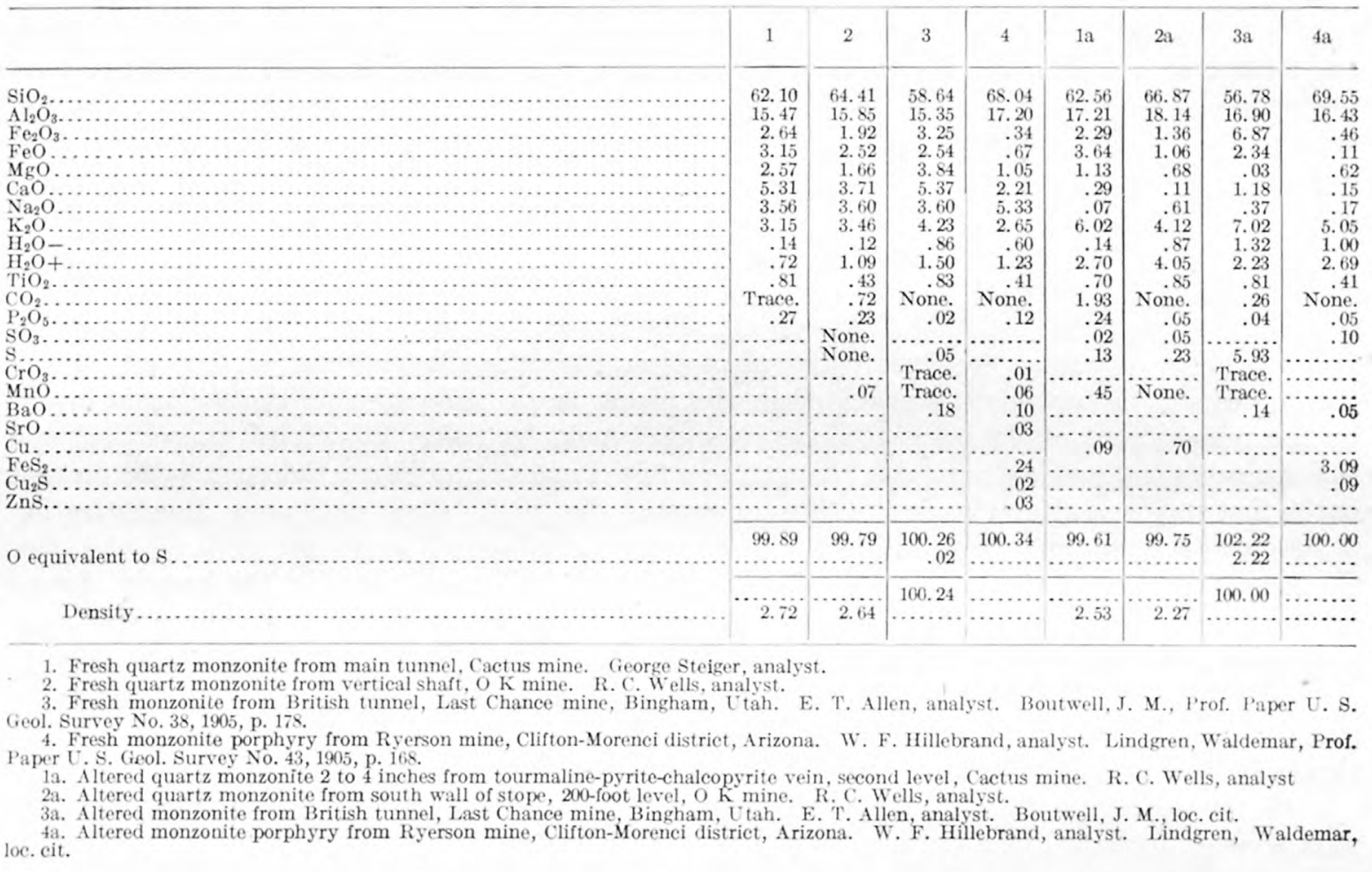

For an accurate comparison of the chemical changes that have occurred in the alteration of the rock, it is necessary to recalculate the analyses so as to show the additions and subtractions that have taken place from a given volume of rock. No evidence was observed in the field to indicate that there had been a marked change in the volume of the rock due to alteration, and in the following calculations it is assumed that the volume remained constant. In the subjoined table is shown the weight of each of the principal oxides in grams in a cubic centimeter of the fresh and altered rock.

Weight of the principal oxides in fresh and altered monzonite.

[Grams in 1 cubic centimeter.]

\begin{tabular}{|c|c|c|c|c|}
\hline & 1 & 2 & $1 \mathrm{a}$ & $2 \mathrm{a}$ \\
\hline 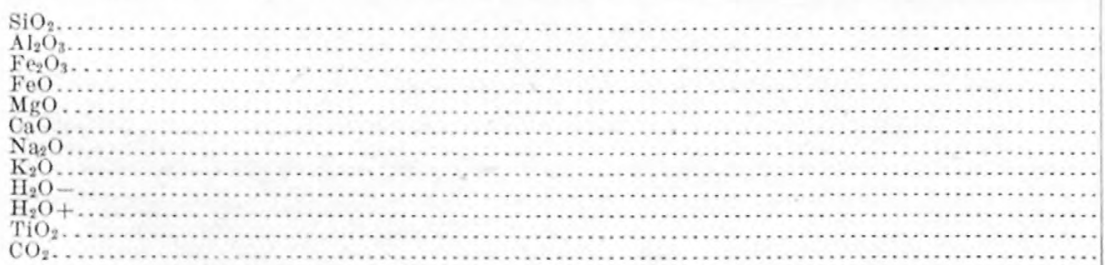 & $\begin{array}{l}1.689 \\
.420 \\
.071 \\
.085 \\
.069 \\
.144 \\
.096 \\
.085 \\
.003 \\
.019 \\
.022 \\
.000\end{array}$ & $\begin{array}{r}1.760 \\
.418 \\
.050 \\
.066 \\
.043 \\
.097 \\
.095 \\
.091 \\
.003 \\
.028 \\
.011 \\
.019\end{array}$ & $\begin{array}{r}1.582 \\
.435 \\
.057 \\
.092 \\
.028 \\
.007 \\
.001 \\
.152 \\
.003 \\
.068 \\
.017 \\
.048\end{array}$ & $\begin{array}{r}1.518 \\
.411 \\
.030 \\
.024 \\
.015 \\
.002 \\
.013 \\
.093 \\
.019 \\
.092 \\
.000 \\
.001\end{array}$ \\
\hline
\end{tabular}

NotE.-The numbers at the heads of the columns correspond to those used in the preceding table. 
This table shows that silica $\left(\mathrm{SiO}_{2}\right)$ decreased, though the decrease is not marked. Alumina $\left(\mathrm{Al}_{2} \mathrm{O}_{3}\right)$ shows little change; in the Cactus deposit it has been slightly increased, in the $\mathrm{O} \mathrm{K}$ deposit slightly decreased. These changes, however, are not greater than might be found in two samples from the same rock mass, and it seems likely that there has been little change in the content of alumina. In the alteration of the Cactus zone the oxides of iron have remained nearly constant, but in the $\mathrm{O} \mathrm{K}$ zone there has been removal of iron. Magnesia ( $\mathrm{MgO}$ ) has been reduced in both zones and there is no doubt that the alteration has resulted in its removal. Both lime $(\mathrm{CaO})$ and soda $\left(\mathrm{Na}_{2} \mathrm{O}\right)$ have been almost completely removed, but potash $\left(\mathrm{K}_{2} \mathrm{O}\right)$, especially in the Cactus zone, shows a marked increase as does also combined water. Titanium oxide $\left(\mathrm{TiO}_{2}\right)$ remains nearly constant. In the Cactus zone there has been a marked addition of carbon dioxide $\left(\mathrm{CO}_{2}\right)$ but this has not been added in the $\mathrm{O} \mathrm{K}$ zone. Sulphur and copper have been added in both zones. The samples selected for analysis contained little sulphide and in this respect do not represent the average of the altered rock.

The chemical change shown by the analyses is similar to that occurring in other districts where similar mineralization has taken place, as shown by the analyses of fresh and altered rock from the Clifton-Morenci and Bingham districts in the table on page 76.

In general, the alteration of the monzonite in the different districts has been very similar though there are some differences, notably the absence of carbon dioxide in the Clifton-Morenci district and its presence at Bingham. In the San Francisco region carbon dioxide is present in the Cactus zone but does not occur in the O K deposit.

The following table shows the mineral changes that have taken place in the alteration of the rocks:

Mineral composition of fresh and altered monzonite, calculated from chemical analyses.

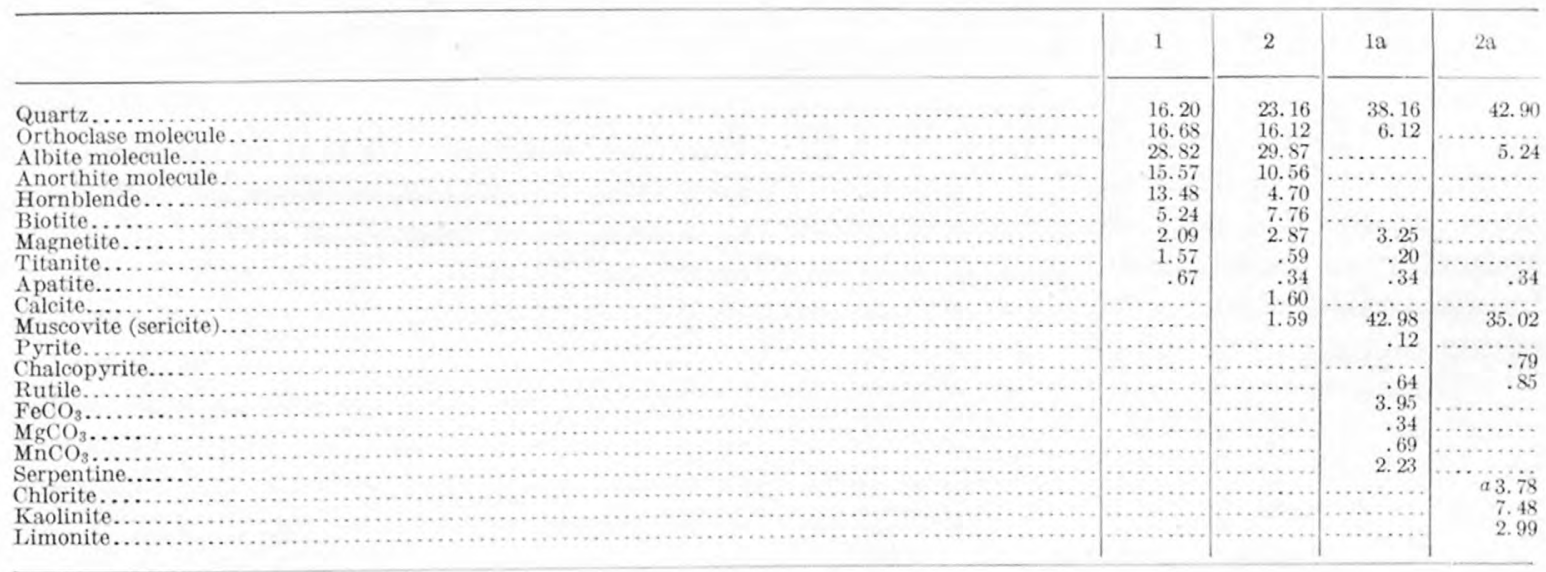

a Clinochlore, MgO: FeO :: $17: 14$.

NotE.-The numbers at the heads of the columns correspond to those used in the two preceding tables,

As stated in the discussion of the microscopic study, the feldspars and ferromagnesian minerals have been altered. No unaltered feldspar was seen in either of the altered rocks, though the calculation of the analyses indicates that some of the potassium in the altered rock of the Cactus zone is present as the orthoclase molecule, and the same is possibly true of the soda in the altered rock of the $\mathrm{O} \mathrm{K}$ zone, although in the latter it may be present as the paragonite molecule in the sericite and the amount of kaolinite may be less than that indicated. Magnetite is more abundant in the altered than in the fresh rock of the Cactus zone, but it is not present in the altered rock of the $\mathrm{O} \mathrm{K}$ zone. Titanite has been largely altered, and rutile becomes the principal titanium mineral. The magnesium of the ferromagnesian minerals that has not been removed is present as chlorite and serpentine, and carbonates become abundant in the altered rock of the Cactus zone.

From the nature of the chemical and mineralogic changes that have taken place in the rock, it is possible to draw some inferences as to the composition of the solutions that produced them. Substances that have been added to the rock by the action of these solutions were 
necessarily carried by them. It does not follow that because the solutions have removed certain elements these same elements were not contained in the solutions before they acted on the rocks, though it seems likely that they were not unusually rich in those elements. From this it may be inferred that the solutions contained potash, sulphur, and copper, and in the Cactus vein also iron and carbon dioxide. It is probable that the two latter constituents were present in the solutions that produced the alteration in other zones but not in sufficient quantities to be added to the rock under the conditions that prevailed when the alteration took place. Although silica has not been added in notable amounts, it is probable that the solutions were rich in silica, for otherwise there would have been a distinct solution and subtraction of it.

Lindgren reaches the following conclusion concerning the nature of the solution that produced the change at Morenci: "The whole course of the alteration indicates waters distinctly deficient in alkaline carbonates, but probably rich in iron and silica." Boutwell states for the Bingham district that "it would appear that the alteration was produced by heated solutions rich in $\mathrm{K}_{2} \mathrm{O}$."

\section{ALTERATION OF LAVAS.}

The lavas have suffered extensive alteration by heated solutions in several areas. The alteration is especially pronounced in the lavas near the base of the San Francisco Range, about Frisco, and in the lava mass forming the central part of the Beaver Lake Mountains, and also in the central portion of the lava mass in the southwestern portion of the San Francisco Range. In the Frisco region the belt showing the most alteration extends from a point near the Horn Silver mine northward along the base of the range to the Beaver Carbonate mine, and the volcanic rocks are highly altered for a considerable distance farther northwest. In the Beaver Lake district the lavas are most altered in the ridge west of the southern quartz monzonite mass and in the central volcanic mass north of the $\mathrm{O} \mathrm{K}$ mine. There has been considerable alteration, however, of all the lavas of this district.

These rocks, after suffering hydrothermal metamorphism, have had their character still further changed through the operation of the ordinary weathering agents. There has been no extensive prospecting in these areas to expose the volcanic rocks below the zone of surface alteration and it is therefore impossible to determine exactly the changes that took place under hydrothermal conditions as distinguished from the surface alteration. It is possible, however, from the material available to get a general idea of the changes in the rock resulting from the effects of heated solutions.

The altered rocks have a light-colored, bleached appearance, being nearly white in many places where they are not stained by secondary iron compounds. Ordinarily they are rather soft, though in some localities where silicification has been pronounced the altered rocks are hard and resistant and stand above the general surface, as is well illustrated in the knobs and ridges in the San Francisco district. (See Pl. VII.)

Under the microscope the rocks are seen to have undergone changes normal to hydrothermal alteration. The ferromagnesian minerals in much of the rock had undergone magmatic alteration, so that in many places only small amounts of these minerals are present in the unaltered lavas. The biotite, which is the ferromagnesian mineral most often seen, is altered to quartz and a colorless mica and possibly some serpentine, though the magnesium appears to have been largely removed in alteration. The iron ore has been altered in some places, and where pyrite or specularite are not present it has apparently been removed and probably deposited where these iron minerals are abundant. In other places iron ore is present in highly altered rock, apparently having suffered little change. The feldspars first show sericitization along cleavage surfaces and eventually the whole crystal is converted into a feltlike mass of sericite and quartz crystals. The groundmass of the fine-grained rocks also suffers sericitization,

The workings of the Frisco Contact mine reveal rock that has suffered comparatively slight surface alteration. It is composed largely of sericite and quartz, together with considerable pyrite and hematite. Hematite forms in seams and is also disseminated through the rock. 


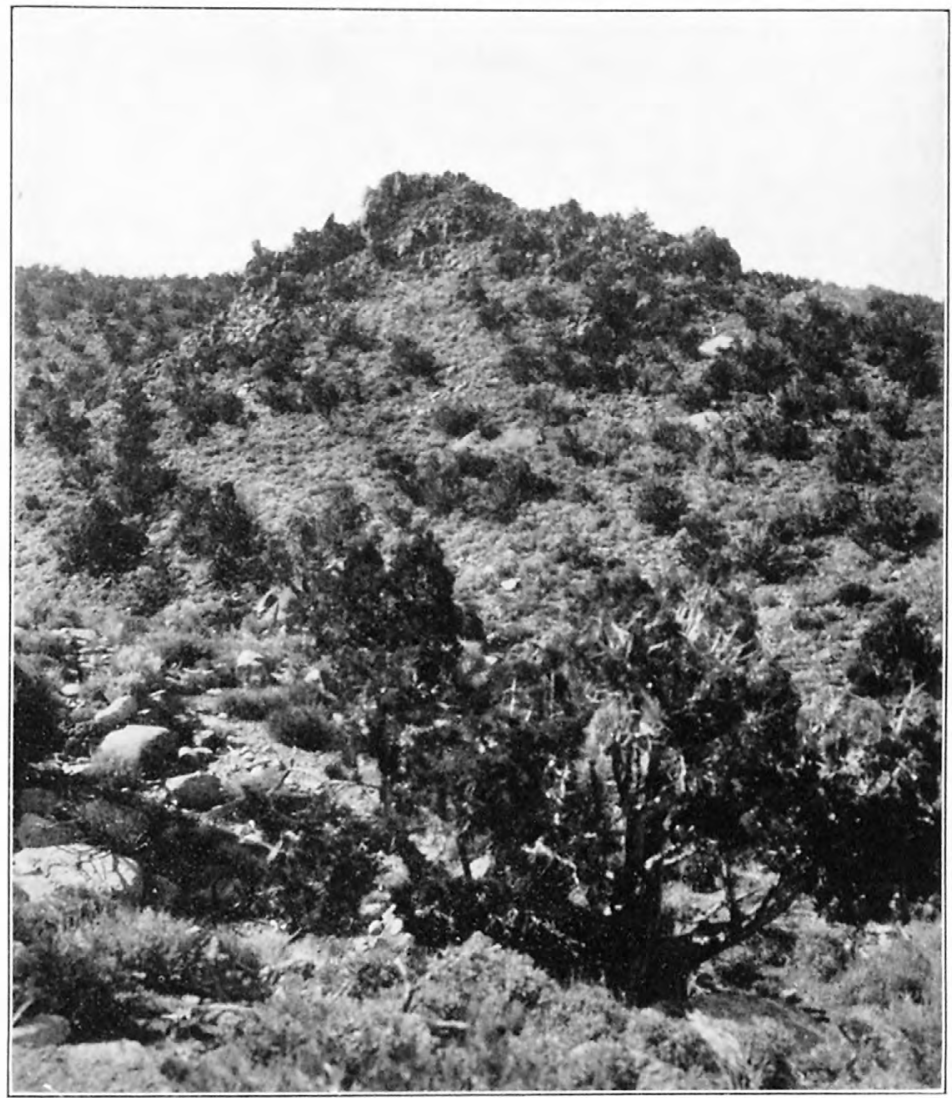

A. INDIAN GRAVE PEAK.

Silicified "reef," near view.

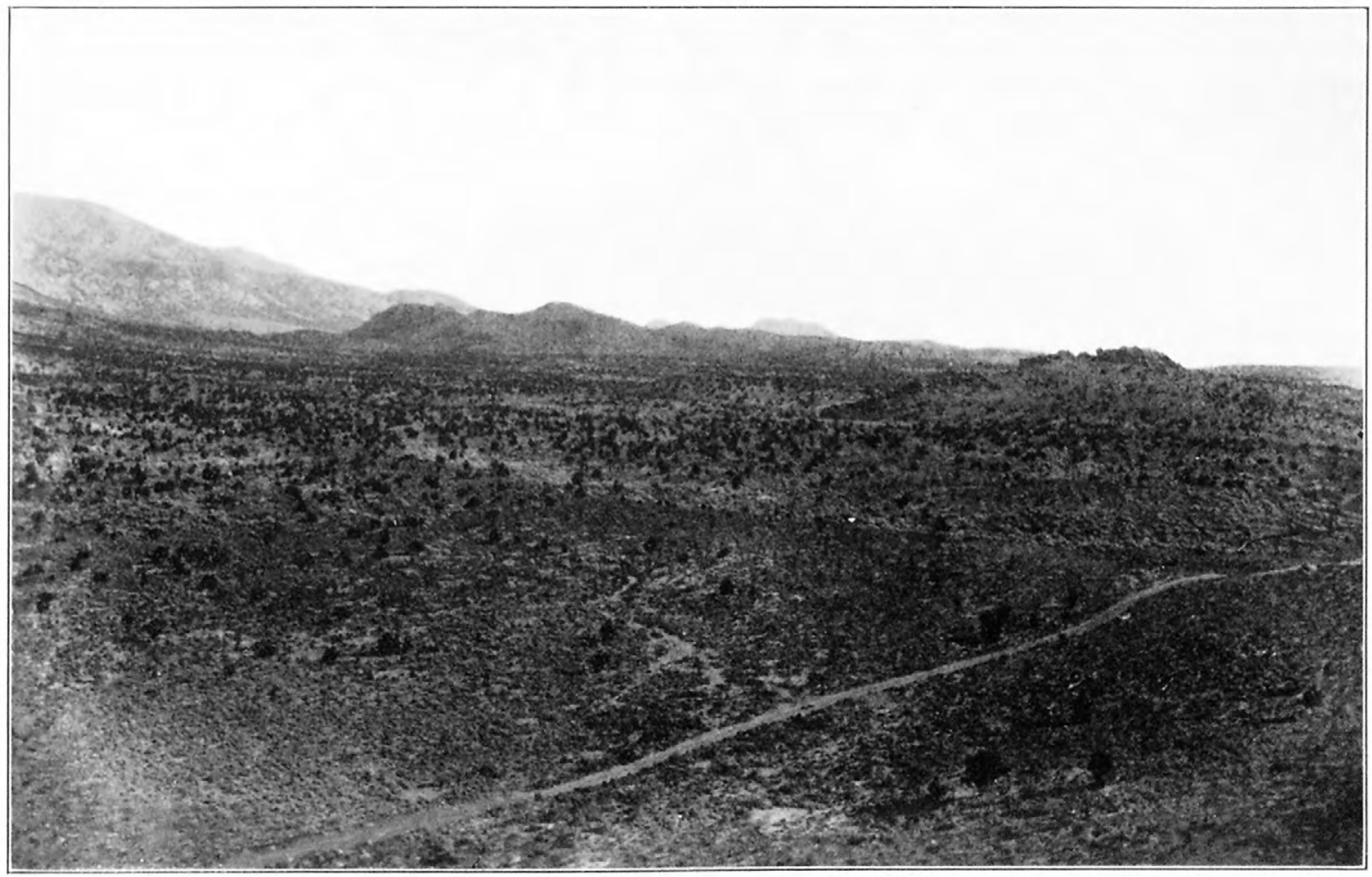

B. SILICIFIED "REEF" SOUTH OF CARBONATE MINE. 

Gypsum is present, forming small irregular microscopic bodies in the rock and also occurring in small veins.

A part of the rock in the volcanic ridges west and north of the $\mathrm{O} \mathrm{K}$ mine has suffered unusually severe alteration. In the field it is difficult to determine whether the rocks are highly altered quartzose sediments or altered volcanic rocks. Their gradation into rock that can be definitely recognized as volcanic, however, indicates that they are all of this origin. Under the microscope, as in the field, the most highly altered rocks have quite as much the appearance of altered sediments as of volcanic rocks, being composed principally of irregular grains of quartz and foils of muscovite together with a mineral in small, irregular grains. This mineral has a mean index of about 1.64, double refraction a little above quartz, optical character negative, with large axial angle and extinction parallel to a good cleavage. Some crystals show slight pleochroism. The mineral corresponds in optical properties closely with andalusite, though the pleochroism is less marked than is usual in that mineral. The quartz grains contain numerous small globular masses with rather high index that appear to be the same mineral. These were included in the quartz during crystallization, and as such inclusions do not occur in the quartz grains of the fresh rock they indicate that the quartz has resulted from crystallization during the metamorphism. In some sections there are small areas of a brownish mineral having moderate refraction and low double refraction, probably kaolinite. Carbonate is usually present in small but varying amounts.

Some sections contain irregular crystals of a mineral with rather strong refraction and high double refraction. This mineral has not been positively identified but in the optical properties determined corresponds with diaspore. A mineral resembling magnetite under the microscope but rather feebly magnetic as tested in the rock powder is present in much of the altered rock. In a specimen where the magnetic mineral is not abundant there are numerous small crystals with high refraction and double refraction. These are probably rutile, resulting from the alteration of ilmenite. Apatite is rather abundant and a mineral with low index and apparently isotropic is present in small amount. This is probably fluorite.

A specimen (No. 2 in the following table of analyses) that still retains the structure of the lava so that it can be definitely recognized in the field as having altered from that rock is composed largely of quartz and sericite, with a few crystals determined as andalusite and numerous areas of small crystals having moderate relief and low birefringence, probably the same mineral, also a brownish fibrous mineral with low double refraction that is probably kaolinite. This rock appears to have just reached the stage where andalusite is beginning to form and stands between the unaltered lava and the highly altered andalusite rock.

The following table shows the chemical composition of the fresh and altered rock. It was not found possible to trace flows from the unaltered into the highly altered zone, and it is not certain or even likely that the specimens were originally of exactly the same composition. All the lavas of the district, however, have a general similarity of composition, and is is probable that the altered rocks had an original composition not differing greatly from that of the specimens whose analyses are shown in the table.

Parial analyses of fresh and altered lava from San Francisco region, Utah.

\begin{tabular}{|c|c|c|c|c|}
\hline 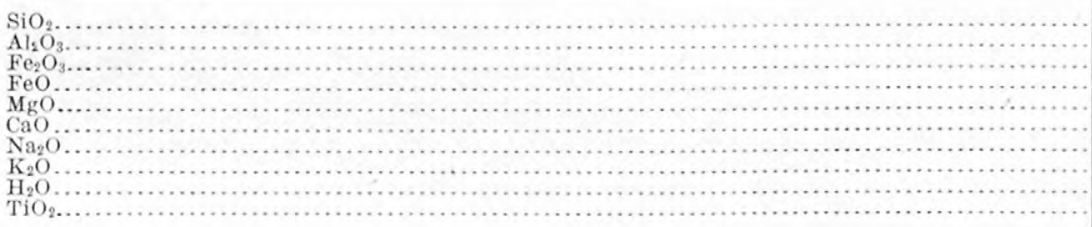 & $\begin{array}{r}64.48 \\
\text { None. } \\
1.95 \\
4.81 \\
3.39 \\
2.1 . \\
\end{array}$ & $\begin{array}{r}76.74 \\
16.10 \\
.10 \\
.34 \\
.58 \\
3.99 \\
2.34 \\
7.2 .\end{array}$ & $\begin{array}{r}72.32 \\
20.96 \\
.50 \\
\text { None. } \\
.15 \\
.55 \\
.93 \\
3.91 \\
1.10\end{array}$ & $\left\{\begin{array}{r}67.93 \\
19.46 \\
.28 \\
1.42 \\
3.54 \\
3.91 \\
\ldots . . .6 .\end{array}\right.$ \\
\hline
\end{tabular}

1. Quartz latite near summit of Beaver Lake Mountains north of O K mine (specimen 187). R. C. Wells, analyst.

2. Altered voleanic rock from ridge north of O K mine (specimen 189). George Steiger, analyst.

3. Highly altered volcanic rock from ridge west of o $\mathrm{K}$ mine (specimen 
The following table shows the approximate mineral composition of the rocks as calculated from the chemical analyses after microscopic study:

Mineral composition of fresh and altered lava from San Francisco region, Utah.

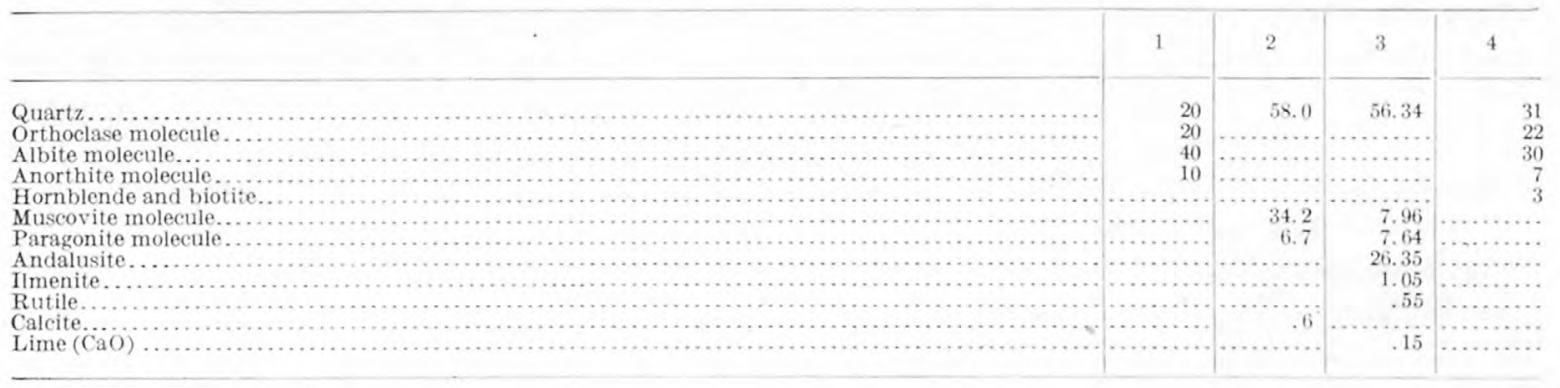

There is some kaolinite present in No. 3, resulting from the surface alteration of the rock, so that the andalusite is somewhat less. The amount shown above is doubtless about correct for the rock before surface alteration took place.

Analyses 1 to 3 represent successive stages in the alteration of the volcanic rocks in the Beaver Lake district. The first two were not made primarily for showing the successive stages of alteration and consequently are not as complete as would be desirable for that purpose.

It is evident that in the alteration which has resulted in No. 2 there has been a decrease in all the oxides except silica, alumina, potash, and water. There has been an apparent increase in silica and potash, at least, but doubtless this is due only to a concentration of these two resulting from the removal of the other oxides. In fact, these also have probably decreased to some extent. Their ratio in the freshest rock is $\mathrm{K}_{2} \mathrm{O}: \mathrm{SiO}_{2}:: 1: 19$ and in the altered rock $1: 19$, indicating that if there has been a notable decrease it has been in about the ratio of their presence in the original rock. It seems more probable that there has been comparatively little change in these two oxides. As alumina was not determined in the fresh rock, it is impossible to make a comparison, but it is probable that there has been little change in the actual amount of this oxide, though, as in the two oxides discussed above, there may be an apparent increase. Iron and titanium have not been determined, but from the microscopic study it appears that in some places iron has been very largely removed, and this is true of No. 2, while in other places the iron ore remains, showing little alteration. Titanium remains in the rock either as iron ore or rutile.

In No. 3 all the oxides show a decrease except silica, alumina, titanium oxide, and water. Silica also may have decreased, though the difference is not sufficiently marked to prove that it is not due to original differences in the rock. It is especially noteworthy that although magnesia, lime, and soda showed a marked decrease from No. 1 to No. 2 potash showed only a slight decrease, but in No. 3 all four oxides have been greatly decreased. Apparently under the conditions that have produced the alteration potash has been much more persistent than the other oxides except alumina and silica.

In studying the mineralogic changes we find that No. 1 is essentially a quartz-feldspar rock, with considerable iron ore not shown in the analyses; No. 2 is essentially a quartz-muscovite rock; and in No. 3 the amount of muscovite has been greatly reduced and we have essentially a quartz-andalusite-muscovite rock. From the microscopic examination it appears that andalusite does not form in important amount while feldspar is still present in the rock. In other words, as long as there was sufficient potash or soda in the rock to unite with the alumina that was liberated by the breaking down of the feldspars and the removal of the lime or alkali to form the more aluminous mineral mica, this combination has been effected rather than the formation of an aluminum silicate in the presence of feldspar. Where all the potash and soda are present as mica, any further removal of these oxides, alumina remaining constant, must leave an excess of alumina which must form either a mineral composed of alumina, a hydrate of 
arumina, or an aluminum silicate. In this region it has usually formed the aluminum silicate andalusite and in some places probably the hydrous aluminum oxide diaspore.

In No. 2 the alteration has just reached the point where soda and potash are present in almost exactly the amounts necessary to form mica. No feldspar could be found in the rock, though there were a few crystals of andalusite, indicating that the stage of alteration of feldspar to mica has just passed and the alteration of mica to andalusite begun. In No. 3 a considerable part of the mica has been altered to andalusite, with removal of the potash. Were this to continue, the rock would be reduced to essentially quartz and andalusite.

\section{DIFFERENCES IN THE CHARACTER OF ALTERATION IN THE LAVAS AND} QUARTZ MONZONITE.

Though the mineralogic changes have been in part similar, it is evident that the alteration which has affected the lavas is markedly different in character from that which has affected the quartz monzonite. In the alteration of the monzonite there was a marked addition of potash and less notable additions in other elements. In all stages of the alteration the alkalies were present in sufficient amounts to unite with alumina to form mica. The solutions affecting the monzonite were evidently rich in potash and carried other oxides, as silica, carbon dioxide, and metallic elements. The solutions that affected the lavas, on the other hand, probably added little to the rocks, the change being a progressive subtraction of certain of the constituents and a rearrangement of those remaining. The difference in alteration therefore appears to be due primarily to the difference in character of the solutions that produced it.

The nature of the solutions that resulted in the alteration of the lavas may be inferred to some extent by a study of examples of alteration in which the solvent is better known. Such an example is found in the ordinary surface weathering of rocks, which so far as chemical agencies are concerned is probably brought about chiefly by the action of water carrying carbon dioxide, though various acids and salts are doubtless active to a minor extent. The chemical change that occurs in weathering is very similar to that which has taken place in the alteration of the lavas, as is shown by the following analyses of fresh and altered rock:

Analyses of fresh and decomposed syenite from Arkansas. ${ }^{a}$

\begin{tabular}{|c|c|c|c|c|}
\hline \multirow[t]{2}{*}{ 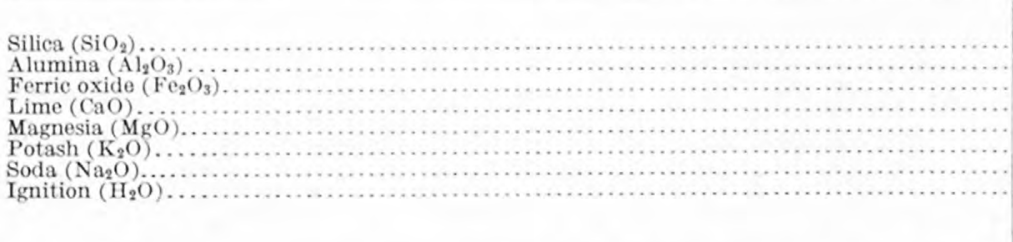 } & $\begin{array}{r}\text { Per cent. } \\
59.70 \\
18.85 \\
4.85 \\
1.34 \\
.68 \\
5.97 \\
6.29 \\
1.88\end{array}$ & $\begin{array}{r}\text { Per cent. } \\
58.50 \\
25.71 \\
3.74 \\
.44 \\
\text { Trace. } \\
1.76 \\
1.37 \\
5.85\end{array}$ & $\begin{array}{r}\text { Per cent. } \\
50.65 \\
26.71 \\
4.87 \\
.62 \\
.21 \\
1.91 \\
.62 \\
8.68\end{array}$ & $\begin{array}{r}\text { Percent. } \\
46.27 \\
38.57 \\
1.36 \\
.34 \\
.25 \\
.23 \\
.37 \\
13.61\end{array}$ \\
\hline & 99.56 & 97.57 & 94.27 & 101.00 \\
\hline
\end{tabular}

a Merrill, G. P., Rocks, rock weathering, and soils, 1906, p. 196.

It is evident that in weathering lime and soda are more readily removed than potash, especially until the amount of these oxides present in the rock is greatly reduced. Iron oxides, alumina, and silica are not greatly reduced, although iron and silica show considerable reduction in the highly altered material. This change is similar to that noted in the lavas, except that potash has shown less reduction relative to soda and lime in early stages of the hydrothermal alterations than in the ordinary weathering.

Mineralogically there is a marked difference in the two types of alteration. In weathering the feldspars break down to kaolinite and quartz with removal of the lime and alkalies; in the hydrothermal alteration the alumina, set free by the removal of lime and alkalies, has united with the alkalies of the feldspar to form the more aluminous mineral mica. When the removal of the alkalies has progressed to a stage where there is an excess of alumina over that required $73363^{\circ}-$ No. $80-13-6$ 
to unite with the alkalies present to form mica, this excess has formed the anhydrous aluminous silicate andalusite, and locally'some of the alumina has formed the hydrous aluminum oxide diaspore.

The similarity in chemical change, accompanied by the formation of different minerals, suggests that the two types of alteration may be due to essentially the same agents acting under different physical conditions. The presence of andalusite and sericite in the lavas indicates that the alteration took place under conditions of considerable heat and possibly considerable pressure. Andalusite, so far as the writer is aware, has been described as occurring only where the conditions indicate that there was high heat and pressure, namely, $(a)$ in pegmatite veins in zones of contact alteration and $(b)$ in areas of regional metamorphism. The conditions in the Beaver Lake district do not indicate that the lavas were deeply buried, and it seems probable that high pressure is not essential to the formation of andalusite. There can be little doubt, however, that the solutions which produced the change were of relatively high temperature. It seems probable, therefore, that the alteration could have been accomplished by waters containing carbon dioxide. Such waters may have been derived in part from the crystallizing quartz monzonite and in part from meteoric waters that found their way into the heated zone. Waters from both these sources may very likely have been active.

Cross ${ }^{1}$ has described the alteration of rhyolite at Mount Robinson, Colo., to a rock composed essentially of quartz and diaspore. This alteration seems to be similar to that of the Beaver Lake Mountains except that the hydrous oxide of aluminum, diaspore, is formed instead of the anhydrous silicate andalusite. Closely associated with the quartz-diaspore rock of Mount Robinson are rocks composed of quartz and alunite which seem to have been formed under similar conditions. No alunite was observed in the San Francisco region except that associated with the ore body of the Horn Silver mine.

\section{ALTERATION OF THE SEDIMENTARY ROCKS.}

LOCAL VARIATIONS IN CHARACTER.

Under contact metamorphism are considered the changes that have taken place in the sedimentary rocks near their contact with intrusive bodies, resulting directly from the intrusion. These changes vary greatly in the different rocks. In the shale and quartzites the change is as a rule relatively slight, but in the limestone it may completely alter the character of the rock. Even in the limestones, however, there is great variation in the amount of alteration at different points along the contact.

Wherever the limestone is in contact with the main masses of the intrusive bodies it has been more or less altered, but the alteration varies greatly in character and intensity. The variation in character is dependent principally on the composition of the limestone and possibly also in part on the composition of the solutions producing the alteration. The variation in the intensity of alteration from place to place appears to be dependent on physical causes that have controlled the flow of the solutions which produced the changes.

\section{METAMORPHISM IN THE SEVERAL DISTRICTS.}

SAN FRANCISCO DISTRICT.

Contact alteration has occurred in the San Francisco district in the sediments at or near the contact with the quartz monzonite stock and the dikes extending out from it and along fissures in the limestone at considerable distances from the contact. The most extensive area of highly altered rock is along the southern border of the quartz monzonite stock of the Cactus area, extending more than half a mile east and west of the Imperial mine. Both east and west of this zone the contact alteration is much less pronounced. The width of the zone of alteration is variable and at the outer border it merges gradually into the unaltered limestone. In the vicinity of the Imperial mine, where this zone is best developed, the limestone has been very largely converted to silicates for a distance of nearly one-fourth of a mile from the visible contact and

${ }^{1}$ Cross, Whitman, Geology of Silver Cliff and the Rosita Hills, Colo.: Seventeenth Ann. Rept. U. S. Geol. Survey, pt. 2, 1896, pp. 263-403. 


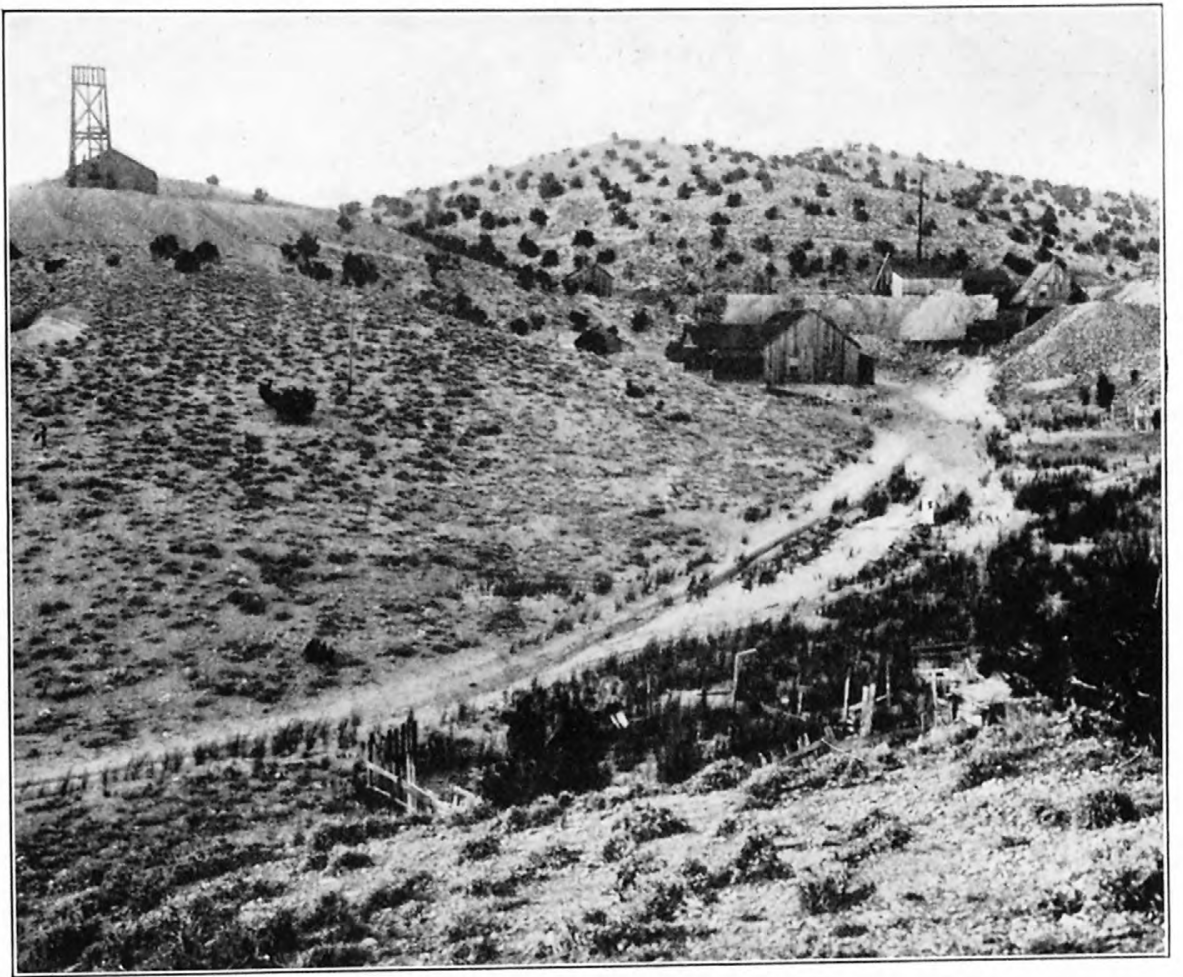

A. O K MINE, BEAVER LAKE DISTRICT.

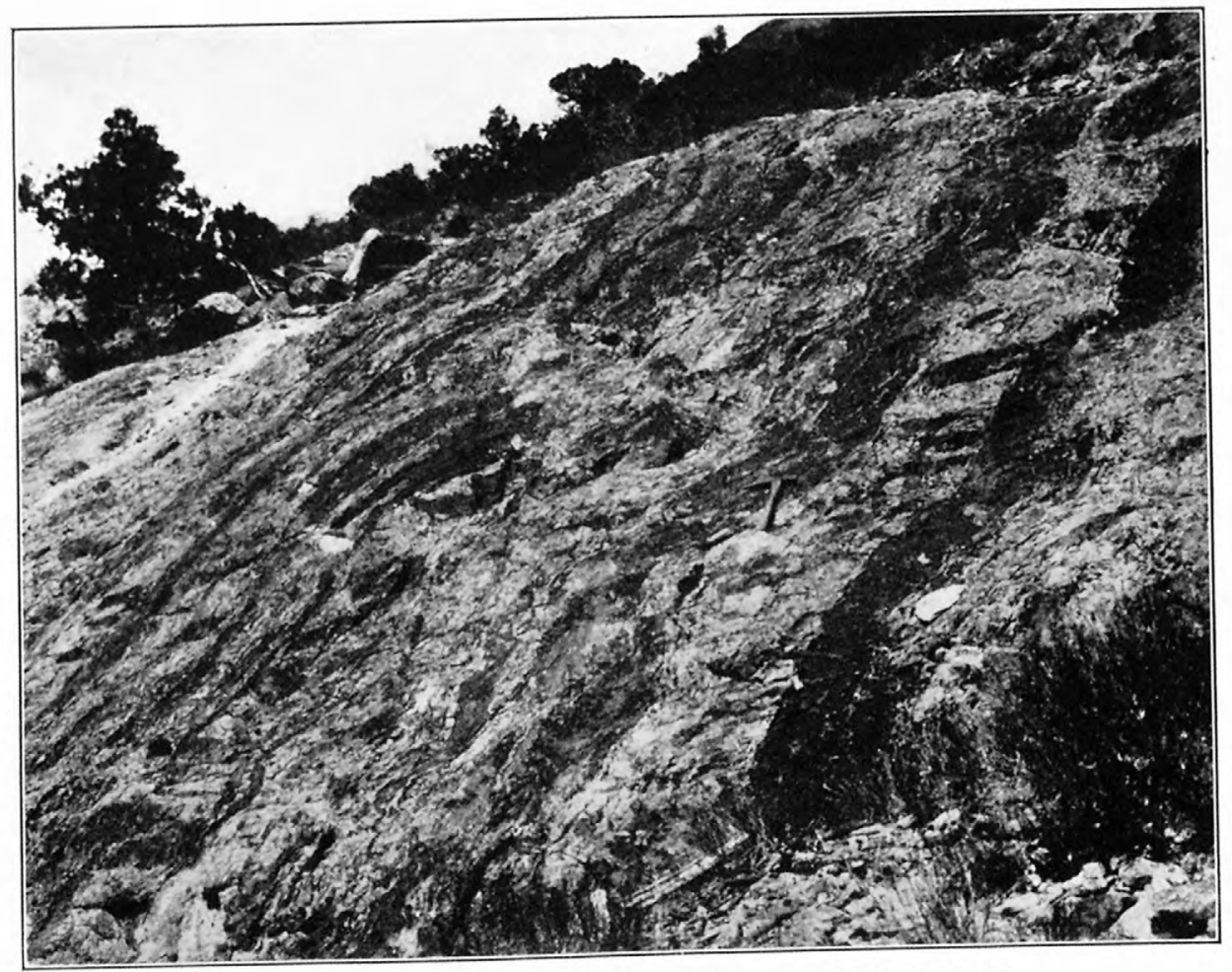

B. CONTACT-ALtered LIMESTONE, LOEBER GULCH.

Garnetized limestone showing original banding. 

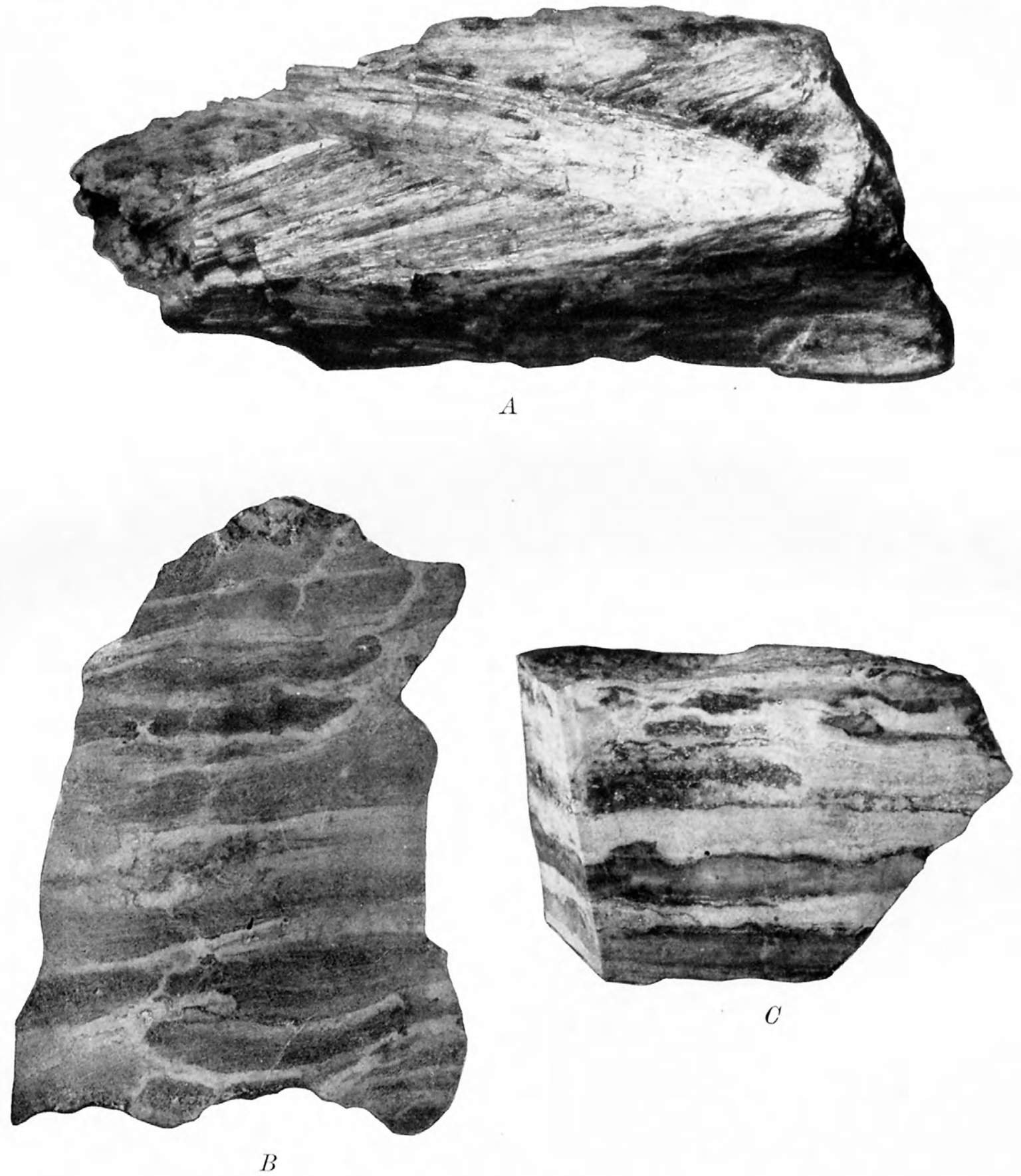

A. TREMOLITE, WASHINGTON MINE. NATURAL SIZE.

B. GARNETIZED LIMESTONE, LOEBER GULCH, SHOWING ORIGINAL BANDING. NATURAL SIZE. c. BANDED LIMESTONE, LOEBER GULCH. NATURAL SIZE. 
has been recrystallized for a considerably greater distance. East and west of this zone of profound alteration the limestone has been recrystallized and contact silicates are found, but they are relatively unimportant in amount and do not form massive bodies as near the Imperial mine. The alteration along the northern border of the stock shows relatively slight mineralogic change, though the limestone has undergone recrystallization and silicate minerals are present in relatively small amounts along this contact.

In the zone of most extensive alteration it has not been found possible to trace individual beds from the unaltered limestone into the highly altered zone and, therefore, it can not be stated positively how far the character of the minerals formed during the alteration has been controlled by the composition of the limestone, but it is believed to have been so controlled to a very large extent. Most and probably all of the original limestone carries some magnesium. There is, however, great variation in the amount, some of the limestone being distinctly dolomitic, whereas other beds, so far as can be judged from general appearance, contain but little magnesium. A distinct difference in the minerals formed in the highly altered zone is believed to correspond to the difference in composition of the limestone beds. East of the Imperial mine, in the beds underlying the quartzite, yellowish-brown to reddish-brown garnet is the most abundant mineral. In the field the rock appears to be composed almost entirely of massive garnet. Under the microscope, however, it is seen to contain important amounts of other silicates. West of the Imperial mine, on the lower slopes of Loeber Gulch, much of the rock is composed largely of fibrous tremolite. This rock on weathering scales off parallel to the surface and produces the rounded, smooth slopes characteristic of the west slope of Loeber Gulch. In this area, as in that to the east, other silicates are present in considerable amounts and individual beds are composed largely of garnet with relatively little tremolite. In many places in Loeber Gulch the minerals formed in different beds of limestone differ so much that the original bedding can still be seen in the highly altered rocks. Such instances are seen in the gulch between the Imperial and Washington mines, where the photographs reproduced in Plate VIII, $B$, and IX, $B$ and $C$, were taken in the valley near the Cupric mine, and in many other localities.

The following minerals have been recognized in this contact zone: Garnet (the grossularite and andradite molecules being present in varying amounts), diopside, tremolite, vesuvianite, muscovite, epidote, chlorite, fluorite, quartz, calcite, dolomite, magnesite in small veins, specularite, magnetite, pyrite, chalcopyrite, molybdenite, and pyrolusite, with sphalerite and galena at some distance from the contact and in many places associated with fissures in the limestone.

The different minerals, as already stated, occur in varying amounts at different points. Garnet is abundant wherever the alteration is profound, especially along the contact east of the Imperial mine. Tremolite is especially abundant west of the Imperial mine and in the vicinity of the Washington mine, but is present throughout the belt. Muscovite was observed most abundantly near the contact to the west near White Mountain and in the workings of the Cupric mine. The sericitic form of muscovite is present in variable amounts in other parts of the zone. Diopside is present in considerable amounts throughout the district; especially well developed crystals occur associated with muscovite in the western part of the zone. Epidote is not an important mineral in this zone but occurs in small amounts in many places. Wollastonite was not determined and is not an important constituent in this belt, but it is not readily distinguished from tremolite except on careful examination, and some may be present, though in the specimens examined it was not found. Chlorite is present in small amounts but nowhere forms an important part of the rock over a large area. Fluorite was identified from the Washington mine and is doubtless present in other parts of the belt. Quartz, calcite, and dolomite occur in all parts of the belt. Magnesite occurs in small veins cutting the limestone of White Mountain. Specularite, magnetite, pyrite, and chalcopyrite are present throughout the zone in small amounts. Galena and sphalerite are of common occurrence at some distance from the contact, associated with contact silicates and usually near fissures in the limestone. Both occur in this manner in the Washington and Peacock mines, and galena is present in the King David mine. Molybdenite was recognized at only one locality near the Imperial mine, where it occurs as small flakes along a fissure in garnet rock. 
In general the minerals of the contact zones appear to have formed at essentially the same time, though in some places metallic minerals have formed later than the silicates as well as contemporaneously with them. This is especially shown at the Imperial mine, where the garnet rock has suffered slight crushing and the fissures have been filled by sulphides of iron and copper and oxide of iron, as shown in Plate XXXII, $B$ (p. 184). In this locality the magnetite

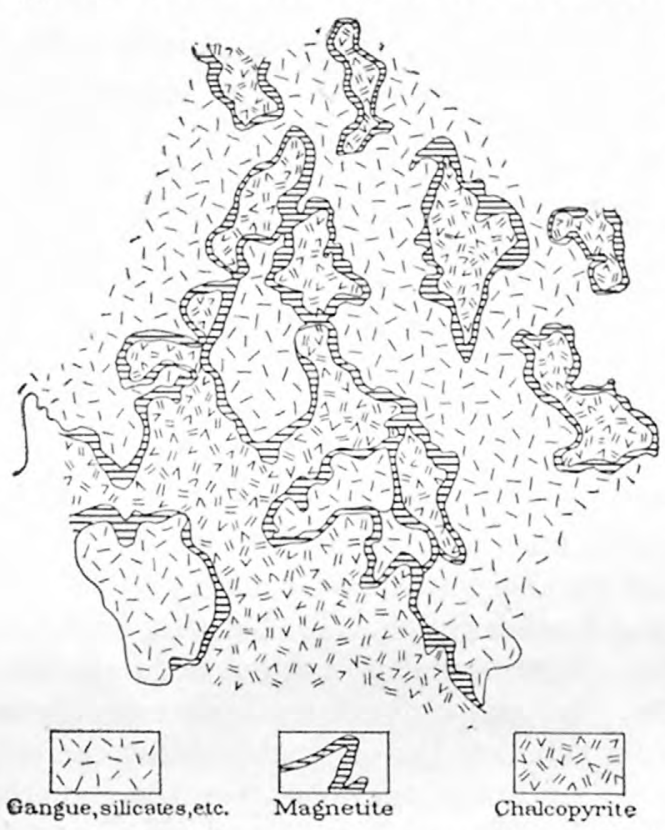

FIGURE 9.-Magnetite surrounding chalcopyrite; generalized drawing from microphotograph, enlarged 30 diameters. has for the most part formed later than the sulphides, occurring as a thin deposit on them, and on casual observation strongly resembling the deposit of chalcocite on grains of sulphide, as shown in figure $9{ }^{1}$ So far as observed the metallic minerals deposited distinctly later than the silicates are of slight importance.

Some specimens gathered from the Imperial mine at the contact of the altered limestone with the quartz monzonite show no sharp line marking the boundary of these rocks. The distance from material that is plainly quartz monzonite to that which is plainly altered limestone may be less than 1 inch (see Pl. X, A), but through this distance there is a gradation from the one to the other. In the sections examined the change in going from the quartz monzonite to the altered limestone is a decrease in the quartz and feldspar and a corresponding increase in the pyroxene. The pyroxene also changes from a nearly colorless augite to a green diopside. In passing from the altered limestone to the quartz monzonite there is a decrease in garnet, an increase in diopside, and the appearance of feldspar as a constituent. Magnetite is more abundant in the zone of change than in either the monzonite or the garnetized limestone.

Near the contact the altered limestone is cut by veinlets (see Pl. X, B) composed of quartz, orthoclase, plagioclase, a little augite, and irregular masses of sulphide and magnetite. The metallic minerals are later than the silicates and the magnetite later than the sulphides, in many places surrounding them.

The chemical composition of slightly altered and highly altered limestone near the Reciprocity mine, in the area south of the contact, is shown in the following table:

Analyses of slightly altered and highly altered limestone from the San Francisco district, Utah.

[George Steiger, analyst.]

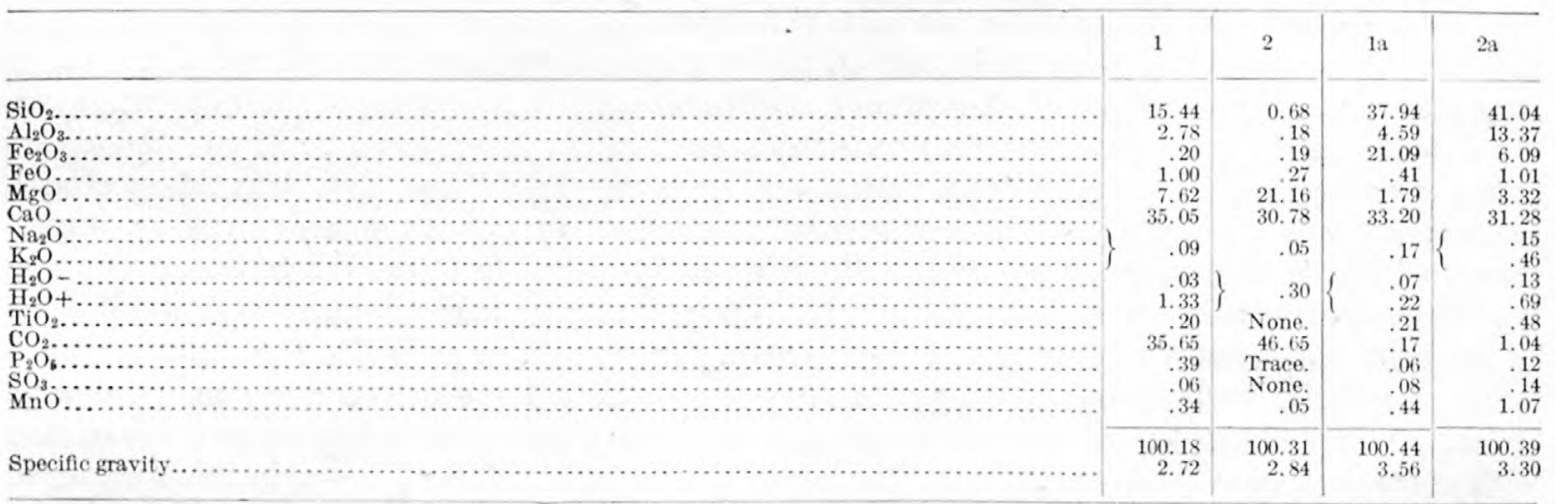

1. Banded crystalline limestone near Reciprocity mine (specimen 123).

2. Gray dolomitic limestone east of Reciprocity mine (specimen 121).

1a. Altered banded limestone near Reciprocity mine (specimen 119).
2a. Massive garnet rock northeast of Reciprocity mine (specimen 124)

A. C. Spencer showed the writer specimens from the Ely district, Nevada, where the relation of magnetite and chalcopyrite was similar to that noted here. 


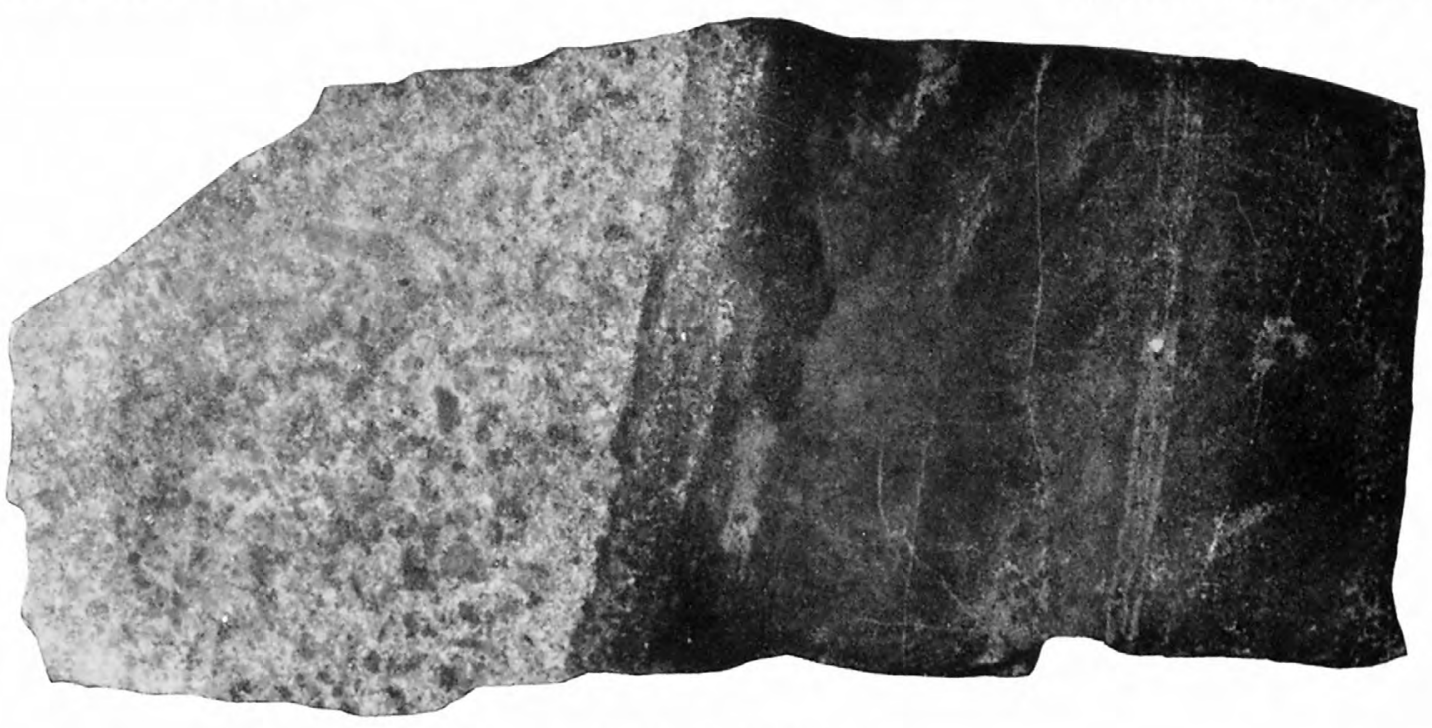

A. HAND SPECIMEN.

Dark area, garnetized limestone; light area to left, quartz monzonite; band between, transition zone.

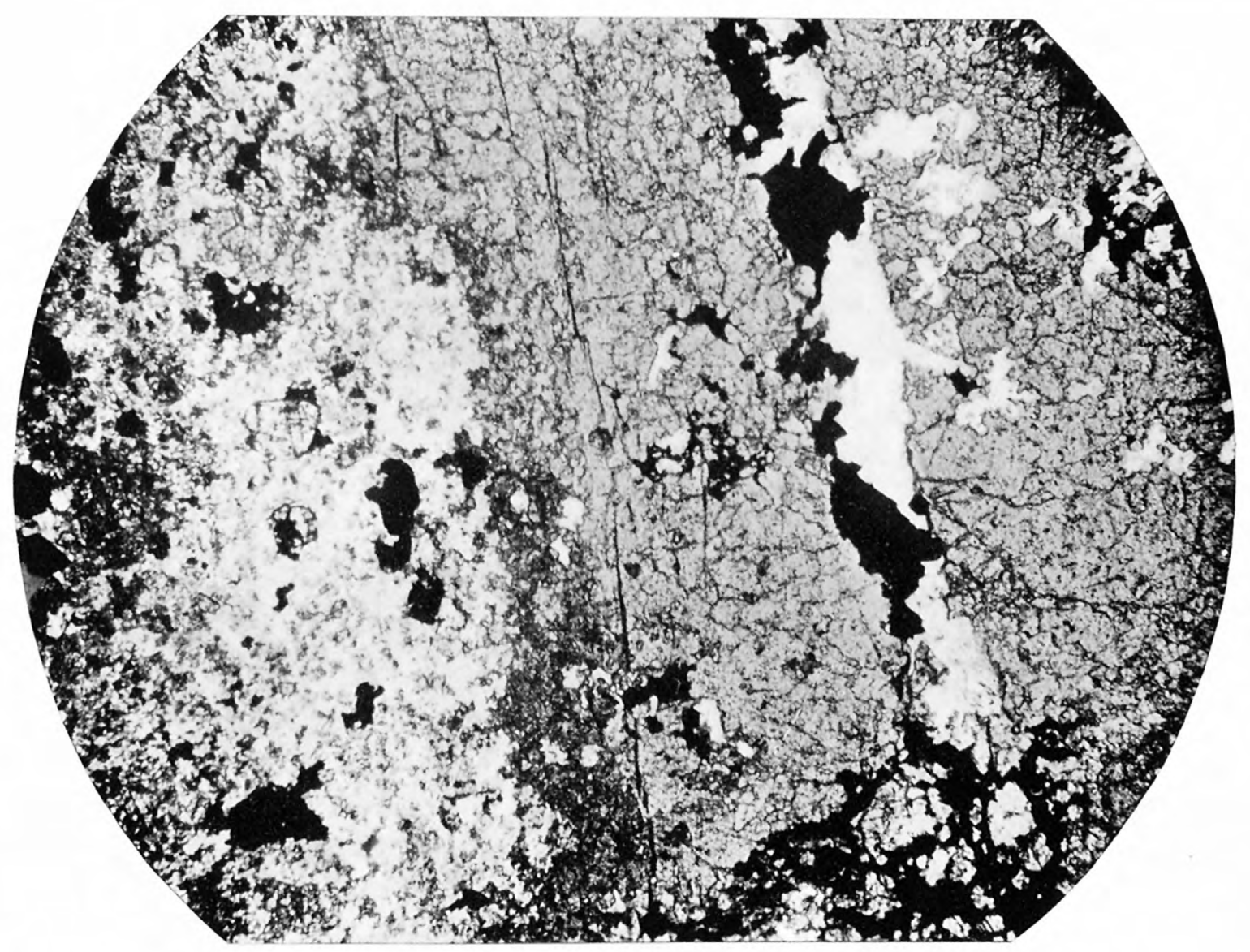

D. PHOTOMICROGRAPH.

Quartz monzonite on left, garnetized limestone on right. Veinlet crossing slide is composed of quartz, feld.

spar, and magnetite. Ordinary light. Enlarged 30 diameters.

CONTACT OF QUARTZ MONZONITE AND ALTERED LIMESTONE, IMPERIAL MINE. 

The following table shows the approximate mineral composition of these rocks as calculated from the chemical analyses and microscopic study.

Mineral composition of slightly altered and highly altered limestone from the San Francisco district, Utah.

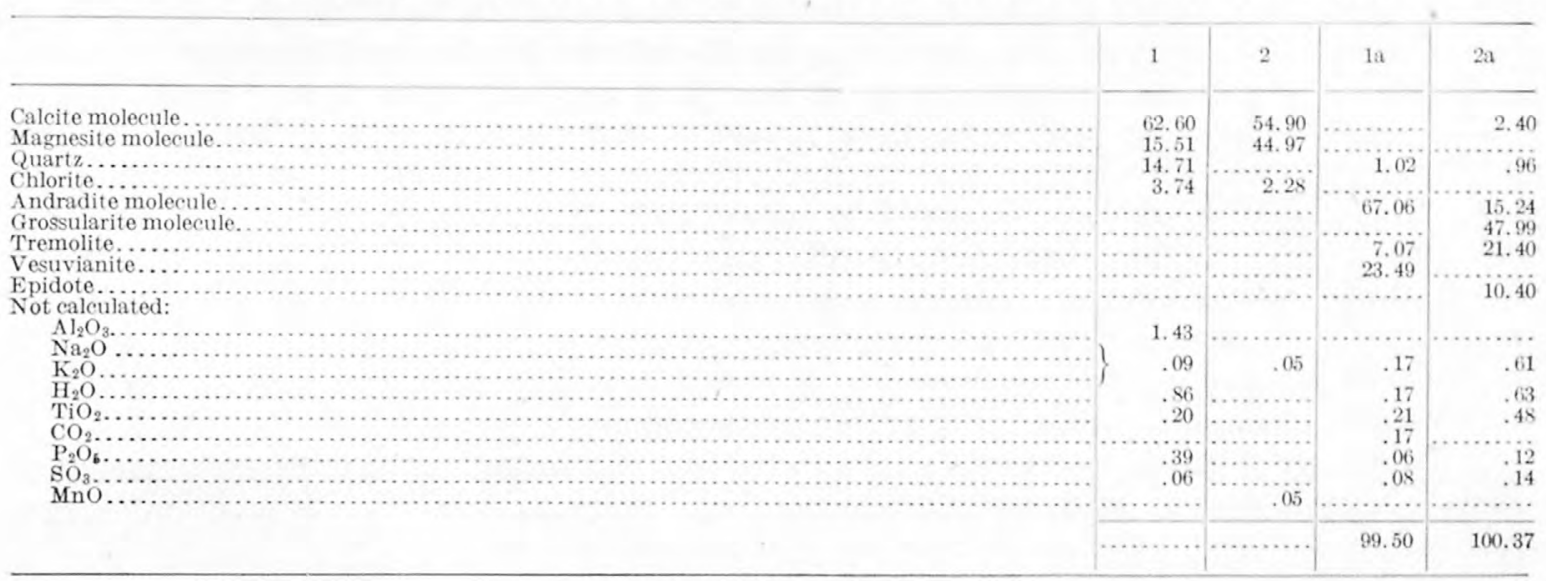

In comparing the analyses of the limestones to determine the changes that have taken place in alteration it is necessary to consider changes in the volume and the density of the rock. It has not been shown positively whether the volume has increased or decreased as a result of alteration, but it is believed that the change has been slight and for the present comparison the volume will be considered as constant. (See p. 88.) The change in density, as shown by the specific gravity of the rocks, has been considerable. If the volume is assumed to have been constant, the amount of addition or subtraction of the several oxides can be determined by calculating the amount of each present in a given volume of rock. The following table shows the amount of each of the principal oxides present in a cubic centimeter of each of the rocks:

Weight of the principal oxides in slightly altered and highly altered limestone from the San Francisco district, Utah.

[Grams in 1 cubic centimeter of rock.]

\begin{tabular}{|c|c|c|c|c|}
\hline & 1 & 2 & 1a & $2 \mathrm{a}$ \\
\hline $\begin{array}{l}\mathrm{SiO}_{2} \\
\mathrm{Al}_{2} \mathrm{O}_{3} \\
\mathrm{Fe}_{2} \mathrm{O}_{3} \\
\mathrm{FeO} \\
\mathrm{MgO}\end{array}$ & $\begin{array}{r}0.419 \\
.075 \\
.005 \\
.027 \\
.207 \\
.953 \\
.969\end{array}$ & $\begin{array}{r}0.019 \\
.005 \\
.005 \\
.007 \\
.001 \\
.874 \\
1.325\end{array}$ & $\begin{array}{r}1.350 \\
.163 \\
.751 \\
.014 \\
.064 \\
1.182 \\
.006\end{array}$ & $\begin{array}{r}1.354 \\
.441 \\
.201 \\
.033 \\
.109 \\
1.032 \\
.034\end{array}$ \\
\hline
\end{tabular}

In discussing the changes that have taken place in the alteration, it must be remembered that the examples given above by no means represent the changes that have occurred throughout the zone, as they vary at practically all points. Some of the more important changes indicated, however, doubtless apply with varying intensity to all parts of the zone and represent the general change that has taken place during alteration.

Attention may be again called to the fact that No. 1 has undergone recrystallization and probably the addition of silica. It is evident that there has been a marked addition of silica in both rocks, the amount in the two highly altered rocks being almost identical. Alumina and ferric oxide also show a marked increase. These oxides show considerable variation in the amount added in the different rocks, but the sum of the two is more nearly equal. Ferrous oxide is not an important constituent in either the unaltered or altered rock. Magnesia shows a decrease, but this can not be taken as representative of the zone. It is certain that some of the altered beds northwest of the Washington mine contain as high a percentage of magnesia as any of the unaltered limestones in the district and therefore possibly represent an addition of this oxide. Such a result would be in accordance with observations made in other districts. 
Boutwell ${ }^{1}$ has shown that there has been a notable addition of magnesia in the contact alteration of limestone in the Bingham district, Utah, and Ransome ${ }^{2}$ finds the same to be true in the Bisbee district, Arizona. It may be noted in this connection that at several points in or near the contact zones veins of magnesite are present. The magnesium carbonate of these veins has probably been derived from the surrounding limestones, and the magnesium content may thus have been considerably reduced Lime, on the other hand, shows a slight increase in both rocks, a condition which again is not in accord with observations in other districts. ${ }^{3}$ It seems probable that the altered rocks were originally slightly lower in magnesia and higher in lime than the unaltered; at least it would be unsafe to draw a definite conclusion from these examples in view of their disagreement with observations in other districts. Carbon dioxide is practically absent from the altered rocks. Besides the oxides above mentioned, there have been notable additions of metallic elements, copper, zinc, lead, and iron, with probably small amounts of manganese and molybdenum. Some sulphur has been added and the presence of considerable muscovite in some areas indicates the addition of potassium.

To sum up, it seems very certain that there have been additions of important amounts of silica, alumina, ferrous oxide, sulphur, copper, iron, and zinc, and lesser amounts of potash, manganese, and lead. Carbon dioxide has been largely removed.

Along the northern contact of the monzonite and limestone the additions resulting from alteration have been comparatively slight, the most pronounced change being the recrystallization of the limestone. Silicate minerals are present in small amounts, however, and sulphides are sufficiently abundant to encourage prospecting. Some ore has been taken out along this contact, but the most important ore bodies thus far developed in this part of the district are associated with fissures at some distance from the contact. In several places small veins of fine-grained white carbonate, largely magnesite, cut the crystalline limestone. It is very likely that the crystalline limestones of this area have been somewhat changed in composition, like those to the south, where some of the limestones that appear to be composed of nearly pure white carbonate are seen on microscopic examination to contain as much as 25 per cent of colorless serpentine (see Pl. XII, A, p. 97), which has apparently resulted from the hydration of some magnesian silicate. The increase in volume due to the hydration has split the inclosing carbonate grains, and the serpentine has been forced into the fissures.

BEAVER LAKE DISTRICT.

Contact alteration is, in general, less conspicuous in the Beaver Lake district than in the San Francisco district, though the limestones have been recrystallized wherever they are in contact with the monzonite. Contact minerals are present at most points along the contact, and locally they become abundant. The most pronounced alteration in the district is that in the vicinity of Skylark Spring and in the northeastern part of the district, near the Beaver Copper, Copper Mountain, and other prospects. Contact minerals are also abundant in the western part of the district in the vicinity of the Larkspur group, and silicification has been pronounced about the Federal group.

In this district, as in the others, there has been great variation in the amount of contact mineralization at different points along the contact. This is especially well shown along the contact of the northern limestone body and the monzonite. In the vicinity of the Black Rock and Utah United mines the alteration is pronounced, but the eastern part of this contact zone does not contain abundant contact minerals, though the limestone has been extensively recrystallized. The blocks of limestone in the monzonite in the northeastern part of the district appear to contain abundant contact minerals, but the covering of late sediments usually prevents the examination of the contacts for more than short distances.

The mineralization is essentially similar to that already described for the San Francisco district, the contact minerals recognized being garnet, pyroxene (near diopside in composition),

1 Boutwell, J. M., Prof. Paper U. S. Geol. Survey No. 38, 1905, p. 189.

2 Ransome, F. L., Prof. Paper U. S. Geol. Survey No. 21, 1904, p. 148.

3 Lindgren, Waldemar, Prof. Paper U. S. Geol. Survey No. 43, 1905, p. 154. 
fibrous amphibole (probably tremolite), epidote, muscovite, magnetite, specularite, pyrite, chalcopyrite, pyrolusite, and, at some distance from the contact, galena. Magnetite is more abundant in this district than in the San Francisco district, and locally specularite occurs in considerable amount. Magnetite is especially abundant in the property of the Utah United Co. Here it occurs immediately at the contact, together with a small quantity of pyrite and chalcopyrite. A few feet from the contact the magnetite is mixed with silicate minerals, and those in turn give place to crystalline limestone. The width of the magnetite zone is variable; in some places this mineral is scanty in amount, though the greatest width observed in which magnetite is the principal mineral is 21 feet. A body of specularite several feet wide has been developed on the property of the Black Rock Co., near the contact of limestone and monzonite. The workings here were not accessible at the time of visit, and the relations to the monzonite could not be definitely determined, though there is no doubt that the specularite is due to contact alteration.

ROCKY DISTRICT.

Sedimentary rocks are present only in the southern part of the Rocky district, where they are in contact with the quartz diorite and quartz monzonite, both of which have produced contact alteration of essentially the same character. The sedimentary rocks consist of a block that has been included in the intrusives, and dikes of the monzonite are numerous in both the limestone and the quartzite. The quartzite has been greatly shattered, and, especially in the extreme southern part of the district, the monzonite entering along the fractures has produced an intrusive breccia.

That the blocks of limestone were included in the monzonite and not faulted into it after its solidification is shown by the development of contact mineralization to a variable extent wherever the two came into contact. Dikes can also be traced from the monzonite mass into the limestone, which would not be the case if this contact were due to faulting.

The quartzite has suffered comparatively slight change where it is in contact with the intrusive rock. The quartz grains are cemented by carbonate, and there is considerable interstitial clouded feldspar that has probably resulted from the contact alteration. This feldspar is usually too clouded for definite determination. It has a low index, and some of it shows twinning. It is all alkali feldspar and, in part at least, albite. A little iron ore is present, and a few crystals of rutile were noted.

The alteration of the limestone has been pronounced. The entire body of limestone has been recrystallized and contact minerals are abundant. Garnet, magnetite, and pyroxene are the most abundant contact minerals, though muscovite, a brown, slightly pleochroic mica that is probably near phlogopite, tremolite, quartz, pyrite, and chalcopyrite are present in notable amounts. Apatite is associated with the magnetite. Magnesite occurs as veins cutting the metamorphosed limestone. Such veins are well exposed in a prospect pit north of Hickory, where they cut magnetite and limestone. They vary from some of almost microscopic size to others $1 \frac{1}{2}$ feet thick. In the limestone area northwest of Hickory similar veins were noted at several points.

The rare and interesting mineral thaumasite occurs in small veins in the altered limestone on the first level of the Old Hickory mine. This was formed later than the contact alteration, as were also the magnesite veins.

Tourmaline was observed in small amount in the prospect shaft in the quartz diorite north of Hickory. This locality is near the contact of quartz diorite and limestone, and dikes of the quartz monzonite are present. The formation of tourmaline is probably the result of the intrusion of the monzonite.

The contact mineralization shows rather marked variation in its development at different points. The block of limestone directly north of Hickory has a strong band of garnet on its western border, with some mica and sulphide minerals but little magnetite. On the eastern border, where it is in contact with the intrusive rock, magnetite is rather abundantly developed. Near the blacksmith shop northeast of Hickory brown mica, probably near phlogopite, is associated with magnetite. The intrusive rock at this point is possibly the quartz diorite. 
Contact alteration is best developed where the quartz monzonite is in contact with limestone. The most common alteration is the change to magnetite at the immediate contact, this gradually giving place to garnet and the garnet in turn to crystalline limestone. Yellow-green and green augite is abundant but does not appear to be confined to any zone, being associated with the magnetite near the contact and with the garnet at considerable distance from the contact.

The development of magnetite and garnet is diverse at different points. The best surface exposures are seen at the Old Hickory mine. Here the quartz monzonite is not exposed at the surface, in part at least being covered by float, but on the first level it forms the west wall of the ore body. The magnetite zone at the surface that has been mined as ore is over 15 feet in width. This is followed by 50 to 60 feet of garnet, which terminates at a layer of quartzite. Beyond this are intercalated strata of quartzite and altered limestone cut by dikes. The presence of quartzite and numerous dikes made it impossible to determine the distance to which the limestone may be altered to garnet, but the formation of abundant magnetite appears to be confined to a zone within 15 or 20 feet of the monzonite. As already stated, the augite was formed throughout the alteration zone, though it is not abundant close to the contact. Sulphides occur in small amount in both the magnetite and garnet. They are for the most part contemporaneous in origin, but a few small veinlets of sulphide were noted cutting the magnetite. The alteration of the limestone southeast of Hickory is in general similar to that at the Old Hickory mine, though the contact between quartz monzonite and limestone is much less regular and the bands are by no means so well marked. Oxidation has also been much more pronounced, much of the iron being present as limonite.

STAR DISTRICT.

In the Star district contact alteration is pronounced wherever the quartz monzonite is in contact with limestone. In the few places where the quartz monzonite is in contact with shale there has been slight alteration, some of the shale being silicified. The limestone near the contact has been altered to a white crystalline limestone, as is well shown in the southeastern part of the district, where the limestone is filled with intrusive masses and the whole body of rock as seen from a distance presents a mosaic of dark and light areas, the dark being the intrusive rock and the light the altered limestone. Typical contact minerals are developed at the contact in all parts of the district, though the amount of mineralization, especially of the silicate minerals, is less conspicuous than in the other districts. In general, the minerals resulting from the alteration are similar to those of the other districts, consisting of quartz, garnet, pyroxene, tremolite, mica, magnetite, and sulphide minerals. These minerals are present not only near the contact, but also along fissures in the limestone at considerable distances from the contact. This is true at the Harrington-Hickory mine, where quartz, tremolite, garnet, magnetite, pyrite, galena, chalcopyrite, and tetrahedrite are present in the altered limestone. At the Wild Bill mine garnet, magnetite, quartz, siderite, and fluorite are present. The Hub mine shows quartz, magnetite, green mica, fluorite, and sulphides. At the Moscow mine muscovite, fluorite, and rhodochrosite are present with the sulphide minerals, replacing limestone. At the St. Mary's mine augite and muscovite are associated with the sulphides pyrite, chalcopyrite, and bismuthinite in the copper ore. Many of the deposits in the southeastern part of the district are near fissures, but at no great distance from the contact. Oxidized iron ores are abundant in these deposits. They have probably resulted from the alteration of sulphides and carbonate.

COMPARISON OF CONTACT ALTERATION IN THE SAN FRANCISCO REGION WITH THAT IN OTHER DISTRICTS.

The studies of contact alteration by different investigators have led to very different generalizations as to the nature of the changes that take place. The different views held have been briefly summarized by Lindgren ${ }^{1}$ and need not be repeated here. Lindgren's report on

1 Lindgren, Waldemar, Prof. Paper U. S. Geol. Survey No. 43, 1905, p. 160. 
the Clifton-Morenci district, Arizona, was one of the earliest detailed studies in this country in which it was shown that large additions had been made to the contact zone from the intrusive rock, though this fact had been recognized by the same author earlier. In the last few years similar occurrences have been recognized in many other districts, but as yet geologists are by no means agreed as to the changes that take place in the contact zone, and it seems possible that this lack of agreement siay be due to the fact that there are essential differences at different localities.

For example, Lindgren believes that the minerals which form the contact zone in the Clifton-Morenci district occupy essentially the same space as that originally occupied by the limestone, and that there has been great change in the chemical composition of the rock. In discussing the alteration of limestone to garnet he reaches the following conclusion: " 460 kilos $\mathrm{CaO}$ and 1,190 kilos $\mathrm{CO}_{2}$ have been carried away per cubic meter, while 1,330 kilos $\mathrm{SiO}_{2}$ and $1,180 \mathrm{Fe}_{2} \mathrm{O}_{3}$ have been added, the latter amount being a minimum because of the magnetite so frequently found associated with garnet. These are astonishing figures and give an idea of the vigorous transfer of material which took place during contact metamorphism."

Concerning the altered zone as a whole he says: "The altered rocks have, beyond all doubt, generally received a great excess of iron, sulphur, copper, and zinc, and in the case of the pure limestones, which over large areas have been converted into almost pure garnet rock, have received immense amounts of ferric oxide and silica."

Leith and Harder ${ }^{3}$ have reached quite different conclusions in regard to the changes that have taken place in the Iron Springs district, southern Utah. Of the general changes they say:

If the principal chemical change in the development of the contact phase has consisted in the elimination of calcite and to a less extent of magnesia, iron, and potassa, leaving alumina and silica substantially unchanged in their ratios, as held to be possible in an earlier paragraph, this has involved a very considerable loss of weight, and, as the densities of the fresh and altered rocks differ so little, the loss in volume also has been large. Kemp, Lindgren, and others have cited lack of structural evidence of diminution in volume at limestone contacts as favoring the view that materials must have been introduced from without to take the place of the calcium carbonate. In the Iron Springs district the field evidence does not positively prove or disprove important volume change, but there is no apparent field evidence to contradict the evidence for diminution of volume here calculated. The limestone, though tilted away from the andesite laccoliths, nowhere shows evidence of crumpling or crowding where the bedding can be observed. In the altered phase the bedding has been destroyed, and it is easy to conceive that this structurally amorphous zone may represent only a part of the volume of the original rock, the calcium carbonate having been driven off and the other constituents concentrated. The change in volume of the limestone would scarcely be expected to stand out conspicuously in the field relations, for it has occurred, if at all, in the band which now does not show original textures or structures, by which change of volume can be measured in crumpling or folding.

In general it appears that there may have been important diminution of volume, accomplished essentially by loss of materials and not by change of density of minerals.

Numerous instances might be cited in support of each of the views expressed in the above quotations, but these are sufficient to show either that there is an essential difference in the character of the alteration at different localities or that the observations or the deductions drawn from them in one or both places are erroneous.

As already shown in the description of the contact zones, the evidence in the San Francisco region seems to indicate important chemical changes without marked changes in volume. It has been stated by the authors quoted above that it has not been found possible to obtain. positive evidence that there has or has not been volumetric change during the process of contact alteration, and the same is true of the San Francisco region, though all the evidence bearing on this point that was collected indicates that the change, if any, has not-been important.

The locality best suited to observations on this point is that on the southern border of the monzonite mass in the San Francisco Range. Here near the central part of the contact zone as exposed contact mineralization is strongly developed, whereas to the east and west the development of contact minerals is relatively slight, the alteration consisting largely in a recrystallization of the limestone. It does not seem probable that there have been any considerable changes in volume in the recrystallization of the limestone, and if there has been large shrinkage in the

1 Lindgren, Waldemar, Prof. Paper U. S. Geol. Survey No. 43, 1905, p. 154.

2 Idem, p. 160.

${ }^{3}$ Leith, C. K., and Harder, E. C., Bull. U. S. Geol, Survey No. 338, 1908, p. 35. 
zone of alteration to silicates it would be shown by structural breaks in the areas lying between this zone and the crystalline limestone. No important structural breaks were observed on either side of the zone of contact minerals and it is therefore thought that the change in volume accompanying the changes in chemical composition was slight. The observations in other parts of the district do not throw much additional light on the subject. At no place, however, were evidences of shrinkage observed.

\section{CAUSE OF CONTACT METAMORPHISM.}

The close association of the contact mineralization with the intrusive rocks leaves no doubt that the alteration of the limestone was a direct result of the igneous intrusion. The great variation in the amount of mineralization at different points along the contact indicates that much of the material added to the limestone was not given off directly from the igneous magma. This variation is well shown in the San Francisco district, where on the north side of the monzonite mass the contact shows slight mineralization but the limestone has been recrystallized and on the south side the alteration is far more extensive in certain places, as already described, and at other places the change is principally a recrystallization of the limestone. The same is true of the contact in the northern part of the Beaver Lake district, in the Rocky district, and to a less marked extent in the Star district. These conditions seem to indicate that the intrusion of the quartz monzonite caused a recrystallization of the limestone through the whole extent of the contact, and doubtless some material was given off from the magma and added to the limestone all along the contact. The great extent of mineralization at certain points, however, suggests that the solutions given off by the crystallizing magma were collected into channels and entered the limestone at these points rather than uniformly along the entire contact zone. It seems not improbable that after the molten magma had entered the sedimentary rocks and the outer margin solidified, channels were formed that directed the course of solutions coming from the interior of the crystallizing mass and concentrated their action at certain points

\section{SUMMARY OF GEOLOGIC HISTORY.}

The earliest event of which there is a record in the rocks of this region is the deposition of the Grampian limestone, in Ordovician and Cambrian(?) time. To the west of the San Francisco district, in the Wa Wa Range, the deposition of the limestone was preceded by that of Cambrian shales and quartzites, and it is probable that the base of the sedimentary series in this district rests upon a basement of pre-Cambrian schists and granites, as it does to the south, where the ancient rocks are exposed in the canyon of Colorado River.

From the time of the deposition of the Grampian limestone to the Triassic period the region was probably beneath the sea much of the time and received sediments. The conditions of sedimentation, however, were subject to numerous changes. At times the area was at a distance from the ancient shore line and was covered by a deep sea. At these times the limestones were laid down. At other periods changes in the level of the land caused the sea to recede and brought the area near shore. Under these conditions were deposited the sands that now form the quartzites. Such a change occurred after the Grampian limestone was formed, resulting in the deposition of the Morehouse quartzite. The area was then again depressed and remained the scene of deep-sea deposition with minor oscillations (as in the Devonian period, when the Mowitza shale was deposited) until Carboniferous time, when it again received near-shore deposits, the Talisman quartzite. This period, however, was comparatively short and at its close the area again received deep-sea deposits, resulting in the Elephant limestone.

At the close of Pennsylvanian time the area was elevated so that it was covered by a shallow sea, and this condition persisted with minor oscillations in the Triassic period and resulted in the deposition of the thick Harrington formation. At times during this period the waters were so shallow that the waves produced ripple marks on the sea bottom, which were buried, and can still be seen in the shales.

It is possible that parts or all of the area may have risen above sea level for short periods previous to the deposition of the quartzites, but there is no evidence that the elevation was sufficient to allow the cutting of valleys by streams. 
The district affords no record of events between the deposition of the Harrington formation (Triassic) and that of the Lake Bonneville beds (Quaternary). If sediments other than the Quaternary deposits were accumulated later than the Harrington formation, they have been entirely removed. From the evidence in surrounding regions it seems probable that the area was above sea level for at least part of this interval. Cretaceous sediments are present in the Iron Springs district, and it is possible that they were deposited in the San Francisco region also, but if so they have been entirely removed.

Upon an old erosion surface were poured out, probably in Tertiary time, great flows of lava, nearly or quite burying the entire area. Soon after this outpouring of lava the region was broken by faulting, mainly along north-south lines, with minor breaks running east and west. At about the same time the region was invaded by extensive masses of intrusive material, forming the stocks of quartz monzonite. This intrusion was accompanied by faulting and fissuring of the earlier rocks and immediately followed by extensive contact alteration of the limestone and the deposition of ores, both close to the intrusive contact and at a distance along fissures that furnished channels for the ready passage of the ore-bearing solutions. The cooling and crystallization of the quartz monzonite masses were accompanied by fissuring, and along the fissures were injected basic and acidic differentiation products, forming dikes. At essentially the same period watery solutions excluded from the crystallizing magma at greater depth escaped through the fissures in the solidified and partly cooled portions, resulting in pronounced alteration of the quartz monzonite and the further deposition of ores.

Nearly contemporaneous with the igneous activity there was a general elevation of the region, accompanied by faulting and tilting of the fault blocks. This was followed by a period of erosion. During this period the rocks covering the intrusive masses have been in part removed and the region reduced to its present topographic form. The material from the higher portions of the area has been deposited in the low intermountain valleys, for the most part as land deposits, though some of it was laid down in Lake Bonneville, whose southern extension at its highest stage covered small portions of this region.

Northeast of the San Franciseo region there has been an outpouring of basalt since the deposition of the Lake Bonneville sediments, and it is possible that with that basalt should be correlated the olivine basalt of this region.

\section{MINERALOGY OF THE SAN FRANCISCO REGION.}

The region here discussed is unusually rich in minerals, including one species that has not hitherto been described, another that has not been previously reported from this continent, and several others that have been reported from but few localities in this country. Many of the minerals show nothing unusual in their character or occurrence and need little discussion; others, on account of their unusual character or interesting occurrence, will be treated in greater detail. The order adopted in the discussion of the minerals is that followed by Dana in his "System of mineralogy."

\section{NATIVE ELEMENTS.}

Sulphur.-Native sulphur is reported to have been present in considerable quantity in the oxidized zone of the Horn Silver mine, and specimens collected from the old dumps indicate that the reports are correct. These specimens are composed of rather massive material of the typical yellow color through which are scattered variable amounts of the secondary lead minerals. Sulphur was also noted in ore from the Red Warrior and Moscow mines, where it occurs as small crystals in the carbonate lead ore, the whole forming a friable mass that is readily crushed in the hand. The occurrence in these ores is local, and the writer did not see the material in place and therefore did not ascertain its relation to the other ores. It is evident from the specimen, however, that the sulphur is found in ores that are completely oxidized. There are probably numerous other occurrences of sulphur in the mines of these districts.

Gold.-Native gold was not seen by the writer. The ores of the area carry small quantities of gold, however, and it is not improbable that in the oxidized ores this is present as native gold. 
Sitver. -Native silver was seen in one specimen of ore from the dump of the HarringtonHickory mine, the specimen having come from a point near the present water level. Though silver is an important constituent of many of the ores, native silver is certainly of rather rare occurrence.

Copper.-Native copper was observed in the ores of the Skylark mine of the Utah United Co, in the Beaver Lake district. In this mine it occurs as small flakes along fractures in magnetite ore. Native copper is reported from the Cactus and $\mathrm{O} K$ mines, where it occurred in the oxidized ores but was not an important ore mineral. It was seen in a small vein in Black Mountain on the Nevada Ready Pay group of claims and in the oxidized ores of the Imperial mine. There are doubtless many more occurrences of copper in the region, but it is nowhere an important ore mineral.

\section{SULPHIDES.}

Stibnite.-The antimony sulphide, $\mathrm{Sb}_{2} \mathrm{~S}_{3}$, has not been positively determined, but some of the Horn Silver lead-antimony ore is seen under the microscope to be composed of two distinct minerals and it is possible that these are stibnite and galena intimately intergrown (Pl. XV, B, p. 108.)

Bismuthinite. - The sulphide of bismuth, $\mathrm{Bi}_{2} \mathrm{~S}_{3}$, was determined in specimens from the St. Marys mine, but is probably not abundant in any part of the region.

Molybdenite.-The sulphide of molybdenum, $\mathrm{MoS}_{2}$, occurs as a primary mineral in the ores of the $\mathrm{O} \mathrm{K}$ mine, where on the lower levels it forms veins 3 or 4 inches thick and several feet long, being most abundant in coarse pegmatitic quartz. In some specimens of chalcopyrite it fills minute fractures in the copper mineral. Though these two minerals were probably formed at essentially the same time, they show a marked tendency to segregate - that is, where molybdenite was deposited in some abundance there is little chalcopyrite. Molybdenite also occurs in the $\mathrm{O} \mathrm{K}$ mine as an original constituent of aplite. It has been recognized in microscopic crystals in the altered rock of the Cactus ore zone and is present in small amount in the contact rock of the Imperial mine. Molybdenum occurs in the lead ores of several of the mines, especially the Harrington-Hickory, but the sulphide has not been recognized, though it is possibly present in the galena.

Molybdenite has not been found in commercial quantities in this region.

Argentite.-The sulphide of silver, $\mathrm{Ag}_{2} \mathrm{~S}$, is doubtless the most important silver mineral of the original ores of the region. It is rarely seen in sufficient quantity to be recognized, usually being contained in small quantity in the other sulphides, especially galena. The pure mineral is reported, however, to have been present in considerable amount in the sparry and siliceous silver ores in the upper levels of the Horn Silver mine.

Gatena.-The sulphide of lead, galena, PbS, is the principal primary lead mineral of the region. It occurs with pyrite and sphalerite in the replacement veins in limestone, being the most valuable mineral of the primary ores of this type of deposit. Together with other sulphides, it occurs in small amounts intergrown with contact silicates in the zone of contact alteration south of the Cactus stock of quartz monzonite, being observed especially at the Washington mine and in the Peacock copper ground. Galena is found in the replacement veins in lavas and is the primary lead mineral of the Horn Silver and Carbonate mines. It is present in small amounts in the ores of the Cactus mine, where it is one of the latest minerals to form. For the most part the galena is a primary ore mineral and as a rule it is rather coarsely crystalline, showing the typical cubical cleavage in the hand specimen. In the Horn Silver mine it has replaced sphalerite to an undetermined but probably slight extent. Some specimens collected from the dump of this mine are very fine grained, showing no typical cleavage in the hand specimen and superficially somewhat resembling chalcocite, though lighter in color. This type may have resulted from the replacement of some other sulphide. Most of the galena carries silver, and commercially it is the most important primary mineral of the region.

Chalcocite.-The copper sulphide chalcocite (glance), $\mathrm{Cu}_{2} \mathrm{~S}$, occurs in the Horn Silver mine, where it is one of the sulphides resulting from the replacement of the sulphides of other metals. 
In part at least it has doubtless been formed by the alteration of covellite. In the $\mathrm{O} \mathrm{K}$ mine it occurs as a replacement of pyrite and probably chalcopyrite. It doubtless occurs in small amounts in some of the other mines. It is reported to have been an important ore mineral in the high-grade ore from the $\mathrm{O} \mathrm{K}$ mine and was probably important also in the copper ores of the Horn Silver mine.

Sphaterite.-The ordinary sulphide of zinc, sphalerite (zine blende or jack), $\mathrm{ZnS}$, is present in many mines of this region. With pyrite and galena it forms the main part of the primary ore of the Horn Silver and Carbonate mines. Sphalerite and wurtzite are the principal minerals in the zinc ore of the Horn Silver mine. Sphalerite is present together with other sulphides intergrown with silicates in the contact-metamorphic zone south of the quartz monzonite stock of the Cactus area. It occurs in many of the mines of the Star district, being noted in especial abundance in some of the primary ores of the Cedar-Talisman and Moscow mines. It is the zine mineral of all the primary ores of the district.

Covellite.-The indigo-blue copper sulphide, covellite, CuS, though a relatively rare copper mineral, is rather abundant in the San Francisco region. It occurs in the Horn Silver mine as replacement of pyrite, zinc sulphides, and galena and as an alteration of chalcocite. It replaces chalcopyrite in the $\mathrm{O} \mathrm{K}$ mine and is present, probably replacing chalcopyrite, in the magnetitecopper ore of the Old Hickory mine. A very little was noted in the Cactus mine.

Covellite was an important copper mineral in the copper ores from the Horn Silver mine and is reported to have been relatively abundant in the ores from the $\mathrm{O} K$ mine.

Greenockite.-The sulphide of cadmium, CdS, was noted in specimens of sphalerite from the Moscow mine, where it forms thin films either deposited on or replacing the zinc sulphide.

Wurtzite.-The hexagonal sulphide of zinc, wurtzite, $\mathrm{ZnS}$, is found in considerable abundance in the zinc ores of the Horn Silver mine. The zinc sulphides of this mine are unusually light-colored, the pure sulphides usually being of a honey-yellow color. On superficial examination the zinc sulphide appears to be composed of one mineral, but in thin sections under the microscope it is immediately apparent that there are two minerals, one the ordinary isotropic sulphide and another that is rather strongly double refracting. A closer examination of the specimens revealed numerous pyramidal crystals, several of which were submitted to W. T. Schaller, of the Geological Survey, for chemical and crystallographic investigation. Mr. Schaller makes the following report:

The crystals show a steep hexagonal pyramid, which is strongly striated horizontally. Accurate measurements were not possible, as the striations caused the crystals to become rounded with consequent absence of plane faces. The crystals were measured on the two-circle goniometer and $\rho$ angle determined for the pyramid faces. This angle corresponds to that between the basal plane (absent on these crystals) and the pyramidal faces. The values obtained are shown below, the pyramid being the form $o(202 \overline{2})$.

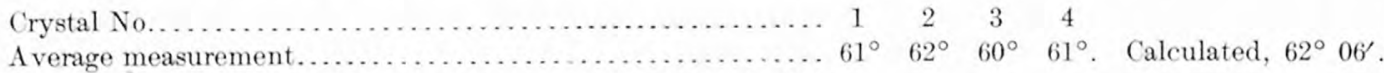

The crystals of wurtzite dissolve readily in $\mathrm{HCl}$, evolving $\mathrm{H}_{2} \mathrm{~S}$. The solution contained abundant zinc and no other metal was present in appreciable quantity.

The following description of artificial wurtzite by Allen, Crenshaw, and Merwin ${ }^{1}$ has recently been published:

The sulphide of zinc occurs in nature crystallized in two different forms-the common sphalerite, or blende, which belongs to the regular system, and the comparatively rare wurtzite, which belongs to the hexagonal system. Both are transparent and straw-colored ${ }^{2}$ when pure, and are distinguished from each other and from amorphous zinc sulphide by the presence or absence of double refraction ${ }^{3}$ and by the magnitude of the indices of refraction. The latter for sphalerite is 2.37 , which in sodium light is slightly less than that of wurtzite for the ray vibrating in the vertical axis, while the other index of the latter mineral is 2.35 (Merwin). These properties were determined on a

1 Allen, E. T., Crenshaw, J. L., and Merwin, H. E., The sulphides of zinc, cadmium, and mercury: their crystalline forms and genetic conditions: Am. Jour. Sci., 4th ser., vol. 34, 1912, p. 341.

2 The blende from Franklin, N. J., and from Nordmark, Sweden, is described as pure white. (Dana, A textbook of mineralogy, 1906, p. 61.) Our purest synthetic products have all been straw-color.

3 For an interesting exception to isotropy in amorphous bodies see the paper by Allen, Crenshaw, und Merwin, p. 383. 
very pure natural sphalerite from Sonora, Mexico, and on the wurtzite formed from it by heating to the proper temperature. The analysis of this mineral was as follows:

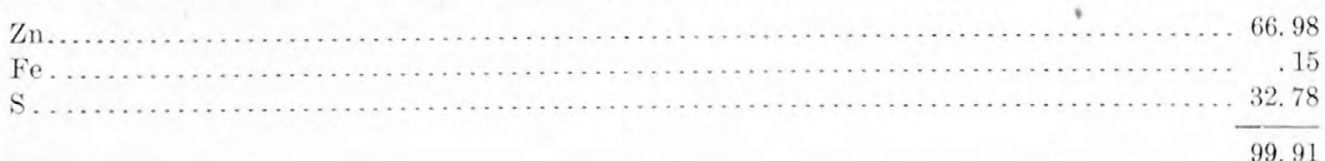

The specific gravity of the two minerals was also determined on the same material by the pycnometer method at $25^{\circ}$.

TABLE 1. - Specific gravities of phalerite and wurtzite.

\begin{tabular}{|c|c|c|c|c|}
\hline \multicolumn{3}{|c|}{ Sphalerite. $a$} & \multirow{2}{*}{\multicolumn{2}{|c|}{$\begin{array}{l}\text { Wurtzite, formed by } \\
\text { heating sphalerite. }\end{array}$}} \\
\hline \multirow{2}{*}{$\begin{array}{l}\text { 1. Sonora, } \\
\text { Mex.; } \\
\text { mineral at } \\
25^{\circ} \text {, water } \\
\text { at } 25^{\circ} \text {. }\end{array}$} & \multicolumn{2}{|c|}{ 2. Same locality. } & & \\
\hline & $\begin{array}{c}\text { Mineral at } \\
25^{\circ} \text {, water } \\
\text { at } 25^{\circ} \text {. }\end{array}$ & $\begin{array}{c}\text { Mineral at } \\
25^{\circ} \text {, water } \\
\text { at } 4^{\circ} \text {. }\end{array}$ & $\begin{array}{c}\text { Mineral at } \\
20^{\circ} \text {, water } \\
\text { at } 20^{\circ} \text {. }\end{array}$ & $\begin{array}{c}\text { Mineral at } \\
20^{\circ} \text {, water } \\
\text { at } 4^{\circ} \text {. }\end{array}$ \\
\hline 4. 101 & 4. 103 & & 4. 098 & \\
\hline 4. 102 & 4. 102 & & & \\
\hline 4. 100 & 4. 102 & & $\begin{array}{l}4.098 \\
4.098\end{array}$ & \\
\hline $\begin{array}{l}4.099 \\
4.001\end{array}$ & & & $\begin{array}{l}4.098 \\
4.100\end{array}$ & \\
\hline Av. 4.100 & Av. 4.102 & Av. 4.090 & Av. 4.099 & Av. 4.087 \\
\hline
\end{tabular}

a For the determination of sample 1 only about 6.5 grams was used; for those of sample 2 about 13 grams was available, and the latter values are subject to less error in consequence.

The hexagonal form, wurtzite, separated from solutions in three extreme habits. (1) Prismatic, hemimorphic crystals strongly striated across the prism faces and reaching 0.8 millimeter in length were produced in the double tube in an acid solution after two days at about $375^{\circ}$. (2) Crystals, tabular parallel to the base and modified by a different pyramid on each end, occurred with these prisms. (3) Hardened amorphous globules from acid solutions at high temperatures become transformed into coherent masses of very small, doubly refracting grains having the mean refractive index of wurtzite. In two cases distinctly radial-fibrous forms, having the characteristics of wurtzite elongated parallel to the prism, were seen. This structure is found in the natural schalenblendes. Experience has shown that these aggregates, immersed in methylene iodide and viewed in ordinary light, may appear entirely isotropic, but mounted in a red mixture of sulphur and selenium having about the same refractive index as the aggregates, they are distinctly doubly refracting in artificial light.

Wurtzite produced by sublimation may appear in slender needles or small stout prisms. Such crystals made from pure zinc sulphide were used for determining the refractive indices under the microscope. The values obtained are as follows: $\omega_{\mathrm{Ll}}=2.330, \varepsilon_{\mathrm{Ll}}=2.350, \omega_{\mathrm{Na}}=2.356, \varepsilon_{\mathrm{Na}}=2.378$. An independent measurement of $\varepsilon-\omega$ on the prisms gave .019 for Li-light and .020 for Na-light. ***

Optical and crystallographic relations between sphalerite and wurtzite.-The development of double refraction is the only conclusive evidence we have of the change of sphalerite to wurtzite by heating. Inasmuch as the transformation is slow, its progress can be studied. In ferriferous blendes transformation appears to be most rapid, starting usually at a single point in a grain and progressing so that the final product has like orientation throughout. In grains of the purest sphalerites the wurtzite usually begins developing at more than one point and in different orientations. The structure produced is an intergrowth of lamellæ of wurtzite, each lamella having its principal axis parallel to one of trigonal axes of the sphalerite grain. It is evident that the strength of the double refraction of a grain thus transformed will be conditioned by the relative development of the four possible sets of lamellæ. J. Beckenkamp ${ }^{1}$ has considered that lamellæ of wurtzite may develop parallel to the trapezohedron of sphalerite. Such lamellæ would outcrop on a cleavage face parallel or normal to cleavages or bisecting the acute angle between cleavage surfaces. All of the outcropping planes would be oblique to cleavage planes. No lamellæ of this sort were seen in the large number of preparations examined during this investigation.

In material furnished by Mr. B. S. Butler, from Beaver County, Utah, prismatic crystals of wurtzite from a brecciated vein have fragments of sphalerite as nuclei. The traces of the prismatic cleavage of the wurtzite and of the cleavage of the sphalerite appear to be parallel. The wurtzite cleaves parallel to the second order prism.

Beckenkamp has discussed in detail the very close crystallographic relations of sphalerite and wurtzite. With these are now correlated the very slight changes in opticai properties, volume, and energy content accompanying the inversion of these minerals.

In many places the wurtzite incloses cores of sphalerite, though this is not universal, as some entire crystals are composed of wurtzite, but elsewhere blades of the wurtzite enter 
the sphalerite, apparently along cleavage planes. The wurtzite appears to be later than the sphalerite and is believed to have been introduced by solutions coming from the oxidizing ores higher in the deposit and to have been precipitated in the sulphide zone. The manner of formation is more fully discussed in the section on secondary alteration of the ores (p. 154).

It is worthy of note that the zinc sulphides in the Horn Silver mine have to an unusual degree the property of triboluminescence, or of giving off light when scratched. Zinc ore is readily detected in the mine by drawing the point of the pick or candlestick across the face of the ore. If zinc sulphides are present the point of the metal is followed by a line of sparks.

Wurtzite has been reported from the Original Butte mine, at Butte, Mont., ${ }^{1}$ where it occurs as fine pyramidal crystals with sphalerite and quartz, and Weed ${ }^{2}$ describes wurtzite from the Gagnon mine in the same district. The mineral is evidently either rare or has been generally mistaken for sphalerite.

Bornite.-The copper-iron sulphide bornite, $3 \mathrm{Cu}_{2} \mathrm{~S} . \mathrm{Fe}_{2} \mathrm{~S}_{3}$, has been reported from the Cactus mine and was seen in the ores of the Imperial mine, but so far as observed is not of commercial importance.

Chalcopyrite.-The yellow copper-iron sulphide, chalcopyrite (copper pyrite), $\mathrm{CuFeS}_{2}$, is by far the most important primary copper mineral of the region. It is the principal copper mineral of the Cactus ore zone, where some of it occurs in open spaces as well-formed tetrahedral crystals (Pl. XI, C, p. 96), though for the most part it is without definite crystal form. It is the commercially important mineral in the primary ores of the contact zones and is the principal copper mineral in the primary ores of the other deposits. It occurs as an original mineral in an aplite dike in the $\mathrm{O} \mathrm{K}$ mine. In many of the deposits the original chalcopyrite has been altered to carbonates, oxides, or secondary sulphides.

Pyrite.-The common sulphide of iron (iron pyrites), $\mathrm{FeS}_{2}$, is present throughout the region wherever there has been mineralization or hydrothermal alteration of the rocks. Usually it is without definite crystal form, but in the Cactus deposit many well-formed pyritohedral crystals are seen. Much of the pyrite in the highly silicified rock of the Horn Silver deposit occurs in well-formed octahedral crystals; in the more massive sulphide ore pyritohedral crystals are abundant. The occurrence of argentiferous pyrite in the Horn Silver mine is of unusual interest. It consists of pyrite in a quartz gangue resulting from the silicification of the volcanic wall rock. The primary ore carries a little silver. In oxidation the pyrite is removed, leaving the silver in the porous rock and thus raising it to a commercial grade.

Throughout the region the pyrite in the upper parts of the deposits has been altered to limonite or other closely allied minerals.

\section{SELENIDES.}

In testing specimens of ore from the Golden Reef mine with the blowpipe, the presence of selenium was detected, but it was not found possible to determine the selenium mineral.

SULPHARSENIDES, SULPHANTIMONIDES, ETC.

Cosalite (?).-A dark-gray metallic mineral with rather prominent striations on the crystal faces was collected from the 700 -foot level of the Cactus mine. This was submitted to W. T. Schaller, who reported that it contained lead, bismuth, sulphur, and a little copper, and that the mineral is cosalite or a closely allied species.

Dufrenoysite.-The sulpharsenate of lead, $2 \mathrm{PbS} . \mathrm{As}_{2} \mathrm{~S}_{3}$, is reported from the San Francisco district by Maynard Bixby but was not collected by the writer.

Jamesonite.-In some of the ores of the Horn Silver mine a dark lead-gray mineral is rather abundant, especially in association with barite. The mineral occurs in massive form and no material showing crystal forms was collected. The mineral contains lead, antimony, and sulphur and is jamesonite or some closely allied mineral.

1 Dana, E. S., A system of mineralogy, 6th ed., 1909, p. 70.

${ }_{2}$ Weed, W. H., Geology and ore deposits of the Butte district, Montana: Prof. Paper U. S. Geol. Survey No. 74, 1912, p. 80. 
Pyrargyrite.-A mineral resembling the sulphantimonide of silver, pyrargyrite (ruby silver), $3 \mathrm{Ag}_{2} \mathrm{~S} \cdot \mathrm{Sb}_{2} \mathrm{~S}_{3}$, was collected from a stope between the 800 and 900 foot levels of the Horn Silver mine. The mineral is deep red to nearly black, but thin splinters are deep ruby red by transmitted light. It occurs in a gangue of barite, forming thin seams along the cleavage surfaces or filling small fissures in the gangue mineral. "Ruby silver" is reported to have been rather abundant in the baritic silver ores extracted from the upper levels of the mine. Material suitable for a quantitative analysis of this mineral was not procured. It is a sulphantimonide of silver and either pyrargyrite or some closely allied mineral.

Proustite.-The sulpharsenate of silver, proustite, $3 \mathrm{Ag}_{2} \mathrm{~S} \cdot \mathrm{As}_{2} \mathrm{~S}_{3}$, has been reported from the San Francisco district by Maynard Bixby but was not collected by the writer.

Tetrahedrite.-The sulphantimonide of copper, tetrahedrite, $4 \mathrm{Cu}_{2} \mathrm{~S}_{.} \mathrm{Sb}_{2} \mathrm{~S}_{3}$, was collected from the Cactus and Harrington-Hickory mines. The composition of the mineral is variable, the formula written above only representing the general composition.

In the Cactus mine tetrahedrite occurs as a dark lead-gray to nearly black massive mineral associated with the later minerals of that deposit. Little of it was seen in the mine, but it is reported that in the high-grade ore it was locally rather abundant, though nowhere of great commercial importance. In the Harrington-Hickory mine only a few small masses were seen associated with pyrite and galena. The mineral is probably present in other deposits of the region.

\section{CHLORIDES AND FLUORIDES.}

Cerargyrite.-The chloride of silver, cerargyrite (horn silver), $\mathrm{AgCl}$, is reported to have been an important mineral in the silver ores in the upper levels of the Horn Silver mine. Chemical tests of the oxidized silver ore from the seventh level of the mine by $\mathrm{R}$. C. Wells showed the presence of chlorine, and the silver in this ore is doubtless present, in part at least, as the chloride.

"Horn silver" is reported from many other mines and prospects of the region, and is doubtless present in much of the ore near the surface, but the writer did not collect any material that proved on laboratory test to be chloride of silver.

Fluorite-Calcium fluoride (fluorspar), $\mathrm{CaF}_{2}$, is present in numerous localities in this region. It was collected from the contact zone south of the Cactus area of quartz monzonite, where it is intergrown with contact silicates. It occurs usually in small crystals not readily noted until seen under the microscope, although in some hand specimens it is apparent as a pale-green mineral with the characteristic cleavage. In the Wild Bill mine some pale-green crystals of fluorite half an inch in diameter are inclosed in magnetite. It is rather plentiful in some of the primary ores from the Hub mine and was noted in ores from the Moscow mine, where it is intergrown with muscovite. (See Pl. XII, B, p. 97.) The mineral is undoubtedly present in many other localities associated with contact silicates.

\section{OXIDES.}

Quartz.-Quartz, $\mathrm{SiO}_{2}$, is one of the most abundant minerals in the region and has formed under diverse conditions. It is an important constituent of most of the igneous rocks, being especially abundant in the aplitic dikes. It forms a large "chimney"-like body associated with the $\mathrm{O} \mathrm{K}$ ore deposit. In this occurrence it is in large crystals and has the general structure and appearance of a coarse pegmatite. In the Cactus mine it occurs as a gangue mineral. In the open spaces it is in well-formed terminated crystals (PI. XI, A) and commonly incloses needle-like crystals of tourmaline (Pl. XI, $B$ ). A very fine-grained cherty variety occurs as a gangue mineral in the ores of the Carbonate mine. Quartz is a product of the hydrothermal alteration of the igneous rocks of the region, both those connected with the ores and those not apparently associated with metalliferous deposits. It has also formed as a replacement of limestone in the replacement veins. It is of course the main constituent of the quartzites of the region and is present in considerable amounts in many of the shales and limestones. It has replaced wood fiber, forming the petrified wood present in some of the shale beds of the Star district. 


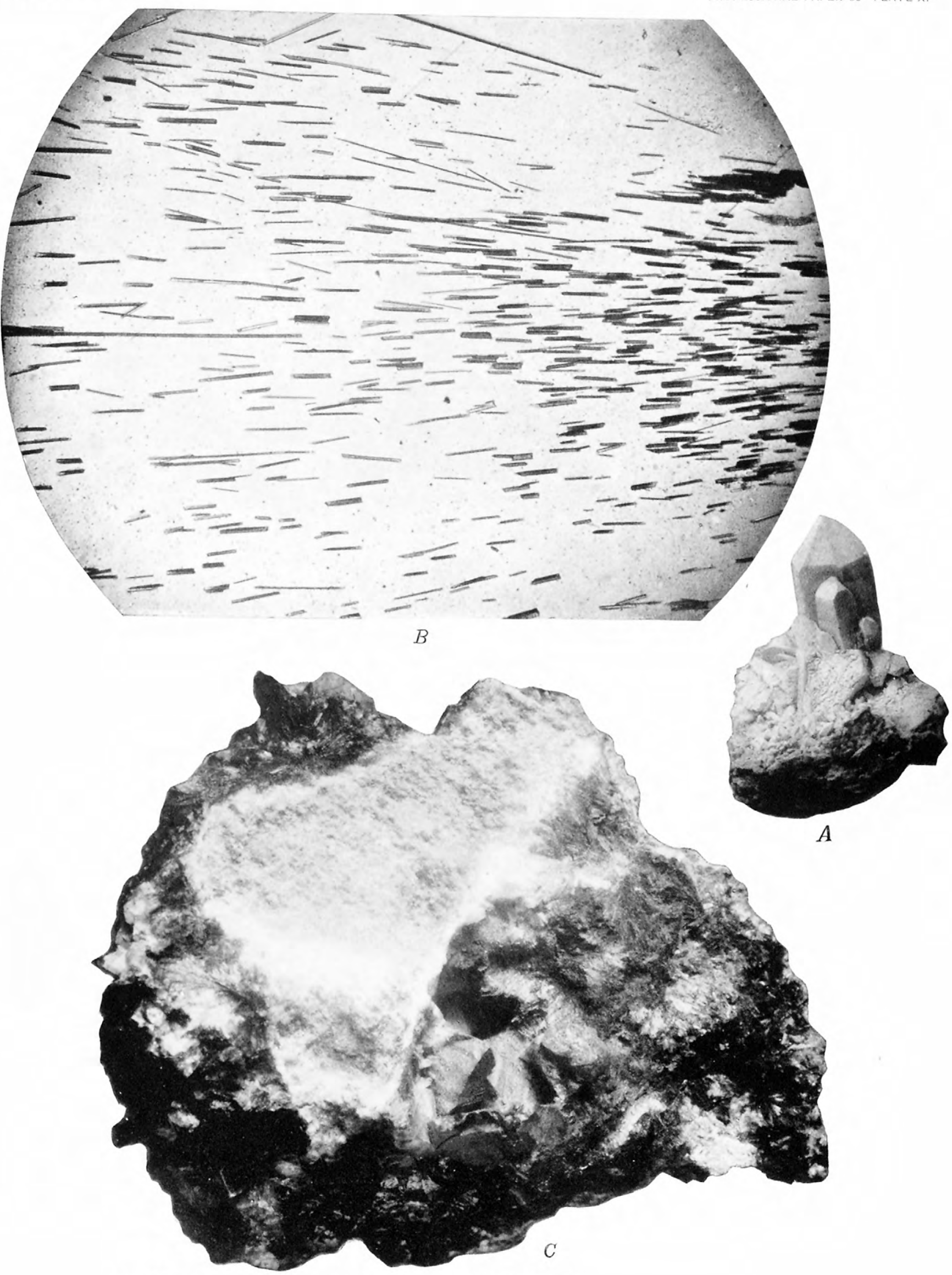

1. QUARTZ CRYSTALS, CACTUS MINE. NATURAL SIZE.

1) TOUPMALINE IN QUARTZ, CACTUS MINE. ENLARGED 30 DIAMETERS.

C. TETRAHEDRAL CRYSTALS OF CHALCOPYRITE, CACTUS MINE. NATURAL SIZE.

Dark areas tourmaline, light areas altered quartz monzonite. 


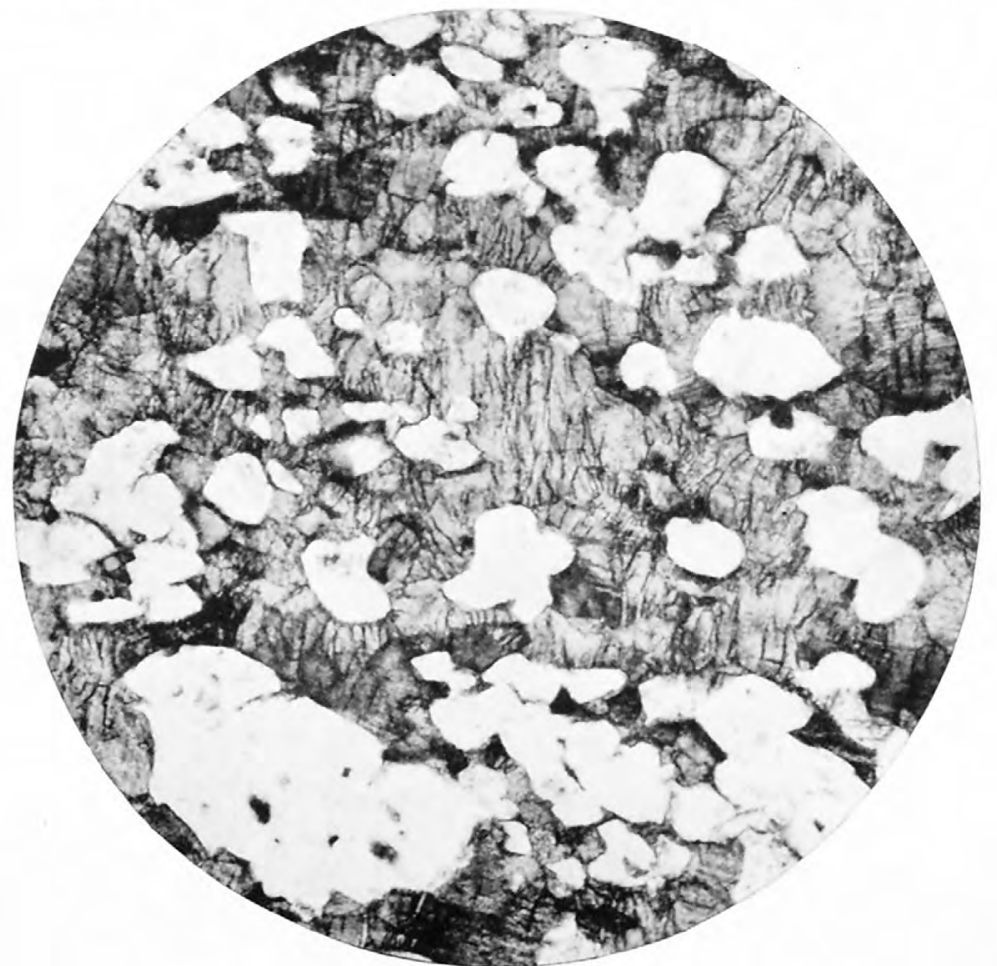

4. SERPENTINE IN LIMESTONE, NEAR CONTACT EAST OF MICHIGAN MINE.

Probably alteration of diopside. The expansion in alteration has fractured the carbonate grains and the serpentine has filled the fissures. White areas serpentine, gray areas carbonate. Enlarged 30 diameters.

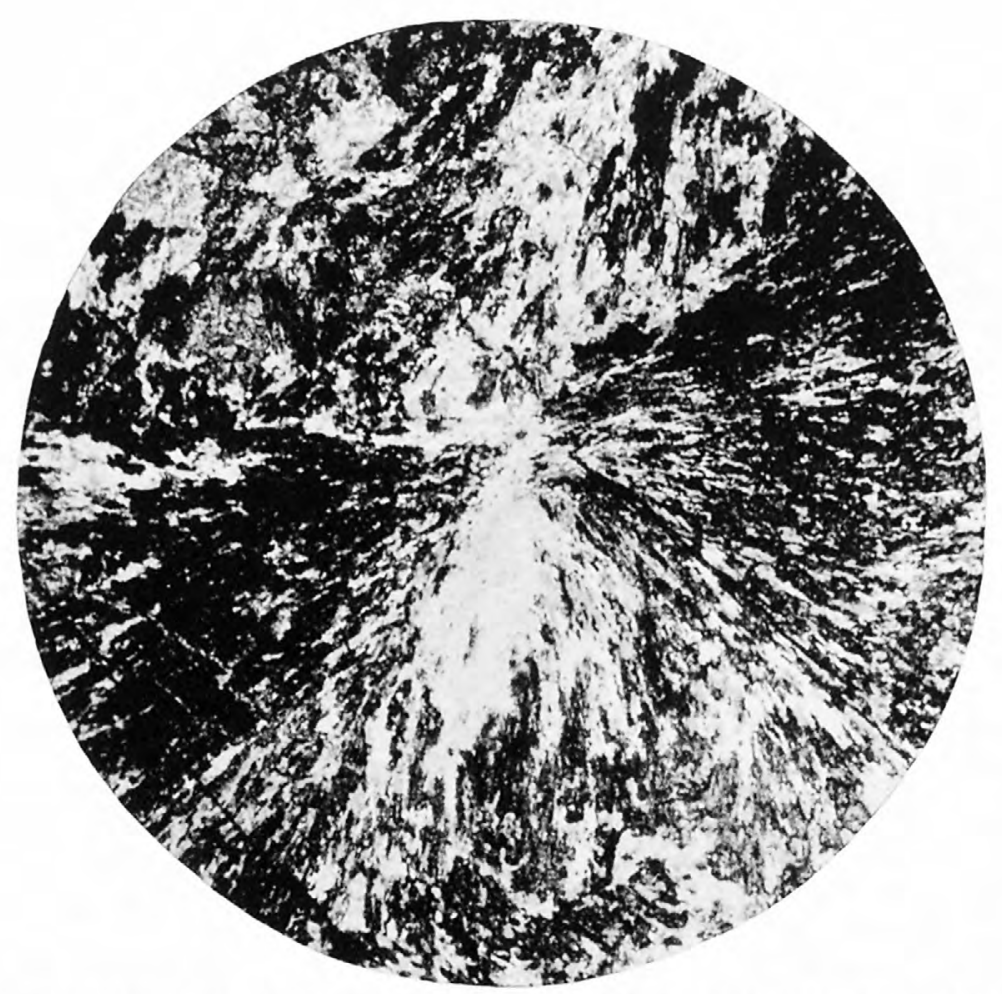

B. INTERGROWTH OF FLUORITE AND MUSCOVITE, MOSCOW MINE.

Light areas muscovite, dark areas fluorite. Crossed nicols. Enlarged 30 diameters. 
Opal.-The amorphous hydrous oxide of silica, opal, is present in considerable amount associated with certain volcanic flows in the area south of the Squaw Springs Pass. A soft material composed principally of hydrous silica occurs in many places on the footwall in the lower levels of the Horn Silver mine. When taken from the mine this material may be readily cut or even molded in the hand, but after exposure to the air it becomes hard. The gangue mineral of some of the oxidized silver ores in the Horn Silver mine is also amorphous silica.

Cuprite.-The copper oxide cuprite, $\mathrm{Cu}_{2} \mathrm{O}$, was collected from the Imperial and Skylark mines. At the Skylark it occurs in small crystals, octahedrons and cubes, and also in the capillary form known as chalcotrichite. In the specimens from this mine it is usually closely associated with native copper. The specimens of red oxide from the Imperial mine are massive, showing no crystal form, and are closely associated with malachite." It is reported that cuprite was rather abundant in some of the rich ores from this mine. The mineral is doubtless present in other localities in the region.

Melaconite.-A rather soft, earthy black material rich in copper, collected from the Skylark mine, is probably in large part the copper oxide melaconite, $\mathrm{CuO}$, though there is doubtless some admixture of manganese. Some of the black "copper pitch" from this mine is rich in manganese.

Hematite.-The iron oxide hematite (specularite, or red iron ore), $\mathrm{Fe}_{2} \mathrm{O}_{3}$, is widely distributed in this region. It is an important gangue mineral in the ores of the Cactus mine, being especially abundant in the upper levels. Nuch of it is closely associated with siderite and in the hand specimen has the appearance of being an alteration product of that mineral, but on microscopic examination it is seen to be earlier than the carbonate, the crystals extending through those of the siderite without regard to structural lines. (See Pl. XIV, B, p. 107.) Much of the mineral in the Cactus mine is slightly magnetic, and some of it rather strongly so.

Hematite and magnetite occur in the contact zone bordering the Cactus area of quartz monzonite. In the northern part of the Beaver Lake district, in the Black Rock group of claims, hematite occurs in a vein in the limestone near the monzonite contact, but the extent of this deposit has not been disclosed. This material is slightly magnetic and may be admixed with magnetite, which is present in considerable amounts in this general zone.

Hematite also occurs in the altered voleanic rocks near the quartz monzonite contact, being noted in especial abundance in the workings of the Frisco Contact mine, where in some places it formed several per cent of the rock. In this as in the other occurrences it is slightly magnetic. The mineral was seen at several points in the contact zones of the Star district but nowhere in great abundance.

Hematite is not of large commereial importance, though it is reported that some iron ore was shipped from the Black Rock claims to the Frisco smelters to be used as flux, and the hematite in the Cactus ores is largely collected in the concentrates and thus raises the iron content.

Imenite. - Some of the lavas of the region contain small crystals of a mineral that resembles magnetite but on being tested with the magnet is only feebly magnetic. Where the lava has suffered hydrothermal alteration, as in the Beaver Lake district, this mineral has been altered wholly or in part to rutile. It is evidently a titanium mineral and doubtless ilmenite, $(\mathrm{Fe}, \mathrm{Ti})_{2} \mathrm{O}_{3}$, or some closely allied mineral.

Magnetite.-The iron oxide magnetite, $\mathrm{FeO} \cdot \mathrm{Fe}_{2} \mathrm{O}_{3}$, is also of widespread occurrence in the San Francisco region. It is a primary mineral in all the igneous rocks and is present in variable amounts in the areas of contact alteration throughout the region. In the Old Hickory mine and neighboring deposits it is the principal gangue mineral, and in the Skylark and other contact deposits it occurs in considerable amount. In the replacement fissure deposits it has been noted in the Harrington-Hickory, Wild Bill, and Hub mines.

In places in the contact zone south of the quartz monzonite stock of the Cactus area magnetite forms around sulphide grains (see fig. 9, p. 84) and also in fissures in sulphides (Pl. XXXIII, $A$, p. 184), being distinctly later than the sulphides, though doubtless formed during $73363^{\circ}-$ No. $80-13-7$ 
the same general period of mineralization. The mineral has been of commercial importance in the Old Hickory mine, where the high iron content has made it possible to mine ores that could not have been profitably handled for their copper and precious metal values alone.

Rutile.-The oxide of titanium, $\mathrm{TiO}_{2}$, is present in small amounts in many places in the region. It has resulted from the hydrothermal alteration of titanite and ilmenite and some of it apparently from biotite. It was also noted in quartzite near the quartz monzonite contact in the southern part of the Rocky district. It occurs invariably in microscopic crystals and was recognized only in the microscopic study of the rocks.

Pyrolusite. - The oxide of manganese, $\mathrm{NnO}_{2}$, or some closely allied mineral, is present in small amounts throughout the region. The dendrites (fernlike forms) that are common along seams in the limestone, especially near ore deposits, consist of this mineral. Mixed with iron oxides it is present in small amounts in the gossans of many of the ore deposits, especially in the Cactus mine, where it has resulted from the alteration of manganiferous carbonate, and in the Horn Silver mine, where the original manganiferous mineral has not been determined. To a lesser extent it has been noted in many of the mines of the district.

\section{HYDROUS OXIDES.}

Diaspore.-The hydrous oxide of alumina, $\mathrm{Al}_{2} \mathrm{O}_{3} \cdot \mathrm{H}_{2} \mathrm{O}$, was noted as a minor constituent of the altered lavas in the Beaver Lake district. The mineral has resulted from the alteration of the rock and is recognized only in microscopic sections.

Goethite.-A hydrous iron mineral having the optical properties of goethite, $\mathrm{Fe}_{2} \mathrm{O}_{3} \cdot \mathrm{H}_{2} \mathrm{O}$, was collected from the gossan of the Cactus mine. The mineral occurs in fine needle-like cystals forming a velvety lining of cavities and closely associated with limonite.

Manganite.-The hydrous oxide of manganese, $\mathrm{Mn}_{2} \mathrm{O}_{3} \cdot \mathrm{H}_{2} \mathrm{O}$, is doubtless associated with the pyrolusite and possibly with other manganese minerals in this region, but material in which it could be definitely determined was not procured.

Limonite.-The hydrous oxide of iron, $2 \mathrm{Fe}_{2} \mathrm{O}_{3} \cdot 3 \mathrm{H}_{2} \mathrm{O}$, is present in all parts of the region. It is the ordinary product resulting from the surface alteration of iron-bearing minerals. In many of the oxidized lead deposits it forms a large percentage of the ore. In the Cactus mine limonite pseudomorph, after both siderite and pyrite, is abundant in the gossan.

It is reported that limonite ore was shipped from the Iron Devil and other claims to the Frisco smelters. The limonite content of many of the lead ores of the district adds materially to their value.

Copper pitch.-The name copper pitch is applied to a black amorphous substance breaking with a conchoidal fracture. It is usually rather soft, though varying in hardness. It is probably variable in composition, but contains considerable amounts of copper, iron, manganese, and water. The mineral is present in many of the copper ores of the district, being especially noted in the Imperial, Skylark, and Lady Bryan mines.

\section{CARBONATES.}

Calcite.-Calcium carbonate, or calcite, $\mathrm{CaCO}_{3}$, occurs most abundantly in the limestone, much of which is composed essentially of calcite, though in many of the beds magnesium becomes an important constituent. Near the contact with the quartz monzonite the limestone has commonly been recrystallized, in some places forming an attractive marble, though usually broken into small pieces by joints. This is especially true of the marble of Grampian Hill. Adjacent to the ore deposits the calcite occurs locally in large crystals showing the characteristic rhombohedral cleavage. This is well shown in the Cupric and neighboring mines. In the oxidized ores of the replacement veins it forms as a lining of cavities and in this mode of occurrence is commonly in very flat rhombohedral crystals resembling flat disks. Especially good crystals of this type were noted lining cavities in the wall rock of the Red Warrior mine. In the Carbonate mine calcite is an important gangue mineral, commonly forming in open cavities as beautiful scalenohedral crystals. In the Cactus mine small veins composed largely of calcium carbonate have formed, filling fissures in the earlier carbonates. The mineral partly fills the gas cavities in many of the vesicular basalts of the district. 
Calcite has been deposited from spring waters, forming with gypsum and other sulphates the greater part of such deposits occurring south of the Frisco Contact mine. It is also a universal product resulting from the surface alteration of the igneous rocks of the region.

Dolomite.-Most of the limestone of the region contains some magnesium, and some of it is distinctly a dolomite, or calcium-magnesium carbonate, $(\mathrm{Ca}, \mathrm{Mg}) \mathrm{CO}_{3}$, containing nearly as large a percentage of magnesium as of calcium. In addition to its occurrence in the sedimentary rocks the mineral has also formed in the secondary ores of some of the mines, crystals of dolomite being seen in the Red Warrior mine closely associated with calcite.

Magnesite. - Small veins of a white fine-grained mineral breaking with a conchoidal fracture were noted in the crystalline limestone near the contact with quartz monzonite at several localities in the region. These veins were especially abundant in White Mountain, on the west side of Grampian Hill, and north and northwest of Hickory in the Rocky district. They are as a rule only a few inches wide and could be traced but a few yards along the strike. A few veins a foot in width occur. Under the microscope the material is seen to be composed of very fine crystals too small for a determination of their optical properties. Material from a vein cutting magnetite exposed in a prospect northeast of Hickory was examined by R. C. Wells, of the chemical laboratory of the Survey, who reported the following composition:

Composition of material from a vein cutting magnetite in prospect north of Hickory, Utah.

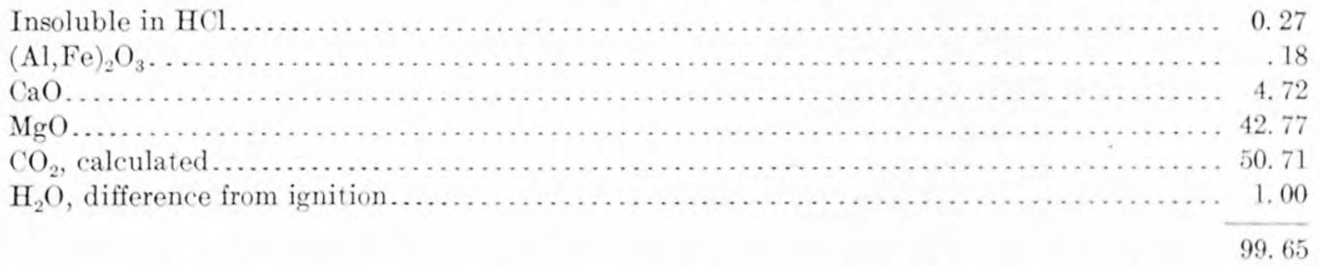

This composition corresponds to 89.80 per cent magnesite, $\mathrm{MgCO}_{3}$, and 8.46 per cent calcite. All the veins of this material examined were formed later than the contact alteration of the rocks in which they occur.

Siderite.-The carbonate of iron, $\mathrm{FeCO}_{3}$, is a rather abundant gangue mineral in the Cactus ore zone. Usually it has formed as a vein mineral filling open spaces, and is one of the latest minerals to form in the deposit. It has the typical cleavage of the rhombohedral carbonates, but differs considerably in color in different parts of the mine. In the lower levels it is commonly light gray, but in the upper levels some of it is dark brown. This difference may be due to a partial alteration of the mineral in the upper levels. A partial analysis by George Steiger of some of the light-colored material from the 700 -foot level gave the composition shown below:

Partial analysis of carbonate from ro\%-foot level of Cactus mine.

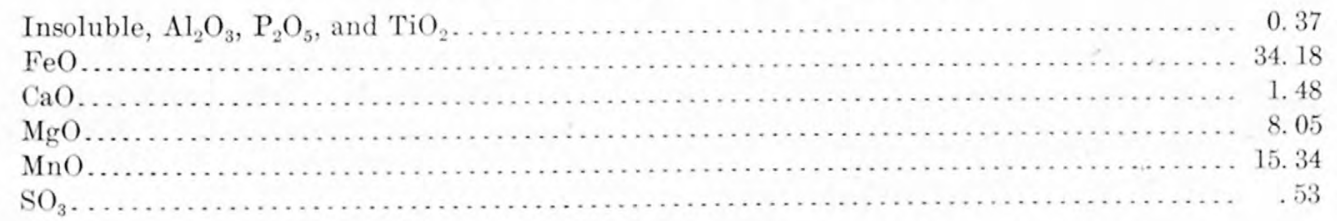

This analysis shows the material to be composed of siderite, rhodochrosite, manganite, and calcite molecules in about the following proportion: Siderite 55.10 per cent, rhodochrosite 23.98 per cent, manganite 16.88 per cent, calcite 2 per cent, with 0.95 per cent of anhydrite and 0.37 per cent of other impurities. The mineral probably varies somewhat in composition from place to place in the mine, but the above analysis is believed to represent the general composition. It is evidently a mixed carbonate and might more correctly be called magnesiummanganese siderite. Light-brown carbonate containing much iron is present in the Cupric mine. In part the crystals occur as scalenohedral crystals upon which has been deposited a coating of calcite.

Rhodochrosite. - The carbonate of manganese, $\mathrm{MnCO}_{3}$, was identified in specimens from the Moseow mine, though it does not appear to be abundant. It forms an important part of the 
impure siderite of the Cactus mine and is probably present in carbonates in other parts of the region.

Smithsonite.-The carbonate of zinc, $\mathrm{ZnCO}_{3}$, is doubtless present at many places in the region, where it has resulted from the alteration of sphalerite. It was especially noted in the Cedar-Talisman mine, where with calamine it forms zinc ore. Specimens were collected above the 650-foot level in the Horn Silver mine and from a fissure in limestone on the 700 -foot level, where it has formed as pseudomorphs after calcite (Pl. XXIV, A, p. 147). In these pseudomorphs the outer form of the calcite crystals is preserved, but the crystals are hollow. Carbonates of copper (azurite and malachite) have been deposited on these crystals in variable amounts.

Aragonite.-The only occurrence of aragonite, the orthorhombic carbonate of calcium, $\mathrm{CaCO}_{3}$, noted in the region was near the contact of quartz monzonite and limestone north of the Cactus mine. The mineral occurs in needle-like crystals radiating from centers and forming irregular masses up to a foot in diameter. From surface to center these masses are divided into successive "shells" one within another. Along the contact of these "shells" the material will readily - separate. The individual crystals extend across one of these layers but terminate at the contact. On either side of such a contact the crystals have the same general direction of elongation, so that the radial structure is not interrupted. The thickness of the "shells" varies greatly, some being as much as an inch thick without a perceptible break, whereas others do not exceed onesixteenth of an inch. The partings are also variable. Some are very distinct to the eye and the specimen readily separates along them, but others are obscure and the tendeney to separate along them is not pronounced.

Aragonite is probably present at other localities in the region.

Cerusite.-The carbonate of lead (sand carbonate), $\mathrm{PbCO}_{3}$, is the most common secondary lead mineral in the district. It has formed from the alteration of galena and is usually mixed with other secondary minerals, especially limonite. Here and there, however, as in the Red Warrior mine, small bodies of nearly pure cerusite are encountered. It is a rather light gray material composed of small crystals and can usually be readily crushed in the hand, though locally it occurs in more massive form. The presence of the lead carbonate in limonitic material can frequently be detected by crushing the material in the hand. If the lead mineral is present it will give a characteristic crunching sound that enables those familiar with the deposits to separate ore from waste.

Cerusite is one of the commercially important lead minerals of the region. It is the principal lead mineral of the oxidized ores in all the mines except the Horn Silver. Besides its lead content it usually carries a considerable amount of silver.

HYDROUS CARBONATES.

Malachite. - The green carbonate of copper, $\mathrm{Cu}_{2}(\mathrm{OH})_{2} \mathrm{CO}_{3}$, is a common oxidation product of copper sulphide in this region and is present in practically all the mines containing copper. It was said to have been present in considerable amount in some of the ores from the O $\mathrm{K}$ mine, and it was an important copper mineral in the ores being extracted from the Lady Bryan mine at the time the writer was in the district.

Azurite.-The blue carbonate of copper, $\mathrm{Cu}_{3}(\mathrm{OH})_{2}\left(\mathrm{CO}_{3}\right)_{2}$, so far as observed, is much less abundant than malachite, though it was noted in small amount in practically all the mines that contain oxidized copper ores.

\section{SILICATES.}

Orthoclase.-The potassium-aluminum silicate orthoclase, $\mathrm{KAlSi}_{3} \mathrm{O}_{8}$, is present in considerable amounts in most of the igneous rocks of the region. It is practically the only feldspar in the aplitic dikes and is an important constituent of both the quartz monzonite and the flow rocks except the basalts. It occurs in rocks adjacent to the ore deposits in the HarringtonHickory mine, where it has evidently resulted from the alteration that has accompanied the deposition of the ores. Some orthoclase in the altered rock associated with the ores of the Carbonate mine appears to have resulted from the alteration of plagioclase. 
Plagioclase.-The plagioclase feldspars, aluminum silicates of sodium and calcium, $n \mathrm{NaAlSi} \mathrm{O}_{8} m \mathrm{CaAl}_{2} \mathrm{Si}_{2} \mathrm{O}_{8}$, having various compositions, occur abundantly in most of the igneous rocks of the region. In the quartz monzonite and latites the plagioclase usually has the composition of andesine, but in the more basic rocks it is labradorite or an even more basic variety. In the southern part of the Rocky district albite is present in the quartzite near the quartz monzonite contact and is probably due to contact alteration.

Diopside.-Diopside, the calcium-magnesium-iron silicate of somewhat variable composition, is the common pyroxene in the contact zone and is present in greater or less amounts wherever contact alteration has been pronounced. At the Old Hickory mine an apple-green variety of diopside occurs, with the magnetite in considerable abundance. This mineral has the optical properties of diopside but is usually granular and differs in general appearance from that seen in other parts of the district. A partial analysis of this material by Chase Palmer gave the following results:

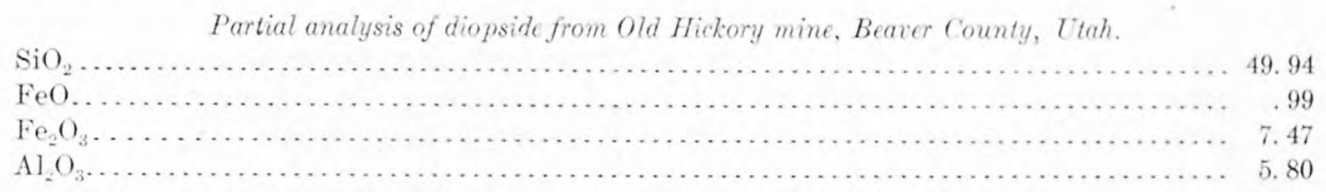

The mineral contains copper in small amount. The copper is probably admixed.

This analysis is especially notable for its high content of ferric iron and low content of ferrous iron. The mineral corresponds in general with the variety of diopside that has been given the name coccolite.

Augite.-The variable silicate of calcium, magnesium, and aluminum, augite, is the common pyroxene of the igneous rocks, being an important constituent in the quartz monzonite.

Wollastonite.-The calcium silicate, wollastonite, $\mathrm{CaSiO}_{3}$, has been recognized in but one locality in the district. It occurs along joints in the quartz monzonite near the limestone contact north of the Cactus mine, where it is associated with epidote, calcite, and some pyrite. Though not in the altered limestone, it is doubtless the result of contact alteration.

Tremolite.-The calcium-magnesium silicate, $\mathrm{CaMg}_{3}\left(\mathrm{SiO}_{3}\right)_{4}$, is present in varying amounts in nearly all the areas of contact alteration. It is especially abundant in the contact zone of Grampian Hill, where locally it forms a large part of the contact rock. At many points fibrous masses of tremolite, several inches to a foot in length, can be seen. The exceptionally smooth slopes southwest of the Imperial mine have resulted from the weathering of rock composed largely of this mineral. It is known to the miners of the region as a rock especially difficult both to drill and to break. (See Pl. IX, A, p. 83.)

Hornblende.-The aluminous calcium-magnesium-iron-sodium silicate, hornblende, is an important constituent of most of the igneous rocks of the region.

Asbestos. - The curious leathery magnesian silicate, asbestos, occurs in fractures in the dolomitic limestone of Grampian Hill, being noted especially in the Grampian tunnel and in fissures in the limestone on the seventh level of the Horn Silver mine.

Garnet.-Grossularite is the calcium-aluminum silicate, $\mathrm{Ca}_{3} \mathrm{Al}_{2}\left(\mathrm{SiO}_{4}\right)_{3}$, and andradite the calcium-iron silicate, $\mathrm{Ca}_{3} \mathrm{Fe}_{2}\left(\mathrm{SiO}_{4}\right)_{3}$. Garnet, composed of variable mixtures of these molecules, is present in varying amounts in nearly all the areas of contact alteration of limestone. At some points in Grampian Hill the contact rock appears to be composed almost entirely of garnet but on microscopic examination is seen to contain notable amounts of other minerals. The garnet in different localities varies notably in composition, some of it being nearly pure grossularite, and some having the andradite molecule greatly in predominance, as shown by the analysis of the altered rocks from Grampian Hill. Where the garnet forms a large part of the altered rock it usually shows no definite crystal form, but where it occurs in small amount scattered through altered limestone well-developed crystals are common.

Olivine.-The magnesium silicate olivine, $(\mathrm{Mg}, \mathrm{Fe})_{2} \mathrm{SiO}_{4}$, occurs as an important original constituent of the basaltic flows of the region.

Vesuvianite.-The hydrous calcium-aluminum-iron silicate, vesuvianite, $\mathrm{H}_{4} \mathrm{Ca}_{12}(\mathrm{Al}, \mathrm{Fe})_{6}$ $\mathrm{Si}_{10} \mathrm{O}_{43}$ ?, has resulted from the contact alteration of the limestone. It is especially abundant in 
the contact zone of Grampian Hill, where in some places it forms a considerable percentage of the rock. The mineral does not usually possess good crystal outline and is recognized only in the microscopic study of the rock.

Zircon.-The silicate of zirconium, $\mathrm{ZrSiO}_{4}$, is present in small amounts as an accessory mineral in the igneous rocks of the district. It is rather abundant in the silicified rock associated with the ores of the Horn Silver mine.

Andalusite.-The aluminum silicate, andalusite, $\mathrm{Al}_{2} \mathrm{SiO}_{5}$, occurs abundantly in the highly altered lavas of the Beaver Lake district. It appears to have formed where the removal of the bases sodium, potassium, and calcium had progressed to a stage in which they were not present in sufficient amounts to combine with alumina and silica. So far as the writer is aware this mineral has not been before described as resulting from the hydrothermal alteration of lavas, its occurrences being confined to pegmatite veins and to areas of contact metamorphism and of recional metamorphism, where it is believed to have formed under conditions of considerable heat and pressure. The presence of andalusite in this region indicates that the alteration of the lavas which has resulted in its formation has been effected at higher temperatures and perhaps under greater pressure than is common in such alteration. The formation of andalusite is more fully discussed in the section on the alteration of the lavas (p. 78).

Epidote.-Epidote, a complex hydrous silicate of calcium, iron, and aluminum, is present in small amounts in the district. It occurs in the areas of contact alteration, but is not an important contact mineral in the district. It is also present in small amounts in the altered igneous rocks.

Calamine.-The most abundant occurrence of calamine, the hydrous silicate of zinc, $\mathrm{H}_{2} \mathrm{Zn}_{2} \mathrm{SiO}_{5}$, observed in this region was at the Cedar-Talisman mine, where with smithsonite it forms the oxidized zinc ores. It has been recognized in specimens from the lower part of the oxidized zone of the Horn Silver mine, but the extent of its occurrence in this mine is not known.

Calamine is probably present as a product of the alteration of sphalerite in other mines of the district.

Tourmatine.-Tourmaline, a complex borosilicate usually containing iron, magnesium, and calcium, and in many places other elements, is an abundant gangue mineral in the Cactus mine. For the most part it has formed as a filling of open spaces between the breccia fragments, but it is present to a slight extent in the altered quartz monzonite. Its ordinary occurrence is as tufts of fine needle-like crystals radiating from centers. Locally these are included in the later minerals.

In the hand specimen the mineral is dark brown or almost black in color. Under the microscope it shows pleochroism from dark brown to a very dark blue. It has a density between 3.18 and 3.19 , which corresponds to an iron tourmaline containing but little magnesium. Tourmaline occurs in close association with an aplitic dike in the quartz monzonite of Black Mountain south of the Cactus mine.

It was noted in microscopic crystals from the $\mathrm{OK}$ mine and is present in the intrusive rock near the limestone contact in a prospect north of Hickory in the Rocky Range.

Muscovite.-The potassium mica muscovite, a hydrous potassium-aluminum silicate, $\mathrm{H}_{2} \mathrm{KAl}_{3}\left(\mathrm{SiO}_{4}\right)_{3}$, is present in variable amounts in the contact zones of the district. It is a lightgreen variety and occurs in crystals varying from microscopic size up to 2 inches in diameter. The larger crystals were noted in greatest abundance near the quartz monzonite contact at White Mountain, west of Grampian Hill, and in the vicinity of the Cupric mine. It is present in considerable amounts in the contact zone in the northern part of the Beaver Lake district and in the Rocky district north of Hickory. The fine scaly or fibrous variety sericite is always present in the hydrothermally altered rock of the district. It occurs in the altered quartz monzonite associated with the copper deposits and is also a principal constituent of the altered lavas, both where they are associated with the ore deposits and in the larger areas that are apparently not connected with important mineralization. It is present to some extent in the replacement fissures in limestone, being noted especially at the Moseow mine, where it is associated with fluorite (Pl. XII, $B$, p. 97). 
Biotite.-The dark mica biotite, a silicate of potassium, magnesium, iron, and aluminum, $\mathrm{Al}_{2} \mathrm{Mgg}_{2} \mathrm{KFeHSi} \mathrm{O}_{12}$, is an original constituent of most of the igneous rocks of the district. It is possibly a secondary mineral in the altered rock associated with the ores of the Carbonate mine. The primary biotite in the rock associated with this deposit has undergone slight alteration and some of the biotite appears to have been a product of the secondary alteration.

A mica that appears to be intermediate between biotite and phlogopite is present in considerable amount in a prospect pit northeast of Hickory. It is associated with magnetite in the zone of contact alteration.

Chlorite.-Under the term chlorite, which is applied to a group of hydrous magnesiumaluminum silicates of variable composition, are included here what would probably prove to be several different members of the chlorite group if material suitable to their accurate determination were available. Chlorite is a common product of the alteration of the ferromagnesian minerals of the igneous rocks. It is present in variable but small amounts in the contact alteration zone. It occurs in considerable quantity in the altered rock associated with the ores of the Carbonate mine and is also abundant in the ores from the Hub mine and is present in lesser amounts in other ores.

Serpentine.-The hydrous magnesium silicate, serpentine, $\mathrm{H}_{4} \mathrm{Mg}_{3} \mathrm{Si}_{2} \mathrm{O}_{9}$, is present in many parts of the region where it has resulted from the alteration of magnesian minerals. A particularly interesting occurrence is in the contact zone of Grampian Hill. Some of the rock that on superficial examination appears to be nearly pure white crystalline limestone is seen on microscopic examination to contain a large percentage of a white fibrous mineral with the optical properties of serpentine. This mineral appears to have resulted from the alteration of some magnesium silicate; the increase in bulk of the mineral due to hydration has split the calcite grains inclosing the original crystals and the serpentine has been forced into these fractures (Pl. XII, A, p. 97).

Kaolinite.-The hydrous aluminum silicate, kaolinite (kaolin), $\mathrm{H}_{4} \mathrm{Al}_{2} \mathrm{Si}_{2} \mathrm{O}_{9}$, is common throughout the region, resulting from the alteration of aluminous minerals by surface solutions. It is also abundant in the altered rock associated with the ores of the Carbonate mine, where it has apparently resulted from the action of the solutions that produced the ore deposits.

Thaumasite.-The rare and unusual mineral thaumasite, a hydrous silicate, sulphate, and carbonate of calcium, $3 \mathrm{CaO} \cdot \mathrm{SiO}_{2} \cdot \mathrm{SO}_{3} \cdot \mathrm{CO}_{2} \cdot 15 \mathrm{H}_{2} \mathrm{O}$, has been reported from but few localities in the world. It was first described in 1878 by Baron von Nordenskiöld from material collected at the copper mines of Areskuta, Jemtland, Sweden. Since then it has been noted at other localities in Sweden, and in 1896 it was described by S. L. Penfield and J. H. Pratt, from material obtained at Berger's quarry, West Paterson, N. J., and it also occurs in other localities in that State. The New Jersey localities are the only ones where it had been noted outside of Sweden previous to its discovery in Beaver County, Utah. ${ }^{1}$ In this district it was collected from but one locality, the Old Hickory mine, where it is present in considerable amount on the first level. On this level the magnetite body has been opened for about 125 feet along the strike. To the east, 10 to 25 feet from the magnetite body, a parallel drift has been run in the altered limestone. A hundred feet south of the shaft a crosscut from this drift extends to the east for about 25 feet, to a point where it encounters quartzite. Throughout this eastern drift and crosscut are a great number of veins of white material varying in thickness from that of paper to more than 2 inches. To the north of the crosscut many of the veins are open with crystals projecting into the opening and others are composed of a dense white substance completely filling the space. The material from these veins proved on examination to be a mixture of quartz and carbonate, the latter probably in large part calcite. In the east crosscut just east of the drift and extending across the drift to a crosscut on the opposite side is a zone of veins having a general northeast-southwest direction, though the individual veins vary in direction and are connected by cross veins, making a network. These veins are composed of thaumasite completely filling the fissures.

1 Butler, B. S., and Schaller, .... T., Thaumasite from Beaver County, Utah: Am. Jour. Sci, 4th set., vol. 31, 1911, pp. 131-134. 
The fissuring occurred later than the contact metamorphism of the limestone, and the filling of the fissures with thaumasite of course occurred at a still later period. The thaumasite was not found associated with the quartz and carbonates in the same veins, and the relative age of the minerals was not determined. At West Paterson, N. J., the thaumasite is in trap associated with heulandite, apophyllite, laumontite, pectolite, chabazite, scolecite, and natrolite, the thaumasite crystallizing later than the zeolites. No zeolites were found associated with the thaumasite at the Old Hickory mine, though they were especially looked for. It seems probable, however, that the mineral was formed under physical conditions similar to those favorable to the formation of zeolites.

In the hand specimen the thaumasite from Beaver County is a nearly pure white mineral with silky luster, due to its fibrous character. It is readily recognized in the field as an unusual mineral by its silky luster and its lightness, the specific gravity being 1.84. Under the microscope it is seen to be composed of minute slender prisms, none of which showed terminal faces. Microscopically thaumasite is most readily distinguished by its low index of refraction and rather high double refraction- $\omega=1.507, \varepsilon=1.468$, as determined by Lévy and Lacroix. The indexes of refraction for the Beaver County mineral were approximately determined by immersion in solutions of known index, as $\omega=1.500+, \varepsilon=1.464+$. The mineral extinguishes parallel to the elongation of the prisms and is probably hexagonal, as it has been found to be in the occurrences previously described. Crystals suitable for measurement and exact determination of the refractive indexes were not found.

Material was submitted to W. T. Schaller for chemical investigation, the result of which is given below.

A determination of the density of the thaumasite by means of the Joly balance gave the value 1.84. A second determination with the Thoulet solution and small fragments of the mineral gave the value 1.85. These figures are slightly lower than those found by Penfield (1.88) on the New Jersey thaumasite. The analysis of the Utah thaumasite and the ratios deduced therefrom are shown below

Analysis and ratios of thaumasite from Bearer County, Utah.

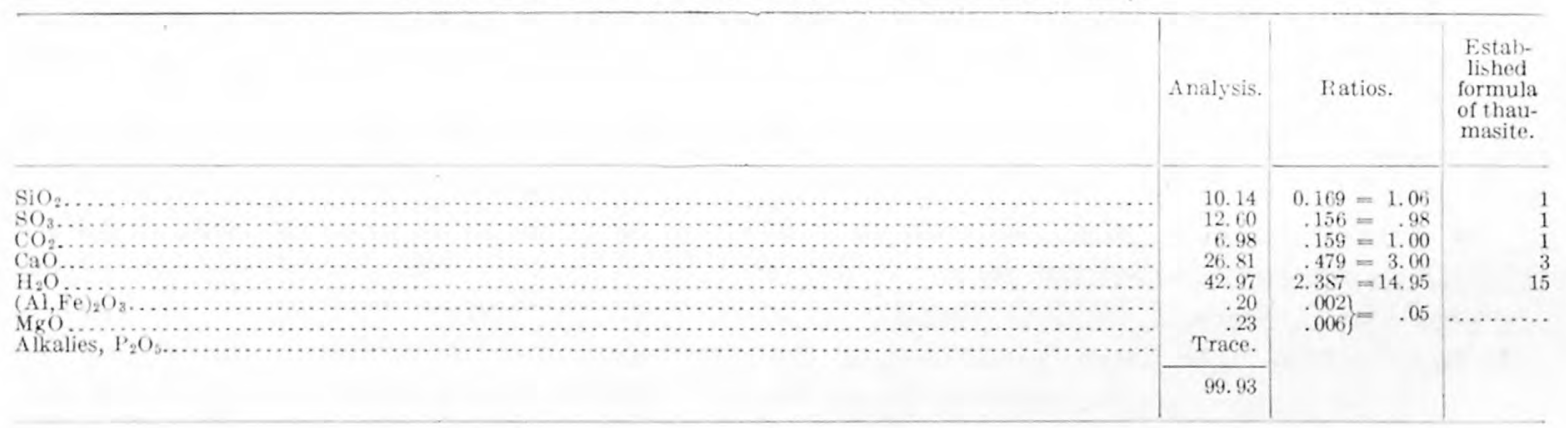

The ratios agree very closely with the established formula $3 \mathrm{CaO} \cdot \mathrm{SiO}_{2} \cdot \mathrm{SO}_{3} \cdot \mathrm{CO}_{2} \cdot 15 \mathrm{H}_{2} \mathrm{O}$, and the mineral is very pure, only a trace of some foreign matter, probably a silicate, being present.

A comparison of the analyses of the mineral from Utah, from New Jersey, and from Sweden (the average of the three original analyses given by Lindström) strikingly shows the uniform composition of this rare mineral.

Comparison of analyses of thaumasite.

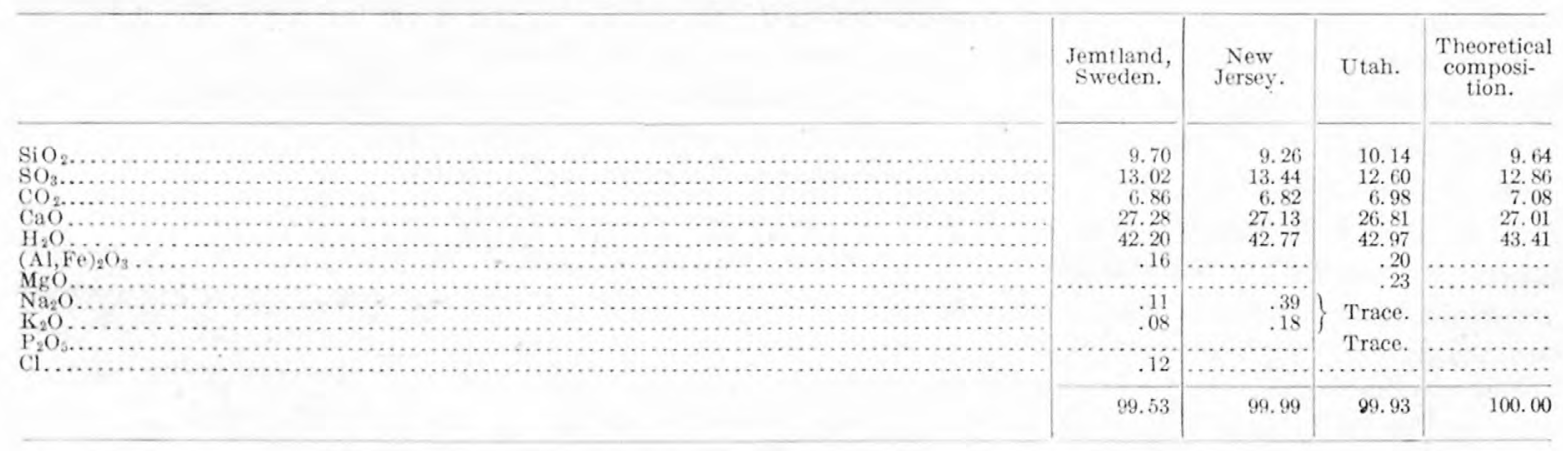

The new locality in Utah makes the third general locality in which this mineral has been found. 
A bibliography of thaumasite is given below.

Вӓскsтröm, H., Geol. För. Förh., vol. 19, 1897, p. 307.

Bertrand, E., Bull. Soc. min., vol. 3, 1880, p. 159; vol. 4, 1881, p. 8; vol. 19, 1896, p. 88; Geol. För. Förh., vol. 9, 1887, p. 131

Butler, B. S., and Schaller, W. T., Am. Jour. Sci., 4th ser., vol. 31, 1911, p. 131

Cohen, E., Jahrb. Mineral., vol. 2, 1881, p. 22.

Lacroix, A., Geol. För. Förh., vol. 9, 1887, p. 35.

Lévy, A. M., and Lacroix, A., Minéralogie des roches, 1888, p. 286.

Lindström, G., Oefv. Akad. Stockholm, vol. 35, No. 9, 1878, p. 43.

Nordenskiöld, A. E., Compt. Rend., vol. 87, 1878, p. 313; Geol. För. Förh., vol. 5, 1880, p. 270; vol. 8, 1886, p. 146.

Penfield, S. L., and Pratt, J. H., Am. Jour. Sci., 4th ser., vol. 1, 1896, p. 229.

Pisani, F., Bull. Soc. min., vol. 19, 1896, p. 85.

Schaller, W. T., Bull. U. S. Geol. Survey No. 509, 1912, p. 110.

Widman, O., Geol. För. Förh., vol. 12, 1890, p. 20.

Zambonini, F., Mem. Accad. sci. Napoli, vol. 14, 1908, p. 11.

Chrysocolla.-The hydrous silicate of copper, chrysocolla, $\mathrm{CuSiO}_{3} \cdot 2 \mathrm{H}_{2} \mathrm{O}$, occurs as a secondary copper mineral in the Horn Silver, O K, and Skylark mines and is doubtless present at other localities. So far as observed it is nowhere in the region an important ore of copper.

Titanite.-The calcium-titanium silicate, titanite (sphene), $\mathrm{CaTiSiO}_{5}$, is an original constituent of the quartz monzonites and to a less degree of the other igneous rocks of the region. In the quartz monzonite of the Cactus area it is relatively abundant and can be readily detected with the hand lens as small yellowish grains having a greasy luster. In the altered rock associated with the ores the titanite has been largely altered to rutile. Titanite occurs also in the altered limestone of the Harrington-Hickory mine, associated with the ores.

\section{Phosphates, ARSENATES, VANADATES, AND ANTIMONITES.}

Apatite.-Fluor-calcium phosphate, apatite, $(\mathrm{CaF}) \mathrm{Ca}_{4}\left(\mathrm{PO}_{4}\right)_{3}$, is present in small amount in practically all the igneous rocks of the region. It is rather abundant in the contact ores of the Old Hickory mine and the altered rock associated with the ores of the Harrington-Hickory mine and is found to a less extent in some other ore deposits.

Vanadinite.-Specimens of oxidized ore from the Harrington-Hickory mine contain yellow velvety incrustations that under the microscope are seen to be hexagonal prisms with pyramidal terminations. The crystals are golden yellow as seen by transmitted light. They could not be readily separated from the accompanying minerals, but tests of such as could be separated showed the presence of vanadium, and the mineral is doubtless vanadinite, lead vanadate, $(\mathrm{PbCl}) \mathrm{Pb}_{4}\left(\mathrm{VO}_{4}\right)_{3}$.

Scorodite.-An olive-green mineral occurs as incrustations in cavities in specimens from the Wild Bill mine. This material was submitted to W. T. Schaller for examination and found to be an iron arsenate, probably scorodite, $\mathrm{FeAsO}_{4} \cdot 2 \mathrm{H}_{2} \mathrm{O}$. Scorodite is reported in Dana's "System of mineralogy" as occurring in the Horn Silver mine of Utah. ${ }^{1}$

Bindheimite.-A dirty-white oxidation product is associated with some of the primary leadantimony mineral of the Horn Silver mine. This contains both lead and antimony and is doubtless bindheimite or some closely allied mineral.

Corkite.-A light yellowish-green mineral that has the properties of corkite, a hydrous phosphate and sulphate of lead and iron, was collected from the Harrington-Hickory and Wild Bill mines. So far as is known to the writer, this is the only locality on this continent from which this mineral has been reported.

In both the mines mentioned the original ores were a replacement of limestone near the intrusive rock and considerable quantities of apatite and contact silicates were formed with the metallic sulphides, mainly pyrite, galena, sphalerite, and chalcopyrite. The corkite is a secondary mineral resulting from the alteration of these ores, the phosphate doubtless being derived from the apatite and the metallic content from the sulphides.

In physical properties the mineral corresponds with that previously described. In the hand specimen it is a light-green earthy-looking material which when crushed in the fingers has a gritty feel, like fine sand. Under the microscope it is seen to be well crystallized, the larger crystals being 0.15 millimeter in diameter. The crystals are golden yellow in color and 
have the general appearance of being a combination of the cube and octahedron. They are rather strongly birefringent, however, and are probably hexagonal rhombohedral. Tho index of refraction is higher than 1.74 .

Material was submitted to the chemical laboratory of the Survey, and on this W. T. Schaller made the following report:

Corkite is readily soluble in boiling hydrochloric acid and from the solution lead chlorite separates out in quantity on cooling. The solution contains, besides lead, abundant ferric iron and the sulphate and phosphate radicles. Qualitative tests failed to show the presence of any arsenic in the American corkite, and only a mere trace of copper is present. Heated in a closed tube the mineral darkens and gives off water.

\section{SULPHATES.}

Barite.-Barium sulphate, $\mathrm{BaSO}_{4}$, is an important gangue mineral in some of the silver ores of the Horn Silver mine and is present in varying amounts in practically all the ores from this mine. It occurs in relatively small amounts in the Cactus mine, but is reported to have been rather abundant in the shoots of rich chalcopyrite ore. Specimens of ore from the Golden Reef mine examined microscopically contain considerable barite, but it was not seen in large crystals or masses from that mine. It is probably present in small amounts in other parts of the region.

Anglesite.-The sulphate of lead, anglesite, $\mathrm{PbSO}_{4}$, was the most important lead mineral of the oxidized ores of the Horn Silver mine. As shown by the analyses in Hooker's report (p. 147), it formed about 75 per cent of the ore in the upper levels of the mine. As a rule it occurs as a soft earthy material, but in some places, especially where it surrounds unaltered galena, it is rather hard and massive. Anglesite was noted in the ores of the Harrington-Hickory mine in well-formed crystals and is doubtless present in small amount in all the oxidized lead ores of the region, though the carbonate is the principal secondary lead mineral in the deposits in limestone.

Anhydrite.-Calcium sulphate, anhydrite, $\mathrm{CaSO}_{4}$, occurs in considerable abundance in the ores of the Cactus mine, where it was one of the latest minerals to be formed. In the upper levels and in part throughout the mine it has been altered to gypsum (Pls. XIII, XIV, $A$ ) and probably a considerable part of the gypsum in the mine has resulted from this alteration. The mineral very readily hydrates to gypsum, as is well shown by material on the dump which, though exposed to the weather but a few years, has been largely altered to a white fine-grained gypsum. This occurrence of anhydrite as a gangue mineral of ore deposits was the first reported in this country. ${ }^{1}$ It has since been reported from the Bully Hill district, Shasta County, Cal. ${ }^{2}$

The occurrence and relation of the anhydrite to the other minerals are more fully discussed in the section on ore deposits (pp. 120-121).

Brochantite.-The basic copper sulphate, brochantite, $\mathrm{Cu}_{4}(\mathrm{OH})_{6} \mathrm{SO}_{4}$, was found in the specimens of oxidized ore from the Horn Silver mine. There was no opportunity to study ore of this class in the mine, but so far as can be judged from the study of specimens taken from the dump brochantite was fully as abundant in it as malachite. The mineral commonly occurs in short prisms of a rather deep emerald-green color, the more perfect crystals forming in open spaces, but the more massive material does not show crystal outline. Brochantite is associated with malachite, chrysocolla, beaverite, and other secondary load-copper minerals. It is not generally recognized as an important copper mineral, though Lindgren ${ }^{3}$ has called attention to its relative abundance in the Morenci district of Arizona and suggested that a more careful study of the supposed malachite would show much of it to be the sulphate rather than the carbonate.

Linarite.-A beautiful azure-blue mineral occurs as an incrustation on cavities in a specimen of oxidized ore collected from the dump of the Horn Silver mine. The mineral is a sulphate of copper and lead and doubtless is linarite (basic lead-copper sulphate, $\mathrm{PbCu}\left(\mathrm{OH}_{2}\right) \mathrm{SO}_{4}$ ) or some closely allied species. It is not known how abundant the mineral was in the ores.

Beaverite. - The hydrous sulphate of copper, lead, and iron, beaverite, CuO. $\mathrm{PbO} \cdot \mathrm{Fe}_{2} \mathrm{O}_{3}$. $2 \mathrm{SO}_{3} \cdot 4 \mathrm{H}_{2} \mathrm{O}$, was first described ${ }^{4}$ from material obtained at the Horn Silver mine. It is rather

1 Lindgren, Waldemar, Anhydrite as a gangue mineral: Econ. Geology, vol. 5, 1910, p. 522.

2 Graton, L. C., The occurrence of copper in Shasta County, Cal.: Bull. U. S. Geol. Survey No. 430, 1910, p. 100.

${ }^{3}$ Lindgren, Waldemar, Ore deposits of the Clifton-Morenci district, Arizona: Prof. Paper U. S. Geol. Survey No. 43, 1905, p. 119

4 Butler, B. S., and Schaller, W. T., Some minerals from Beaver County, Utah: Am. Jour. Sci., 4th ser., vol. 32, 1911 , p. 418. 

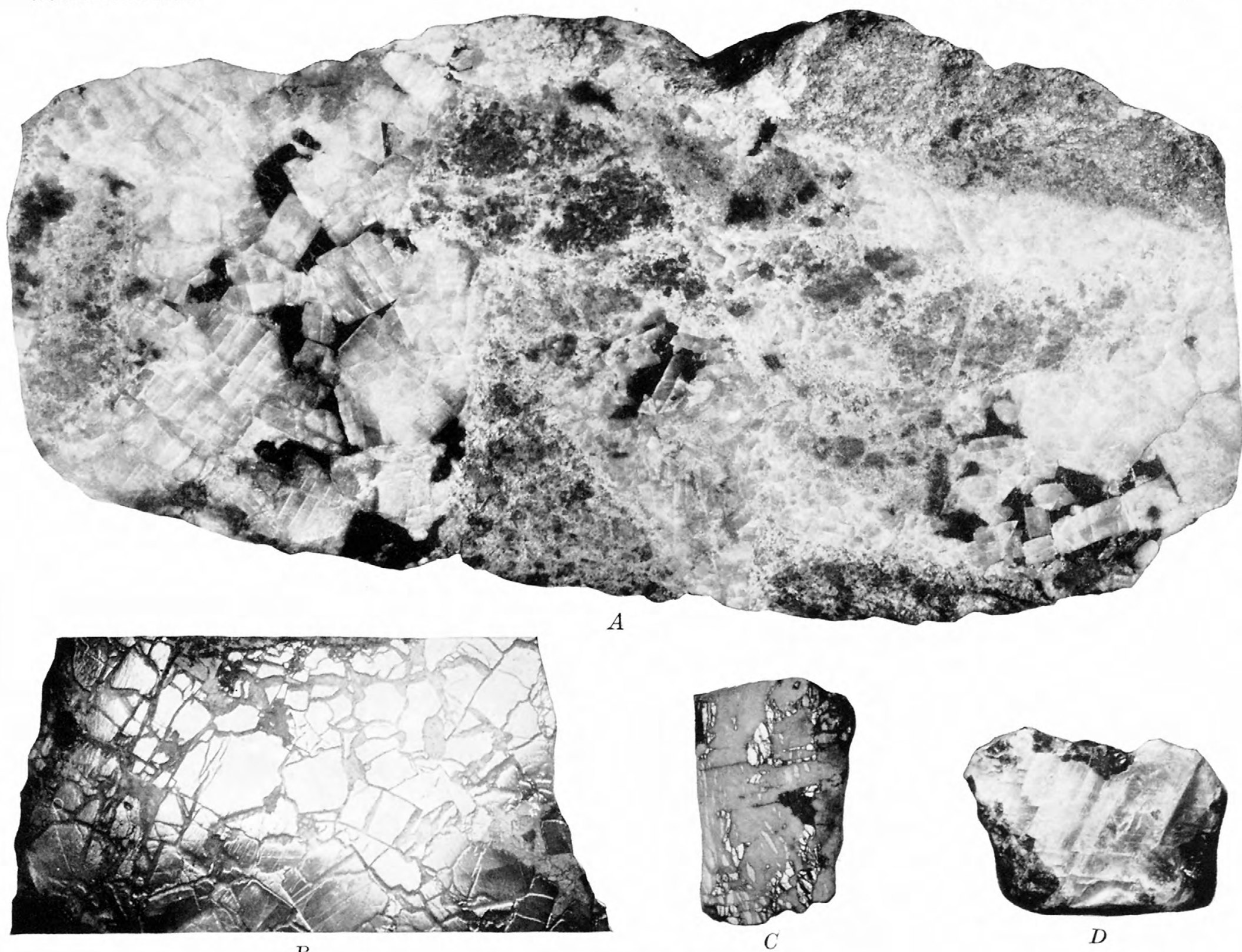

ANHYDRITE AND GYPSUM, CACTUS MINE.

4. Hand specimen natural size. white crystalline material anhydrite, dark areas sulohides, gray mottled areas altered quartz monzonite. $B$ and $C$ Anhydrite altering to gypsum; $(B)$ dark.gray areas along cleavage, gypsum; $(C)$ ground 


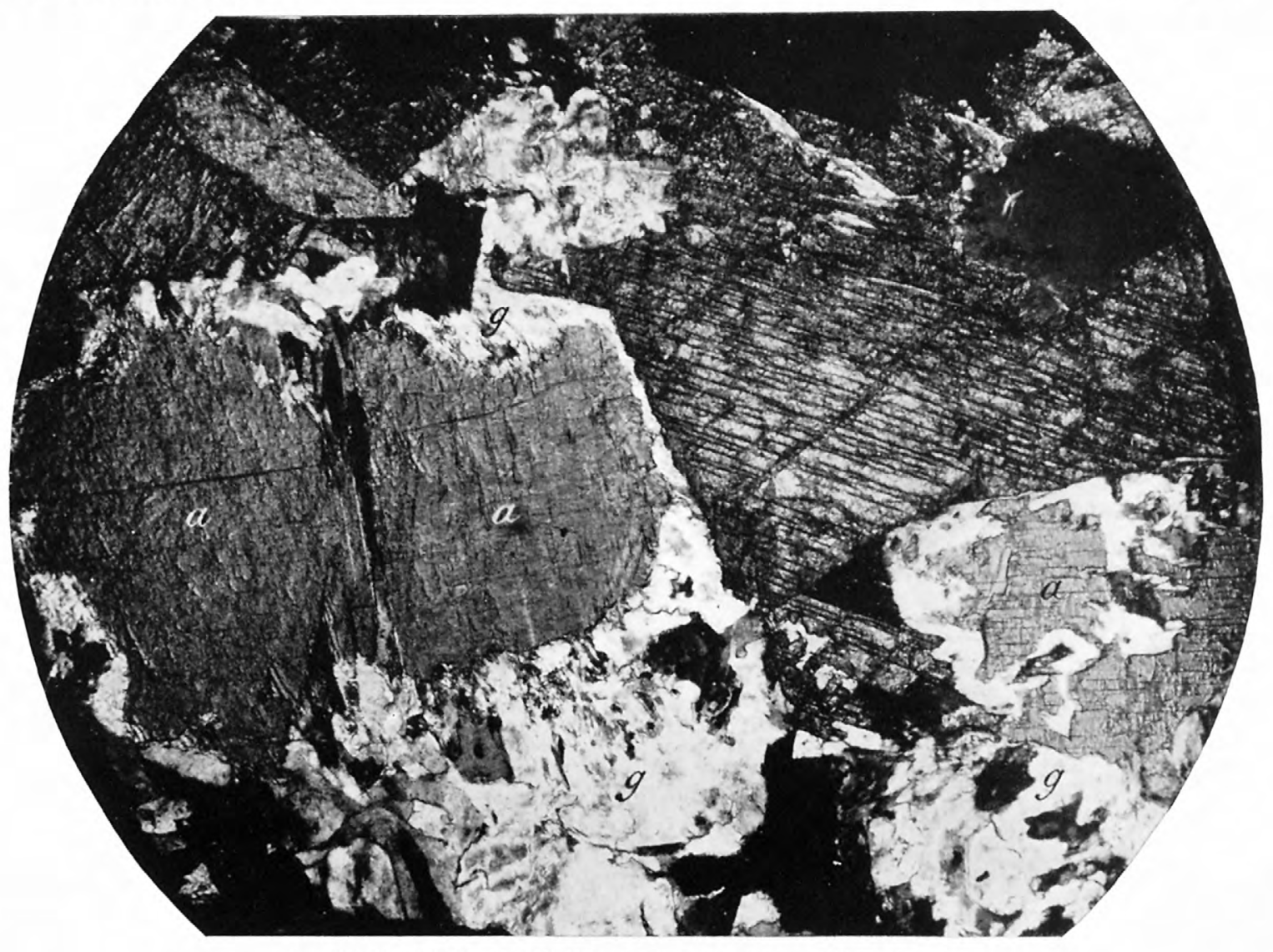

A. ANHYDRITE ALTERING TO GYPSUM, CACTUS MINE.

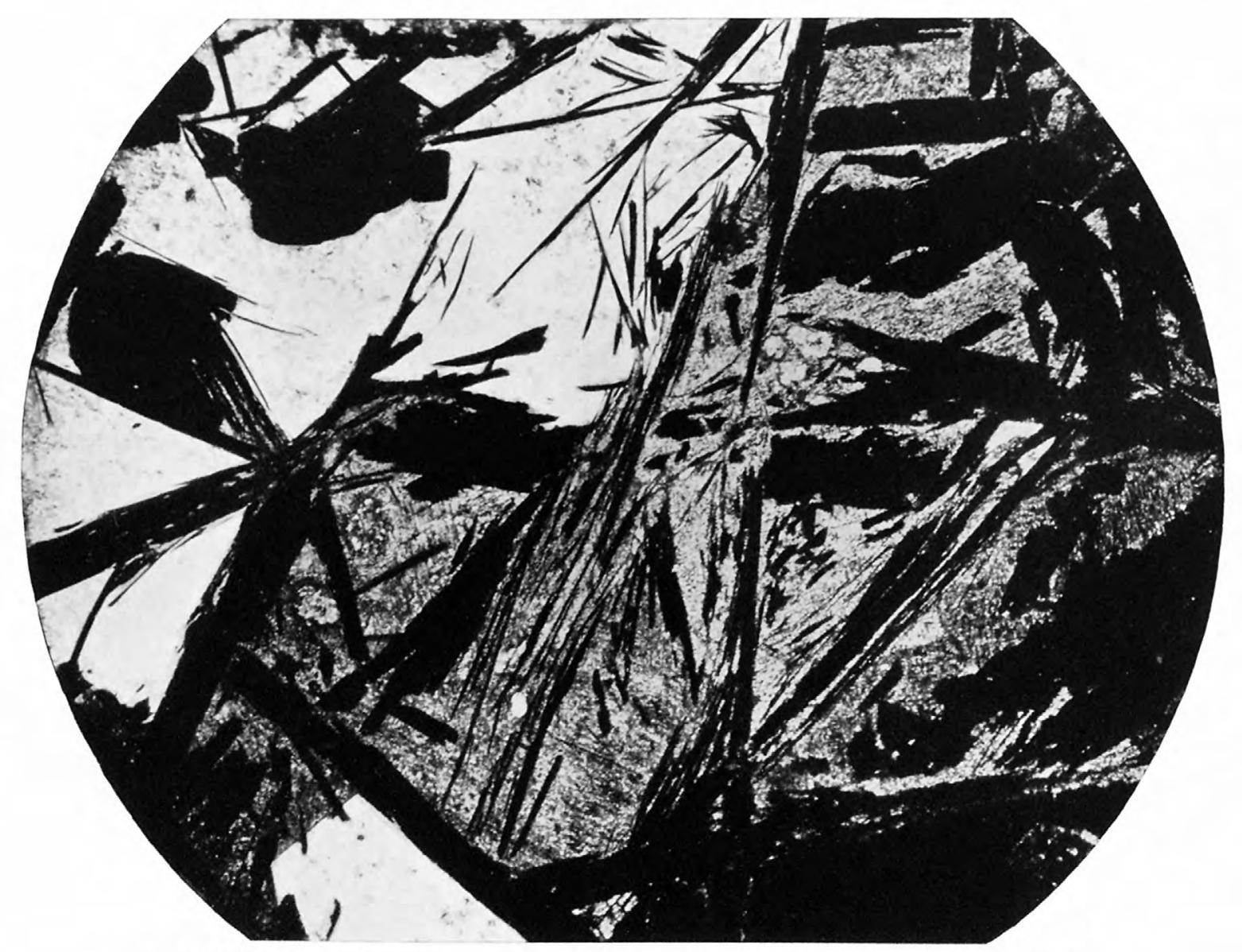

B. HEMATITE INCLOSED IN QUARTZ, SIDERITE, AND PYRITE, CACTUS MINE.

Light areas quartz, gray areas siderite, irregular black areas pyrite, lath-shaped bodies hematite. Enlarged 30 diameters. 
abundant in the secondary minerals on the old dumps and must have been of considerable importance in the oxidized ores of the mine.

The mineral is a canary-yellow earthy-looking material commonly mixed with other secondary lead and copper minerals but found here and there in small masses that appear to be composed of a single mineral. Such masses are easily crushed in the fingers. Under the high power of the microscope the material is seen to be crystallized in distinct hexagonal plates. These are too small for accurate measurement of the crystal angles or determination of the optical character. The refractive index of the light ray vibrating perpendicular to the plates is approximately 1.80 .

Almost every crystal contains a minute inclusion whose character has not been determined. The material analyzed appeared under the microscope to be very pure except for these inclusions, and it is possible that the silica that appears in the analysis is due to them. The mineral was submitted to the chemical laboratory of the Survey for investigation and W. T. Schaller reports as follows:

The mineral is soluble in boiling hydrochloric acid, leaving the insoluble matter, chiefly silica, behind. On cooling, lead chloride separates out in considerable amount. The lead reaction can also readily be obtained with sodium carbonate on charcoal. On adding ammonia in excess to the hydrochloric acid solution, the ferric iron is thrown down as a voluminous brown precipitate, and the solution has the deep-blue color indicative of copper. By the quantitative determination the presence of a small amount of alumina was established. The insoluble matter consists mostly of silica, only a slight residue remaining after treatment with hydrofluoric acid.

The average of the results of the chemical analyses is shown in the table below. The ratios obtained therefrom are also given.

Analysis and ratios of beaverite.

\begin{tabular}{|c|c|c|c|}
\hline & Analysis. & Ratios. & Formula. \\
\hline $\begin{array}{l}\text { Insoluble } \\
\mathrm{CuO} \ldots \ldots \\
\mathrm{PbO} \ldots \ldots \\
\mathrm{Fe}_{2} \mathrm{O}_{3} \ldots \\
\mathrm{Al}_{3} \mathrm{O}_{3} \ldots \\
\mathrm{SO}_{3} \ldots \ldots \\
\mathrm{H}_{2} \mathrm{O} \ldots \ldots\end{array}$ & $\begin{array}{r}10.05 \\
9.70 \\
29.44 \\
17.28 \\
3.64 \\
21.32 \\
9.02\end{array}$ & 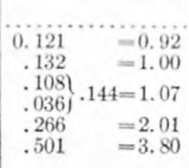 & $\begin{array}{l}1 \\
1 \\
1 \\
2 \\
4\end{array}$ \\
\hline & 100.45 & & \\
\hline
\end{tabular}

The ratios agree well with the formula $\mathrm{CuO}$. $\mathrm{PbO} \cdot \mathrm{Fe}_{2} \mathrm{O}_{3} \cdot 2 \mathrm{SO}_{3} \cdot 4 \mathrm{H}_{2} \mathrm{O}$, in which the copper and lead are assumed to be present in equal molecular amounts and in which a little ferric iron is replaced by alumina. As the ratio of $\mathrm{Fe}_{2} \mathrm{O}_{3}$ to $\mathrm{Al}_{2} \mathrm{O}_{3}$ is as $3: 1$, the formula can be written more exactly as $4 \mathrm{CuO} .4 \mathrm{PbO} \cdot 3 \mathrm{Fe}_{2} \mathrm{O}_{3} \cdot \mathrm{Al}_{2} \mathrm{O}_{3} \cdot 8 \mathrm{SO}_{3} \cdot 16 \mathrm{H}_{2} \mathrm{O}$. A comparison of the analysis reduced to 100 per cent after deducting the insoluble matter, with the values calculated for the formula last given, is shown below.

Comparison of analysis of beaverite with calculated values.

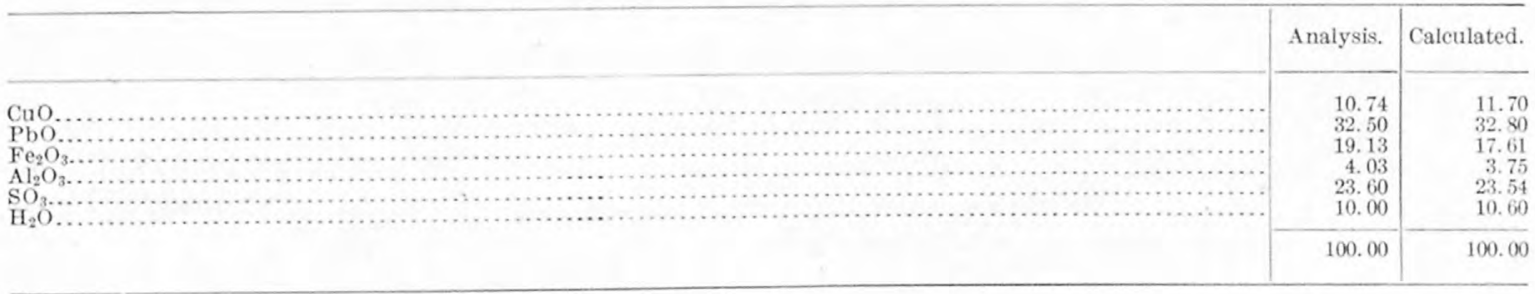

The water is all constitutional, as none was driven off below $250^{\circ}$. The actual results obtained are as follows:

Loss of weight of beaverite on heating.

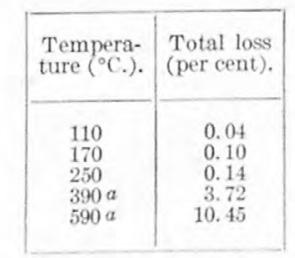

$a$ Heated in an electric furnace. 
The loss at $590^{\circ}$, as given, is higher than the true value, as a little of the material was lost by adhering to the thermal couple, which accidentally dropped into the crucible.

No known mineral could be found with which beaverite seems related, so that at present it must stand as an isolated member of the sulphate group.

Gypsum.-Gypsum, the hydrous sulphate of calcium, $\mathrm{CaSO}_{4} \cdot 2 \mathrm{H}_{2} \mathrm{O}$, is of widespread occurrence in the region. It is present in considerable amount as a gangue mineral in the Cactus mine, where it has probably in large part resulted from the alteration of anhydrite. It is also present as small veins outside of the ore zone. It is rather plentiful in parts of the Horn Silver mine and in the wall rock adjacent to the deposit and also occurs in the altered volcanic rocks elsewhere in the region, being noted especially at the Frisco Contact mine. Gypsum occurs in fissures in the limestone in many places, where it has apparently resulted from the action of sulphuric acid produced by the oxidation of sulphides on limestone. The mineral is now being deposited from spring waters south of the Frisco Contact mine, and the spring deposits contain also calcite, epsomite, and probably other hydrous sulphates.

Epsomite.-The hydrous magnesium sulphate, epsomite, $\mathrm{MgSO}_{4} \cdot 7 \mathrm{H}_{2} \mathrm{O}$, occurs as a white efflorescence on the walls of a short tunnel that has been excavated in the spring deposits south of the Frisco Contact mine. It is evidently present in considerable quantity in these deposits, which consist principally of gypsum and calcite.

Goslarite.--The hydrous zinc sulphate, goslarite, $\mathrm{ZnSO}_{4} \cdot 7 \mathrm{H}_{2} \mathrm{O}$, is present as a white efflorescence on the walls of old workings nearly everywhere in the lower levels of the Horn Silver mine and was found in considerable abundance on the eleventh level, the lowest one examined. On the walls of some of the openings in zinc ore it is very abundant, hanging in beautiful festoons several inches in length. The zinc sulphate has resulted from the oxidation of zinc sulphide and, being very soluble, is carried in solution till it emerges into openings, where the water evaporates and the mineral is deposited. It is doubtless present in other parts of the region where zinc ores are in process of oxidation.

Chalcanthite.-The hydrous copper sulphate, chalcanthite, $\mathrm{CuSO}_{4} .5 \mathrm{H}_{2} \mathrm{O}$, occurs as an efflorescence on the walls of old workings in the Horn Silver and O K mines. At some points these workings present a velvety-blue appearance from the presence of the mineral. It occurs on all the lower levels of the Horn Silver mine, being abundant on the eleventh level, the lowest examined. In the O K mine it occurs on the 400-foot level, which is the lowest that has been opened. The mineral has formed from the alteration of copper sulphides and is carried in solution till the waters emerge into openings and are partly evaporated, when the copper sulphate is precipitated.

Alunite.-The hydrous potassium-aluminum sulphate, alunite, $\mathrm{KAl}_{3} \mathrm{~S}_{2} \mathrm{O}_{11} \cdot 3 \mathrm{H}_{2} \mathrm{O}$, is present as a rather persistent band along the footwall of the ore body on the upper levels of the Horn Silver mine. In the deeper levels this gives place to an amorphous material composed largely of silica. The alunite is a white earthy material of so fine texture that even when it is ground between the teeth almost no grit can be detected. Under the high power of the microscope it shows no crystalline character. It has probably resulted from the action of sulphuric acid derived from the oxidation of sulphides on potassium-aluminum silicates. It has evidently been transported for some distance from the position of the silicates from which it was formed and for some reason not readily apparent has been deposited on the footwall against the limestone.

Jarosite. - The hydrous potassium-iron sulphate, jarosite, $\mathrm{KFe}_{3} \mathrm{~S}_{2} \mathrm{O}_{11} \cdot 3 \mathrm{H}_{2} \mathrm{O}$, was noted in several of the mines of the district. It is one of the minerals resulting from the oxidation of the sulphide ores. Some of the most beautiful specimens of it were collected in the Wild Bill mine. Jarosite is a golden-yellow micaceous material which crushes readily in the fingers and sticks to the skin like fine flakes of graphite. Under the microscope it is seen to be composed of small hexagonal plates of a golden-yellow color. The crystals are uniaxial and optically negative, with strong birefringence. In general physical properties the mineral closely resembles the closely allied plumbojarosite described below. At other mines the jarosite is of a dark-brown color but otherwise resembles that described.

Jarosite has not been frequently described as a mineral in ore deposits, but it was noted in several of the oxidized deposits in this region and has since been seen by the writer in other 


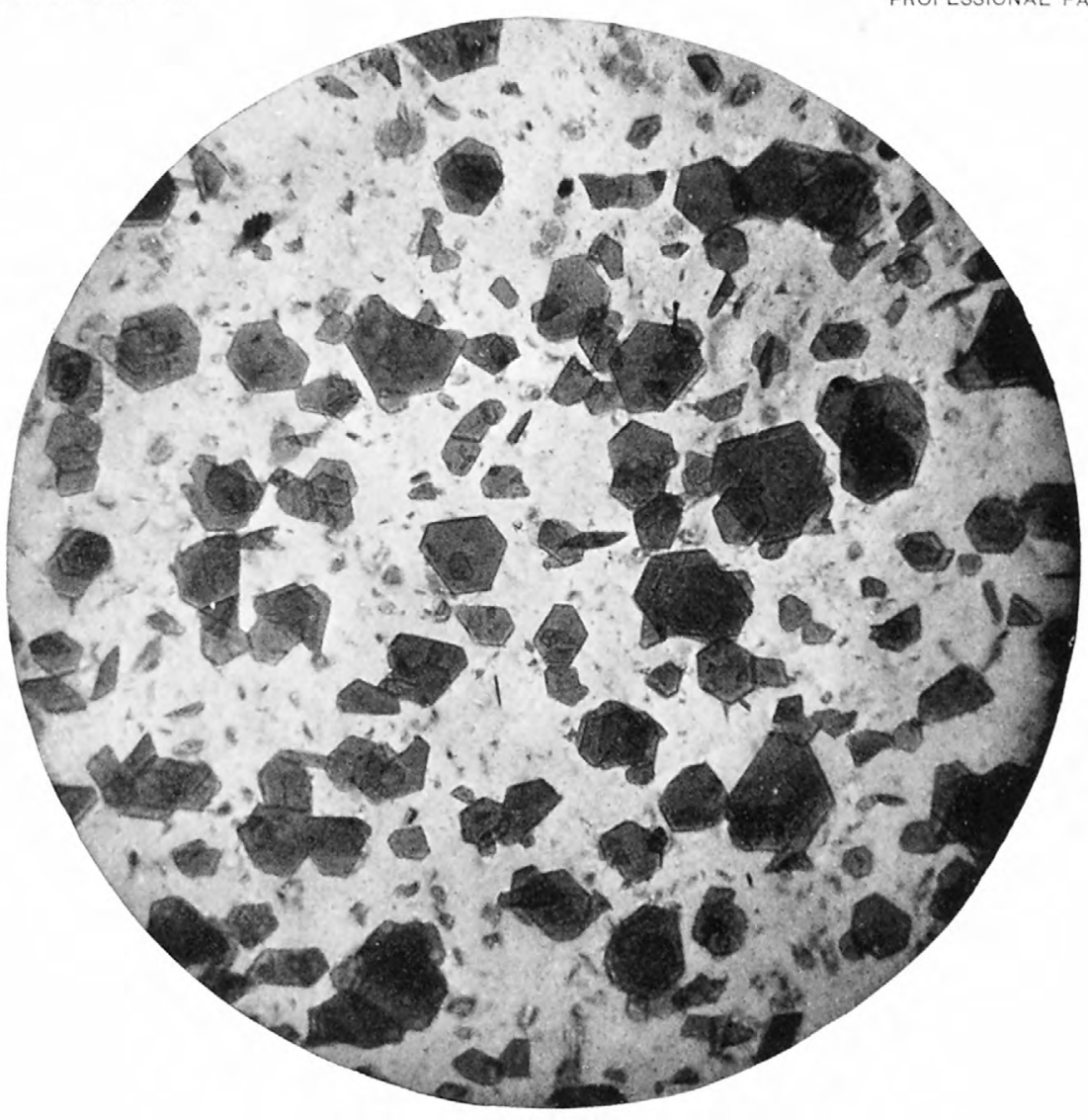

1. Plumbojarosite, moscow mine.

Enlarged 45 diameters.

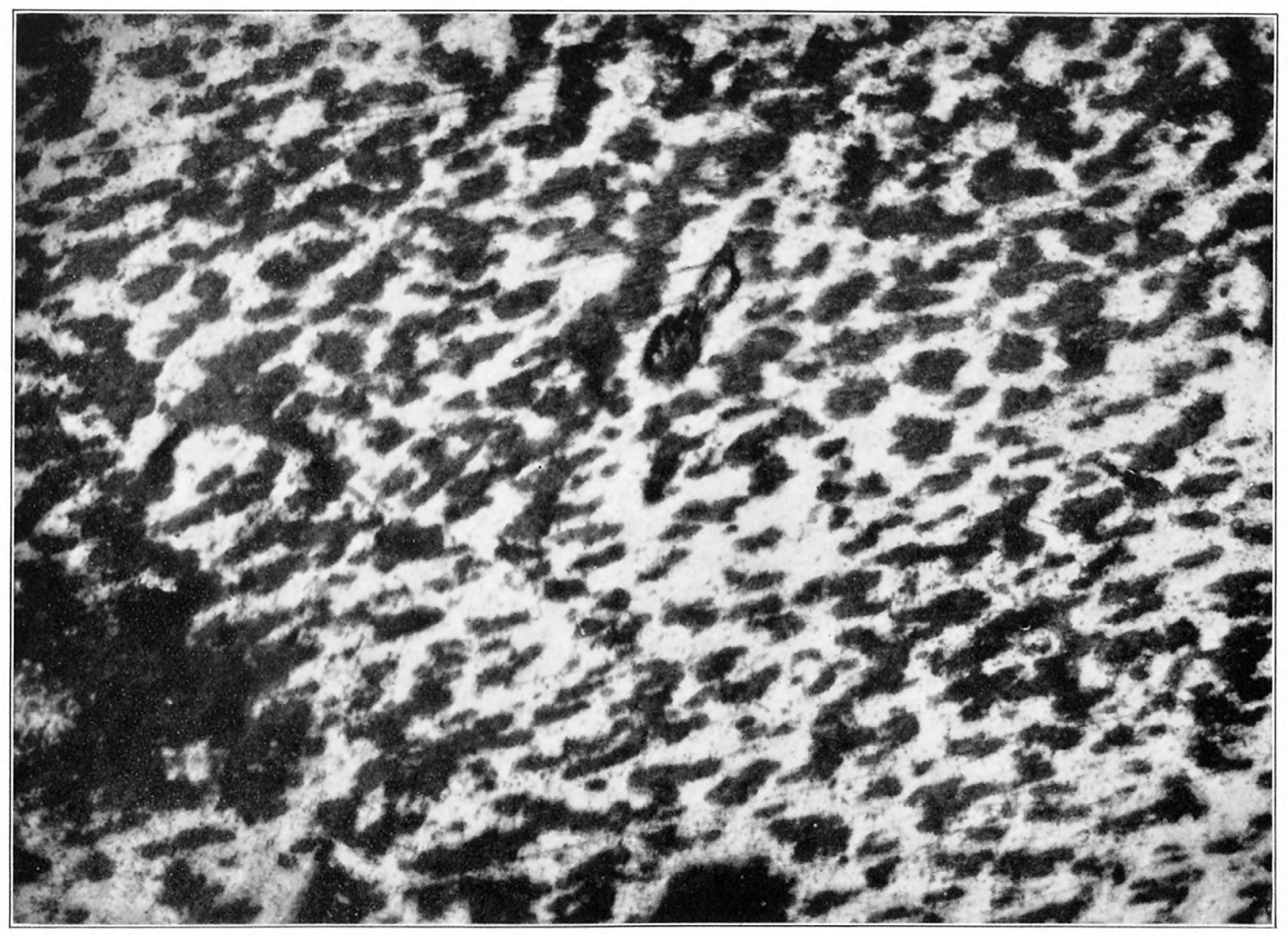

B. ANTIMONIAL LEAD ORE, HORN SILVER MINE. 

districts in Utah. There seems little doubt that it is commonly formed in the oxidation of sulphides under the conditions prevailing in this region.

Plumbojarosite.-Previous to the description of plumbojarosite, the hydrous lead-iron sulphate, $\mathrm{PbO} .3 \mathrm{Fe}_{2} \mathrm{O}_{3} .4 \mathrm{SO}_{3} .6 \mathrm{H}_{2} \mathrm{O}$, from this region ${ }^{1}$ only two occurrences of the mineral had been described-at Cooks Peak, N. Mex., ${ }^{2}$ and at American Fork, Utah ${ }^{3}$-although this mineral was probably analyzed years before by Dr. Hillebrand from material collected from the oxidized ores of Leadville, Colo., the analyses showing the following composition: $\mathrm{Fe}_{2} \mathrm{O}_{3} 44.40, \mathrm{PbO}$ 19.50, $\mathrm{SO}_{3} 25.07, \mathrm{H}_{2} \mathrm{O} 8.99 .{ }^{4}$

As this mineral has been so rarely noted, it was a matter of some surprise to find it in no less than five mines and one prospect in the San Francisco region, in some of them in such abundance that a considerable quantity could be picked from the ore bins and dumps. The writer was told by one superintendent that several tons of the mineral had been thrown on the dump and later on, being found to contain metal values, had been shipped to the smelter.

Plumbojarosite has been determined from the Horn Silver, Hub, Moscow, Red Warrior, and Harrington-Hickory mines, and an unnamed prospect pit, and probably is present in still others. The mineral is secondary, resulting from the alteration of ore composed mainly of sulphides of iron, lead, copper, and zinc. The secondary minerals for the most part are the oxides, sulphates, carbonates, and silicates of these metals, and with these are plumbojarosite, jarosite, and other minerals in varying amounts. It is of interest to note that the Horn Silver mine was found to contain three members of the jarosite group - jarosite, plumbojarosite, and alunite.

As seen in the hand specimen, the material is dark brown in color and distinctly micaceous in appearance, with a silky luster. Where the crystals are very fine the micaceous character is less pronounced and the mineral, if not examined with some care, might be mistaken for limonite or some iron-stained material. Although much of the plumbojarosite is in rather large pieces as it comes from the mine, it is readily crushed in the fingers and has an oily look and feel, like fine graphite. Under the microscope the crystals are seen to be thin hexagonal plates ( $\mathrm{Pl} . \mathrm{XV}, A)$ of a light golden-yellow color. The crystals vary greatly in size, but rarely exceed 0.25 millimeter in width. The crystals have not been measured, but are undoubtedly hexagonal, and so far as their properties have been determined they correspond to the material from the American Fork locality examined by Wright. The crystals are uniaxial and optically negative, with strong birefringence. It may be noted that jarosite and plumbojarosite from the same mine are so similar in physical properties that a distinction can be made only by chemical tests.

A specimen of the material from the Red Warrior mine was submitted to the chemical laboratory of the Survey for investigation and W. T. Schaller reported the composition shown in the table below. The analyses of the mineral from the two localities previously described and the composition calculated from the formula are given for comparison.

Analyses of plumbojarosite.

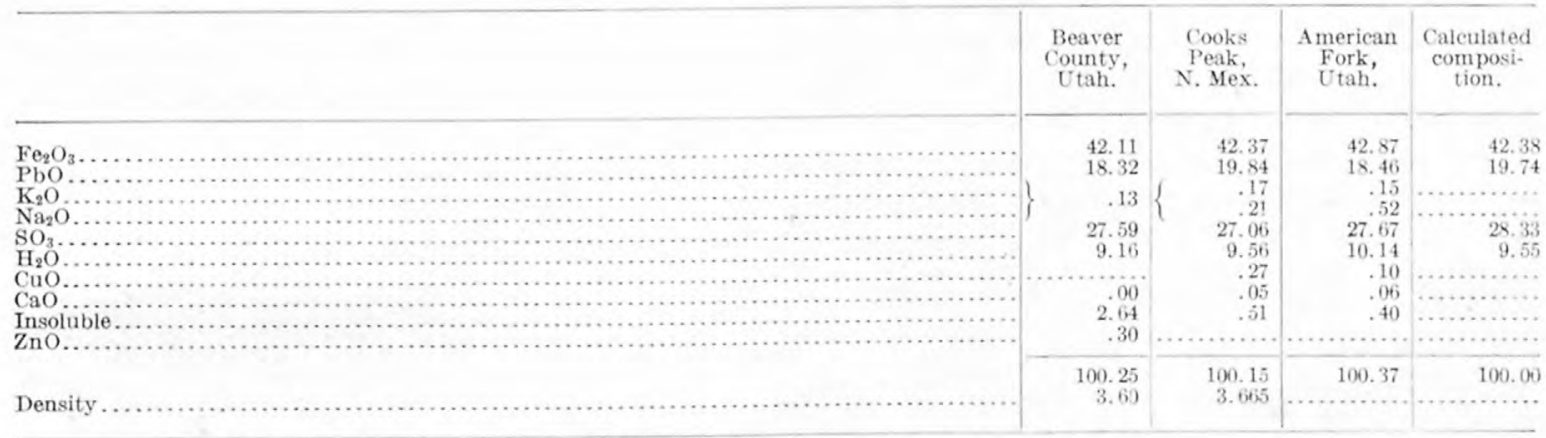

${ }_{1}^{1}$ Butler, B. S., and Schaller, W. T., Some minerals from Beaver County, Utah: Am. Jour. Sci., 4th ser., vol. 32, 1911, p. 422,

${ }^{2}$ Hillebrand, W. F., and Penfield, S. L., Am. Jour. Sci., 4th ser., vol. 14, 1902, p. 213.

3 Hillebrand, W. F., and Wright, F. E., idem, vol. 30, 1910, p. 191.

4 Emmons, S. F., Geology and mining industry of Leadville, Colo.: Mon. U. S. Geol. Survey, vol. 12, 1886, p. 606. 
The three analyses show a close agreement among themselves as well as with the calculated values.

Plumbojarosite has been recognized by the writer in other districts in Utah and there is little doubt that, like jarosite, it is not an uncommon product of the oxidation of sulphide ores under the conditions prevailing in this region. In places it may be sufficiently abundant to constitute an ore of some importance, though of course not of high grade.

\section{MOLYBDATES.}

Powellite.-Calcium molybdate, powellite, $\mathrm{CaMoO}_{4}$, occurs in the $\mathrm{O} \mathrm{K}$ mine as yellow incrustations on quartz and as pseudomorphs after molybdenite. Many of the incrustations are composed of minute tetragonal crystals, though the mineral does not always show definite crystal form. Powellite that has formed as pseudomorphs after molybdenite is a greenish-gray mineral having the structure of the mineral that it has replaced. All the powellite has resulted from the alteration of molybdenite.

Wulfenite.-Lead molybdate, wulfenite, $\mathrm{PbMoO}_{4}$, was observed most abundantly in the Harrington-Hickory mine, where it is an important constituent of some of the ores. It usually occurs in thin tabular tetragonal crystals, though it is not all well crystallized. It was noted in lesser amounts at other localities, especially at the Washington mine and the Horn Silver mine. The wulfenite appears to have resulted from the alteration of galena ore carrying molybdenum. A careful microscopic study of cores of galena that were surrounded by wulfenite has failed to reveal any molybdenite and it seems probable that the molybdenum has crystallized as an isomorphous mixture with the lead in the galena.

\section{ORE DEPOSITS. EARLY DEVELOPMENT.}

The first settlement in Beaver County was started by the Mormons at Beaver City in $1856^{1}$ by Simeon F. Howd, James P. Anderson, and Wilson G. Mowers. Three years later, in 1859, Minersville was settled, with J. H. Rollins as bishop of the ward. In the following year, 1860, the Rollins mine (now known as the Lincoln mine) was discovered in the Mineral Range a few miles northeast of Minersville. During the next two or three years a few tons of lead bullion was produced, ore from this mine being reduced to the metal in a crude way by the settlers. This is commonly reported to have been the first mine opened in the State of Utah.

Mining did not become an important industry in the county, however, till some years later. The first mining district organized was the Star district, July 8, 1870 . From 1872 to 1875 mining operations were active in this district, and a considerable output of lead and silver was made.

The discovery of the Horn Silver mine in September, 1875, was a most important event to this part of the State, for it resulted in the extension of the Utah Southern Railroad (now a part of the San Pedro, Los Angeles \& Salt Lake Railroad) to Frisco in 1880-years before it would have been extended but for the traffic offered by this mine. Not only was the immediate vicinity of Frisco furnished with railroad facilities but Frisco and Milford to the east became distributing centers for a region extending many miles west, south, and east.

A most excellent summary of the early history of the mining industry of Utah, prepared by D. B. Huntley, special expert detailed to Utah, under the direction of S. F. Emmons and G. F. Becker, was published in the report of the Tenth Census ${ }^{2}$ and will be quoted in the following discussion of the several districts.

\section{SAN FRANCISCO DISTRICT.}

Huntley gives the following account of the San Francisco district previous to the summer of $1880:^{3}$

The San Francisco district is situated in the center of Beaver County, about 225 miles south-southwest of Salt Lake City and 98 miles northeast of Pioche, Nev. The district is about 7 miles square and lies upon both flanks of a small range called the San Francisco Mountains. The San Francisco district was organized August 12, 1871, but

1 Bancroft, H. H., History of Utah, San Francisco, 1889.

2 Tenth Census U. S., 1880, vol. 13, Precious metals, pp. 405-489.

Idem, pp. 464-471. 
was of little importance until 1876, a year after the discovery of the Horn Silver mine. Frisco, the town and post office, has (August, 1880) about 800 inhabitants and is the terminus of the Utah Southern Railroad extension.

The country rock of the range consists of crystalline dolomitic limestone on the south, granite in the center, and a light-red quartzite on the north. The entire eastern slope is overlain by a volcanic rock, which has perhaps erroneously been called trachyte, a short distance above the level of the valley. Still farther east are extensive beds of tufa. The water in the district is very bad and scarce. Boilers with flues can not be used, or at most but a few days, owing to the great quantity of scale formed. Drinking water is brought on the railroad from Black Rock, from 30 to 40 miles distant, or hauled 10 miles from springs in the Wa Wa Range.

About 740 locations had been made in the district, but not over 200 were claimed at the time of the writer's visit and not over 30 had $\$ 500$ worth of work upon them. The principal mines of the district are the Horn Silver and the Carbonate.

The Horn Sitver mine.-This remarkable body of ore was discovered September 24, 1875, by James Ryan and Samuel Hawkes. They sank a short shaft 30 feet in the ore, which came within 10 feet of the surface, and, fearing that the ore would fail, sold for $\$ 25,000$ to A. G. Campbell, Matthew Cullen, Dennis Ryan, and A. Byram on February 17, 1876. These persons sold ore, erected smelting works, developed the ore body in the mine, and in 1879 sold the greater part of their interest at the rate of $\$ 5,000,000$ for the whole property. The Horn Silver Mining Co. was incorporated under the laws of Utah on February 17, 1879. The capital stock is $\$ 10,000,000$ in 400,000 shares. The property of the company consists of the Horn Silver claim, 1,440 by 600 feet, patented; two 5-acre smelter sites in the town of Frisco, also patented; a complete three-stack smelting plant; refining works at Chicago, Ill.; some iron-flux mines near Frisco; charcoal kilns; a 40-mile telegraph line to Beaver; two large stores in Frisco, and other minor property. Two very elaborate reports were made upon the property in March, 1879, one by W. A. Hooker, E. M., and one by Henry Cummins. The following are extracts from Mr. Hooker's report:

"The quantity of ore extracted up to February 1, 1879, is given as 22,712 tons. During February about 90 tons daily were raised, making a total of 25,000 tons of ore. The extraction of this 90 tons was barely enough to keep the mine in good shape and prevent the breasts of ore from crowding too much upon the timbers. The present expense of mining is low. We have as the cost of taking out 90 fons daily:

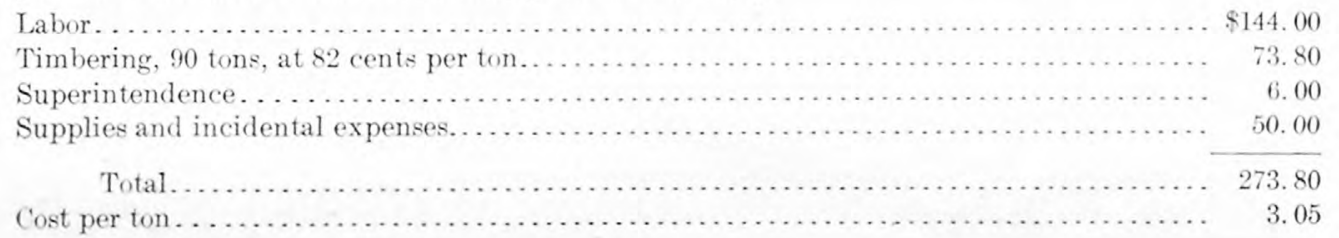

"The expense of mining the 22,712 tons up to February 1 was, of course, somewhat higher, amounting to $\$ 4.46$ per ton. This expense included surveying and application for patent, mail service, the initiatory expenses of the enterprise; in short, all the expenditures of the mine up to that date.

"Of the 25,000 tons mined about 5,500 tons have been sold to various parties; the remainder has been treated in Frisco by the Frisco Smelting Co. and in the company's own works.

"The smelting plant of the company consists of three shaft furnaces with 40-horsepower engine and boilers,'one No. 6 Root's blower, a Blake crusher, and other necessary appurtenances.

"The furnaces are placed in line with four dust chambers between stacks, or eight in all ( 6 feet by 5 feet 9 inches by 6 feet 2 inches each). The furnaces are circular, the hearths being built of a firestone of excellent quality (volcanic tufa) found in the immediate vicinity. Two of the furnaces have the following principal dimensions, the third being somewhat smaller:

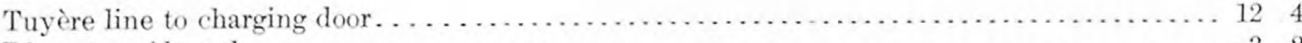

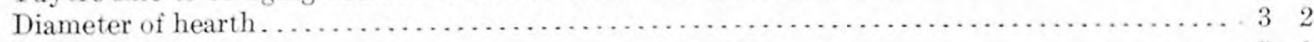

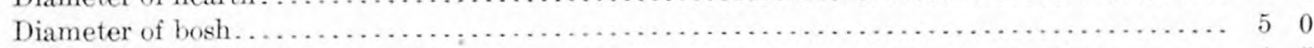

Diameter at throat. . . . . . . . . . . . . . . . . .

"The furnaces are provided each with five water tuyères, 3-inch nozzle. The hearth below the tuyères is protected by cast-iron plates arranged hexagonally. The stack is built of fire brick and common brick supported by cast-iron pillars. The average campaign is 60 days. A single furnace only has been run at a time owing to the scarcity of water. The smelting of the ore is preceded by a calcination or roasting in heaps with wood, and, although it is far from being a complete roasting, it nevertheless puts the ore in good shape for charging into the furnace and has the great advantage of economy. The fuel used for smelting is an inferior quality of charcoal. The principal flux used is iron oxide from various mines in the neighborhood, and at present about one-sixth of the ore smelted consists of milling ore. The product is from 6 to 9 tons of lead bullion per stack per diem, carrying an average of 150 ounces silver to the ton. About $1 \frac{1}{2}$ tons of matte is also produced daily, which, after a partial roasting, is charged back into the furnace. From 1,200 to 1,500 pounds of flue dust are saved daily. The following is the work for Janaury, 1879:

Amount of ore smelted........................................... tons. . 723. 1125

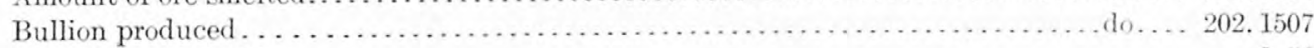

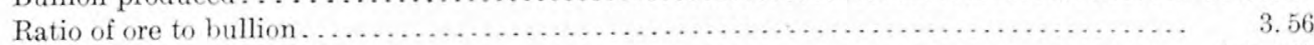

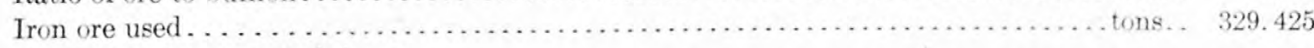
Or 50.78 per cent of the ore. 


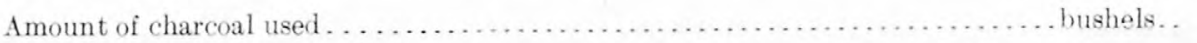
Or 46 bushels per ton of ore.

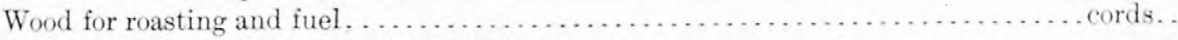

Or three-tenths of a cord per ton of ore.

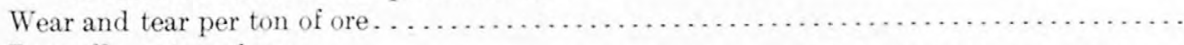

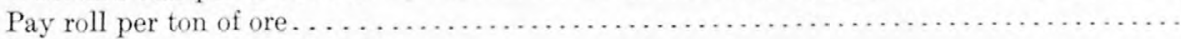

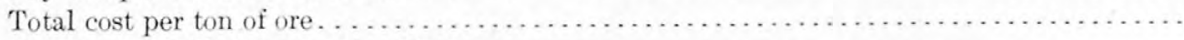

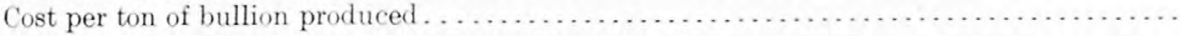

"The force employed during the census year was about 40 miners (10-hour shifts) at $\$ 3.50$ and 15 other workmen. It was the intention to extract the ore in the future by contract at so much per carload. The amount raised during the year was 16,0533 tons. The total product of the mine to the end of the census year was given at 29,380 tons. Its average product or value was unknown, but a rough estimate placed the assay value at 45 ounces silver and 35 per cent lead."

The smelter.-Besides Mr. Hooker's description of the furnaces, there are a few items which may be mentioned. Before smelting, the ore is roasted in heaps of varying size, about 30 feet wide and 140 feet long being an average. Cedar cordwood is piled 4 feet high, 20 inches of ore is spread upon it, another layer of wood 1 foot, and a final 1 foot of ore. This requires two or three weeks to burn. One cord of wood for 3 tons of ore is used. Wood costs $\$ 2.50$ per cord. As the ore which comes from the mine is already oxidized, it is difficult to see how this roasting affects it, except to volatilize some arsenic and antimony and to burn off some sulphur still unoxidized. In proof of this, the furnaces still continued to form large quantities of matte, as when treating unroasted ore. In further proof, also, the following partial analyses, made in the company's laboratory, indicate the same result. They are averages of several analyses made. The samples were not necessarily from the same lots of ore:

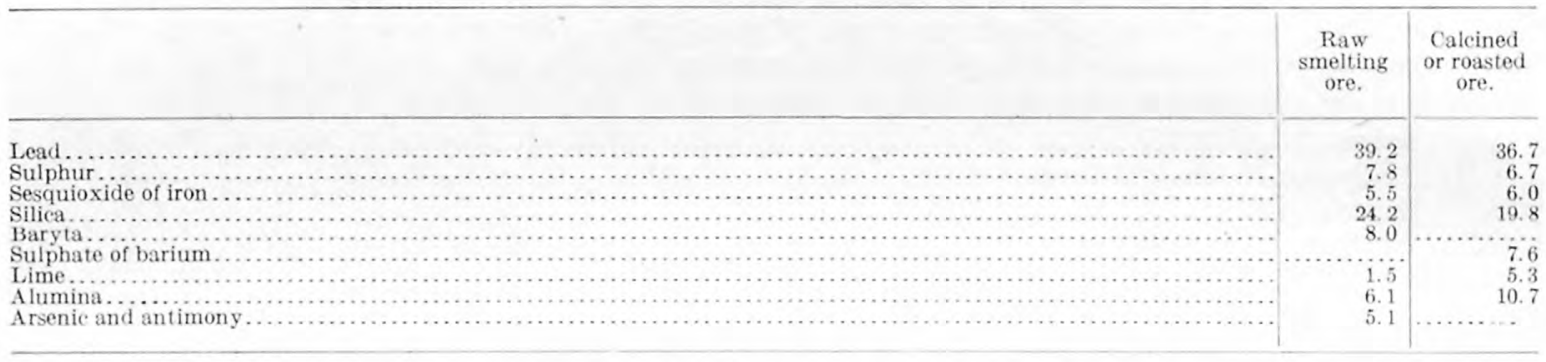

Two of the furnaces are lined with a tufa found in the district. The lining is 16 inches thick, and extends 3 feet high. It usually lasts 30 to 40 days. A new lining costs $\$ 130$. The third furnace is a cast-iron water jacket, vertical for 15 inches, and having a batter at the boshes of 6 inches per side in the remaining 13 inches. These furnaces run with a closed front. A varying quantity of limestone and iron flux is used. The limestone is quite pure and costs $\$ 2.50$ per ton. The iron flux is a limonite and hematite averaging from 55 to 64 per cent iron. It comes from the Wa Wa Range, Iron Springs, Star, Beaver Lake, and San Francisco districts, and costs about $\$ 8$ per ton. The charcoal used is about 25 per cent of the smelting charge. It is an inferior quality compared with that used in the northern part of the territory, and costs 18 cents per bushel for kiln and 16 cents for pit coal. Heretofore no flue dust has been saved. The lead and iron matte, which was quite abundant, is roasted in heaps and resmelted. It is said that there is considerable difference in the silver and lead contents of the mattes from the stone and water-jacket furnaces. No regular assays have been made, but the average of a few showed results in favor of the water jacket of 24 ounces silver and 7.5 per cent lead. Whether the charge in each furnace was exactly the same or not is unknown. The furnace lead was quite hard and contained several per cent of antimony. Since the completion of the railroad, cost of shipping to Chicago has been reduced to $\$ 33.50$ per ton. Some partial analyses of slag made at the company's office are as follows:

\begin{tabular}{|c|c|c|c|}
\hline 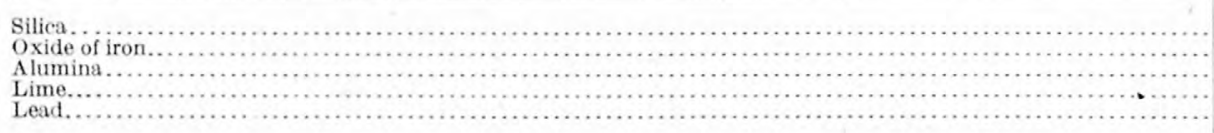 & $\begin{array}{r}32.3 \\
46.9 \\
5.0 \\
7.0 \\
8.6\end{array}$ & $\begin{array}{r}35.1 \\
44.1 \\
11.7 \\
4.2 \\
0.5\end{array}$ & $\begin{array}{l}29.3 \\
45.6 \\
13.2 \\
10.4 \\
(?)\end{array}$ \\
\hline
\end{tabular}

During the census year $10,573 \frac{3}{4}$ tons of ore were smelted, producing $2,886 \frac{3}{4}$ tons of bullion. Besides this about 4,000 tons of ore were sold to the Frisco (o.

Owing to the high price of labor, lack of water, poor quality, and constantly increasing price of charcoal, the company intended to shut down these furnaces and erect others at South Cottonwood.

A "draft furnace" to work Horn Silver ore was built in 1877 by a private company. It was built like an ordinary furnace but had a flue extending up the side hill several hundred feet. It was hoped that this would create sufficient 
draft to dispense with an engine and blower. A few tons of bullion was made, but the draft could not be regulated. The fire would approach the surface of the charge and the bottom would "freeze."

A small leaching plant erected by a private company was completed in the spring of 1878. Some Horn Silver ore was worked raw, and from 40 to 80 per cent obtained. A roasting furnace was erected, and the works then did much better. The tailings were reworked, yielding 82 per cent. The leaching works were not altogether successiul and were shut down after a few months, having treated less than 150 tons.

[Other mines.] - The Grampian is a prospect in the dolomite on the hill above and beyond the Horn Silver. In March, 1880, it was sold to a Chicago company, the Grampian Silver Mining Co, for a round sum, and a considerable force of men have been prospecting since. A vein of ocherous lead ore assaying about $\$ 50$ silver and some gold was found near the surface and followed down 80 feet, showing from 1 foot to 8 feet of ore. It then contracted, as is frequent with ore bodies in limestone, and in subsequent prospecting had not widened again. Little stoping had been done. The mine is developed by a tunnel and an incline having a windlass. The total cuttings amounted to 515 feet. Less than 200 tons have been shipped.

The Frisco Mining \& Smelting Co. was incorporated in September, 1879, and is a reorganization of the Frisco Smelting Co. It has a capital stock of $\$ 2,000,000$ in 80,000 shares. The company's property consists of one smelting plant in Frisco, the Carbonate group of mines in San Francisco district, stone quarry, wood ranches, charcoal kilns, furnace site, barns, wagons, and animals in the same district, the Cave mine and its group in Bradshaw district, and an iron-flux mine in Rocky district. The smelting furnace was built in the summer of 1877. It is situated in the town of Frisco and has usually run as a custom furnace or bought ore from the Horn Silver. The plant is a complete one and consists of a Blake rock breaker, a No. 5 Baker blower, two horizontal boilers, one 40-horsepower horizontal engine, several pumps, a shaft furnace and a flue-dust chamber, a reverberatory flue-dust slagging furnace 10 by 36 feet, and five charcoal kilns adjacent to the works. The Horn Silver ore which the company smelted was roasted in heaps in the same manner as by the Horn Silver Co. The company worked the ore for $\$ 20$ per ton, guaranteeing 80 per cent of the silver and lead contents. The ore was smelted with an iron flux from the Cave and other iron mines and required about 30 per cent flux and 46 bushels of charcoal per ton. About 5 per cent of flue dust was caught, assaying 35 per cent lead and 30 ounces silver. The matte, of which from 5 to 10 per cent was formed, assayed about 20 per cent lead and 30 ounces silver. It was roasted in heaps and resmelted. The slag assayed about $1 \frac{1}{4}$ ounces silver and $2 \frac{1}{2}$ per cent lead. The furnace force consists of 18 men on 8 to 12 hour shifts, receiving from $\$ 3$ to $\$ 4$.

The Carbonate mine is situated on nearly level ground on the eastern side of the San Francisco Mountains, $2 \frac{1}{2}$ miles northeast of Frisco. It was discovered in the autumn of 1878. Campbell, Burke \& Donaldson bought it in February, 1879 , for $\$ 10,000$, sunk a shaft to the depth of 212 feet, and sold the property to the Frisco Mining \& Smelting Co. in September, 1879, for $\$ 100,000$. The group of flanking and overlapping locations consisted of seven claims, 1,500 by 600 feet each, viz, the Carbonate, Ingomar, Rattler, Stepmother, Homestake, North Side, and South Side. Some showed ore, but little had been done on any except the Carbonate. This was discovered by trenches dug on the surface of the ground in the search for the source of rich float. It was impossible to learn the average grade of the ore. One hundred and forty tons were smelted by the company, but the value was not given. About 700 tons of low-grade ore were raised during the census year and are now upon the dump. From various assays the average value of the ore was estimated to be from 30 to 45 ounces silver and from 15 to 25 per cent lead. The mine is opened by a single-compartment vertical shaft, 5 feet 10 inches by 4 feet 10 inches, to a depth of 330 feet. The shaft was sunk 40 feet north of the croppings. At 80 feet a little water was found (at the period under review 50 gallons per hour was hoisted with a bucket), and the ore changed from carbonate to galena. Drifts had been run every 100 feet, but the extreme limit of horizontal development was 225 feet. The total cuttings amounted to 1,315 feet. Every drift was timbered with 8 by 10 inch or 10 by 10 inch posts and caps, and 2 to 3 inch plank. It was found necessary to ease them once each month. No stoping had been done. All work had been to prospect the mine. There were small steam hoisting works, containing a 12-horsepowar engine, supposed to be capable of sinking the shaft 500 feet. About 20 men had been regularly employed. Owing to the low grade of the ore, no attempt was intended to be made to smelt it until after concentration. At the time of the writer's visit the company was erecting a 30 by 96 foot building in which to concentrate the ore, by means of Paddock's pneumatic separators. These were a new invention. They had been tested for several months on copper and lead sulphurets in Maine and had also worked several tons of this ore at the Butterfield Canyon concentrating works, in West Mountain district, and had given satisfaction. The machinery to be employed was to consist of 1 rotary drier, 1 rock breaker, 3 sets of Cornish rolls, 6 elevators, 5 revolving screens, having a 35 to 110 mesh, 10 Paddock's separators, and 1 Frue concentrator. It was thought this apparatus would concentrate 50 tons in 24 hours.

The other mines of the San Francisco district are:

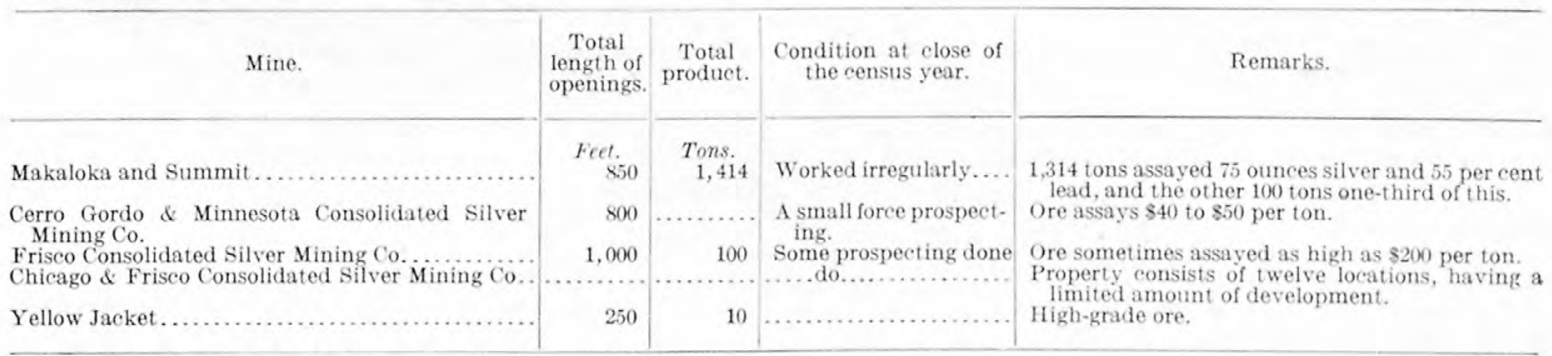

$73363^{\circ}$-No. $80-13 \longrightarrow 8$ 
Copper.-In the northern part of the San Francisco district there are several very large ledges of pyrite and chalcopyrite ore. Some work was done upon them, and a small amount of a very high grade silver ore was mined several years ago. The principal claims are the Comet, Cactus, and Copper Chief.

Charcoal burning.-Thirty-six beehive charcoal kilns ${ }^{1}$ supply the furnaces of the district with fuel. They were in eight groups, under separate individual management, at places where wood was accessible, and at distances of from 6 to 18 miles from Frisco. Some pit coal is burned in the $\mathrm{Wa}$ Wa Mountains, but it is sold for 1 or 2 cents per bushel less than the kiln coal, as the latter is cleaner and of better quality. The kilns are made of granite float found in the neighborhood and a lime mortar. They are of various sizes, from 16 to 26 feet in diameter. It is the rule in this section to make the height of the kiln equal to the diameter. The thickness varies from 18 to 30 inches at the base and from 12 to 18 inches at the summit. There are two openings, closed by sheet-iron doors, one at the ground level, 4 by 6 feet, and the other in the side two-thirds of the distance to the apex, 3 by 4 feet. There are also three rows of vent holes, 3 by 4 inches, near the ground. The lower row is at the surface of the ground. The rows above are 18 inches apart, having vent holes 3 feet apart in each row. The kilns cost from $\$ 500$ to $\$ 1,000$ each and lasted a very long time if used regularly. The 16 -foot kiln holds about 15 cords of wood and the 26 -foot kiln 45 cords. Sometimes the wood is piled radially, but generally very closely in cordwood fashion. The wood is all piñon pine, and is cut at all seasons by Mormons at $\$ 1.25$ per cord. It is brought from 1 to 4 miles by sledges or wagons to kilns for from $\$ 1.50$ to $\$ 2.50$ per cord. The kilns are fired in the center at the bottom (though sometimes at the top), and the fire is drawn to the top by leaving a small unsealed space around the upper door. This is then closed entirely, and the fire is regulated by the vent holes. The duration of burning is from three to seven days and of cooling from three to six days. Charring, which includes packing the wood in the kiln and drawing the coal, is usually done by contract and costs from $2 \frac{3}{4}$ to $3 \frac{1}{2}$ cents per bushel. About 50 bushels are produced per cord charred. The coal is bought by weight, 17 pounds making a bushel. It is shipped to the smelters in racks, at a cost of from 3 to $5 \frac{1}{2}$ cents per bushel for hauling, depending on the distance. The price received is 18 cents per bushel. Kiln hands are paid from $\$ 2$ to $\$ 2.75$. The labor required averages one man per kiln per 24 hours.

The Horn Silver Co.'s smelter at Francklyn was completed in June, 1881, but some ores were treated at Frisco till June, 1882, when smelting at Frisco ceased.

A plant for milling the Horn Silver ores was built in 1893-94 and although shortly afterward destroyed by fire it was rebuilt and operated for about 10 years. In 1905 the Peck mill was constructed on the property but was never operated. In 1911 the old mill was remodeled and operated for a short time. The mine has been a continuous producer from the time it was opened except for a short period after the extensive cave in 1885 .

The Carbonate mine was an active producer till 1885, but operations then ceased till 1908, when an attempt to reopen it was made. The ore body was opened on the 700-foot level in 1909 , but no important production has been made in recent years. Attempts to work the copper ores of Copper Gulch were made in the early eighties and a small smelting plant was constructed on the property in 1897, but little ore was treated. In 1903 the Newhouse Mines \& Smelters Corporation acquired the property and began an active campaign of development. The railroad was extended from Frisco to Newhouse. The town of Newhouse was built and concentrating works constructed. Production began in 1905 and continued till the fall of 1907. After an idleness of one and one-half years operations were resumed and it has been a steady producer since that time.

\section{STAR DISTRICT.}

Huntley ${ }^{2}$ gives the following account of early operations in the Star district:

The original Star district, 12 miles square, situated on the Picacho Range a few miles southwest of Milford, was organized July 8, 1870. On November 11, 1871, the northern portion was reorganized as the North Star district, and the two districts, called respectively North Star and South Star, have kept up their organizations since. In the South Star the books showed 1,046 and in the North Star 581 locations, but probably not over 350 were owned at the period under review. The mines occur entirely in the limestone and quartzite, and are usually bedded veins and pipes of ore, dipping with the stratification from $40^{\circ}$ to $70^{\circ} \mathrm{E}$. or SE. The mines are at an altitude of from 5,000 to 6,000 feet above sea level, in ridges a few hundred feet above the Beaver River bottom lands. Water is very scarce and $\operatorname{costs}$ from 5 to 9 cents per gallon. For this reason the mines are worked mostly in the winter season, when there is about a foot of snow on the ridges. The prosperous days of the district were in $1872,1873,1874$, and 1875 . Then there were the thriving mining camps of Shauntie, Shenandoah City, Elephant City, and South Camp. Shauntie contained 40 houses but was destroyed by fire in the summer of 1876 . Few have been rebuilt. The work in the district has been done for the most part by poor men upon their own claims. Hence there are a host of rudely worked prospects, with very little development. During the census year 40 men were working and prospecting in the two districts.

'It is said that this style of kiln was first made by J. C. Cameron, in Marquette County, Mich., in 1868.

${ }^{2}$ Op. cit., pp. 471-474, 
Most of the ore produced was treated at the Shauntie smelter. Two small stacks were built at the town of Shauntie in the summer of 1873. In the following spring these were torn down, and one stack of 20 tons' capacity was built. This was burned in June, 1875, was rebuilt in the following autumn, and was shut down in the summer of 1877 . A short run was made in 1878. It has been idle since. The furnace is quite dilapidated. About 12,000 tons of ore were worked, which produced about 3,000 tons of bullion, containing $\$ 325,000$ in silver and $\$ 10,000$ in gold.

The Troy furnace erected in 1875 on the Beaver River bottoms, 5 miles south of Milford, to smelt Mammoth mine ore, ran but a few months. It has been idle since and was burned in June, 1880.

The Latey \& Williams smelter is a single-stack custom smelter and was erected at Milford, east of the districts, in the autumn of 1876. The owners had worked about 500 tons of Star ore, 1,500 tons from the Horn Silver, and 400 tons from the Cave mines, which had produced about 770 tons of bullion. The smelter had been idle for over a year but was started again August 17, 1880. The plant consists of a stone shaft furnace, a No. $4 \frac{1}{2}$ Baker blower, a horizontal boiler and engine, and a small flue-dust chamber.

The Milford 10-stamp mill is in a fair state of preservation. It is in the town of Milford, and was erected in the fall of 1873 , at a cost of $\$ 45,000$, by a Scotch and Canadian company, called the Harrington \& Hickory Consolidated Mining Co., to work the ores of the Old Hickory mine, which had been sold to it for about $\$ 100,000$. The mill ran a few months on about 35-ounce ore in the winter of $1873-74$ and produced from $\$ 9,000$ to $\$ 12,000$ in base bullion. It was then idle until leased by the Cave Co., in August, 1876. This company ran about five months and produced $\$ 19,000$ in very fine bullion. The mill has been idle since. The watchman sued for his wages and took the property in 1878. The machinery consisted of a fine 60-horsepower engine, two horizontal boilers, a Dodge rock crusher, ten 750-pound stamps, six small wooden pans, three iron settlers, and a retort. At the time of the writer's visit a sampling mill was being erected. It was to be completed and ready to receive consignments of ore in a few months.

Mines of North Star district.

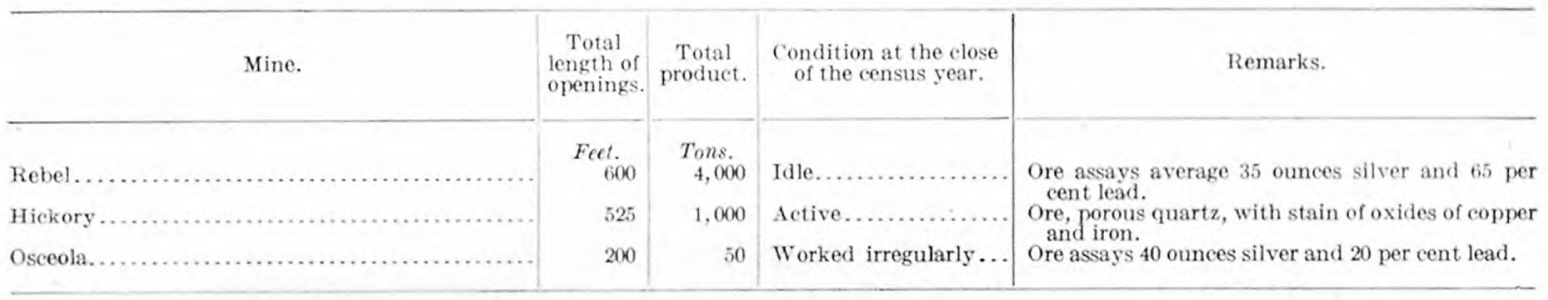

Mines of the eastern foothills of Star district.-The Vulcan, an iron-flux mine, situated 6 miles southwest of Milford, was discovered in the spring of 1872 , but serious work was not begun until April, 1879. It was regularly worked by the owners, and the product sold to the Horn Silver Co. for $\$ 8$ per ton. The mine consists of large bodies of ocher on the hanging wall of a small contact vein between a dolomite hanging and a granite foot wall. There are several of these extremely irregular bodies from 1 foot to 15 feet wide, already prospected 75 feet horizontally and 125 feet on a dip of $60^{\circ}$. The ocher shows traces of gold, silver, and cerusite. Occasional bunches of 45-ounce ore are found. The total cuttings are 400 feet. About 900 tons of the flux had been shipped in the year; very little previously. The cost of transportation, which the mine paid, was $\$ 4$ per ton.

The Vicksburg mine was discovered in 1872. It has been idle since 1877, except assessment work. It is a north and south vertical vein, from 5 to 10 feet wide, in limestone near granite. An ocherous ore, containing from 15 to 50 ounces of silver and from 15 to 50 per cent lead, was encountered in a chimney dipping about $40^{\circ} \mathrm{N}$. Several tons of pure granular sulphur were found in a layer from 2 to 20 inches thick beneath the richest portion of the ore. Crystals of gypsum also occurred with the ore. The mine is opened by a 220 -foot incline and 150 feet of other cuttings. Probably 200 tons of all grades have been shipped. There are several thousand tons of a soft low-grade ocher upon the dumps and in sight in the mine.

The Golden Era is a nearly vertical north and south vein, from 16 inches to 5 feet wide, in limestone. One chimney, 9 feet wide and 20 feet long, dipping $40^{\circ} \mathrm{N}$. in the vein, has been followed over 200 feet. The ore is an ocherous carbonate assaying as high as 55 ounces of silver, 40 per cent lead, and $\$ 5$ gold. There is a 245 -foot incline on the vein, also 100 feet of other cuttings. A whim is used for hoisting. Three men have been working during the year. The total product has been about 250 tons, principally an iron flux.

Mines of Wistern Star district.

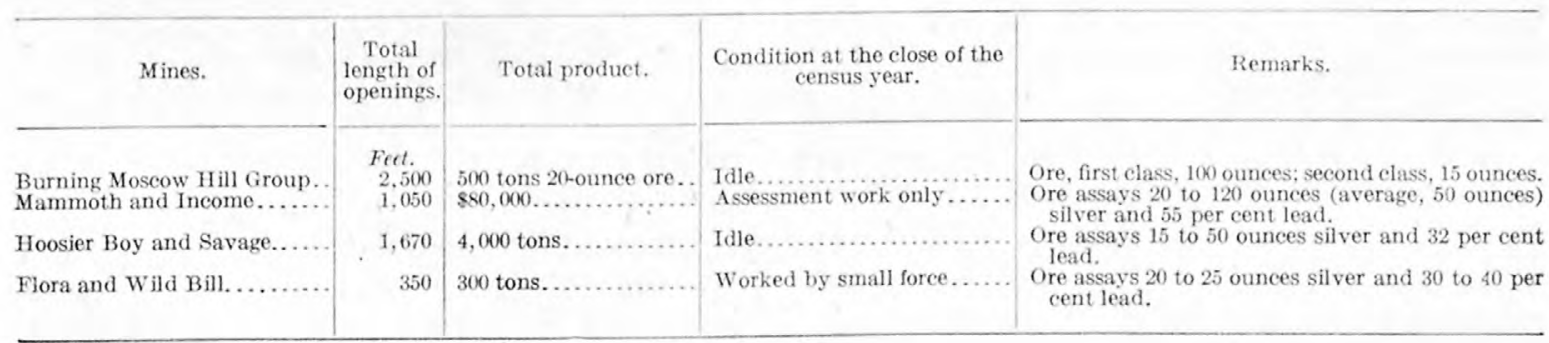


Mines of South Star district.-The Wasco mine is at South Camp, $7 \frac{1}{2}$ miles southwest of Milford, on one of the spurs of the highest peak of the Picacho Range. It was discovered in the fall of 1874. It was worked until March, 1875, was idle for a year and a half, and was worked again until June, 1879 , since which time it has been idle. It consists of a single pipe of a soft yellowish limonite and carbonate ore, bedded in limestone and dipping from $35^{\circ}$ to $40^{\circ} \mathrm{NE}$. One chimney began at the surface and has been followed 833 feet and still continues. There are two or three contracted places or slight faults in it, and it varies in size from 1 foot to 10 feet thick and from 10 to 30 feet wide, but is continuous. A tunnel 180 feet long cuts the pipe 300 feet from the surface and is used to lessen the windlass work. The ore, when sorted, contains from 30 to 40 ounces silver, from $\$ 4$ to $\$ 10$ gold, and 40 per cent lead. The assay of the total product is estimated at 40.000 ounces silver and $\$ 5.000$ gold.

The Harrisburg Hill Mining Co. was incorporated in April. 1880. and was a consolidation of the interests of the mine owners on the hill to develop their property. The mining property is at South Camp, near the Wasco, and embraces 11 overlapping locations, which cover an area of about three full claims. They are all in a dolomite or limestone country rock and, with the exception of the Harrisburg and Mountaineer, have but limited developments. The ore is a low-grade ochery carbonate, which, when sorted, will assay from 25 to 150 ounces silver, from $\$ 3$ to $\$ 5$ gold, and 30 per cent lead. It occurs in chimneys, pipes the size of a barrel, and irregular deposits.

The entire hill is seamed with small veins containing ocher. The principal work has been done on one chimney in the Harrisburg claim, in a bedded vein dipping from $40^{\circ}$ to $65^{\circ} \mathrm{E}$. A very irregular incline follows this chimney 225 feet on the dip and explores it horizontally 75 feet. The ore is found in irregular deposits from 6 to 20 inches wide. The first-class ore, when sorted, assays $\$ 100$ silver, 60 per cent lead, and $\$ 4$ gold. In the vein, on either side of the ore body, is a band of fibrous gypsum from half an inch to 3 feet thick. Sometimes layers of mud alternate with the gypsum. In the lower works from 1 foot to 3 feet of "black spar," a calcareous rock containing a large percentage of oxide of manganese. is found. In general the country is much broken in the vicinity of this vein, one horizontal fault of 20 feet being found 90 feet from the surface. The total product of the mines of the group is estimated at 700 tons, a veraging 50 ounces silver and 50 per cent lead. There is much low-grade ore upon the dumps.

The other mines of South Star district are:

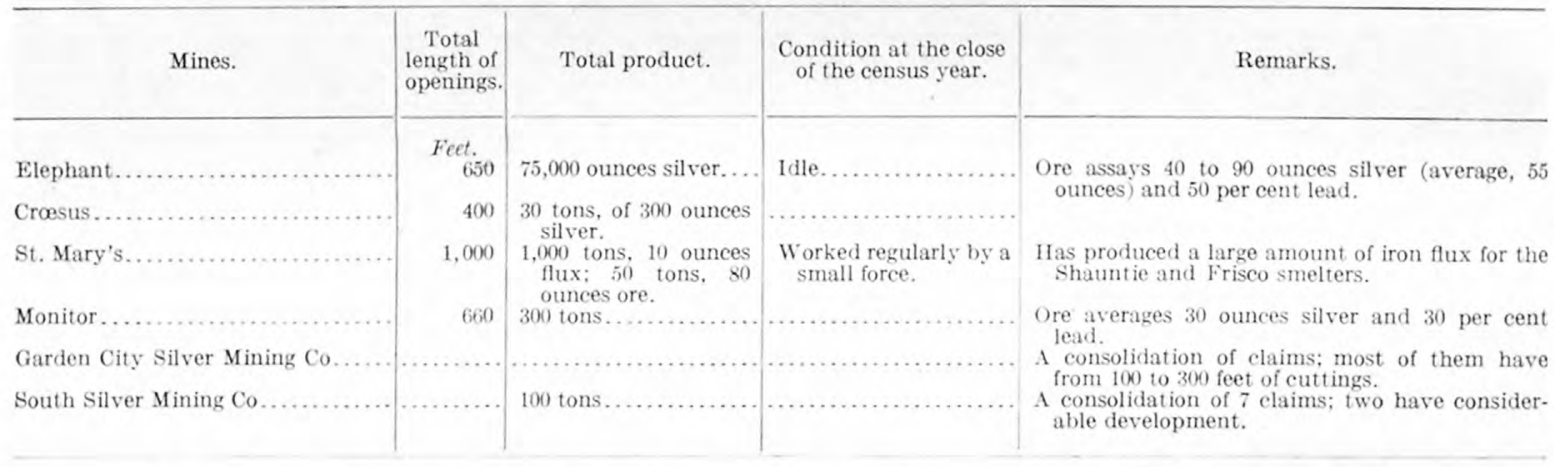

In addition to the above-mentioned mines of the Star districts there are very many claims with less development which have shipped from 10 to 80 tons.

For nearly 25 years subsequent to 1880 there was little activity in the Star district and the metal output was not important. In 1904 it again became a producer and since that time has contributed regularly to the metal output of the State. The recent operations have been mainly concerned with opening the old mines to greater depths. The ore is all shipped to the Salt Lake Valley smelters.

BEAVER LAKE DISTRICT.

The early operations in the Beaver Lake district are recorded by Huntley ${ }^{1}$ as follows:

The Beaver Lake district is situated north of the Star and Rocky districts and was organized in August, 1871, upon the discovery of a belt of copper veins from an inch to 2 feet in width. Some work was done in 1872 and 1873 , and a few tons of ore were shipped, assaying 30 per cent copper, 16 ounces silver, and $\$ 12$ gold. These copper veins have been idle since. In September, 1872, lead and silver ores were discovered. The leading mine is the San Francisco, which was sold for $\$ 10,000$. A bout $\$ 8,000$ worth of high-grade silver-lead ore has been extracted from a 110 -foot shaft. It has been idle since 1873. The Dexter and Mountain King are iron mines and shipped 400 tons of flux each between 1873 and 1877. A small vein containing graphite (or molybdenite) was also discovered. Little work has been done in the district in the last few years. The Riverside smelter was erected in 1873 at a point 7 miles north of Milford to work the copper ores of this district. It produced a few tons of copper matte and also a few tons of lead bullion in the few months that it ran. It has long been abandoned.

The largest production from this district came from the O K mine about 1900-1901, and the mine was again operated in 1906 and 1907. Since that time there has been no important production from this district. 
ROCKY DISTRICT.

Huntley ${ }^{1}$ gives the following account of the early history of the Rocky district:

Rocky district is about $1 \frac{1}{2}$ by 3 miles in extent and includes a small isolated range north of the Star district and east of the San Francisco. It was organized in 1872 and had, at the period under review, about 25 locations, although six times that number have probably been made. The country rock is granite, quartzite, and limestone. The principal work has been done upon the following claims:

Big Mountain tunnel. - On the side of a mountain there is an east and west vein 10 feet wide in granite. From a 100 -foot shaft about 31 tons of assorted ore were shipped to Salt Lake City, which, it is said, averaged 30 per cent copper, 25 ounces silver, and $\$ 12$ gold.

June iron mine.-This mine had shipped 1,500 or more tons of flux to Frisco in the previous few years.

Rocky iron mine. - This claim was owned by the Frisco Mining \& Smelting Co., and is said to have shipped 2,000 tons of flux since its discovery. It is worked through great open cuts upon the surface.

Copper mine.-This is an immense vein of copper ore with croppings 100 feet wide. The ore is a carbonate stain in the joints of a siliceous rock and taken together is of very low grade; but 30 per cent copper ore, assaying $\$ 12$ silver and $\$ 10$ gold, can be sorted from it. Some has been shipped. There is to all appearances a 50 -foot vein of an impure magnetic ore one side of this vein of copper. Shafts 75 and 55 feet deep have been sunk.

During the prevailing high price of copper in 1906 and 1907 considerable iron-copper ore was shipped from the Old Hickory mine to the Salt Lake smelters. With the fall in price of copper it was no longer possible to operate the mine at a profit, and there has been little activity in the district till 1912, when shipment was resumed.

In 1903 the Majestic Mining \& Smelting Co. completed a smelting plant south of Milford for the treatment of ores from the Star, Beaver Lake, and Rocky districts. The amount of ore developed was not sufficient to keep the plant running, and after operating a few days it was shut down and has been idle since.

\section{PRODUCTION.}

Accurate statistics of mine production have been collected by the United States Geological Survey since 1902, and the metal output of the districts here discussed since that time is shown in the following tables. There is no accurate record of the metal output of the districts previous to 1902, but the writer has collected the available data, which are believed to be approximately correct.

For 1902 to 1910 the value of the production is calculated on the basis of the average selling price of the metals during the year in which they were produced, and the same plan has been used for the earlier production so far as possible, though in numerous instances it has not been possible to ascertain the metal output of a mine for individual years. The general average, however, is probably not far from correct.

No account has been taken of the iron ore used as a flux for other ores, which has been of considerable value but has not added to the metal output of the district.

Metal produetion of the San Francisco and Preuss districts, Utah, to the close of 1910.

\begin{tabular}{|c|c|c|c|c|c|c|c|}
\hline $1870-1902 \ldots$ & $\begin{array}{c}\text { Tons. } \\
\ldots \ldots \ldots \\
\end{array}$ & $\begin{array}{r}\text { Fine ounces. } \\
3,545\end{array}$ & $\begin{array}{l}\text { Fine ounces. } \\
13,718,280 \\
\end{array}$ & $\begin{array}{l}\text { Pounds. } \\
4,327,047\end{array}$ & $\begin{array}{l}\text { Pounds. } \\
290,040,964\end{array}$ & $\begin{array}{l}\text { Pounds. } \\
\text { P............ }\end{array}$ & $\$ 20,142,479$ \\
\hline 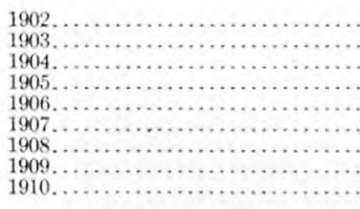 & $\begin{array}{r}18,250 \\
17,347 \\
15,912 \\
141,519 \\
236,229 \\
215,204 \\
220,005 \\
53,385 \\
77,781\end{array}$ & $\begin{array}{r}202.73 \\
807.86 \\
545.04 \\
1,616.00 \\
2,667.67 \\
2,354.75 \\
2,032.19 \\
647.26 \\
596.75\end{array}$ & $\begin{array}{r}112,813 \\
96,027 \\
110,541 \\
137,412 \\
289,165 \\
279,379 \\
106,877 \\
205,974 \\
249,156\end{array}$ & $\begin{array}{r}717,353 \\
432,409 \\
1,588,287 \\
3,427,918 \\
5,108,127 \\
4,626,736 \\
5,609,611 \\
1,114,085 \\
984,310\end{array}$ & $\begin{array}{l}3,657,063 \\
5,505,694 \\
7,432,855 \\
3,464,007 \\
4,762,488 \\
3,811,321 \\
1,900,371 \\
3,528,134 \\
3,908,122\end{array}$ & $\begin{array}{r}391,676 \\
1,358,000 \\
780,276 \\
933,136 \\
656,457 \\
451,879\end{array}$ & $\begin{array}{r}293,690 \\
347,988 \\
417,902 \\
894,088 \\
1,553,814 \\
1,415,469 \\
918,939 \\
452,476 \\
468,245\end{array}$ \\
\hline $1902-1910 \ldots$ & 995,632 & $11,470.25$ & $1,587,344$ & $23,608,836$ & $37,970,055$ & $4,571,424$ & $6,762,611$ \\
\hline Total $1870-1910$. & & $15,015.25$ & $15,305,624$ & $27,935,883$ & $328,011,019$ & $4,571,424$ & $26,905,090$ \\
\hline
\end{tabular}

Detailed statements of the output of the Horn Silver, Cactus, and Carbonate mines, the principal producers of the San Francisco district, will be found in the description of those mines. 


\begin{tabular}{|c|c|c|c|c|c|c|c|}
\hline Year. & Ore. & Gold. & Silver. & Copper. & Lead. & Zine. & Total value. \\
\hline $1870-1902$. & $\begin{array}{c}\text { Tons. } \\
\ldots . . . . . . . \\
\end{array}$ & $\begin{array}{r}\text { Fine oz. } \\
750\end{array}$ & $\begin{array}{c}\text { Fine oz. } \\
500,000\end{array}$ & $\begin{array}{c}\text { Pounds. } \\
\end{array}$ & $\begin{array}{c}\text { Pounds. } \\
11,000,000\end{array}$ & $\begin{array}{l}\text { Pounds. } \\
\text { P.......... }\end{array}$ & $\$ 1,100,000$ \\
\hline 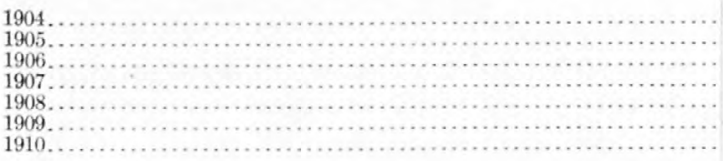 & $\begin{array}{l}1,100 \\
1,714 \\
1,985 \\
4,265 \\
2,835 \\
4,343 \\
4.660\end{array}$ & $\begin{array}{r}36.28 \\
247.00 \\
60.50 \\
73.05 \\
71.40 \\
39.23 \\
53.84\end{array}$ & $\begin{array}{l}10,310 \\
43,500 \\
34,603 \\
49,179 \\
41,550 \\
67,098 \\
88,628\end{array}$ & $\begin{array}{r}62,500 \\
128,000 \\
67,994 \\
176,896 \\
94,276 \\
129,449 \\
141,533\end{array}$ & $\begin{array}{r}93,000 \\
739,149 \\
556,300 \\
597,282 \\
1,144,329 \\
2,198,484 \\
2,300,102\end{array}$ & $\begin{array}{r}2,391 \\
\cdots \\
106,008 \\
54,902 \\
6 \quad \ldots 1,854\end{array}$ & $\begin{array}{r}17,580 \\
86,088 \\
69,267 \\
107,258 \\
86,583 \\
147,065 \\
171,491\end{array}$ \\
\hline $1902-1910$. & 20,902 & 581.30 & 334,868 & 800,648 & $7.628,646$ & 225,155 & 685,332 \\
\hline Total, $1870-1910$. & $\ldots$. & 1,331 & 834,868 & 800.648 & $18,628,648$ & 225,155 & $1,785,332$ \\
\hline
\end{tabular}

As shown in the above table the ores shipped from the Star district from 1902 to 1910 averaged about 16 ounces of silver to the ton, slightly above 18 per cent of lead, and nearly 2 per cent of copper. Figures of the tonnage of ore from the district treated in the early days are lacking, but, according to Huntley's report already quoted (p. 114), the ore treated at the Shauntie smelter averaged about 25 ounces of silver to the ton and 25 per cent of lead.

Metal production of the Beaver Lake and Rocky districts, Utah, to the close of 1910.

\begin{tabular}{|c|c|c|c|c|c|c|}
\hline Year. & Ore. & Gold. & Silver. & Copper. & Lead. & $\begin{array}{c}\text { Total } \\
\text { value. }\end{array}$ \\
\hline $\begin{array}{l}1870-1902 \\
1902-1910\end{array}$ & $\begin{array}{l}\text { Tons. } \\
20,799\end{array}$ & $\begin{array}{r}\text { Fine oz } \\
225 \\
193\end{array}$ & $\begin{array}{r}\text { Fine oz } \\
13,250 \\
20,920\end{array}$ & $\begin{array}{r}\text { Pounds. } \\
931,000 \\
1,052,483\end{array}$ & $\begin{array}{l}\text { Pounds. } \\
80,000\end{array}$ & $\begin{array}{r}\$ 105,000 \\
226,645\end{array}$ \\
\hline $1870-1910 \ldots$ & & 418 & 34.170 & $1,983,483$ & 80,000 & 331,645 \\
\hline
\end{tabular}

The copper ores shipped from the O $\mathrm{K}$ mine during its earlier operations were of high grade, but the ore extracted during 1906 and 1907 had a much lower metal content. The ores from the Rocky district were relatively low in copper, but contained a high percentage of iron, which made their extraction commercially possible.

A pproximate metal output of the San Francisco and adjacent districts, Utah, to the close of 1910.

\begin{tabular}{|c|c|c|c|c|c|c|}
\hline Distriet. & Gold. & Silver. & Copper. & Lead. & Zinc. & Total value. \\
\hline $\begin{array}{l}\text { San Francisco and Preuss...... } \\
\text { Star and North Star.......... } \\
\text { Beaver Lake and Rocky ..... }\end{array}$ & $\begin{array}{r}\text { Fine oz. } \\
15,01.5 \\
1,331 \\
418\end{array}$ & $\begin{array}{r}\text { Fine oz. } \\
15,305,624 \\
834,868 \\
34,170\end{array}$ & $\begin{array}{r}\text { Pounds. } \\
27,935,883 \\
800,648 \\
1,983,483\end{array}$ & $\begin{array}{r}\text { Pounds. } \\
328,011,019 \\
18,628,648 \\
80,000\end{array}$ & $\begin{array}{r}\text { Pounds. } \\
4,571,424 \\
225,155 \\
\ldots \ldots \ldots \ldots\end{array}$ & $\begin{array}{r}\$ 26,905,090 \\
1,785,332 \\
331,645\end{array}$ \\
\hline ' & 16,764 & $16,174,662$ & $30,720,014$ & $346,719,667$ & $4,796.579$ & $29,022,067$ \\
\hline
\end{tabular}

NATURE OF THE ORE DEPOSITS.

GENERAL RELATIONS.

The ore deposits of the San Francisco region are believed to be of essentially the same age, the deposition of all the ores closely following the intrusion of the quartz monzonite. The marked differences in the deposits are probably due to differences in several factors, among the more important of which are (1) the character of the rock in which the deposits were formed; (2) the distance from the intrusive body, which affected the temperature, pressure, etc.; and (3) the time in the general period of mineralization in which the deposits were formed, the solutions in the later part of the period probably being of somewhat different composition from those that were active when mineralization began.

The character of the rock in which the deposits were formed was doubtless one of the more important factors in determining the general type of the deposit, and on this basis a classification of the deposits can be made that is convenient for the purpose of description and that groups deposits having a general similarity. 
Under this classification the deposits of the region may be divided into three general groups(1) deposits in the quartz monzonite; (2) deposits in the sedimentary rocks; (3) deposits in the lava flows.

DEPOSITS IN THE QUARTZ MONZONITE.

The quartz monzonite has been mineralized at numerous localities in the region, but so far the mineralization has been shown to be of commercial importance at only two places - in the Cactus ore zone, in Copper Gulch, and in the O $\mathrm{K}$ ore zone, in the Beaver Lake district. The deposits of this type are characteristically copper deposits with some gold and silver, though veins carrying galena have been opened in the quartz monzonite, notably at the Michigan mine and northwest of the Frisco (ontact mine.

\section{MINERALOGY.}

Although the deposits of this type differ to some extent mineralogically, their resemblances are far more striking than their differences. The most abundant gangue minerals are the quartz and sericite that have resulted from the alteration of the quartz monzonite by the orebearing solutions. (See p. 74.) The sulphides, pyrite and chalcopyrite, are common to all deposits of this type. In other minerals there is considerable difference shown in the different deposits. Magnetite, hematite, tourmaline, siderite, and anhydrite are plentiful in the Cactus deposit but are rare or absent in the $\mathrm{O} \mathrm{K}$ deposit. Molybdenite, on the other hand, is a common mineral in the $\mathrm{O} K$ deposit, but only a few small flakes were seen in the Cactus deposit. This difference in mineralogic composition is probably due in part to different conditions under which the ores were deposited, though it may also be due in part to differences in the composition of the ore-bearing solutions. It may be noted that the earliest minerals to form, the quartz and sericite, together with the sulphides of iron and copper, were the same for both deposits, whereas the minerals present in the Cactus deposit and not in the $\mathrm{O} K$ deposit were for the most part of later formation (see p. 121), suggesting that the Cactus deposit passed through a longer and more varied period of mineralization.

In order to give a clear idea of these deposits, which show a close relation to deposits of wide distribution in the West but which in some respects are rather unusual, a detailed description of the mineralization in the Cactus and $\mathrm{O} \mathrm{K}$ ore zones is presented below.

ORE AND GANGUE MINERALS IN THE CACTUS ORE ZONE.

The principal metallic minerals in the Cactus ore zone are pyrite, chalcopyrite, and hematite, with small amounts of tetrahedrite, bornite, covellite, galena, cosalite, limonite, goethite, pyrolusite, malachite, and native copper. The important gangue minerals are sericite, quartz, carbonate, tourmatine, anhydrite, gypsum, and barite, with small amounts of rutile and apatite.

Pyrite occurs, together with other minerals, filling open spaces between breccia fragments and replacing the monzonite. It is found both massive and in well-formed crystals. The crystal form is usually a combination of the cube and pentagonal dodecahedron. The pyrite is of variable importance in different parts of the deposit. At some points it is the principal metallic mineral, as near the machine shop on the sixth level, whereas at other points it is of relatively slight importance.

Chalcopyrite, like pyrite, occurs both as a filling of open spaces and replacing monzonite. It is usually massive, though in the open spaces in the upper levels are seen many well-formed tetrahedrons of chalcopyrite (Pl. XI, C, p. 96).

Hematite occurs most commonly as micaceous crystals in the open spaces and inclosed in the later minerals, though it is in part in more massive form inclosed in siderite and associated with sulphídes. It is also present in small quantities in the altered monzonite. Much of the hematite is slightly and some of it rather strongly magnetic. Dana states in his "System of mineralogy" that the magnetic property of some hematite is probably due to the admixture of magnetite. If this is true, the Cactus ore deposit contains considerable magnetite.

Tetrahedrite is of relatively slight importance. That observed by the writer is massive and formed contemporaneously with the later vein minerals. Bornite has been reported from the deposit but was not seen by the writer. 
Galena is reported to have been present in small amounts in the high-grade ore, and a little was collected by the writer from the seventh level of the mine. It was deposited with the later minerals. Cosalite was seen at but one point on the seventh level. It was deposited contemporaneously with the later minerals. Covellite was observed coating chalcopyrite on the first level but is of no importance as an ore mineral.

Limonite is abundant at the outcrop of the deposit but extends only a short distance below the surface. Much of it is in well-preserved pseudomorphs after pyrite and carbonate, but some of it is in fibrous botryoidal masses inclosing cores of chalcopyrite or lining open cavities. At the surface most of the quartz crystals are covered by a thin coating of limonite. Most of the limonite contains manganese.

Goethite was noted in several specimens in the zone of oxidation, as a rule closely associated with partly altered sulphide.

Pyrolusite was not observed as a pure mineral, but manganese is present in most of the limonite in the zone of oxidation. Malachite is present in the zone of oxidation, occurring usually as small, irregular masses of radiating crystals deposited in open spaces. Less commonly it is in more massive form filling the spaces between other minerals.

Native copper is reported as occurring in the zone of oxidation but was not observed by the writer.

Sericite, the finely crystalline form of muscovite, is a principal constituent of the altered monzonite and one of the most abundant gangue minerals in the ore.

Quartz is an abundant constituent of the altered monzonite and also occurs in well-formed crystals in the open spaces, being abundant in this form in the upper levels of the mine. In many places it incloses crystals of tourmaline (see Pl. XI, $B$, p. 96) and hematite.

Tourmaline occurs most abundantly as tufts of radiating crystals projecting outward from the breccia fragments and in places inclosed in the later minerals. It is present in small quantities in the altered monzonite. It is very dark brown in color, appearing nearly black as seen in the ore. Under the microscope it shows pleochroism from dark brown to a very dark blue. The tourmaline has a density between 3.18 and 3.19 , which corresponds to an iron tourmaline containing but little magnesium.

Siderite occurs in irregular masses with other minerals in the spaces between the breccia fragments and to a slight extent in the altered monzonite. It is an impure variety composed of an isomorphous mixture of iron, manganese, magnesium, and calcium carbonates. A specimen from the seventh level analyzed by George Steiger gave the following percentages of the different component molecules: Siderite, 55.10; rhodochrosite, 23.98; magnesite, 16.88; calcite, 2.00 ; anhydrite, 0.95 ; insoluble, 0.37 . The carbonate probably varies considerably in composition at different points in the mine, but the above analysis doubtless closely represents the general composition of the mineral. It is evidently a manganese-magnesium siderite, but may be referred to simply as siderite. The mineral has the typical rhombohedral cleavage of the carbonates. It varies considerably in color at different points in the mine. On the lower levels it is rather light grayish brown, but locally in the upper levels it is dark brown. The dark color is probably due to incipient alteration. A little carbonate occurs in veins cutting the siderite. This is lighter colored and probably contains less iron and more lime.

Anhydrite occurs with other minerals between the breccia fragments, usually in irregular masses, though tabular crystals are common. It has cleavage in three directions at right angles, though the cleavages are not equally perfect. Usually the color is pale lilac, though in some places it is pale blue. An approximate analysis by W. T. Schaller of material collected by Waldemar Lindgren ${ }^{1}$ gave the following composition: Lime, 39.84 ; sulphuric anhydride, 55.89; loss on ignition, 3.57. The freshest material shows some alteration to gypsum, and undoubtedly considerable gypsum was present in the material analyzed. Anhydrite was found in the mine from the second to the ninth level. A large part of that originally present, however, has altered to gypsum. This alteration takes place readily and can be seen in the freshest specimens. It begins along the cleavage planes (Pls. XIII, XIV, A, p. 107) and proceeds outward until the

${ }^{1}$ Lindgren, Waldemar, Anhydrite as a gangue mineral: Econ. Geology, vol. 5, 1910, p. 522. 
whole area between the cleavage cracks is altered. In some places white granular gypsum is formed, but commonly the anhydrite is converted into clear plates of selenite inclosing the minerals originally inclosed in the anhydrite. (See Pl. XIII, D, p. 106.)

Gypsum, besides being present as pseudomorphs after anhydrite as just described, is abundant as veins of fibrous gypsum through the ore zone. In this form also it has probably resulted in part from the alteration of anhydrite but has been carried from its original position in solution and deposited in later fissures. Some gypsum has doubtless resulted from the reaction of sulphuric acid with the carbonate gangue of the ore.

Barite is not plentiful in the mine as a whole, but is reported as being rather abundant associated with the high-grade ore. Rutile and apatite occur only in small quantity as microscopic constituents of the altered monzonite.

The diagram presented in figure $10^{1}$ shows the relative period of formation of the principal primary ore and gangue minerals. Three periods of mineral formation may be distinguished. Some of the minerals were formed throughout the time of deposition, and for some other minerals there is more or less overlap in the several periods which it is not always possible to estimate more than approximately. Each period, however, is so distinguished by the formation of certain minerals as to give a rather clear-cut division between the principal periods of deposition.

The first alteration in the monzonite produced by the mineralizing solutions was the formation of sericite and quartz with lesser amounts of other minerals. The altered rock all contains small amounts of pyrite and probably chalcopyrite, though it is not certain that chalcopyrite began to form as early as pyrite. Hematite or magnetite is also universally present and doubtless began to form at an early period from the alteration of iron-bearing minerals. Siderite is present in all the specimens of altered monzonite examined, but from its close association with the iron ore it is believed to have resulted from the alteration of hematite or magnetite and therefore began to form later than the iron ore.

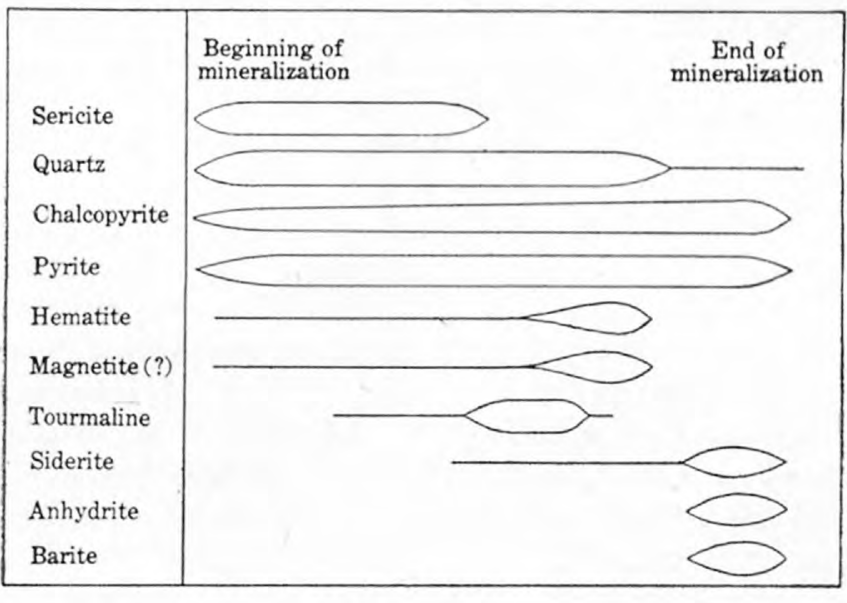

Figure 10.-Diagram showing the relative period of formation of the principal ore and gangue minerals of the Cactus ore zone. Tourmaline is present in the sericitized monzonite but is very largely confined to fissures, the line between the tourmaline and the altered monzonite usually being perfectly sharp, and in many places the two are separated by a zone composed of small quartz crystals attached to the monzonite wall and pointing into the fissure. The sericitization of the monzonite must have been nearly completed before the deposition of the tourmaline, as it is hardly probable that the solutions which brought in the tourmaline could have penetrated and altered the wall rock to any considerable extent without depositing tourmaline. The beginning of the deposition of tourmaline in notable amount may be considered as marking the close of the first distinct period in the alteration. In this period the monzonite was converted into sericite and quartz and the change was accompanied by the deposition of pyrite, chalcopyrite, and small amounts of iron ore, siderite, and tourmaline.

This period was followed by the abundant deposition of tourmaline and hematite in the open fissures. In general, the main deposition of tourmaline seems to have preceded the main deposition of hematite, much of which contains needles of tourmaline. Some of the hematite, however, is free from tourmaline and it is probable that the two minerals were being deposited at the same time, the formation of tourmaline being more active in the early part of the period and that of hematite in the later part. Quartz, pyrite, and chalcopyrite were deposited through-

${ }_{1}$ This method of indicating the relative period of formation of minerals has been used by J. E. Spurr (Twenty-second Ann. Rept. U. S. Geol. Survey, pt. 2, 1901, p. 840). 
out this period. Many of the well-formed quartz crystals present in the open cavities inclose branching tufts of tourmaline, as shown in Plate XI, $B$ (p. 96), and are therefore distinctly later. The deposition of quartz continued somewhat later than that of tourmaline and possibly later than that of hematite. The second period may be considered as closing when the important deposition of quartz ceased. At the close of this period the open fissures had been partly filled with quartz, tourmaline, hematite, chalcopyrite, and pyrite.

The second period was followed by one in which pyrite, chalcopyrite, tetrahedrite, galena, siderite, anhydrite, and barite were deposited. As has been noted, the deposition of siderite probably began much earlier, but it certainly was not formed in considerable amounts until after the deposition of tourmaline and hematite, and the last-named minerals have in none of the specimens examined been found to be later than anhydrite or barite. In all the specimens of tetrahedrite examined, this mineral was formed contemporaneously with the later minerals mentioned above, though possibly it may occur as a secondary mineral in the mine. The galena was also deposited in the later period of mineralization. Cosalite was noted in only one specimen from the seventh level, in which it was formed contemporaneously with siderite and anhydrite.

At first it seems difficult to account for this unusual association of minerals in the light of present knowledge of their modes of occurrence, as determined by studies of other deposits and experimental data.

The alteration of the first period, namely, the sericitization of the monzonite and the deposition of sulphides with the formation of small amounts of iron ore and carbonates, is in general similar to the alteration described as occurring in many other localities and may be attributed, with a good deal of assurance, to the action of heated aqueous solutions that have separated from the monzonite magma.

The alteration of the second period, consisting of the continued deposition of quartz and sulphides and in addition the deposition of tourmaline and hematite, may well be attributed to the same agency, though there was probably a change in the composition of the solutions and possibly also in the physical conditions under which the minerals were formed. It is hardly likely that the solutions that effected the sericitization of the monzonite could have carried a large amount of tourmaline or iron in solution without depositing considerable amounts throughout the altered zone, and it seems equally unlikely that the later solutions would have been so generally confined to the open fissures and have entered and replaced the wall rock to so slight an extent had the same physical conditions persisted through both periods.

It seems reasonably certain that there was a change in the composition of the ore solutions before the second period, possibly due to further differentiation, and that there was a physical change which may be attributed to a decrease in either temperature or pressure or both. A marked decrease in pressure would decrease the tendency of the solutions to penetrate the wall rock, and if the temperature was lowered sufficiently to allow the solutions to pass from the gaseous to the liquid state, this tendency would be further decreased. It does not seem probable, however, that the solutions depositing the tourmaline were liquid, as this mineral is characteristic of deposits formed at high temperature, probably above the critical temperature of water.

The third period, during which siderite, anhydrite, and barite were deposited, together with the continued deposition of pyrite, chalcopyrite, and small amounts of other metallic minerals, would be most naturally considered as a continuation of the first two periods, the chemical character of the solutions and the physical conditions having undergone further change.

Siderite, from its association with minerals in other localities, is known to form under conditions varying from those of the high temperature and pressure of deep-seated veins to the reverse in deposits formed near the surface. It might well form throughout periods of varying conditions, as it appears to have formed in this deposit.

Barite is stated by Lindgren ${ }^{1}$ to form in the deeper vein zone and the middle and upper vein zone, and W.H. Emmons ${ }^{2}$ says that it occurs in deposits which have formed at moderate

1 Lindgren, Waldemar, The relation of ore deposition to physieal conditions: Econ. Geology, vol. 2, 1907, p. 125.

2 A genetic classification of minerals: Econ. Geology, vol. 3, 1908, p. 618. 
and shallow depths. There is little doubt that barite usually forms under conditions of less heat and pressure than tourmaline. The sulphides are known to form under varying conditions, so that as far as the minerals characteristic of the third period thus far discussed are concerned, it might reasonably be supposed that they were deposited by solutions that came from the same source as those depositing the earlier minerals, but under conditions of less heat and pressure, and that had undergone some change of composition from further differentiation. The presence of anhydrite in the deposit, however, seems in some ways opposed to such a conclusion. Anhydrite is apparently unusual as a gangue mineral, only one other occurrence in this country having been described - that in the Bully Hill district, ${ }^{1}$ Shasta County, Cal., where the physical conditions are believed to correspond to those of the middle vein zone, namely, conditions of moderate heat and pressure. Experiments indicate that anhydrite would not be deposited from a cooling solution. The experimental data concerning this mineral have been summarized by Arthur C. Melcher ${ }^{2}$ in an article describing experiments to determine the solubility of certain minerals at different temperatures and need not be repeated here. The accompanying diagram (fig. 11), taken from the publication cited, shows the change in solubility at different temperatures. It is evident from this diagram that anhydrite, contrary to the general rule for minerals, decreases in solubility with increase in temperature, the decrease being very rapid up to $100^{\circ}$, and that at $218^{\circ}$ the mineral is practically insoluble. Whether these conditions exist in a complex solution such as that depositing ores and under considerable pressure can not be stated, but if they do, highly heated solutions could carry but very small amounts of anhydrite and there would be no tendency to deposit it as the solutions become cooler.

Several conditions may be assumed under which the mineral may have formed. First and most naturally, it may be supposed to have come up with the ore solutions and have been deposited in the fissures together with its accompanying minerals, the deposition being brought about by a decrease in temperature and pressure. But if its behavior in nature is similar to its behavior in the laboratory and its decrease in solubility continues to high temperatures, this would not take place, as a solution that was saturated at a high temperature would be below the saturation point when a lower temperature

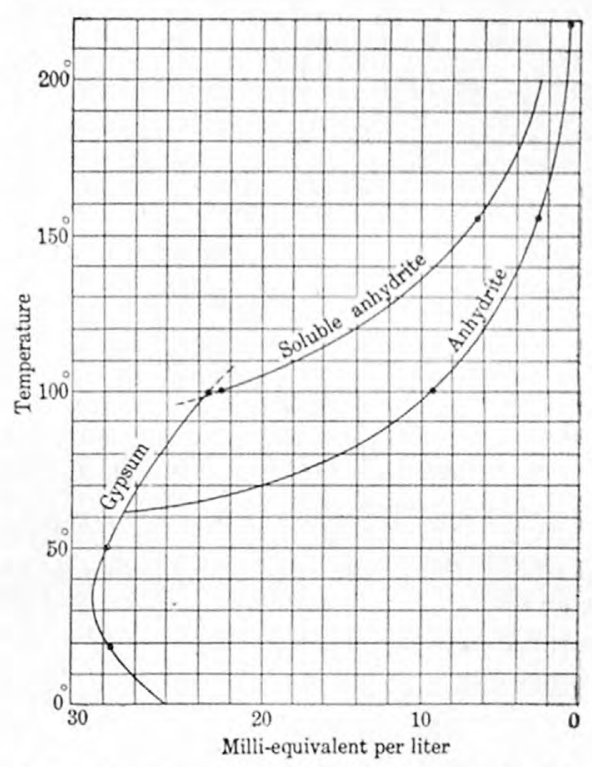

Figure 11.-Curve showing the solubility of anhydrite at varying temperatures. was reached; moreover, a solution at high temperature would carry but very little anhydrite.

Second, it may be supposed that the ascending ore solutions contained free sulphuric acid or sulphates other than calcium sulphate, which reacted with calcium compounds in a region where the temperature was at least moderately high, and the resulting calcium sulphate, being nearly insoluble at such a temperature, was deposited. That free sulphuric acid was present in the ascending ore solutions is unlikely, for the alteration of the wall rock does not show its action. That sulphates other than calcium were present is probable, but a source of calcium to react with these sulphates in the ore zone to form anhydrite must be postulated. The lime was very largely removed from the monzonite in the early stages of alteration, as shown by the analyses of the altered rock, and no other source of calcium aside from the ore solutions themselves seems to be available, unless it is assumed that circulating solutions brought in calcium leached from the monzonite or limestone outside of the ore zone.

Third, the anhydrite may be supposed to have been formed by descending solutions carrying either calcium sulphate in solution or sulphuric acid, which reacted with calcium com-

1 Graton, L. C., The occurrence of copper in Shasta County, Cal.: Bull. U. S. Geol. Survey No. 430, 1910, p. 100.

2 Jour. Am, Chem. Soc., vol. 32 , 1910, pp. 50-66. 
pounds in the ore solutions. The formation of sulphate minerals by descending solutions below the zone of oxidation has been discussed recently by Ransome, ${ }^{1}$ who has shown that two methods of formation of sulphuric acid are to be considered-first, that it has resulted from the oxidation of sulphides at higher levels; second, that it is the result of the oxidation of the hydrogen sulphide of the ore solutions at and near the surface. The sulphuric acid thus formed has subsequently leached back and mingled with the rising solutions.

In the case of the Cactus ore deposit, either of these methods might be considered so far as the formation of anhydrite alone is concerned. Sulphuric acid formed from the oxidation of sulphides might have reacted on limestone, which is present a few thousand feet from the present outcrop, forming calcium sulphate. In passing to lower levels and regions of higher temperature, the sulphate would become more insoluble and be deposited. The same result would be brought about if the sulphuric acid had been formed from hydrogen sulphide. In either of these modes of formation the later minerals must have formed while the ore zone was still at a moderately high temperature and doubtless before ascending solutions had entirely ceased. The descending solutions carrying sulphate would meet the ascending solutions carrying hydrogen sulphides and alkali sulphides. The metals would be deposited as sulphides, while calcium sulphate, whether descending into a zone of greater heat or formed in a heated zone by reaction of the solutions, would be deposited as anhydrite. Such a formation of ore, as Ransome has pointed out, would be likely to occur only near the surface.

Lindgren, ${ }^{2}$ who first called attention to anhydrite in this deposit, gives the following suggestion ${ }^{3}$ as to its origin:

It is suggested as a possibility that during the later part of mineralization the anhydrite was precipitated by a reaction between ascending solutions of sodium sulphate and descending solutions containing calcium carbonate.

The formation of sodium carbonate and gypsum under surface conditions has been attributed to a reaction between calcium bicarbonate and sodium sulphate. ${ }^{4}$ If the reaction took place at a high temperature, anhydrite would doubtless form.

In considering the foregoing hypotheses to determine the one most probably accounting for the ore formation, it seems that certain of them can be eliminated. If it is accepted that anhydrite in a complex ore solution in nature and in a simple solution in the laboratory behaves similarly, the theory that the anhydrite came up in the ore solutions is untenable. It also seems doubtful that lime was present in considerable amounts in the ore solutions, for the alteration produced by these solutions nowhere indicates that they carried much lime, but rather that they extracted lime from the wall rocks. The siliceous differentiation of the magma with progressively decreasing calcium content, of which the ore deposits are the final phases, indicates that calcium would be practically absent from the ore solutions. It is possible, however, that lime may have been taken into solution from the wall rock at greater depth. If the ascending solutions did not carry the lime it must have been present in the ore zone or have been derived from descending solutions. As the early alteration of the monzonite resulted in the removal of practically all the lime from the ore zone, there remains the hypothesis that the lime must have been derived from descending solutions. These would most naturally be either sulphate or bicarbonate solutions. As the deposition of sulphates closely followed that of tourmaline and specularite, it is likely that the latest mineralization must have taken place at considerable depth, and it seems more probable that descending solutions carrying bicarbonate of lime would have found their way into the ore zone and reacted with alkaline sulphates in the ascending solutions to form the anhydrite than that solutions carrying calcium sulphate should have reached such a depth with notable amounts of calcium sulphate still in solution.

This conclusion must be regarded, however, as only tentative. The anhydrite in Shasta County, Cal., appears to have been deposited directly from ascending solutions, and it is not safe to place too much reliance on the results of experiments conducted under conditions known

\footnotetext{
1 Ransome, F. L., The geology and ore deposits of Goldfield, Nev.: Prof. Paper U. S. Geol. Survey No. 66, 1909, pp. 189-195.

${ }^{2}$ Lindgren, Waldemar, New occurrence of willemite and anhydrite: Science, new ser., vol. 28, 1908, p. 933.

¿Lindgren, Waldemar, Anhydrite as a gangue mineral: Econ. Geology, vol. 5, 1910, p. 522.

4 Clarke, F. W., The data of geochemistry, 2d ed.: Bull. U. S. Geol. Survey No. 491, 1911, p. 229.
} 

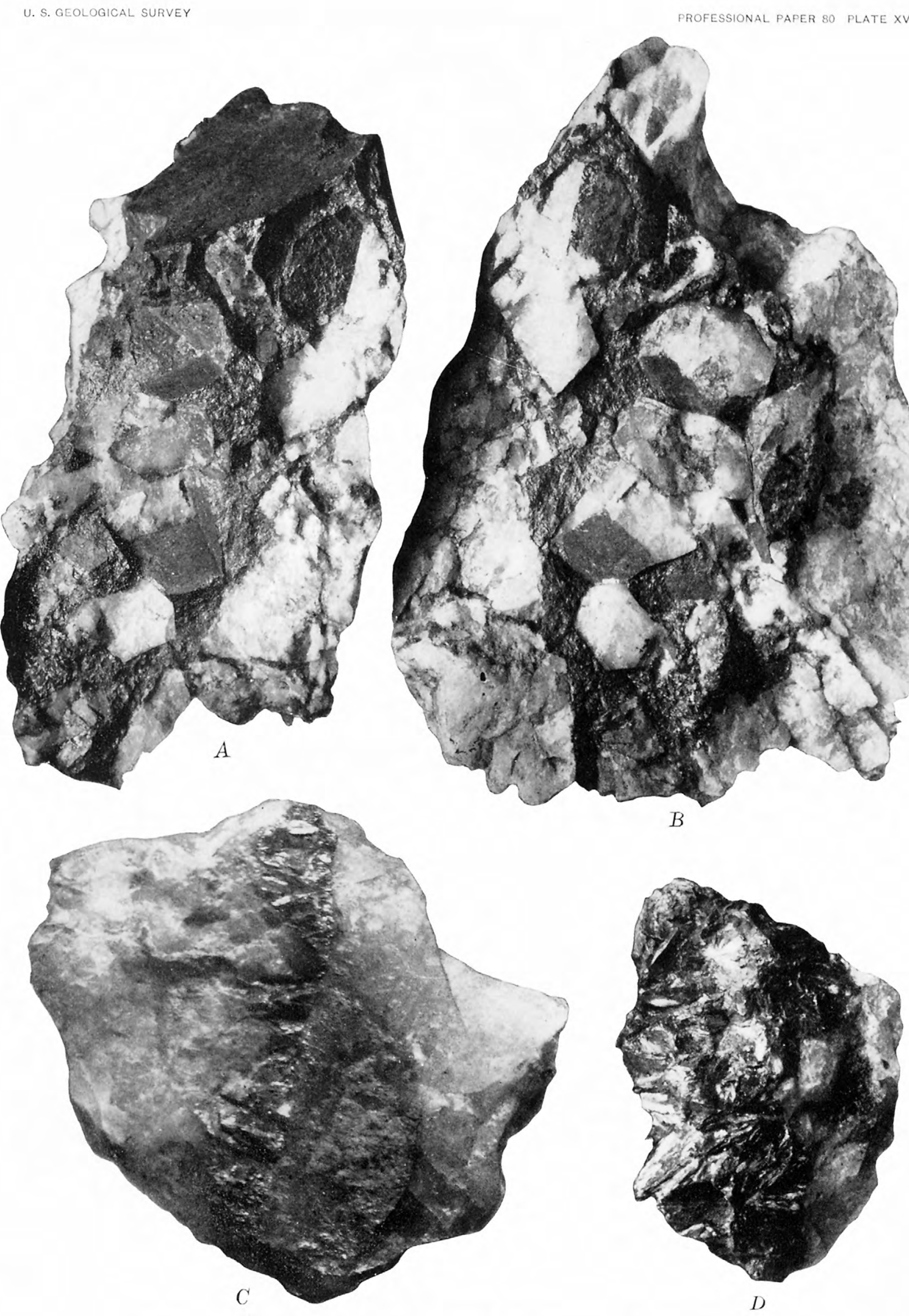

4. B. SPECIMENS CONTAINING INTERSTITIAL CHALCOPYRITE. NATURAL SIZE. (, l). SPECIMENS CONTAINING MOLYBDENITE.

COARSE PEGMATITIC QUARTZ, OK MINE. 

to be so different from those under which the minerals were formed in nature. More examples are needed before generalization will be justified.

The ores of the Cactus mine show rather marked differences in character at different depths. On the upper levels there is much more open space between the breccia fragments and the ore minerals have very largely formed as a filling between these fragments. At greater depth the breccia fragments are generally smaller, there is less space between them, and the ore minerals have formed to a much greater extent as a replacement of the monzonite and to a correspondingly less extent as a filling of open spaces. This change of the ore with increasing depth is more fully discussed in the description of the Cactus mine (p. 172).

There is also a difference in mineralization in different parts of the zone that seems to correspond in a general way to the periods of formation of different minerals - that is, some blocks of ground in the mine show slight alteration by the ore solutions, others show strong sericitization but contain none of the later minerals, and still others show sericitization and carry abundant tourmaline but do not contain the later minerals. It is believed that this difference is due to the fact that slight movements were taking place in the zone during the process of mineralization and that the gouges formed as a result of these movements have from time to time deflected the mineralizing solutions from certain areas. This difference in mineralization is also more fully discussed in the description of the Cactus mine (p. 175).

ORE AND GANGUE MINERALS IN THE O K ORE ZONE.

The primary ore and gangue minerals in the $\mathrm{O} \mathrm{K}$ ore zone are in general similar to the earlier minerals in the Cactus zone. The principal primary ore minerals are pyrite, chalcopyrite, and molybdenite; the gangue minerals are quartz and sericite.

The quartz of this deposit is in part the result of alteration of the quartz monzonite of the wall rock and in part coarsely crystalline quartz that has been deposited in open cavities. (See fig. 12.) The quartz of the latter type forms an irregular "chimney"-like body that has been opened to the fourth level. The dimensions and shape of this body vary at different points, but the maximum diameter observed exceeds 100 feet. The quartz is in large crystals, some having a maximum diameter of 10 inches, and many individuals 2 feet in length were seen. The body as a whole strongly resembles a coarse pegmatite, though no feldspar or mica was seen. Extending from this body into the wall rock are veins of quartz that divide and subdivide till they gradually disappear. The quartz that has resulted from the alteration of the wall rock is similar to that in the Cactus ore deposit (p. 120).

Sericite occurs as an alteration product of the quartz monzonite, similar to that of the Cactus mine. This alteration is described on page 74 .

Chalcopyrite is present to some extent in the "chimney" of pegmatitic quartz, having

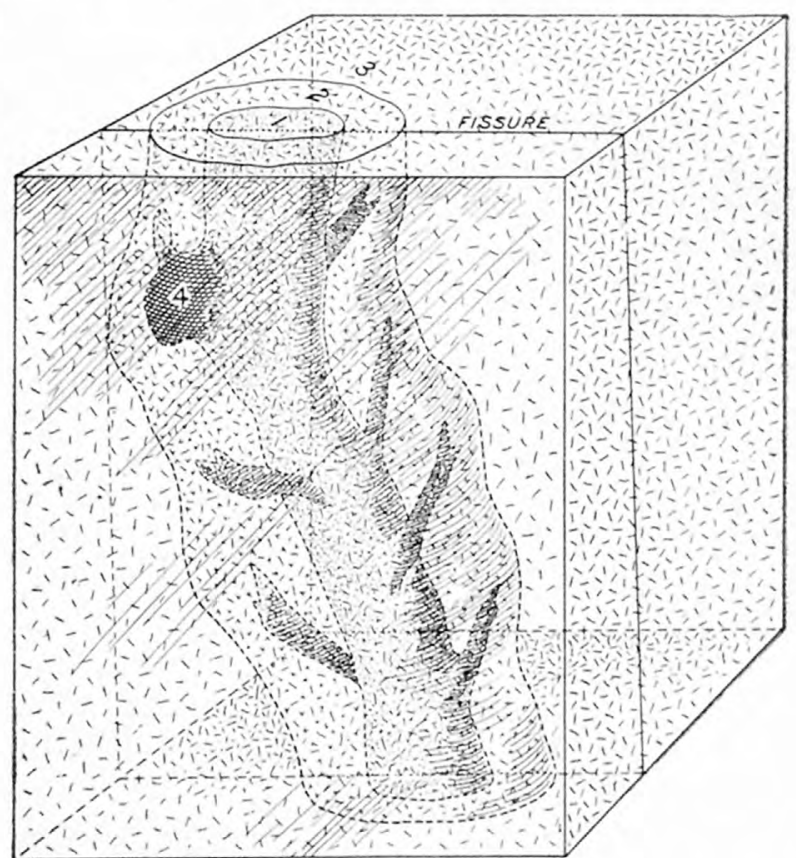

FIGURE 12,-Generalized stereogram showing the relation of pegmatitic quartz and altered and mineralized quartz monzonite in the $\mathrm{O} \mathrm{K}$ mine. 1, Pipe of quartzite; 2 , altered monzonite; 3 , monzonite; 4 , high-grade ore. formed for the most part later than the quartz and occupying spaces between the quartz crystals (Pl. XVI, $A, B$ ), though to a slight extent it is inclosed in the quartz. In the veins of quartz extending from the main body in to the wall rock the relative proportion of chalcopyrite is much greater, and in general the proportion of sulphide increases with the distance from the main 
quartz body. In the irregular ore body above the second level, which is more fully discussed in the description of the mine (p. 189), the relative proportion of sulphide was much greater than the normal for the quartz body. Chalcopyrite also occurs in small veinlets and grains disseminated through the altered wall rock.

Pyrite is similar in occurrence to chalcopyrite but is not abundant in the mine. Molybdenite also occurs in a similar manner, occupying spaces between the quartz crystals (Pl. XVI, $C, D)$. Both the molybdenite and the chalcopyrite were probably being formed at the same

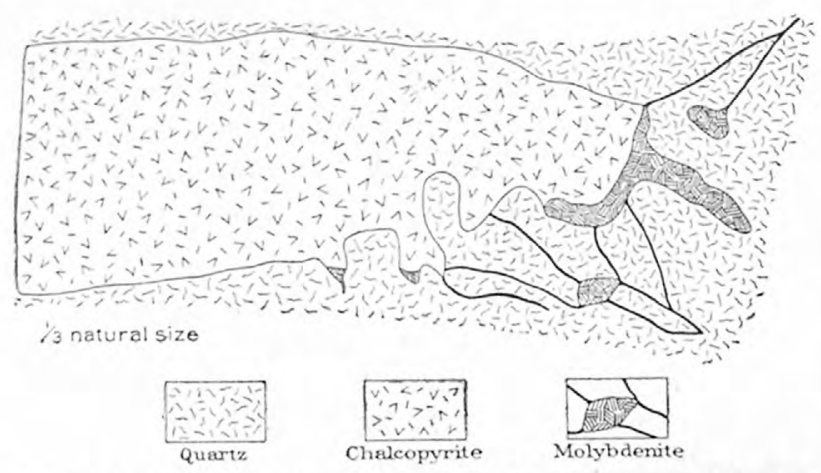

Figure 13.- Sketch near the end of small quartz sulphide vein, $\mathrm{O} \mathrm{K}$ mine, showing the relation of chalcopyrite and molybdenite. time, but in the smaller veins the molybdenite shows a tendency to form near the terminations of the veins (fig. 13), and where molybdenite is abundant chalcopyrite is usually absent or scarce. In some places molybdenite has formed in fissures in the chalcopyrite, indicating that in part it is the later mineral of the two.

Both molybdenite and chalcopyrite are present as original minerals in what appears to be an aplite dike encountered in the lowest workings of the mine. The "dike" rock is composed of quartz, orthoclase, and the sulphides. The rock shows but slight alteration, and there is little doubt that it is an aplitic dike, though the developments did not disclose the relations clearly.

Secondary alteration has played an important part in the formation of this deposit, but is discussed on page 139 and need not be considered here.

\section{STRUCTURE OF THE DEPOSITS.}

The two deposits of this type that have been sufficiently developed to reveal their structural relations show many similarities. Both are connected with movements that have resulted in brecciation of the rock, but so far as determined not in extensive displacement. In form both are "chimney"-like deposits. This characteristic is best shown in the $\mathrm{O} \mathrm{K}$ mine, where the ore channel consists of a chimney of coarsely crystalline quartz closely resembling in general structure a coarse pegmatite, though the feldspar common to pegmatite is not present. The rock surrounding this quartz chimney has been altered (sericitized) and mineralized, and veins of the quartz extend from the chimney in to the adjacent rock. These veins split up into small veinlets at a distance from the main chimney. In general the wall rocks show a gradual decrease in the amount of alteration as the distance from the ore channel increases. It is notable also that the wall rock near the channel is highly silicified. Many of the fragments of the monzonite in the quartz chimney and in the larger veins are rounded in outline and show pronounced corrosion by the altering solutions. The shape of the deposit and the character of the alteration suggest that the quartz and accompanying minerals were not deposited in an open space formed by dynamic movements, but that the solution dissolved the material of the wall rock and thus gradually enlarged its channel. Later, as the chemical action became less vigorous, the space thus formed was filled by the quartz and other minerals deposited from the solutions. It may be recalled at this point also that at the bottom of the $\mathrm{O} K$ shaft there is what seems to be an aplitic dike composed of quartz and orthoclase, with chalcopyrite and molybdenite formed contemporaneously.

The Cactus ore deposit has many of the characteristics just described. The rock has been brecciated (see Pls. XVII, XVIII) apparently by slight movement, as no considerable faults can be traced from the ore zone. Solutions passing through this breccia zone have greatly corroded the rock, so that in places the fragments have the appearance of rounded bowlders. In this manner the amount of open space must have been greatly increased. Later this space was largely filled by ore and gangue minerals. 


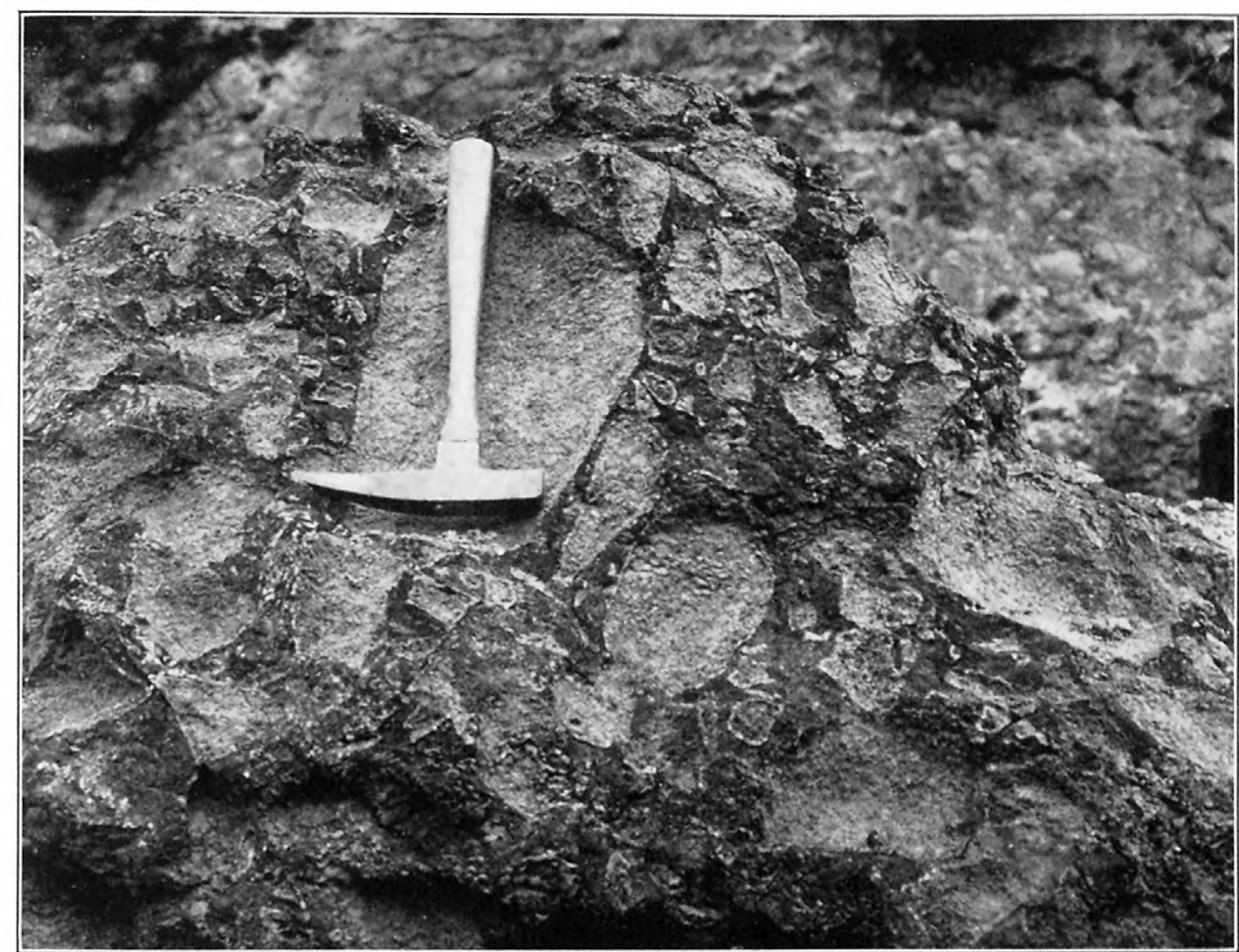

A. BRECCIA ORE, CACTUS GULCH.

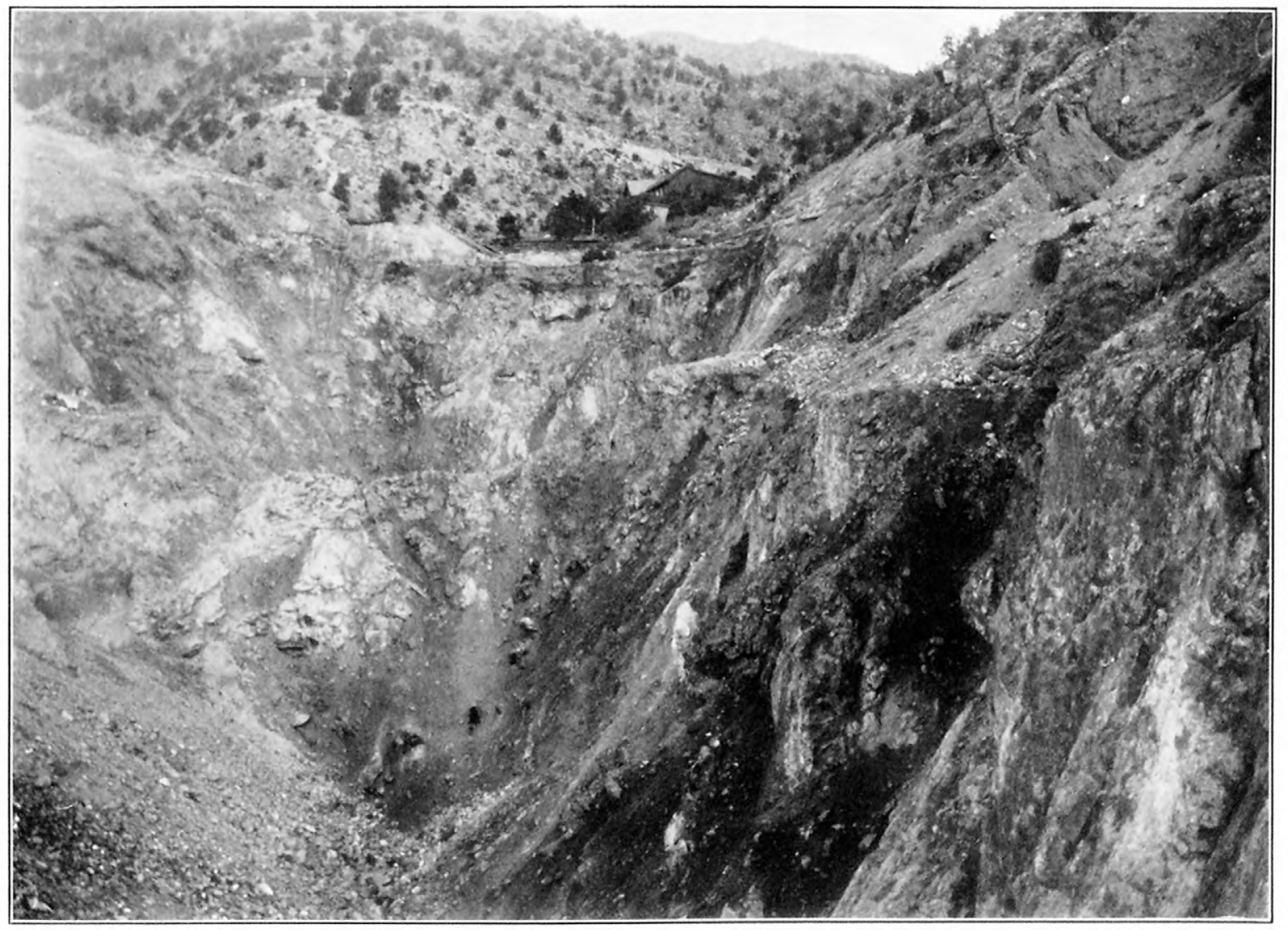

B. GLORY hOLE, CACTUS Mine. 


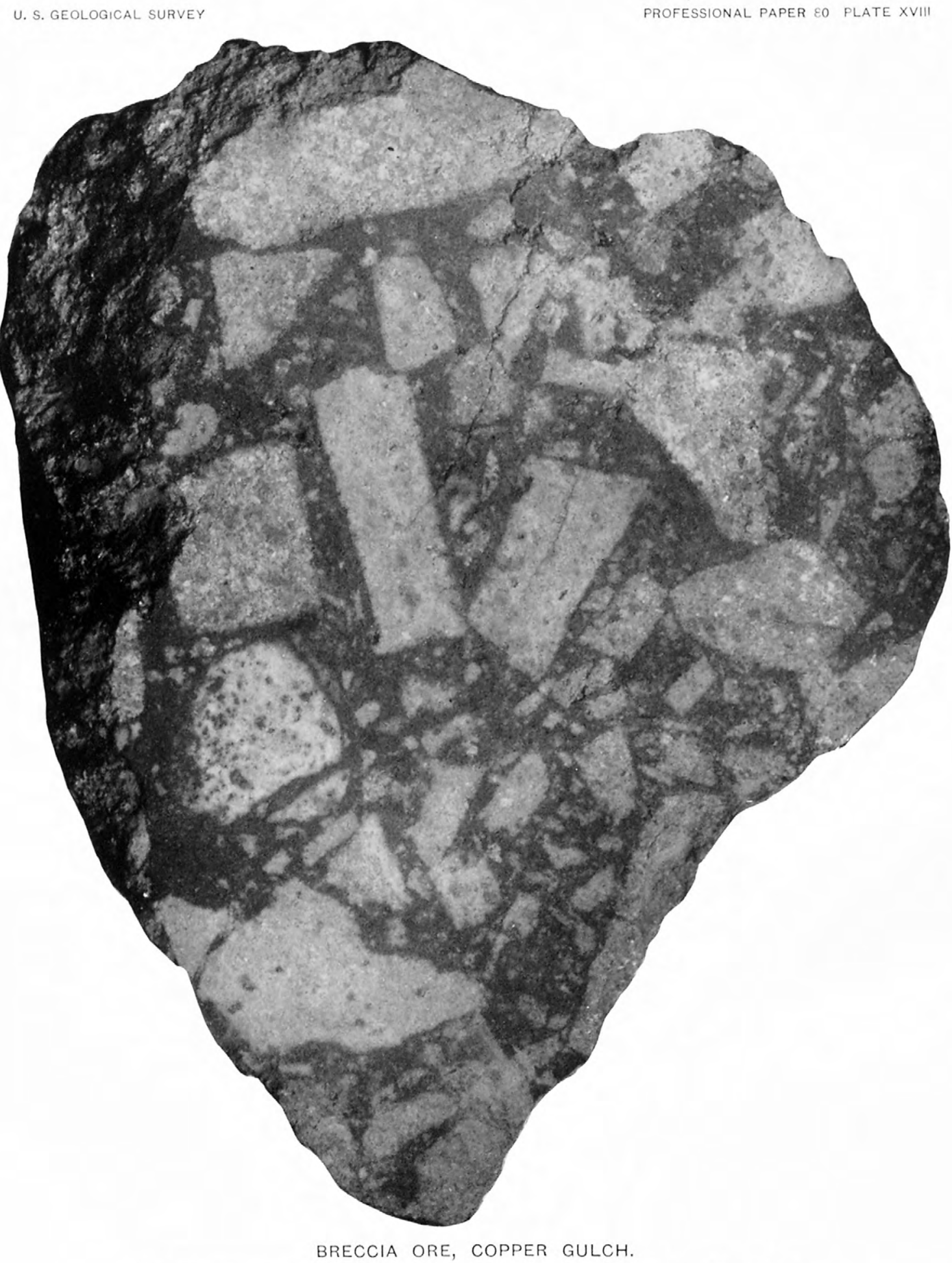

Dark areas tourmaline, light-gray areas altered quartz monzonite. Natural size. 
In the Cactus ore zone there was no channel noted where the solution had been so complete as in the quartz "chimney" of the O K mine, as the solutions seem to have been less confined, and as a result they spread over a arger area and the action was less vigorous in any one channel.

In both deposits there have been slight movements since the deposition of the ores, resulting in crushing and slickensiding of the ores along the planes of movement. The most important feature of the movements that took place before and during the deposition of the ores was the formation of impervious gouges that deflected the ore solutions, as is noted in the description of the Cactus mine.

The secondary alteration by surface waters in this type of deposit has been variable. In the Cactus deposit it has been slight and below the 100-foot level has had little effect except in the formation of gypsum. At the surface the iron and copper sulphides have been altered to hydrous oxides and carbonates, with some native copper, and the mixed carbonate has been altered to hydrous oxide of iron and manganese. There has been practically no sulphide enrichment of the copper ores.

In the $\mathrm{O} \mathrm{K}$ mine, on the other hand, alteration has gone on to a much greater depth. The surface alteration has been similar in character, the iron and copper sulphides being altered to hydrous oxides and carbonates, though much of the copper content has been carried to lower levels and redeposited in a zone of sulphide enrichment. The enrichment of the deposits is more fully discussed in another place (p. 139).

\section{SIMILAR DEPOSITS IN OTHER DISTRICTS}

Deposits similar to those described above have been noted at several widely separated points and a brief summary of them may be of interest. No systematic attempt has been made to include references to all deposits of this character that have been described.

A number of quartz-tourmaline-chalcopyrite deposits similar to that of the Cactus mine have been described. From a summary of such deposits by Lindgren ${ }^{1}$ the following is quoted:

In the type of veins distinguished by a gangue of tourmaline and quartz the country rock is generally subject to strong metasomatic changes. The vein-forming agents, which contained boron and some fluorine, appear to have attacked the adjoining rock strongly and caused a more or less complete metasomatic conversion into tourmaline. Von Groddeck ${ }^{2}$ has described an occurrence of this kind from Tamaya, chile, in which veins containing copper ores cut gabbro and porphyrites. The tourmaline is here not only present in the filling of the fissure but is also distributed through the adjoining country rock. A further contribution to the knowledge of veins carrying tourmaline was given by $A, W$. Stelzner ${ }^{3}$ in his description of occurrences of this kind from chile. The rocks examined, from the mining district of Las Condes, 90 miles east of Santiago, consist of granite and greenish porphyritic rocks, which the author is inclined to consider as altered andesites. The vein filling was pyrite, chalcopyrite, quartz, and a loose porous mass of tourmaline needles. By a specific-gravity separation of the latter, Stelzner obtained, as a residue, zircon in welldeveloped crystals, as well as specularite and anatase. The zircon is probably developed under the influence of the vein-forming solutions, the anatase and specularite quite certainly so. Again the fact is emphasized that the adjoining country rock is bleached and filled with pyrite and tourmaline.

Dr. E. Hussak ${ }^{4}$ has recently described the auriferous quartz vein of Passagem, in Minas Geraes, Brazil. This vein, which lies, parallel to the stratification, between mica schist and itabirite (hematite-mica schist), shows a filling of quartz, tourmaline, and arsenopyrite, with smaller quantities of pyrite and pyrrhotite. The arsenopyrite is strongly auriferous. A very interesting feature is the occurrence of zircon and monazite in the ore, formed apparently simultaneously with it. Here too the tourmaline is present in the adjoining country rock. Muscovite or sericite is also described as very plentiful in the schistose rock adjoining the vein. Certain crystals of andalusite, occurring (as inclusions?) in the vein, are completely altered into sericite, rutile, arsenopyrite, and pyrite. * * *

Again, similar deposits have been described from Meadow Lake, Nevada County, Cal. ${ }^{5}$ where granitic and dioritic rocks contain fissure veins with pyrite, arsenopyrite, pyrrhotite, zinc blende, and various secondary copper ores, indicating primary chalcopyrite in a gangue of quartz and tourmaline, with which some yellow epidote is usually associated. Chlorite is also common in the gangue, as well as a brown mica, probably biotite. A colorless mica and a little calcite were also observed. In contrast to the usually clearly defined fissure veins of the gold belt of California, in which the quartz filling is the predominant ore, these veins show very irregular and undefined walls, and it is clear that the mineral-forming solutions rose along very narrow fissures, from which they penetrated more or less deeply

1 Lindgren, Waldemar, Metasomatic processes in fissure veins: Trans. Am. Inst. Min. Eng, vol. 30, 1901, pp. $626-643$.

${ }_{2}$ Zeitschr. Deutsch. geol. Gesell., vol. 39, 1857, p. 237.

${ }^{3}$ Zeitschr. prakt. Geologie, 1897 , p. 41 .

${ }^{4}$ Idem, 1898, p. 345.

${ }^{6}$ Lindgren, Waldemar, Am. Jour. Sci., 3d ser., vol. 46, September, 1893, p. 201. 
in to the adjoining country rock and there, by metasomatic replacement, deposited the auriferous ores. One of these occurrences * * * shows a granitic rock traversed by a narrow fissure, from which an intense alteration has proceeded, converting the immediate rock in to an aggregate of quartz and tourmaline. * * *

Prof. Vogt ${ }^{1}$ describes certain veins in Telemarken, Norway, which he considers as related to the cassiterite veins proper. These contain chalcopyrite, bornite, and chalcocite, also a little native silver and gold, all associated with a gangue of fluorite, tourmaline, apatite, muscovite, and calcite. They are considered to be genetically connected with the granite in which they appear, and the presence of tourmaline and apatite certainly suggests their close relationship to normal cassiterite veins. The country rock is a normal biotite granite, with orthoclase, microcline, and oligoclase and no muscovite. The alteration extends for several feet on both sides of the veins, and all transitions are plainly visible. The first part of the process consists in a peripheric change of biotite to muscovite and a little epidote; then the feldspars are attacked, muscovite and quartz, together with a little calcite, forming on the cleavage planes; and finally the feldspars and biotite are entirely decomposed. The result is muscovite, quartz, calcite, rutile, zircon, and apatite, the latter two not altered but constituting the only material remaining fresh from the unaltered rock. A little fluorite, chalcopyrite, or bornite is also occasionally present in the product of alteration. Regarded from a chemical standpoint the process is not always the same. Sometimes, according to Vogt, substance is added; sometimes taken away. Quartz may occasionally prevail; at other places muscovite predominates. Prof. Vogt calls this altered rock a greisen, but the process of alteration as described by him is so nearly that of ordinary sericitic replacement that it may be questionable whether it would not be better to reserve the term greisen for the characteristic rock accompanying the cassiterite veins. The process of formation in the case of the Telemarken veins was probably not carried on under the extreme conditions attending the normal cassiterite veins.

Lindgren ${ }^{2}$ has described similar deposits in the Blue Mountains, Oreg., in part as follows:

The tourmaline type is characterized by chalcopyrite and pyrite associated with a gangue of quartz and tourmaline. The deposits form fissure veins or irregular replacements probably connected with fissures. Only two representatives of this type have been found.

The Copperopolis mine, on the east fork of Dixie Creek in the Quartzburg district, is the first. Brown fibrous tourmaline (blue and brown in thin section) is intimately intergrown with quartz, containing very abundant, mostly round aqueous inclusions. The quartz is in part normal coarse vein quartz, in part idiomorphic, in part finer-grained allotriomorphic. The latter as well as the intermixed dirty-brown tourmaline were formed by replacement of the country rock, a diabase. The chalcopyrite is intergrown with quartz and tourmaline.

The Jessie vein, in the Mineral district, is the second. This is a fissure vein in diorite, accompanied in the hanging wall by a dike of basalt. The vein matter is a black gangue with massive pyrite and chalcopyrite. Thin sections of the ore show a somewhat interlocking, fairly coarse aggregate of quartz, calcite, and dolomite, all in anhedral development. In addition, a mineral which greatly resembles vesuvianite is present, also chlorite and an acicular or prismatic blue or dirty-brown tourmaline. Thin steel-gray lamelle of specularite, single and in bunches, are embedded in both quartz and calcite. In translucent light the thin plates are deep red. Pyrite and chalcopyrite are intergrown with quartz, tourmaline, and specularite. The ore has been crushed, and along the cracks calcite has infiltrated.

This mineral combination is very remarkable for a fissure vein. Especially is the occurrence of specularite noteworthy. It emphasizes the opinion given in another place ${ }^{3}$ that the tourmaline veins are as a rule connected with deep-seated processes and formed under higher pressure and temperature than ordinary hydrothermal gold and silver veins.

The copper deposits owned by the Braden Copper Co. in the province of O'Higgins, Chile, are of this general type. These deposits have been described by Yeatman, ${ }^{4}$ who says:

The ore bodies occur around the periphery of the crater in the andesite, at its contact with the tuff. These occurrences represent andesite, which is more or less shattered and near the contact of the tuff often considerably brecciated, carrying the copper minerals in the cracks and openings.

The mineral was deposited after the time of great volcanic disturbance, "during the closing stages of igneous activity and is aqueo-igneous in development." The minerals making up the ore have been deposited from ascending hot solutions, mainly filling cracks or replacing some of the constituent minerals of the andesite. The richer portions are apt to be where the greatest brecciation is, except where the brecciated material has been closely filled with tuff, "originally in the form of mud forced into the interstices of the breccia as an emulsion." In the case of the Teniente "pipe," which represents an old hot-spring channel, the loosely agglomerated bowlders of tuff and breccia have been coated by mineral, either deposited in open channels or replacing some of the tuff itself. * * *

Metallic minerals are iron pyrites, magnetite, chalcopyrite, bornite, and secondary chalcocite, a mineral said to resemble tetrahedrite and zinc blende, in the sulphide zone, and in the zone of oxidation limonite, cuprite, metallic copper, and the carbonates and silicates of copper. The principal nonmetallic minerals, outside of the original constituents of the rocks, are tourmaline, quartz, ankerite, calcite, chlorite, sericite, mica, epidote, and zircon.

1 Zeitschr. prakt. Geologie, 1895, p. 147.

${ }^{2}$ Lindgren, Waldemar, The gold belt of the Blue Mountains of Oregon: Twenty-second Ann. Rept. U. S. Geol. Survey, pt. 2, 1901, p. 629.

${ }^{3}$ Lindgren, Waldemar, Metasomatic processes in fissure veins: Trans. Am. Inst. Min. Eng., vol. 30, 1901, pp. 626-643.

Y Yeatman, Pope, The Braden Copper Co.: Eng. and Min. Jour., vol. 92, 1911, p. 1128. 
The writer has seen no description of a deposit that closely corresponds to that of the O $\mathrm{K}$ mine, where a chimney of pegmatitic quartz contains sulphides and is surrounded by an area of disseminated sulphide. Both this and the Cactus deposit are, however, very closely allied to the type commonly known as disseminated deposits, of which there are numerous examples in the West. The general character of such deposits has been outlined in the descriptions of the mines and need not be repeated here, but the following references may be made:

The disseminated deposits of the Bingham districts, Utah, have been described by Boutwell. ${ }^{1}$ The very similar deposits in the Ely district, Nevada, have been described by Lawson ${ }^{2}$ and those of the Clifton-Morenci district, Arizona, by Lindgren. ${ }^{3}$ The disseminated deposits in the Globe district, Arizona, which are closely allied to those just mentioned, have been described by Ransome, ${ }^{4}$ Tolman, ${ }^{5}$ and Higgins. ${ }^{6}$ The very similar deposits of the Ray district, Arizona, have been described by Weed ${ }^{7}$ and Tolman. ${ }^{8}$ The similar deposits in the Santa Rita district, New Mexico, have been described by Graton. ${ }^{9}$ Many other deposits of this type have been noted, but the references given are sufficient to show that they are of widespread occurrence. All the deposits occur in siliceous rocks, either schists, monzonites, or some closely allied rocks. These have been fractured and highly altered by ore-bearing solutions. The fissures are filled by veins of quartz and sulphides, and grains of sulphides are also disseminated through the altered rock. Both pyrite and chalcopyrite are usually abundant primary sulphides. The commercial ore is as a rule the result of enrichment.

DEPOSITS FORMED BY THE REPLACEMENT OF SEDIMENTARY ROCKS.

TYPES.

The deposits occurring as replacements of sedimentary rocks may be separated into two types, contact deposits and replacement fissure deposits. In their typical development these types are readily recognized, but there are all gradations between the two, and it is difficult to determine to which type some deposits should be assigned; in fact, they possess some of the characteristics of both types.

CONTACT DEPOSITS.

The typical contact deposits occur as a replacement of the limestone near the quartz monzonite contact. They are irregular in form, in general following the irregularities of the intrusive contact, and the ore minerals are most abundant within a few feet of the igneous rock. Deposits of this type show great diversity along any one contact. At some point the limestone has been almost entirely altered to and replaced by contact minerals, whereas at other points along the same contact there has been little development of contact minerals, the change being simply a crystallization of the limestone.

Copper is the important metal of these deposits. The characteristic minerals are pyrite, chalcopyrite, magnetite, and hematite, together with silicate minerals, of which garnet and diopside are the most abundant, though vesuvianite, muscovite, epidote, chlorite, other silicates, and fluorite are present in varying amounts. (See p. 85.) The silicate minerals are always abundant in the deposits of this type, but the iron oxides vary considerably in different deposits. In the Imperial mine they are of relatively slight importance, but in the Old Hickory deposit the ore is composed largely of magnetite - in fact, the high iron content has made it possible to handle the ore commercially. In the Skylark mine of the Utah United Co. magnetite is likewise abundant, but in the prospects in the northeastern part of the Beaver Lake district it is variable though usually in small amounts.

1 Boutwell, J. M., Economic geology of the Bingham mining district, Utah: Prof. Paper U. S. Geol. Survey No. $38,1905$.

${ }_{2}^{2}$ Lawson, A. C., The copper deposits of the Robinson mining district, Nevada: Bull. Dept. Geology Univ. California, vol. 4, 1906, p. 287.

3 Lindgren, Waldemar, The copper deposits of the Clifton-Morenci district, Arizona: Prof. Paper U. S. Geol. Survey No. 43 , 1905.

4 Ransome, F. L., Geology of the Globe copper district, Arizona: Prof. Paper U. S. Geol. Survey No. 12, 1903.

6 Tolman, C. F.,jr., The Miami-Inspiration ore zone: Min. and Sci. Press, vol. 99, 1909, p. 646.

${ }^{6}$ Higgins, Edwin, Copper deposits of the Globe-Kelvin districts: Eng. and Min. Jour., vol. 89, 1910, p. 769.

7 Weed, W. H., The Ray copper mining district, Arizona: Min. World, vol. 34, 1911, p. 53.

8 Tolman, C. F., jr., Disseminated chalcocite deposits at Ray, Ariz.: Min. and Sci. Press, vol. 99, 1909, p. 622.

' Lindgren, Waldemar, Graton, L. C., and Gordon, C. H., The ore deposits of New Mexico: Prof. Paper U. S. Geol. Survey No. 68, 1910, p. 305. $73363^{\circ}-\mathrm{No} .80-13-9$ 
In some places there has been a slight fissuring after the formation of the contact minerals, and in the fissures have been deposited pyrite, chalcopyrite, quartz, and locally, orthoclase. (See Pl. X, B, p. 84.)

Secondary alteration has been variable, depending on the physical conditions. The sulphides have been altered to limonite and carbonates, oxides, and silicate of copper. Secondary sulphides of copper have also been formed to a slight extent. The ore that has been extracted from the Imperial mine was the product of secondary alteration. The deposit is, however, massive, and secondary alteration has extended only to relatively shallow depths. The Old Hickory deposit has also undergone comparatively slight secondary alteration, but in the Skylark and other prospects in the northeastern part of the Beaver Lake district secondary alteration has been pronounced and extends to the lowest workings opened.

REPLACEMENT FISSURE DEPOSITS.

The second type of replacement deposits consists of replacements of the sedimentary rocks along fissures. In the massive limestone deposits the replacement may occur rather uniformly in different beds, producing locally a roughly tabular deposit parallel with the fissure. Where the sediments are of varying physical character and chemical composition, however, the ore depo-

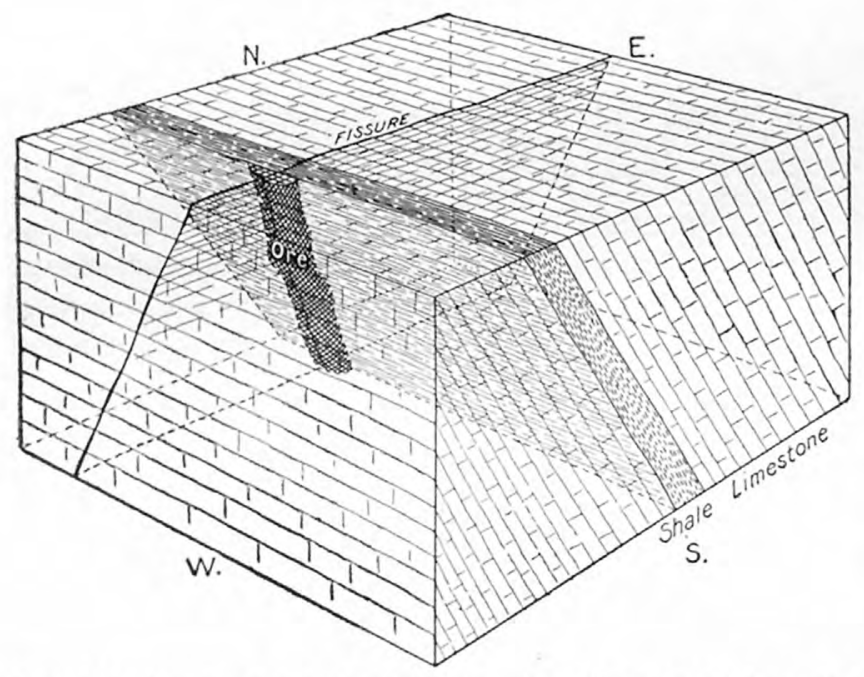

FIGURE 14.- Stereogram showing ore shoot beneath shale. The shoot follows the intersection of the ore fissure and the limestone bed beneath the shale. The ore makes out from the fissure along the limestone bed. sition has extended out from the fissure in certain beds for considerable distances, though adjacent beds have suffered little if any replacement by the ore minerals. This selective replacement of the beds is probably due in part to differences in the physical character of the beds and in part to differences in chemical composition.

The tabular development is perhaps best shown in the Mammoth mine. This deposit is in the massive Topache limestone, and though it shows a pronounced swelling or extension into some of the beds the intervening beds also have been replaced to a considerable extent. The replacement along certain beds is well shown in the HarringtonHickory mine and in the mines, underlying the Mowitza shale, especially the Red Warrior and Moscow. In these deposits the replacement has been effected almost exclusively along certain beds, the resultant deposits forming "chimneys" following the intersection of the ore fissure and the replaced bed. (See fig. 14.) In the deposits underlying the Mowitza shale the reason for this selective deposition seems to be largely physical. Where the fissures pass through the shale the character of this rock has caused them to be "tight" and relatively impervious to the passage of solutions. The ore-bearing solutions, rising along the fissures till they came to this zone, were forced to spread out under the shale and thus replaced the more permeable beds underlying it. A similar formation of ore bodies beneath shale beds has been noted in several localities in the West.

In the Harrington-Hickory mine the chemical composition of the beds has undoubtedly had an influence on the form of the deposit. The series is made up of interbedded limestone, quartzite, and siliceous shales and limestones. The main ore deposition has been in the limestone, the siliceous beds being very slightly replaced, and though the physical character of the beds may have had some effect on the deposition it is thought that the chemical composition was the controlling factor.

The most important metals of this class of deposits are lead and silver, though they contain varying amounts of zinc and copper. The deposits have undergone extensive secondary altera- 
tion and but few of the present developments have disclosed the primary ore. From the information at hand, however, it may be stated with considerable certainty that the chief primary minerals were pyrite, galena, chalcopyrite, and sphalerite. The principal gangue minerals were calcite and quartz, silicification being the typical alteration of the wall rock.

Secondary alteration has been extensive in the deposits of this type and, as already stated, the main output to date has been derived from secondary ores. The metallic minerals of these ores are typically limonite and carbonate of lead, together with varying amounts of carbonates and silicates of copper and zinc. To a minor degree the sulphate of lead is present, together with small amounts of more complex sulphates, phosphates, etc.

\section{TRANSITION TYPE.}

Deposits that may be considered as constituting a transition type are formed as a replacement of limestone along fissures, like the replacement fissure deposits, but the alteration of the wall rock has resulted in the formation of minerals similar to those occurring in the contact deposits, namely, garnet, magnetite, fluorite, muscovite, etc. These deposits occur at no great distance from the igneous rock. Such deposits are present in the Wild Bill and Hub mines, where, in fact, they merge into true contact deposits. The Harrington-Hickory and Moscow mines may also be considered of this type, for they contain contact minerals in considerable amount, but as contrasted with the Wild Bill and Hub mines they approach the replacementfissure type rather than the contact type. Though the replacement deposits in sediments are confined mainly to the limestones or highly calcareous sediments, some ore occurs as a replacement of quartzite, the general relations being similar to those of the deposits in limestone.

SIMILAR DEPOSITS IN OTHER DISTRICTS.

Replacement deposits in sedimentary rocks closely associated with granitic, monzonitic, and dioritic intrusives are very abundant and widespread and an attempt to summarize such occurrences would be out of place in this report. Some of the deposits that have been more carefully studied have already been mentioned in the discussion of contact alteration and it will suffice to call attention to some of the near-by deposits of similar character. The replacement fissures in the limestone in the Bingham district, ${ }^{1}$ which are both silver-lead and copper, are very like the deposits in the San Francisco region, and the same is true of the deposits of the Tintic district, ${ }^{2}$ the Park City district, ${ }^{3}$ and many other districts in Utah and adjacent States.

MINERALIZATION IN THE LAVA FLOWS.

LOCATION AND GENERAL CHARACTER.

The mineralization in the volcanic rocks that to the present time has been shown to be of commercial importance is confined to two deposits on the eastern flank of the San Francisco Range- the Horn Silver and the Beaver Carbonate. Mineralization in the lavas has taken place elsewhere, however, and it is possible that other deposits of commercial value exist.

The deposits are of the type known as replacement fissure veins, in which the ore and gangue minerals in part filled open fissures and in part replaced the rock adjacent to the fissures. In the Horn Silver deposit the ores occur in and adjacent to a strong north-south fault that has a displacement exceeding 1,600 feet. In the Beaver Carbonate deposit the mineralization has occurred along an east-west fault of undetermined displacement.

\section{ALTERATION OF THE WALL ROCK ADJACENT TO THE FISSURES.}

In deposits of this type the rock adjacent to the fissure has been highly altered, though the two deposits mentioned show considerable difference in the intensity of this alteration.

The alteration of the lavas adjacent to the Horn Silver ore deposit is in a general way similar to that described for the lavas of the district that are not directly connected with ore bodies. (See p. 78.) It differs, however, in intensity and the final results show a chemical and mineral-

\footnotetext{
1 Boutwell, J. M., Economic geology of the Bingham mining district, Utah: Prof. Paper U. S. Geol. Survey No. 38, 1905, p. 123.

${ }_{2}$ Tower, G. W., jr., and Smith, G. O., Geology and mining industry of the Tintie district, Utah: Nineteenth Ann. Rept. U. S. Geol. Survey, pt. 3,1899 , pp. $601-767$.

${ }^{3}$ Boutwell, J. M., Geology and ore deposits of the Park City district, Utah: Prof. Paper U. S. Geol. Survey No. 77, 1912, p. 105.
} 
ogic difference. The similarity in the alteration is shown by the progressive removal of all the oxides except silica, without notable additions other than metallic sulphides, sulphantimonides, and the sulphate barite.

The feldspars are first sericitized and where the alteration has been more intense both the potash and aluminum have been removed so that there has been no formation of aluminum silicates. The iron of the ferromagnesian minerals has probably combined with sulphur to form pyrite, which is present in all the altered rock, but the other constituents have been carried away. The final result of this alteration is a dense rock composed of finely crystalline quartz, usually containing abundant crystals of pyrite and in places a little barite and seattered zireon crystals. As exposed in the crosscuts from the main shaft to the ore body, this intense silicification has extended 100 to 125 feet from the fault plane in the lower levels of the mine. (See Pl. XXX, p. 166.) This zone was not seen by the writer below the eleventh level, but it is reported to extend to the sixteenth level, the deepest workings of the mine. In the upper levels it was not possible to determine the extent of the silicified zone, but it is said to be much less than in the lower levels and does not show prominently at the surface. This silicified zone forms the hanging wall of the ore body throughout its extent, and where the ore gives out on its lower side, as in the north end of the mine below the third level and in the south end below the tenth level, the ore zone is represented by this highly silicified rock. Along the fault north and south of the ore shoot there is little evidence of strong silicification.

The limestone forming the footwall of the ore body has suffered comparatively little alteration. It is in general recrystallized and silicified to a varying but usually slight extent. The limestone adjacent to the ore body shows no greater alteration than can be found in other areas no nearer the quartz monzonite where the alteration can be attributed with much assurance to the effects of the introduction of the intrusive rock.

There has been slight replacement of the limestone by the ore solutions along the faults, but where such deposits have been followed by drifts they have been found to pinch out within very short distances. In several places near the surface bodies of ore have been followed for short distances into the limestone, but as yet the limestone has not been found to contain ore bodies of large commercial importance.

The evidence as a whole indicates that the amount of alteration was controlled to a very large extent by the physical character of the rocks. The massive limestone that suffered little brecciation did not favor the free circulation of solutions and consequently was not much altered. The porous and highly brecciated lavas offered slight resistance to the circulation of ore solutions and were consequently highly altered. (See Pl. XIX.)

In the Beaver Carbonate mine the most conspicuous alteration of the rock in the vein is the formation of chlorite, kaolinite, and carbonate. The plagioclase feldspars have been entirely altered to carbonate, quartz, and a sericitic mineral that usually has a light-brown color and slight pleochroism, and in many places orthoclase that is probably secondary is present in these aggregates. A chloritic mineral not definitely determined is abundant and a little epidote is locally present. The orthoclase has suffered relatively slight alteration, but chlorite and a little sericite are usually present. Hornblende has been entirely altered to iron ore, chlorite, carbonate, quartz, and rarely a little biotite. Biotite has suffered little alteration. Some of it is partly altered to chlorite and carbonate, but many perfectly fresh biotite crystals contain inclusions of the ore sulphides, usually accompanied by quartz and in places by apatite. A fine kaolin-like mineral that has not been positively identified in places makes up a considerable portion of the rock. Apatite and zircon are present in small amounts.

From the foregoing descriptions it is evident that there has been considerable difference in the intensity of the alteration in the two deposits. In the more intense alteration of the Horn Silver deposit there has been a progressive leaching of the more soluble oxides, only silica and iron remaining where the alteration has been greatest - the former as quartz, the latter combined with sulphur as pyrite. In the Beaver Carbonate deposit the potash minerals have suffered relatively slight alteration, and though the other minerals have been altered, soda is the only constituent that has been largely removed, the lime, magnesia, and iron remaining as chlorite and carbonate. 


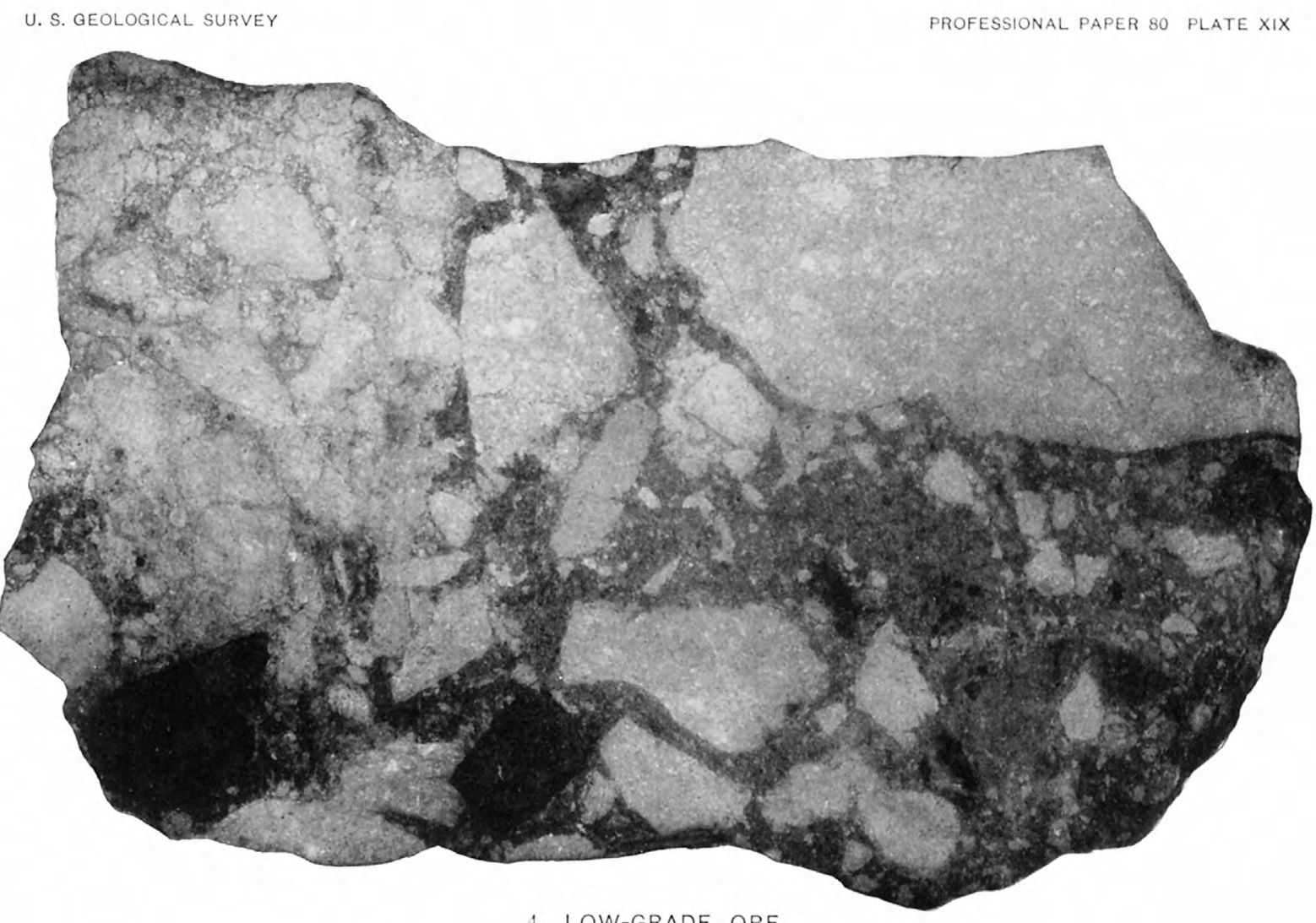

1. LOW-GRADE ORE.

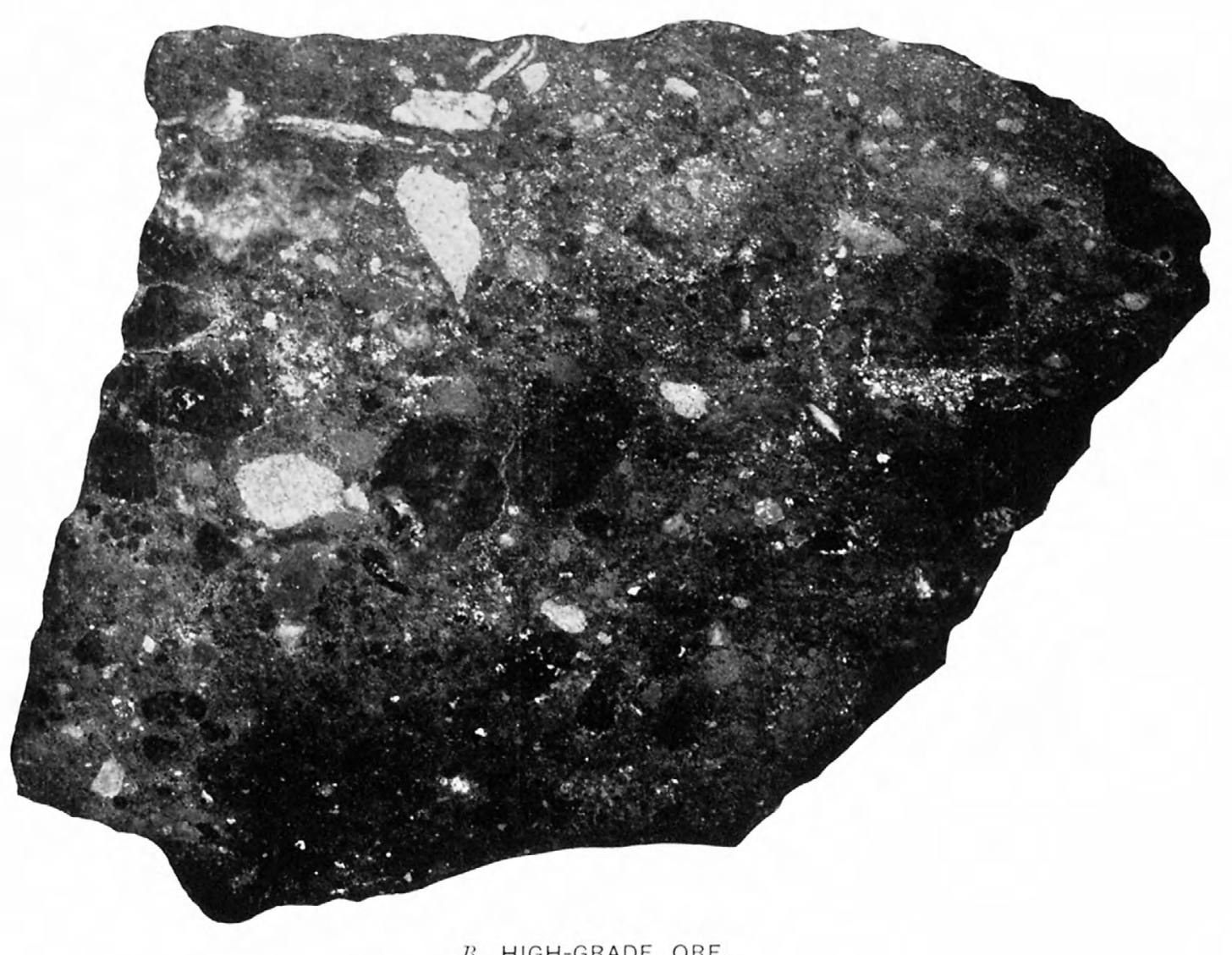

B. HIGH-GRADE ORE.

BRECCIA ORE, HORN SILVER MINE.

Light areas altered country rock, dark areas largely sulphides. Three-fourths natural size. 


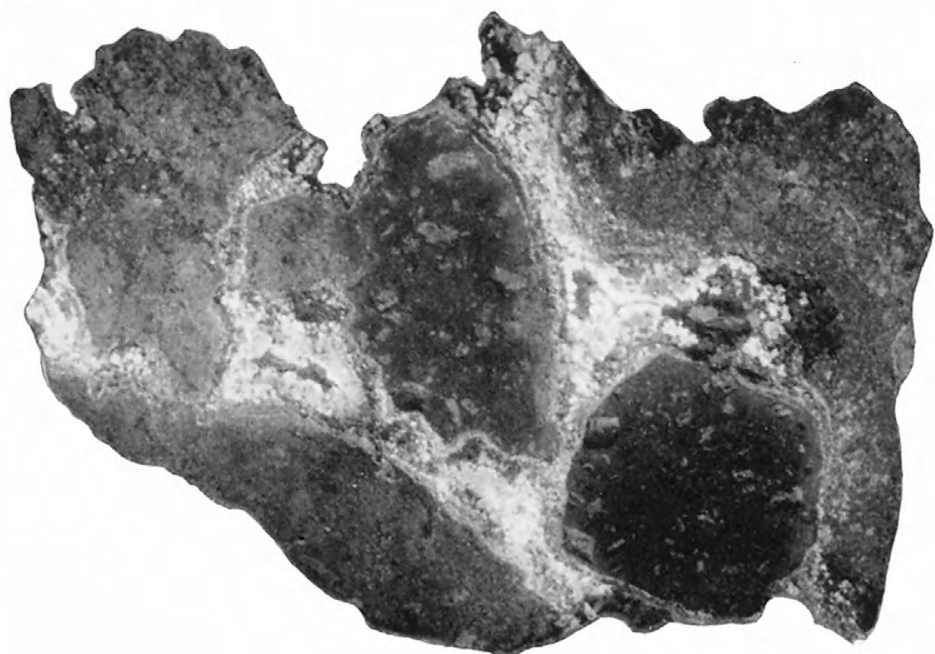

1. HAND SPECIMEN.

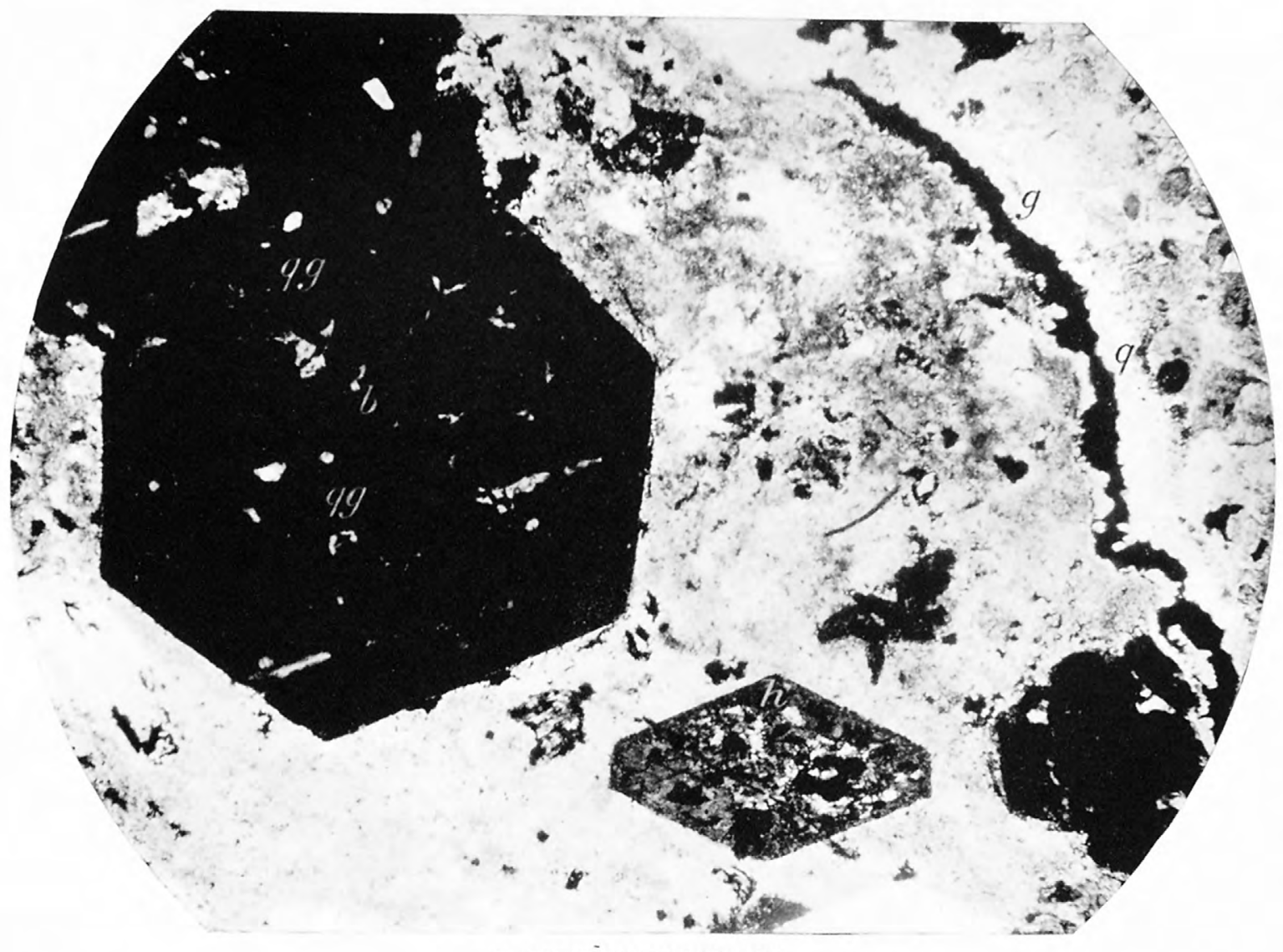

B. PHOTOMICROGRAPH.

$b$, Unaltered biotite; $q 9$, grains of galena in biotite associated with quartz; $h$, altered hornblende crystal; $g$, vein of galena with gangue of quartz $(q)$. Enlarged 30 diameters.

ORE FROM CARBONATE MINE. 
ORE MINERALS OF THE DEPOSITS IN LAVA.

In the Horn Silver deposit the principal primary ore minerals are galena, pyrite, and sphalerite, with lesser amounts of sulphantimonides and sulpharsenides. The ore minerals occur almost entirely as a replacement of the volcanic rocks and the different minerals are believed to be essentially contemporaneous in origin. The important primary gangue minerals are quartz, barite, and the altered country rock.

In the Beaver Carbonate mine the primary ore minerals are galena, pyrite, and sphalerite, and the principal gangue minerals are carbonate and quartz, together with the altered country rock. These minerals are disseminated through the altered rock and fill open spaces between the breccia fragments. (See Pl. XX.) The minerals forming in the open spaces are fine cherty quartz, sulphides, and calcite, deposited in general in the order named. The periods of deposition are not sharply defined, however, as some sulphide was deposited with the quartz, some calcite with the sulphides, and a little quartz with the calcite.

Although the principal ore minerals in the two deposits are the same, there is a notable difference in the gangue, carbonate being important in the Beaver Carbonate mine and sulphate in the Horn Silver mine. This difference points to a difference in the character of the solutions that deposited the ores, and a similar difference is indicated in the alteration of the rock adjacent to the deposits. The extensive removal of alumina from the rock of the Horn Silver deposit and the presence of abundant sulphates is contrasted with the failure to remove alumina and the presence of calcite in the Beaver Carbonate deposit.

Secondary alteration has been important in the Horn Silver deposit but of little importance in the Beaver Carbonate deposit. This change is discussed in the section on secondary alteration (p. 134).

SIMILAR DEPOSITS IN OTHER DISTRICTS.

Deposits similar to those in the volcanic rocks of the San Francisco region are not abundant in the Great Basin. Most of the veins in the lavas are gold-silver veins and carry relatively small amounts of the baser metals. Some of them, however, carry small amounts of copper, lead, and zinc.

The deposits resemble far more closely those of western Colorado, which are fissure deposits in volcanic rocks carrying important amounts of copper, lead, and zinc, though their principal value is in silver.

In the Marysvale district, Piute County, Utah, there are veins carrying important amounts of the base metals, though their principal values are in gold and silver. These resemble the deposits in western Colorado and also those of the San Francisco region. Closely associated with the deposits carrying base metals in the Marysivale district are gold-silver veins of the type of widespread occurrence in the Tertiary lavas of the Great Basin and neighboring regions.

\section{GENESIS OF THE ORES.}

As has already been stated, it is thought that the ores of the San Francisco region were all formed during the same general period of mineralization and that they have a common origin. In the case of the ores in the volcanic rocks, however, this belief is based on the general relation and character of the deposits and on their similarity to deposits in other districts where the relations are more clearly shown, rather than on any positive local evidence connecting them with the other deposits.

The ores of the region are closely associated with the intrusive quartz monzonite and the evidence indicates that this rock was the source of the metallic content, that the deposits of different types have a common source, and that the variations are due to differences in the kinds of rock in which the deposits were formed, to differences in the physical conditions under which the ores were deposited, and probably to some change in the chemical character of the solutions during the period of deposition.

In the discussion of the hydrothermal alteration of the quartz monzonite and the contact alteration of the limestone (pp. 74 and 82 ) it is shown that the solutions which effected these 
changes were essentially similar or that the elements introduced by the solutions were in large part the same. For example, the alteration in the quartz monzonite and the abundant quartz of the ore deposits indicate that the solutions were rich in silica; and the alteration of the limestone shows important additions of silica. In the case of alumina the similarity is less striking; the quartz monzonite shows little change in alumina, but in the contact zone there is considerable addition. It seems possible, however, that in both kinds of alteration the solutions carried notable amounts of alumina. That the solutions of both classes carried abundant iron (principally ferric iron) is shown by the abundance of hematite in the Cactus ore body and the large additions of iron to the contact zone. Potash was doubtless an important constituent of the solutions effecting the alteration of the quartz monzonite, and the local abundance of muscovite in the contact zone indicates that it was also present in the solutions that altered the limestone. In lesser amounts sulphur, copper, and lead and some of the rarer elements were common to the two solutions. The most notable difference is the presence of boron in the solutions producing the Cactus ores, as shown by the abundance of tourmaline, whereas no minerals containing this element have been noted in the contact zone, though careful search was made for them.

In general, then, it may be said that the solutions, as judged from the additions made by them, were similar in composition. It does not seem likely that they were exactly the same or that the composition remained constant for any considerable period, for they were continually taking material into solution and depositing other material. For example, a solution might originally be deficient in soda, lime, magnesia, etc., but after extracting these constituents from the quartz monzonite, as was evidently done, the solution might then be relatively rich in them and under favorable conditions redeposit them. On the other hand, a solution originally rich in iron, potassium, silica, etc., after depositing considerable amounts of these materials might become deficient in them and under certain conditions might even extract them from the rock through which it passed. As the action of a solution on the rocks and the substances deposited by it are the criteria by which it may be judged, it would thus appear that a solution traveling over a long course might show quite different characteristics at different points. If this is true, it is not very likely that solutions having a common origin will produce the same effect at all points, even if they traverse rock of the same character, and it is still less likely if the character of the rock changes. It therefore does not seem necessary that the action of the solutions should indicate more than a general similarity of composition to justify the hypothesis that they are of common origin provided that this hypothesis is supported by other evidence.

There can be no reasonable doubt that the contact deposits and the replacement fissures in limestone have a common origin, for all gradations from the one type to the other are present. The difference in mineral character of the deposits is to be attributed to a difference in physical conditions under which they were formed. The solutions forming the contact deposits near the intrusive mass must have been at a high temperature, not improbably above the critical temperature, and therefore in the form of water gas, and the minerals of these deposits are characteristically high-temperature minerals, such as garnet and magnetite. As the distance from the quartz monzonite mass increased the temperature would naturally decrease, and this change is reflected in the mineralogic character of the deposits-garnet, magnetite, etc., becoming less abundant till they are entirely lacking and the deposition of quartz and silicification of the rock becoming more pronounced.

The sulphides of the deposits also show a notable change in passing from one type to the other. In the typical contact deposit pyrite and chalcopyrite are the only abundant sulphides. In the replacement veins galena and sphalerite are among the principal constituents. Pyrite is abundant and chalcopyrite varies in amount. It seems evident, then, that the difference in metal content of the two types is due to the fact that at high temperatures the lead and zinc remained very largely in solution, while copper and iron were in part deposited. As the temperature decreased lead and zinc were deposited as well as copper and iron. 
There seems to be no doubt that the solutions forming the different types of deposit in the sedimentary rocks were of the same origin, and there is good reason for supposing that the solutions forming the deposits in the quartz monzonite were of similar origin.

The relation of the deposits in the lava flows to the other deposits is not susceptible of positive proof, but the general relations strongly suggest that they are of common origin. By reference to the map it may be seen that a tongue of the quartz monzonite extends out from the main mass in the direction of the Horn Silver deposit and that a dike of the intrusive rock is exposed in the limestone but a short distance from the deposit. It is reported that a rock resembling the quartz monzonite is present on the eleventh level in the mine, and it is not improbable that at greater depth the quartz monzonite reaches the Horn Silver fault. The Carbonate mine is also in line with the eastward extension of the quartz monzonite mass and the fissure in which the deposit occurs would naturally reach that rock underground. In location, therefore, these deposits bear a relation to the intrusive rock that may be considered as more than accidental. In metal content the ores are similar to the replacement fissure deposits in the limestone carrying iron, lead, zinc, and copper. In the alteration of the wall rock and in gangue minerals, however, the similarity does not exist nor do the two deposits in the lava show a strong similarity to each other. In one, as has been pointed out, the alumina has been removed and sulphates deposited; in the other there has not been a notable leaching of alumina and carbonate has been deposited. In neither of these deposits does the character of the alteration correspond closely to that of any of the other types. It may be pointed out, however, that the sulphates in the Horn Silver deposit are suggestive of the later stages of mineralization in the Cactus deposit, but the deposits of the Carbonate mine might be produced from the earlier carbonate solution under conditions of less heat and pressure than prevailed at the time that the deposits in the quartz monzonite were formed.

In the Marysvale district, Piute County, ${ }^{1}$ occur deposits that in many respects resemble those in the volcanic rocks in the San Francisco region. Some of these deposits show a marked leaching of alumina from the wall rock and the deposition of sulphates; in others carbonate is an important gangue. These deposits are believed to be generically connected with intrusive quartz monzonite.

It therefore seems highly probable that the deposits in the volcanic rocks of the San Francisco region are genetically connected with the quartz monzonite and thus are closely related to the other types of deposit in origin, though the proof of this is less positive than could be desired.

\section{ORIGIN OF ORE-BEARING SOLUTIONS.}

The origin of the ore-bearing solutions is not readily susceptible of positive proof, but certain facts indicate that the quartz monzonite magma was the original source of all these solutions.

In seeking for the origin of the solutions two sources may be considered-first, meteoric or surface waters circulating through the rocks and thus collecting their metal contents; second, waters given off by the crystallizing quartz monzonite magma containing the metallic elements in solution. That waters and metallic deposits are derived from both these sources is too well known and has been too frequently discussed to make it necessary or desirable to treat the subject in detail in this place.

It is certain that the solutions forming the deposits were hot, as shown by the character of the minerals, and this relation between certain minerals and the temperature of the solutions forming them is well known and generally accepted, so that it need not be further discussed. These hot solutions may have been given off by the crystallizing magma or they may have resulted from the heating of surface waters that came into proximity with the heated igneous rock, or they may have been furnished from both of these sources. In seeking to determine

1 Butler, B. S., and Gale, H. S., Alunite, a newly discovered deposit near Marysvale, Utah: Bull. U. S. Geol. Survey No. $511,1911$. 
which of these sources has furnished the solutions or which has been dominant, we may first discuss the deposits in the quartz monzonite.

As has been noted in the section on petrography (p. 62), the quartz monzonite contains many aplitic dikes composed principally of quartz and feldspar, and the composition and relations of these dikes indicate that they are the siliceous differentiation products of the quartz monzonite. In the bottom of the $\mathrm{O} \mathrm{K}$ shaft what appears to be an aplitic dike contains chalcopyrite and molybdenite as original constituents of the rock, thus seeming to indicate that the sulphides were relatively abundant in the siliceous differentiation product of the magma. In the same mine the "chimney" of quartz with sulphides of copper and molybdenum, which forms the ore channel, has every appearance of a coarse pegmatite, although feldspar was not found in it, and it seems reasonable and logical to consider this a further stage in the differentiation of the quartz monzonite magma. As the same solutions that carried and deposited the pegmatitic quartz undoubtedly deposited the ore minerals in this quartz and altered the surrounding rock and deposited the sulphides in it we are led to the conclusion that these solutions were derived from a differentiation of the quartz monzonite magma.

The similarity of the Cactus deposit to that of the $\mathrm{O} \mathrm{K}$ mine leaves no room for doubt that the solutions had a similar origin, though they passed through a more varied cycle of physical conditions, the later minerals of the Cactus deposit not having been formed in the OK deposit. Moreover, the presence of tourmaline and copper minerals intimately associated with an aplitic dike on Black Mountain, south of the Cactus deposit, point to the same conclusions concerning the origin of the solutions for this as for the $\mathrm{O} K$ deposit.

The evidence as to the origin of the solutions that produced the deposits in the sedimentary rocks is most conclusive for the contact deposits. These are invariably most intimately associated with the intrusive rock, a fact which of itself is suggestive that they were derived from the intrusive. Moreover, where the contact alteration has been most intense there is a blending of the igneous rock with the contact rock - a gradual transition from one to the other (see PI. $\mathrm{X}$, p. 84) — so that it is impossible to determine the boundary. Such a blending is most readily explained by supposing that solutions from the quartz monzonite were acting on the limestone and formed at the contact minerals characteristic of both the altered limestone and the igneous rock.

Small fissures that were opened in the altered limestone probably soon after the intrusion as a result of the readjustment of stresses, contain veinlets or dikelets composed of quartz, feldspar, magnetite, and sulphides. These do not differ greatly in composition from the aplitic dikes in the quartz monzonite, and it is most natural to suppose that they had a similar originthat is, that they were a differentiation from the quartz monzonite magma. The similarity in the composition of the solutions that effected the alteration in the quartz monzonite and in the limestone also points to a common origin.

The close relation between the different types of deposit in the sedimentary rocks indicates a similar origin for each type. It is entirely possible, however, that meteoric waters may have played some part in the formation of the deposits at a distance from the intrusive body. It is not believed that they were of importance in the formation of the deposits in the quartz monzonite or near the contact and it is thought that the metal content of all the deposits was derived from the quartz monzonite magma. These conclusions agree in general with those arrived at by others in the study of similar deposits; in fact, it may seem to some that it is no longer necessary to give detailed evidence to substantiate such conclusions.

In metal constituents the deposits in the lava flows are similar to the replacement fissure deposits in limestone, both types being characteristically lead-silver-zinc-copper ores with very little gold. The general relations of the ores in the lava indicate that they have been derived from the quartz monzonite magma and this agrees with observations in other districts, but such an origin for the deposits in this region has not been positively demonstrated. 


\section{ALTERATION OF ORES. ${ }^{1}$}

GENERAL CONDITIONS.

The change produced in the mineral deposits of this region by the action of surface solutions has been an important though variable element in the production of the ore deposits as they now exist. It is a striking fact that some of the deposits have been but little affected by such alteration, whereas the character of neighboring deposits has been completely changed. The region is in some respects especially favorable for a study of certain features of the problem of secondary alteration, and this will be discussed in some detail.

Secondary alteration is dependent on several factors, among the more important of which are the position of the ground-water table, the rapidity of erosion, the physical character of the deposit, and the mineral composition of the deposit. All these factors have doubtless had some effect in all the deposits, but in several of the deposits some one of them seems to have exerted a dominant influence.

\section{WATER LEVEL.}

In general it may be said that the position of the ground-water level is the most important factor determining the extent of secondary alteration in ore bodies, for extensive alteration will not extend very far below this level, though if given sufficient time it will reach this level regardless of other conditions. Other factors may be of great importance, however, in determining the rate at which alteration shall proceed.

In but few of the mines of the district has the water level been determined. The accompanying diagram (fig. 15) shows the elevation above sea level of the outcrop of several of the deposits, the lower limit of important secondary alteration, and the approximate ground-water level. The upper limit of ground water is shown in the figure, but the actual position may be considerably lower. In the Cactus mine there was but little water on the lowest (ninth) level in the summer of 1909, though this level had been idle for months and no pumping was being done. Later, however, considerable water was encountered in a fissure on the seventh level.

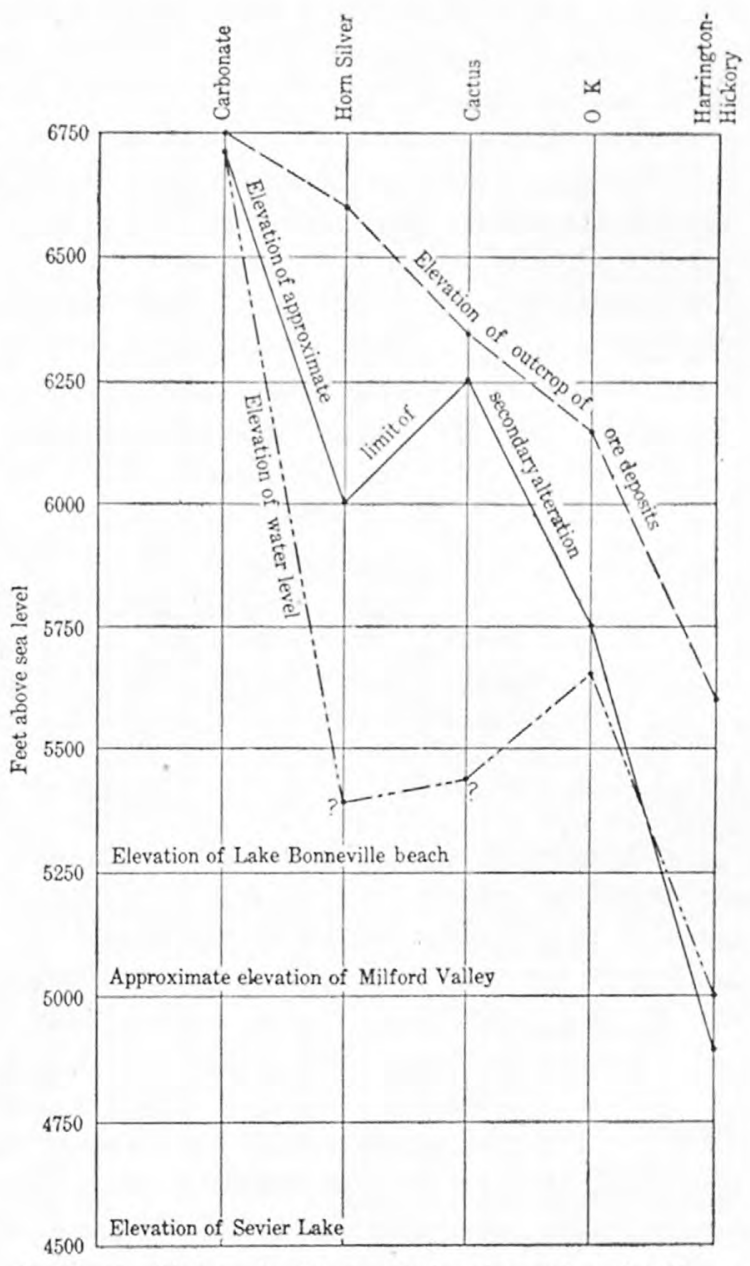

FigURE 15.-Diagram showing the relation of secondary alteration to outcrop of ore body and to water level.

In the Horn Silver mine water did not rise to the twelfth level, and it was reported that little water was encountered till the fourteenth level was reached. In the Carbonate mine the water

1 Since this report went to press several important papers on the alteration of ores by downward-moving solutions have been published. These papers have a bearing on the alteration of the ores in the districts under discussion. It is not feasible to revise the text to make the references to the papers in the proper places, but the titles are given below.

Tolman, C. F., jr., Secondary sulphide enrichment of ores: Min. and Sci. Press, vol. 106, 1913, p. 42.

Spencer, A. C., Chalcocite deposition: Jour. Washington Acad. Sci., vol. 3, 1913, p. 70.

Bastin, E. S., Metasomatism in downward sulphide enrichment: Econ. Geology, vol. 8, 1913, p. 51.

Graton, L. C., and Murdock, Joseph, The sulphide ores of copper; some results of microscopie study: Trans. Am. Inst. Min. Eng., February, 1913,

Cook, H. C., The secondary enrichment of silver ores: Jour. Geology, vol. 21, 1913, p. 1.

Emmons, W. H., The enrichment of sulphide ores: Bull. U. S. Geol, Survey No. 529, 1913. 
level was probably but a short distance below the surface, as water is encountered in many places in the volcanic rocks at very shallow depths. This is due to the fact that the rock is traversed by numerous fissures and the clay gouges that accompany these fissures form impervious dams which prevent the waters from circulating and from escaping from the rocks. On the other hand, on account of this lack of ready movement of the water a block of ground once drained gives little trouble. In the O K mine water was encountered about 90 feet below the fourth level, but sinking was not continued and it can not be stated that this is the actual position of ground water. In the Harrington-Hickory mine water was encountered at about the fifth level.

It is not likely that the water level has remained constant for long periods in the past. In fact, there are good reasons for believing that it has been both higher and lower than it is now. The beaches of the old Lake Bonneville are about 750 feet above the present surface of Sevier Lake, and because of the more humid climate prevailing at that time it is reasonable to suppose that the water level throughout the region was considerably higher than at present. On the other hand, the great alluvial cones at the mouths of the valleys upon which the Bonneville beaches were deposited testify to a long period of aridity preceding the Lake Bonneville epoch, and it is not unlikely that at that time the water level was lower than at present.

The inability to determine the position of the water level in the past makes it impossible to state a maximum depth to which alteration might have extended, but it is practically certain that in some of the deposits secondary alteration has never reached the ground-water level even in its highest stages. This is especially true of the Cactus mine, where the water level in Lake Bonneville time must have been considerably below the present zone of alteration, and it is doubtless true of the Horn Silver mine. On the other hand, at the Harrington-Hickory mine oxidized ores are present on the sixth level, 100 feet below the present position of the ground water, indicating a lower water level at an earlier period.

The Carbonate mine is the only one in the region where the present water level and the zone of oxidation show a close relation. In that mine the water level is but slightly below the surface, and this has prevented any extensive alteration of the ore body.

\section{RAPIDITY OF EROSION.}

The rate at which the surface is lowered by erosional agencies may in some localities be an important factor in determining the extent of the zone of secondary alteration, for if erosion is sufficiently active the altered rock may be removed almost as rapidly as it is formed. There is little doubt that erosion is at present lowering the surface in some parts of the district more rapidly than in others. For example, in the San Francisco Range, which rises to an elevation of fully 5,000 feet above the bottom of the neighboring Wa Wa Valley, erosion would naturally be more active than in the Beaver Lake Mountains, which are but 2,000 feet above the Milford Valley. This difference is amply shown by the character of the topography in the two ranges, the relatively narrow, canyon-like valleys of the San Francisco Mountains being strongly contrasted with the open valleys and mature slopes of the Beaver Lake Mountains. From this it is to be expected that the zone of alteration will be thinner in the San Francisco Range than in the Beaver Lake Range, and comparison of the very similar Cactus and $\mathrm{O} \mathrm{K}$ deposits proves this to be the case. As will be shown later, however, it is thought that the shallowness of the zone of alteration in the Cactus mine is due in part, possibly in large part, to causes other than rapid erosion, although its situation in the bottom of Copper Gulch is favorable to rapid erosion, and this agency has doubtless been important. The effect of erosion in removing the metal content of the deposit may be better discussed after the changes caused by secondary alteration have been more fully considered.

EFFECT OF PHYSICAL CHARACTER OF DEPOSITS.

It is readily apparent that the physical character of a deposit will have an important influence on the rate at which it will yield to secondary alteration. A massive, dense deposit or one for 
some other reason relatively impervious to solutions must necessarily alter more slowly than an open, porous one, other conditions being equal. As examples of this difference may be cited the massive garnetiferous deposits like that of the Imperial mine, which have suffered but relatively superficial alteration, and the more open fissure deposits like some of those in the Star district, which have been altered for at least several hundred feet below the outcrop. The influence of the physical condition, however, may be offset by other factors, as in the Cactus deposit, which although open and readily permeable has been but superficially altered.

\section{EFFECT OF MINERALOGIC CHARACTER OF DEPOSITS.}

The mineralogic character of a deposit may be an important factor in determining the rate at which secondary alteration will take place and also the character of such alteration. As the results are very different in different deposits and are of interest not only mineralogically but also commercially, they will be discussed in some detail. In this discussion the alteration in the different types of deposit will be considered separately.

\section{ALTERATION OF COPPER DEPOSITS IN QUARTZ MONZONITE.}

O K DEPOSIT.

The principal primary minerals in the $\mathrm{O} \mathrm{K}$ deposit are pyrite, chalcopyrite, and molybdenite, together with the gangue minerals quartz and the muscovite (sericite) resulting from the alteration of the quartz monzonite. The sulphides were first attacked by oxidizing solutions penetrating the deposit from the surface. The changes that took place in the alteration of these sulphides are not perfectly understood as yet, though the end products are better known. Lindgren ${ }^{1}$ has discussed the alteration of numerous minerals by surface solutions, and what he says concerning the alteration of pyrite and chalcopyrite is in part quoted below:

The oxidation of pyrite is a subject which has been extensively discussed by many writers on chemical geology, but, as remarked by Mr. Ransome, ${ }^{2}$ it is still in need of treatment from the experimental standpoint. ${ }^{3}$ At the surface pyrite in general oxidizes according to the formula $\mathrm{FeS}_{2}+7 \mathrm{O}+\mathrm{H}_{2} \mathrm{O}=\mathrm{FeSO}_{4}+\mathrm{H}_{2} \mathrm{SO}_{4}$. This reaction involves several intermediate stages in which $\mathrm{S}, \mathrm{H}_{2} \mathrm{~S}$, and $\mathrm{SO}_{2}$ may be formed. The ferrous sulphate upon further oxidation yields ferric sulphate, and the latter is easily decomposed to various basic sulphates and ferric hydrates and free acid. The sulphuric acid is ready to oxidize remaining pyrite, if cupriferous, while the ferric sulphate also attacks pyrite and other sulphides, changing them to sulphates, being itself reduced to ferrous sulphate. A cycle of reactions will thus be initiated which will continue until all of the sulphides exposed to oxidation have been transformed into various oxysalts and most of the iron has changed to limonite. Pseudomorphs of limonite after pyrite have been noted under the microscope in decomposed porphyries from Coronado and Metcalf, and some of these carry a kernel of chrysocolla.

The change that has taken place in the oxidation of the sulphides in the $\mathrm{O} K$ deposit in general agrees with those described above. The final product as shown in the gossan zone is limonite, in places mixed with secondary silica to form jasperoid, and much of the copper has been removed, though some remains as carbonate, probably produced by the reaction of carbonate in the waters with copper sulphate resulting from the oxidation of chalcopyrite. Pyrite is not abundant in the deposit, and suitable material for a microscopic study of the alteration of the pyrite was not procured, but some good specimens showing the oxidation of chalcopyrite were collected. The alteration first began along fractures, and in the hand specimen the altered material has the appearance of small veinlets of brown limonite, with here and there a little copper carbonate. Where the alteration has advanced these veinlets have widened at the expense

1 Lindgren, Waldemar, The copper deposits of the Clifton-Morenci district, Arizona: Prof. Paper U. S. Geol. Survey No. 43, 1905, p. 177.

2 Ransome, F. L., The geology and ore deposits of the Bisbee quadrangle, Arizona: Prof. Paper U. S. Geol. Survey No. 21, 1904, p. 155.

3 The subject is treated in the following papers:

Bischof, G., Lehrbuch der chemischen und physikalischen Geologie, 2d ed., vol. 3, Bonn, 1866.

Roth, J., Allgemeine und chemische Geologie, vol. 1, Berlin, 1879.

Doelter, C., Chemische Mineralogie, Leipzig, 1890.

Brauns, R., Chemische Mineralogie, Leipzig, 1896.

Emmens, S. H., The chemistry of gossan: Eng. and Min. Jour., vol. 54, 1892, pp. 582-583.

Penrose, R. A. F. The superficial alteration of ore deposits: Jour. Geology, vol. 2, 1894, pp. 285-317

Emmons, S. F., The secondary enrichment of ore deposits: Trans. Am. Inst. Min. Eng., vol. 30, pp. 177-217.

Weed, W. H., The enrichment of gold and silver veins: Idem, pp. 424-448.

Weed, W. H., Enrichment of metallic veins by later metallic sulphides: Bull. Geol. Soe. America, vol. 11, 1900, pp. 179-206.

Winchell, H. V., Synthesis of chalcocite: Bull. Geol. Soc. America, vol. 14, 1903, pp. 269-276. 
of the intervening chalcopyrite till the whole was converted to a brown ferruginous material containing kernels of chalcopyrite, or as a final stage the chalcopyrite was entirely removed.

When specimens of the partly altered chalcopyrite are cut and polished and studied microscopically it is seen that the veinlets are not composed of a uniform substance filling the space, but that there is always a relatively open channel way at the center. This channel may contain some limonite and rarely a little copper carbonate. The space is, however, never filled solidly from wall to wall. On either side of the central channel is a zone of limonite. Between the unaltered chalcopyrite and the limonite there is a narrow zone occupied by material having a rather light slate-blue color. This merges rather gradually into the zone of limonite. The relation of these several bands is shown almost diagrammatically in the microphotograph $(\mathrm{Pl}$. $\mathrm{XXI}, B)$. The zone between the chalcopyrite and the limonite is always narrow, as shown in Plate XXI, $B$, and it has not been possible to make a separation of the minerals in it for chemical tests. When the oxidizing material as a whole was treated with hydrochloric acid the resultant solution gave reactions for sulphate, copper, and iron. As no other mineral was recognized that could furnish the sulphate radicle, it is believed that this material is a sulphate, and it seems not improbable that it is a double sulphate of copper and iron, possibly pisanite ${ }^{1}$ or some closely allied mineral, and that under the conditions prevailing the first reaction was possibly $\mathrm{CuFeS}_{2}+8 \mathrm{O}=2(\mathrm{CuFe}) \mathrm{SO}_{4}$, which took on water of crystallization, forming ( $\left.\mathrm{FeCu}\right) \mathrm{SO}_{4} \cdot 7 \mathrm{H}_{2} \mathrm{O}$, and that this compound readily broke down into $\mathrm{CuSO}_{4}$ and $\mathrm{FeSO}_{4}$, the former being carried away in solution and the latter being largely reduced to limonite, as indicated above.

Much of the molybdenite in the higher levels has been altered to powellite. In some places this mineral has been recrystallized; in others it occurs as pseudomorphs after the molybdenite.

The conditions at this mine were not particularly favorable to a careful study of the zone below the zone of oxidation, as the material had been very largely removed from this lower zone, which contained the commercial ore. So. far as could be determined from the observations possible, the alteration in the lower zone did not differ materially from those of deposits previously described ${ }^{2}$ - that is, the copper content of the sulphate solutions descending from the zone of oxidation, on coming into contact with the sulphides lower down, was precipitated as chalcocite and covellite. The notable feature about this deposit was that, so far as determined by observations and reports concerning the character of the ore, the more abundant secondary sulphide was covellite, whereas commonly the more abundant secondary sulphide is chalcocite. It may be noted here that chalcopyrite was the most abundant primary sulphide and that much of the secondary sulphide resulted from a replacement of that mineral. The alteration was effected by a replacement along cracks in the chalcopyrite (see $\mathrm{Pl}$. XXI, $A$ ), the covellite extending into the chalcopyrite from the main veinlets along lines that from their arrangement suggest cleavage lines (see Pl. XXII, $A, B$ ), though cleavage lines could not be otherwise detected. The central portions of the main veinlets are almost invariably occupied by a light slate-blue mineral resembling the one already described as occurring next to the chalcopyrite in the zone of oxidation. In these veinlets, however, the slate-blue mineral is separated from the chalcopyrite by a zone of covellite. The central band has every appearance of representing the passageway through which the interchange of material was made, and it seems not improbable that when the artificial conditions stopped the process before completion the substances which were mingled in this passage, largely cupric and ferrous sulphates, crystallized, possibly, as suggested above, as pisanite or some allied mineral. In this band, as in the corresponding bands in the oxidized zone, tests showed the presence of sulphate. Unfortunately the contrast between the blue of the covellite and that of the central band is not sufficient to be well brought out in the microphotograph (Pl. XXII, B), but it is perfectly distinct to the eye. H. N. Stokes ${ }^{3}$ has given the following equation representing the reaction between

\footnotetext{
${ }^{1}$ It is recognized that pisanite is a soluble mineral and that the material under discussion does not have exactly the properties of that mineral.

${ }^{2}$ Emmons, S. F., The secondary enrichment of ore deposits: Trans. Am. Inst. Min. Eng., vol. 30, 1901, p. 212. Weed, W. H., The enrichment of gold and silver veins: Idem, p. 426. Lindgren, Waldemar, The copper deposits of the Clifton-Morenci district, Arizona: Prof. Paper U. S. Geol. Survey No. 43,1905, p. 183.

${ }^{3}$ Experiments on the action of various solutions on pyrite and marcasite: Econ, Geology, vol, 2, 1907, p. 14.
} 


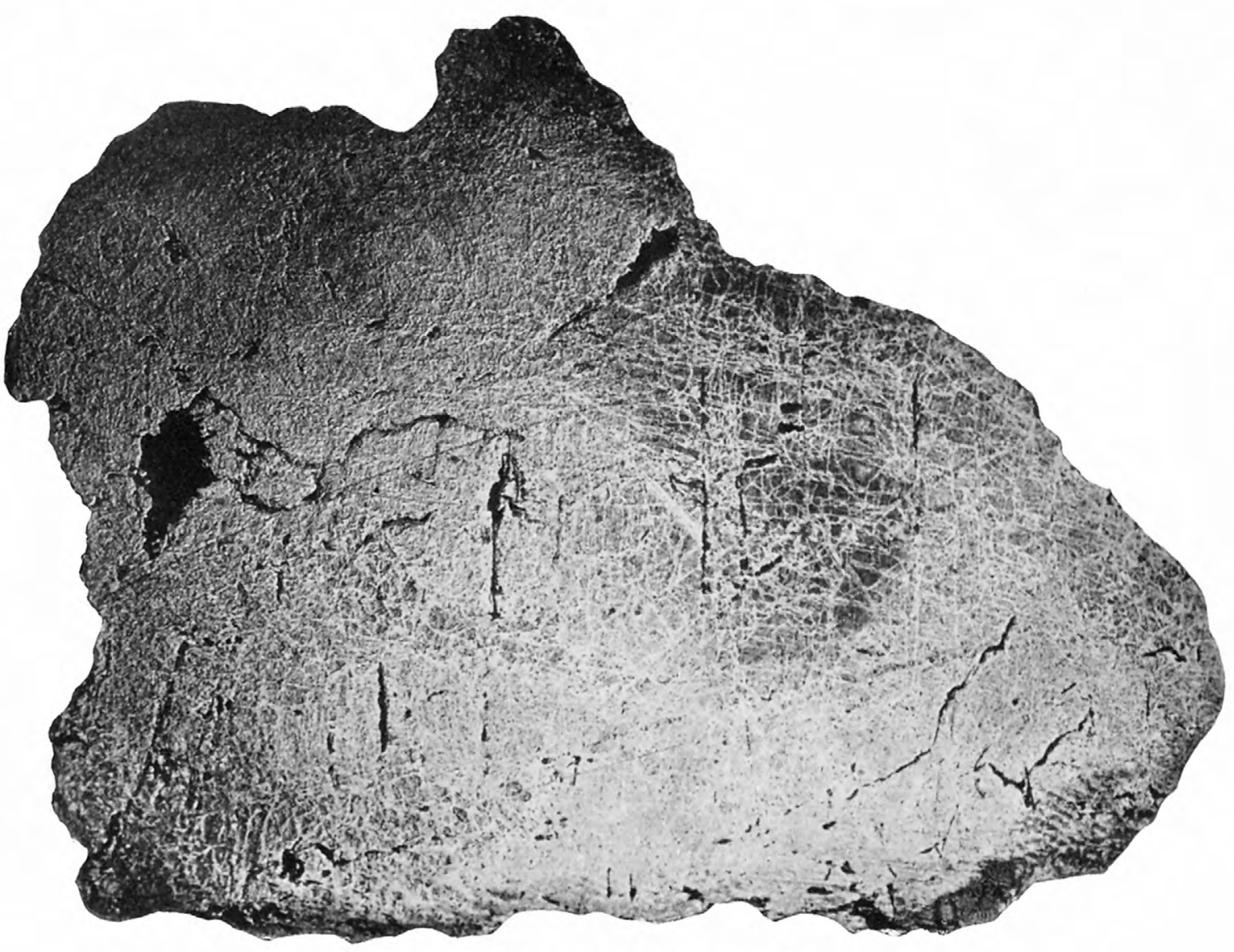

A. covellite replacing chalcopyrite, oK mine.

Enlarged $3 \frac{1}{2}$ diameters.

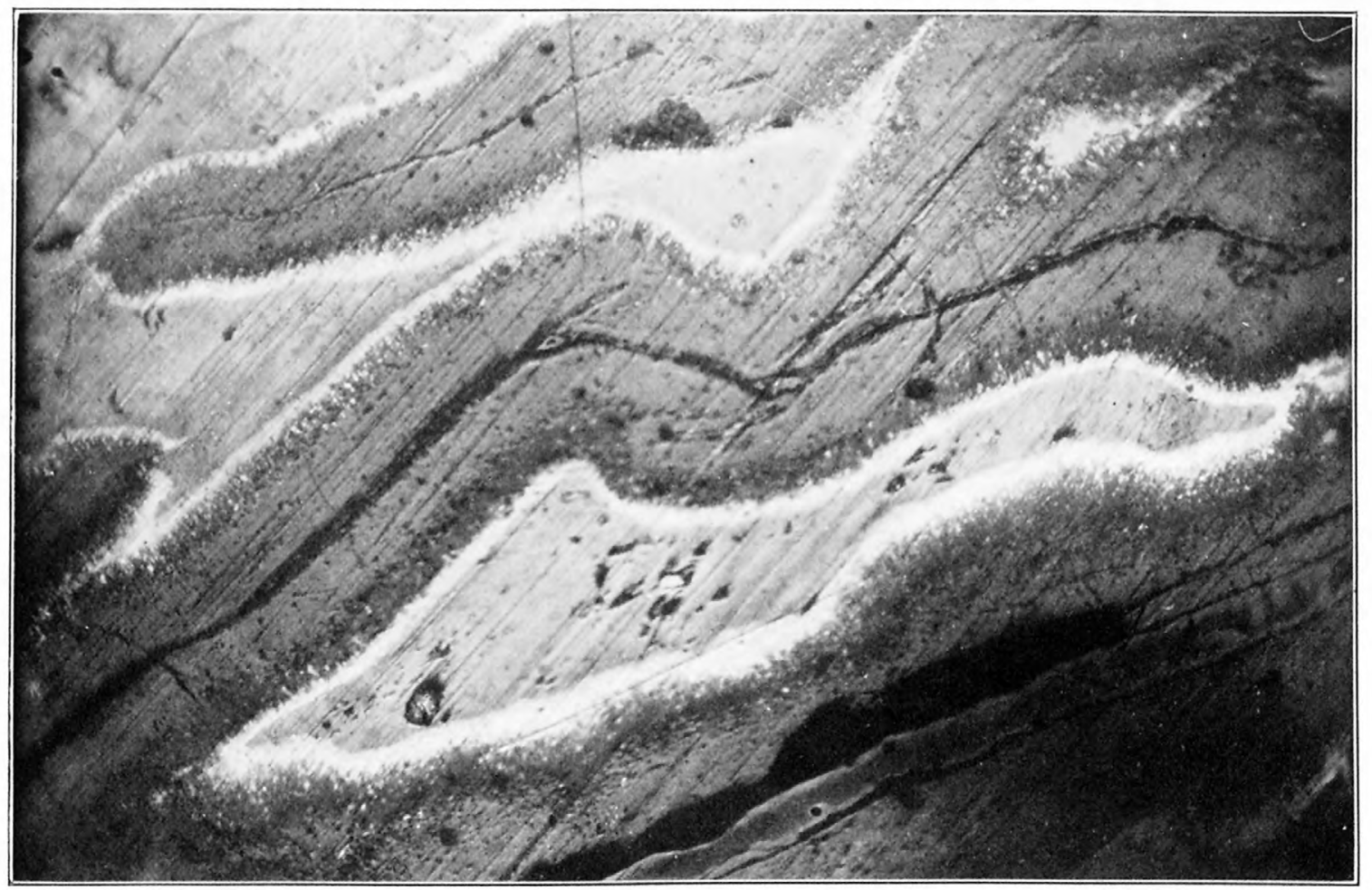

B. OXIDATION OF CHALCOPYRITE, O K MINE.

Dark areas hydrous iron oxide, light margins undetermined sulphate?, light-gray areas unaltered chalcopyrite. Enlarged 180 diameters. 


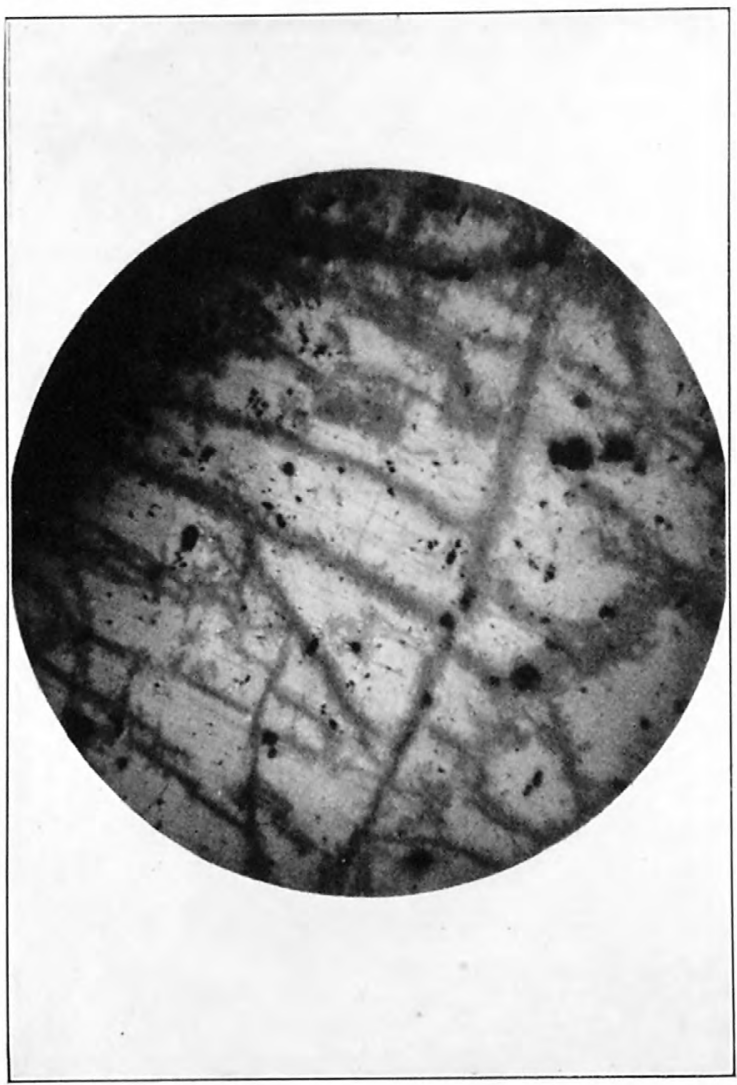

A

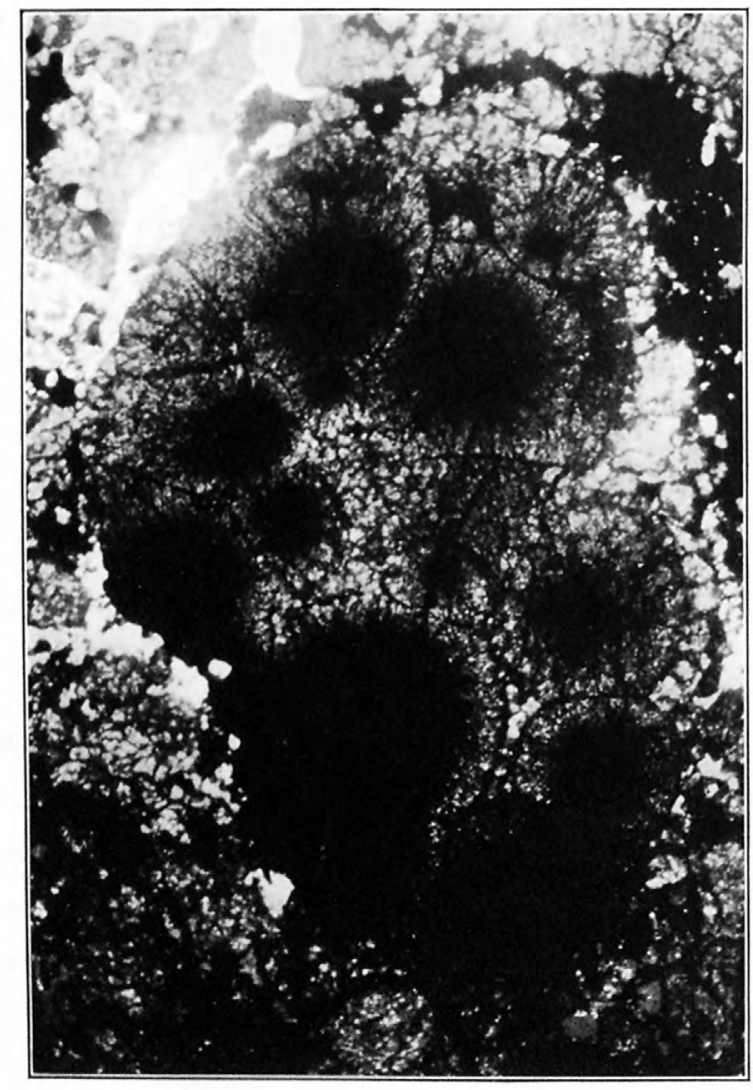

(

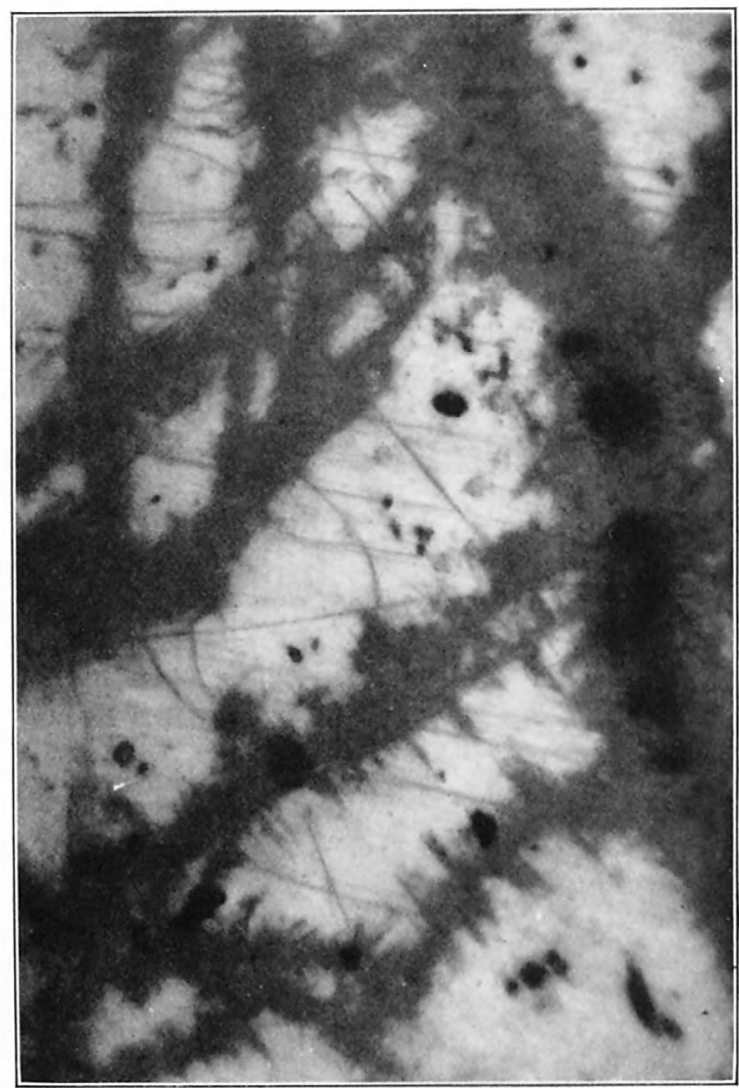

$B$

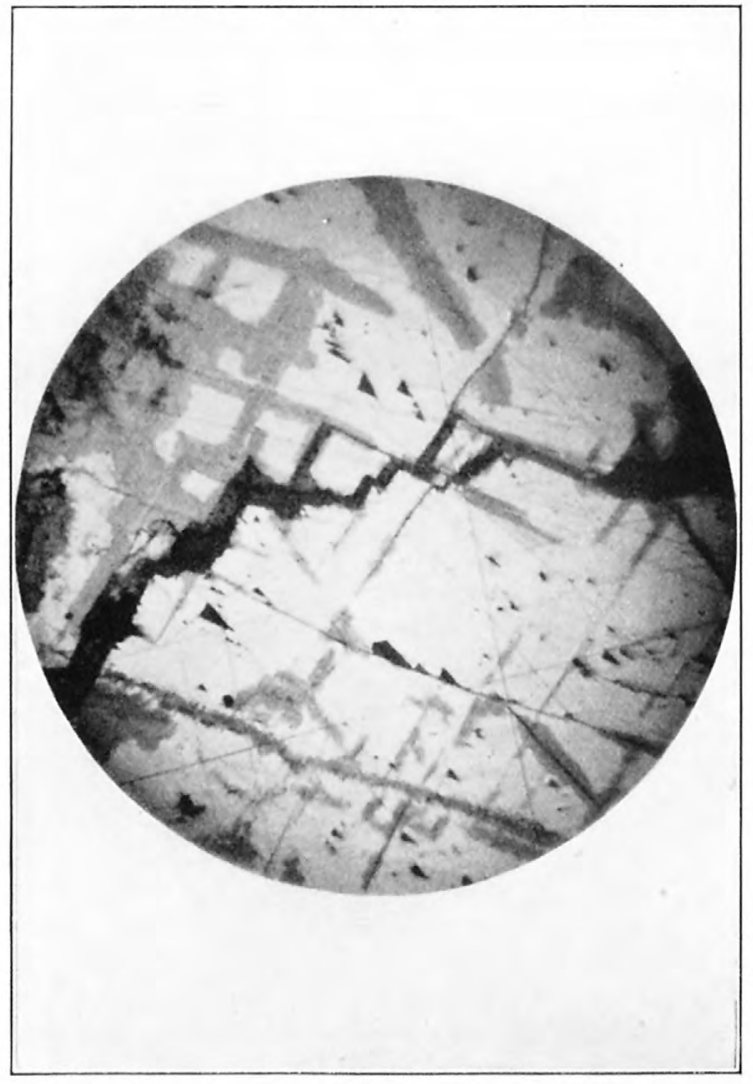

1)

ALTERATION MINERALS, OK AND HORN SILVER MINES.

A, Covellite replacing chalcopyrite, O K mine. Enlarged 40 diameters. B, Same specimen. Enlarged 210 diameters. C, Spheroidal "crystals" of wurtzite, Horn Silver mine; dark centers due to deep-red color; ordinary light. En. larged 43 diameters. D, Galena partly replaced by covellite and sulphates, Horn Silver mine; dark.gray areas partly covellite and partly undetermined sulphate; the two alteration minerals photograph the same, though perfectly distinct to the eye. Enlarged 40 diameters. 
neutral cupric sulphate solution and pyrite, which is considered by Lindgren as possibly representing closely the reaction that has produced the chalcocite of the Clifton-Morenci district:

$$
5 \mathrm{FeS}_{2}+14 \mathrm{CuSO}_{4}+12 \mathrm{H}_{2} \mathrm{O}=7 \mathrm{CuS}+5 \mathrm{FeSO}_{4}+9 \mathrm{H}_{2} \mathrm{SO}_{4}+3 \mathrm{H}_{2} \mathrm{SO}_{4} \text {. }
$$

A possible reaction between a solution of cupric sulphate and chalcopyrite, the principal substances involved in the deposit under discussion, may be written as follows:

$$
\mathrm{CuFeS}_{2}+\mathrm{CuSO}_{4}=2 \mathrm{CuS}+\mathrm{FeSO}_{4} \text {. }
$$

The presence of cupric sulphate in the solutions of the mine is shown by the efflorescence of the hydrous copper sulphate chalcanthite, $\mathrm{CuSO}_{4} \cdot 5 \mathrm{H}_{2} \mathrm{O}$, on the walls of the openings in the mine. Chalcocite occurs as a replacement of the primary sulphide grains disseminated through the altered quartz monzonite and is reported as occurring in the main ore body, though the specimens collected by the writer from that ore body showed only covellite as the secondary sulphide. The conditions which govern the deposition of the one or the other of the secondary sulphides have not been determined.

The secondary sulphide in the main ore body has been partly oxidized to carbonates and oxides. As the ore from this zone was practically all removed before the writer's examination was made, sufficient data were not gathered to make a discussion of this phase of the alteration of the deposit profitable.

CACTUS DEPOSIT,

In the discussion of the alteration of the ores of the Cactus deposit it may first be recalled that the primary ore consists of pyrite and chalcopyrite in a gangue of quartz, siderite (calciummagnesium-manganese-iron carbonate; see p. 119), tourmaline, hematite, and anhydrite, together with the sericite (muscovite) of the altered quartz monzonite and other minerals in small amount. The alteration in the oxidized zone of the Cactus mine has in general been similar to that in the $\mathrm{O} \mathrm{K}$, namely, the sulphides pyrite and chalcopyrite have been altered to limonite, with some carbonate of copper and native copper. The specularite at the surface has also been altered to limonite, and the mixed carbonate has been converted into a hydrous oxide of iron and manganese.

The initial change in the oxidation of the sulphide was doubtless similar to that described on page 139, forming ferrous sulphate, cupric sulphate, and sulphuric acid. The cupric sulphate, however, instead of passing in solution to lower levels would immediately react with the carbonate present to form the carbonate of copper, which, being relatively insoluble, would remain in the zone of oxidation and thus prevent a downward leaching of the copper content of the ore. The sulphuric acid produced in the oxidation of the sulphides and in the oxidation and breaking down of ferrous sulphate would also immediately react with the carbonate, producing sulphates of calcium, magnesium, manganese, and iron. The sulphates of calcium and magnesium would be carried away in solution or deposited, and the sulphuric acid involved in the reaction thus be removed from further activity in the alteration of the ore body. The cycle of alteration which goes on in a sulphide body, sulphuric acid being released by the oxidation and breaking down of ferrous sulphate, again to act on additional sulphide and again to break down, is interrupted when the sulphur is locked up or carried away in the form of the more stable sulphates of calcium and magnesium. It is apparent that under these conditions alteration can not be rapid and that until the carbonate has been altered there will be no downward migration of copper in the form of sulphate. If carbonate is abundant and generally distributed through the ore body, so that the sulphuric acid and sulphates come into contact with it, little migration of copper is to be expected, and the oxidation will be slow. In the Cactus mine extensive oxidation is confined to a zone within 40 or 50 feet of the present surface, and secondary alteration is almost lacking below the first level except for a hydration of the anhydrite. Moreover, there has been slight migration of the copper and no sulphide enrichment.

COMPARISON OF CACTUS AND O K DEPOSITS.

It may be recalled that the important difference in the original minerals of the Cactus and $\mathrm{O} \mathrm{K}$ deposits consists in the presence in the former of hematite, tourmaline, carbonate, anhydrite, and small amounts of other minerals that are almost or quite lacking in the latter. 
Of these minerals the only one that seems to have had a direct effect on the character and extent of the secondary alteration is the carbonate. So far as the writer has been able to determine, it is the presence of the carbonate in one deposit and its absence in the other that have resulted in a shallow zone of oxidation and no sulphide enrichment in the one and a relatively deep zone of oxidation and extensive sulphide enrichment in the other. It should be recalled, however, that recent erosion has been more rapid in Copper Gulch than in the Beaver Lake Mountains, a fact which has doubtless had an effect on the extent of the zone of oxidation but in no way accounts for the absence of sulphide enrichment. D. C. Bard ${ }^{1}$ has called attention to the absence of secondary sulphides in deposits containing calcite as a gangue. Recently Walsh and Stewart ${ }^{2}$ have conducted experiments indicating a similar result.

A more extended comparison of disseminated deposits in monzonite or other siliceous rocks with reference to their content of carbonate and the extent of secondary alteration would be of interest, but at the present time the data for such a comparison are not available. As already shown, however, the analyses of the altered rock connected with the Clifton-Morenci and Bingham ore deposits indicate that carbonate was present in the latter but not in the former. Enrichment has been more extensive in the Arizona district than in the Utah district, much of the copper in the latter being in the form of chalcopyrite. An interesting deposit in this connection is that of the Braden mine, in Chile, which shows slight enrichment, and according to Yeatman (see p. 128) has calcite and ankerite as gangue minerals. Until more data are available, however, any generalizations concerning the effect of carbonate on enrichment in this type of deposit are not justified.

\section{ALTERATION OF CONTACT DEPOSITS.}

Alteration in the contact deposits has been variable but has consisted generally in the formation of carbonates and oxides, with small amounts of secondary sulphides. In these deposits the original ores consisted of pyrite and chalcopyrite, with smaller amounts of magnetite, specularite, contact silicates, and residual carbonates. The oxidation of the sulphides has doubtless proceeded in a manner similar to that already outlined and the sulphates produced have reacted with the carbonates present, the copper being converted to carbonate and the iron, as in the alteration already described, reduced to limonite. The reaction in the formation of the copper carbonates may be written as follows: ${ }^{3}$

$$
\begin{gathered}
2 \mathrm{CuSO}_{4}+2 \mathrm{CaCO}_{3}+\mathrm{H}_{2} \mathrm{O}=(\mathrm{CuOH})_{2} \mathrm{CO}_{3}+2 \mathrm{CaSO}_{4}+\mathrm{CO}_{2} \text {, or } \\
\text { cupric sulphate }+ \text { calcite }=\text { malachite }+ \text { calcic sulphate. } \\
3 \mathrm{CuSO}_{4}+3 \mathrm{CaCO}_{3}+\mathrm{H}_{2} \mathrm{O}=\mathrm{Cu}(\mathrm{OH})_{2} \cdot \mathrm{Cu}\left(\mathrm{CO}_{3}\right)_{2}+3 \mathrm{CaSO}_{4}+\mathrm{CO}_{2} \text {, or } \\
\text { cupric sulphate }+ \text { calcite }=\text { azurite }+ \text { calcic sulphate. }
\end{gathered}
$$

In many places the carbonates are accompanied by cuprite or melaconite, both of which are present in the Imperial deposit, or by native copper, as in the Skylark mine. An undetermined hydrous oxide of copper, iron, and manganese has also resulted from this oxidation, and silicates have been formed to some extent.

Enrichment of the sulphides appears to have gone on only where there was comparatively little carbonate present to react with the sulphate solutions or where the condition of the deposit caused a concentration of the solutions along certain lines, so that they reacted with all the carbonate along these channels and finally with the sulphides to produce chalcocite, bornite, and, in the Old Hickory deposit, covellite. That there has been some migration of the copper during the process of alteration is indicated by the presence of bunches of relatively rich ore in the zone of oxidation and the absence, so far as observed, of corresponding bunches in the original ores. The extent of the zone of oxidation in these deposits has not generally been determined. In the Imperial deposit it is shallow, owing largely to the physical character of the deposit, but in the Beaver Lake district it is deeper, though developments have not yet shown to what depth it extends.

\footnotetext{
1 Econ. Geology, vol. 5, 1910, p. 59.
${ }^{2}$ Walsh, T. W. B., and Stewart, C. A., Note on the effect of calcite gangue on the secondary enrichment of copper ores: Econ. Geology: vol. 7,1912 , p. 785.

${ }^{3}$ Lindgren, Waldemar, The copper deposits of the Clifton-Morenci district, Arizona: Prof. Paper U. S. Geol. Survey No. 43, 1905, p. 190.
} 
ALTERATION OF REPLACEMENT FISSURE DEPOSITS IN SEDIMENTARY ROCKS.

The alteration of the replacement fissure deposits in sedimentary rocks was not as well shown in this region at the time of study as is necessary for a satisfactory investigation, owing to the fact that but few of the mines operating on deposits of this type had reached the zone of primary mineralization. The secondary ores were exposed in many places and could be satisfactorily studied, and from residual portions of the primary ores and a few exposures of the primary ores it is possible to infer, with a good deal of certainty, the character of the alteration that has taken place.

The primary ore minerals were mainly galena, pyrite, sphalerite, and chalcopyrite in varying proportions, together with small amounts of other metallic minerals. The gangue minerals were residual carbonate and quartz resulting from the silicification of the limestone and, in some of the deposits, contact silicates.

The oxidized ores in general are composed of limonite, cerusite, and small amounts of copper and zinc, usually as the carbonates. In some places copper and zine are more abundant constituents of the oxidized ore, zinc being present in the Cedar-Talisman mine and copper in some of the ores of the Moscow and Lady Bryan mines.

To a small extent sulphates have been formed in these deposits, including anglesite and the more complex sulphates jarosite and plumbojarosite. Where these were observed in the mines they had been formed along channels of relatively free circulation, this being especially true of the jarosite seen in the Wild Bill mine. Other minerals are present locally, such as corkite in the Harrington-Hickory and Wild Bill mines and wulfenite apparently resulting from the alteration of molybdenum-bearing galena in the Harrington-Hickory mine and to a less extent in other deposits. From the data at hand it seems that the lead of these deposits has migrated little from its original position, the sulphide having been altered directly to the insoluble carbonate or sulphate. The silver, which was originally present in considerable amounts in the other sulphides, has, like the lead, shown little migration. The abundance of limonite in the oxidized ores leaves little doubt that practically all the iron has remained in the oxidized ores and the same is probably true of copper, though the local abundance of copper in some of the ore shoots suggests that there has been some migration of this metal. Zinc, on the other hand, is less abundant in the oxidized ores than in the primary ores in the relatively few places where these were seen, and there seems little doubt that considerable amounts of zinc have been removed from at least the upper part of the oxidized zone. In the thoroughly oxidized ores sulphur has been practically eliminated except for the relatively small amount that has entered into the sulphates and locally some native sulphur. In general, there has probably been some addition of carbon dioxide to form the carbonates, though in many places the carbon dioxide present in the ore minerals is not greatly in excess of that in the calcite of the original gangue. In the change of pyrite to limonite there is a distinct loss of weight and enrichment of iron. In the alteration of galena to cerusite there is a slight increase in weight and corresponding lowering of the percentage of lead, but this increase is much more than counterbalanced by the calcite gangue that has been removed. In the change from chalcopyrite to azurite and malachite there is a distinct enrichment in copper. In the change from sphalerite to smithsonite there is a slight impoverishment in zinc, but both the zinc and sulphur of the sphalerite have been in large part removed from the upper oxidized zone. The result of oxidation therefore is the production of a porous mass occupying essentially the same space as the original ores and containing essentially the same amount of iron, lead, and silver but much less zinc and possibly slightly less copper. A given volume of the oxidized ore as it occurs in the mine, including the open spaces due to shrinkage, weighs materially less than the same volume of the original sulphide ores. If the two volumes contain essentially the same amount of iron, lead, and silver, it is apparent that in percentage of weight these metals have gained, and so far as they are concerned the oxidized ores are richer than the sulphide ores. In addition, the oxidized ores are in general more desirable for smelting. It is likely, therefore, that when the primary ores are reached they will be of lower grade and less desirable for metallurgic treatment, but this does not imply that they may not be profitably extracted. 
It is not improbable that the zinc that has been removed from the upper portions of the deposit will be found in greater concentration at lower levels as the carbonate and silicate, though the present developments did not permit a determination of this interesting and important point.

SECONDARY ALTERATION OF DEPOSITS IN LAVA FLOWS.

EXAMPLES.

The Horn Silver deposit is the best example of secondary alteration of the deposits in the lavas and presents some exceptional opportunities for study. It is unfortunate that a detailed study of the upper levels of the mine was not made while they were accessible, but a good idea of the general character of the ore in those levels can be obtained from the reports of Hooker and Cummings, though these reports were concerned more with the commercial than with the scientific problem involved.

The Carbonate mine is the only other deposit in the volcanic rocks that has been developed to any considerable extent, but no opportunity was afforded to make a careful study of its upper levels. As already stated, however, so far as can be learned from reports there was little secondary ore in the mine, the lack of alteration apparently being due to the fact that the local water table is but slightly below the present surface.

The following discussion relates to the Horn Silver mine.

PRIMARY MINERALS.

The important primary ore minerals in the mine are galena, sphalerite, and pyrite, with small amounts of jamesonite or some closely allied mineral, chalcopyrite and possibly other copper minerals, argentite, and pyrargyrite or some mineral closely allied to it. The original distribution of the lead, zinc, and copper minerals in the main ore deposit was probably fairly uniform, though it is to be expected that the relative proportions of these metals would vary somewhat from place to place, and they were essentially contemporaneous, but pyrite is in some places abundant where lead and zinc minerals are relatively scarce or almost lacking and these portions of the deposit may be of slightly different age. Such portions are especially well exposed in the seventh and eighth levels in the north end of the mine. The "silver stopes" are in the oxidized portion of this deposit. Some of the "sparry" ore in the upper levels is reported to have consisted chiefly of barite and rich silver minerals with little or no lead and zinc. These types, however, are of relatively slight importance when compared with the deposit as a whole.

SECONDARY MINERALS.

The most important secondary lead mineral is the sulphate anglesite, which, as shown in the analyses on page 147, formed a large percentage of the ore in the upper levels. In addition there are relatively small amounts of plumbojarosite, beaverite, cerusite, linarite, and a secondary lead-antimony mineral, probably bindheimite. Zine occurs in secondary minerals as smithsonite, calamine, goslarite, and wurtzite. The secondary copper minerals are covellite, chalcocite, brochantite, malachite, azurite, chrysocolla, chalcanthite, and the lead-copper minerals beaverite and linarite already mentioned. Cerargyrite was the only important secondary silver mineral observed. Hydrous oxides of iron and manganese are present in the secondary ores but are not usually abundant.

The most important secondary gangue minerals are chalcedony and kaolin, which are abundant in the secondary silver ore. Gypsum is present in considerable amounts and alunite forms a rather continuous band on the footwall in the upper levels. Native sulphur was also rather abundant in the upper levels.

GENERAL CHARACTER OF THE ORES.

Attention has been called by S. F. Emmons ${ }^{1}$ to the rather unusual distribution of the metals in the mine and to the possibilities of interesting results from the study of the secondary

1 The Delamar and Horn Silver mines; two types of ore deposits in the deserts of Utah and Nevada: Trans. Am. Inst. Min. Eng., vol. 31, 1902, pp. 65s-683. 
alteration of the deposit. In the upper levels zinc and copper were practically absent, the ore being an oxidized lead-silver ore. From a depth of about 650 to 750 feet there were bodies of rather high grade zinc and copper ore, and in about the same vertical position are small bodies of rather high grade silver ore. On the lower levels the deposit consists of mixed sulphide ores of relatively low grade. All the richer ores are believed to be the result of enrichment and the value of the deposit has been due very largely to this process.

TYPES OF ORE.

The ore body may be divided into three zones which show perfectly definite characteristics, though they grade from one to the other. The zone of oxidized ore extends from the surface to the fifth and probably nearly to the sixth level, though showing much irregularity. In the north end of the mine the silver ore has been highly oxidized as far as the eighth level, whereas in the south end some sulphide ores are reported above the fifth level. The zone of enriched sulphide ores comprises the bodies of rich copper and zinc ores extending from about the 650foot level to the 750-foot level in places and to much greater depths where the conditions were favorable, especially around the margins of the deposit and in portions that have suffered strong brecciation. The zone of primary sulphides extends from the lower limit of secondary alteration to the extreme depth of the deposit. This zone also is irregular, but as alteration has extended downward only along the more favorable lines much of the ore below the 850-foot level may be considered as practically primary ore.

For a number of years the Horn Silver Mining Co. kept a record of the ore mined and the metal content by levels. This is shown in the following tables, the first giving the total ore and the metal content, and the second the content expressed as percentages and ounces per ton.

Partial record by levels of the ore taken from the Horn Silver mine.

\begin{tabular}{|c|c|c|c|c|c|}
\hline , & Total ore. & Lead. & Silver. & Gold. & Copper. \\
\hline 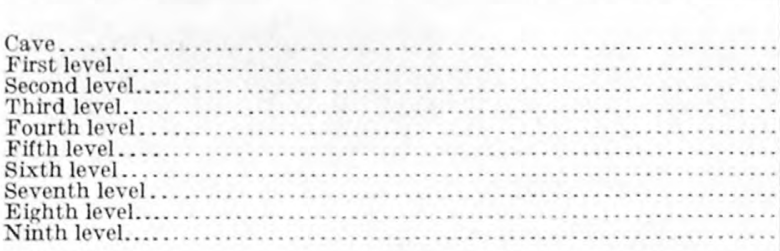 & $\begin{array}{c}\text { Tons. } \\
2,888.338 \\
15,263.751 \\
47,667.035 \\
31,725.30 \\
5,351.818 \\
4,140.49 \\
69,667.526 \\
26,796.815 \\
53,620.409 \\
10,959.108\end{array}$ & $\begin{array}{c}\text { Tons. } \\
1,339.294 \\
5,644.161 \\
18,173.67 \\
12,794.469 \\
2,325.78 \\
1,363.89 \\
26,221.84 \\
8,564.314 \\
18,327.163 \\
3,095.835\end{array}$ & $\begin{array}{r}\text { Ounces. } \\
69,151.28 \\
982,943.71 \\
1,730,093.09 \\
1,062,755.91 \\
108,129.87 \\
181,717.43 \\
1,823,067.08 \\
831,493.05 \\
1,535,203.26 \\
250,823.24\end{array}$ & 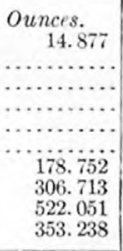 & 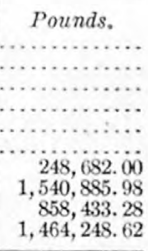 \\
\hline & $268,080.59$ & $98,150,415$ & $8,575,377.92$ & $1,375.631$ & $4,112,249.88$ \\
\hline
\end{tabular}

Partial record by levels of percentage of lead and copper and ounces per ton of silver and gold taken from Horn Silver mine.

\begin{tabular}{|c|c|c|c|c|}
\hline & Lead. & Silver. & Gold. & Copper. \\
\hline \multirow{9}{*}{$\begin{array}{l}\text { Cave } \\
\text { First level......... } \\
\text { Second level... } \\
\text { Third level... } \\
\text { Fourth level... } \\
\text { Fifth level..... } \\
\text { Sixth level...... } \\
\text { Seventh level.. } \\
\text { Eighth level... } \\
\text { Ninth level.... }\end{array}$} & \multirow{8}{*}{$\begin{array}{r}\text { Per cent. } \\
46.37 \\
36.97 \\
38.12 \\
40.32 \\
43.45 \\
32.94 \\
37.63 \\
31.91 \\
34.18 \\
28.24\end{array}$} & \multirow{8}{*}{$\begin{array}{r}\text { Ounces per } \\
\text { ton. } \\
23.94 \\
64.39 \\
36.29 \\
33.49 \\
20.20 \\
43.88 \\
26.16 \\
31.02 \\
28.63 \\
22.88\end{array}$} & \multirow[t]{2}{*}{$\begin{array}{c}\text { Ounce per } \\
\text { ton } \\
0.00515\end{array}$} & Percent. \\
\hline & & & & \\
\hline & & & & \\
\hline & & & & \\
\hline & & & .002565 & .1789 \\
\hline & & & .01144 & 2.875 \\
\hline & & & .00973 & .80 \\
\hline & & & .03223 & 6.68 \\
\hline & 36.61 & 31.98 & .005131 & . \\
\hline
\end{tabular}

These tables have been compiled from the reports of the Horn Silver Mining Co. without change. Unfortunately they do not represent exactly the levels from which the ore was extracted, but in some instances apparently the level from which it was hoisted. For example, the copper ore that is shown in the tables as coming from the ninth level is stated in another part of the company's report to have come from the seventh and eighth levels.

$73363^{\circ}-13-$ No. $80-10$ 
ZONE OF OXIDATION.

So far as the statistics in the preceding tables are concerned, the zone of oxidation may be considered as extending from the surface to the fifth level. South of the fault that limits the main ore body in the upper levels this zone, as already stated, did not extend to so great a depth, and north of the fault it extended to a much greater depth in the silver ore body. The ore from these parts of the deposit, however, was not mined during the periods in which a record of the output was kept by levels and was comparatively small in amount.

In this zone the sulphides have been practically altered entirely to secondary minerals, the lead being present for the most part as sulphate and the silver probably very largely as chloride. No careful examination of this part of the mine or of the ores was possible at the time of visit, but the following descriptions and analyses taken from the Hooker and Cummings reports give a very good idea of the character of the ore.

The subjoined quotation from Hooker's report describes the character of the ore on the upper levels:

The Horn Silver ores are distinguished at the mine as milling ore, smelting ore, and leaching ore. The latter, however, is properly also a smelting ore, but as it has certain features different from the rest the name, although not altogether a correct one, will be retained in this report.

Milling ore.-The name milling ore has been applied to that portion of the ore consisting essentially of heavy spar carrying chloride of silver, sulphide of silver, and ruby silver. It includes both the sparry ore, so frequently mentioned, and that described as mottled ore, besides certain other varieties found adjoining or interspersed with these.

The term of milling ore has been adopted because, being for the most part free from lead, it is adapted to the milling process. It may, however, be smelted also, and is thus treated at Frisco. While the crystallized sparry ore consists wholly of sulphate of baryta, except, of course, the silver minerals contained in this gangue, the mottled ore contains more silica and, as will be seen, the gangue of some varieties of the milling ore is made up principally of silica. The milling ores constitute the richest portions of the deposit, carrying from 75 to 200 ounces in silver per ton in quantity, while smaller samples run into the thousands.

Assays of selected specimens of milling ore.

[Silver, per ton of 2,000 pounds.]

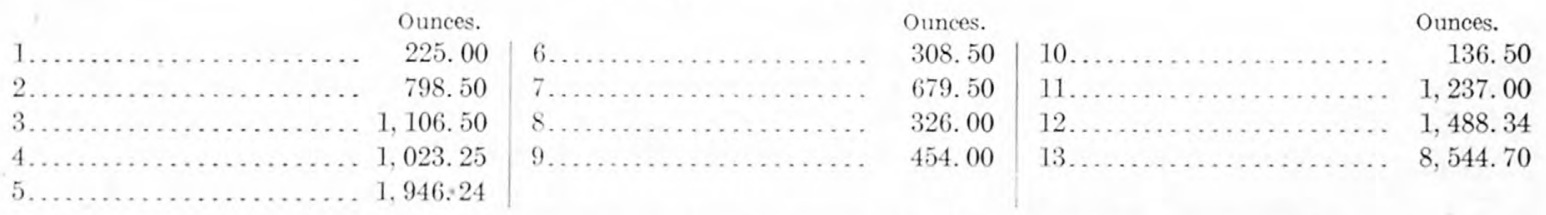

These assays were made from the specimens numbered, respectively, 1 to 13 , which accompany this report. They may be described in brief as follows:

1. Heavy spar with ruby silver, partly decomposed.

2. Heavy spar with chloride of silver.

3. Heavy spar with ruby silver, partly decomposed.

4. Heavy spar, with chloride of silver.

5. Heavy spar, some silica, ruby silver.

6. Sparry and mottled ore, ruby silver, chloride of silver.

7. Mottled ore, some spar, a little lead, chloride of silver.

8. Sparry and mottled ore, with ruby silver.

9. Sparry and mottled ore, ruby silver, and chloride of silver.

10. Mottled ore, siliceous, ruby silver, partially decomposed.

11. Yellow and white siliceous ore, hard and compact, containing ruby silver and chloride of silver.

12. Soft white siliceous ore, carrying chloride of silver. Gangue consists of silica ( 87.30 per cent by analysis), sesquioxide of iron and alumina, and a little sulphate of baryta.

13. Same gangue as last, with ruby silver and chloride of silver.

Very little ore such as is represented by the specimens 11,12 , and 13 has been met with in the mine.

Smelting ore.-The smelting ores proper comprise the greater portion of the ore mass. These are soft and earthy, consisting essentially of sulphate of lead, with some plumbic ocher and carbonate of lead-all carrying silver. They have no gangue rock or vein unless the silica, oxide of iron, and alumina (forming a sort of clay) be reckoned as such. The amount of lead and silver contained in these ores varies somewhat between certain limits, the lead running from 30 per cent to 60 per cent and the silver from 30 ounces to 75 ounces per ton. In order to determine the relative proportions of the different ingredients and impurities of this ore, a sample was submitted to Mr. S. B. Newberry, E. M., of the School of Mines, New York, for analysis, who reports as follows: 


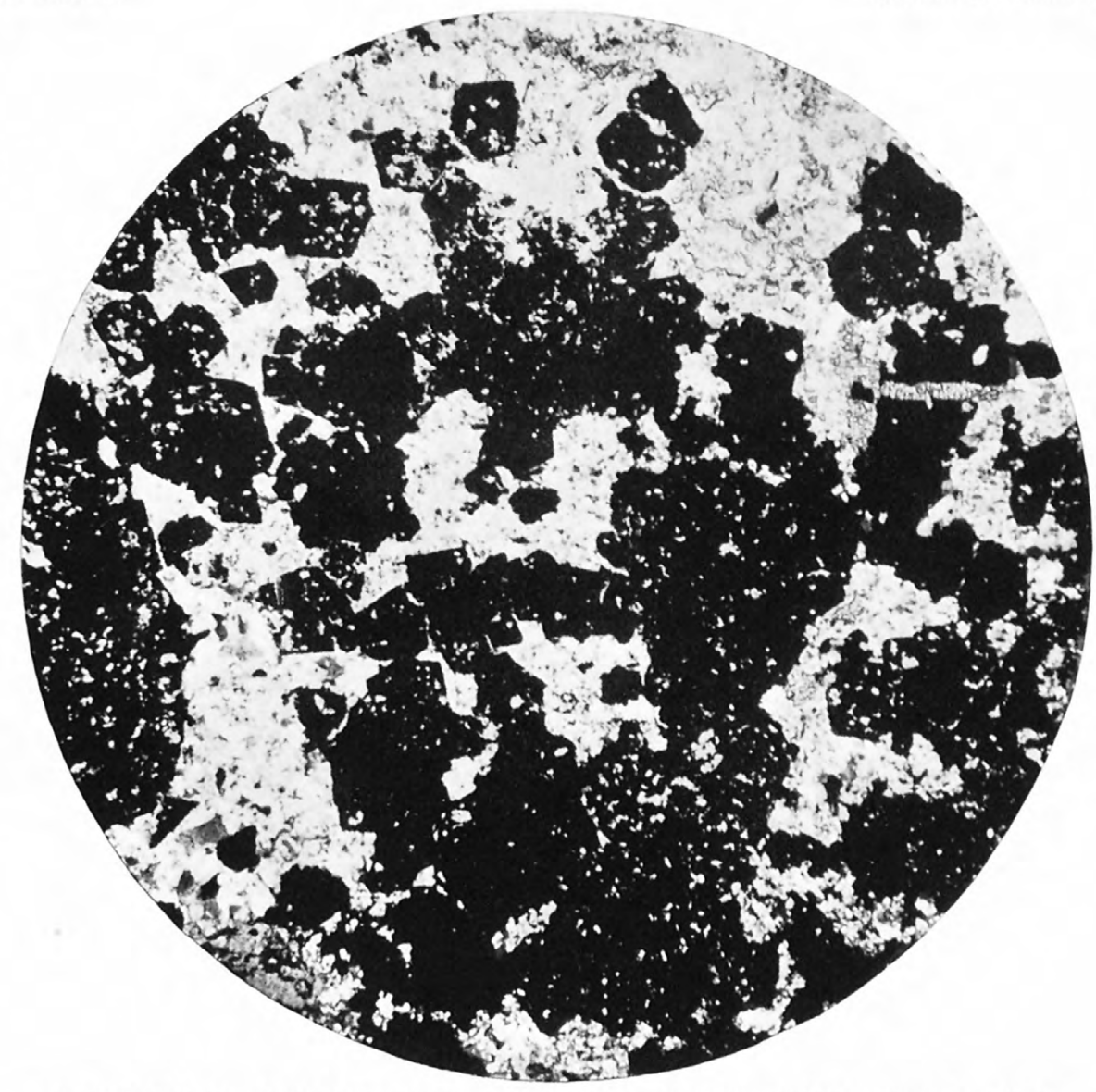

A. PYRITE IN GANGUE OF QUARTZ AND BARITE, HORN SILVER MINE.

Pyrite incloses abundant quartz. Enlarged 40 diameters.

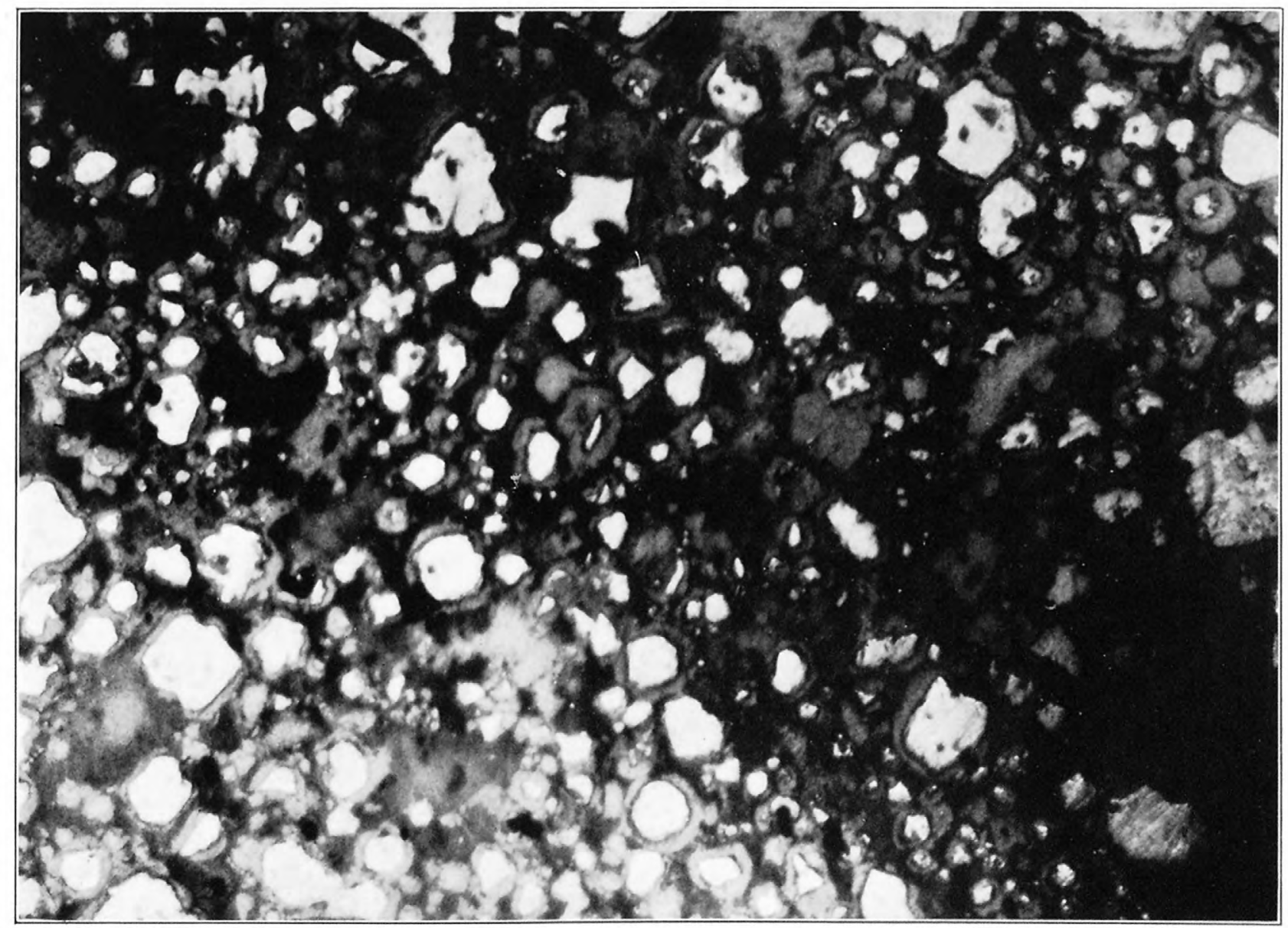

B. COVELlite REPLACING PYRITE, HORN SILVER MINE.

Pyrite (light grains) surrounded by covellite (dark material). Enlarged 275 diameters. 


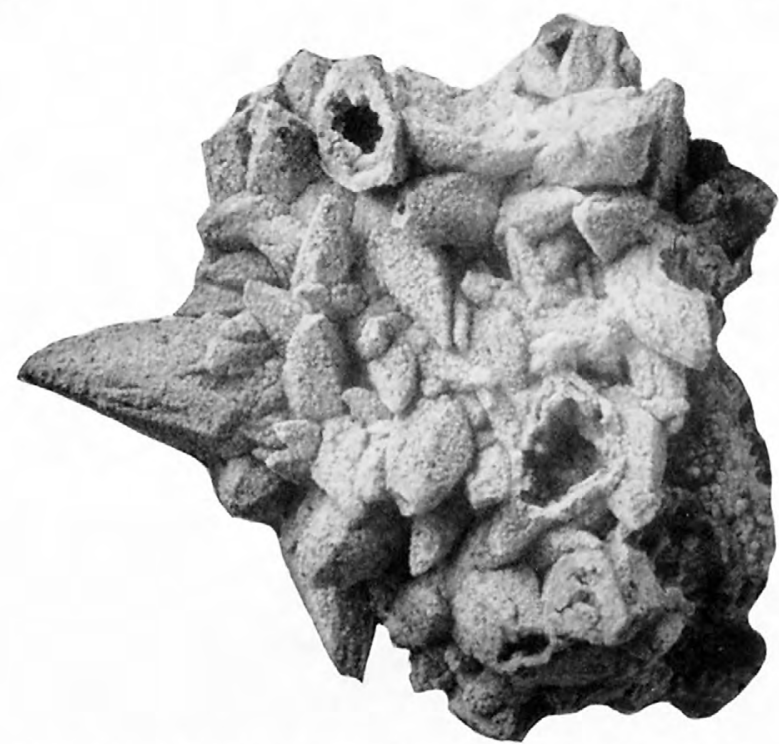

A. SMITHSONITE PSEUDOMORPHS AFTER CALCITE CRYSTALS, SEVENTH LEVEL, HORN SILVER MINE. NATURAL SIZE.

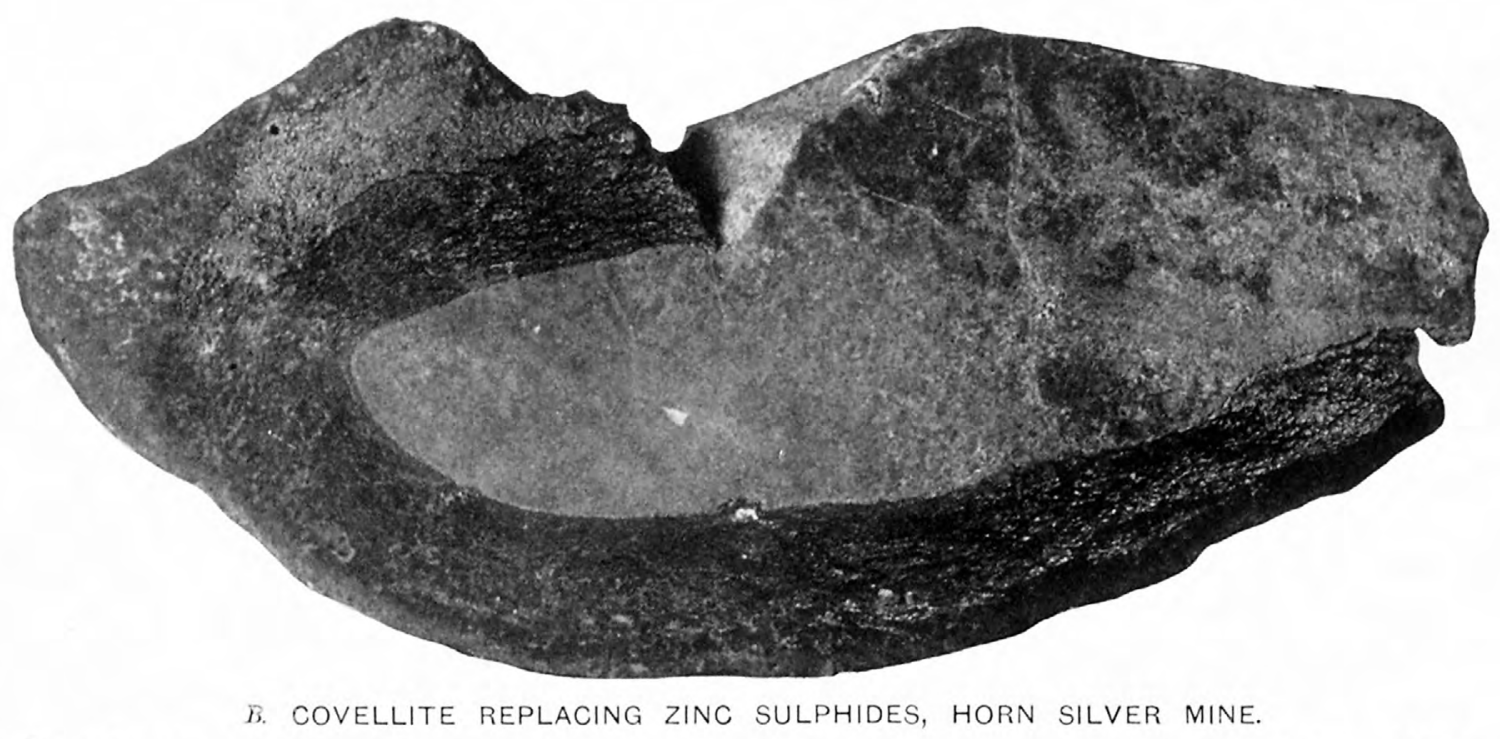

Zinc sulphides in the center, surrounded by zone of covellite containing considerable unreplaced zinc sulphide. Specimen collected by D. P. Rolfing. 
Moisture.

Per cent.

Silica. Undetermined.

(1)

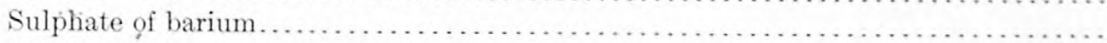

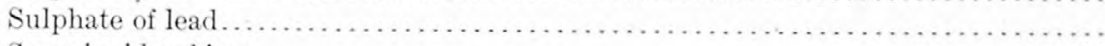

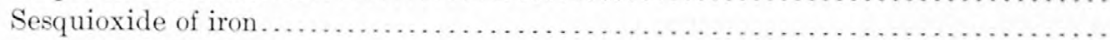

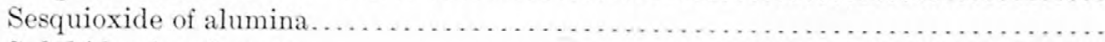

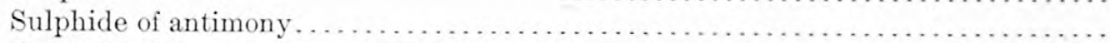

Sulphide of arsenic . . . . . . . . . . . . .

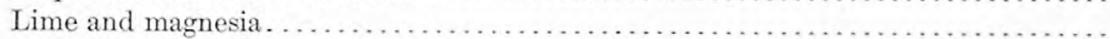

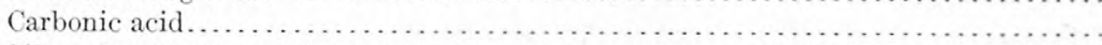

Silver (by fire assay, 78.33 [ounces] per ton).

15.17

.49

74.51

4. 80

1. 71

.37

1.12

.50

.62

99.62

"No zinc was found; the quantity is certainly very small and did not show itself, although a special determination was made to ascertain it. The metallic lead, arsenic, and antimony in the ore are as follows: Lead, 50.90 per cent; arsenic, 0.93 per cent; antimony, 0.26 per cent. The amount of moisture in the ore is very small, the average of the run-of-mine being less than 3.5 per cent, and the sample analyzed above had been thoroughly dried."

Leaching ore.-The so-called leaching ore has been referred to as occurring on the fourth and fifth levels. It is somewhat distinct from any of the ores previously described and quite different in appearance. It is more or less hard and compact, red, white, and yellow in color. A partial analysis of a sample of this ore was also made by Mr. Newberry, showing its principal ingredients. The following are the results:

Partial analysis of Horn Silver ore No. 2.

Per cent.

Silica . . . . . . . . . . . . . . .

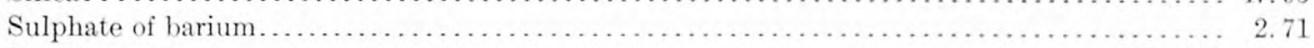

Sulphate of lead . . . . . . . . . . . .

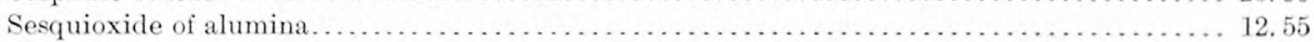

Silver (by fire assay, 86 ounces per ton).

92.01

"In addition to these constituents the ore contains a little zinc, carbonic acid very little, more arsenic and antimony than ore No. 1, a trace only of lime, and a small but quite noticeable amount of magnesia."

While these are the main distinctions in the character of the Horn Silver ores, the lines between them can not always be drawn so closely. They vary greatly in different parts of the mine, sometimes in very short intervals, rich ores alternating quickly with leaner ones and pure smelting ores with those containing no lead. That which has for convenience been designated as mottled ore often carries considerable lead and is more properly a smelting than a milling ore, and much of the leaching ore contains less lead than is shown in the above analysis.

The ore coming from the mine has, with the exception of the sparry ore, a yellow color, due to sulphate and oxide of lead; the more siliceous portions are somewhat hard, but the bulk of the run-of-mine is quite soft. It is difficult to make an estimate of the relative amounts of the different kinds of ore found in the different workings and impossible to give an exact one. The amount of pure crystallized heavy spar ore at present disclosed may be stated at about 2,000 tons; that described as mottled ore occupies much more space, and the so-called leaching ore comprises at least half of the ore disclosed on the fourth level.

The following statement taken from the same report shows the average metal content of the ore above the present 300-foot level, as determined at that time:

Estimate of average contents of the ore.

\begin{tabular}{|c|c|c|}
\hline & Silver. & Lead. \\
\hline 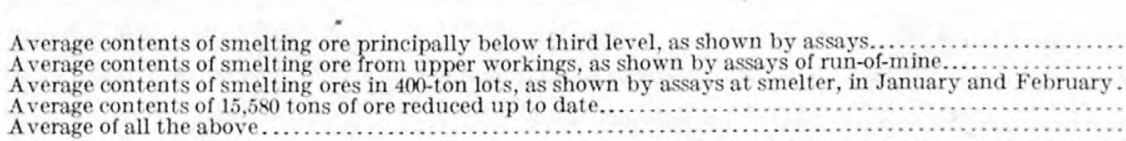 & $\begin{array}{r}\text { Ounces. } \\
72.66 \\
4.87 \\
41.31 \\
47.75 \\
51.37\end{array}$ & $\begin{array}{r}\text { Per cent. } \\
44.16 \\
45.48 \\
47.00 \\
38.25 \\
43.72\end{array}$ \\
\hline
\end{tabular}

Or we may call it 51 ounces silver per ton and 43.50 per cent lead. This estimate is exclusive of the milling ores - the richer portion of the ores. If these be taken into account, the result will be to materially increase the relative amount of silver per ton and to decrease the percentage of lead. In the judgment of the writer, therefore, the above figures will serve as a very safe basis upon which to estimate the value of the ore now in sight in the mine. 
The average metal content of the ore extracted above the fifth level, as shown in the table compiled from the Horn Silver report, amounting to 107,030 tons, is, lead, 38.99 per cent; silver, 38.63 ounces to the ton. It should be remembered, however, that the table does not include all the ore extracted above this level.

The notable features about this zone are the practical absence of zinc and copper. The latter metal is not even mentioned in the reports of Hooker and Cummings or in the early reports of the Horn Silver Mining Co, and so far as can be learned it was not found in important amounts above the sixth level except in the small area south of the fault. Zinc was not found in any considerable amounts above the fifth level except in the same area, and it was reported from the extreme north end of the first level. It is possible, however, that the material referred to by Hooker as "plumbic ocher" may have been beaverite, the sulphate of copper, lead, and iron, or some other ferric sulphate, because lead oxide was not found in the dump, whereas considerable beaverite was seen. The failure to report antimony in greater amounts in the upper levels may also be due to the fact that the secondary minerals of this metal were not recognized.

The only point at which the oxidized zone was well exposed at the time of visit was in the silver ore body on the seventh level and just above and below that level. In this part of the mine both the ore produced by the original mineralization and the secondary ore are well exposed.

The primary mineralization consisted principally in the formation of pyrite with varying but small amounts of galena, sphalerite, and jamesonite, in a gangue composed of the silicified lava and more or less barite. The amount of sulphides formed in the original mineralization varies greatly from point to point. Where most abundant the ore is composed of a mass of small pyrite crystals surrounded by fine crystalline silica. Under the microscope it is seen that irregular crystals of quartz are inclosed in the pyrite, showing that they were being formed at the same time. (See PI. XXIII, A, p. 146.) Microscopic crystals of barite are abundant and are of the same age as the quartz gangue but were not observed inclosed in the pyrite crystals. Microscopic crystals of zircon are also abundant. In the less strongly mineralized portions well-formed octahedral crystals of pyrite are irregularly scattered through the gangue. Where well crystallized, the pyrite usually has the simple octahedral form. This pyritic ore carries some silver, but not enough to be of commercial grade.

On oxidation both the iron and the sulphur of the pyrite are removed in solution, probably as sulphate. Sphalerite is also removed as zinc sulphate, but the lead remains as the insoluble sulphate and the silver originally present in the pyrite also remains, probably as the chloride, as a test for chlorine can be obtained from the ore. The typical material resulting from the alteration is a white to yellowish mass filled with cavities retaining the shape of the pyrite crystals. In the low-grade ore the rock is so cellular that it will readily float in water until it becomes water-logged, and in the higher-grade ore the walls separating the cavities are so fragile that the mass crumbles to powder in the fingers.

In the process of alteration the gangue has also been changed in part to a white, chalky, brittle material. Under the microscope this is seen to be an amorphous mass, with index below that of Canada balsam. It contains both silica and alumina and is probably kaolin or an allied mineral mixed with amorphous silica. In the specimens of primary ore examined no aluminous mineral was present, and the alumina present in the secondary silver ore must have been introduced during the process of alteration. The enrichment in the secondary ore is due to the removal of the pyrite which formed the mass of the original minerals, the silver contained in the pyrite being left. There was probably no important addition of silver to a given volume of ore, but the weight of a given volume was greatly reduced and the silver content by weight correspondingly raised. In this type the more cellular and bulky the ore the richer it is. Ore of this type shipped during 1906 averaged from 35 to 83 ounces of silver and 0.10 to 0.16 ounce of gold to the ton, and contained little lead, in some shipments no lead being reported. 

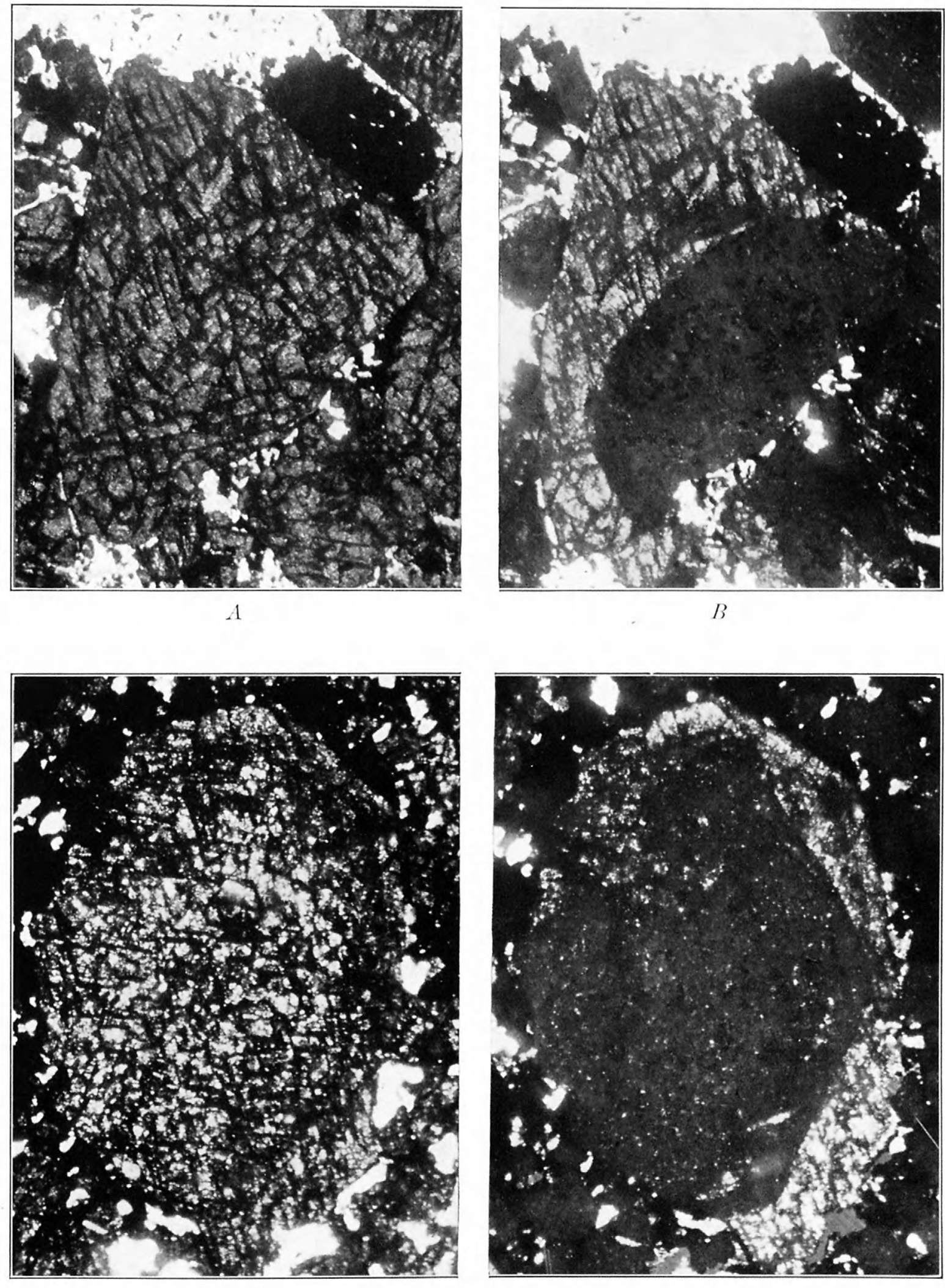

$C$

$D$

ZINC SULPHIDES, HORN SILVER MINE.

A, Dark-gray zinc sulphides, sphalerite, and wurtzite; ordinary light. Enlarged 43 diameters. $B$, Same specimen as $A$, with crossed nicols; dark areas sphalerite, light-gray areas wurtzite. C, Crystals of zinc sulphides ordinary light. Enlarged 43 diameters. D, Same specimen as (', with crossed nicols; light areas wurtzite, surrounding a center of sphalerite. 


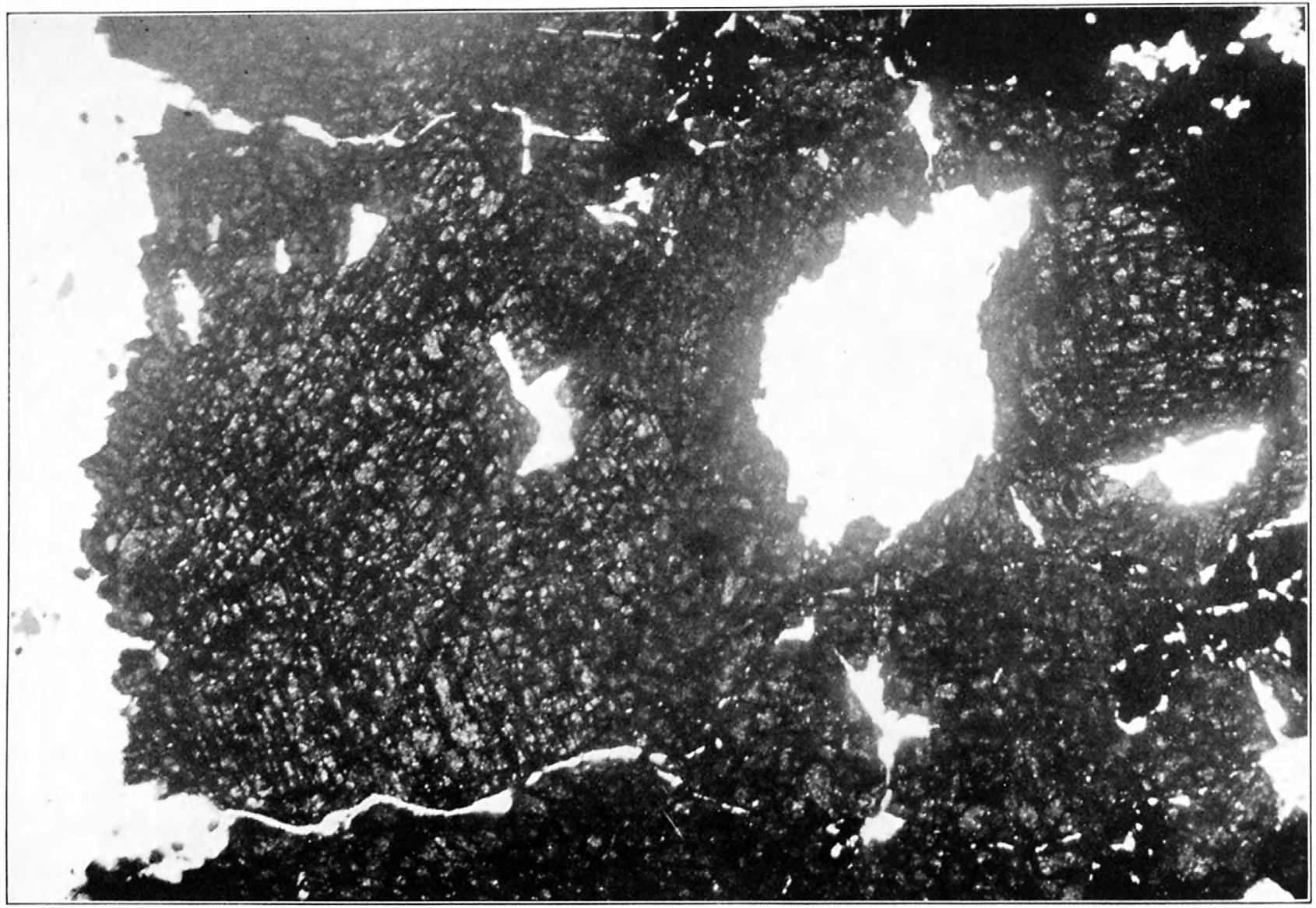

4. ZINC SULPHIDES, HORN SILVER MINE.

Light areas holes in the section, dark areas galena, gray zinc sulphides. Ordinary light. Enlarged 43 diameters.

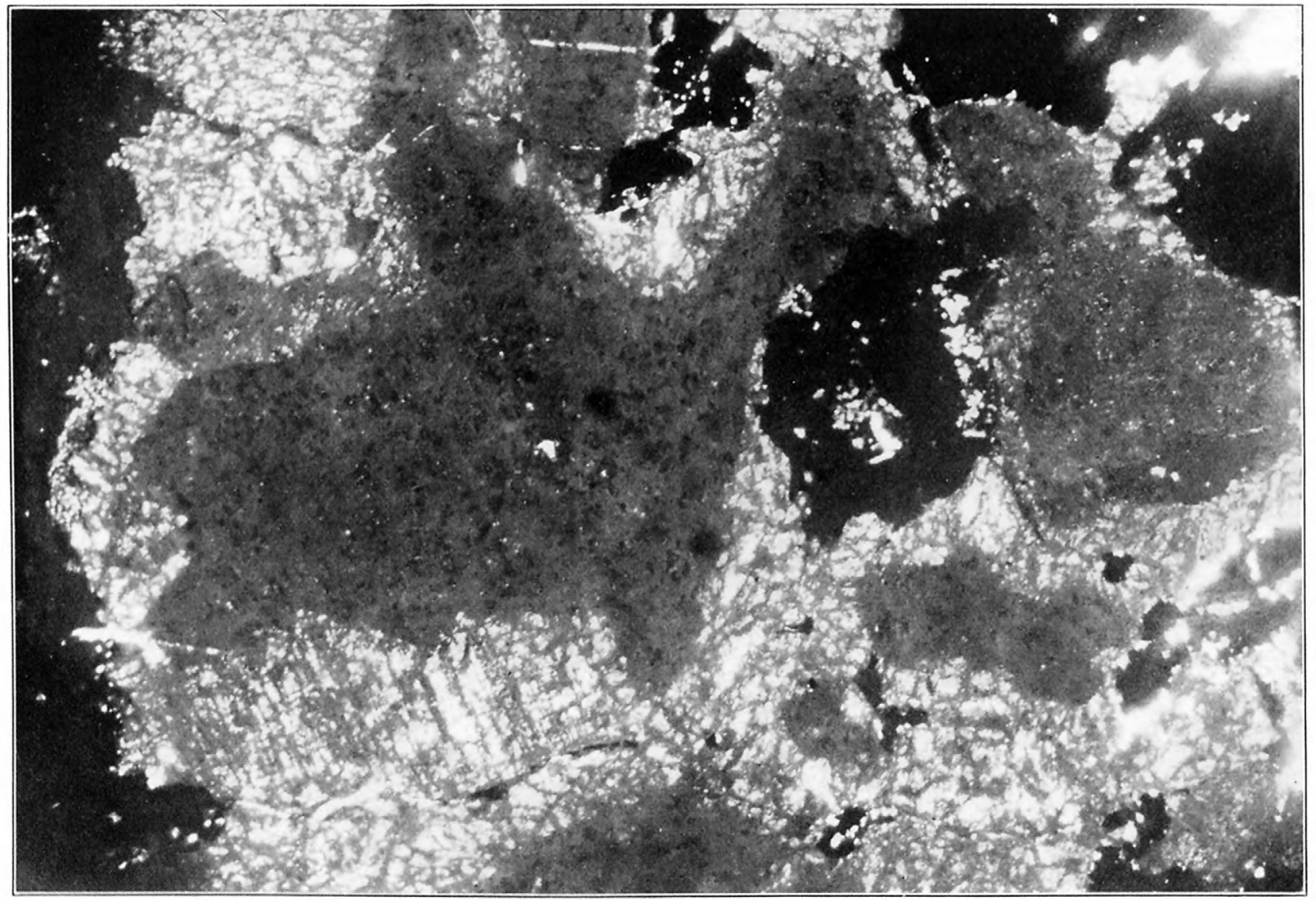

B. SAME SPECIMEN AS $A$, WITH CROSSED NICOLS. 
In 1893 a shipment was made of ore from the eighth level that carried 300 ounces of silver to the ton and 18.5 per cent of lead. This ore was possibly of the same type. It is probable that some of the rich, siliceous silver ores in the upper levels of the mine were also of this type. As already noted, however, the ore of this type is of relatively slight extent and quite different in character from the bulk of the deposits.

ZONE OF SULPHIDE ENRICHMENT.

The zone of sulphide enrichment is characterized by the presence of the secondary copper sulphides covellite and chalcocite and the secondary zinc sulphide wurtzite. The high-grade copper and zinc ores that have been extracted are believed to be the result of secondary alteration.

The copper minerals are covellite and chalcocite and probably a copper sulphate, either brochantite or chalcanthite, as a strong sulphate test can be obtained from any of the copper ores. These minerals have been formed as a replacement of sulphides of zinc (Pl. XXIV, $B$ ), iron, and lead (Pl. XXII, D, p. 141). Where the zinc and lead sulphides have been replaced there is commonly a thin film of a slate-blue mineral between the unaltered material and the copper sulphide. It has not been possible to get sufficient of this mineral for chemical determination, but it is believed to be a sulphate, as the ore gives a test for sulphate. It is possibly a complex sulphate of copper and lead or copper and zinc. The relation of this mineral to the primary and secondary ore is similar to that already described (p. 139), as shown in the altered chalcopyrite from the $\mathrm{O} \mathrm{K}$ mine. Covellite is the more common copper sulphide in the specimens examined, but chalcocite is also present and no evidence bearing on the conditions which determined the formation of one or the other of these minerals was obtained. In the specimens examined microscopically in which pyrite has been replaced (see Pl. XXIII, B, p. 146) no mineral is seen between the iron and copper sulphides.

In the richer zinc ores the hexagonal zinc sulphide wurtzite is rather abundant. Its most common mode of occurrence is wholly or partly incasing irregular grains of sphalerite and somewhat resembling in relation the copper sulphides that have replaced zinc and pyrite. (See Pls. XXV, XXVI.) The cleavage planes of the wurtzite and sphalerite commonly coincide and in ordinary light they have the appearance of being homogeneous mineral grains. It is only when placed between crossed nicols that the difference is apparent. In many places well-formed pyramidal crystals of wurtzite project from the sphalerite and are surrounded by the gangue minerals. Here and there blades of the wurtzite penetrate the sphalerite grains, usually along cleavage lines, and give a general appearance similar to that produced in twin crystals. Not uncommonly under the high power of the microscope a film of wurtzite is apparent along the cleavage cracks of sphalerite grains that under the low power appear to be composed entirely of the isotropic sulphide. Many mineral grains are composed entirely of wurtzite. These are commonly the small grains but include a few of the larger grains. A rather exceptional type as indicated by the sections studied consists of more or less spherical grains composed of radiating wurtzite crystals. (See Pl. XXII, C, p. 141.) These are commonly reddish yellow to brown, the color becoming deeper toward the center of the grain. In several specimens a core of wurtzite was apparently surrounded by the isotropic sulphide, though this relation appears to be the exception and in no instance could the wurtzite be shown to be entirely surrounded. Small grains of wurtzite are entirely inclosed in vein quartz that has been formed since the brecciation of the ore.

In the massive sulphide showing slight brecciation the zinc is present almost entirely as sphalerite. Under the high power of the microscope some double-refracting material that is probably wurtzite can be detected along the cleavages.

The study of the ores brings out these facts concerning the occurrence of the wurtzite: It is very largely confined to the highly brecciated ore; it is most abundant in the richest zinc ore; very commonly it surrounds grains of sphalerite, many of which then have the outline of wurtzite crystals. 
In accounting for the origin of the wurtzite and the relation between the wurtzite and sphalerite several possibilities must be considered.

It may be assumed that the wurtzite and sphalerite are both primary minerals and essentially contemporaneous. The fact that the wurtzite is almost absent from the massive primary sulphide ores, however, leaves little room for doubt that such an assumption is not correct.

The wurtzite may have resulted from alteration of the sphalerite or, on the other hand, the sphalerite may be the result of alteration of the wurtzite. As sphalerite is known to change to wurtzite at a high temperature, and as it is possible that the wurtzite might change to sphalerite under favorable conditions, both these assumptions are possible. The former is naturally suggested, because the wurtzite is confined to the brecciated ore, and it might be supposed that in the brecciation sufficient heat was generated to effect the transformation. If this had taken place the wurtzite should have formed, it would seem, as pseudomorphs after the sphalerite; as a matter of fact, however, much of it has the crystal form of wurtzite. The same objection applies to the assumption of the reverse change, for the sphalerite has nowhere been noted to have the crystal form of wurtzite.

It might be expected that zinc sulphide would replace pyrite, as has the copper sulphide. The apparent decrease in pyrite that in some places accompanies an increase in zinc sulphide would further suggest this idea. A careful search, however, has failed to reveal a single instance where it could be shown that wurtzite or sphalerite has replaced pyrite.

Finally, it may be supposed that the zinc that formed the wurtzite has been introduced into the zone where it occurs after the formation of the sphalerite and on precipitation has formed around the sphalerite, which has furnished centers of crystallization, and to a less extent has crystallized from new centers. This theory seems to meet all the conditions better than any other. The zinc may have been derived by leaching from the oxidized zone. The presence of the rich zinc ores along the breccia zones is to be expected, as these zones would be the natural channels for the descending solutions. The cleavage planes of wurtzite may be made to coincide with those of sphalerite, and H. E. Merwin, who has examined specimens of the ore, has suggested that the continuation of the cleavages across the contact is due to the fact that the sphalerite cores controlled the orientation of the wurtzite that crystallized around them. This seems a very reasonable and natural explanation of this phenomenon. The blades of wurtzite extending into the sphalerite and the cores of wurtzite that are apparently almost surrounded by sphalerite are not easily explained if the wurtzite originated in the manner indicated. The predominance of evidence, however, seems to favor this origin, though it is by no means impossible that some wurtzite may have been formed in other ways.

The formation of secondary zinc sulphide has been but rarely noted in western ore deposits. Ransome ${ }^{1}$ suggests that there has possibly been a secondary deposition of sphalerite in the galena-sphalerite veins of the Breckenridge district, Colorado, and Weed ${ }^{2}$ has noted the presence of wurtzite in the Gagnon mine at Butte, Mont., but does not state that it is of secondary origin, as hoted elsewhere (p. 152). Pearce found wurtzite in the upper levels of the Gagnon mine.

In several places in the Horn Silver mine galena was observed filling fissures in sphalerite and surrounding sphalerite grains in a manner which suggested that the lead sulphide has replaced the sphalerite.

PRIMARY ZONE.

The primary zone extends from the zone of sulphide enrichment downward. As already noted, along channels favorable to circulation alteration has taken place to the bottom of the deposit as far as developed. In the more massive portions, however, there has been relatively slight alteration below the 850-foot level, and in some of the ore sulphide enrichment has probably been slight even a short distance below the oxidized ores. The primary zone contains a mixture of galena, pyrite, sphalerite, and small amounts of other minerals in a siliceous gangue. The amount of the different sulphides varies from place to place, but all are abundant. The ore thus far extracted from this zone has been mined for its silver and lead, the zinc content not

1 Ransome, F. L., Geology and ore deposits of the Breckenridge district, Colorado: Prof. Paper U. S. Geol. Survey No. 75 , 1911, p. 169.

2 Weed, W. H., Geology and ore deposits of the Butte district, Montana: Prof. Paper U. S. Geol. Survey No. 74, 1912, p. 80. 
being high enough to make it a profitable zinc ore. As already noted, however, along zones of pronounced crushing the enrichment in zinc has extended to the bottom of the deposit.

CHEMISTRY OF THE ALTERATION.

In discussing the chemistry of the enrichment of the Horn Silver deposit some of the changes that have been observed in other districts may be cited and their bearing on this deposit indicated. Such equations as are given are not supposed to represent the actual chemical processes that have taken place but only the end products. It is believed that in the alteration intermediate substances were formed, and it is improbable that under such complex conditions the reactions were as simple as is represented in the equations given.

Changes in zone of oxidation.- - It has already been pointed out that pyrite and chalcopyrite are readily oxidized. The reactions may be written as follows:

$$
\begin{aligned}
& \text { Pyrite: } \mathrm{FeS}_{2}+7 \mathrm{O}+\mathrm{H}_{2} \mathrm{O}=\mathrm{FeSO}_{4}+\mathrm{H}_{2} \mathrm{SO}_{4} \text {. } \\
& \text { Chalcopyrite: } \mathrm{CuFeS}_{2}+8 \mathrm{O}=\mathrm{CuSO}_{4}+\mathrm{FeSO}_{4} \text {. }
\end{aligned}
$$

The iron sulphate may break down to limonite and sulphuric acid, a result which is very common in the formation of iron gossans. In this deposit, however, much of the iron has apparently been removed from the ore zone, probably as the sulphate. To a slight extent the sulphate of copper has probably reacted with carbonic acid to form the carbonates of copper. This reaction may be written as follows:

$$
2 \mathrm{CuSO}_{4}+2 \mathrm{H}_{2} \mathrm{CO}_{3}+\mathrm{H}_{2} \mathrm{O}=\mathrm{Cu}(\mathrm{OH})_{2} \mathrm{CO}_{3}+2 \mathrm{H}_{2} \mathrm{SO}_{4}+\mathrm{CO}_{2} \text {. }
$$

The secondary copper sulphides have to a considerable extent oxidized to the basic sulphate brochantite, this mineral being apparently more abundant than the carbonates. Lindgren ${ }^{1}$ has given the following equation as probably representing the reaction that takes place in the formation of-brochantite from chalcocite:

$$
2 \mathrm{Cu}_{2} \mathrm{~S}+10 \mathrm{O}+4 \mathrm{H}_{2} \mathrm{O}=\mathrm{H}_{6} \mathrm{Cu}_{4} \mathrm{SO}_{10}+\mathrm{H}_{2} \mathrm{SO}_{4} .
$$

To a less extent have been formed the more complex sulphates of copper and lead (linarite), and of copper, lead, and iron (beaverite), and the silicate of copper (chrysocolla).

The galena has been altered mainly to the sulphate anglesite and the change may be represented by the equation $\mathrm{PbS}+4 \mathrm{O}=\mathrm{PbSO}_{4}$. The anglesite is but slightly soluble and appears to have moved but a short distance from the position in which it was formed. It is slightly soluble, however, and in a region where water circulated in abundance considerable lead might have been removed, but under the conditions existing in this district the amount of lead removed has been slight. Some lead carbonate has been formed, and the reaction may be represented by the equation $\mathrm{PbSO}_{4}+\mathrm{H}_{2} \mathrm{CO}_{3}=\mathrm{PbCO}_{3}+\mathrm{H}_{2} \mathrm{SO}_{4}$. To a relatively slight extent the more complex lead sulphates plumbojarosite, linarite, and beaverite have been formed during the process of oxidation.

The change that takes place in the alteration of sphalerite may be represented by the equation $\mathrm{ZnS}+4 \mathrm{O}=\mathrm{ZnSO}_{4}$, or, in the presence of sulphuric acid, $\mathrm{ZnS}+\mathrm{H}_{2} \mathrm{SO}_{4}=\mathrm{ZnSO}_{4}+\mathrm{H}_{2} \mathrm{~S}$. The sulphate of zinc is readily soluble and has been very largely removed from the zone of oxidation. At the present time it is being deposited on the walls of the openings in the lower part of the mine as goslarite. To an unknown but probably very small extent the zinc carbonate smithsonite and the zine silicate calamine have been formed. The former has resulted from the replacement of calcite, the reaction being represented by the equation $\mathrm{ZnSO}_{4}+\mathrm{CaCO}_{3}=$ $\mathrm{ZnCO}_{3}+\mathrm{CaSO}_{4}$.

Satisfactory material for a study of the alteration of the antimony minerals and the silver minerals was not procured. Some of the silver in the oxidized ores is present as chloride, but to what extent the alteration to chloride has taken place can not be stated.

The rather abundant sulphur that is present in the oxidized ores can possibly be attributed to the oxidation of hydrogen sulphide generated in the alteration of the sulphide in the lower

\footnotetext{
${ }_{1}^{1}$ Lindgren, Waldemar, The copper deposits of the Clifton-Morenci district, Arizona: Prof. Paper U. S. Geol. Survey No. 43, 1905, p. 188.
} 
zơne. The original source of the manganese has not been ascertained. No carbonate or silicate of this mineral was observed. It may be present in small amounts in the sulphides of the district.

Changes in zone of sulphide enrichment. - That sulphides of certain metals will precipitate other metals from their oxidized salts, the metal of the original sulphide going into solution, is too well established to make it necessary or desirable to give the evidence on which such a conclusion has been based. Schürmann established the following series of the metallic sulphides stated in the order of the relative affinity of the metals for sulphur: Palladium, mercury, silver, copper, bismuth, cadmium, antimony, tin, lead, zinc, nickel, cobalt, ferrous iron, arsenic, thallium, and manganese. It was later shown that the replacement of one metal by another is probably dependent on the relative solubility of the salts of the metals under the conditions of the replacement. The order of solubility is, however, essentially the same as that given by Schürmann. From this it is to be expected that copper sulphide will precipitate the silver from oxidized silver salts, that lead sulphide will precipitate both copper and silver, that zine sulphide will precipitate silver, lead, and copper, and that iron sulphide will precipitate all these metals as sulphides. Although this order has long been known and geologists have been on the lookout for occurrences in ore deposits, by no means all the combinations have been found.

The precipitation of copper by iron sulphides is common and has been repeatedly described, the reaction that takes place being essentially that already given. Why chalcocite is precipitated in some places and covellite in others is not well understood. Dr. E. T. Allen informed the writer that it had been found experimentally that solutions of ferrous iron dissolve half of the copper from chalcocite, leaving covellite, and metallurgic practices point to the same conclusion, but sufficient work has not been done on this subject to warrant any general statements. The precipitation of copper by pyrite in the Horn Silver deposit appears in no way different from that described for other deposits.

The precipitation of copper by sphalerite has been observed much less frequently than the precipitation by iron sulphides. Lindgren ${ }^{1}$ has described the replacement of sphalerite by covellite in the Ryerson mine in the Morenci district, Arizona, and gives the equation $\mathrm{ZnS}+$ $\mathrm{CuSO}_{4}=\mathrm{ZnSO}_{4}+\mathrm{CuS}$ to represent the reaction. He states that chalcocite has probably also formed as a replacement of sphalerite. From experimental data Wells ${ }^{2}$ has found the same reaction to take place. Irving and Bancroft ${ }^{3}$ have described covellite replacing sphalerite in the Lake City district, Colorado. They state also "that "chalcocite is probably the only secondary [sulphide] mineral that has not been definitely identified in intimate association with zinc blende." Weed ${ }^{5}$ has noted the replacement of sphalerite by both covellite and chalcocite in the Butte district, Montana.

Richard Pearce ${ }^{6}$ has described an interesting mineral association in the upper levels of the Gagnon mine, at Butte, Mont., which in some respects is suggestive of that at the Horn Silver mine. He says:

Perhaps by far the most interesting feature is the occurrence in very large quantities of a rich silver and copper bearing zine blende. This mineral was discovered between the 200 and 300 foot levels of the Gagnon, and some thousands of tons of it were mined and smelted, principally at Argo, Colo. Smelter returns show varying contents of shipments as follows: Silver, from 50 to 200 ounces per ton; copper, from 1 to 42 per cent; and zinc, from 7 to $48 \frac{1}{2}$ per cent.

The ore may be described as a brownish-black mineral, with a small amount of quartz and barite but without any indications whatever of the ordinary copper-bearing minerals. It was perfectly homogeneous, and the only guide one had in estimating the amount of copper it contained was the slight variation in color from brown to black, the blacker varieties being richer in copper. I have every reason to believe, judging from the peculiar structure of the mineral and the almost entire absence of crystallization, that it is a massive wurtzite, which is zinc blende occurring in a different crystalline system, viz, the rhombohedral. After some years of careful searching for a crystal of the mineral, I was fortunate enough to discover some small crystals (having the form of the hexagonal prism, with the planes of the pyramid) which are undoubtedly wurtzite.

This occurrence of zinc blende, containing so large a percentage of copper, is indeed remarkable. I think it probable, however, that the varieties which are so high in copper have undergone some change, the copper being enriched

1 Lindgren, Waldemar, The copper deposits of the Clifton-Morenci district, Arizona: Prof. Paper U. S. Geol. Survey No. 43, 1905, p. 182.

2 Wells, R. C., The fractional precipitation of sulphides: Econ. Geology, vol. 5,1910 , p. 5.

${ }^{3}$ Irving, J. D., and Baneroft, Howland, Geology and ore deposits near Lake City, Colo.: Bull. U. S. Geol. Survey No. 478,1911, p. 64.

- Idem, p. 65.

Weed, W. H., Geology and ore deposits of the Butte district, Montana: Prof. Paper U. S. Geol. Survey No. 74, 1912 , p. 101.

'Trans. Am. Inst. Min. Eng., vol. 16, 1888, p. 62. 
by the oxidation and partial disappearance of the zinc. Very fine specimens of goslarite (sulphate of zinc) are now to be found on the walls of the levels in the Gagnon, which would indicate beyond a doubt that the zinc blende has been oxidized to a large extent. I have also reason to believe that the same influences which effected the oxidation and removal of the zinc may have caused the disappearance of a portion of the silver, for we find as a rule, in the lots of ore smelted, that an increase in the percentage of the copper accompanies a corresponding decrease in the silver contents, and the presence of native silver in very thin plates throughout the masses of the blende would indicate some sort of secondary deposition of the silver.

In the deeper levels of the mine pyrite is more abundant than in the upper workings and there is a marked decrease in the quantity of zinc blende.

Scattered through the lode we often find a bronze-looking pyrite, having a structure somewhat different from that of ordinary pyrite, namely, conchoidal; and this mineral is often rich in silver. Some specimens which I have examined contained as much as 3 per cent.

A mineral which was found about a year ago in the 500 -foot level in very small quantities interested me very much, on account of its richness in silver and its peculiar composition. An analysis of a selected specimen gave:

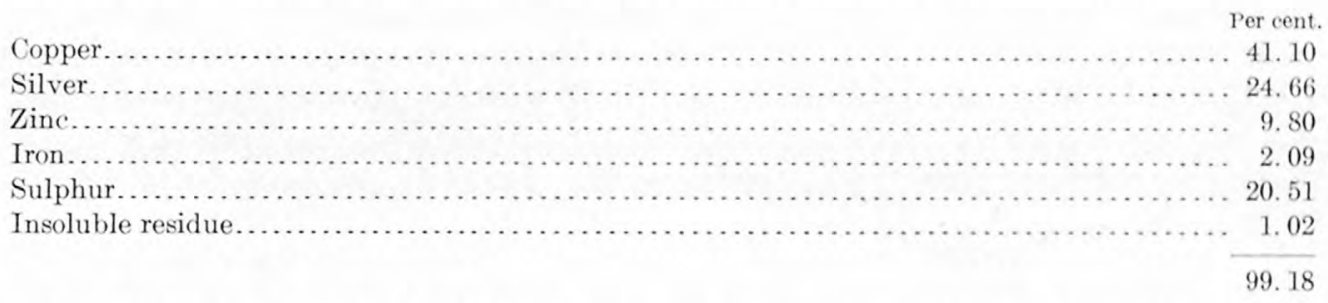

I have been inclined to the belief that this is a new compound (a copper-silver-zinc mineral). If we regard the iron as replacing a portion of the zinc, we arrive at the formula $3 \mathrm{Cu}_{2} \mathrm{~S}+\mathrm{Ag}_{2} \mathrm{~S}+\mathrm{ZnS}$. Whether the zinc may be regarded as an accidental admixture or as part and parcel of the mineral I am not prepared to say, but judging from the uniform character of the mineral I should be inclined to believe that zinc enters into its composition.

It seems to the writer highly probable that the ore described in the foregoing quotation has resulted from a partial replacement of zinc by copper ore. Specimens collected from the Horm Silver mine that have the appearance of a single mineral under the microscope are at once seen to be composed of zinc sulphide partly replaced by copper sulphide. Pearce evidently saw that there had been an enrichment in copper at the expense of zinc, and if the process of enrichment had then been well understood he would possibly have recognized that process as having produced the Butte ore.

In the Horn Silver mine covellite is the only copper sulphide observed to replace zinc, though some of the covellite has probably been later altered to chalcocite. The occurrences described seem to indicate that covellite more commonly than chalcocite replaces sphalerite, whereas the reverse is true in the precipitation of copper minerals by the iron sulphides. It will not be surprising if further observations show that the normal reaction batween sphalerite $(\mathrm{ZnS})$ and copper sulphate $\left(\mathrm{CuSO}_{4}\right)$ produces covellite (CuS) rather than chalcocite $\left(\mathrm{Cu}_{2} \mathrm{~S}\right)$.

For the reaction of copper salts with galena, Wells ${ }^{1}$ has given the equation $\mathrm{PbS}+$ $\mathrm{Cu}\left(\mathrm{NO}_{3}\right)_{2}=\mathrm{CuS}+\mathrm{Pb}\left(\mathrm{NO}_{3}\right)_{2}$. The corresponding reaction with the sulphate may be written $\mathrm{PbS}+\mathrm{CuSO}_{4}=\mathrm{PbSO}_{4}+\mathrm{CuS}$. It is by no means certain that more complex sulphates are not formed during the reaction. Such sulphates are present in the mine and it is possible that some of the lead has been transported in the form of a complex sulphate that is more soluble than anglesite.

From their relative solubilities it is to be expected that zinc sulphide would precipitate lead from solution, and such a replacement of sphalerite by galena has been noted by Irving and Bancroft ${ }^{2}$ at Lake City and by Ransome ${ }^{3}$ in the Breckenridge district, in Colorado.

In some of the zinc ores galena has been formed along fractures in the grains of zinc sulphide (both sphalerite and wurtzite), and it is practically certain that there has been a replacement of the zinc sulphide rather than a simple filling of the fissures. In other places grains of zinc sulphide are surrounded by galena in a manner suggesting replacement, but the galena does not enter along the cleavage planes, as might be expected. This, however, can not be taken as evidence that there has been no replacement, for in some places where copper

1 Wells, R. C., The fractional precipitation of sulphides: Econ. Geology, vol. 5, 1910, p. 4 .

${ }^{2}$ Irving, J. D., and Bancroft, Howland, Geology and ore deposits near Lake City, Colo.: Bull. U. S. Geol. Survey No. 478, 1911, p. 64.

${ }^{3}$ Ransome, F. L., Geology and ore deposits of the Breckenridge district, Colorado: Prof. Peper U. S. Geol. Survey No. 75,1911, p. 168. 
sulphides have replaced the zine the line between the two is remarkably sharp. (See Pl. XXIV, $B$, p. 147.) The chemical change that has taken place may be represented by the reaction $\mathrm{ZnS}+\mathrm{PbSO}_{4}=\mathrm{PbS}+\mathrm{ZnSO}_{4}$. It is possible, however, that the lead was in the form of some salt more soluble than the simple sulphate. It might be expected that pyrite would be replaced by galena also, but no example of this was noted in the specimens examined. It is not likely that secondary galena has been formed in very large amounts in the mine, for most of the lead in the upper levels has been transformed to the very slightly soluble sulphate and there is no evidence of any considerable migration of the lead, as there is for the copper and zinc.

The reaction that has taken place in the precipitation of zinc sulphide is somewhat uncertain. It is to be expected that zine would replace pyrite and it semms that pyrite has been removed from at least some of the ore to which considerable zinc sulphide has been added, a fact which may be interpreted as meaning that the pyrite has been replaced and the iron removed as sulphate. In none of the ore examined can the zinc sulphide be seen replacing the iron, but there are abundant specimens that show wurtzite surrounding sphalerite, apparently as a later growth on it. This suggests that the precipitation has been effected by agents other than the pyrite and that the attraction of the sphalerite has caused the secondary sulphide to be added to it.

The raaction corresponding to the one given by Stokes ${ }^{1}$ for copper salts may be written as follows:

$$
4 \mathrm{FeS}_{2}+7 \mathrm{ZnSO}_{4}+4 \mathrm{H}_{2} \mathrm{O}=7 \mathrm{ZnS}+4 \mathrm{FeSO}_{4}+4 \mathrm{H}_{2} \mathrm{SO}_{4} .
$$

The iron would be removed in solution, while the sulphuric acid might oxidize pyrite, producing hydrogen sulphide and iron sulphate, the latter being removed in solution. Stokes found that pure pyrite was not attacked by sulphuric acid but that cupriferous pyrite was. Satisfactory tests of the pyrite in the Horn Silver mine could not be made, as in all parts of the mine the ore contains some soluble sulphate of iron. From the above reaction pseudomorphs of zine sulphide after pyrite would be expected.

On the other hand, zinc may have been precipitated by hydrogen sulphide, the reaction being represented by the equation $\mathrm{H}_{2} \mathrm{~S}+\mathrm{ZnSO}_{4}=\mathrm{ZnS}+\mathrm{H}_{2} \mathrm{SO}_{4}$. This reaction would produce an acid solution, but Allen has shown that zine sulphide will precipitate from an acid solution that is relatively weak. In this reaction the zinc sulphide might naturally be supposed to crystallize around the sphalerite grains, forming the additions of wurtzite as they now appear.

The reaction just given calls for the presence of hydrogen sulphide. This may have been generated by the action of sulphuric acid on the sulphides essentially at the point where precipitation took place, but as zinc sulphide is one of the sulphides most readily acted upon by sulphuric acid it seems hardly probable that any of the sulphides present were being attacked by sulphuric acid at a point where zinc sulphide was being precipitated. E. T. Allen and J. L. Crenshaw have suggested that acid solutions containing zine sulphate and hydrogen sulphide in solution on having their acidity reduced would precipitate zinc sulphide. That such solutions are formed in the zone of oxidation there can be little doubt, and as they pass to lower levels their acidity may be reduced either by solutions from the adjacent limestone or by reaction with the alkali silicates that form a part of the gangue of the ore.

Buckley and Buehler ${ }^{2}$ have given the following equations as indicating the reaction that takes place in the formation of hydrogen sulphide and the precipitation of zinc sulphide by alkali sulphides:

$$
\begin{aligned}
& \mathrm{CaS}+\mathrm{H}_{2} \mathrm{SO}_{4}=\mathrm{CaSO}_{4} \cdot 2 \mathrm{H}_{2} \mathrm{O}+\mathrm{H}_{2} \mathrm{~S} . \\
& \mathrm{ZnSO}_{4}+\mathrm{CaS}+2 \mathrm{H}_{2} \mathrm{O}=\mathrm{ZnS}+\mathrm{CaSO}_{4} \cdot 2 \mathrm{H}_{2} \mathrm{O} .
\end{aligned}
$$

The reaction between the hydrogen sulphide and the zinc sulphate would be the same as indicated above. There is abundant gypsum in and near the ores, and it may have been formed by a reaction similar to that given above or it may have resulted from the reaction of sulphuric acid with calcium solutions that were active in reducing the acidity of descending

1 Stokes, H. N., Experiments on the action of vartous solutions on pyrite and marcasite: Econ. Geology, vol. 2, 1907, p. 14.

2 Buckley, E. R . and Buehler, H. A., The geology of the Granby area: Missouri Bur. Geology and Mines, 2d ser., vol. 4, 1906, p. 89. 
acid solutions. Which of these processes caused the precipitation of the zinc can not be positively stated and it is possible that more than one may have been in operation. The writer, however, is inclined to favor the former.

Allen and Crenshaw ${ }^{1}$ have recently obtained some very interesting and important results from the artificial production of the zine sulphides which have a direct bearing on the problem here discussed. Some of the results of their work are given in the following quotations:

Enantiotropic relation between sphalerite and wurtzite.-If sphalerite is heated to a temperature of about $1,100^{\circ}$ and cooled with moderate rapidity - that is, to $100^{\circ}$ inside of two hours-microscopic examination shows that it is completely transformed into wurtzite. ${ }^{2}$ The heating curve, however, shows no break to indicate that any heat change has accompanied the transformation. ***

Formation of sphalerite by precipitation with alkali sulphides. - The precipitate from zinc salts by alkali sulphides in the cold, or under ordinary conditions at a boiling temperature, shows no indications of crystallinity. However, when pretty concentrated solutions of the soluble sulphides act on amorphous zinc sulphide at higher temperatures sphalerite is obtained. As previously stated, experiments with concentrated alkaline solutions gave much trouble. The glass tubes were so badly attacked that the products obtained in them were quite impure, greatly increasing the difficulties of microscopic analysis, while at $300^{\circ}$ the tubes were sometimes eaten entirely through. The difficulty was finally overcome by putting the solutions into platinum tubes which were then set inside of glass tubes, the latter being afterwards sealed. Satisfactory platinum tubes which are not so expensive as to be prohibitive may be fashioned from foil by the use of the oxyhydrogen blowpipe. Ours had a diameter of about 15 millimeters and a total capacity of about 40 cubic centimeters.

In our first successful experiment amorphous zine sulphide was put into a tube of Jena combustion glass ${ }^{3}$ with sodium sulphide of about 20 per cent concentration; the tube and its contents were heated three days in a steel bomb at $350^{\circ}$. Small though good crystals of sphalerite, both octahedrons and tetrahedrons, were obtained. Again, amorphous zinc sulphide was heated in a platinum tube sealed inside a glass tube, as described above, with potassium sulphide of about 35 per cent at $200^{\circ}$ for 11 days. Minute tetrahedrons of sphalerite were obtained. A solution of 10 per cent potassium sulphide heated with amorphous zinc sulphide in a similar manner at $200^{\circ}$ for two months ${ }^{4}$ gave a product which was entirely crystallized in minute isotropic crystals with evident faces but rather rounded edges. A second experiment with 10 per cent sodium sulphide, lasting six weeks at $100^{\circ}$, failed to yield any crystals. Thus we find, as we should expect, that the lower the temperature and the more dilute the reagent the longer is the time required to produce recognizable crystals. It is a notable fact that sphalerite only was obtained by this method, never wurtzite.

Zinc sulphide from acid solutions.- When zine sulphide is precipitated by hydrogen sulphide from solutions which are either neutral or acid at the start, at temperatures ranging from the ordinary up to $200^{\circ}$, the product is always amorphous so far as our observation goes. The double-tube method, which proved so satisfactory in the formation of some other sulphides, did not generate hydrogen sulphide at a rate slow enough to give crystals. True, the products were frequently though not always doubly refracting, and for some time we were misled into the belief that they were wurtzite, but the measurement of their refractive index later on showed that they were in all probability amorphous and that the double refraction was caused by strains produced in the hardening of precipitates originally gelatinous. Experience in qualitative analysis might lead one to believe that zinc salts could not be precipitated by hydrogen sulphide from solutions containing much free acid. As a matter of fact precipitates are obtained from rather strong acid solutions, provided only sufficient time is allowed, as Glixelli ${ }^{5}$ has proved.

Table 6 shows our own results on this point. In it are given the times which elapsed after hydrogen suiphide was introduced before a precipitate was observed, and the composition of solutions after 10 days' standing. The concentration of the zinc was $0.2 \mathrm{~N}$ at the beginning in all the solutions except the last; the hydrogen sulphide was kept at a pressure of approximately one atmosphere, by uncorking the flasks and passing in fresh gas from time to time, while the concentration of the sulphuric acid varied as stated in the table. The experiments were carried out at room temperature. It will be noted that a partial precipitation was obtained in the above manner from solutions which contained about 5 per cent sulphuric acid at the start and nearly 6 per cent at the end of the experiment. With a higher initial concentration of zinc or a higher pressure of hydrogen sulphide, precipitation would naturally be obtained from solutions containing still more acid. The textbooks commonly assume equilibrium in these systems and use them as examples of the mass law. Preliminary work on the subject has convinced us that such is not the case. *** If one begins with the same precipitates, adding different concentrations of acid and maintaining the hydrogen sulphide at one atmosphere, different results are obtained. More work on this subject is under consideration, but the results given show well enough that hydrogen sulphide will in time precipitate zinc from solutions which are quite strongly acid.

1 Allen, E. T., and Crenshaw, J. L., The sulphides of zine, cadmium, and mercury; their erystalline forms and genetic conditions: Am. Jour. Sci., 4th ser., vol. 34,1912 , pp. 341-376.

$2 \mathrm{~J}$. Weber heated small plates of sphalerite in a Bunsen flame and cooled quickly. He found they had become anisotropic. Zeitschr. Kryst., vol, 44, 1908, p. 212. Biltz expressed the opinion that sphalerite might change to wurtzite without sublimation. Zeitschr. anorg. Chemie, vol. 59, 1908, p. 273 .

3 Out of a large number of experiments with glass tubes, this was the only one in which the product could be recovered.

4 By mistake the temperature was dropped to $100^{\circ}$ for a part of the period.

5 Zeitschr. anorg. Chemie, vol. 55,1907, p, 297 . 
Crystalline zinc sulphide from acid solutions. $-A$ great number of experiments have been made with the purpose of preparing crystalline zinc sulphide from acid solutions at low temperatures, yet so far without success. This seems very remarkable when we consider how slowly the sulphide forms in strong acid solutions (see Table 6), and we have as yet no explanation for it. At temperatures of $250^{\circ}$ and upward, by the use of the double-tube method, ${ }^{1}$ crystalline products can be obtained. The results are sufficiently interesting to be stated in detail. In all the experiments the source of hydrogen sulphide was about 6 grams $\mathrm{Na}_{2} \mathrm{~S}_{2} \mathrm{O}_{3} .5 \mathrm{H}_{2} \mathrm{O}$ in $15-20$ cubic centimeters water, which was placed in the outside tube. The inside tube ${ }^{2}$ in each case contained 10-15 cubic centimeters of 10 per cent $\mathrm{ZnSO}_{4} \cdot 7 \mathrm{H}_{2} \mathrm{O}$. The time in all cases was two or three days. The concentration of the sulphuric acid in the latter solutions and the temperature to which the tubes were heated varied in the different experiments.

TABLE 6. - The action of hydrogen sulphide on $0.2 \mathrm{~N} \mathrm{ZnSO}_{4}$, with varying concentration of $\mathrm{H}_{2} \mathrm{SO}_{4}$.

\begin{tabular}{|c|c|c|c|c|c|c|c|}
\hline \multirow{2}{*}{ No. } & \multicolumn{2}{|c|}{$\mathrm{H}_{2} \mathrm{SO}_{4}$. } & \multirow{2}{*}{ Approximate tíme before precipitation began. } & \multicolumn{2}{|c|}{$\begin{array}{c}\text { Zine in solution after } \\
10 \text { days. }\end{array}$} & \multicolumn{2}{|c|}{$\begin{array}{c}\mathrm{H}_{2} \mathrm{SO}_{4} \text { after precipi- } \\
\text { tation. }\end{array}$} \\
\hline & Normality. & Per cent. & & Normality. & Per cent. & Normality. & Per cent. \\
\hline $\begin{array}{l}1 \\
2 \\
3 \\
4 \\
5\end{array}$ & $\begin{array}{r}0.1 \\
.2 \\
.5 \\
1.0 \\
1.5\end{array}$ & $\begin{array}{r}0.49 \\
.98 \\
2.45 \\
4.90 \\
7.36\end{array}$ & 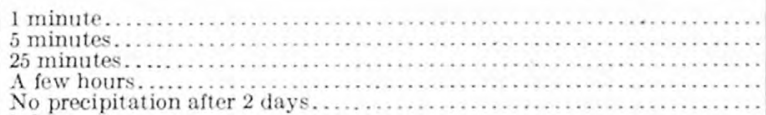 & $\begin{array}{r}0.0000 \\
.0031 \\
.0089 \\
.0338\end{array}$ & $\begin{array}{r}0.000 \\
.010 \\
.029 \\
.111\end{array}$ & $\begin{array}{r}0.300 \\
.398 \\
.691 \\
1.183\end{array}$ & $\begin{array}{l}1.47 \\
1.95 \\
3.39 \\
5.80\end{array}$ \\
\hline $6 a$ & 1.5 & 7. 36 & 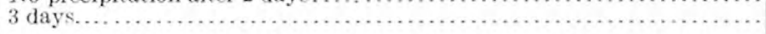 & 0923 & .302 & 1.609 & 7.89 \\
\hline
\end{tabular}

a Concentration of $\mathrm{ZnSO}_{4}$ in No. 6 was increased to $0.214 \mathrm{~N}$ after two days.

Experiment 1. Temperature $300^{\circ} ; 10$ per cent $\mathrm{H}_{2} \mathrm{SO}_{4}$ used. The product consisted of spherulitic aggregates, all doubly refracting and having the refractive index of wurtzite.

Experiment 2. Temperature $300^{\circ} ; 7.5$ per cent $\mathrm{H}_{2} \mathrm{SO}_{4}$. Crusts and spherules consisting of felted fibers which were unquestionably wurtzite sometimes surrounded by amorphous sulphide, indicating that the precipitate first formed was amorphous. 5-10 per cent of more transparent irregular masses of isotropic substance having the refractive index of sphalerite.

Experiment 3 . Temperature $300^{\circ} ; 5$ per cent $\mathrm{H}_{2} \mathrm{SO}_{4}$. The product consisted of globules with crystal faces growing out of them. Nearly all were isotropic and showed the refractive index of sphalerite, though there was perhaps 5 per cent of doubly refracting wurtzite.

Experiment 4. Temperature $300^{\circ} ; 4$ per cent $\mathrm{H}_{2} \mathrm{SO}_{4}$. A bout 30 per cent amorphous sulphide, the rest wurtzite.

Experiment 5. Temperature $300^{\circ} ; 1$ per cent $\mathrm{H}_{2} \mathrm{SO}_{4}$. The product showed crystalline faces and was apparently isotropic. Practically all of it had the index of sphalerite, though there were a few pieces of amorphous material.

Experiment 6. Temperature $250^{\circ} ; 5$ per cent $\mathrm{H}_{2} \mathrm{SO}_{4}$. The product consisted almost entirely of large spherules showing both radial fibers and felted fibrous structure. Inside of some were nuclei of amorphous material, indicating again that the precipitate was at first amorphous. Crystalline material all wurtzite.

Experiment 7. Temperature $250^{\circ} ; 2.5$ per cent $\mathrm{H}_{2} \mathrm{SO}_{4}$. Both large and small spherules, the last in clustered form and amorphous, the large ones mostly doubly refracting and crystalline wurtzite.

Experiment 8. Temperature $350^{\circ} ; 5$ per cent $\mathrm{H}_{2} \mathrm{SO}_{4}$. Possibly 30 per cent wurtzite, the rest sphalerite.

Experiment 9 . Temperature $350^{\circ} ; 10$ per cent $\mathrm{H}_{2} \mathrm{SO}_{4}$. Perhaps 80 per cent wurtzite, the rest sphalerite.

Experiment 10. Temperature $350^{\circ} ; 2.5$ per cent $\mathrm{H}_{2} \mathrm{SO}_{4}$. Most of the product consisted of small spherules, of which about 30 per cent was amorphous, the rest felted aggregates of wurtzite.

Experiment 11. Temperature $250^{\circ} ; 1$ per cent $\mathrm{H}_{2} \mathrm{SO}_{4}$. Consisted almost wholly of irregular granules, much of it isotropic and having the refractive index of sphalerite. In strong light considerable of it shows double refraction and the index of wurtzite.

Experiment 12. Temperature $300^{\circ} ; 2.5$ per cent $\mathrm{H}_{2} \mathrm{SO}_{4}$. All apparently isotropic irregular forms having the index of sphalerite.

TABLE 7.--Influence of temperature and acid concentration on the crystalline form of zinc sulphide.

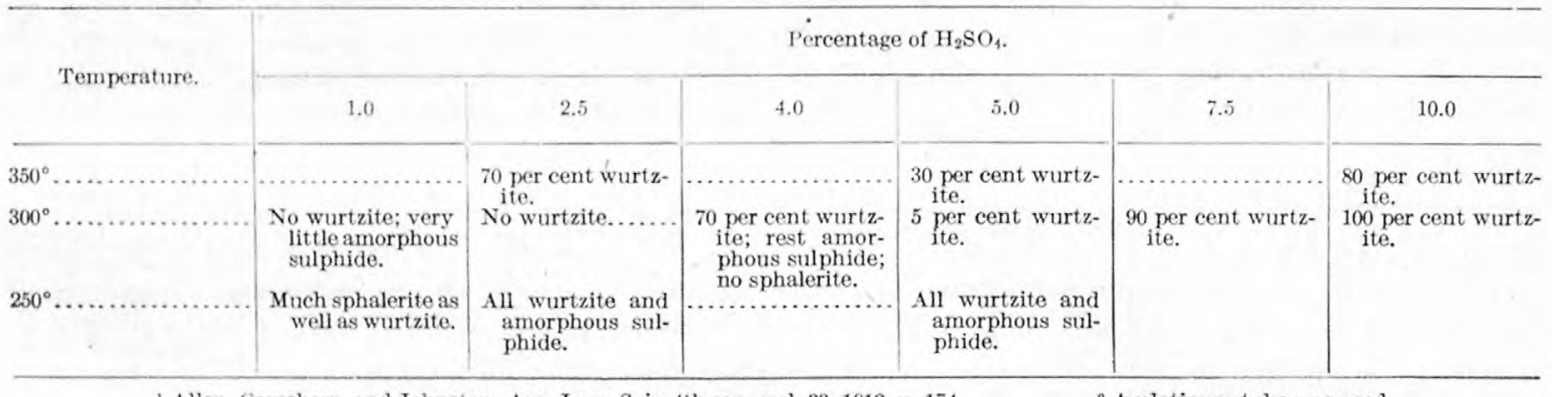

Allen, Crenshaw, and Johnston, Am. Jour. Sci., 4th ser., vol. 33, 1912, p. 174.

2 A platinum tube was used. 
The results of these experiments are summarized in Table 7 . When all the data are carefully compared, it will be seen that temperature and acid concentration appear to be the two factors which determine the product; and if we omit 2 experiments out of the 12 done at three different temperatures, we find the following regularity: For a given temperature the higher the acid concentration the greater is the quantity of wurtzite found in the product, and for a given acid concentration the higher the temperature the greater is the quantity of sphalerite found in the product. More work ought to be done on this point, but the above conclusion gains support from the fact that the same rule proved true in the case of the disulphides of iron. ${ }^{1}$ There the quantity of pyrite increased with the temperature for a given acid concentration, and the quantity of marcasite increased with the acid concentration for any given temperature. When it is remembered that pyrite and sphalerite are stable forms, while marcasite and wurtzite are unstable, the analogy becomes striking.

In one respect this synthetic work on sphalerite and wurtzite may appear inadequate to the geologist, namely, the temperature of formation. Field observation points to lower temperatures in many instances than the lowest at which we have succeeded in forming these minerals. Although it would be highly desirable to obtain positive results at lower temperatures, it may be pointed out that there is nothing in our knowledge of the minerals to indicate anything more than continuous changes in the necessary conditions as the temperature falls. We must admit, however, that the temperature interval is still too long to extrapolate accurately, so that we might predict, for example, what concentration of acid would be necessary at ordinary temperature to give rise to pure wurtzite. Since even quite dilute solutions of soluble sulphides and zinc salts always give an immediate amorphous precipitate at the ordinary temperature, and since amorphous.sulphides are seldom met with in nature, we are constrained to believe that the natural sulphides, which have been deposited even as low down as $100^{\circ}$, must have been crystallized from very dilute solitions indeed and therefore exceedingly slowly.

The genesis of the natural sulphides of zinc.-The sphalerite of deep veins has in all probability been formed from hot solutions, and the latter are generally alkaline, as we know both from field observation of hot springs and from our knowledge of the hydrolysis of alkali silicates, like the feldspars, with hot water. In accord with this we have found that alkaline solutions always give rise to sphalerite, never to wurtzite.

The conditions under which the sphalerite of the Mississippi Valley region was deposited have been much discussed by geologists. We may call attention, in this connection, to the fact that sphalerite can be formed from acid as well as alkaline solutions. If the temperature is as high as $300^{\circ}$, only sphalerite seems to be deposited from solutions containing 1 per cent of free sulphuric acid, while only a few per cent of wurtzite is formed when the concentration of acid is as high as 5 per cent. However, when the temperature drops to $250^{\circ}$, a solution containing as much as 2.5 per cent acid deposits practically pure wurtzite. In other words, from $350^{\circ}$ down to $250^{\circ}$, which is as low as we have been able to get crystalline products, the lower the temperature the smaller is the percentage of acid required to give pure wurtzite. Unfortunately we can not say what that percentage may be at ordinary temperature, because we can not imitate the slow rate of crystallization which presumably proceeds in nature. But certainly sphalerite may be what geologists call a secondary mineral if the temperature and acid concentration fall within certain limits. On the other hand, to judge from the synthetic work wurtzite can never be anything but a secondary mineral, ${ }^{2}$ since we have obtained it only from acid solutions. Our knowledge of natural wurtzite is still rather limited. Mr. B. S. Butler, of the United States Geological Survey, has acquainted us of an interesting occurrence of this mineral, to which he has given careful study. In the Horn Silver mine, near Frisco, Beaver County, Utah, wurtzite seems to be undoubtedly a product of secondary sulphide enrichment. The original ore, still fresh in the lower levels, contains galena, pyrite, and sphalerite, a little chalcopyrite, and possibly other copper minerals. The upper part of the deposit has been largely oxidized to sulphates, minor quantities of carbonates, and other secondary minerals forming also. Octahedral cavities in the rock bear testimony to former presence of pyrite, which though plentiful lower down, has now disappeared from the oxidized zone. Below this lies a zone of secondary sulphide enrichment carrying secondary (reprecipitated) chalcocite, covellite, and wurtzite in large quantities, much of the last-named precipitated around original sphalerite cores. The chemistry of these processes must have involved first the oxidation of the sulphides of zinc, copper, and iron to sulphates, and since the original ore contained pyrite, the oxidized solution must have contained sulphuric acid. As this solution moved downward, the sulphuric acid gradually decomposed the more soluble sulphides of the unoxidized ore, with the formation of sulphates and hydrogen sulphide. At greater depths, after the oxygen of the solution was entirely used up and the acid reduced, the sulphides were reprecipitated. The difficultly soluble sulphides of copper would readily precipitate on the more easily soluble sulphide of zinc. Of course the sphalerite could not have precipitated wurtzite directly out of the solution, since wurtzite should be the more soluble of the two, but when the acid in the solution had become sufficiently neutralized or used up in any way whatever, the hydrogen sulphide present would precipitate the zinc after the less soluble sulphides of copper.

In this instance, therefore, the formation of wurtzite is well explained by our synthetic experiments and it will be interesting to learn whether other occurrences of wurtzite may not be similarly explained. It appears quite possible that wurtzite may often have been taken for sphalerite on account of the general similarity between the two and the lack of careful examination.

The origin of "schalenblende," which seems to consist of alternate layers of the two forms of zinc sulphide, is difficult to explain, but the suggestion is made that some systematic alternation of conditions may have resulted in the periodic neutralization of a slightly acid solution.

\footnotetext{
${ }^{1}$ Allen, Crenshaw, and Johnston, Am. Jour. Sci., 4th ser., vol. 33, 1912, p. $179 . \quad 2$ At least, it can form only from acid solutions.
} 
It may be noted that the precipitation of zinc appears to have been less rapid than that of copper, the zone of enrichment extending over a considerably greater vertical range.

No material was collected suitable for a careful study of secondary silver salts. From its relative solubility silver would normally be precipitated by all the other important sulphides in the mine and such precipitation has doubtless taken place. It is not believed that the silver has migrated far, probably because in the presence of the other sulphides it would be precipitated before traveling far and also because the chlorine introduced by the descending waters would combine with the silver to form the slightly soluble silver chloride. It is probable that by the time the sulphides were oxidized sufficient chlorine would be introduced to combine with all the silver.

A few specimens in which an antimony mineral rich in silver has formed along cleavages and cracks in barite were collected, and ore of this character is reported to have been found in considerable quantity in the upper levels of the Horn Silver mine. It has not been shown, however, that this ore is the result of alteration by surface solutions.

CHANGE IN METAL CONTENT OF ORES DUE TO ALTERATION.

If it is assumed that the upper portions of the ore body were originally of essentially the same character as the primary ore now present in the lower levels-and there is little doubt that they were, though it is not susceptible of absolute proof - it is at once apparent that there has been a marked rearrangement of the metal content of the ores. The oxidized ores in the upper levels are rich in lead and silver but contain little zinc or copper. During the oxidation the zine and copper have evidently been removed. The enrichment in lead and silver is due largely and perhaps entirely to the concentration resulting from the removal of the other constituents.

During the period in which the record of the output of the mine was kept by levels only the richer ores were being extracted. These ores, of course, do not represent the average of the mine and owing to the lack of accurate average figures for the upper and lower levels it is impossible to make a quantitative calculation of the changes that have taken place during the process of alteration. It is believed, however, that the general change in the metallic content of the ore is clearly shown.

The following tables show the average composition of several lots of ore from different parts of the mine:

Hetal content of some ores from the Horn Silver mine.

\begin{tabular}{|c|c|c|c|c|c|c|c|c|}
\hline & 1 & 2 & 3 & 4 & 5 & 6 & 7 & 8 \\
\hline 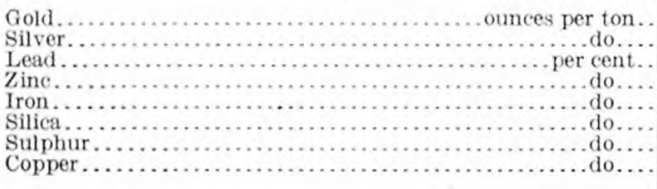 & $\begin{array}{r}78.33 \\
50.90 \\
0.00 \\
3.36 \\
15.7 \\
\cdots \cdots\end{array}$ & $\begin{array}{l}51.00 \\
43.50 \\
0.00 \\
(b) \\
(b) \\
(b) \\
\left(\begin{array}{l}0 \\
0\end{array}\right.\end{array}$ & \begin{tabular}{r|}
$(a)$ \\
$(a)$ \\
8 \\
40 \\
4 \\
20 \\
28
\end{tabular} & $\begin{array}{l}0.013 \\
6.50 \\
10 \\
35 \\
3 \\
35 \\
15\end{array}$ & $\begin{array}{l}0.000 \\
5.59 \\
9.41 \\
35.40 \\
\text { (a) } \\
\text { (a) } \\
\text { (a) }\end{array}$ & $\begin{array}{l}0.000 \\
2.83 \\
17.41 \\
(a) \\
(a) \\
(a) \\
(a) \\
23.7\end{array}$ & $\begin{array}{l}0.013 \\
10 \\
11.6 \\
20.7 \\
5.3 \\
35.4 \\
18.0 \\
\cdots\end{array}$ & $\begin{array}{l}0.032 \\
22.88 \\
28.24 \\
(a) \\
\text { (a) } \\
\text { (a) } \\
\text { 6. } 68\end{array}$ \\
\hline \multicolumn{9}{|c|}{ 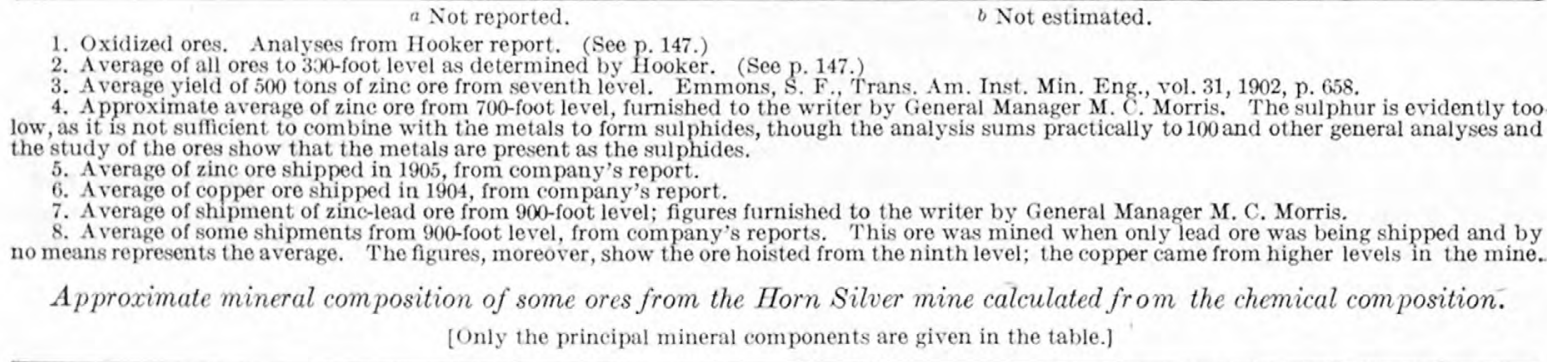 } \\
\hline & & & & & $1 a$ & 3 & 4 & 7 \\
\hline 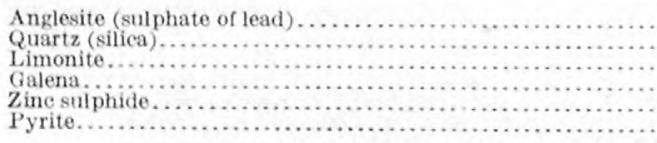 & & & & & $\begin{array}{c}75 \\
15 \\
5 \\
\cdots \\
\cdots \\
\cdots\end{array}$ & $\begin{array}{r}20 \\
\cdots \cdots \\
10 \\
61 \\
9\end{array}$ & $\begin{array}{r}35 \\
11 \\
50 \\
6\end{array}$ & \\
\hline
\end{tabular}

a The numbers of the columns correspond to those of the preceding table. 
The average for the zone of oxidation is probably considerably too high, for when the ores were sampled material that would now be classed as good ore was classed as waste on account of the high cost of treatment, transportation, etc. A glance at the table giving the average metal content of the output by levels will show that the average of ore extracted even when high-grade ores were being mined was considerably below this, and it is doubtful if the average of all the ores extracted from the zone of oxidation would much exceed 35 per cent of lead and about an ounce of silver per unit of lead.

The figures given for the lower levels are probably nearer the true average, though it should be remembered that the deposit contains all gradations from nearly pure sulphides to slightly mineralized rock and of course only such material as can be profitably handled is extracted.

If an ore similar to that shown in analysis No. 7 , representing the zinc-lead ore from the 900-foot level, should have all the zinc sulphide and part of the iron removed and the silica reduced to a content as low as that shown in analysis No. 1 , representing the oxidized ores, the lead content would be raised above 30 per cent and the silver, which is largely associated with the lead, would show a corresponding increase. This gives an ore of considerably lower grade than that shown in analysis No.1; but, as already noted, this analysis is probably considerably above the average for the oxidized ores, while the other (No. 7) is apparently below the general average for the primary ores. There may have been some enrichment in lead in the upper part of the sulphide zone as a result of the precipitation of galena by sphalerite, but it is not believed that such enrichment has been very great or that there has been any considerable migration of the lead. In the rich zinc ores in the zone of sulphide enrichment there has been an apparent impoverishment in lead, due to an actual addition of zine sulphide, so that galena became relatively less abundant. This is exactly the reverse of what has taken place in the upper levels. It is evident, therefore, that so far as the content of lead is concerned the primary ores are intermediate between the oxidized ores and the enriched sulphide ores.

For the main body of ores the silver appears to be closely associated with the lead and in general to vary with the lead content. The average of sulphide lead ores hoisted from the eighth and ninth levels, as shown in the table, was lead 33.27 per cent and silver 27.63 ounces to the ton. The ores from the ninth level ran lead 28.24 per cent and silver 22.88 ounces to the ton. The average metal content of the oxidized ores from the first five levels is lead 38.99 per cent and silver 38.63 ounces to the ton. These figures, however, include some of the rich silver ores. The average content for all the ores mined has been lead 33.61 per cent and silver 32.04 ounces to the ton. It is apparent from the figures given that in the process of oxidation there has been an enrichment in silver essentially corresponding to the enrichment in lead. In the enriched sulphide ores the silver content is low and is even lower in proportion to the lead than in either the primary ores or the oxidized ores. The following table, giving the assay value of 10 shipments of zine ore in 1905 , illustrates the variation of the silver content with the lead content:

Metal content of zinc ore shipped from Horn Silver mi
\begin{tabular}{|r|r|r|r|}
\hline Net weight. & Silver. & Lead. & Zinc. \\
\hline & & & \\
\hline & Ounces & & \\
Pounds. & per ton. & Per cent. & Per cent. \\
281,966 & 2.70 & 8.80 & 41.60 \\
309,236 & 2.05 & 7.65 & 42.15 \\
331,747 & 1.65 & 7.15 & 42.65 \\
311,057 & 2.80 & 7.30 & 42.75 \\
237,963 & 1.45 & 5.75 & 42.60 \\
308,959 & 1.60 & 6.05 & 37.85 \\
315,516 & 2.95 & 8.55 & 40.55 \\
353,945 & 2.10 & 7.15 & 41.65 \\
284,328 & 1.80 & 5.25 & 38.50 \\
324,321 & 1.40 & 4.50 & 38.10 \\
\hline
\end{tabular}

The reason for the low silver content as compared with lead in the enriched sulphide zone is not readily understood. It might be supposed that the galena in this zone was partly secondary, and that in moving downward it had left the silver behind, but as the sulphide enrichment has gradually passed down through all the oxidized ores this seems hardly likely. The same relation is even more pronounced in the enriched copper ores, the average metal content for a 
considerable quantity of these being silver 2.83 ounces to the ton, lead 17.41 per cent, and copper 23.7 per cent.

In the silver ores that have resulted from the oxidation of argentiferous pyrite there has been a pronounced change in silver content. Some material that was too low in silver to be of commercial grade has been changed to good ore.

The zinc content of much of the zinc ore in the zone of sulphide enrichment has been raised from probably 20 or 25 per cent to 35 per cent or more. This increase has been due to an actual addition of zinc sulphide and possibly also to some extent to the removal of pyrite. In the upper levels there has been an impoverishment in zinc, that from the zone of oxidation, in part at least, being added to the enriched sulphide ores.

As the primary ore carries but a fraction of 1 per cent of copper, it is evident that there has been a very marked addition of this metal to the ores that are commercially valuable for their copper content, and as this added copper must have been derived from the zone of oxidation, it follows that there must have been an impoverishment in copper in the oxidized ores.

Relatively little gold is present in the mine, and data are not available for determining the effect of secondary changes in this metal. As shown in the table of yield by levels (p. 145), gold was not reported as recovered from most of the ores in the upper levels. The fact that it has been recovered from some ores from the cave near the surface and from the oxidized silver ores would indicate that there has probably been slight if any movement of gold.

SUMMARY.

The process of secondary alteration has resulted in the enrichment of the oxidized ores in silver and lead. Primary ores only moderately rich in these metals have been changed to highgrade ores. In the zone of sulphide enrichment primary ores that were too low in zinc to be profitably handled under the existing conditions have been made of commercial grade and primary ores that contained but very little copper have been converted into rich ores.

\section{SUGGESTIONS AS TO PROSPECTING.}

It is well known that many of the best mines of the country have been discovered and developed by men who made no pretense to a knowledge of geology; indeed, this very lack of knowledge may have been the reason why some of them had courage to continue till their efforts were rewarded. It is believed, however, that when a district has been sufficiently developed to permit the study of the geologic occurrence of the ores in a large number of mines and prospects, the information gained in such a study should be of assistance in the prospecting and development of other deposits. In the following paragraphs the writer will attempt to present some general conclusions gathered from his study of the San Francisco region that seem to have a bearing on determining the best method of searching for ore. For the most part the principles laid down have been well established by studies in other districts, but are apparently not yet thoroughly appreciated and consequently a repetition is justified.

In this region, as in many others, the assertion is repeatedly made that all that is necessary to make the region a great producer is to carry development to a considerable depth, and when money is available it is sometimes expended in deepening the workings as far as possible, only too frequently to be rewarded by bitter disappointment. The study of the alteration of the ores throws considerable light on the probability of change with increasing depth that should be of value in prospecting. So far as has been ascertained there has been little migration of lead and silver during the process of alteration in the San Francisco region and the ores have in general been somewhat enriched in these metals by the removal of other material. The lead-silver ores, therefore, are not to be expected to increase in value with increasing depth. To be sure, the outcrop may chance to be a narrow or lean part of the vein or shoot and may be found to enlarge or increase in value as it is followed downward, but the reverse is quite as likely to be the case. The sinking of expensive shafts or the driving of long tunnels to cut deposits of this character that have not proved of commercial size or grade near the surface is likely to meet with disappointment. 
So far as the writer was able to observe, practically every commercially important deposit of this character that has been developed in this region shoved as much promise a short distance below the surface as it has shown at any greater depth. The early miners followed these bodies of ore down from the outcrop until increasing depth or decrease in value rendered further operations unprofitable. Later, with improved hoisting and transportation facilities, it has been found possible to work the deposits to greater depth. This seems by far the safer method to pursue. It is, of course, needless to say that if sufficient ore is developed it may be profitable to go to greater expense in providing means for its extraction.

In some of the copper deposits there has been considerable leaching of the metal from the upper portion of the vein and it may be necessary to attain considerable depth before the ore is found. Where oxidation and leaching are apparent it is reasonable to suppose that the copper may have been reprecipitated at lower levels, and if the outcrop indicates extensive mineralization it is reasonable to expect secondary copper deposits of corresponding extent at greater depth. On the other hand, when the sulphide zone is reached there is no reason for expecting improvement by going deeper.

Zinc has in many places been removed from the upper portions of the veins and may be found at greater depth, though opportunity for a study of the zinc deposits except in the Horn Silver mine has been too meager to warrant any generalizations.

The general modes of occurrence of the ores of the different types have been discussed in the section on ore deposits (p. 110) and need not be taken up here. It is probably needless to say that no one should attempt to develop a deposit until he has familiarized himself with the ore occurrences of the type the deposit is believed to represent, not merely by reading descriptions of them but by visiting them so far as possible and thus profiting by the experience gained from work already accomplished. Nothing is of greater benefit, in the development of a mining district, than a free interchange of information among operators and a willingness on the part of each to allow his neighbor to profit by his experience, whatever that experience may be.

One of the chief advantages enjoyed by a geologist making a general study of a district is that in reaching his conclusions he is permitted to use the data and experience gathered by many operators over a considerable period. It is obvious that if each operator could enjoy the same advantage, over a much longer time, he should be able to develop his property at a much lower cost and with better assurance of success. Plainly, therefore, the best interests of any mining district are generally furthered by frank interchange of experience gained in the development of the several portions of that district.

\section{FUTURE OF THE REGION.}

\section{DIFFICULTY OF MAKING FORECAST.}

In a geologic report on a mining district one of the parts that is of greatest interest to those engaged in its development is that containing the conclusions that may be drawn concerning the future possibilities of the district. The geologist, however, would gladly omit this portion, for there are always many uncertainties, and on further development the outlook for the future may be entirely changed for the better or worse. One needs but to scan the literature of mining districts of the Western States for a period of years to see how many prophesies, both of failure and of success, have not been fulfilled. Moreover, the people of a district may be overoptimistic, and if the investigator does not see as roseate a future for their properties as they profess to see, they promptly accuse him of disparagement, honest or otherwise. On the other hand, it is not improbable that an engineer in reporting on a property for a prospective purchaser may condemn it, although there is really a fair chance of its making a mine, because he is uncertain and feels that his professional reputation will be safer if he recommends no purchase.

Those who have the best interests of mining at heart deplore an unwarranted "boom," as it is sure to react to the detriment of a district, even though it may assist a few people to dispose of their property, but on the other hand, few mines have been made without the risking of some money in the prospecting and development, and, as already suggested, some prospects $73363^{\circ}-$ No. $80-13-11$ 
that were thought by competent judges to be of little value have developed into paying mines. In developing a district it is evidently possible to be too cautious as well as too rash. If money were spent in prospecting only where results are certain, few mines would be developed.

The writer will attempt below to present the future possibilities of the San Francisco region as he sees them, but with no elaim that the conclusions reached are infallible and with a full realization that others may honestly, and perhaps with good reason, entertain very different opinions. In discussing this matter the writer assumes that money invested in mining should earn considerably better rates of interest than in the less uncertain industries, and in addition that before the mine is exhausted the original purchase price and total cost of development, equipment, operation, and treatment must be returned. It is possible, however, that when a property is partly developed additional money may be spent with reasonable assurance that good returns will be received from the later investment, even though there is little or no chance of recovering the money originally spent.

In this discussion the deposits may well be treated according to the types under which they have been considered in preceding pages.

\section{DEPOSITS IN QUARTZ MONZONITE.}

The two deposits in the quartz monzonite that have yielded any considerable returns are those of the Cactus and the $\mathrm{O} K$ mines. Neither of these mines has to the present time been able to pay dividends. The Newhouse Mines \& Smelters Co. declared one dividend, but it was soon followed by an assessment that fully counterbalanced it. In both mines some of the most promising ground has been prospected and the best of the ore developed has been extracted. If these properties are to yield a profit on the original capital invested they must pay dividends that will cover the interest on the capital invested over a considerable period of years in the past, in addition to paying current interest, and before the deposits are exhausted they must return the original investment. It is doubtful if even those who are most enthusiastic over these mines expect that they will be able to accomplish this result. This statement, however, does not imply that the mines in their present condition are not worthy of further development, but the records are not encouraging for the starting of new projects in deposits of this type. So far as can be judged from the outcrops the two deposits mentioned are among the most promising in their respective districts, and therefore it does not seem likely that larger and richer deposits of this kind exist elsewhere in the region.

There is little doubt that the region contains undeveloped deposits of copper ore of this type, and such of these as can be developed from present mine workings may possibly be worked at a profit. It is not believed, however, that under present conditions the opening of a new deposit of this character can be undertaken with reasonable assurance that the money invested will be returned with interest. Improvement in metallurgic processes or an increase in the price of metal may at some time give greater encouragement to the development of these deposits.

\section{DEPOSITS IN SEDIMENTARY ROCKS.}

The deposits in sedimentary rocks consist of two types - contact deposits and replacement fissure deposits. The strictly contact deposits contain mainly copper; the replacement fissure deposits are mixed ores in which lead and silver are important constituents.

\section{CONTACT DEPOSITS.}

In the oxidized zone of the contact deposits the copper has been concentrated, forming "pockets" of high-grade copper ore that have been extracted at a profit, and it is reasonable to suppose that others of this nature await discovery. These deposits are, however, notoriously "pockety," and it is a matter of some doubt whether much profit would be derived from a systematic search for the high-grade ore.

The primary ore is generally of low grade and as it is not readily susceptible to concentration would have to be smelted. The grade of the ore would not permit long transportation, and consequently a mine to be profitably worked would be obliged to be served by a smelter near by. Ores of the general character of the contact ores of this region have been mined and treated in other districts, probably at a profit, and it is not unlikely that the same thing could be done 
in this district provided sufficient ore could be obtained. It may be remarked, however, that with average low-grade ores a large quantity must be treated in order to yield a profit, and the construction of a reduction plant before such a quantity is developed is likely to prove disastrous.

\section{REPLACEMENT FISSURE DEPOSITS.}

The ore of the replacement fissure deposits is usually of a grade that will stand shipment, and consequently no metallurgic plant is necessary near the mine. The ore extends practically to the surface, and therefore little work is necessary before some return is made. The careful development of ores of this type is consequently attended by little risk, for if the project does not prove satisfactory it can be abandoned without great loss. The primary ore has been reached in but few places and its average grade is unknown, but it is safe to assume that this ore will be of lower tenor than the oxidized ores. Several ore shoots that were profitably worked for considerable distances below the surface have pinched out, although the fissure and vein matter persisted to greater depth; other deposits have shown little change to the greatest depth to which they have been opened.

Deposits of this type have produced considerable metal in the past, some of it at a profit, and there is no reason for thinking that the same will not be true of similar output in the future. Deposits of this general character have been very profitable producers in other districts in the State, but present developments do not indicate that the ore bodies in this region approach in size those of Park City, Tintic, and Bingham. This does not imply, however, that a given amount of capital invested here may not bring returns as satisfactory as those obtained from larger deposits. It is believed that the deposits of this type are worthy of development with reasonable hope that some of them may afford paying mines.

\section{DEPOSITS IN LAVA.}

The Horn Silver and the Carbonate are the two important deposits in volcanic rocks that have been developed. The Horn Silver was unusually rich and there is no doubt of the ability of such a property to pay good returns on the money necessary for developing it. At the time the two deposits were discovered it would have seemed reasonable to predict that additional deposits of this character would be found. With the unsuccessful prospecting of some of the more promising areas, however, the likelihood of finding similar deposits has decreased and at the present time such a prediction would be less justified, though it is still possible that such deposits exist and may be discovered. The effusive rocks have suffered profound hydrothermal alteration over large areas and it is not improbable that the deposition of ores has been associated with this alteration.

\section{DETAILED DESCRIPTIONS OF MINES.}

\section{SOURCES OF INFORMATION.}

In the following descriptions is presented such information as the writer has been able to collect concerning the different properties. The amount of space given to different mines and the detail of description varies greatly. This is due to several causes. Many of the properties were not active at the time of visit and consequently the writer was not able to make a study of them and can describe only the general relations as seen on the surface and gathered from those familiar with the mines or from old reports. Other mines have presented especially favorable conditions for the study of particular features of the ore deposition and have been investigated in as much detail as possible. In still other mines the relations are simple and although the deposits may be of much value or promise they may be described in comparatively few words. It is apparent, therefore, that the amount of space given to the description of the several properties does not necessarily bear any relation to the writer's opinion of their probable value.

The maps showing the workings of the several mines have been taken from the records of the mining companies. Many of them include portions of the mines that were not accessible at the time of visit, and the writer therefore had no opportunity to judge of their accuracy. He has no reason to doubt the correctness of any of these maps but of course can assume no responsibility for them. 
SAN FRANCISCO AND PREUSS DISTRICTS.

The San Francisco and Preuss districts are located in the western part of the area under discussion. The San Francisco district covers the south end of the San Francisco Range and contains the mines that have made the largest outputs of metal. The Preuss district includes the mines in the sedimentary rocks north of the Cactus area of quartz monzonite. (See Pl. XXVII.)

\section{HORN SILVER MINE. \\ LOCATION}

The Horn Silver mine (PI. XXVIII, $A$ ) is located at the east base of Grampian Hill, about a mile southeast of Frisco, at an elevation of 6,550 feet.

HISTORY.

W. A. Hooker, in a report to the Horn Silver Mining Co., dated April 5, 1879, makes the following statement concerning the discovery and early history of the mine:

This remarkable deposit of ore was discovered September 24, 1875, by James Ryan and Samuel Hawkes. A shaft was commenced and had been sunk about 30 feet in ore when the claim was sold, February 17, 1876, to A. G. Campbell, Matthew Cullen, Dennis Ryan, and A. Byram, to whom is due the credit of having developed the mine and brought, the district to its present state of prosperity. These developments have resulted in proving the vein to a depth of over 280 feet, and about 25,000 tons of ore have been extracted and turned into bullion.

On February 17, 1879, the mine came into the possession of the Horn Silver Mining Co., and it has been worked by that company to the present time. From 1880 to 1884 it was one of the largest producers of lead and silver in the State. On February 12, 1885, the ground, which had been settling for some time, caved to the seventh level. The shaft was closed and extraction of ore was interrupted for some time. The mine was reopened, however, and has since been a steady producer. The following table, compiled from the company's reports, except as noted, shows the production of metals and their value from the opening of the mine to the close of 1909. The figures for the value and the metallic content of the ore mined previous to the acquisition of the property by the Horn Silver Co. have been estimated, but are believed to be very close to the true figures.

Ore and metal produced from the Horn Silver mine, 18\%6-1909.

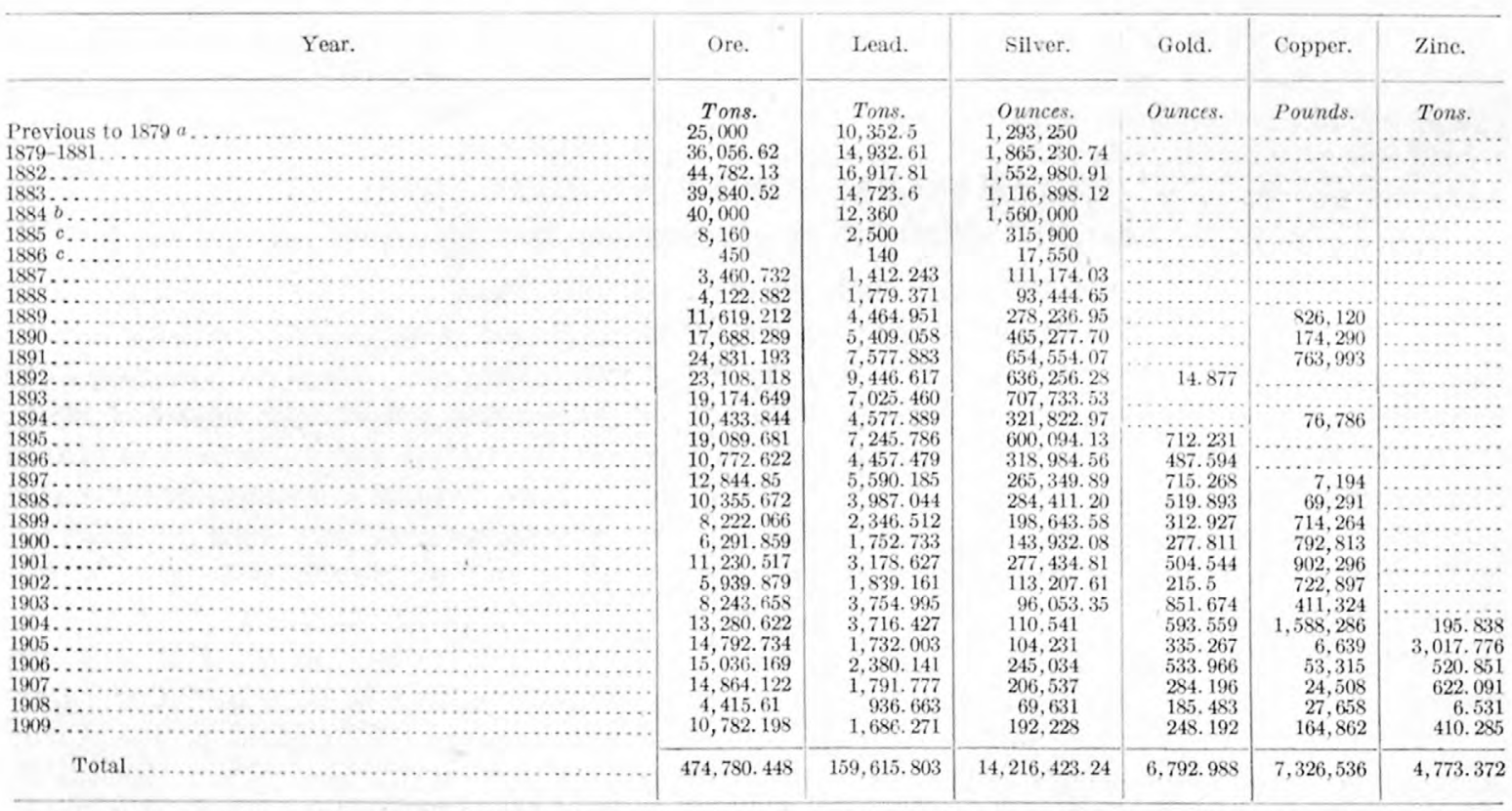

a Production previous to 1879 estimated by W. A. Hooker, in report to Horn Silver Mining Co., March, 1879. Metal content is calculated on

the basis of the yield for $1879-1881$.

Mineral Resources U. S., for 1883-84, U. S. Geol. Survey, 1885, p. 417. 


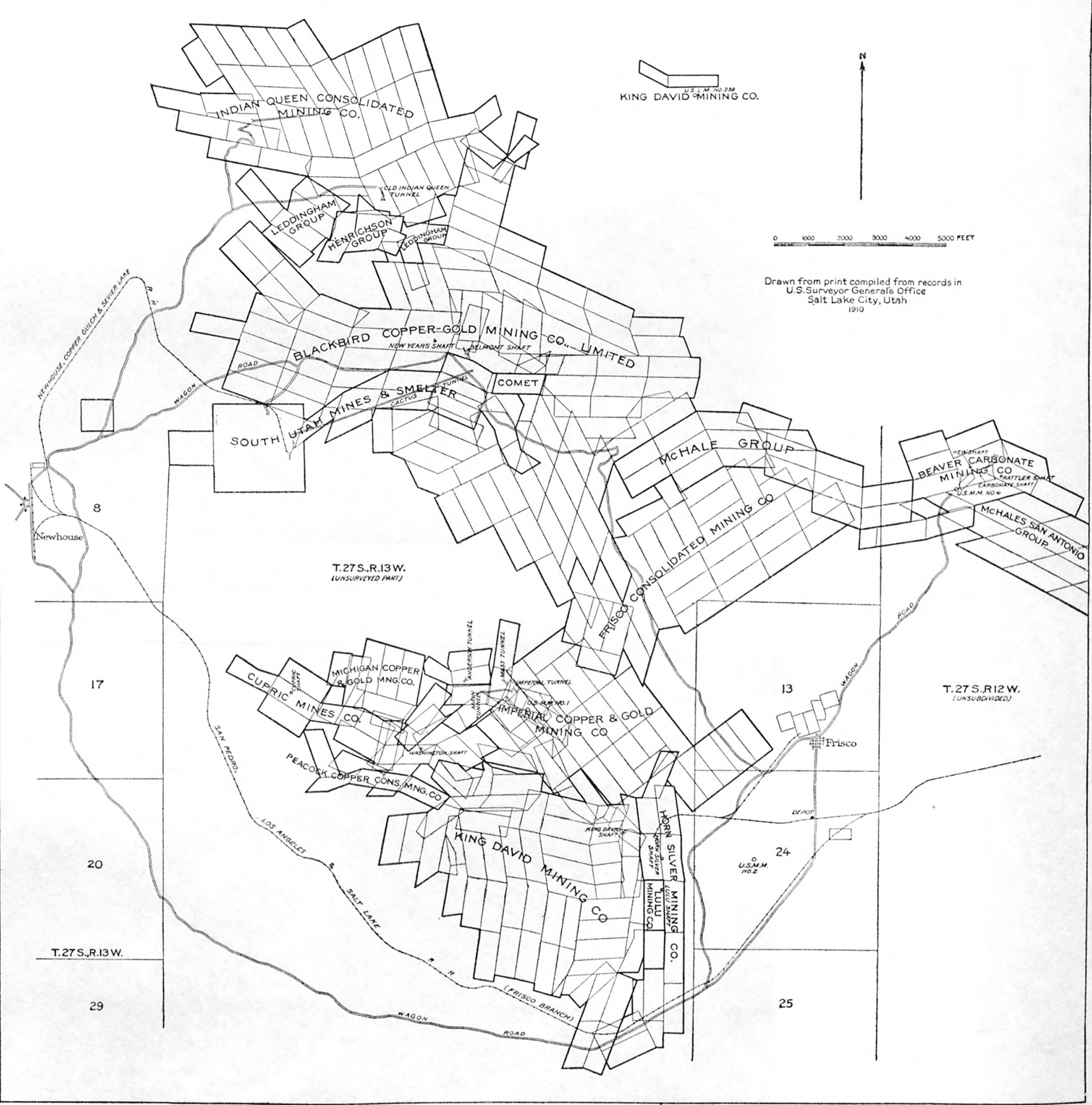

CLAIM MAP OF THE SAN FRANCISCO AND PREUSS DISTRICTS.

From map compiled by E. B. Andrews. 



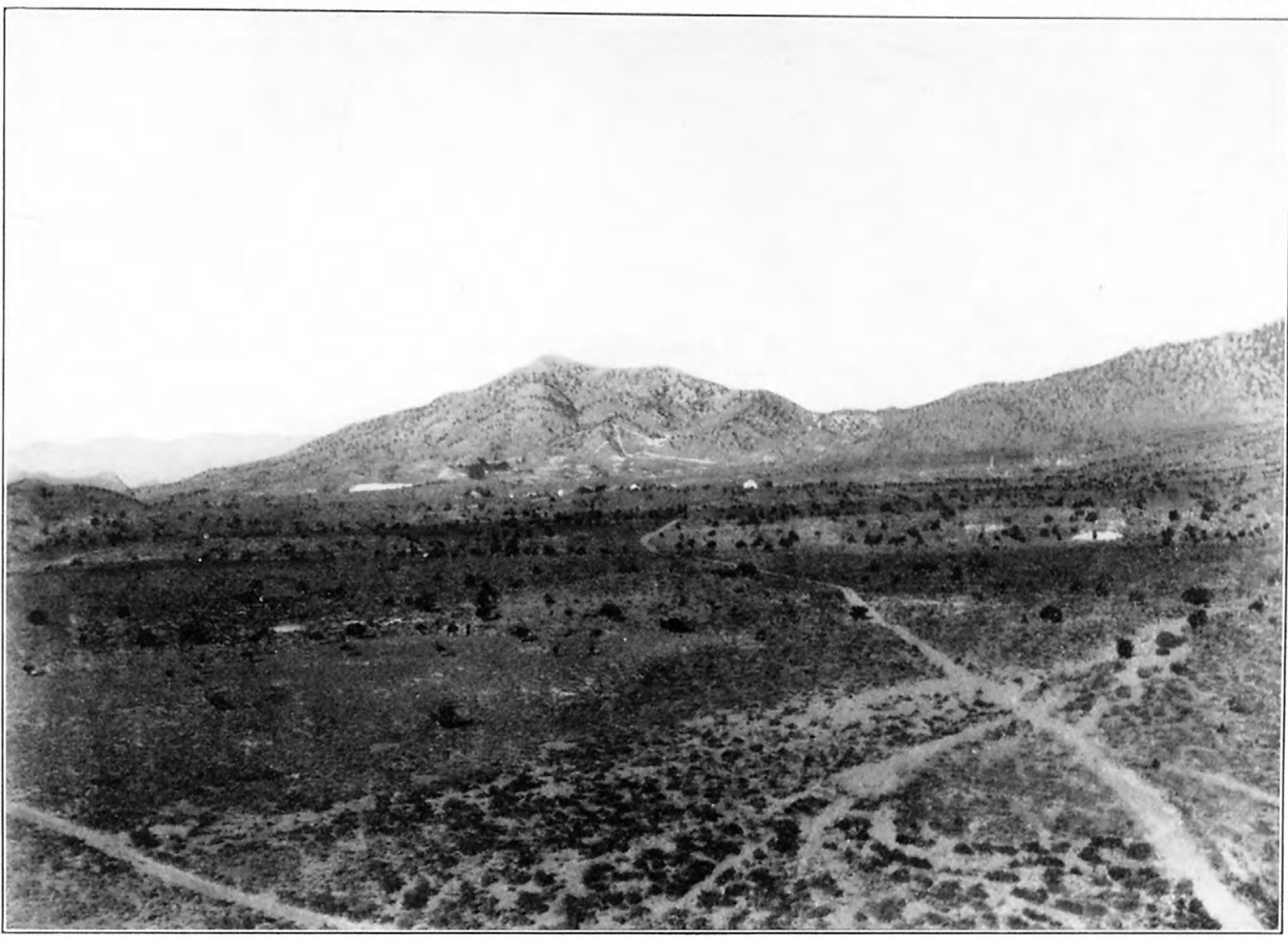

1. HORN SILVER MINE AND VILLAGE OF FRISCO.

Contact of quartz monzonite and limestone in the low saddle. Squaw Springs Pass at left.

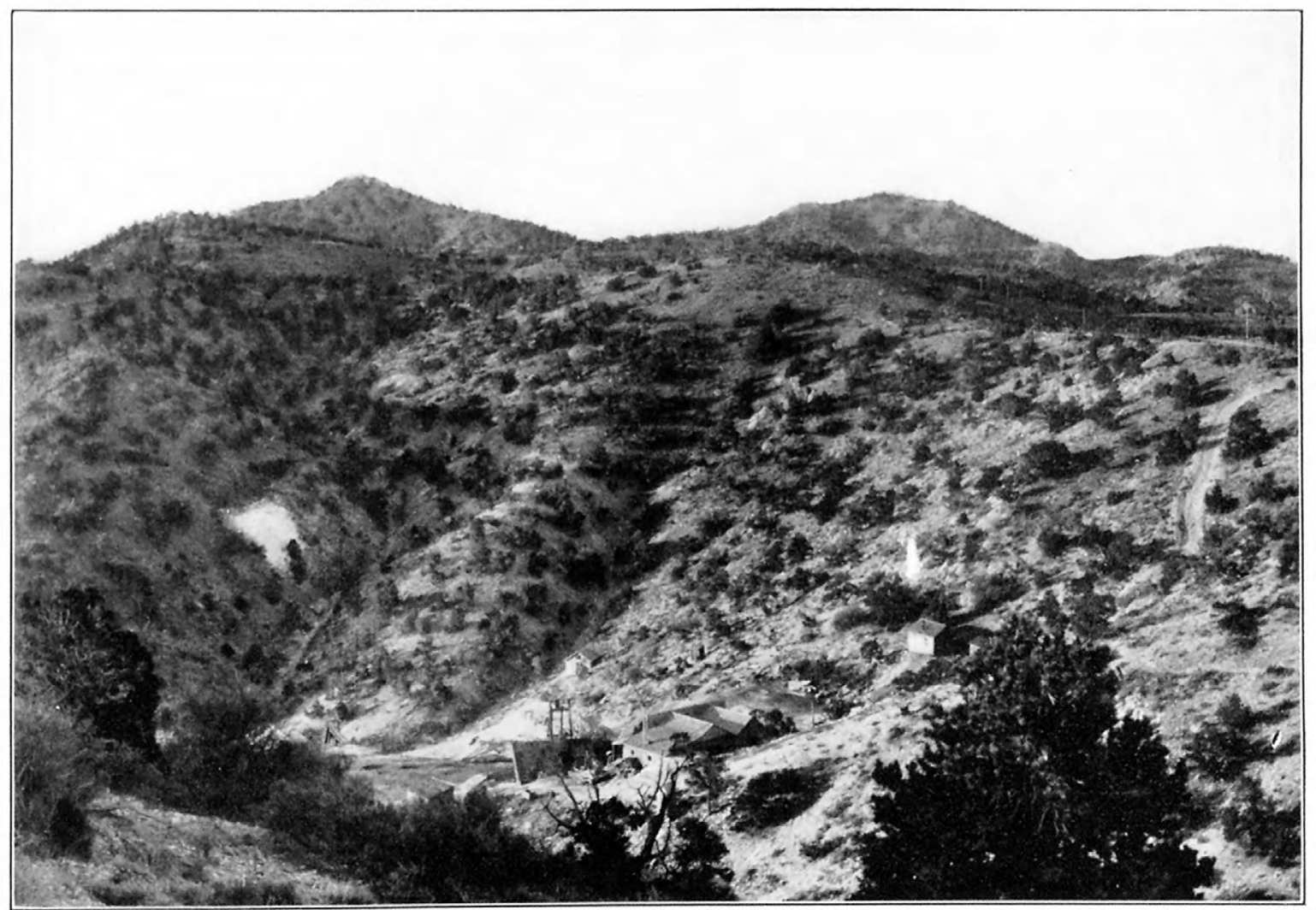

B. RED WARRIOR MINE, STAR DISTRICT.

Outcrop of ore body near the road on right. 

Value of metal production of Horn Silver mine and dividends paid, 1876-1909.

\begin{tabular}{|c|c|c|c|c|c|}
\hline & Value. & Dividends. & & Value. & Dividends. \\
\hline 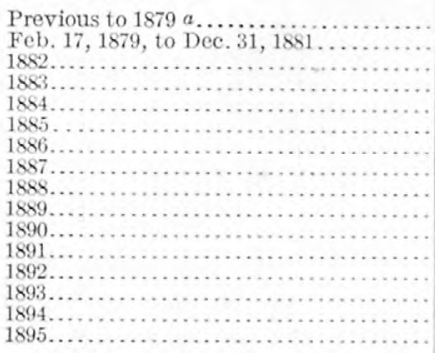 & $\begin{array}{r}\$ 2,542,750.00 \\
3,667,240.73 \\
3,370,113.84 \\
2,585.819 .17 \\
2,446,358.76 \\
498,652.74 \\
83,763.14 \\
111,525.28 \\
119,947.85 \\
280,024.10 \\
341,306.06 \\
362,737.68 \\
377,025.88 \\
491,429.89 \\
185,115.86 \\
392,416.17\end{array}$ & 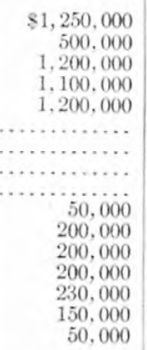 & 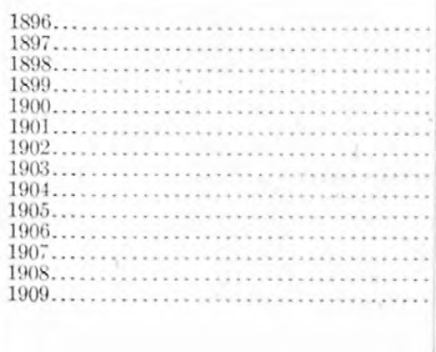 & $\begin{array}{r}\$ 213,543.02 \\
244,263,39 \\
235,506.21 \\
217,203.72 \\
172.350 .85 \\
229,150.10 \\
109,706.96 \\
126,361.47 \\
212,387.78 \\
174,522.12 \\
190,618.75 \\
110,181.52 \\
54,865.98 \\
120,189.21 \\
20,267.078 .23\end{array}$ & $\begin{array}{r}\$ 50,000 \\
20,000 \\
80,000 \\
20,000 \\
20,000 \\
72,000 \\
20,000 \\
60,000 \\
80,000 \\
80,000 \\
60,000 \\
\cdots, \ldots . \cdots \\
6,892,090\end{array}$ \\
\hline
\end{tabular}

This deposit has proved to be one of the rich ore deposits of the State, the average value per ton of ore being $\$ 42.68$. During the eariy years of production, when silver brought much better prices than at present, the value of the metal recovery exceeded $\$ 100$ per ton of ore. The mine, however, has not reached the production that was estimated in its earlier history.

A careful examination of the character, extent, and value of the deposit was made for the Horn Silver Mining Co. by W. A. Hooker and Henry Cummings soon after that company acquired the property, and a comparison of their calculated values with the results of over 30 years of operation is of interest, especially at a time when it is the proper thing formining companies to calculate ore resources and profits for years ahead, possibly in some instances with an overoptimistic view of the future. At the time of their examination the mine had been developed to a depth of 282 feet below the surface and they estimated as "technically now in sight" 513,000 tons of ore that would yield a profit of $\$ 17,955,000$. In addition to this, what might now be termed probable and possible ore was referred to by Hooker as follows: "The continuance of the vein beyond can not be doubted, and there is every reason to anticipate that this amount of ore as estimated will be many times multiplied before the deposit is exhausted." Since the examination by these men, ore has been mined nearly to the 1,000-foot level, and to the close of 1909 a total of 474,780 tons of ore had been extracted, including 25,000 tons mined previous to the examination, the total value being $\$ 20,267,078$ and the profit to the company $\$ 5,642,000$. These figures are not given to cast a reflection upon the reports cited, which seem to be based on an examination as careful as many that are made at the present time, but to point out the fact that fluctuation in metal prices and irregularities in ore deposits are larger factors in determining mine values than is sometimes admitted. It may be further noted that the ore body is not yet exhausted and undoubtedly contained a larger tonnage than the estimate, but this did not all lie within the ground on which the estimate was made.

Previous to the acquisition of the property by the Horn Silver Mining Co., the ores were smelted at the company's works at Frisco and by the Frisco Mining \& Smelting Co., which also operated a smelter at Frisco. The resulting bullion was freighted by wagon at first to Salt Lake City and later to the terminal of the railroad as it was pushed southward. The cost of smelting at Frisco was high, owing to lack of water and scarcity of fuel, the cost for January, 1879, being given by Henry Cummings as $\$ 18.31$ a ton of ore, and on the completion of the Utah Southern Railroad to the mine, in the summer of 1880 , the company constructed a smelting plant at Francklyn, about 6 miles south of Salt Lake City. Smelting of ores was begun at this plant in June, 1881. The company owned a refinery in Chicago, to which the bullion was shipped from both smelting plants. In June, 1882, operations at the Frisco smelter were discontinued. From this time until the caving of the mine in 1885 the bulk of the ores were treated at Francklyn. The Francklyn plant was closed in March, 1885, after the caving of the mine in February, and smelting was not resumed when the mine was reopened.

Late in 1893 the mine was equipped with a 20-stamp mill having twelve 6-foot Frue vanner tables for concentrating the low-grade ores. This mill was put into operation early in 1894, but 
in April of that year the entire plant was destroyed by fire. The plant was immediately reconstructed, the new mill having 30 stamps and 18 tables, with a daily capacity of 200 tons of ore. This mill was operated until 1905, when it was closed. During the same year the Peck mill was constructed on the property. This mill was designed to separate the lead and zinc values but after a trial run was closed. Early in 1911 the old mill was remodeled and operated for a short period.

UNDERGROUND WORKINGS.

The mine was first opened by a shaft sunk in the northwestern portion of the ore body. Later a working shaft was sunk about 250 feet east of the outcrop of the ore. This shaft was eventually sunk to the eighth level and all the upper levels were connected with it by crosscuts. It was partly closed by the caving of the mine and at present operations are conducted through a shaft located 500 feet east of the outcrop. This shaft has been sunk to the depth of the sixteenth level and connected by crosscuts with the third, fifth, seventh, ninth, tenth, eleventh, twelfth, and sixteenth levels. A shaft and incline 1,150 feet north of the main shaft connect the seventh level with the surface. Drifts on the several levels have explored the ore zone to the north and south for distances ranging from 1,500 feet on the seventh level to a few hundred feet on the lower levels. The amount of drifting on the several levels can be best seen by reference to Plate XXIX. In this plate the relations of the rocks and ore in the upper levels have been shown largely as given on the company's maps made by D. P. Rohlfing, as the writer was able to see only small pertions of the deposit above the 700 -foot level.

GEOLOGIC RELATIONS.

The west wall of the deposit is the limestone of Grampian Hill and the east wall consists of the volcanic rocks lying to the east. It is reported that "syenite" formed the footwall for a part of the distance where it was exposed in the north drift on the 1,100-foot level. This level was not accessible at the time of visit, but so far as can be judged by descriptions the "syenite" corresponds to the quartz monzonite of the San Francisco Range.

FAULTS.

The Horn Silver fault, striking nearly north and south and dipping steeply to the east. has thrown the volcanic rocks down against the limestone. The throw of this fault has not been determined, but it is at least 1,600 feet, the depth of the mine, and undoubtedly considerably more. It is a normal fault with the downthrow on the east. The dip of the contact is rather irregular, especially in the upper part, as can be seen by reference to Plate XXX. The general dip from the surface to the fifth level is between $60^{\circ}$ and $65^{\circ} \mathrm{E}$., although there are marked variations at different points. Between the fifth and tenth levels the fault is nearly vertical, with local dips to the west, making the limestone the hanging wall. Below the tenth level the fault again dips to the east, becoming slightly flatter in the lower levels. A part at least of this irregularity in the direction of the fault is due to movement along the bedding planes of the limestone subsequent to the fault. In the elevation and tilting of the block there has been slipping along planes of weakness in the bedded rocks, resulting in the projection of certain strata beyond their normal position.

Since the formation of the Horn Silver fault there has been faulting in a transverse direction, with some lateral displacement. Evidence of the extent of vertical movement was not obtained in the mine, but the faults can be traced to the west toward the summit of the range, where the vertical displacement has not been great. Unfortunately it was not possible to see these faults underground except in a few places. The data on which the following discussion is based are derived largely from the company's map and could not be verified by the writer.

At the south end of the open cut there is a fault striking almost exactly east and west and standing nearly vertical. This fault, according to the mine maps, can be traced to the eighth level. From the surface to the third level the fault is nearly vertical; below the third level it dips to the north at an angle of about $75^{\circ}$. The limestone to the south of the fault has been thrown about 40 feet to the east, so far as could be determined at the surface. There has 


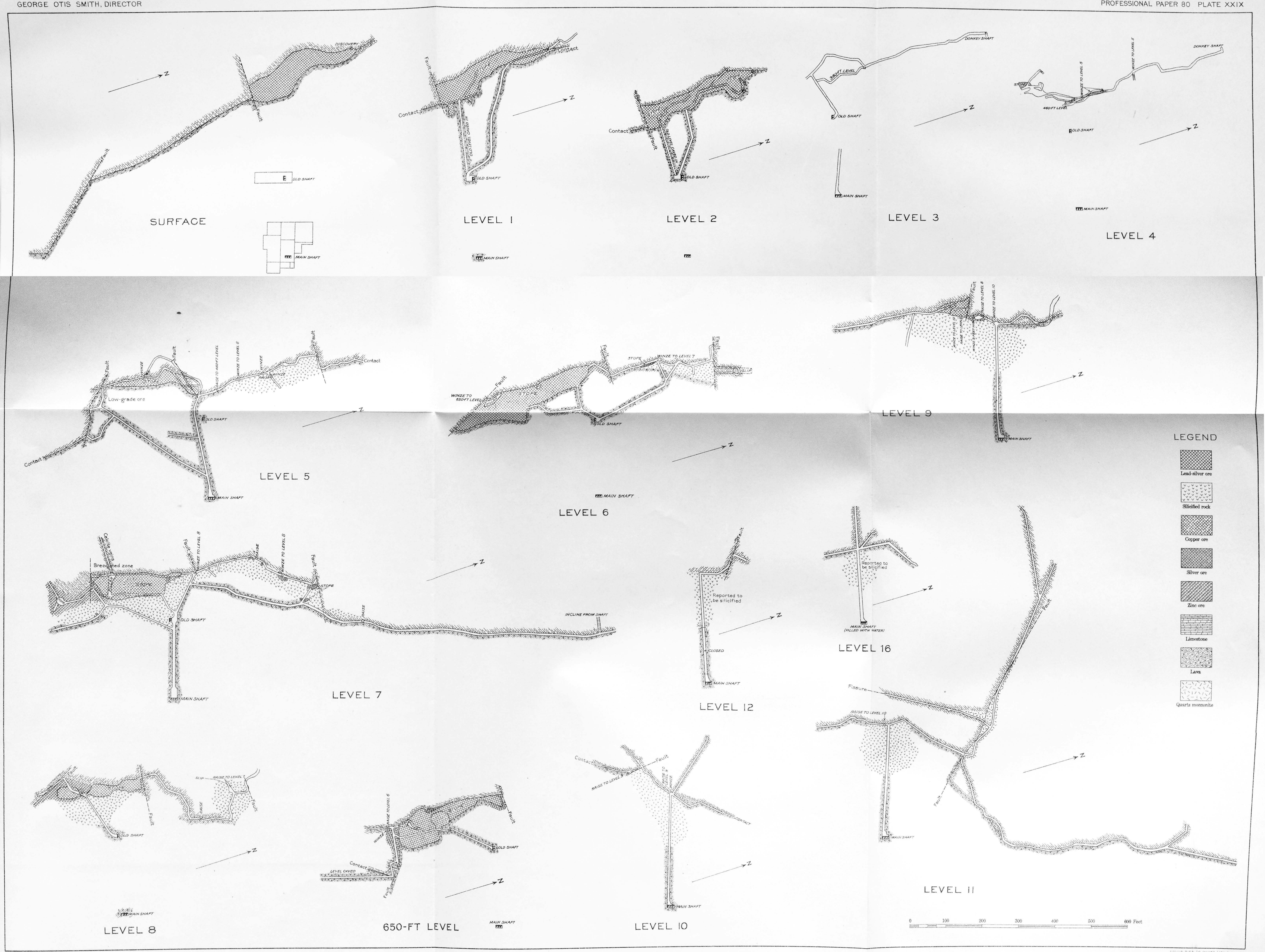




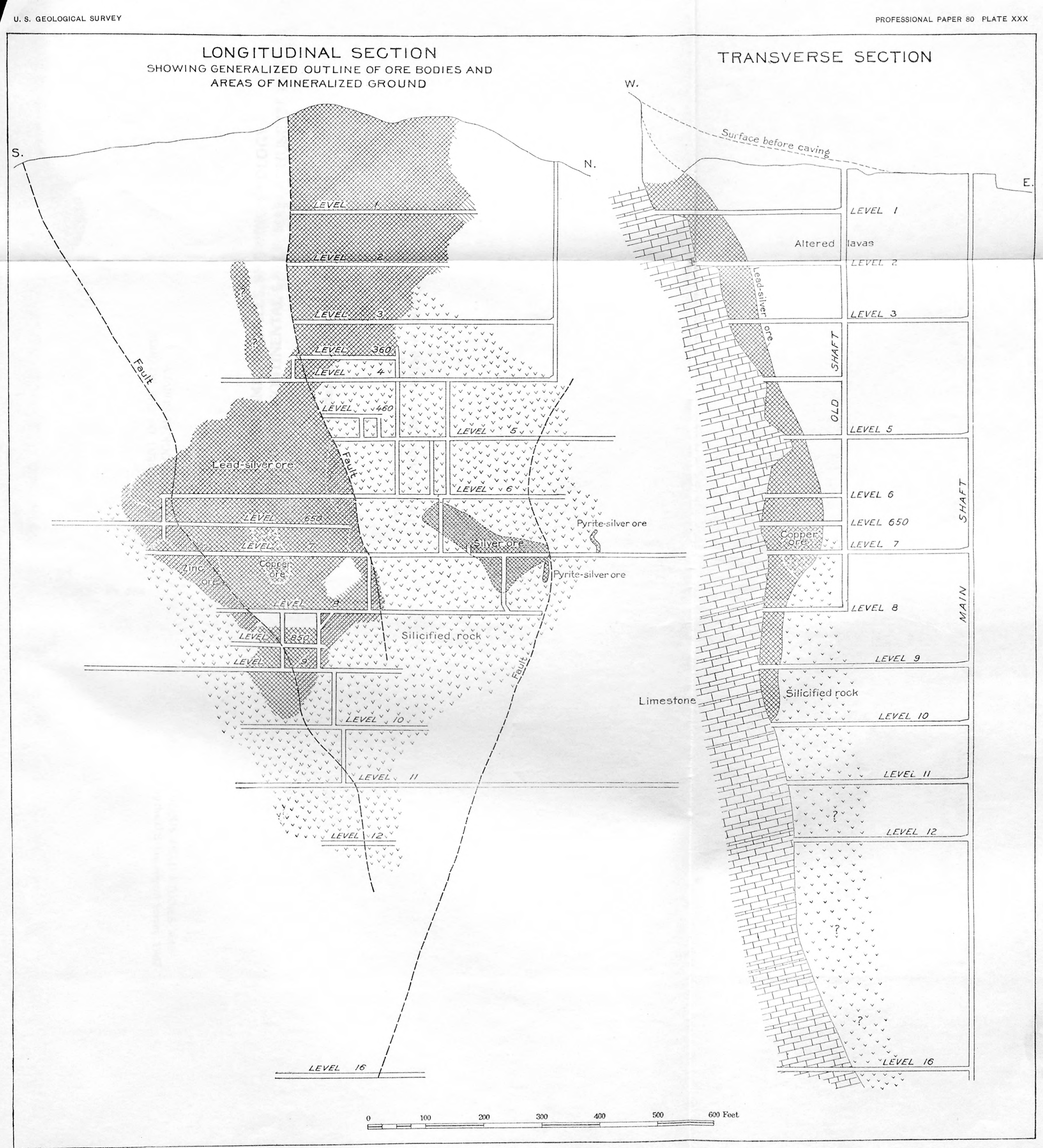

SECTIONS OF THE HORN SILVER ORE BODY. 
been considerable slumping of the limestone, however, and the actual movement may have been greater. The fault is represented with a throw of 50 to 60 feet on the first and second levels. On the lower levels the horizontal displacement decreases, and on the seventh level, where it was accessible at the time of visit, it is very slight. Below the eighth level it has not been recognized.

About 500 feet south of the fault just mentioned is another in which the block to the south is again offset to the east. The strike is about S. $45^{\circ} \mathrm{E}$. and the offset as seen at the surface is fully 225 feet. This fault, or one thought to be the same, was first encountered in the mine workings on the 500-foot level. At this point the offset was about $140 \mathrm{feet}$; on the sixth level it had decreased to 125 feet, and on the tenth level to 80 feet. Below the tenth level the throw has not been determined. The general dip from the surface to the tenth level is between $60^{\circ}$ and $65^{\circ} \mathrm{NW}$. There is considerable variation at different points, however, especially between the fifth and sixth levels, where the dip is nearly vertical.

A third prominent fault encounterd in the mine is first shown on the fifth level, where it is 350 feet north of the crosscut from the shaft. The strike of this fault, like that of the one next to the south, is nearly east and west, but in this instance the block to the north has been thrown to the east about 70 feet. The fault was exposed on the seventh level at the time of visit but not in such manner as to permit a determination of the amount of movement. On the eleventh level it is represented as having a throw of 150 feet. The dip averages about $75^{\circ} \mathrm{S}$., though between the sixth and eighth levels it is nearly vertical.

In the two faults that are so exposed as to give fairly complete data concerning the amount of movement there is a distinct and progressive decrease in the horizontal displacement with increase in depth, the displacement in the lower levels being comparatively slight. These faults are later than the Horn Silver fault, as is plainly shown by the fact that they cut and offset it where they cross.

The facts that the faults are later than the Horn Silver fault and that the displacement decreases with depth, taken together with the evidence of slipping along the bedding planes in the upper levels of the mine, producing the apparent horizontal offset of the Horn Silver fault, suggest the following hypothesis to account for the conditions. The Horn Silver fault when formed had a fairly uniform dip and strike, as would be normal to a fault of this magnitude. In the tilting of the limestone which followed the faulting there was slipping along the bedding planes, causing certain strata to project beyond the original fault line and thus producing the horizontal displacement of the original fault. Moreover, the limestone was fissured in an east-west direction, and when the limestone strata slipped these fissures were lines of movement and allowed one portion of a given stratum to slip farther than an adjoining portion. This caused the lateral displacement of the north-south fault. In the lower levels, where there was little horizontal movement, the lateral displacement of the east-west fault is also slight, whereas the reverse is true in the upper levels.

If this hypothesis is correct, it indicates that the east-west faults are probably little more than fissures along which there has been movement due to the local slipping of the limestone beds, and that there has not been notable vertical displacement. This agrees with the observations regarding other fissures within the limestone. That there has been some vertical movement, however, is evident from the vertical striations on the slickensided faces of the walls of the fault, and in the places where the direction of this movement was observed the downthrow has been to the south. In this respect the faults correspond to the important east-west Squaw Springs fault.

Movement along both the north-south Horn Silver fault and the east-west faults has taken place at successive periods. The most extensive movement undoubtedly occurred at the time of the uplift of the San Francisco Range, which is believed to have taken place contemporaneously with or immediately after the intrusion of the quartz monzonite. As the block was doubtless being tilted while the vertical movement along the Horn Silver fault was in progress, it is highly probable that the lateral movement along the east-west faults was in progress at the same time. This movement along cross faults seems to have been an important factor in producing the 
brecciated rock that occurs at these points. After the first faulting the ores were deposited and subsequently there have occurred repeatedly sufficient movements along both the northsouth and the east-west faults to produce brecciation and slickensides in the ore adjacent to the faults. This was especially well shown at the time of visit in connection with the southern east-west fault on the ninth level. South of this fault near the limestone wall the slickensides indicate a nearly vertical movement along the north-south fault, and along the east-west fault the slickensides indicate a similar though less clearly defined movement. In the areas between the east-west faults there is little evidence of intense brecciation either before or after the deposition of the ores. This is well shown in connection with the silicified rock surrounding the silver stopes, which is a replacement of the lava with little evidence of the brecciation of that rock. The movement along the north-south fault has not been entirely confined to a single plane, but occurred to some extent along parallel planes separated by limestone, as is well shown in the open cut, where a tabular block of the limestone several feet thick that formed the south wall of the ore body has fallen away and exposed a second well-defined fault plane essentially parallel to the first. So far as was ascertained, the east-west movement was more generally confined to a single plane.

The massive limestone was more resistant than the weak lavas and the brecciation was consequently very generally confined to the volcanic rock. The highly altered condition of the rock along the contact renders it impossible to determine positively in all places what the original rock was, but it is certain that most of the altered and brecciated rock was lava.

\section{ALTERATION OF THE WALL ROCK.}

The alteration of the wall rock adjacent to the ore zone shows a general leaching of all the principal oxides except iron and silica, the resultant rock being composed mainly of finely crystalline silica and pyrite, with some barite. Where the alteration was less intense the feldspars show sericitization, but the potassium and aluminum are largely removed in the zone of more intense alteration. The iron of the ferromagnesian silicates has apparently all combined with sulphur and remained in the rock as pyrite.

The limestone forming the footwall of the ore body shows much less alteration. It is generally recrystallized and along fissures slightly silicified and replaced by ore minerals. Near the surface in several places ore has been followed for some distance into the limestone along fissures, but extensive bodies of ore have not yet been found in the limestone.

The extent of alteration of the wall rock appears to have been controlled by the physical character of the rock. The massive limestones, being relatively impervious, have suffered little alteration, whereas the more porous volcanic rock has permitted a free circulation of the mineralizing solutions and has undergone intense alteration.

ORE AND GANGUE MINERALS.

The mine presents an unusual variety of minerals. This is due to the presence of several metals which on oxidation of the original minerals have formed various secondary compounds. For the purpose of description the minerals may be considered as primary, those formed in the original deposition of the ore body, and secondary, those formed by the alteration of the primary minerals.

PRIMARY MINERALS,

Galena is by far the most important of the lead minerals. It occurs both as a coarsely crystalline variety and a very finely crystalline variety showing but little crystal structure in the hand specimen and resembling massive chalcocite in general appearance, though somewhat lighter in color. All gradations between these types are to be seen.

A sulphantimonide of lead is also of common occurrence. It is usually dark gray and finely crystalline, though here and there it includes small masses of more coarsely crystalline material. Before the blowpipe the mineral gives a slight odor of arsenic, this metal probably replacing the antimony in small amounts. Under the microscope it is seen to be made up for the most part of one mineral, which has not been positively determined, but is probably 
jamesonite. It is very commonly associated with barite, though small specimens were collected from the dump that do not show this association. Locally there are microscopic intergrowths (see Pl. XV, B, p. 108) of a darker mineral that has not been determined but is possibly stibnite.

Zinc occurs in the primary ores as sphalerite, the common sulphide of zinc. Closely associated with this is wurtzite, the zine sulphide that crystallizes in the hexagonal form, which is believed to be secondary. In the hand specimen the zine ore has the appearance of being made up of honey-yellow sphalerite, but in thin sections under the microscope a considerable portion is seen to be rather strongly double refracting. Careful examination revealed some crystals terminated by hexagonal prisms. These were submitted to W. T. Schaller for erystallographic and chemical examination and were found to correspond in properties to wurtzite.

The zine sulphides have the property of triboluminescence, or of giving off light when scratched, to so marked a degree that zinc ore can be readily detected in the mine by drawing the point of a candlestick or pick across the rock. If zinc ore is present the point of the metal will be followed by a line of light. This property of zinc sulphide has been noted at various localities in this country and abroad. It is very commonly associated with light-colored sulphides containing little iron, but the same property has been noted in specimens of dark sphalerite containing considerable iron. So far as the writer is aware no satisfactory explanation of this property of the zinc sulphide from certain deposits has been offered, and no explanation of it has been discovered in the present investigation.

Original copper minerals are rarely seen in the ore. A little chalcopyrite is present here and there, and as no other original copper mineral has been found it may be that most of the copper was originally deposited as that mineral, though it is by no means improbable that the sulphantimonides and possibly other minerals contained small amounts of copper.

The only primary silver mineral that has been identified is a sulphantimonide of reddishpurple color occurring as thin plates and films along the cleavage planes of barite crystals. Crystals of this mineral were not obtained for identification, but it is pyrargyrite or some very closely allied mineral. The sulphide of silver, argentite, is reported by Hooker from the upper levels of the mine, and it is probable that the silver contained in the sulphides is largely in this form.

Antimony and arsenic are shown in all the analyses of the ore and are doubtless present in all parts of the mine. As already shown, antimony is present in the sulphantimonide of lead, jamesonite, and the sulphantimonide of silver, pyrargyrite. The form in which the arsenic is present has not been determined, but it probably occurs in sulpharsenides of lead and silver.

Iron is present in all the primary ore as pyrite, which locally forms a large percentage of the ore. Iron is doubtless also present in small amounts in the other sulphides, though in this connection it may be noted that the zinc sulphides are unusually free from iron.

Where galena, sphalerite, and pyrite occur together, their relations indicate that they were formed at the same time. This is especially true of the galena and sphalerite, which are in many places intimately intergrown, but is less apparent in the relation of the pyrite to the other minerals. The pyrite usually occurs in small crystals, and none of these were seen to inclose other sulphides. On the other hand, pyrite is commonly present in the fine-grained galena but less abundant in the coarse galena and zinc sulphide. The sulphantimonide minerals, as already stated, are probably present in varying amounts in all the lead and zinc ores and were deposited contemporaneously with them. Where these minerals were observed in abundance, however, they are associated with barite and were later than that mineral, forming around the crystals and along the cleavage planes. The barite is remarkably free from inclusions of other minerals, and appears to have been one of the earliest to form. Though the relations of the sulphide minerals in individual specimens indicate that they were all being formed at the same time, their general distribution in the mine suggests that the main period of deposition of some of the sulphides may possibly have been earlier than that of others. This is especially well shown on the seventh level north of the shaft in the silver stopes, where the principal sulphide present is pyrite; where the pyrite has been altered the cavities in the siliceous gangue preserve the form of pyrite crystals, showing that this was the main mineral present. Ore of this character 
extends below the seventh to the eighth level and doubtless still farther down and is reported to extend above the fourth level. This ore, however, grades into the normal lead ore and may be due to other factors than a difference in the period of deposition. The distinction between the primary lead and zine sulphides is much less marked than that already noted for the pyritic ore. All the zinc ore contains considerable lead and all the primary lead ore contains zinc.

According to the reports of Hooker and Cummings, in the upper levels of the mine there were small bodies of "sparry ore," consisting mainly of barite and silver minerals and containing but little lead. Ore of this type was not observed in the lower levels of the mine.

On considering all the evidence, it seems likely that the earliest action of the ore-bearing solutions resulted in the silicification of the lava and, at the same time, the deposition of abundant pyrite carrying silver. Barite was also deposited at this time, as it is found in small amounts in the silicified rock and locally formed an abundant gangue mineral. Later the solutions deposited lead and zinc sulphides and continued to deposit pyrite, but in less amounts. Sufficient data concerning the barite ore have not been obtained to warrant any conclusion concerning its relation to the other ores.

SECONDARY MINERALS.

Alteration of the ores by solutions moving downward from the surface has had considerable effect on the character and value of the ores in different parts of the mine, and the mine therefore presents a favorable opportunity for the study of alteration of this character. It is unfortunate that a detailed study of the upper levels could not have been made when they were accessible, but a good idea of the general character of the ores in those levels can be obtained from the reports of Hooker and Cummings, though these reports were concerned more with the commercial than with the scientific problems involved.

By far the most abundant secondary lead mineral is the lead sulphate anglesite. This formed a large percentage of the ore in the upper levels of the mine. Cerusite, the carbonate of lead, is present in the secondary ores but in relatively slight amounts. Plumbojarosite, the sulphate of lead and iron, is also present in unknown but probably small quantities. Numerous specimens of this mineral were found in the old dumps, but as it has not been generally recognized as a lead mineral no information was obtained concerning the amount that was present. Another sulphate of lead, copper, and iron, beaverite, a canary-yellow earthy mineral, is present in all the old dumps, and was probably fairly abundant in the secondary ore. Linarite, the hydrous sulphate of lead and copper, was found incrusting cavities in specimens taken from the dump.

On some specimens of jamesonite there is a dirty-white alteration product containing lead and antimony. This is probably the hydrous antimonate of lead, bindheimite. The carbonate of zinc, smithsonite, replaces calcite crystals in fissures in the limestone and was also collected on and above the 600-foot level of the mine. Calamine, the hydrous silicate of zinc, was also collected above the 600-foot level. It has not been possible to determine the amounts of these minerals occurring on the fifth and sixth levels.

Goslarite, the hydrous sulphate of zinc, is present as an efflorescence in all the lower levels of the mine, in many places forming feltlike festoons with fibers several inches in length. This mineral was seen on the eleventh level, the lowest examined.

Of the secondary copper minerals the most abundant are the sulphides chalcocite and covellite. These replace pyrite, sphalerite, and galena, and locally are so abundant as to form rich copper ore. Brochantite, the basic hydrous copper sulphate, and beaverite, the yellow lead-copper-iron sulphate already mentioned, are abundant.

The green hydrous copper carbonate, malachite, is common, but is not an important ore mineral, and the same is true of the blue carbonate, azurite. Chrysocolla, the hydrous silicate of copper, is rather abundant. Chalcanthite, the hydrous copper sulphate, like the zinc sulphate, is present as an efflorescence in places on the walls of the lower workings, and was found in the deepest workings examined. It is also present to some extent in the sulphide copper 
ores. When these are crushed and placed in water, enough copper sulphate is extracted to give chemical reactions for both copper and sulphate.

The only secondary silver mineral that has been recognized in the mine is cerargyrite, the silver chloride, which is reported to have been rather abundant in the upper levels. A test by R. C. Wells of the silver ore from the seventh level showed the presence of chlorine, and probably the silver in that ore is present, in part at least, as the chloride.

The most abundant secondary gangue mineral is chalcedony (amorphous silica), which has resulted from the alteration of quartz and forms the main gangue of the siliceous silver ore. Kaolin occurs in the altered silver ore. Gypsum is present in considerable amount in all the workings of the mine and in the wall rock. Alunite, the hydrous sulphate of aluminum and potassium, forms a rather continuous band along the footwall of the deposit. In the upper levels it is an earthy, friable mineral, which crumbles to powder in the hand. In the lower levels it is mixed with amorphous silica. A specimen taken from the ninth level proved to be composed almost entirely of amorphous silica. When taken from the mine this material is soft and cuts like wax, but on drying out it becomes hard. It is not improbable that the alunite is mixed with kaolinite also. Hydrous oxides of iron and manganese are present in the oxidized ores in varying amounts, being locally abundant. Native sulphur was seen on the dump in sufficient quantity to indicate that it was not an uncommon mineral in the upper levels of the mine, and the writer is reliably informed that it was abundant in some of the ores near the surface.

CHARACTER OF THE ORES.

The alteration of the ore has resulted in a considerable rearrangement of the metal constituents and a marked change in the character of the ores in different parts of the mine. The deposit may be roughly divided into three zones - the zone of oxidized ores, the zone of enriched sulphides, and the zone of primary ore. A general description of the character of the ores in these zones is given below, and a more detailed discussion of the changes that have taken place will be found in the section on secondary alteration (p. 144).

ZONE OF OXIDATION.

Throughout the mine the zone of oxidized ores extends to about the fifth level, and in the north end, in the body of silver ore, oxidation has been extensive below the seventh level. In the main or body the oxidized ore consists mainly of sulphate of lead, anglesite, carrying silver and minor amounts of other sulphates and some carbonates. In the north end of the mine, about 50 feet above and below the seventh level, are bodies of siliceous silver ore that have resulted from the leaching of argentiferous pyrite, the sulphur and iron being removed and the silver remaining probably as chloride. It is likely that some ore of this character was present in the upper levels, together with "sparry" ore, consisting of rich silver minerals in a barite gangue.

In the lower part of the zone of oxidation are some copper ores that have resulted from the oxidation of the rich secondary sulphide ores. The most important mineral of these ores is the sulphate, brochantite, with minor amounts of carbonate and silicate. They were present in the upper part and around the margin of the main copper deposit.

Some oxidized ores of zinc, both smithsonite and calamine, were seen above the sixth level, but oxidized zinc ores are in general not abundant.

Much of the oxidized ore carried from 35 to 45 per cent of lead and from 25 to 40 ounces of silver to the ton.

ZONE OF SULPHIDE ENRICHMENT.

The zone of enriched sulphides is much less definite than that of the oxidized ores and probably is nowhere extensive over a complete horizontal section of the mine. Along the bodies of brecciated ore adjacent to the faults, however, it has a very considerable vertical range. This ore is of two classes - copper ore that has resulted from the replacement of iron, zinc, and lead sulphides by secondary copper sulphides and zinc ore that has resulted from the addition of zinc sulphide to the original ore. 
The copper ore had its best development near the hanging wall, extending from about the 650-foot to the 750-foot level, though lower-grade copper ore has been opened in other parts of the mine, especially in the north end above the 700-foot level. The copper sulphides are covellite and chalcocite, and much of the ore was of high grade, carrying from 20 to 40 per cent of copper.

The main bodies of zinc ore occur in the breccia areas along the faults, the largest body being associated with the southern east-west fault extending from about the sixth level to below the eighth. Smaller bodies of zinc ore are associated with the middle fault, and still smaller bodies occur in other parts of the mine. The main zinc minerals are sphalerite and wurtzite, and all the ore carries considerable lead and silver. The zinc content varies, but the ores that have been shipped have averaged from 35 to about 40 per cent of zinc.

ZONE OF PRIMARY ORE.

The zone of primary ore, as already indicated, is variable in its vertical extent. At many points it extends upward practically to the zone of oxidation, but in the highly brecciated ores it may be practically absent.

The ores of this zone are characteristically composed of lead, iron, and zinc sulphides carrying some silver. The ores are of relatively low grade and ordinarily only the lead and silver are recovered. The higher grades of these ores have ranged from 25 to 35 per cent of lead and from 20 to 30 ounces of silver to the ton.

CACTUS MINE.

Location and history.- The Cactus mine, owned by the South Utah Mines \& Smelters Co., is located in Copper Gulch about $2 \frac{1}{2}$ miles a little north of east of the town of Newhouse. The outcrop of the ore body is at an elevation of about 6,450 feet above sea level, or 1,200 feet higher than the valley at Newhouse. The outcrop is prominent and was discovered about 1870, being one of the earliest to be located in the district. Between that time and 1900 several different companies attempted to work the property without success. In the early eighties a French company did considerable development work but produced little metal. In 1892 a small smelting plant was erected in Copper Gulch, but very little ore was smelted before this plant was closed and operations again ceased. In 1900 the property was acquired by Samuel Newhouse and associates, and in 1903 it was taken over by the Newhouse Mines \& Smelters Corporation, which operated it until early in 1910, when the company was reorganized as the South Utah Mines \& Smelters Co. Production began in March, 1905, and to the close of 1909 the mine had yielded 19,419,319 pounds of copper, 7,510 ounces of gold, and 176,365 ounces of silver. The following table shows the ore and metal output of the mine by years from 1905 to 1909 :

Ore and metal output of the Cactus mine, 1905-1909.

\begin{tabular}{|c|c|c|c|c|c|c|}
\hline & Crude ore. & $\begin{array}{l}\text { Concen- } \\
\text { trates. }\end{array}$ & Copper. & Gold. & Silver. & $\begin{array}{l}\text { Total } \\
\text { value. }\end{array}$ \\
\hline 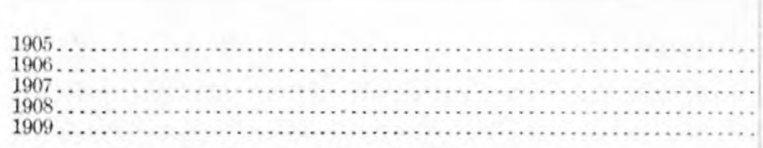 & $\begin{array}{l}\text { Tons. } \\
126,727 \\
221,002 \\
198,870 \\
215,448 \\
41,552\end{array}$ & $\begin{array}{r}\text { Tons. } \\
16,897 \\
200,359 \\
21,426 \\
21,882 \\
4,307\end{array}$ & $\begin{array}{l}\text { Pounds. } \\
3,421,279 \\
5,020,992 \\
4,537,418 \\
5,581,358 \\
858,272\end{array}$ & $\begin{array}{r}\text { Fine ounces. } \\
1,281.00 \\
2,101.23 \\
2,030.73 \\
1,846.58 \\
250.42\end{array}$ & $\begin{array}{r}\text { Fine ounces. } \\
33,181 \\
42,670 \\
59,054 \\
36,099 \\
5,361\end{array}$ & $\begin{array}{r}\$ 593,917 \\
1,038,938 \\
998,438 \\
794,044 \\
119,539\end{array}$ \\
\hline & 803,599 & 84,871 & $19,419,319$ & $7,509.96$ & 176,365 & $3,534,876$ \\
\hline
\end{tabular}

Equipment.-In 1905 the mine was equipped with an 800-ton concentrating mill, which was remodeled in 1909 and the capacity is reported to have been raised to 1,000 tons a day. When the mine began operation it was equipped with a steam plant, but this was later replaced by an electric equipment, the power being furnished by the Beaver River Power Co. from its plant on Beaver Creek. The mill, compressor, trolley road on the tunnel level of the mine, and principal hoists are operated by electric power. The company owns and operates the standardgage steam railroad connecting the mine and the mill, and also owns the boarding houses, the club house, and most of the dwellings at Newhouse. 
Development.-The mine is developed by a main shaft 600 feet deep, from which six levels approximately 100 feet apart have been opened. The sixth level, 5,847 feet in elevation at the shaft, is connected with the surface by a main haulage tunnel 6,016 feet long, through which all ore passes to the crusher house. Below the tunnel level the mine is developed by an inclined shaft 316 feet deep, from which the seventh, eighth, and ninth levels are opened.

Above the sixth level the mine has been extensively opened and large blocks of ore have been stoped. Previous to 1908 the square-set method of mining was in use, pillars being left as supports. During that year the pillars on the fifth level crushed and the mine caved, so that at the time of visit (in the summer of 1909) only small portions of the workings above the sixth level were accessible. Since 1908 a modified form of the caving system has been adopted, and it is believed by the company that a large percentage of the ore in the caved area can be extracted, though this ore will necessarily be mixed with waste and consequently of lower grade than that previously mined. The surface has been stripped and an attempt was made to mine the ore by the use of a steam shovel. Some ore was extracted in this manner, but much of it proved to be too hard for the successful employment of this method and it was discontinued.

E. P. Jennings, in a report to the company dated May 24, 1909, made the following estimate of ore:

Estimate of ore in Cactus mine.

\begin{tabular}{|c|c|c|}
\hline & Tons. & $\begin{array}{l}\text { Copper con- } \\
\text { tent (per } \\
\text { cent). }\end{array}$ \\
\hline $\begin{array}{l}\text { Ore in sight } \\
\text { Partly developed and probable ore partly exposed by surface outerop and developed on } 400 \text { and } 1500 \text { foot levels } \\
\text { Partly developed ore } \\
\text { Possible ore, } 500 \text { feet in length of undeveloped territory on the west end of cactus ground. }\end{array}$ & $\begin{array}{l}1,127,053 \\
1,000,000 \\
1,000,0000\end{array}$ & $\begin{array}{r}1.8 \\
2.0 \\
1.0-1 \frac{1}{4}\end{array}$ \\
\hline
\end{tabular}

No attempt was made in the study of the mine by the writer to determine the amount or average grade of the ore.

The following statement, taken from the report of W. Lee Heidenreich, general manager of the South Utah Mines \& Smelters Co., dated August 19, 1912, gives the production from September 1, 1910, to June 30, 1912. This added to the above figures of production gives the total output of the mine:

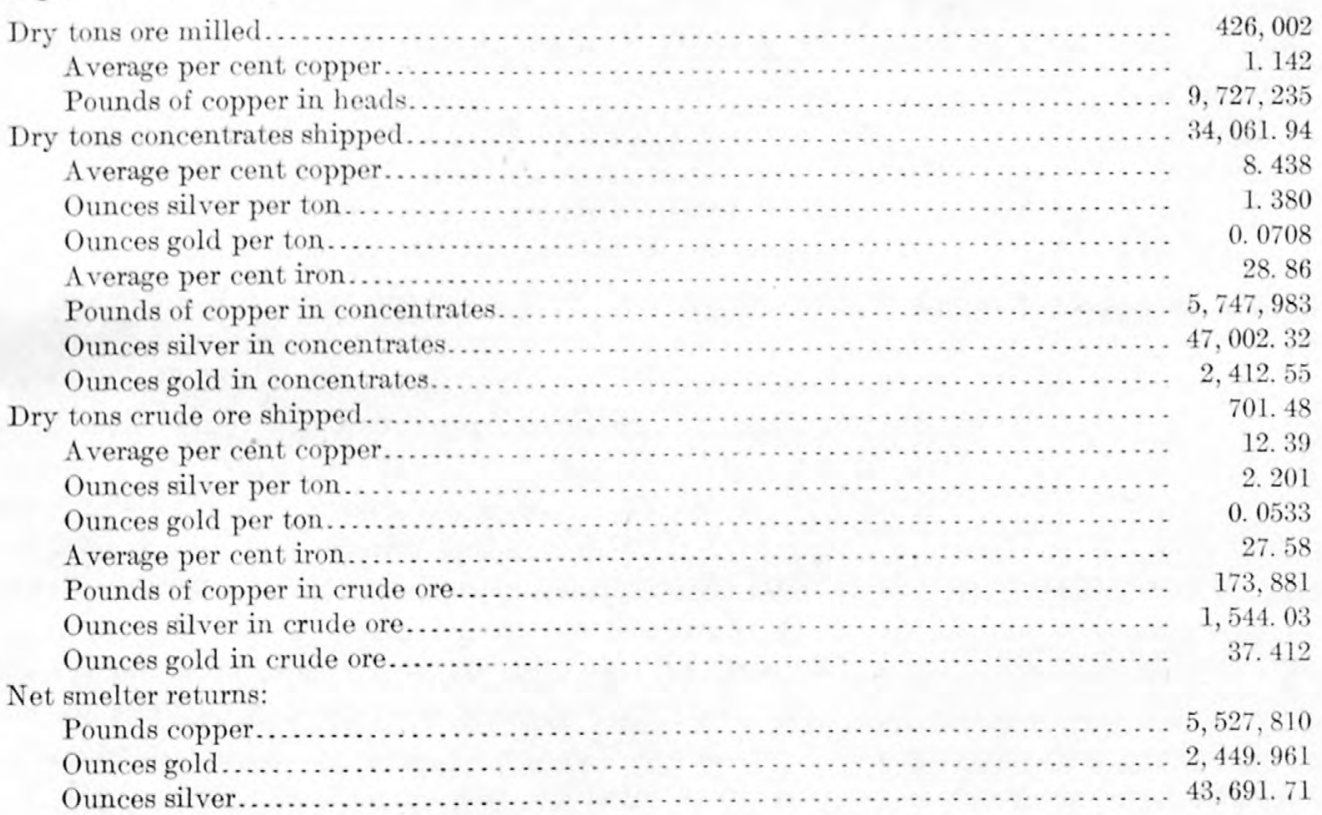

The general manager's estimates of the ore reserves on the date of his report are given in the following quotation: 
Owing to the fact that too much was expected of the large caves on the 609,604 , and 700 levels, the mine has little ore reserve developed. These caves contain at present about 600,000 tons of 1.6 per cent ore, but the waste is mixing with this ore to such an extent as to probably cause the loss of the greater part of it. This tonnage consists mainly of a great number of big pillars leit between caved or waste filled square set stopes. None of this ore is visible or accessible, and there is no way of ascertaining when the waste will make the ore in the caves too low grade to mine. I believe that we can recover from the old part of the mine, above the 700 level, about 100,000 tons running 1 per cent copper or better, but the information regarding this ore is not definite enough to strictly classify it as an ore reserve.

Between the 700 and 800 levels the main ore body contains 90,000 tons of 1.5 per cent ore, 55 per cent of which will be broken in the stopes and the remainder caved. The French ore body between the 700 and 600 levels contains 15,000 tons of 1.40 per cent ore, of which 4,000 tons is at present broken in the stopes.

The No. 2 French ore body is the most promising find of the year. This body has been opened on the 600 level for a length of 125 feet and a width of 135 feet. As yet the ore body has not been reached on any other level, but we are drifting toward it on the 500 and 300 levels. This body extends in an east and west direction and only the south wall has been found. The main west development drift and the north crosscut are both in ore averaging 1.80 per cent. This ore is in virgin ground to the surface and if its development on the other levels is as favorable as on the 600 level it will be a big asset to the mine. At present each foot of height proved in this ore body means a reserve of 1,350 tons. This ore body averages, including a bunch of low grade in the center, a little better than 1 per cent of copper.

The French ore body between the 700 and 800 levels has not been reached but will probably contain about 90,000 tons. The big iron ore body, which was of good grade on the 300 and 400 levels but too low grade on the 500,600 , and 700 levels, will probably make ore between the 700 and 800 levels. The 700 level shows up considerably better than the 600 level.

The main ore body, which contained good ore from the 800 level to the surface, will probably prove disappointing on the 900 level. So far as opened on this level the ore is small in size and of low grade.

Geology.-Plates XXXI and XXXII, showing the geology of the Cactus mine, have been in large part taken from the company's maps, as it was possible to see only a small portion of the workings above the 600-foot level at the time the writer made his study of the mine. The 600 -foot level and those below were accessible, and the geology for these levels was studied by the writer.

The Cactus ore zone lies entirely within the monzonite. It is a rather irregular stockwork having a general northwest-southeast trend and nearly vertical dip, so far as shown by present developments, in which the rock has suffered brecciation, alteration, and mineralization. This brecciated rock extends from the New Year's claim of the Blackbird Co. at the west to the Comet claim of the Nevada-Utah Co. at the east, a distance of about 2,700 feet. Northwest of the New Year's claim the monzonite is covered with float for a short distance and the zone can not be traced beyond this float. To the southeast the monzonite at several points has been considerably altered, but it was not found possible to trace the zone definitely to the southeast or east, beyond the Comet claim.

The general strike of the ore zone is about N. $55^{\circ} \mathrm{W}$. It is not uniform throughout the length of the zone, however. In the eastern part it is about N. $65^{\circ} \mathrm{W}$; in the western part it is approximately N. $40^{\circ} \mathrm{W}$. About 1,500 feet of this zone is included in the Cactus property.

Outside of the main ore zone there are smaller bodies of altered and mineralized rock, such as that of the Purity claim, which is separated from the main zone at the surface by about 300 feet of slightly altered monzonite. Within the main zone are blocks of comparatively unaltered monzonite, as is well shown in the area just northwest of the Cactus claim, where the highly altered rock of the Cactus claim is separated from that of the New Year's claim by several hundred feet of rock that is but slightly altered.

Within the ore zone the monzonite has been brecciated or broken into irregular fragments, varying from a fraction of an inch to several feet in greatest dimension. Some of these fragments have been corroded by the ore solution so that they present the appearance of a bowlder conglomerate with the spaces between the bowlders partly or entirely filled with ore and gangue minerals. Usually, however, the fragments are angular, as in a typical breccia. In general the breccia in the upper levels is coarser than that lower down, the spaces between the individual breccia fragments are larger, and many of the spaces have not been entirely filled with later minerals. In the stopes above the sixth level the breccia was well exposed but is finer than in the upper levels and contains practically no unfilled openings; the ore minerals have 
$c$

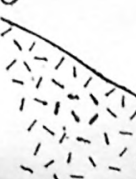

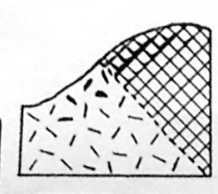

$40-F O O T L E V E L$

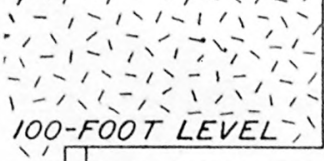

$\because, 4$

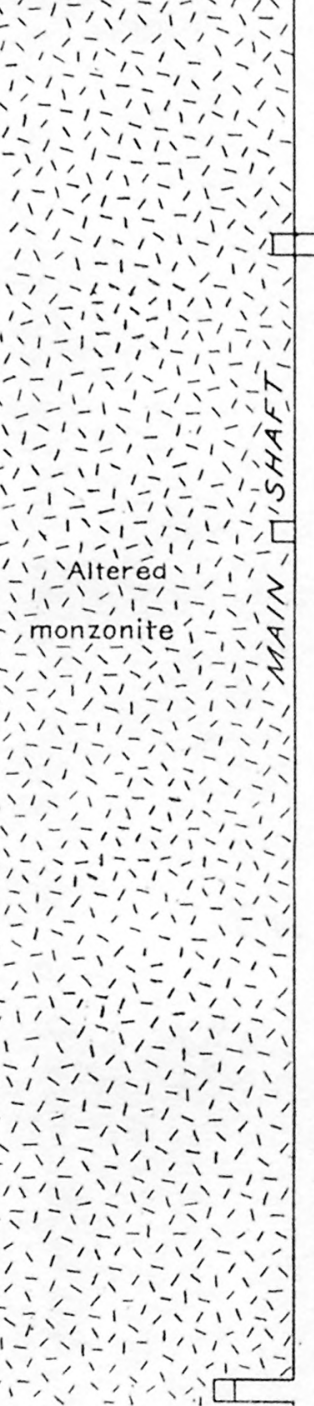

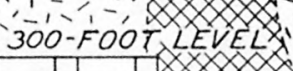

Altered mónzonite

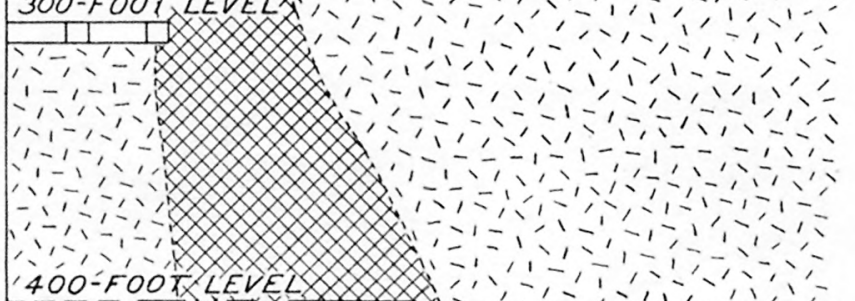

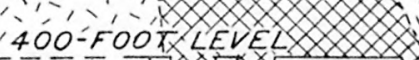

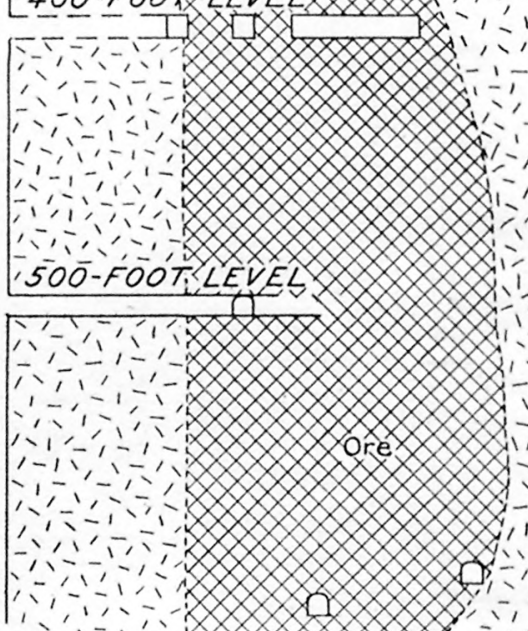

CROSS SECTION ON LINE E -F

E

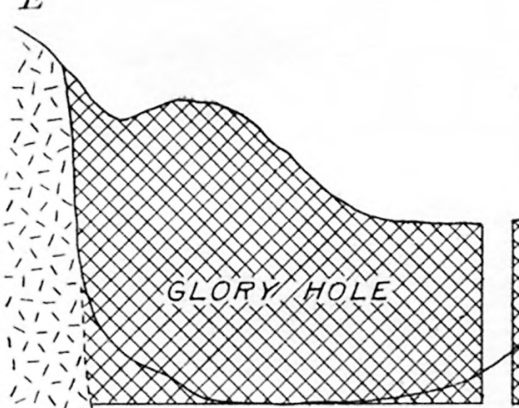

WOOFOTLEVELXX

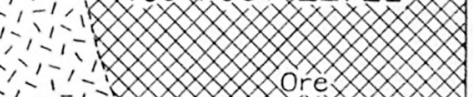

ore

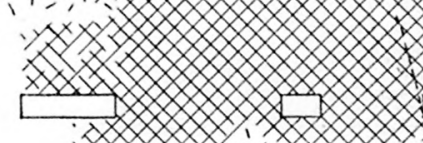

100-00T LEVEL

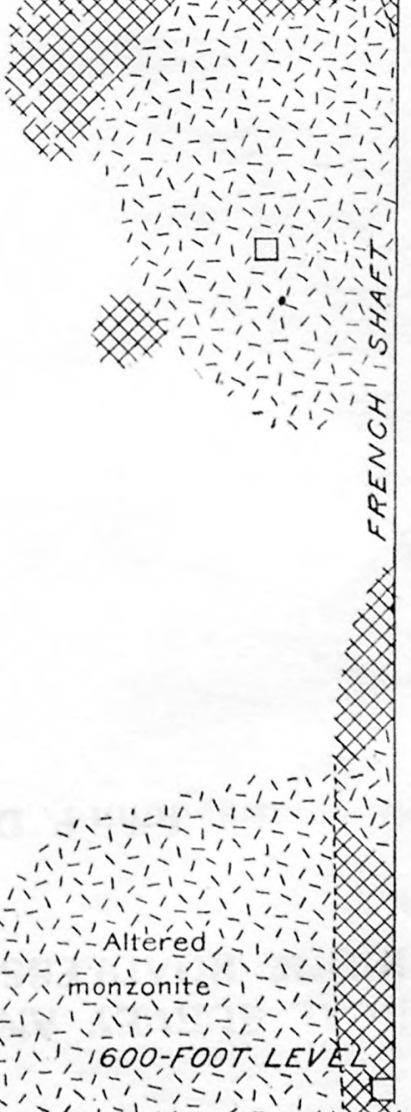

年

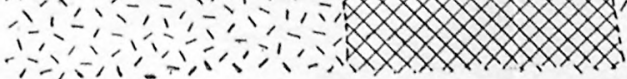

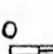

100 
also replaced the rock to a greater extent. On the seventh level brecciation is less pronounced and the ore minerals very generally replace the monzonite. The same is true on the eighth and ninth levels, so far as is revealed by the small amount of development.

The cause of this brecciation has not been positively determined, though it seems probable that it is due to slight movements resulting from readjustments in the cooling monzonite body. The presence at this locality of the pink monzonite, which is believed to be slightly later than the main mass, suggests that this was a zone of weakness into which the portions of the magma last to solidify could be forced, and such a zone of weaknes, would be likely to be affected by slight movements brought about by shrinkage and adjustment in the cooling mass, resulting in the brecciation of the rock.

Faults are abundant within the ore zone, but, as already stated, they can not be traced outside of this zone. The faults within the ore zone do not show a dominant direction, and, moreover, individual faults apparently die out even within the zone, though some, such as the one that limits the ore shoot on the east on the fifth, sixth, and seventh levels, can be traced for several hundred feet. The fact that the faults have no dominant direction and can not be traced outside of the immediate zone indicates that they are slips resulting in slight displacement. The cause for such faults is probably the same as that producing the brecciation, the larger adjustments resulting in slight movements along certain planes of weakness.

The chief importance of the faults lies in the fact that the crushing of the rock along these lines of movement has resulted in the formation of gouges of a clayey, impervious material that has had an influence on the circulation of the ore-bearing solutions. These gouges range in thickness from a fraction of an inch to 2 or 3 feet. They are found in all parts of the ore zone and the crushing that produced them appears to have been in progress throughout and after the period of ore deposition, as shown by the fact that some of the gouges contain little or no ore mineral, whereas others are composed essentially of crushed ore.

In the crosscut near the west end of the sixth level a block of slightly altered monzonite is bounded on the north and south by faults containing heavy gouges. These gouges have been but slightly mineralized, and in the southern fault especially the mineralization is next to the ore. The gouges were apparently formed previous to the mineralization, though there has been slight movement along them since mineralization, which has crushed some of the ore near the fault. There is a little mineralization east of the fault that limits the ore body to the east on the sixth and seventh levels, and the gouge is composed of crushed monzonite that had been sericitized and slightly mineralized. Here the limiting of the ore body is doubtless due to two influences- the massive character of the monzonite, which prevented free circulation of solutions in the errly stages of mineralization, and subsequent to the faulting the gouge has still further prevented circulation to the east.

It should be noted here that where the monzonite has not been highly brecciated but remains in massive blocks the mineralizing solutions have not penetrated to any considerable distance from fissures, even where no gouge is present. This is evident at many points on the south wall of the ore zone but is especially well shown in a stope about 120 feet southeast of the French shaft on the 200-foot level, where a massive block of monzonite, fully 15 feet in diameter, is embedded in ore but shows mineralization only along joint planes, though it is not protected by gouge.

The movement and formation of gouges at different times during the period of ore deposition may also have exerted an important influence on the varying character of the mineralization in different parts of the mine, as is shown on page 121.

Mineralogy.-The mineralogy of the Cactus ore zone has been described in detail in the section on ore deposits (p. 119) and need be only summarized here. The principal primary metallic minerals are pyrite, chalcopyrite, and hematite, with small amounts of tetrahedrite, bornite, galena, and cosalite. The important gangue minerals are sericite, quartz, tourmaline, siderite, anhydrite, and barite, with small amounts of rutile and apatite. These minerals have 
been formed over a considerable period of time and under somewhat different conditions, and probably the solutions depositing them have undergone chemical changes. The order of formation was in general as follows, the different periods overlapping to some extent: (1) Sericitization of the quartz monzonite and deposition of pyrite and chalcopyrite; (2) deposition of tourmaline and specularite with continued deposition of pyrite and chalcopyrite; (3) deposition of siderite, anhydrite, and barite with continued deposition of pyrite and chalcopyrite. On the upper levels alteration has produced numerous secondary minerals, the more abundant being limonite, pyrolusite, and malachite, through goethite and native copper are also present. Gypsum is also a rather abundant secondary mineral in the mine.

Character of the ore.-The zone of oxidation is remarkably shallow, considering the climate of the district and the fact that the deposit is open and offers little resistance to the passage of solutions. It was not found possible to determine the exact depth to which oxidation has extended below the original surface. Above the present rim of the south glory hole the hematite and siderite have been entirely altered to limonite or a mixture of hydrated iron and manganese oxides, and the sulphides have been largely altered, though here and there a kernel of chalcopyrite still remains surrounded by limonite. Pseudomorphs of limonite after pyrite and siderite are very common. The limonite surrounding kernels of chalcopyrite is botryoidal, and in many places limonite of this character lines cavities. Malachite is sparingly present. Six feet below the rim of the glory hole, probably about 40 feet below the natural surface, limonite is present only in subordinate amounts, but hematite is very abundant, together with some siderite. On the 100-foot level limonite was not found, and hematite is less abundant than near the surface. Hematite is also much less abundant lower in the mine than in the glory hole. Siderite and hematite are abundant on the dump from the Comet tunnel, though their relation to the surface was not determined. They were found, however, at no great depth below the surface. The change from hematite with comparatively little siderite in the upper part of the glory hole to siderite with very much less hematite on the 100-foot level strongly suggested surface alteration, the siderite being first altered to hematite and later to limonite. Microscopic study, however, shows that in every specimen examined where hematite and siderite are present together the hematite was formed first. It appears, therefore, that in the original deposition, for some reason not determined, hematite formed more abundantly at this level than at greater depth. The siderite alters to the hydrous oxides more readily than the hematite. Malachite is practically absent on the 100-foot level and probably has not formed below the limonite zone, certainly not in any considerable amounts. Native copper is also reported from the zone of oxidation, though none was observed by the writer.

Secondary sulphides are almost entirely absent. A little covellite coating chalcopyrite was observed in one specimen from the first level. Malachite was also associated with the covellite. Some tetrahedrite in the deposit may be secondary, though that observed by the writer was primary. Chalcocite was not observed in the mine. A little pyrite and chalcopyrite in almost microscopic crystals, deposited on the earlier sulphides, were observed in specimens from the first level. It is certain that practically no sulphide enrichment has taken place in the mine.

Ore shoot.-The ore shoot developed in the Cactus ground has a maximum length slightly exceeding 700 feet and a maximum width of about 200 feet, though the average width is considerably less. The dimension of the ore body as developed on the several levels can be best understood by reference to Plates XXXI and XXXII. In the upper levels the major part of the ore is in the western portion of the developed ground, but in the lower levels the greatest development is in the eastern portion. The ore in the lower levels is also slightly farther to the north, giving the ore shoot as developed a steep pitch apparently to the northeast. That the ore shoot pitches steeply to the north there is no doubt; the eastward pitch, however, may be only apparent. There is certainly barren ground in the west ends of the lower drifts, but this may give place still farther west to another branch of the ore shoot. Within the limits of the ore shoot there are numerous blocks of barren ground. The largest of these is that in the eastern part of the shoot, extending from the surface to and below the 300-foot level, though 
this block contains a small amount of ore on and above the third level. At the time of visit it was impossible to see the relations of this block to the surrounding ore underground. As shown on the company's map, however, it is bounded on the east and west by faults, and its vertical extent is limited by a nearly horizontal fault at about the cighth floor above the fourth level. The writer was unable to verify this structure except as to the fault forming the western boundary, which was exposed in the glory hole. The rock within this block, so far as could be judged from the surface, has been highly sericitized, but does not contain important amounts of tourmaline or the later gangue minerals.

The block of barren ground exposed in the north drift in the west end of the sixth level is separated from the mineralized ground by faults with prominent gouges. Other portions of the deposit show strong sericitization and abundant tourmaline, but carry only relatively small amounts of sulphides. A good instance of such a portion is that in the extreme southwestern part of the third level. It could not be demonstrated that faults separated this lowgrade mineralized ground from the ore. Other blocks of slightly altered rock are certainly not bounded by faults, but the mineralization shows a gradation, usually rather rapid, from ore to barren and slightly altered rock.

From the observations above recorded, there appears to be a close connection between the character of the different blocks of barren ground and the different periods of mineralization. Blocks of ground that were surrounded by faults and gouges before mineralization began, as that on the sixth level already mentioned, have suffered little alteration. Where movement took place after the period of sericitization was well advanced and before tourmaline was deposited in large amounts, the conditions are similar to those in the large block in the eastern portion on the upper levels. Where movement took place after the deposition of tourmaline but before that of the later minerals, the ore-bearing solutions might well be diverted and produce such conditions as are found in the southwestern portion of the third level.

That there were slight movements within the ore zone during the period of ore deposition appears certain. It does not seem likely that such planes of movement would entirely inclose a block of ground. It is not necessary, however, to assume that a block was entirely surrounded by slips, as a slight movement in but one plane might close an ore channel leading into a certain block and thus practically stop mineralization in that direction.

Concentrating and smelting ore.-The ores of the mine may be classified commercially as smelting and concentrating ores, the latter being by far the more abundant. The principal shoot of high-grade ore developed previous to the summer of 1909 was present in the eastern portion of the property near the north wall of the ore body. This shoot was about 30 by 50 feet in size on the fourth level and continued to the sixth level with some variation in dimensions at different points. A much smaller shoot was present in the eastern part of the mine about midway between the footwall and hanging wall, extending above and below the 500-foot level. This portion of the mine was not accessible at the time of visit, and the following statements are based on information obtained from various sources and are believed to be reliable, though the writer was unable to verify them.

Chalcopyrite formed a large part of much of the ore, large masses being almost pure chalcopyrite. The gangue minerals were siderite, anhydrite, gypsum, and barite. Galena was also present in small amounts. Tourmaline, specularite, and quartz are relatively rare and are probably associated with included fragments of altered monzonite. The ore on the sill floor of the fourth level is stated by the company to have averaged 18 per cent of copper, and individual assays showed as high as 30 per cent.

The above statements, a part of which the writer was able to verify by examination of specimens, indicate with little doubt that this ore is essentially the same as that deposited during the later period in the small fissures, and the unusual richness of the ore in the high-grade shoots may be attributed to unusually favorable conditions for the circulation of solutions during the closing part of the period of ore deposition.

The concentrating ores which have furnished the greater part of the output of the mine vary considerably in character at different levels. In the upper levels the sulphides, together $73363^{\circ}-$ No. $80-13-12$ 
with the gangue minerals, have been formed largely in the open spaces between the breccia fragments and in relatively large masses. In the lower levels the sulphides are much more generally disseminated in small grains through the altered monzonite. Ore of this character requires much finer grinding to free the sulphides from the gangue than the ore in the upper levels. This difference in the ore required important changes in the milling practice in order to make satisfactory recovery possible.

The average recovery from both concentrating and smelting ore for the fiscal year ending June 30, 1908, as shown by the company's report, was 2.02 per cent of copper, with 0.0097 ounce of gold and 0.276 ounce of silver to the ton.

The zone of oxidized ore is very shallow and the ore usually too low in grade to be shipped profitably. It is only very near the surface that the chalcopyrite has been completely altered to carbonates. In the lower part of the oxidized zone much of the copper is still present as chalcopyrite, though the iron sulphide has been altered to hydrous oxides.

BEAVER CARBONATE MINE.

Location.-The Beaver Carbonate mine is located about $1 \frac{3}{4}$ miles northwest of Friseo, at an elevation of 6,750 feet. The property consists of a group of 11 claims and fractions. The principal developments have been made in the Carbonate and Rattler claims.

History.-The Carbonate mine was discovered in the fall of 1878 . In the following February it was sold to Campbell, Burke \& Donaldson for $\$ 10,000$. After a shaft had been sunk to a depth of 212 feet it was sold to the Frisco Mining \& Smelting Co. in September, 1879, for $\$ 150,000$. Soon afterward the Rattler mine was opened and the property was an active producer till 1885 , when it was closed. It remained inactive until 1908, when a new shaft was sunk to the 700 -foot level and considerable development work done.

During the early operations the product was reduced to bullion at the works of the Frisco Mining \& Smelting Co. at Frisco, which also treated ores from the Horn Silver and Cave mines. On the closing of this plant, in 1884, the output went to the valley smelters near Salt Lake City. Most of the ore was of concentrating grade and was milled at a plant near the mine. The concentrates produced had an average assay value of 43.63 per cent of lead and 94.09 ounces of silver to the ton. The saving in this plant was not very high, as the tailings still contain considerable mineral. In 1909 a small plant with two Wilfley tables was operated for a short time on the old tailings, but this did not prove to be profitable and operations ceased.

The subjoined table shows the known production of the mine. No record of the amount of ore treated by the mill is available, but the production of lead and silver as recorded is believed to be very close to the actual output, and the total value, calculated at the average price of the two metals at the time of production, is approximately correct. No separate data as to the amounts derived from the Carbonate and Rattler mines are available, but it is reported that the greater part of the output came from the Rattler.

Output of the Carbonate and Rattler mines, 1879-1909.a

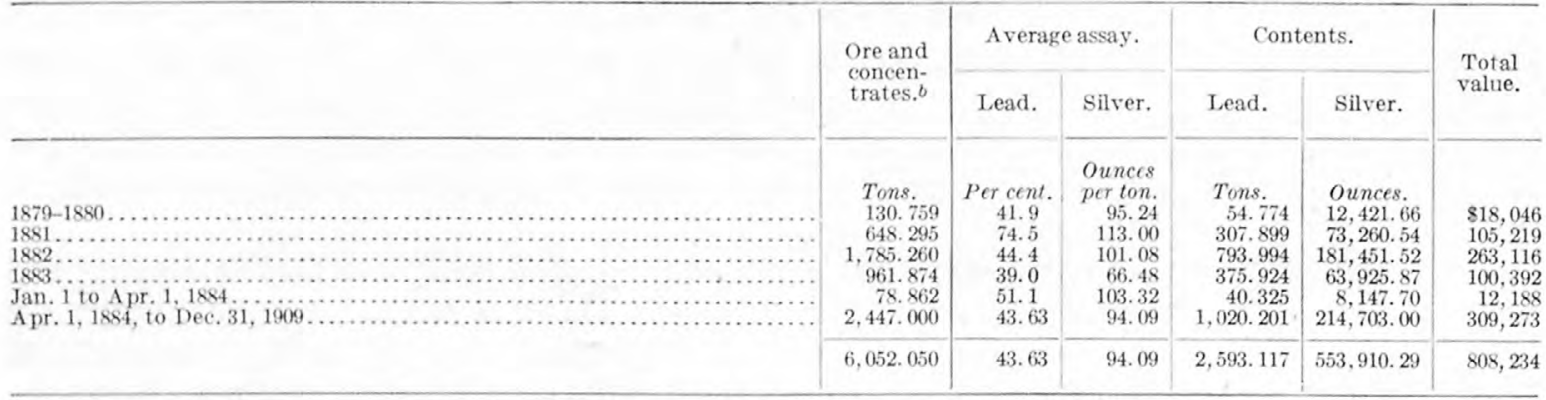

a The production to Apr. 1, 1884, is taken from a statement to the Frisco Mining \& Smelting Co. by Frank Godbe, secretary, dated Apr. 1, 1884. The production subsequent to Apr. 1, 1884, is estimated from a statement by Benjamin Hampton of the value of the product shipped after prevailing prices of lead and silver at the time of production.

$b$ Ore and concentrates treated at the Frisco smelter and shipped to other plants. No record of the amount of ore concentrated has been obtained. 
Underground developments,-No accurate map or complete description of the early workings has been obtained by the writer, but a sketch map of the old Carbonate workings and a report by Joshua E. Clayton, in which the developments to June 1, 1882, are briefly described, were furnished by Mr. Benjamin Hampton. A report on the Rattler mine, dated March 26, 1885, by John Hays Hammond, briefly describes the workings in that mine, but the map that accompanied the report was not available.

According to the data at hand, the Carbonate mine was first developed by an incline sunk at an angle of about $45^{\circ}$ which followed the ore for about 60 feet. A vertical shaft was then sunk to a depth of 144 feet and continued on an incline of about $80^{\circ}$ to a depth of 687 feet. Eight levels were opened at about the following depths. First level, at 50 feet; drift extended east 30 feet and west 60 feet. Second level, at 135 feet; drift east 60 feet and west 130 feet. Third level, at 187 feet; drift east 150 feet, west 75 feet. Fourth level, at 287 feet; drift east 300 feet, west 75 feet. Fifth level, at 347 feet; drift east 60 feet, west 60 feet. Sixth level, at 447 feet; drift east 75 feet, west 40 feet. Seventh level, at 547 feet; drift east 20 feet, west 40 feet. Eighth level, at 647 feet; drift west 40 feet. A sump extended 40 feet below the eighth level.

In the upper levels the principal ore shoot was east of the shaft, the stope extending to about the fourth level. In the lower levels the principal shoot was west of the shaft and was followed from a point above the fourth level to the eighth level. The ore shoot is reported by Clayton to have been about 50 feet long at the surface; on the second level it exceeded 100 feet in length. The width varied from 3 to 20 feet.

At the time of Hammond's examination the Rattler mine had been opened to the eighth level, but as the map that accompanied his report could not be obtained it is not possible to give the amount of development on the several levels.

In the present workings a double-compartment shaft has been sunk to the 700 -foot level. At a depth of 250 feet a crosscut has been run south about 135 feet. At a depth of 350 feet a crosscut is extended to the vein and a drift run toward the old Carbonate workings for a distance of about 150 feet. At the seventh level a drift has been run along the vein for about 700 feet to the east and about 250 feet to the west. Along the east drift the vein has been crosscut at several points, as shown by the accompanying map of the level (fig. 16).

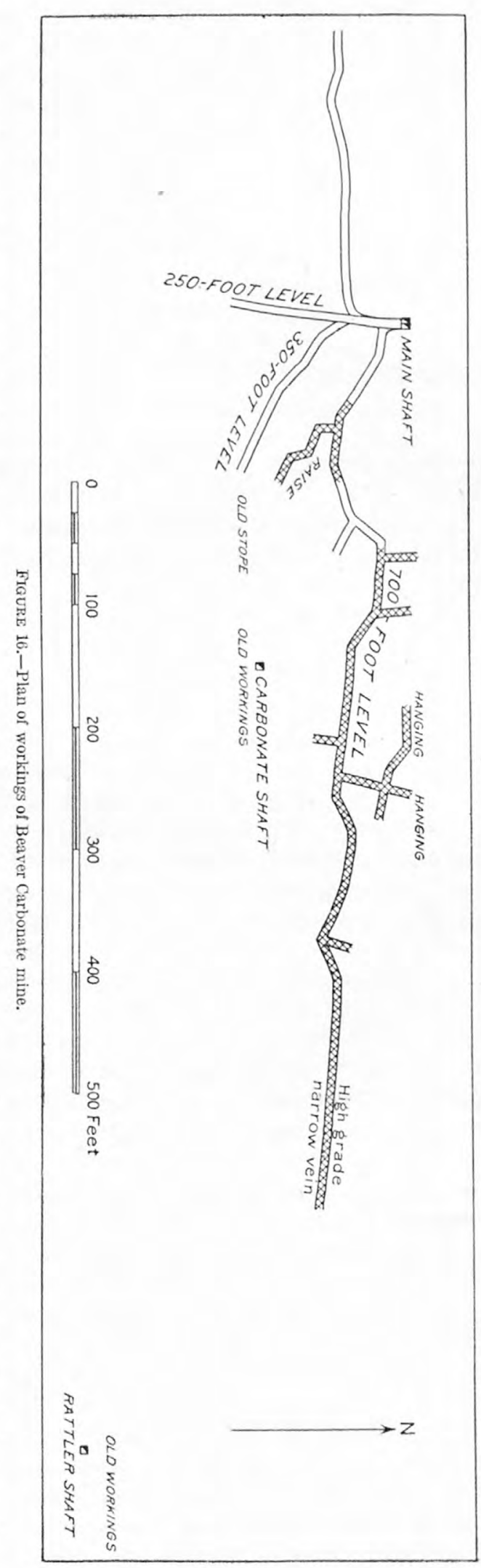


Geologic relations. - The ore occurs in a fissure in the volcanic rocks. At the surface and on the 700-foot level of the new workings the rock is similar to the quartz latite of the vicinity described on page 44. It is a dark greenish-gray rock, containing abundant crystals of feldspar and biotite. For the most part it is tuffaceous in character, containing pebbles and bowlders of varying size in a matrix of fine material. East of the mine, in Carbonate Gulch, the rhyolite tuff crops out, and the dump at the Rattler shaft indicates that this rock was encountered underground. The fissure in which the ore occurs, as followed on the 700foot level, trends N. $85^{\circ} \mathrm{E}$., and the greatest width of the mineralized zone, bounded by slips that are supposed to be the walls of the fissure, is about 60 feet. The dip is steep to the north, but the present developments do not furnish data for determining the exact angle.

According to the Clayton report, the vein in the Carbonate mine had a "general course of $\mathrm{N} .70^{\circ} \mathrm{E}$. and S. $70^{\circ} \mathrm{W}$. (magnetic)," and the dip varied from $70^{\circ} \mathrm{N}$. to nearly vertical, the general dip being $80^{\circ} \mathrm{N}$. The Hammond report on the Rattler mine states:

The vein has an average strike or course on the lower levels (taking the hanging wall as an index) of $23^{\circ}$ south of west. The dip or pitch of the vein is to the north, and between the sixth and seventh levels, a vertical distance of 100 feet, the hanging wall travels 10 feet to the north, notwithstanding the fact that the walls on these levels appear almost vertical. This is a dip of nearly $80^{\circ}$ measured from the horizontal.

On reducing the magnetic readings to true readings we have the following directions as determined in the three workings: Rattler, N. $83^{\circ}$ E.; Carbonate, N. $86^{\circ}$ E.; new workings, N. $85^{\circ} \mathrm{E}$. The dip in both of the old workings is approximately $80^{\circ} \mathrm{N}$., and that in the new workings, though not definitely determinable, as most of the work is on one level, appears to be about the same.

The available data concerning the position of the old workings are too few to make it possible to construct a plan showing the position of the vein at the different points. From the descriptions, however, it seems that there must be a fault between the east end of the new workings and the old Rattler workings, throwing the portion on the east of the fault relatively to the south, or else the Rattler workings were developed on a different vein. The Rattler report speaks of strong gouges in the west end of the drift which bounded the ore, and these were thought by Hammond to represent a fault.

The supposed footwall and hanging wall are slips showing pronounced slickensiding and usually a heavy gouge formed by the rock ground up by the movement. Between these walls, however, there are slips and gouges nearly or quite as prominent as those bounding it, and some exploration beyond these walls seems necessary before it can be conclusively stated that they limit the ore deposit. In the new workings the greatest width of the ore zone as shown by crosscuts is 60 feet, but the width varies from place to place. In the east end of the workings, which was not examined by the writer, the zone is said to be narrower but to carry better values. According to the Clayton report, the width of the "ore channel" in the Carbonate mine varied from 50 to 80 feet. Hammond states that in the upper levels of the Rattler mine the "vein" reaches a width of 40 feet.

The rock within the ore zone has suffered much crushing and open spaces were formed between the fragments, but there were no large open fissures. Where the movement was greatest the rock was ground to a gouge. Within the ore zone the gouge planes have various positions and are not uniformly parallel with the walls of the vein.

The most conspicuous change made in the rock by the ore-bearing solutions is the formation of abundant chlorite. The plagioclase feldspars have been entirely altered to carbonate, some quartz, and a sericitic mineral that usually has a light-brown color and slight pleochroism, and in many of these aggregates orthoclase that is probably secondary is present. A very finely divided chloritic mineral whose exact character can not be determined is abundant, and a little epidote is present in much of the rock. The orthoclase crystals have suffered relatively less alteration, but chlorite and a little sericite are usually present. Hornblende has been entirely altered to iron ore, chlorite, carbonate, and quartz, and a few of these pseudomorphs contain a little biotite. Biotite has suffered relatively slight alteration. Some of the crystals are partly altered to chlorite and carbonate, but many perfectly fresh biotite 
crystals contain inclusions of the ore sulphides, usually accompanied by quartz and in places by apatite. Throughout the rock there is a very fine mineral that has not been positively determined, but has the general appearance of kaolinite. Locally this makes up a large percentage of the rock. Apatite is more abundant in the ore than in the unaltered rock examined and appears to have been introduced with the ore minerals. Small crystals of zircon are also rather abundant in the ore.

The minerals forming in the open spaces are very fine crystalline vein quartz that has the appearance of chert in the hand specimen, the ore sulphides, and calcite. These are not all present in all the veins, but where they are the order of deposition was, first, quartz; second, sulphides; and third, calcite. The boundary between these minerals, however, is not sharp. Some sulphide was deposited contemporaneously with the quartz, some calcite with the sulphides, and even a little quartz with the calcite. Where all are present in a vein, however, there is a distinct banding, the quartz forming on the wall, followed by the sulphides, and the calcite crystallizing latest, with well-formed scalenohedral crystals extending into open vugs. In addition to the minerals formed in the open spaces, galena, pyrite, and sphalerite occur as small grains disseminated through the altered rock.

Ore minerals. - Galena, with its content of silver, is the only ore mineral of commercial importance in the mine. Sphalerite is present in all the ore and locally is relatively abundant, but no data as to its average percentage are available. Pyrite is present in small amounts in all the ore. Chalcopyrite occurs in the ore, but nowhere was it seen in notable amounts. No silver mineral has been recognized, and silver is probably present in the galena as sulphide. No antimony or arsenic minerals were recognized. The gangue consists of quartz, calcite, and the minerals composing the altered rock.

Character of the ore.-The ore may be divided into two types - that forming in open spaces and that disseminated through the altered rock. In the first type, as already indicated, the ore consists of sulphides in a gangue, made up principally of quartz and calcite. The ore is banded, the quartz forming first next to the wall, followed by sulphides, and these in turn by calcite. The quartz is absent from some of the ore, in which the sulphides are deposited directly on the wall, more rarely the veins consisting of calcite alone. A very common mode of occurrence of this ore is as an incrustation on the harder bowlders of rock. The open fissures in the workings examined are all small, and this ore must be mined with the rest of the vein, so that for the most part concentration is necessary.

In the ore of the second type the sulphides are present as small grains, disseminated through and replacing the rock minerals. This ore varies greatly in richness; in places a rather high percentage of sulphide is present, whereas elsewhere there are but scattered grains.

In mining, the ores of both types are stoped together, forming a concentrating ore. Both the rock and the ore in the vein are soft, in some places requiring little "shooting." When exposed on the dump for a short time the ore crumbles to a powder.

Enrichment.-The secondary alteration of the ore has been very slight. In the two reports cited, describing the Carbonate and Rattler mines, no mention is made of oxidized ores near the surface, and so far as the writer is aware secondary alteration was of slight importance. On the 700-foot level the only evidence of secondary alteration is the presence of a little stain of hydrous iron oxides in the ore, no secondary lead or zinc minerals being seen.

This absence of secondary alteration is in striking contrast to the conditions in the Horn Silver mine, where secondary alteration is in process to the lowest levels examined. It is believed to be due to the local presence of water very near the surface, because of the impervious gouges that prevent its free movement and escape. Although in the Horn Silver mine little water was encountered until the lower levels were opened, at Frisco water can be obtained in shallow wells. In the summer of 1909 the Rattler shaft was nearly filled with water which was being pumped to supply the concentrator, but the workings on the 700-foot level of the new shaft contained little water, though only a few hundred feet away. In several small shafts west of the Carbonate, however, water has been encountered only a few feet below the surface. It is evident that the water does not circulate freely in the volcanic rocks but is ponded by dams formed by 


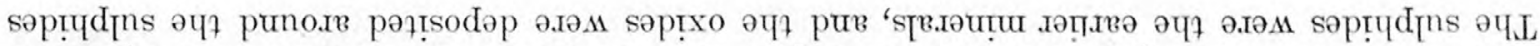

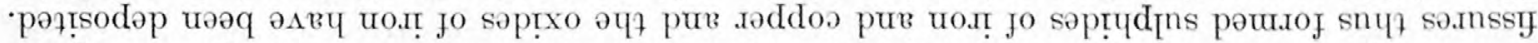

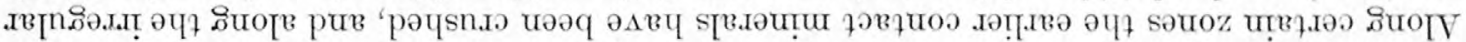

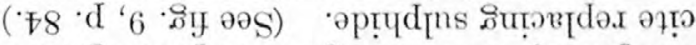

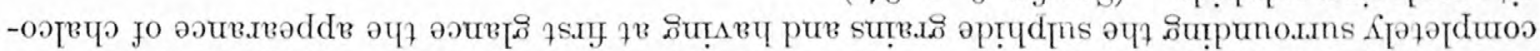

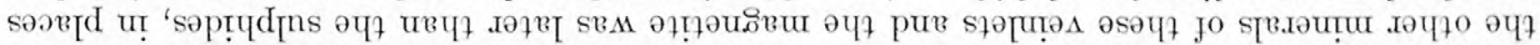

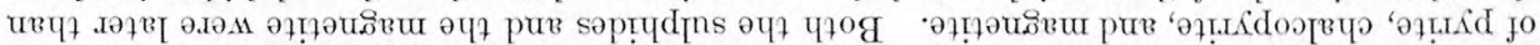

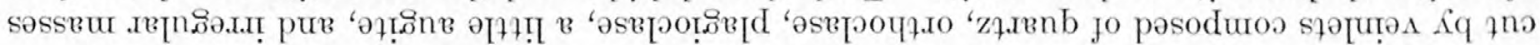

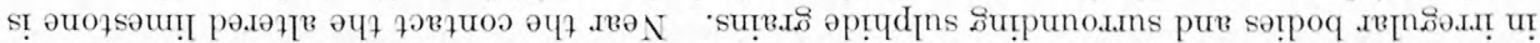

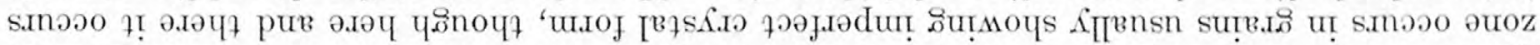

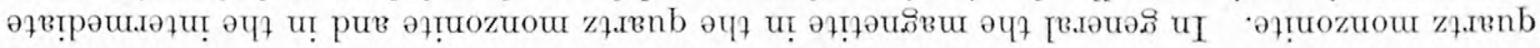

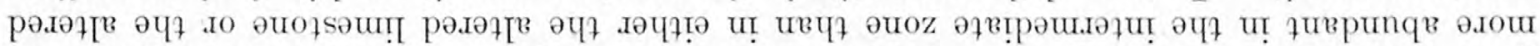

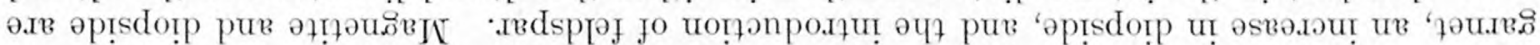

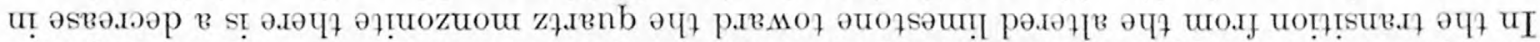

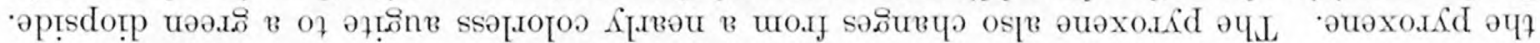

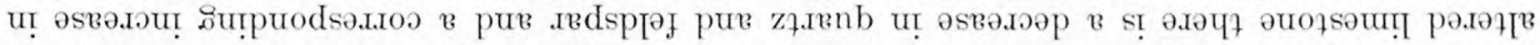

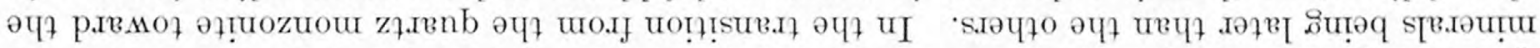

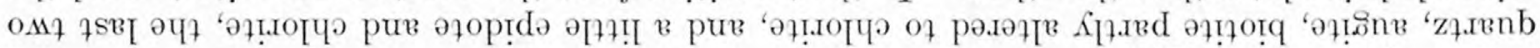

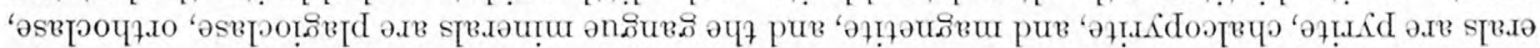

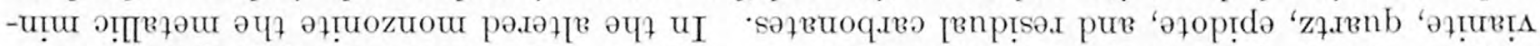

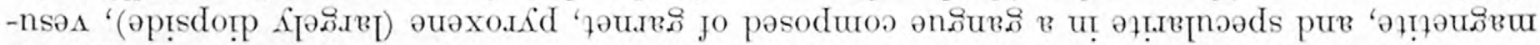

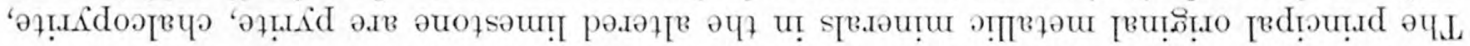

·

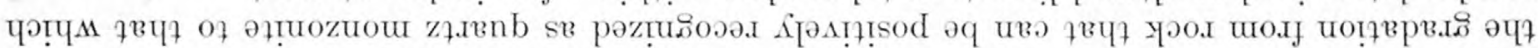

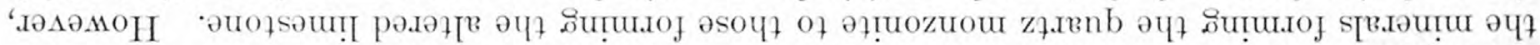

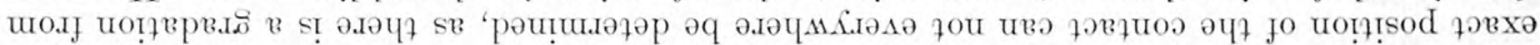

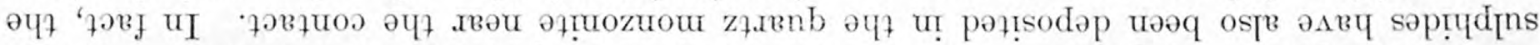

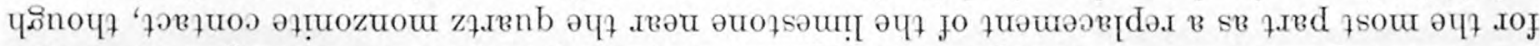

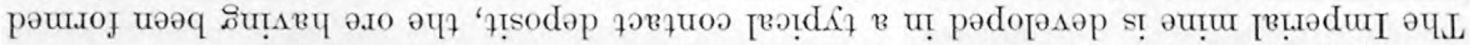

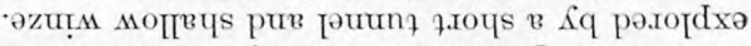

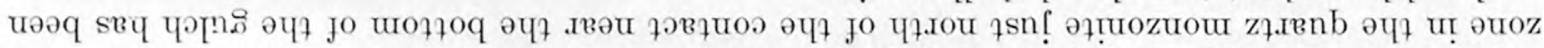

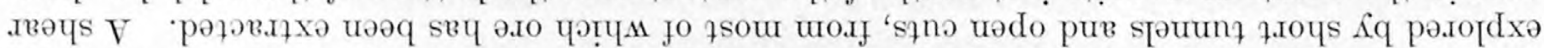

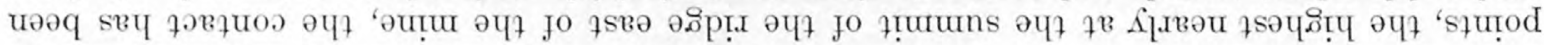

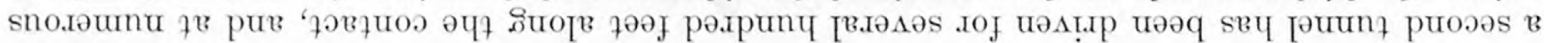

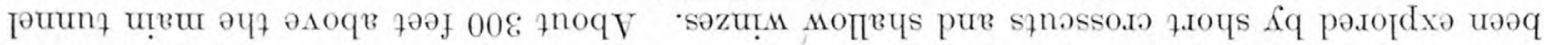

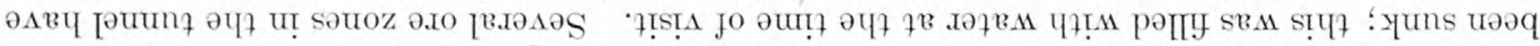

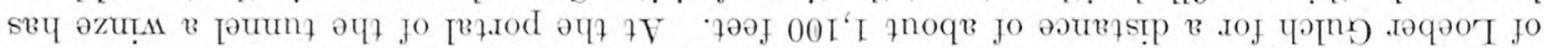

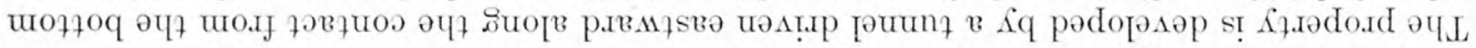

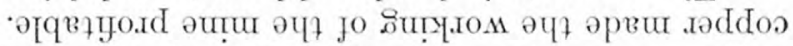

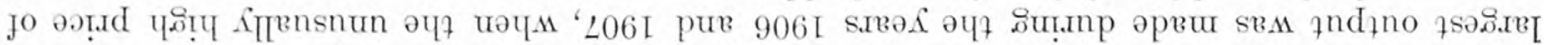

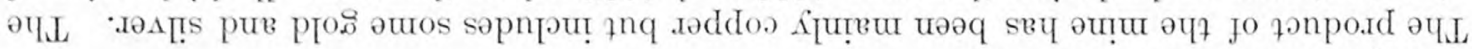

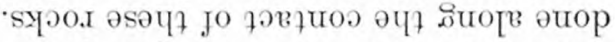

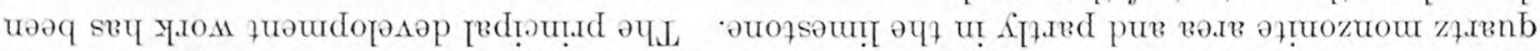

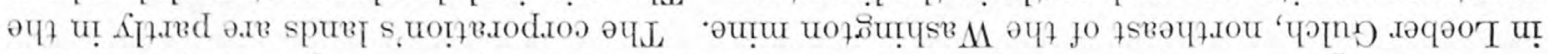

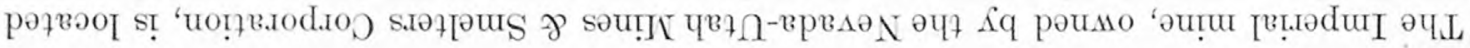

\section{'अNIT TVIYसdII}

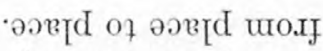

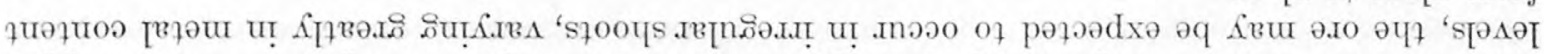

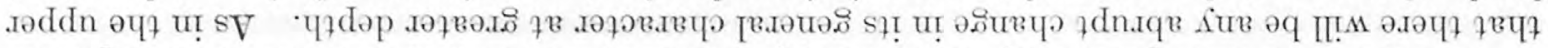

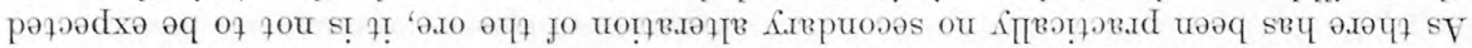

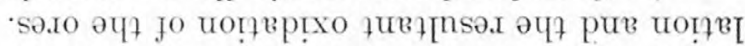

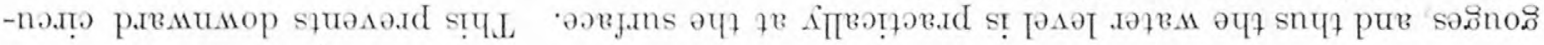


and in irregular branching masses among the earlier contact minerals. In some sections containing both pyrite and chalcopyrite the iron oxides have formed around the chalcopyrite, though the pyrite is practically free from such deposit. In many places the general appearance strongly suggests the partial replacement of the sulphides by the oxides, but such replacement was not positively demonstrated, and it is believed that the magnetite and specularite were simply deposited around the sulphides. Small veins of magnetite and specularite inclosing sulphides cut the contact minerals, showing the same age relations as at the Washington mine, where sulphides are inclosed in magnetite and specularite, and at the Cupric mine, where magnetite veins cut sulphides. (See Pl. XXXIII, B, p. 184.)

So far as shown by present developments, the deposits of commercial importance are close to the contact, though along fissures mineralization may extend a few score feet from the igneous rock.

Secondary alteration has not extended to a great depth below the present surface, though it has been an important process in producing the ore thus far extracted. The characteristic alteration has been to carbonates and oxides. Sulphide enrichment has been of slight extent. In an open cut near the base of the quartzite near the top of the ridge some secondary bornite was observed and chalcocite is reported, though none was seen by the writer.

The main ore extracted, so far as could be ascertained by observation and reports from those in charge of the mine, consisted of a mixture of the red oxide, cuprite; carbonates, largely malachite; and copper pitch, a black amorphous material with brown streak which is probably a mixture of hydrous oxides of iron and manganese and oxide of copper. This material was not obtained in sufficient purity to permit a careful determination of its composition and it may prove to be a definite mineral species. Native copper is also reported from the mine. The gangue minerals consist of hydrous oxides of iron and the silicate minerals of the contact zone. The ore is found but a few feet below the surface, under a capping of hydrous iron and manganese oxides containing little copper.

The depth of the zone of oxidation can not be stated, but in the main tunnel the ores show slight indication of secondary changes.

The oxidized ores extracted to the present time have been of shipping grade, but the primary ores thus far developed are of low grade and can not be profitably shipped under present conditions. The hard and heavy gangue in which they are inclosed renders them difficult of concentration and probably precludes that method of treatment. The high iron content of the garnet, together with some magnetite, probably renders the ores nearly self-fluxing, so that they could be smelted at a reasonably low cost, and if a sufficient quantity of ore could be developed this treatment might be profitably employed for the primary ores.

\section{WASHINGTON MINE.}

The Washington mine, owned by the Cupric Mining Co., is located in Loeber Gulch, southwest of the Imperial mine. It is reported that some high-grade ore obtained near the surface has been shipped from this mine, but the ore body was not of large size.

An inclined shaft has been sunk and considerable exploration work done to locate the continuation of the deposit at greater depth. In the summer of 1909 operations had ceased at the property and the workings were not accessible, so that observations were confined to those made on the surface, in some shallow surface workings, and on the dumps from the deeper workings. From these observations, however, it is possible to state the general character of the mineral occurrence. The deposit is similar to that at the Cupric mine (p. 184), except that contact silicates are much more abundant.

The mine is at a considerable distance from the main contact of the limestone and quartz monzonite as exposed on the surface, but the presence of dikes of the intrusive rock and the abundant development of contact silicates suggest that the main intrusive body may underlie the limestone at no great depth. The limestone has been fissured by the intrusion of the quartz monzonite and the strongest development of ore minerals is near these fissures, though it can not 
be said to be confined to them. The entire mass of the limestone has been altered to contact minerals, and sulphide minerals are present in small amounts where they do not appear to be closely associated with fissures.

The principal contact minerals present are tremolite, garnet, diopside, vesuvianite, quartz, fluorite, chlorite, and recrystallized carbonates, together with the sulphide minerals sphalerite, galena, pyrite, and chalcopyrite. The sulphides are intimately intergrown with the contact silicates (see Pl. XXXIV) and were formed at the same time, soon after the intrusion of the quartz monzonite.

So far as could be judged, secondary alteration has been slight in this deposit and has extended but a short distance below the surface.

CUPRIC MINE.

The Cupric or Iron Devil mine, owned by the Cupric Mines Co., is located at the east end of the White Mountain ridge, about 2 miles southeast of Newhouse. The mine was worked in the early days of mining in the district, the surface ores, which were high in iron, being shipped to the local smelters as flux. The present company, which is under the same management as the Horn Silver Co., is developing the mine at greater depth.

The old workings consist of several shallow shafts and inclines from which drifts have been run. The deepest of these old workings are reported to be more than 100 feet deep. The development in progress during the summer of 1909 consisted in the sinking of a vertical shaft, which in September had reached a depth of slightly more than 300 feet. It is reported that since that time considerable exploration work has been done at a depth of about 325 feet.

The mine is near the main contact of the limestone and quartz monzonite, and dikes and irregular bodies of the quartz monzonite are present in the limestone. The intrusion of the igneous rock resulted in the formation of fissures in the limestone extending in various directions and also in the metamorphism of the limestone and its replacement by ore and gangue minerals. This action was most vigorous along the fissures, which furnished easy passage for the mineralizing solutions, and it is in connection with these fissures that the ores thus far developed occur. The rock along the fissures has been altered to coarsely crystalline carbonates through which the ore and gangue minerals are disseminated. The original copper mineral is chalcopyrite; associated with this are pyrite, specularite, magnetite, and the silicate minerals muscovite, garnet, tremolite, and diopside. The contact silicates in this deposit are, however, relatively scanty in amount. An interesting feature about the occurrence of the magnetite is that much of it incloses grains of chalcopyrite and has the general appearance of chalcocite replacing chalcopyrite, as in this contact zone in general the magnetite was in part later than the sulphides, surrounding grains of sulphide and filling fissures in pyrite. (See Pl. XXXIII, C.)

At the surface and for a considerable depth below the surface the sulphides have been entirely altered, the ore consisting of hydrous iron oxides and the carbonates of copper in a gangue of carbonate and silicates. The depth to which this alteration has extended was not determined, but the sulphides encountered in the shaft at about 300 feet below the surface were entirely unaltered. No indication of a zone of sulphide enrichment was observed nor was any enriched ore reported from the mine.

The ore exposed in the shaft at the time of visit was of good grade and it is reported that similar ore was encountered in the later developments, though not in commercial quantities.

KING DAVID MINE.

The King David Mining Co. controls an extensive group of claims on Grampian Hill west of the Horn Silver mine. The company was organized in the summer of 1908, taking over several groups of claims. A pipe line was laid to Morehouse Spring, about 5 miles to the north, to furnish a water supply, and a steam plant with compressor hoist and other equipment for extensive prospecting was installed. Considerable prospecting has been done on the several 

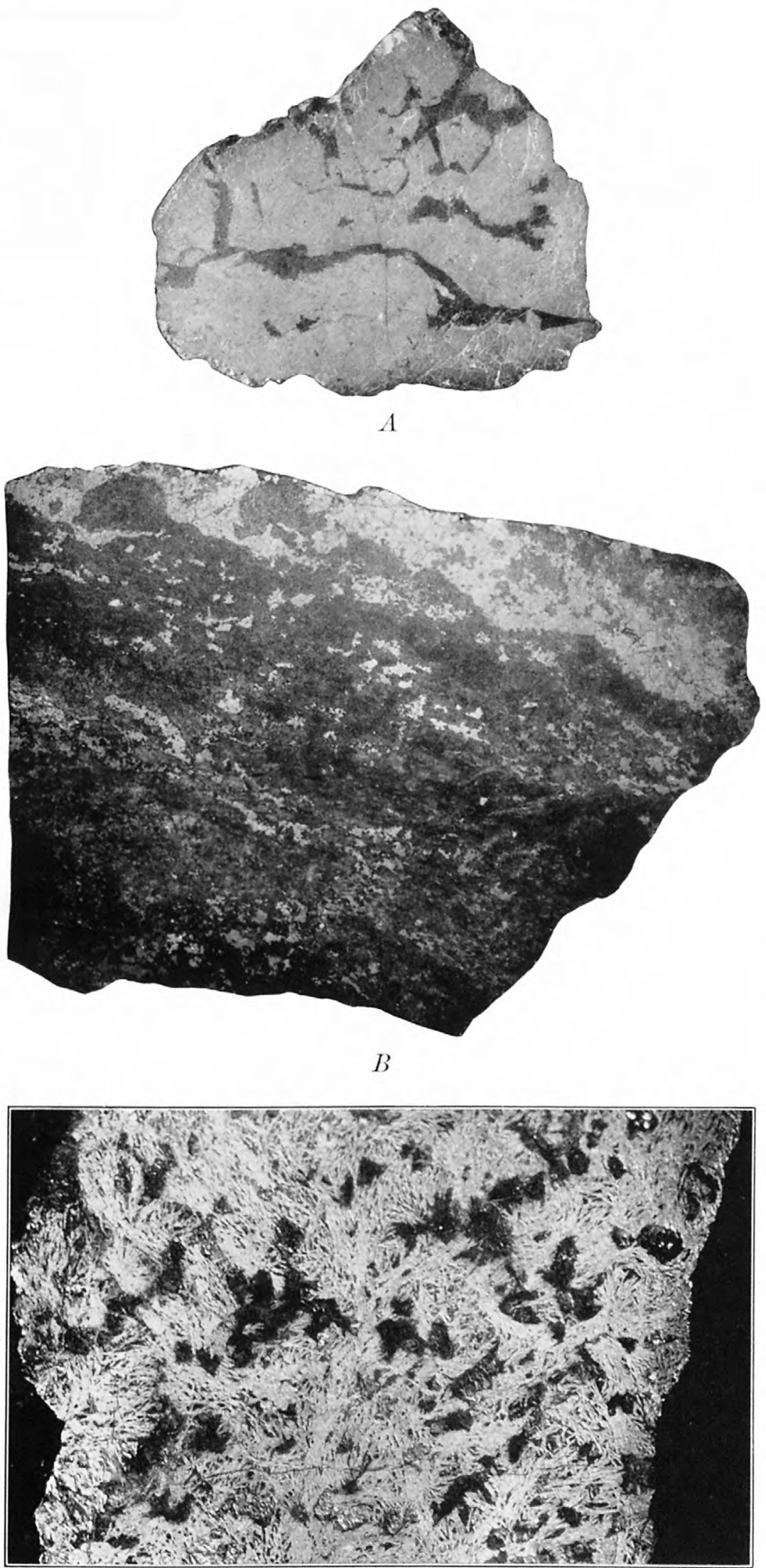

C

IRON OXIDES WITH PYRITE AND CHALCOPYRITE.

$A$, Vein of magnetite in pyrite, Peacock copper mine; dark areas magnetite; three-fourths natural size. $B$, Veins of iron oxides and sulphides in crushed garnetized lime. stone, Imperial mine; light areas metallic minerals; three-fourths natural size. (') Chalcopyrite and pyrite inclosed in iron oxide. Cupric mine: dark areas sulphides, fibrous mineral iron oxide which has general structure of hematite but is strongly magnetic. Enlarged 3 diameters. 

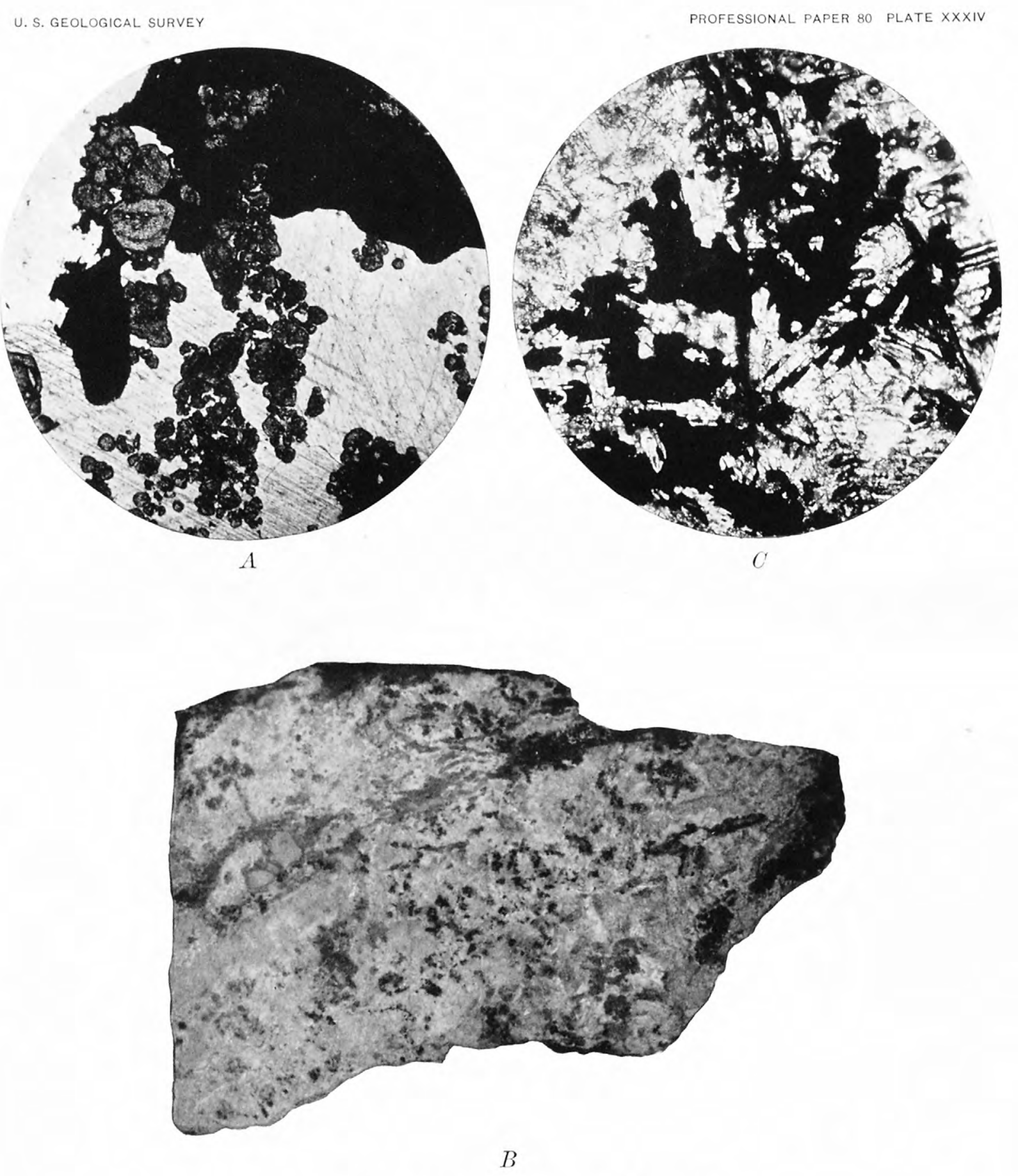

CONTACT MINERALS, WASHINGTON MINE.

A, Galena, garnet, and muscovite replacing limestone; black areas galena, dark-gray areas garnet, light area to left muscovite; mineral showing cleavage calcite. Enlarged 20 diameters. B, Galena, garnet, and tremolite re. placing limestone; light-gray areas tremolite, dark-gray areas garnet, black spots grains of galena. $C$, Intergrowth of tremolite and galena; light areas tremolite, dark areas galena. Enlarged 20 diameters. 
claims since the beginning of mining in the district, and it is reported that some ore was shipped in the early days, but the amount could not be ascertained.

In the summer of 1909 operations consisted in the sinking of the shaft in the gulch about a quarter of a mile northwest of the Horn Silver mine and in driving a tunnel in the Grampian claim to cut at depth an east-west fissure from which, it is reported, some rich ore had been extracted near the surface. At the time of visit a double-compartment shaft had been sunk to a depth of 440 feet and some exploration had been done on the 200-foot and 300-foot levels. Considerable additional development was reported from this shaft before operations were discontinued at the property. The tunnel in the Grampian claim intersected the fissure developed at the surface, but little mineralization had been found.

The claims are located for the most part in the limestone, which is cut by dikes of the quartz monzonite and has undergone contact alteration. As in other parts of this zone, the limestone has been fissured and the mineralization has taken place mainly along these fissures. The principal mineralization was contemporaneous with the intrusion of the quartz monzonite. The east-west faults that displace the Horn Silver fault in the Horn Silver and Lulu properties extend into the limestone and there has been some mineralization along these fault planes, though so far as can be judged from surface indications and developments in the Horn Silver mine the mineralization has been slight. The ore encountered in the workings from the shaft consists principally of pyrite in small lenses in a gangue of contact silicates and residual carbonates. A little galena is present in small grains and irregular veinlets in the altered limestone.

\section{PEACOCK COPPER GROUP.}

The Peacock Consolidated Mining Co.'s group of claims is located in the limestone between Loeber Gulch and Marble Gulch. The limestone has been cut by dikes of the quartz monzonite and by green porphyritic dikes resembling the basic dikes in the quartz monzonite. The intrusion of the quartz monzonite has caused contact alteration in the limestone, consisting in a recrystallization of the carbonates and the formation of contact minerals. Mineralization has taken place along fissures in the limestone, and galena and sphalerite are also present in the altered limestone, where their association with large fissures is not apparent, though they are probably associated with small fissures. Such minerals were seen at the surface, but no development work had been done at the time of visit and their relation to fissures was not determined.

A shaft has been sunk in one of the larger fissures and some drifting on the fissure is reported. The property was idle at the time of visit and the underground workings were not examined.

\section{MICHIGAN GROUP.}

The Michigan Gold \& Copper Co. controls a group of claims west of the Imperial group. These claims lie in both the quartz monzonite and the limestone and contain the contact west of the Imperial group. In the summer of 1909 an inclined shaft was being sunk on a fissure in the quartz monzonite a short distance from the contact. The ore minerals of the fissure consist of pyrite and galena with a little chalcopyrite in a gangue of quartz and carbonate. The carbonate is light brown in color and contains considerable iron. These minerals have been deposited in an open fissure. Quartz, which was the earliest mineral, projects in well-formed crystals from the walls of the fissure in comb structure. The walls have been highly silicified and mineralized with pyrite. The ore is said to carry considerable gold, which is unusual for this district. Ore in commercial quantities had not been developed at the time of visit.

NEVADA READY PAY GROUP.

The Nevada Ready Pay Mining Co. controls a group of claims on White Mountain and in the quartz monzonite north of the mountain. This group includes the western part of the limestone and quartz monzonite contact. A little prospecting has been done on the contact and on fissures in the limestone, but ore in commercial quantities has not been disclosed. 
GOLDEN REEF MINE.

The Golden Reef group of claims is located on the east side of the San Francisco Range, about 5 miles nearly due north of Frisco. The elevation of the tuinel and collar of the shaft is about 7,750 feet.

The principal development consists of a tunnel driven into the mountain for about 1,800 feet and a shaft that in July, 1909, was nearly 200 feet deep. From this shaft levels had been opened at depths of 60 and 140 feet and a small amount of drifting had been done on each level. In addition, there has been some open-cut work and shallow pits have been opened on several veins on the property.

A carload of ore was shipped from the property in 1909 and small shipments had been made previous to that date.

Unlike most of the deposits of the district the ore is valuable chiefly for its gold, the lead and silver being of relatively slight importance. The ore varies in the content of the different metals. The siliceous oxidized ore is said to carry more than an ounce of gold to the ton, with a rather low lead content and a little silver; the sulphide ore is richer in lead but carries less gold.

The Golden Reef mine is located near the fault that determines the eastern boundary of the San Francisco Mountain block. West of the fault are the sedimentary rocks and east of it are the volcanic rocks. The sediments in this part of the range comprise interbedded shales, calcareous shales, and fine quartzites at the base, overlain by massive white quartzite several hundred feet in thickness, a series of shaly slates 40 to 60 feet thick, and the massive pink quartzite that forms the upper part of the range. The base of the range is buried in quartzite float coming from the higher slopes.

Besides the main Golden Reef fault, which has thrown the volcanic rocks down against the sediments, there are several minor faults striking a little east of north, in general parallel to the Golden Reef fault, which have resulted in only slight movement, but have produced zones of brecciation in the quartzite. Data are not available to determine the extent of movement along the Golden Reef fault, but from the general relations it is believed to be considerable. The movement along the faults in the sediments parallel to the Golden Reef fault has been slight. The tunnel has been driven in the shale series for 1,800 feet and crosses several of the breaks that appear at the surface. Nowhere in the tunnel is the throw of a fault shown to be more than a few feet and in many faults the throw is only a few inches. In a few places the amount of throw can not be determined definitely, but appears to be slight. There is also slight folding in the shale strata. These minor faults and folds in the shale are represented in the overlying brittle quartzite by zones of brecciation. The west fault, which appears to be the strongest of these minor north-south faults, has dropped the east side down so that the shaly slates are in contact with the quartzite, but the throw is probably measured by a few feet. This fault has not been encountered in the tunnel. In addition to the north-south faults, there are several cross fissures that are represented by breccia zones in the quartzite. The most prominent of these fissures is known as the Galena and strikes $\mathrm{N} .60^{\circ}-65^{\circ} \mathrm{W}$.

Mineralization has taken place in the breccia zones in the quartzite along both these sets of fissures. The most extensive mineralization thus far encountered is along the Golden Reef fault, where small bodies of ore have been found in the quartzite at depths of 60 and 140 feet.

The only important primary ore mineral determined is galena. Much of that seen is finely erystalline, but some of it is in moderately coarse crystals. In one test of this material a reaction for antimony was obtained, but no definite antimony mineral has been determined. In several tests on charcoal the odor of selenium was distinctly detected, and in one assay the brownish-red coating characteristic of selenium formed on the charcoal. The form in which the selenium is present has not been determined. Pyrite occurs in small amounts in the galena. The form in which the gold is present is not known, but it is probably not free, for colors can not be obtained by panning. The only gangue minerals are barite, which is rather abundant, some quartz deposited with the ore, and the residual quartz grains of the quartzite. 
The secondary alteration has resulted principally in the formation of the lead carbonate, cerusite, from the galena. The ore minerals fill the interstitial spaces between the breccia fragments of the quartzite and surround and partly replace the quartzite grains. So far as developed, the ore is found entirely within the quartzite. Where the volcanic rock is encountered in the shaft it is separated from the ore by a rather strong gouge. No prospecting has been done in the lava, and whether or not it carries ore is therefore not known. It seems probable, however, that the quartzite breccia has been the easiest channel for the passage of the ore solutions.

OTHER PROSPECTS IN THE IAVA.

Prospecting has been done in the lavas at many points in the district, but the most extensive search for ore has been made by the Lulu Mining Co. and the Frisco Consolidated Mining Co.

The Lulu Mining Co.'s property is immediately south of the Horn Silver mine, and development on it began soon after the discovery of the Horn Silver deposit. A shaft has been sunk to the 650-foot level, and drifts have been extended along the contact at this level and at the 400-foot level. The general geologic relations are the same as those in the Horn Silver mine. The Horn Silver fault, which throws the volcanic rocks down against the limestone, passes through the property, and is offset by east-west faults. The lavas, however, have suffered but slight alteration, in marked contrast to the pronounced silicification in the Horn Silver mine. At a few points in the workings small masses of silicified rock were noted, and associated with these was a little galena, but ore in commercial quantities has not been encountered.

The Frisco Consolidated Mining Co. has a large group of claims about $1 \frac{1}{4}$ miles northwest of Frisco. The principal development has been done at the Frisco Contact mine and the Kruse mine. At the former, in 1909, a shaft had been sunk to a depth of about 700 feet, and a crosscut extended toward the quartz monzonite contact at a depth of about 600 feet. At the Kruse an old shaft was being pumped out, preparatory to further development. The company's holdings include areas of both the quartz monzonite and of the rolcanic rocks. Northwest of the Frisco Contact workings an inclined shaft has been sunk on a fissure in the monzonite, and it is reported that some good lead-silver ore was taken from this shaft and shipped. Leadsilver ore has also been found in other fissures in the monzonite. At the time of visit in 1909 no ore had been encountered in the Frisco Contact workings, but there has been some mineralization by pyrite and specularite. At the Kruse, it is reported, ore was encountered in the old workings, and some mineralization is apparent in a fissure in the monzonite north of the shaft.

BLACKBIRD GROUP.

The Blackbird Gold \& Copper Mining Co. controls a large area in and near Copper Gulch, including a part of the north limestone and quartz monzonite contact. The most extensive developments in this company's group of claims are those on the New Year's, Belmont, and Purity claims in Copper Gulch, adjoining the Cactus property. The works on these claims were nearly all inaccessible at the time of visit, so that observations were confined to those made on the surface.

The shaft on the New Year's claim is reported to have been sunk to a depth of about 300 feet, and several hundred feet of drifting has been done. Considerable development work has also been done on the Belmont and Purity claims. All the developments on these claims are within the general mineralized zone of Copper Gulch, and the mineralization is similar in character to that of the Cactus mine. The mineralized outcrop on the New Year's claim is in line with the general strike of the ore zone of the Cactus mine, but is separated from this zone on the surface by several hundred feet of unmineralized monzonite. The rock is in part the normal monzonite and in part the porphyritic type that is exposed along the north side of Copper Gulch. Both have suffered the same brecciation and mineralization.

The mineralized outcrop on the Belmont claim is similar to that on the New Year's, and the two are connected by a narrow zone of mineralized ground. The position of the New Year's-Belmont mineralized zone with respect to the Cactus zone suggests that the two were once continuous, and that they have been separated by movement along a fault with a northeast- 
southwest strike that has thrown the western portion 200 to 300 feet to the north. Definite evidence of the presence of such a fault was not obtained, and it is thought more probable that the unmineralized area separating the two zones is similar to the smaller blocks of similar character within the Cactus mine.

On the Purity claim the mineralized outcrop has an irregular form, and is about 300 feet in greatest dimension. It is surrounded on all sides by slightly altered monzonite, rock of the porphyritic type being present to the north. The alteration and mineralization are similar to those in the Cactus mine, and the general relations at the surface suggest that this ore body is a chimney-like offshoot from the main ore zone, which it joins underground.

The developments on these claims are not sufficient to warrant a statement as to the extent of mineralization or grade of the ore. The mineralization is similar to that in the Cactus mine, but determination of whether or not the ore will prove of commercial importance must await further development.

In the summer of 1910 the company was prospecting near the limestone and quartz monzonite contact by means of core drills, but at the time of visit, early in September, little progress had been made. It is doubtful if core-drill prospecting will prove entirely satisfactory for deposits of the character found in this district.

\section{COMET MINE.}

The Comet claim, owned by the Nevada-Utah Mines \& Smelters Corporation, is located at the east end of the Cactus mineral zone. It has been developed by a shaft and a tunnel, but the extent of these workings is not known, as they were not accessible in the summer of 1909. The mineralization is of the same general character as that of the Cactus mine. Some ore has been extracted, and is on the dump.

\section{INDIAN QUEEN GROUP.}

The Indian Queen Consolidated Mining Co. controls a large group of claims located mainly in the limestone north of the quartz monzonite stock. The main production from this group was made in the early days of mining in the district from the old Mountain Queen workings, located at the summit of the ridge about a quarter of a mile north of the main quartz monzonite and limestone contact. It is reported that considerable high-grade lead-silver ore was extracted from these workings and treated at a smelter near Wa Wa Springs.

For a considerable distance north of the igneous contact the limestone has been altered to a white crystalline rock. A few dikes and irregular bodies of quartz monzonite are present in the limestone, but only one, that near the Indian Queen tunnel, was observed at any considerable distance from the main contact. The limestone is traversed by fissures, the more abundant having a general north-south direction and a less number trending east and west. In some localities there has been slight displacement along both sets of fissures. Mineralization has occurred along these fissures, that associated with the north-south fissures being the more extensive so far as shown by present developments. The ore in the Mountain Queen workings occurred as a replacement of limestone along one of these north-south fissures. The ores were extracted near the surface; where the vein was cut by tunnels at greater depth it was nearly barren, but was not extensively explored. Some development work has been done on several other fissures, but no large ore bodies have been located.

The Indian Queen tunnel was planned to crosscut the limestone with the expectation of developing several fissures that carry some mineral at the surface. The tunnel is started on an east-west fissure, showing considerable brecciation, but does not follow it for any considerable distance. At the time of visit, August 18, 1909, the tunnel had been driven a distance of 3,323 feet. Several fissures having a general north-south strike had been cut and prospected to a small extent. These fissures contain some iron oxide and gypsum, which indicate the former presence of sulphide, but no commercial ore had been encountered. The face of the tunnel is reported to have been advanced to about 4,200 feet before work was discontinued. At the mouth of the tunnel the company had a plant that was well equipped for prospecting, the motive power being electricity. 
OTHER PROPERTIES.

Some prospecting has been done north of the Indian Queen property, but no deposits of commercial importance have been encountered.

Considerable development work has been done along the northern contact of the quartz monzonite and limestone, especially on the Hendrickson property. Sulphides are present in many places along this contact and some ore has been extracted, but no large ore bodies have yet been encountered. The properties were not being worked at the time of visit, and consequently the underground workings were not examined.

\section{BEAVER LAKE DISTRICT.}

The Beaver Lake district includes the area within the Beaver Lake Mountains. To the present time the main production from this district has come from the $\mathrm{O} \mathrm{K}$ mine, though there has been considerable development of other properties.

\section{O K MINE.}

Location.-The O K mine, owned by the Majestic Mines Co., is located in the southern part of the Beaver Lake Mountains at an elevation of about 6,150 feet. (See Pl. VIII, A, p. 82.)

History.-This district has been known to contain ore deposits since the early days of mining in the region, but as copper is the principal metal in this part of the range the district received little attention in the early days, when the prospectors and miners were seeking lead, silver, and gold. In 1900 the Majestic Copper Mining \& Smelting Co., predecessor of the present Majestic Mines Co., was organized, the O K being one of its properties. The mine was developed by this company, and considerable high-grade ore was shipped. It was reported by the company that up to January 1, 1902, the mine had produced 1,145 tons of ore averaging 40 per cent of copper and giving returns of $\$ 95,000$. A shipment of 258 tons of selected ore in 1901 gave smelter returns of 40 per cent of copper, $\$ 3.80$ to the ton in gold and 7.5 ounces to the ton in silver. The rich ore developed had been all taken out in 1902, but lower-grade material was mined later, especially during the period of the prevailing high price of copper1905 to 1907 . With the fall of price in copper in 1907 the mine was closed, and it has not since been reopened.

If the figures quoted above for the early production of the mine are correct, its total output of copper has been nearly $1,000,000$ pounds and the total value in excess of $\$ 100,000$.

Development. - The mine was first developed by an inclined shaft sunk at an angle of about $65^{\circ}$ to a depth of about 175 feet. Later a second incline was sunk with an average dip to the north of about $62^{\circ}$ following the vein. The dip is not uniform, being steeper in the upper part of the shaft and flatter in the lower part. This shaft has been carried 90 feet below the 400 -foot level. Still later a vertical shaft was sunk to the 300-foot level. The principal development has been on the 200, 300, and 400 foot levels, though there has been some exploration above the 200-foot level. The extent of these developments can best be seen by consulting the accompanying diagram of the workings (Pl. XXXV).

Geologic relations.-The mine is entirely within the quartz monzonite and is associated with a fissure striking about $\mathrm{N}$. $80^{\circ} \mathrm{W}$. and dipping $60^{\circ}-65^{\circ} \mathrm{N}$. A strong gouge formed of crushed quartz monzonite, with prominent slickensides, testifies to the movement that has taken place along this fissure, but no evidence of the amount of movement is available. In minor fissures, gouges and slickensides have been formed where the movement has been but a few inches, and it is not necessary to suppose large movement to have taken place along the main fissure.

In the bottom of the inclined shaft is exposed an aplitic rock, probably a dike, though its relations are not clearly seen. This rock is composed principally of orthoclase and quartz, with a little muscovite, rutile, zircon, apatite, chalcopyrite, and molybdenite, all apparently original minerals, except a little of the muscovite, which may be secondary. The order of crystallization of the constituent minerals was, first, apatite, zireon, and rutile; second, orthoclase; third, quartz; and last, in general, the sulphides, though some sulphide crystallized contem- 
poraneously with the quartz and some formed as early as the feldspar. In contrast to the normal mineralized quartz monzonite this rock shows very slight secondary alteration, scattered foils of muscovite being the only secondary mineral.

In addition to the types of rock mentioned, the mine contains what may be termed a "chimney" of quartz. On the 200-foot level this has a greatest apparent dimension east and west of approximately 100 feet. As exposed on the lower levels it shows slightly varying dimensions and a steep dip to the northeast. At the outcrop the quartz is less prominent than in the mine. This body is composed almost entirely of very coarse crystalline quartz having the general character of a coarse pegmatite, but without the feldspar and mica that are present in pegmatite. The quartz crystals attain a maximum diameter of 10 inches and many of them are more than 2 feet in length. Open cavities are of common occurrence and into these the quartz crystals project. Toward the margin the quartz body includes corroded masses of highly altered quartz monzonite that have the appearance of bowlders. Veins of quartz extend into the altered monzonite, having formed along fissures which appear to have been enlarged by the solution of the intrusive rock. This fact, together with the corroded bowlders of quartz monzonite included in the quartz and the general shape of the body, suggests that this "chimney" of quartz was formed by actual solution of the monzonite and subsequent deposition of quartz in the space thus produced. After the deposition of the quartz the solutions deposited small amounts of chalcopyrite and molybdenite in the open spaces between the quartz crystals. In the body of the chimney the sulphides are not abundant, but in the small veins extending into the monzonite the sulphides are relatively greater in amount. Both sulphides were probably being deposited at the same time, but in small fissures where both are present a marked tendency was noted for the molybdenite to occur near the ends of the small branch fissures rather than in the main fissures, and where molybdenite is most abundant chalcopyrite is not present. In some places where the chalcopyrite has been slightly crushed molybdenite has been deposited along the fractures, indicating that some of the molybdenite was later than some of the chalcopyrite.

Alteration of the wall rock.-The alteration of the wall rock by the ore-bearing solutions and subsequent surface solutions has been discussed in detail on page 74 , and here it is necessary only to say that the quartz monzonite has been converted into a rock composed essentially of quartz and muscovite (sericite), with minor amounts of kaolin, chlorite, rutile, rarely tourmaline, and sulphides, including chalcopyrite and lesser amounts of pyrite and molybdenite.

Ore and gangue minerals.- The primary sulphide minerals are pyrite, chalcopyrite, and molybdenite, the gangue being quartz and the altered quartz monzonite. Secondary alteration has been important in producing the ore thus far extracted. The secondary copper minerals in the zone of oxidation are malachite, azurite, chrysocolla, and cuprite, malachite being the most abundant. Native copper was not noted. The iron in the oxidized zone is in the form of hydrous oxide, probably in large part limonite, which in many places is mixed with secondary silica to form jasperoid. The outcrop of the ore is a mass of jasperoid stained with copper carbonates and containing well-formed crystals of quartz. Carbonates and oxide were not found to any great extent below the second level, but it is said that they formed an important part of the ore in the main body on and above the second level.

Below the oxidized zone is the zone of sulphide enrichment, in which covellite and chalcocite have partly replaced pyrite and chalcopyrite. The relative amounts of these minerals can not be stated. Both are reported as present in the main ore body, but in the specimens taken from fissures in the walls of the stope covellite was the only secondary sulphide noted. In the grains disseminated through the monzonite chalcocite was present almost to the exclusion of covellite in the specimens examined.

Along favorable channels secondary alteration has taken place to the lowest level, where the walls of the drifts at some points are covered with the hydrous sulphate of copper, chalcanthite, leached from the ore. In the quartz body also on the fourth level small masses of hydrous iron oxide indicate the alteration of sulphides. Little enrichment has taken place on the fourth level, however, and it is doubtful if much has occurred below this level, even along 


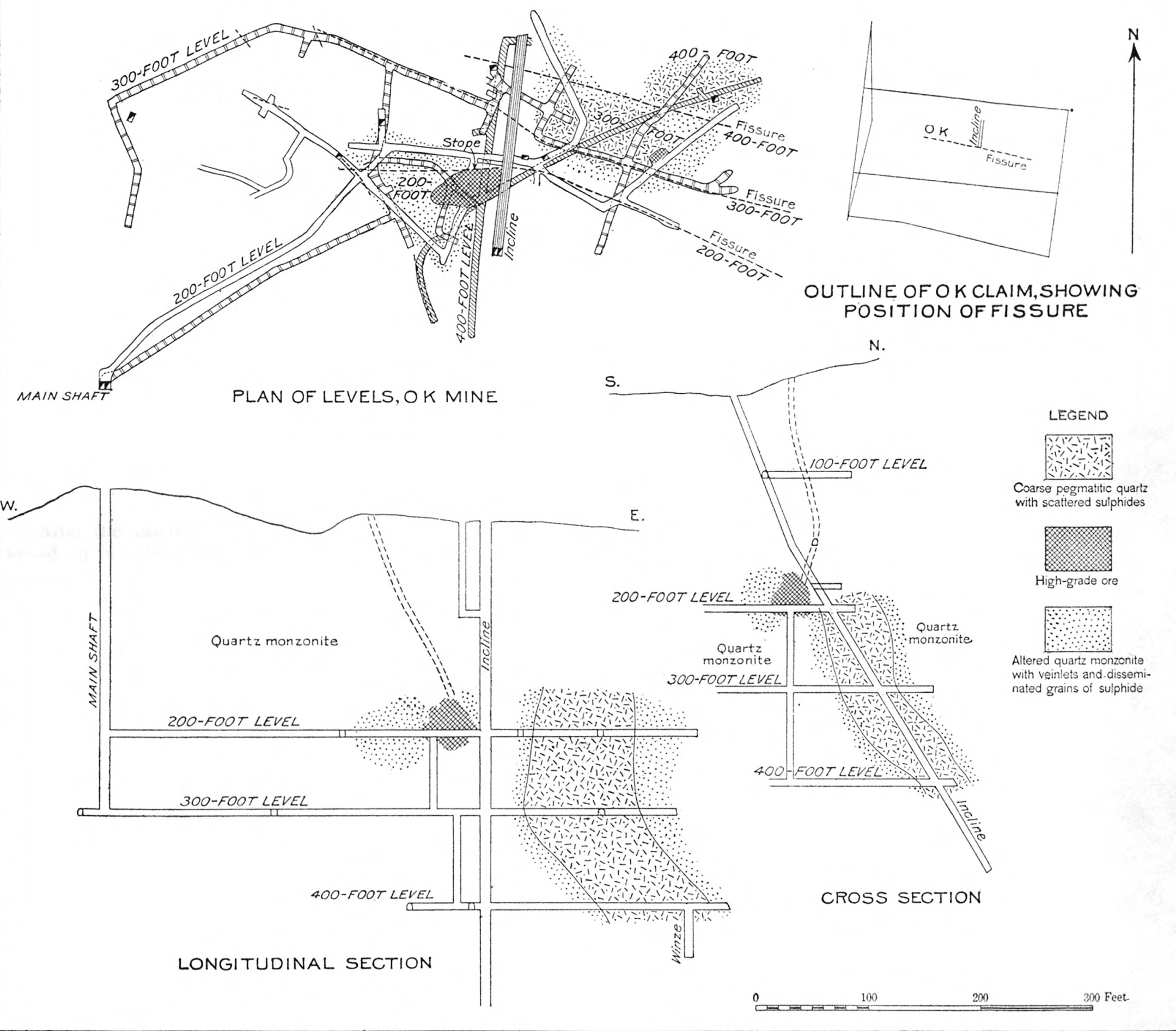


the zones more favorable for the circulation of solutions. The molybdenite has been altered, wherever alteration has been noted, to powellite, the calcium molybdate. This mineral occurs as pseudomorphs after the molybdenite and as yellow erystals deposited on the quartz.

Character of the ore.- The ores of the mine may be conveniently divided into two types - the high-grade ores and the disseminated ores, or the smelting and concentrating ores. The highgrade ores thus far developed have been principally in one body, located just west of the shaft on the 200-foot level and extending about 40 feet above the level and 6 to 8 feet below. This body on the second level had a maximum length east and west of about 70 feet and a maximum width of about 35 feet. The ore was composed of carbonates, oxides, and sulphides of copper in a quartz gangue, the general character of the original mineralization apparently being similar to that of the large chimney, but the percentage of ore minerals was much greater. Outside of this main ore body a little of the higher-grade ore has been mined from the second and third levels, mainly around the margins of the quartz chimney. The relation of the body of high-grade ore to the main quartz chimney has not been clearly determined. They are on opposite sides of the fault fissure and it is possible that their separation is due to movement along that plane. It seems more probable, however, that the smaller body is an offshoot from the larger, the connection not being apparent on account of lack of development at the point which would show it.

The disseminated ore occurs in the quartz monzonite surrounding the quartz body and consists of small veins containing quartz and sulphides and grains of sulphides disseminated through the altered quartz monzonite. On the second level these grains are partly or wholly replaced by chalcocite, and here and there the chalcocite has altered to cuprite. On the 400-foot level secondary sulphides are not abundant, except along lines especially favorable to movement of solutions. Mineralization of this character, so far as shown, has in general not extended more than 50 feet from the quartz body. No production has yet been made from ore of this type and under present conditions it gives little promise of being of commercial importance.

PROSPECTS IN THE QUARTZ MONZONITE IN THE BEAVER LAKE DISTRICT.

After the discovery of the body of rich ore in the $\mathrm{O} \mathrm{K}$ mine extensive prospecting was carried on in neighboring properties. Although mineralized outcrops similar to that at the $\mathrm{O} \mathrm{K}$ mine, but less extensive, are present in this district, commercial ore has not been found outside of this property. None of the properties were in operation at the time of visit nor were the workings accessible and descriptions are therefore not possible.

In the monzonite body in the northern part of the district some prospecting in the monzonite has been carried on, the most extensive being that at the Wasatch King mine. At the time of visit no commercial body of ore has been developed in the quartz monzonite in the northern part of the district.

\section{SKYLARK MINE.}

The Skylark mine, owned by the Utah United Copper Co., is located in the northern part of the Beaver Lake district, about 12 miles from Milford, at an elevation of about 6,500 feet. The mine is developed by two shafts and some short tunnels. The deeper shaft has been sunk 400 feet, and considerable drifting has been done at that depth. At the time of visit this shaft was not in operation and not accessible, but the second shaft had reached a depth of 365 feet, and some drifting had been done at about the 100-foot level and at the 365-foot level. The mine has been under development for several years, but up to the present time the production has been small.

The deposit is located on the contact of the limestone and quartz monzonite and is a typical contact deposit. The limestone along the contact has been recrystallized and partly replaced by muscovite, garnet, tremolite, diopside, magnetite, hematite, and sulphides in varying amounts.

The primary ore minerals are magnetite, pyrite, and chalcopyrite in a gangue of contact silicates and residual calcite. To the depth of the present workings the sulphides have generally been oxidized, the copper being present as the carbonates malachite and azurite, the silicate 
chrysocolla, the oxide cuprite, and native copper, together with considerable copper pitch, a mixture of hydrous oxides of copper, iron, and manganese. The magnetite has generally remained unaltered.

The ore thus far developed lies in the limestone immediately at the contact with the quartz monzonite. The ore zone is absent at some points, but where present its width as exposed at the time of visit varied from a few inches to a maximum of 20 feet in the drift at the 100 -foot level. The variation from point to point is so great that no general estimate is possible. The ore extends to the bottom of the 365-foot shaft and is reported to be present to the bottom of the 400-foot shaft and in bunches along the drift from that shaft. The ore is in general of rather low grade, but much of it is high in iron and consequently a desirable smelting ore.

BLACK ROCK MINE.

The Black Rock property lies just west of the Utah United Copper Co.'s property and is on the same limestone and quartz monzonite contact. The general geologic conditions are the same as those already described for the Skylark mine. The property is developed by several shallow shafts and pits. The mineralization is similar to that at the Skylark mine except that so far as the developments show there is less magnetite and more hematite (specularite). It is reported that some iron flux was shipped from this property to the smelters in the early days of mining in this district.

\section{OTHER CONTACT DEPOSITS.}

In the northeastern part of the district the quartz monzonite contains many irregular masses of limestone. The area is low and largely covered by float, so that the relations are not clear, but many of the limestone masses appear to be blocks surrounded by the intrusive rock. Contact alteration has been pronounced in all these masses and in numerous places development along these contacts has exposed ore. The limestone has been altered in similar manner to that of the other contact deposits described, namely, to garnet, diopside, tremolite, epidote, mica, magnetite, hematite, and the sulphides pyrite and chalcopyrite. At the surface the sulphides are very generally altered to secondary minerals. It is reported that some ore has been shipped from the deposits in this part of the district, but no large bodies of commercial ore had been developed at the time of visit.

The Copper Mountain mine, just north of the area mapped, has been developed by a vertical shaft 100 feet deep from the bottom of which an incline extends 75 feet. At the bottom of this incline several hundred feet of drifting has been done along the contact and some ore extracted. A number of large solution caverns in the limestone indicate the free circulation of water at this depth. The ores occur as a replacement of limestone at the contact with quartz monzonite. They are mostly oxidized, the copper being present as the carbonates and silicate. Magnetite is not an abundant mineral and the ores are more siliceous than many of the other contact ores of the district.

The Beaver copper mine, which is located just at the northern margin of the area mapped, is similar in general character to the Copper Mountain deposit. The property was not in operation at the time of visit and the underground workings were not examined.

Some prospecting has been done on several other properties in this part of the district.

At several points in the southern part of the Beaver Lake district shafts have been sunk through the shallow covering of wash, and in some of them the contact between quartz monzonite and limestone has been encountered.

The mineralization is similar to that in other parts of the district, so far as could be judged from the mine dumps. None of the properties were in operation and the underground workings were not examined.

In the western part of the district some work has been done on contact deposits, principally the Larkspur and the Federal group of claims. The mineralization is similar in character to that in other parts of the district, but development has not been sufficient to show its extent. 
REPLACEMENT FISSURE DEPOSITS IN LIMESTONE.

In the limestone body in the northern part of the Beaver Lake district there are numerous fissures along which the limestone has been replaced by ore minerals. At the time of visit but little development work had been done on deposits of this type and no considerable ore bodies had been discovered. The general geologic conditions are similar to those in other districts in the area studied where lead-silver deposits occur and future developments may disclose commercial bodies of ore.

\section{ROCKY DISTRICT.}

The Rocky district includes the Rocky Range, a small isolated group of hills east of the Beaver Lake Mountains. The mineralization in this district is confined mainly to the southern part of the range and is closely associated with the limestone. Farther north there has been some slight mineralization along fracture lines in the monzonite. As stated on page 87, the sedimentary rocks in the Rocky Range constitute a block that has been included in the intrusive quartz monzonite. As this block is nearly or quite surrounded by the intrusive rock, it is probably not of great vertical extent. Dikes are abundant throughout the area of sediments, and in the highly shattered quartzite at the extreme south of the district they have been converted into intrusive breccia by the entering of the monzonite along the many fracture planes. Typical contact alteration has occurred wherever the limestone is in contact with either the earlier or the later intrusive rock. The nature of this alteration has already been discussed (p. 87).

\section{OLD HICKORY MINE.}

The Old Hickory mine, owned by the Majestic Mines Co., has long been known, as the ore body crops out prominently, but it has not been extensively dexeloped or operated until recent years. Its main production was during 1906 and 1907, when the high price of copper made the shipment of the low-grade ore commercially profitable.

The mine is opened by a shaft about 300 feet deep and a tunnel that cuts the ore body about 100 feet below the outcrop. Two levels, the third and fourth, have been opened below the tunnel. The first level is about 25 feet above the tunnel. On the tunnel level drifting has been carried along the general line of the ore body for about 1,100 feet. The third level is developed by about 1,200 feet of drifts and crosscuts. The fourth level has about 600 feet of workings The development on the level above the tunnel is confined largely to the ore body and does not aggregate more than a few hundred feet. The extent of development can be seen by reference to Plate XXXVI. Stoping has been carried on principally above the tunnel level, though some ore has been extracted from the east end of the property between the tunnel and the third level. The ore body has been developed for a length of over 500 feet in the tunnel, though for only about 300 feet has it been shown to be of dimensions and grade to permit profitable extraction. The stoping width at the surface and on the tunnel level is from 15 to 20 feet. Below the tunnel the dimensions of the limestone block, and in consequence the size of the ore body, rapidly decrease. On the fourth level the rock is largely quartz monzonite.

The rocks associated with the ores are limestone, quartzite, and quartz monzonite. The sedimentary rocks at this point strike nearly north and south, and the dip is nearly vertical. The monzonite has locally been intruded along the bedding, though in many places it cuts across the bedding. The surface near the Old Hickory mine is partly covered with float, especially west of the mine, and the relation of the rocks is not clear. On the tunnel level monzonite is exposed at numerous points along the west wall of the ore, and doubtless forms the west wall of the main ore body. Next east of the monzonite is a body of magnetite carrying sulphides, garnet, and diopside; magnetite is the dominant mineral for a distance of 15 to 20 feet from the monzonite. This zone gives place to a zone of garnet with diopside, magnetite, and sulphide 50 or 60 feet wide, which in turn gives place to interbedded strata of quartzite and limestone cut by quartz monzonite dikes and showing pronounced contact alteration. As stated earlier, the sediments here appear to be but an isolated block surrounded by quartz monzonite. $73363^{\circ}-$ No. $80-13-13$ 
The conditions in the lower levels of the mine suggest this idea, as the monzonite appears to underlie the sediments entirely at no great distance below the lower workings of the mine.

There has been some faulting and movement subsequent to the intrusion of the monzonite and the formation of the ore. This disturbance, however is not believed to have resulted in great displacement or to be of great structural significance. Movement with the formation of gouge has occurred between the monzonite and ore. So far as noted, however, this has nowhere resulted in bringing together unmineralized limestone and quartz monzonite. The magnetite invariably lies close to the quartz monzonite, whether faulting is present or not, and the silicates and slightly altered limestone are at greater distance.

The ore body, as already indicated, is tabular in form, occupying the position of certain limestone beds that have been replaced.

The mineralized zone varies in character, being made up in some places of magnetite carrying small amounts of silicates and sulphides and in others of silicates carrying small amounts of magnetite and sulphides. The minerals are in the main contemporaneous, although there are a few small veins of magnetite and sulphide cutting the earlier minerals. The primary sulphides are pyrite, chalcopyrite, and bornite.

OTHER DEPOSITS.

Mineralization has occurred at numerous other points in this part of the district near the contact of the quartz monzonite and limestone, but as yet the deposits at these points have not been extensively developed. East of the Old Hickory deposit some development work has been done in oxidized iron ores, and it is reported that some ore was shipped to the Frisco smelters for flux. North of Hickory there has been some development along the contact, disclosing mineralization, but extensive bodies of commercial ore have not yet been opened.

STAR DISTRICT.

The area north of Elephant Canyon, in the Star Range, is sometimes known as the North Star district and that south of Elephant Canyon as the Star district, but at present the two areas are commonly referred to as the Star district. Active mining in Beaver County began in this district, and for several years in the seventies it was an important producer, but after that period it was practically inactive till a few years ago, when development was again undertaken. This district is now more active than any other district in the county. Many of the old mines are still idle, however, and consequently the study of the district has been less satisfactory than could be desired. The following pages include descriptions of the properties that were accessible and such observations on others as could be made on the surface and from the old dumps. (See Pl. XXXVII.)

\section{HARRINGTON-HICKORY MINE.}

The Harrington-Hickory mine, owned by the Majestic Mines Co., is located on the east side of the Star Range near the north end, at an elevation of about 5,600 feet. It is about 5 miles from Milford, the nearest station on the San Pedro, Los Angeles \& Salt Lake Railroad.

The mine was first worked in the early days of mining in the district, when, according to reports, considerable rich lead-silver ore was taken out near the surface. Since 1900 it has been intermittently worked by the Majestic Mines Co. and its predecessors. In 1909 the mine was equipped for the use of electric power and pumps were installed to permit development below the water level. Electric power is purchased from theBeaver RiverPowerCo. No accurate record of the total metal output of the mine is available.

The mine is developed by several shafts and numerous drifts and crosscuts, as shown in the accompanying diagram (Pl. XXXVIII). The deepest working is in the Gomer shaft, which has been sunk to a depth of about 600 feet below the surface. In addition to the development shown in the diagram, which is confined to two of the fissures crossing the property, there are numerous pits and open cuts on parallel fissures to the south.

The deposits occur in a series of interbedded limestones, calcareous shales, and highly siliceous shales. The general strike of the beds is N. $10^{\circ}-15^{\circ} \mathrm{E}$. and in the hill south of the 


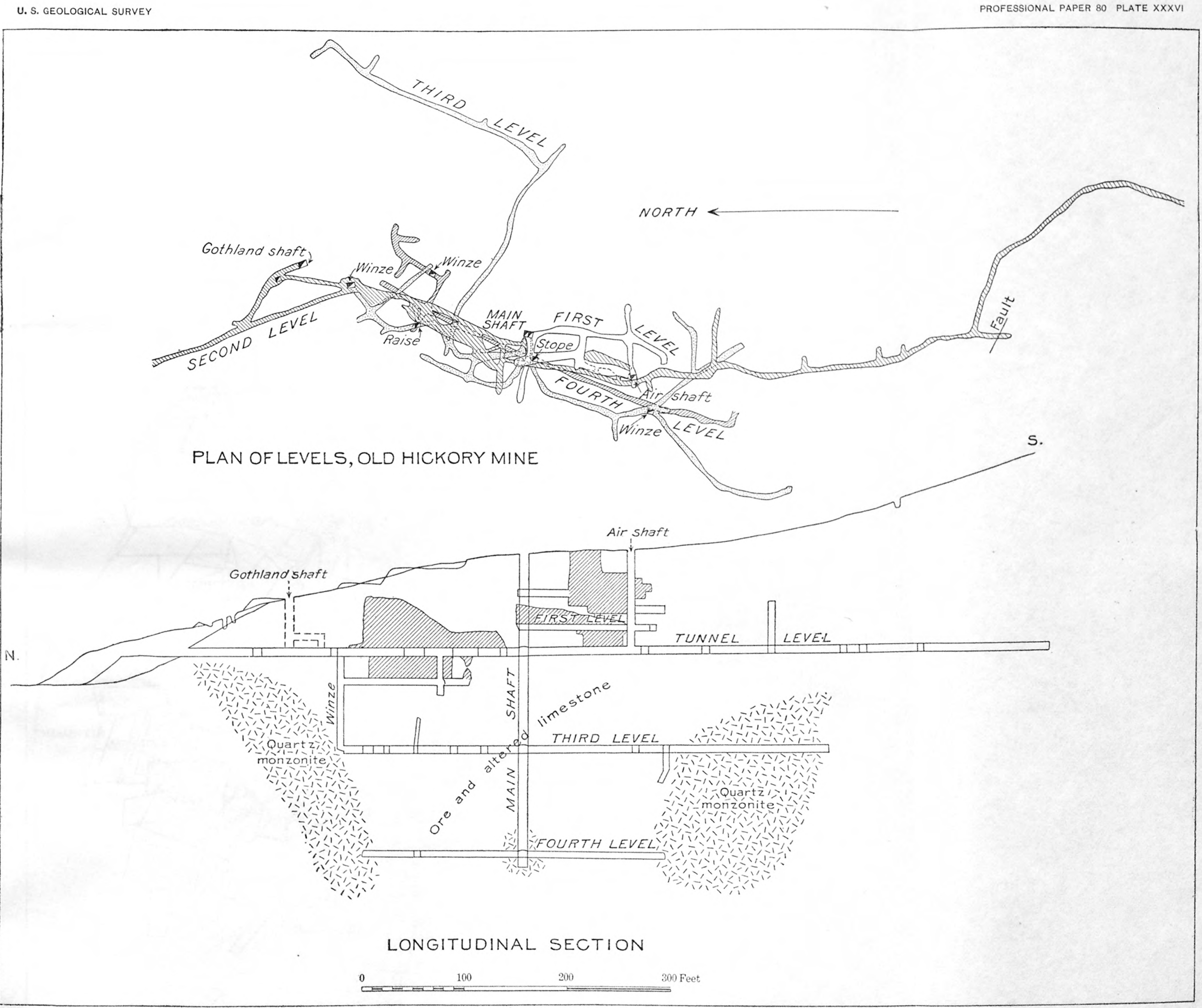

PLAN AND SECTION OF THE OLD HICKORY MINE. 

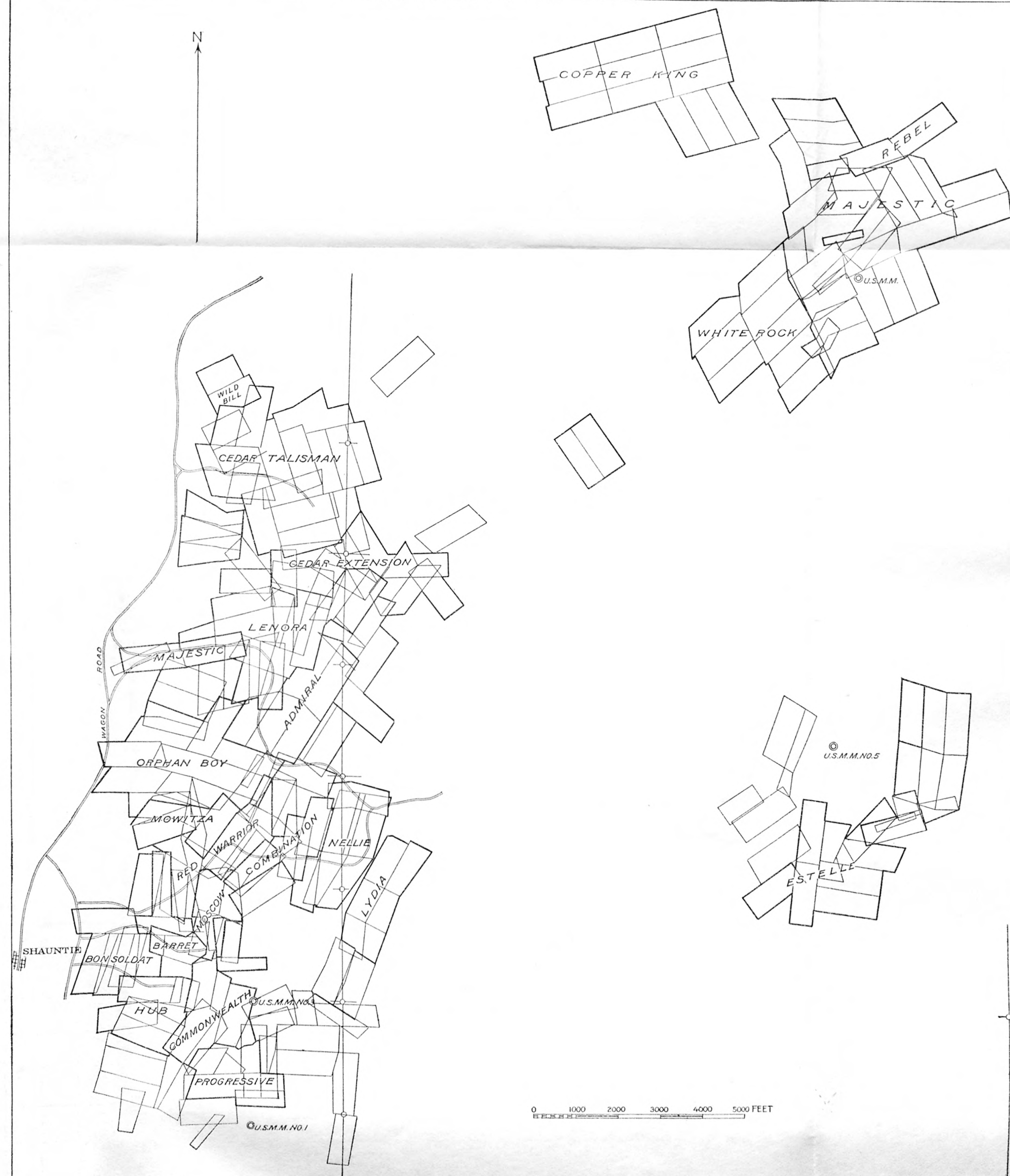


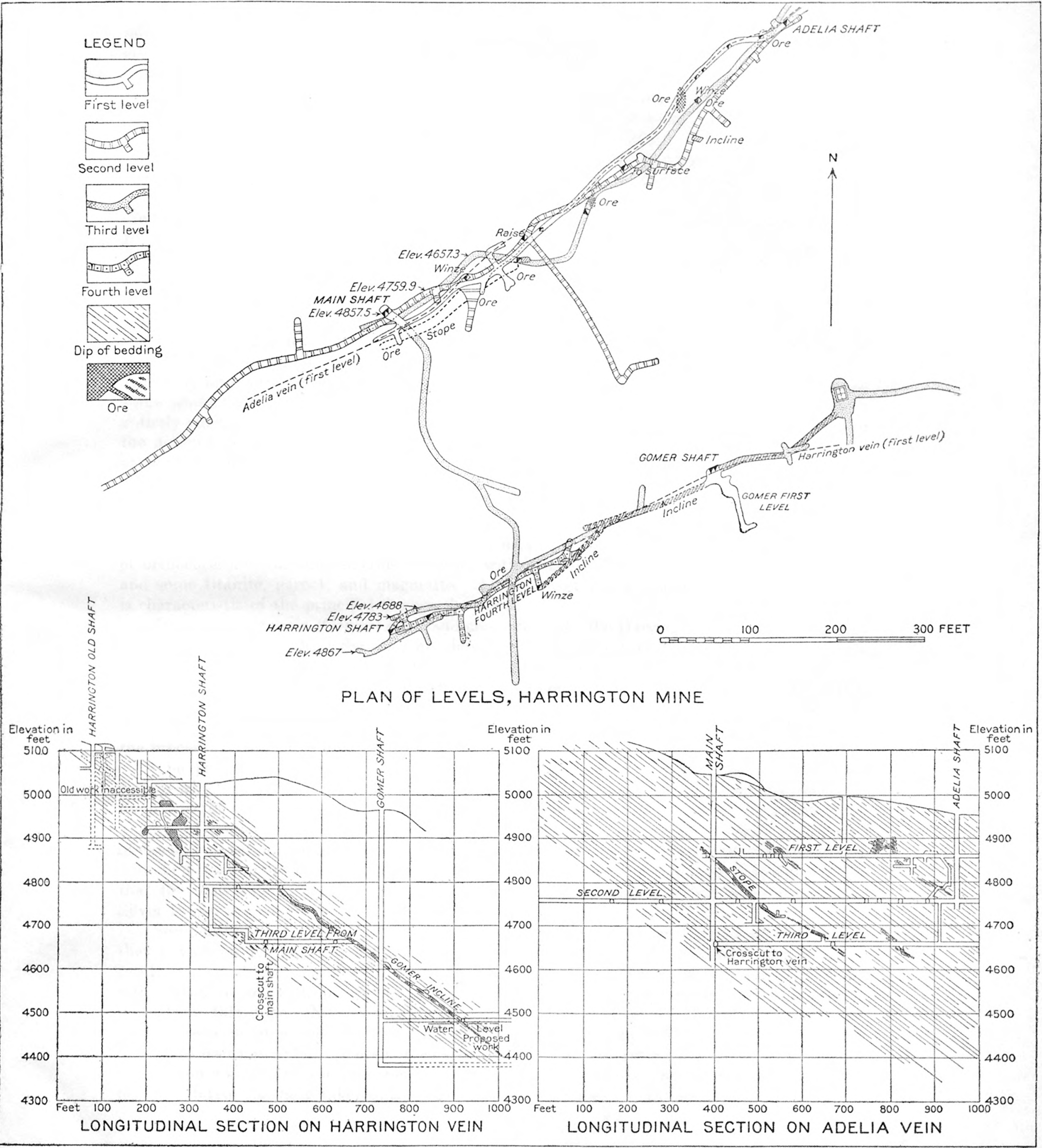

PLAN AND SECTIONS OF THE HARRINGTON-HICKORY MINE. 

mine they dip about $50^{\circ} \mathrm{E}$., but in the mine the beds show some variation in dip, though in general the angle is $45^{\circ}$ to $50^{\circ}$. No intrusive rocks were seen in the mine workings, but about a quarter of a mile east of the mine and separated from the sedimentary rocks by a débris-filled valley is a body of quartz diorite porphyry that is probably intrusive into the sedimentary series, and three-fourths of a mile north of the mine is a mass of quartz monzonite with dikes extending into the limestone considerably south of the main contact.

The sedimentary strata are broken by a series of nearly parallel fissures having a general strike of N. $55^{\circ}-60^{\circ}$ E., and a very nearly vertical dip. The main operations on the property have been confined to two of these fissures, the Adelia and the Harrington. The workable ore bodies have been formed by the replacement of certain limestone beds for varying distances, 10 to 30 or even 40 feet from the fissures, thus forming chimneys of ore with a general dip to the northeast, following the intersection of the beds and fissures. This relation is well shown by reference to Plate XXXVIII, showing sections of the mine.

The strata cut by the fissures show great differences in the amount and character of the alteration produced by the ore-bearing solutions. This is due very largely to a difference in the chemical composition of the rocks and in lesser degree to the fact that in some places the rocks have been crushed more than in others and are consequently more readily acted upon. The shaly and siliceous sediments have undergone but slight alteration, but some of the limestone strata for a distance ranging from a few feet to 20 or 30 feet from the fissure have been entirely changed in character and composition. The limestone beds show great differences in the amount of alteration, the reason for which is not entirely clear. In part they may be attributed to differences in the composition of the limestone, but a more effective factor is probably the crushing of certain beds, due to slight movement along the bedding planes at the time the sediments were tilted from the horizontal to their present positions. The most prominent change in the limestone is silicification. In much of the highly altered rock the limestone has been practically removed and the rock consists of quartz with a relatively small amount of orthoclase and the ore minerals, together with considerable apatite in very small crystals and some titanite, garnet, and magnetite. Alteration of this character in varying intensity is characteristic of the principal fissures developed.

In sinking the main (Gomer) shaft and crosscutting to the Harrington vein smaller fissures were encountered in which the minerals showed little secondary change. The limestone beds adjoining these fissures have been altered to tremolite and garnet with varying amounts of quartz and sulphides. Tremolite and garnet in small amounts were formed during the alteration of the main vein, and there can be no doubt that both the main vein and the smaller veins are of the same character and vary simply in the amount of the different minerals resulting from the process of alteration.

The primary ore minerals recognized are galena, sphalerite, chalcopyrite, pyrite, and tetrahedrite. Molybdenum in some form is present in the primary ore. The ordinary mode of occurrence of this element in primary ores is as the sulphide molybdenite, and it was thought likely that this mineral occurred here intergrown with galena, but a careful microscopic study of galena incased in alteration products, including wulfenite, failed to disclose any molybdenite. Although this can not be considered as conclusive evidence that it is not present, it seems likely that the molybdenum may be crystallized with the lead sulphide as molybdiferous galena. Silver is also present in the galena, probably as the silver sulphide.

Secondary alteration has affected the ores in the main veins to the greatest depth to which they have been developed, namely, slightly below the 500-foot level. The secondary minerals resulting from this alteration of the sulphide are cerusite, anglesite, wulfenite, corkite, vanadinite, malachite, and hydrous iron oxides, largely limonite. Native silver was noted in ore specimens from this mine. No secondary zinc minerals were seen in the mine, but the oxidized ore carries some zinc and the secondary zinc minerals are undoubtedly present. The most important lead mineral in the ore is the carbonate, cerusite, though locally the sulphate, anglesite, becomes abundant and in some parts of the mine ore carrying considerable wulfenite, the lead molybdate, has been taken out. A greenish-yellow mineral of earthy appearance is rather 
abundant in the ores taken from the lowest workings. This mineral has not been obtained in sufficient purity for chemical analysis, but from optical study and qualitative chemical work by W. T. Schaller it seems to correspond to corkite, a hydrous mineral of uncertain formula containing the oxides of phosphorus, sulphur, iron, and lead. This is the first locality on this continent at which the mineral has been observed. A little vanadinite occurs as small crystals in the ores containing wulfenite.

The ore all carries a small percentage of copper, largely as the carbonate, though other secondary copper minerals are doubtless present. The average grade of the ore that has been taken from the mine is not known, but it is reported that some high-grade ore was taken out in the early days. It was stated to the writer that the ore body in the Gomer shaft, which was being worked in 1909, just above the water level, carried from 15 to 20 ounces of silver to the ton, 20 to 25 per cent of lead, and a little copper and gold.

In the summer of 1910 the Gomer shaft had been sunk to the 600 -foot level, or about 100 feet below the water level, and a crosscut started to reach ore that had been located by diamond drill, apparently as a downward extension of the shoot followed by the Gomer incline. When this crosscut intersected the fissure before reaching the ore bed a heavy inflow of water required increased pumping facilities before work could be continued. When the writer left the field the ore had not been encountered on that level, and sufficient pumping had not been done to demonstrate how serious the water problem would prove to be in the downward development of the mine.

REBEL MINE.

The Rebel mine is about three-eighths of a mile north of the Harrington-Hickory mine. It was one of the earliest mines worked in the district and is reported to have been one of the largest producers in the early days, though accurate statistics of the metal output are not available. When the rich surface ores were exhausted operations were discontinued and the mine remained idle for many years. In 1908 operations were resumed to explore the ground at greater depth, and in the summer of 1909 a shaft had been sunk to a depth of 200 feet and considerable exploration done at that level, though no commercial ore body had been opened.

The general geologic relations are similar to those at the Harrington-Hickory mine. The sediments are the same series of limestones and siliceous shales, but, being nearer to the large body of quartz monzonite, they have been more disturbed by the intrusion and have suffered greater alteration.

\section{WHITE ROCK MINE.}

The White Rock group of claims is located southwest of and adjoining the HarringtonHickory mine. There are on the property a few shallow workings where ore was taken out in the early days of the district, but these do not indicate any considerable production. In the summer of 1910 developments were in progress on the property and in August two shafts were being sunk. One had reached a depth of 60 feet and the other 70 feet.

The same series of parallel northeast-southwest fissures that are present in the HarringtonHickory mine cross the White Rock group, and it is on two of these that operations were being conducted. Ore had been encountered in both, but at the time of visit developments were not sufficient to indicate the extent of mineralization.

The primary mineralization, so far as shown by the meager development, was similar to that in the neighboring mines, but secondary alteration has been much less, galena and other primary sulphides being present only a few feet below the surface.

WILD BILL MINE.

The Wild Bill mine is in the northwestern part of the Star district, about 8 miles from Milford in a direct line but nearly 12 miles by road. It is at an elevation of about 6,400 feet. The Wild Bill mine was one of the producers in the early days of mining in the district but later was idle for many years. In the summer of 1909 the property was equipped for development at greater depth than that attained in the old workings, and during 1910 some ore was taken out and shipped. 


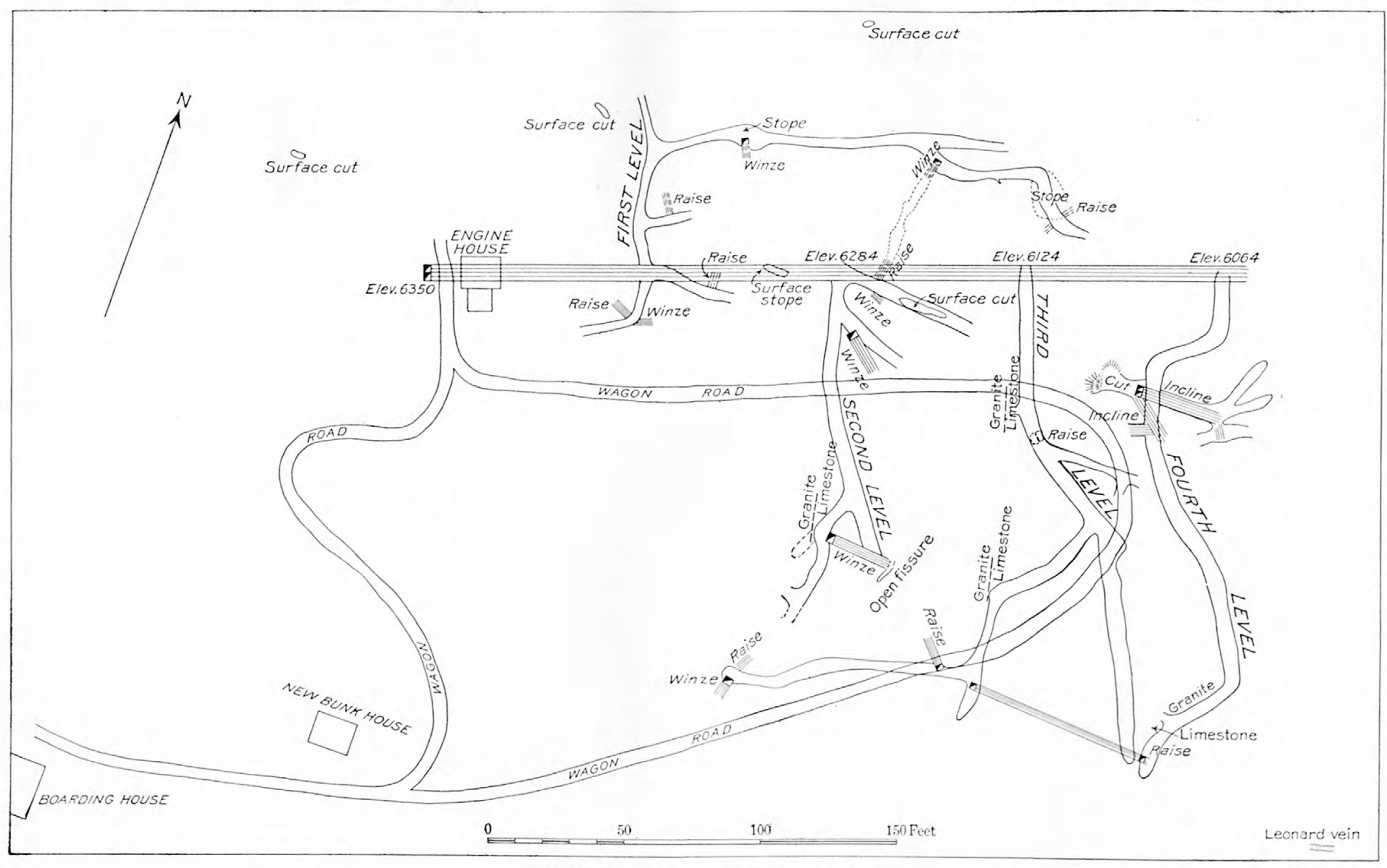

PLAN OF THE WILD BILL MINE. 
The main workings consist of a shaft sunk at an average incline of about $45^{\circ}$ to a depth, in August, 1910, of 470 feet, with four levels opened. Several hundred feet of opening has been accomplished on these levels, as shown in the accompanying diagram of the workings (Pl. $\mathrm{XXXIX).} \mathrm{In} \mathrm{addition} \mathrm{to} \mathrm{the} \mathrm{main} \mathrm{shaft,} \mathrm{there} \mathrm{are} \mathrm{several} \mathrm{shallow} \mathrm{shafts} \mathrm{and} \mathrm{open} \mathrm{cuts} \mathrm{on}$ the property.

The sedimentary rock in the vicinity of the mine is the Topache limestone, of Carboniferous age. This has been intruded by quartz monzonite, which in this mass is of a rather acidic type, approaching true granite. Associated with the quartz monzonite is some aplitic rock composed principally of quartz and orthoclase. This rock occurs presumably as dikes, though its relation to the quartz monzonite was not clear, owing to poor exposure. A few hundred feet west of the mine the volcanic flows are present, but these are not connected with the ore deposits. The limestone adjacent to the quartz monzonite shows typical contact alteration, consisting in a recrystallization of the carbonates and a partial replacement of the carbonates by contact silicates, garnet being the most abundant, with lesser amounts of tremolite, diopside, magnetite, specularite, fluorite, and sulphides.

The intrusion of the quartz monzonite has resulted in a fissuring of the limestone and the ore deposits have formed in the limestone close to the contact, replacing the limestone along the fissures. The ore to the present depth of development has been almost entirely altered to secondary minerals and it is therefore impossible to state what the primary minerals were. From the nature of the secondary minerals and analogy with similar deposits where the primary mineralization is shown, it is inferred that the primary minerals were the sulphides of lead, copper, iron, and probably zinc, with the contact silicates, iron oxides, quartz, carbonates, and small amounts of apatite and possibly other minerals.

Secondary alteration, as already stated, has extended to the lowest workings. The principal secondary lead mineral is the carbonate, cerusite. The ore contains also some anglesite and the rather rare mineral corkite, which is of common occurrence in the ores, but not an important ore mineral. Jarosite is not uncommon, and plumbojarosite was identified in specimens from the mine. Copper is present as the hydrous carbonates, azurite and malachite, and the silicate, chrysocolla. Zinc minerals were not observed, but they are doubtless present in the primary ores and probably to some extent in the secondary ores.

The iron oxides have not been greatly altered, but hydrous iron oxide, mainly limonite, with some manganese oxide, has resulted from the alteration of pyrite and other iron and manganese bearing minerals.

CEDAR-TALISMAX MINE.

The Cedar-Talisman group of claims is located south of and adjoining the Wild Bill mine. It comprises what were formerly the Cedar and Talisman properties. Both of these properties were producers in the early days, but no record of their output is available. During the last few years the mine has made shipments of lead-silver and zinc ore from time to time.

The mine has been developed by an inclined shaft 500 feet in depth and by drifts and crosscuts from this shaft. In the old workings each company worked through its own shaft, but the present operations are conducted from one shaft.

The workings of the mine are in the Topache limestone, a few hundred feet below the base of the Talisman quartzite. The strata are rather massive at the mine, but to the west and lower in the series they become more shaly and siliceous. The beds strike about N. $15^{\circ} \mathrm{W}$. and dip about $35^{\circ} \mathrm{E}$. The beds are cut by a main fissure striking nearly north and south and dipping steeply to the west. Another fissure striking nearly with the bedding and dipping west intersects the main fissure, and most of the zinc ore thus far developed has been along this second fissure. Other fissures are present, but so far as present developments show they have not been important mineralizing channels.

The ore has formed as a replacement of certain beds of limestone on either side of the fissure. Ore has been extracted from three different beds. The distance from the fissure to which replacement has extended varies greatly from place to place but does not usually exceed 40 feet. 
The ore is practically all oxidized, so that it is not possible to state positively the character of the original mineralization. It seems highly probable, however, that the primary minerals eonsisted of sulphides of lead, iron, copper, and zinc in a siliceous gangue. The oxidation of these sulphides has produced the ores as they are now. The lead ores consist of both the carbonate, cerusite, and the sulphate, anglesite, with some galena and a little copper carbonate and silicate in a siliceous gangue. The lead ore carries considerable silver. The specimens of zinc ore collected were largely the silicate, calamine, with some carbonate, smithsonite.

CEDAR EXTENSION.

The Cedar Extension is a group of claims lying south of the Cedar-Talisman mine. No work was in progress on this group at the time of visit and so far as learned little production has been made from this property. Some development work has been done, but as the property was closed no examination of the underground workings was made. The claims include parts of the areas of Topache limestone and Talisman quartzite.

LEONORA GROUP.

The Leonora is an extensive group of claims south and southwest of the Cedar Extension. Some ore has been shipped from the property, but the production has never been large. Most of the developments have consisted in shallow workings along fissures, but in 1909 a tunnel was being driven to cut a supposed ore body at greater depth. At the time of visit this tunnel had not reached the objective point and no ore had been developed.

The property includes parts of the areas of Topache limestone and Talisman quartzite. The principal development work has been done along fissures with a general north-south strike, the ore forming as a replacement of the limestone.

ADMIRAL GROUP.

South of the Leonora group is the Admiral group. It is reported that a small shipment of ore has been made from this property. A tunnel that was being driven in the quartzite to cut a fissure that carried lead ore near the surface was closed at the time of visit, but it was reported that the tunnel had not yet reached the fissure.

The property includes parts of the areas of Topache limestone and the Talisman quartzite, the developments being in the quartzite.

HOOSIER BOY MINE.

The Hoosier Boy mine, owned by the Majestic Mines Co., is at the head of Elephant Canyon, on the west side of the district.

The mine made a considerable production in the early days and has produced from time to time since, some ore being shipped during 1910. The mine was idle at the time of visit, but is reported to be developed by a shaft 250 feet in depth.

The ore deposit, like several others in the district, is located in the Red Warrior limestone immediately underlying the Mowitza shale. As the underground workings were not examined, no details of the occurrence of the ore were obtained.

\section{ORPHAN BOY GROUP.}

The Orphan Boy group of claims is located in the western part of the district, south of Elephant Canyon. The principal development consists in a tunnel in the eastern part of the group, near the Elephant mine. At the time of visit ore had not been encountered in the tunnel.

\section{ELEPHANT MINE.}

The Elephant mine is located south of Elephant Canyon, near the central part of the district. This was one of the earliest mines developed in the district and is reported to have made a considerable production from rich ores near the surface. With the exhaustion of these ores operations were discontinued and the mine has been idle for most of the time since. 
The early workings consist of a series of irregular stopes following the ore from the surface down. Later a tunnel was driven to cut the deposit at greater depth, but at the time of visit no ore had been developed in the tunnel. The mine lies just south of the Elephant fault and the strata are considerably disturbed. The fault zone in the tunnel is represented by zones of gouge formed by the grinding up of the rocks. The deposit is one of the series that has formed in the limestone just beneath the Mowitza shale. The ore replaces limestone adjacent to a fissure with a general east-west strike.

\section{MOWITZA MINE.}

The Mowitza mine is in the western part of the Star district, north and west of the Red Warrior group. Ore was shipped from the Anvil claim in the early days, but no record of the metal output is available, though it was not great, to judge from the size of the stopes. In the summer of 1908 a shaft was started on the Anvil claim to explore the property below the old workings. At the time the mine was visited, in the summer of 1909, the shaft had been sunk to a depth of about 300 feet and several hundred feet of exploration done. Subsequently the shaft was continued to a considerably greater depth.

The mineralization in the Mowitza mine is in the limestone underlying the Mowitza shale, but at a horizon slightly below that of the neighboring Red Warrior mine. The sediments for the most part are rather heavy bedded blue limestone with some light-gray limestone, a conspicuous bed of this character outcropping just west of the shaft and along the road. Overlying these beds is the limy shale formation that has been mapped as the Mowitza shale, which crops out conspicuously on the low saddle just northeast of the boarding house.

The strike of the beds is about N. $16^{\circ} \mathrm{E}$., almost exactly magnetic north, and the dip is about $40^{\circ} \mathrm{E}$. The beds are cut by several fissures having a general northeast-southwest strike and dipping about $70^{\circ} \mathrm{E}$. The displacement along these fissures has been slight, though slickensides and some gouge testify to some movement. About 100 feet north of the shaft on the second level the beds are cut by a nearly east-west break dipping to the south. There has been some movement along this break, the portion to the north appearing to have been moved relatively to the west. The amount of the movement was not determined but is slight.

Along several of the bedding planes there is evidence of movement parallel to the bedding. This has had somewhat different effects in different beds. In some places it has resulted in the formation of a layer of gouge; in others the limestone has been broken into small angular blocks. In both cases the movement has apparently been slight.

The ore, as in neighboring mines, occurs as a replacement of beds of limestone near the intersection of fissures. The primary ore was doubtless galena with varying amounts of other sulphides. The ore remaining in the upper workings was mostly oxidized, largely carbonate of lead carrying silver.

In the deeper workings the conditions appear to be identical with those near the surface; in fact, the continuity of the ore-bearing fissures to the deeper level has been established. Though there has been slight mineralization, no commercial ore had been encountered at the time of visit.

RED WARRIOR MINE.

The Red Warrior group (Pl. XXVIII, $B$, p. 164) is near the center of the Star district, 8 miles from Milford. To the north is the Mowitza group and to the south the Moscow. The Red Warrior, like many of the other mines of the district, was worked in the early days and then remained idle for years except for occasional shipments by lessees. In 1907 it was taken over by the present management and a plant installed to explore the property below the old workings In 1908 shipment of ore was begun, and the mine has been a producer since that time. It is equipped with a gasoline engine and hoist and a three-drill air compressor.

In the summer of 1910 the shaft had been sunk to the fifth level, about 450 feet below the surface; three levels, the first, second, and fifth, had been opened from the shaft; and two sublevels between the third and fifth had been opened by a winze. The extent of the developments is shown on the plan of the mine workings (Pl. XL). 
The Red Warrior deposit is entirely within the limestone, the shoot of ore developed in the present workings being in a bed of limestone a little below the Mowitza shale. The limestone is mostly a rather heavy bedded blue and gray limestone and is overlain by a limy fossiliferous shale carrying thin beds of limestone.

The strata in which the ore occurs are thin bedded but not shaly in character. The hanging wall is formed by a rather massive white bed; the footwall is a massive blue limestone. The ore beds show considerable crushing, but apparently the movement accompanying this was slight, as the rock is in few places ground to a gouge. It seems probable that the ore beds being weaker than the adjacent beds, suffered crushing when the strata were tilted to their present position.

No intrusive rock was seen in the mine, though a few small, highly altered dikes crop out a short distance to the southwest. These dikes so far as determined have had no influence on the deposition of the ores.

The beds of limestone in this property, as in the neighboring groups, are cut'by fissures having a general northeast-southwest trend. The main fissure connected with the developed ore shoot strikes N. $45^{\circ}-50^{\circ}$ E. and dips steeply to the northwest. Minor fissures with different directions are present but appear to have had little effect on the ore body. The displacement along the fissures is slight, but that some movement took place is shown by the slickensided faces and gouges along the fissure planes. The amount and direction of the throw is not everywhere readily apparent, but in most places where it is determined the portion north of the break has been thrown relatively to the west.

The alteration of the rock adjacent to the fissures has been less than in many of the other mines of the district. The limestone has suffered a little silicification, but contact silicates were not noted and certainly are not abundant. The limestone in both the footwall and hanging wall, as well as in the ore beds, has been dissolved, so that in places it is rather cellular, and secondary carbonates, calcite, and dolomite have been deposited in the open spaces. This alteration, however, is probably due to water descending from the surface and is not related to the original deposition of the ores.

Primary ore has not been encountered except for scattered nodules in the oxidized ore, so that little is known of the character of the primary mineralization except what can be deduced from the composition of the secondary ores and comparison with similar deposits where the primary ores have been seen. The few specimens of sulphide ore collected consisted of galena with some pyrite and a little chalcopyrite. Sphalerite was not noted in any of these specimens, but as zinc occurs in small amounts in the ore there is little doubt that the zinc sulphide was present in the primary ores. The abundance of iron in the secondary ores indicates that the primary ore contained much pyrite. It may be inferred, then, that the original ore bodies were formed by the replacement of limestone by galena, pyrite, sphalerite, and chalcopyrite.

The ore mined at present is the result of secondary alteration of the sulphides, the most important minerals being cerusite, carrying silver, and limonite, with small amounts of carbonate of copper and some zinc mineral, probably smithsonite. Besides these there are small amounts of the sulphate of lead, anglesite, the hydrous sulphate of lead and iron, plumbojarosite, and the hydrous sulphate of potassium and iron, jarosite. The latter two minerals as they occur in the mine are identical in appearance and can be recognized only by chemical tests. The oxide of manganese is present in small amounts and native sulphur occurs here and there.

The approximate composition of the ores being mined in the summer of 1910 was about as follows: Iron, 25 to 30 per cent; lead, 25 to 30 per cent; silica, 5 to 10 per cent; sulphur, 1 to 2 per cent; copper, 0 to 1 per cent; zinc, 1 to 3 per cent; moisture, 7 to 12 per cent; silver, 8 to 10 ounces to the ton; gold, trace. The company reports that 15 carloads of ore shipped in 1908 averaged 0.75 per cent of copper, 31.3 per cent of lead, 1.9 per cent of zinc, 11.28 ounces of silver to the ton, and 0.018 ounce of gold to the ton.

The ore body thus far developed, as already stated, has replaced a bed of limestone to varying distances from its intersection with the ore-bearing fissure. This has formed a chimney of ore pitching in a general northeasterly direction, with the intersection of the two planes mentioned above. The distance from the fissure to which the replacement has extended varies 


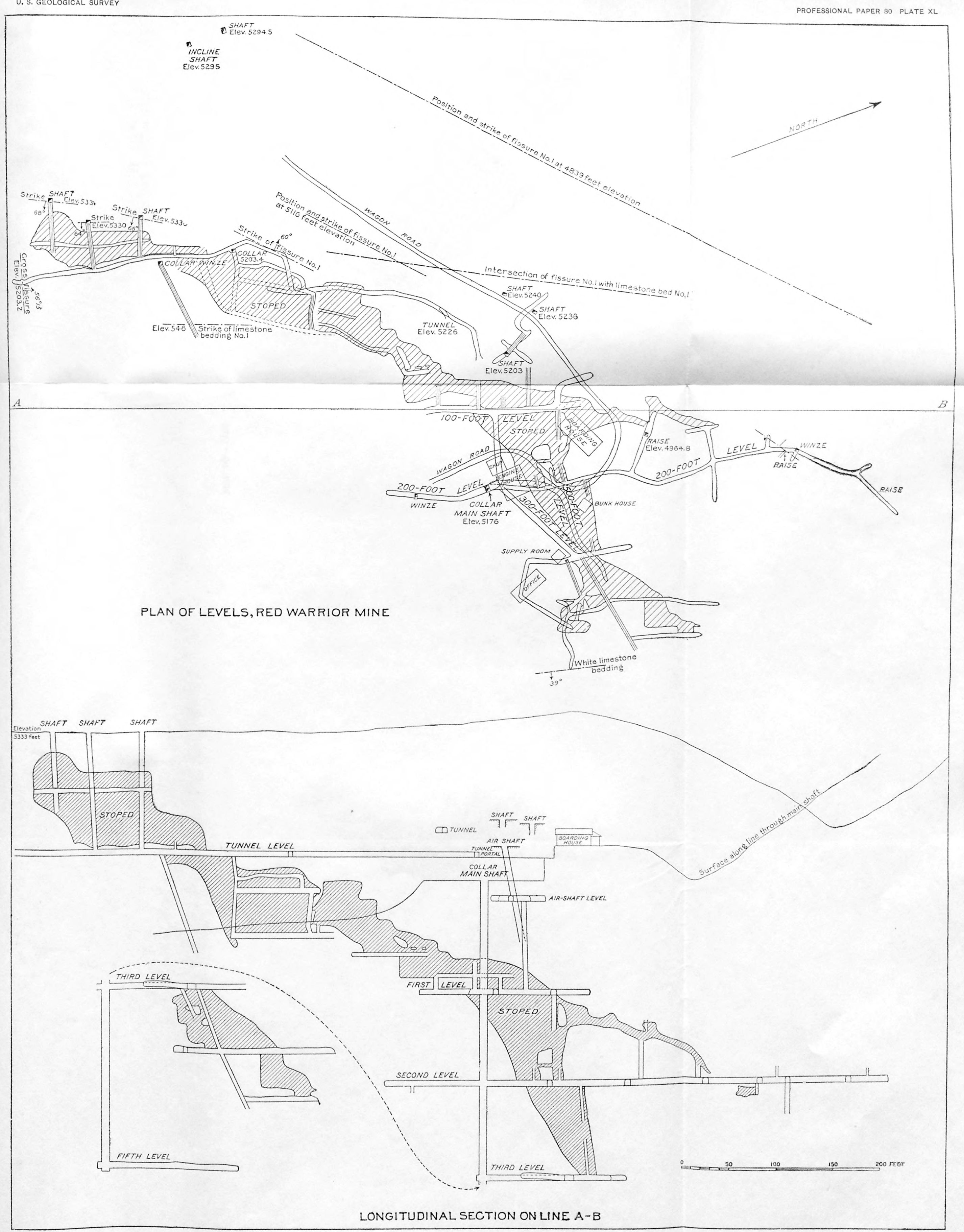


from place to place, giving an irregular outline to the deposit. Here and there the bed has been replaced for 100 feet along the strike; elsewhere the ore body narrows to a few feet. The variation can best be seen by reference to the accompanying diagram of the mine workings (Pl. XL).

This deposit, like others along this belt, is believed to have had its origin in deep-seated solutions rising along the fissures in the limestone, which at greater depth probably are connected with the masses of intrusive quartz monzonite. The localization of the deposit may be attributed to two controlling causes - the dam interposed by the relatively impermeable Mowitza shale and the crushing and consequent porosity of the ore beds.

As has been noted by many observers where a fissure in massive limestone encounters a bed of shale, either the fissure becomes discontinuous, or if it passes through the shale that rock is ground to a gouge which closes the fissure. Solutions rising along such a fissure very commonly spread out beneath the shale and deposit material in solution. The erushing of the ore beds has produced porous strata that are easily penetrated by solutions, and as the ore solutions rising along the fissures were stopped from further progress by the shaly barrier they spread out along the lines of least resistance- that is, through the crushed limestone strataand deposited the material held in solution.

\section{MOSCOW MINE.}

Location and history.-The Moscow mine is in the southern part of the Star district, adjoining the Red Warrior group on the south. Its elevation is about 6,600 feet. This mine, like most of the other mines of the district, was a producer in the early days and then remained idle for many years. On the renewal of mining activity in the district the Moscow was one of the earliest to become productive. Shipment of ore began in 1905 and the mine has been operated continuously since that time. No record of the early production of the mine is available and it is therefore impossible to state the metal output.

Development.- In the summer of 1909 the mine had been opened by a main shaft 450 feet

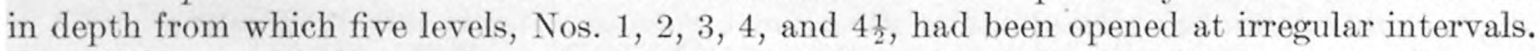
The old Moscow shaft extends to the third level of the main shaft. In addition to the development by shafts, the upper part of the deposit has been opened by a tunnel, inclines, and open cuts. The extent of the developments can best be understood by reference to the accompanying diagram of the underground workings (Pl. XLI).

Geologic relations.-The Moscow deposits, like those of the Red Warrior, occur in the limestone underlying the Mowitza shale. The limestones are the heavy-bedded blue and gray rocks, in general similar to those of the Red Warrior and Mowitza, and the shale is the same limy fossiliferous rock containing thin beds of limestone. The sedimentary beds, like those to the north, strike nearly north and south, magnetic, or about $\mathrm{N} .15^{\circ} \mathrm{E}$. true, and dip $45^{\circ}-50^{\circ} \mathrm{E}$.

Less than a quarter of a mile southwest of the mine is a stock of quartz monzonite, which forms a large part of the range south of the area mapped. The limestone contains a few small highly altered dikes of what was probably a rock of dioritic composition, though at present it is too greatly altered to allow determination of the original constituents. These dikes have been forced in along the fissures in the rock, those observed having a general east-west strike. Two of them are exposed in the mine workings and others are seen on the surface. They are eroded more easily than the limestone, and consequently their outcrop is readily overlooked where it has not been exposed by prospecting or mining operations.

The limestone is cut by fissures, most of which trend nearly at right angles to the bedding and dip steeply to the north. Along most of these fissures there is no evidence of much movement. In the north end of the fourth level, however, there appears to have been considerable movement along an east-west break. Developments at the time of visit were not sufficient to make it possible to determine positively the amount of movement, but the beds appear to have been displaced more than 150 feet, the portion to the north being thrown relatively to the east. 
In addition to the fissures and faults just described there are at several points on and above the fourth level strongly slickensided surfaces having the general appearance of nearly horizontal planes that have suffered warping. On these surfaces strikes and dips in almost every direction can be obtained, but they are always flat, approaching the horizontal. The strong slickensiding indicates movement along these planes, but the amount and direction of the movement and its importance as related to the ore deposits were not determined. Further development will be necessary before the relations can be deciphered.

Ore deposits. - The ore deposits in this mine, as in most of the others in the district, occur as irregular chimneys following the intersection of certain beds of the limestone and the orebearing fissures and in general pitching northeastward with the intersection. The distance to which the replacement has extended varies from place to place, giving the ore bodies an irregular form.

The main production of the mine has come from one bed, but there has been some replacement of other beds, especially of what is known as the zinc bed, which underlies the principal ore body and in which the ores show relatively little oxidation and carry a relatively high zine content.

Most of the ore mined to the present time has been oxidized, that from the lowest workings, the winze in the north end of the fourth level, being composed almost entirely of secondary minerals.

At some points, however, where the circulation has apparently been less free, the original ores are still present. This is especially true of the bodies of zinc ore in the south end of the fourth level, where there has been very slight oxidation.

The sulphide ores are composed of galena, sphalerite, pyrite, chalcopyrite, and a little greenockite, with rather abundant sericitic muscovite and fluorite as gangue minerals, together with carbonates that represent unreplaced portions of the limestone and a little rhodochrosite. The proportion of these constituents probably varied in different parts of the ore body. Most of the unoxidized ore seen in the mine contains considerable sphalerite, but some nodules of original sulphide in the oxidized bodies of lead ore are composed very largely of galena, and it is probable that this was the predominating mineral in the original ore in these bodies.

The galena has been oxidized principally to the carbonate, cerusite, but some anglesite occurs and also the hydrous lead and iron sulphate, plumbojarosite. The iron in the oxidized ore is present as limonite, with some jarosite, the hydrous sulphate of potassium and iron. The copper has been largely altered to carbonates. Smithsonite is present in the secondary ores, though not in large amounts, and it is not improbable that some of the zinc has been removed and may have been deposited as secondary minerals at some lower point. The ore in general is rather high in iron and low in silica, and consequently is a desirable smelting ore for this region. Most of the ore mined to the present date has been a lead-silver ore carrying some copper. A general average of the metal content of the ore mined is about 20 per cent of lead, 20 to 25 ounces of silver to the ton, and 2 to 5 per cent of copper. Some ore carrying much more copper has been shipped, also some zinc ore.

Origin of the ore.-The ores, like those of the other mines of the district, are believed to have been formed after the intrusion of the quartz monzonite and to have been derived from solutions given off by that magma. The deposition at this particular point is thought to be due to the influence of the Mowitza shale, which on account of its physical character did not afford an open channel when intersected by the ore fissures and thus obstructed the passage of the solutions rising along the fissures and caused them to spread out along favorable beds beneath the shale.

HUB MINE.

The Hub group, owned by the Utah Mining, Milling \& Transportation Co., is located in the southeastern part of the Star district south of the Moscow mine. The main workings are at an elevation of about 6,700 feet. Some lead-silver ore has been shipped from this property, but it has not been an important producer. The mine is developed by a vertical shaft 200 feet in 


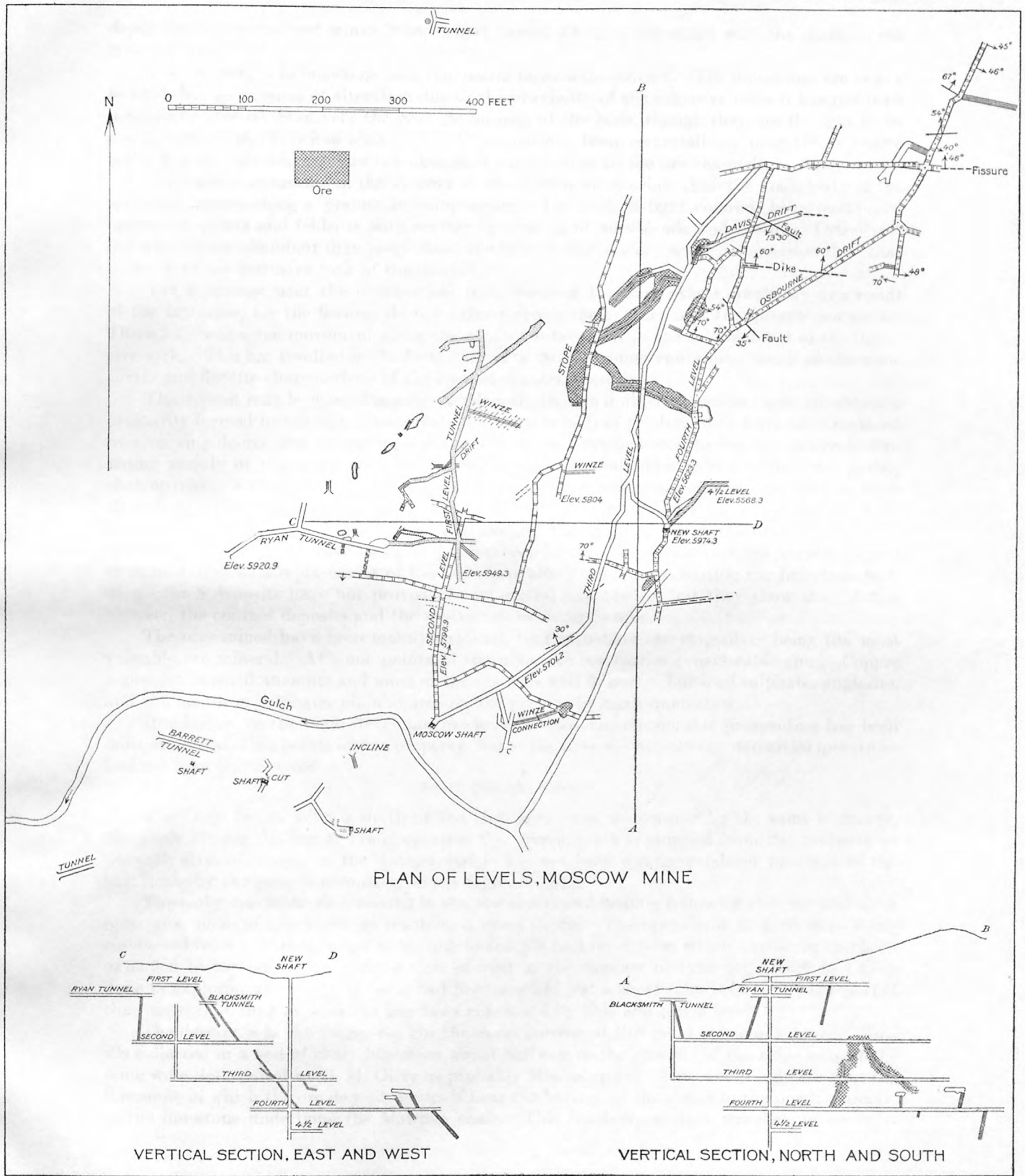

PLAN AND SECTIONS OF THE MOSCOW MINE. 

depth and by an inclined winze from a short tunnel which is connected with the shaft on the 200-foot level.

The ore body is in limestone near the quartz monzonite contact. The limestones are heavy bedded, but on account of alteration due to the proximity of the intrusive mass it has not been possible to identify positively the geologic horizon of the beds, though they are thought to be not far below the Mowitza shale. The limestone has been recrystallized near the intrusive body, but contact minerals are not abundant except close to the ore channels.

The quartz monzonite in the vicinity of the mine is more acidic than the main body of the intrusive, approaching a granite in composition. The rock is light colored, being composed largely of quartz and feldspar with scattering crystals of hornblende and biotite. Orthoclase is slightly more abundant than plagioclase, the latter being of more acidic composition than that in much of the intrusive rock of the district.

The limestone near the contact has been fissured to some extent, probably as a result of the intrusion, for the fissures do not extend across the contact into the quartz monzonite. There has been some movement along the contact subsequent to the solidification of the intrusive rock. This has resulted in the formation of a talcose gouge containing much of the muscovite and fluorite characteristic of the zone of contact alteration.

The deposit may be classed as a contact deposit, though it differs somewhat from the deposits ordinarily formed by contact mineralization. Certain beds of the limestone have been replaced to a varying degree and to varying distances from the intrusive rock by contact minerals consisting mainly of muscovite, fluorite, magnetite, and the sulphides galena, sphalerite, pyrite, chalcopyrite. Some chlorite and serpentine are present, but these minerals are due to later alteration. The ore shows a marked tendency to form where the limestone is the hanging wall. Where the granite becomes the hanging wall along the irregular contact, little or no ore is found.

Though most of the ore so far developed has been found along the contact, ore has also formed to, some extent as a replacement of the limestone along the fissures cutting the limestone bedding. Such deposits have not proved of commercial importance, but they show the relation between the contact deposits and the replacements along fissures.

The ores mined have been mainly oxidized, lead carbonate carrying silver being the most valuable ore mineral. At some points in the mine the ore carries considerable zinc. Copper is present in small amounts and most of the ore runs well in iron. The lead sulphate, anglesite, and the lead-iron sulphate, plumbojarosite, are present in small quantities.

In addition to the main developments described above considerable prospecting has been done at several other points on the property, but at the time of visit, ore in commercial quantities had not been encountered.

\section{LADY BRYAN MINE.}

The Lady Bryan mine is south of the Hub group and is operated by the same company, the Utah Mining, Milling \& Transportation Co. Some ore was shipped from the property in the early days of mining in the district, but it has not been a large producer previous to the shipments by the present company, which began in 1910 .

The early development consisted in shallow shafts and inclines following the vein and some open pits, none of the workings reaching a great depth. The operations in 1910 were being conducted from a shaft that had been sunk to the 300-foot level, from which a crosscut had been extended to the ore body. At the time of visit in the summer of 1910 little work had been done in exploring the ore body, as it had been reached but a short time before. It is reported that since that time exploration has been continued on this and lower levels.

The deposit is in the limestone, but the exact horizon at this point is in some doubt. Fossils collected in a bed of shaly limestone about halfway to the summit of the ridge east of the mine were determined by G. H. Girty as probably Mississippian. This would indicate that the limestone in which the ore deposit occurs is near the horizon of the mines to the north, namely, in the limestone underlying the Mowitza shale. This fossiliferous shale member, however, is 
less prominent at this point and no fossils were found that correspond to those in the shaly member at the Moscow, Red Warrior, and Mowitza mines.

The strike of the limestone beds is in general north and south with easterly dip but shows less regularity than that to the north on account of the close proximity to the extensive intrusive masses of quartz monzonite north and west of the mine. The limestone is cut by a series of east-west fissures with steep northerly dip. The one on which developments are being conducted has a dip of about $70^{\circ}$.

The limestone along the contact with the quartz monzonite has been recrystallized and locally along the contact and along the fissures near the contact has been replaced by contact minerals. Muscovite and fluorite are rather abundant in this zone, as at the Hub mine, and epidote, pyroxene, and some tremolite were also observed. With these are magnetite, pyrite, and chalcopyrite. In connection with the main ore body contact silicates were not observed and there was relatively slight silicification of the limestone, the replacement apparently being principally effected by sulphides, though the unaltered ore has not been encountered.

The ore body at present developed occurs as a replacement of limestone along the eastwest fissure. At the time of visit it had been shown that the limestone had been replaced along several beds to varying distances up to 20 feet or more from the fissure; in fact, all the beds exposed by the workings had been replaced more or less. In general character the ore shoot, like that of the other mines in this district, was a chimney of ore pitching to the northeast following the intersection of the readily replaced beds and the fissure.

All the ore thus far developed is oxidized, being composed principally of limonite and carbonates of lead and copper, carrying some silver. The ore is high in iron and consequently a desirable smelting ore for this district.

ST. MARYS MINE.

The St. Marys mine is in the southern part of the Star district, on the east side of Topache Peak. It was opened in the early days and considerable ore was taken out near the surface. It was then idle for many years, but in the summer of 1909 work was again in progress.

The main output of the mine has been lead, silver, and iron flux, carrying small amounts of other metals. Some copper ore has been extracted and shipped. The metal output of the mine in the early days of its production is not known.

The early development of the mine consisted in following the ore shoots from the surface to a depth where the extraction of the ore ceased to be profitable. In the old workings a vertical depth from the outcrop of possibly 200 feet was attained.

In 1909 a tunnel was being driven and a shaft sunk to develop the ground at greater depth. The mine is in the Topache limestone, which is rather heavy bedded and has the general north-south strike and easterly dip common to the district. The only other rock observed in or near the mine workings was a dike of altered green porphyritic rock exposed in the tunnel. This is similar to other dikes cutting the limestone and is not believed to have had an important bearing on the formation of the ore deposits.

The limestone is cut by nearly east-west fissures and certain beds of limestone have been replaced for short distances from these fissures by ore minerals, forming chimney-like masses of ore following the intersection of the fissure and the bedding.

The lead-silver ore is oxidized to the depth to which it has been developed. It consists mainly of carbonate of lead, cerusite, and limonite, with a little copper carbonate. The copper ore shows less oxidation. The primary mineralization was similar to that of the contact deposits, the ore consisting of chalcopyrite and pyrite in a gangue of garnet, muscovite, and calcite. Some specimens collected contained bismuthinite, but whether or not this mineral occurs in considerable amounts is not known.

\section{PROGRESSIVE MINE.}

The Progressive mine is in the southern part of the Star district, a little north of the St. Marys mine. A few shipments of ore carrying copper, lead, and silver have been made from this mine in the past few years, but it has not been a large producer. 
This mine, like the St. Marys, is located in the Topache limestone and the ore bodies have formed as a replacement of certain beds of limestone near the intersections of fissures.

\section{COMMONWEALTH MINE.}

The Commonwealth mine lies in the southern part of the Star district, north of the Progressive mine and east of the Lady Bryan. A little ore has been taken from the mine, but it has never been an important producer. It is developed mainly by a tunnel about 1,200 feet in length, extending in a general westerly direction, though varying from point to point. From this tunnel several drifts have been run following certain beds and fissures. In addition to the main tunnel there have been shallow workings at several other points.

The main workings are in the Topache limestone, the only other rock being dikes of altered green porphyry similar to that found at many other points in the district. These dikes appear to have been intruded along the limestone beds. The limestone is broken by fissures extending in several directions, nearly east-west, northwest-southeast, and northeast-southwest. All the fissures were apparently formed before the mineralization, as some mineralization has occurred along them all. Some movement has taken place along the fissures, but so far as determined it has been slight. It has, however, resulted in some places in a brecciation of the rock and in others in the formation of a rather strong gouge.

The mineralization occurred along the fissures and extended for short distances along certain beds of the limestone. Present developments show but little ore and most of this is not of high grade.

\section{MAMMOTH MINE.}

The Mammoth mine is in the central part of the Star district, about half a mile east of the Red Warrior mine. This was one of the earliest mines of the district and was one of the largest producers in the early days. With the exhaustion of the ores near the surface operations were discontinued and the mine was idle for many years. In the last few years additional prospecting has been done and a little ore has been taken out. No exact record of the metal output of the mine is available.

The early development consisted of a short tunnel cutting the ore body but a few feet below the outcrop. The ore shoots were worked by winzes from this tunnel. Later a tunnel was run from Mammoth Canyon that cut the ore fissure at a depth of about 230 feet below the upper tunnel. A winze has been sunk about 60 feet below the lower tunnel level, and a raise has connected it with the upper workings. Several hundred feet of drifting has been accomplished on the tunnel level.

The mine workings are in the Topache limestone, which is rather heavy bedded and uniform in character. The cherty zone of this formation overlies the limestone in which the mine is developed. It is reported that a small dike of porphyry is exposed in the mine workings, but this was not seen by the writer.

The limestone is cut by a fissure striking nearly east and west and dipping about $60^{\circ} \mathrm{N}$. A second fissure strikes about northwest and southeast and dips about $60^{\circ} \mathrm{NE}$. The limestone is too uniform in character to make it possible to detect slight movement along these breaks, but so far as could be determined there has been little displacement.

So far as shown by present development, the mineralization occurred almost entirely along the east-west fissure. Considerable drifting has been done on the northwest-southeast fissure, but only small bunches of mineral have been encountered.

The ore minerals show less tendency to replace certain beds than in most of the other mines of the district but rather have replaced all the limestone beds adjacent to the fissure, though to a varying extent, the mineralization extending farther from the fissure in some beds than in others. It is noteworthy also that the mineralization has extended farther from the fissure near the surface than in the lower workings. On the tunnel level the drift in the fissure shows few mineralized beds along the fissure more than 3 feet in width, but in the upper workings the replaced beds may be several times as wide. 
The original sulphides have all been altered to the depth of development, so that it is impossible to state the character of the original mineralization. The ore that has been extracted has consisted, so far as has been learned, of lead carbonate carrying silver and limonite. In the lower levels the lead minerals are largely absent and the fissure zone is filled with limonite.

The ore shoot that has been mined extended from the surface to a depth of about 140 feet. From this point to the tunnel level, about 90 feet, and in the winze below the tunnel level, about 60 feet, only a few small bunches of ore have been encountered, though the fissure continues strong and carries abundant limonite.

LYDIA MINE.

The Lydia mine is located on the east side of the quartzite ridge south of the Elephant Canyon road. It is reported that several carloads of lead-silver ore have been shipped from this property. The mine is developed by an inclined shaft about 175 feet in depth. The mine workings are in the Talisman quartzite, which conforms to the general structure of the region, striking in a general north-south direction and dipping $45^{\circ}-50^{\circ} \mathrm{E}$.

The mine is developed on a fissure cutting the quartzite with a north-south strike and a dip of about $45^{\circ} \mathrm{W}$. The mineralization consisted principally of the formation of galena replacing the quartzite adjacent to the fissure. On the first level several small chimneys of ore have been stoped along the fissure. There has been no drifting below the first level, but the fissure is said to be exposed in the bottom of the shaft.

OTHER MINES.

There are numerous other mines and prospects in the Star district which were not in operation at the time of the writer's visit and consequently detailed information concerning them was not obtained. Among the more important of these are the Kemple mine, the Estelle mine, and the Vicksburg mine.

The Kemple mine is located in the valley about half a mile east of the Commonwealth mine. Considerable development work has been done by shallow shafts. No record of the output is available.

In the southeastern part of the Star district the Harrington formation has been intruded by the quartz monzonite, so that the two form a veritable mosaic of intrusive and sedimentary rock. In many places small blocks of the sedimentary rocks not exceeding a few hundred feet in greatest dimensions are entirely surrounded by the monzonite. Where the intrusive rock is in contact with the limestone there has been contact mineralization with the deposition of sulphides of lead, copper, zinc, and iron. Similar mineralization has also occurred along fissures in the limestone. The Estelle and Vicksburg mines and numerous prospects have been operating deposits of these types, and it is reported that considerable metal production has been made from this section of the district, though no detailed figures were procured. 


\section{INDEX.}

$A$.

Page.

Acknowledgments to those aiding . . . . . . . . . . . . . . . Admiral group, description of ........................... 198

Allen, E. T., and Crenshaw, J. L., cited . ................ 154, 155 Alteration. See Metamorphism.

Alunite, occurrence and character of .................... 108

Andalusite, occurrence and character of ................... 102

Anglesite, occurrence and character of ....................... 106

Anhydrite, occurrence and character of . . . . . . . . . 120.125 solubility of figure showing.

views of....

(106, 107

(1)

A patite, occurrence and character of ..................... 105

Aplitic dikes, distribution and character of . .............. $61-62,136$

Aragonite, occurrence and character of . ..................... 100

Argentite, occurrence and character of . . . . . . . . . . . . . . . .

Asbestos, oceurrence and character of . .................... 101

Augite latite, analysis of.

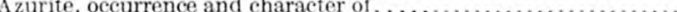

Ball, S. H., cited............

Baneroft, I., and Irving, J. D., cited ...................... 152

Bard, D. C., eited ....................................... 142

Barite, occurrence and character of................... 121, 122-123

Barrel Spring Canyon, roeks of ...................... 31-32,62

asalt, distribution and character of

Beaman, W. M., work of. ...

Beaver Carbonate mine, geology near.

history of

location of.

(181-133, 181-182 enrichment of ................................ 181-182 minerals of . ................................... 181 prodiction

workings of . . .

figure showing. Beaverite, analyses of

occurrence and character of . . . . . . . . . . . . .

Beaver Lake district, alteration in .................. 80-81, 86-87

alteration in, analyses showing ...................... $79-80$

early history of ..................................... 110

lavas of .......................................... $80-81$

analyses of . . . . . . . . . . . . . . .

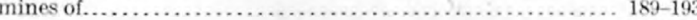

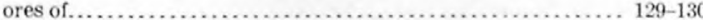

production of ..................................... 118

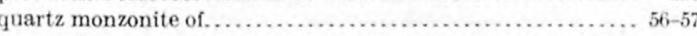

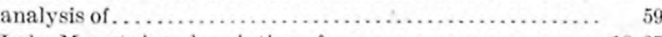

Beaver Lake Mountains, description of .................. 18-27

erosion in ..................................... 138.

rocks of ............................... $48,49,50,51,56-57,63,70$ structure of ................................................ section showing ............................... 26 view of ......................... 19

Beaver mine, description of ........................... 192

Beaver Creek, flow of .............................. 19,21

Belmont claim, description of .......................... 187-188

Bibliography.

Big Cottonwood Canyon, section in

Big Wash, view of..

Bindheimite, occurrence and character of
Biotite, occurrence and character of Page.

Bismuthinite, oceurrence and character of .......................... Blackbird Gold \& Copper Mining Co.'s mines, description of .... 187-18 Black Rock mine, alteration near ............................ 86-87 description of.

$40-41$

Blue Mountain, ore deposits of .......................... 128

Bonneville, Lake, geology of ................................ 44

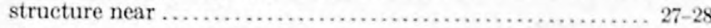

Bornite, occurrence and character of ........................ 95

Boutwell, J. M., cited ........................ 40, 66, 71, 78, 86

Brasil, ore deposits in .................................. 127

Breccia ore, views of .......................... 126, 127, 132

Brochantite, occurrence and character of ................... 106

Buckley, F. R., and Buehler, H. A., cited..................... 154

Butch Canyon, rocks of . . ...................................

Butte, Mont., igneous rocks in, age of ................... 67

C.

Cactus Gulch, ore in, view of ........................ 126

Cactus mine, description of .............................. 172-174

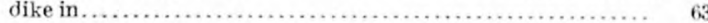

future of ....................................... 162

glory hole in, view of............................ 126

history of ........................................... 172

location of .................................... 172

outcrops of, views of .............................. 74

structure of ................................... 126-127

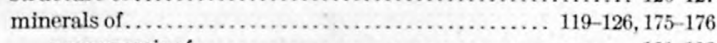
paragenesis of . . . . . . . . . . . . . . . . . . . . . . . views of ................................ 96, 106, 107

ores of............... 13, 119-126, 136, 141 alteration of.................... $82,127,138,141-142,176-178$ analyses showing............................... 76,77

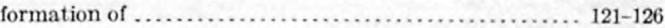

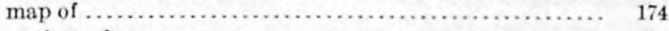

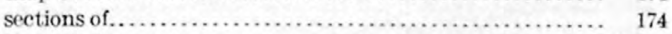

production of .................................. 172-174

quartz monzonite of ............................ $52-56$

analysis of $\ldots \ldots \ldots \ldots \ldots \ldots \ldots \ldots \ldots \ldots \ldots \ldots \ldots \ldots \ldots \ldots \ldots \ldots \ldots \ldots \ldots \ldots \ldots \ldots, 76,77$

views of . . . . . . . . . . . . . . . .

rocks of and near...................... $39,52,56,61,74,174-175$

water in .......................................... 137-138

Calamine, occurrence and character of ..................... 102

Calcite.............................................. 98-99

California, geologic events in ...........................6. $67-68$

Cambrian rocks, distribution and character of ............... 28-31

Carbonate mine, description of ......................... 113

fissures in and near................................. 74

future of $. \ldots \ldots \ldots \ldots \ldots \ldots \ldots \ldots \ldots \ldots \ldots \ldots \ldots \ldots \ldots \ldots \ldots \ldots \ldots \ldots \ldots \ldots, 163$

lava from, analysis of ............................. 49

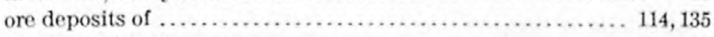

alteration of ................................... 14, 144

view of....................................... 133

rocks near...................................... 45,50

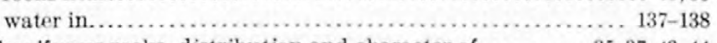

Carboniferous rocks, distribution and character of ........ 35-37, 43-44

Cedar-Extension mine, description of ........................ 198

Cedar-Talisman mine, description of..................... 197-198

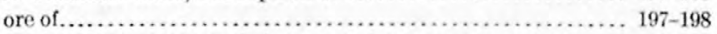

Cerargyrite, occurrence and character of ........................ 96

Cerusite, occurrence and character of .......................... 100

Chalcanthite, occurrence and character of.................. 108

Chalcocite, occurrence and character of ..................... 92-93

Chalcopyrite, occurrence and character of......... 93, 119, 121-122, 125-126 
Chalcopyrite, oxidation of ................... Page. views of . . . . .

Charcoal, use of

Chile, ore deposits in

Chlorite, occurrence and chameter................

Chrysocolla, occurrence and charact

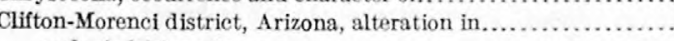
geologic history in.

rocks of, section or.

Climate, nature of.

Comet mine, description of.

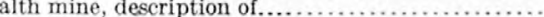

Cones, alluvial, occurrence of ....

Contact deposits, alteration of ...

character of.

enrichment of

future of....

Copper, alteration of occurrence and character of.. 92,114, 117, 120, 129, 162-163,169, 170-171 precipitation of ..................................... 152-158 production of .................................. 117-118

Copper Gulch, geology in ........................ 39, 53,61,64 mines in ............................... 187 ore in, view of.

mine, description of.

Copper pitch, occurrence and character of

Corkite, occurrence and character of.

Correlation, discussion of . $. .4 .40-43$

Cosalite, occurrence and character of ........................ 95,122

Covellite, occurrence and character of .

93

views of .

Coyote Springs, location of ................................... 20

rocks near...........................................

Crenshaw, J. L., and Allen, E. T., cited.

154,155

Cross, Whitman, cited.

Cupric mine, description of ores of.......

$$
\text { view of... }
$$

rocks near......

Cuprite, occurrence and character of ....

$$
\text { D. }
$$

Dacite, analyses of

...

Darton, N. H., cited ..

Davis, W. M., cited.

Depth, relation or,

Devonian rocks, distribution and character of ................. 33-35, 43

Diaspore, occurrence and character of.

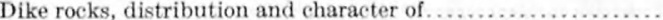

varieties of.

See also particular varieties.

Diopside, occurrence and character of......

Diorite, analysis of.

nd character of

Dolomite, occurrence and character of

Doming, eause of...............

$$
\text { figure showing... }
$$

Drainage, nature of .

Drake, N. F., and Lindgren, W., cited.

Dufrenoysite, occurrence and character of

$$
\text { E. }
$$

Earthquakes, prediction of

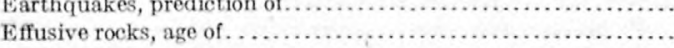
composition of deposits in...

description of.

dikes associated with.............................. 62-63,64

extent of ............................................... 44-45

relations of.

water from.

See also particular lavas.

Elephant Canyon, mines in

rocks of ....

strueture in

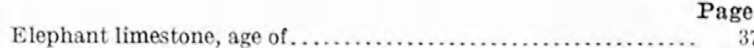

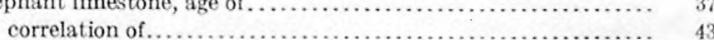

deposition of ........................................... 37,90

distribution and character of ......................... 29, 37

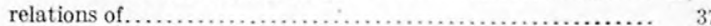

Elephant mine, description of ......................... 198-199

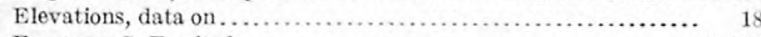

Emmons, S. F., cited ...................................... 144-145 work of . . . . . .

Emmons, W. H., cited................................ 122

Enrichment. See Metasomatism.

Epidote, occurrence and character of .................... 102

Epsomite, occurrence and character of...................... 10

Erosion, relation of, to ore deposits ..................... 138

Estelle mine, location of .............................. 200

Fairview Springs, water of $\ldots \ldots \ldots \ldots \ldots \ldots \ldots \ldots \ldots \ldots \ldots \ldots \ldots \ldots \ldots \ldots \ldots \ldots \ldots, 20$

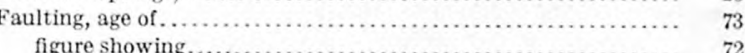
occurrence and character of . $11,22-24,26,71-73,91$

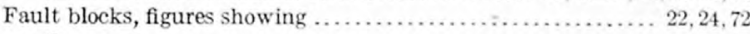

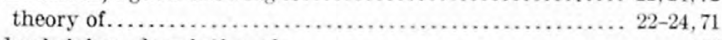

Federal claims, description of . . . . . . . . . . . . . . .

Field work, extent of ................................ 15

Field work, old, extent of ............................. 16

Fissures, deposits in. See Replacement fissure deposits. occurrence and character of ......................... $73-74$

Fluorite, occurrence and character of ........................ 9

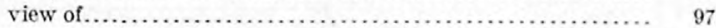

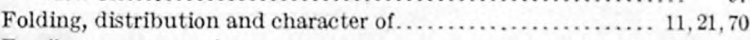

Fossils, occurrence of .................................. 11 See also particular formations.

Frisco, diorite near, analysis of $\ldots \ldots \ldots \ldots \ldots \ldots \ldots \ldots \ldots \ldots \ldots \ldots \ldots \ldots \ldots, 62$ fissures near................................... 74 lava near...................................... $45-46$ analysis of .................................................. 46,49

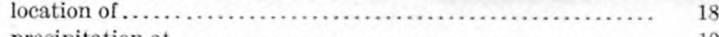
precipitation at ................................... ${ }^{19}$ rocks near.......................... 45-46, 60, $62,63,78$

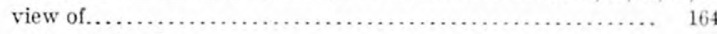
water at, depth to............................... 20 water supply of ................................... 20

Frisco Contact mine, description of ..................... 187 rocks of ................................................. $74,78,187$ Frisco Mining \& Smelting Co., property of .................... 113$$
\text { G. }
$$

Galena, occurrence and character of ............... 92,120,122,168 views of ......

Gangue minerals, in veins in quartz monzonite ............ 119-126

Garnet, occurrence and character of ........................... 101 views of ........................................... 185

Geographic position, map showing ..................... 17

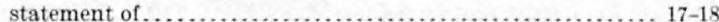

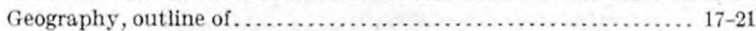

Geologic history, summary of .......................... $90-91$

Geology, discussion of .......................... 11-12, 28-90

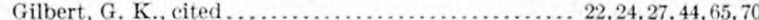

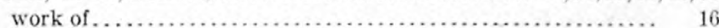

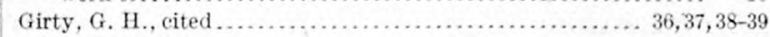
work of . . . . . . . . . . .

Goethite, occurrence and character of .................. 98, 120

Gold, occurrence and character of ........................ 91 production of ........................................ 117-118

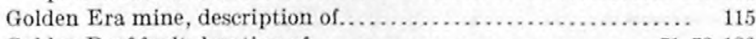
Golden Reef fault, location of . .......................... $71-72,186$

Golden Reef mine, description of ..................... 186-187

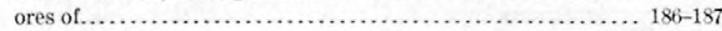

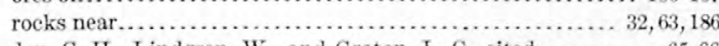
Gordon, C. H., Lindgren, W., and Graton, L. C., cited............ $65-66$ Goslarite, occurrence and character of ...................... 108

Grampian Hill, mines on .............................. 184 rocks of .......................................... $28,32,61$

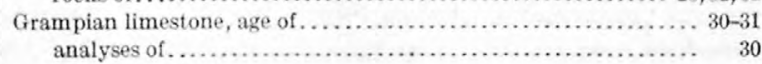


Grampian limestone, deposition of .... distribution and character of fossils of...

Grampian prospect, description of

Granodiorite porphyry, analysis of definition of. distribution and character of. petrography of. relations of.

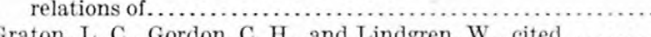

. . . . and Lindgren, W., cited........... $65-60$

Great Basin structure, discussion of ....................... 21-24 figures showing....

Greenockite, occurrence and character of ....

Gypsum, occurrence and character of........... 108, 121 view of.

\section{H.}

Hammond, J. H., cited . 179

Harder, E. C., and Leith, C. K., cited........................ 64, 89

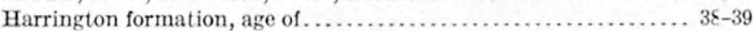
correlation of.

deposition of.

distribution and character o

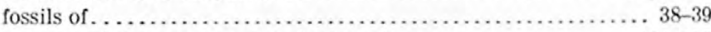

Harrington-Hickory mine, description of. ore deposits in......

$130,131,143,195-196$ rocks of . section and plan of structure near. $37,47,51,57,58,88,194-195$ water in....

Co.s property, description of . ........ 116

Hematite, occurrence and character of ............... 97, 119, 121-122

Hendrickson claim, description of ....................... 189

Henry Mountains, geologic events in .................... 65

Hickory, mines near . . . . . . . . . . . . . . . . . . . . . . . . . 194 rocks near .............. 51,63,87

Historical geology, summary of . . . . . . . . . . . . . . . $99-91$

Hooker, W. A., cited........................... 146-147, 164, 165, 170

Hoosier Boy mine, description of .......................... 198

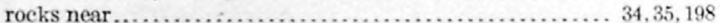
Hornblende, occurrence and character of .................. 101

Horn Silver fault, location of. . . . . .

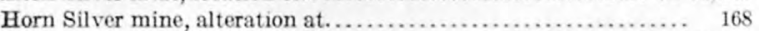
copper in .................................. 149,169, 170-172 description of . ................ 111-113 description of .

geology or.

history of m. lead of . .

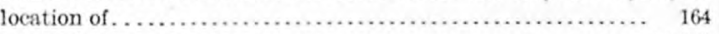

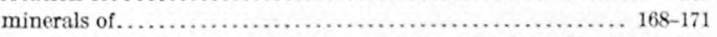
views of......................... 108, 141, 146, 147, 148, 149 ore deposits of ... alteration of ............................... 14,133, 146-160 chemistry of . . . . . . . . . . . . views of ...................................... 132 ores of.....

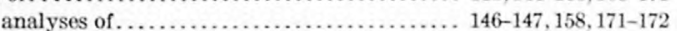
change in metal content of ....................... $15 \$-160$

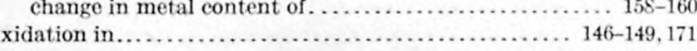

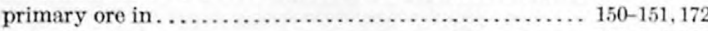
production of . ................................ 145, 164-165 sections of , plate showing . . . . . . . . . . . . . . . . . . . . . 166

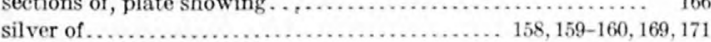
smelter of ................................... 112-113,114 strueture in .................................... $72-73$ sulphide enrichment in ................ 149-150,171-172

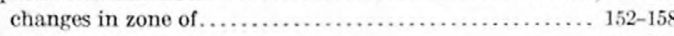

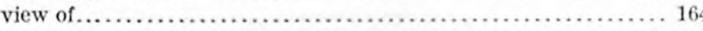

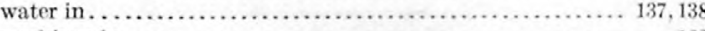
workings in $\ldots \ldots \ldots \ldots \ldots \ldots \ldots \ldots \ldots \ldots \ldots \ldots \ldots \ldots \ldots \ldots \ldots \ldots \ldots, 166$

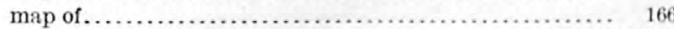
zinc in ............................... 149-150, 159-160, 169, 171 Horn Silver Spring, location of ........................... 20 Hot solutions. See Solutions, hot.

Hub mine, description of . . . . . . . . ore deposits in $\ldots \ldots \ldots \ldots \ldots \ldots \ldots \ldots \ldots \ldots \ldots \ldots \ldots \ldots \ldots \ldots \ldots \ldots \ldots \ldots \ldots \ldots \ldots \ldots \ldots \ldots \ldots \ldots \ldots \ldots \ldots \ldots \ldots \ldots \ldots \ldots \ldots$
rocks at.

Humboldt region, Nev., geologic history in.... $73363^{\circ}-$ No. $80-13-14$
Page. by Hussak E., cited ................................. 127-128 Hydrothermal alteration, nature of ........................ 74

I.

Idaho, igneous rocks in, age of ......

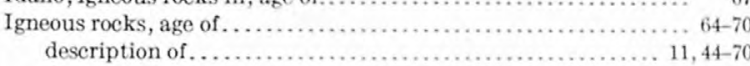
See also Effusive rocks; Intrusive rocks.

Ilmenite, oceurrence and character of..........

Imperial mine, description of . . . . minerals of ...................................... 182-183 view of........................................ 18

ores of ....................................... $82-84,183$ figure showing .... rocks of and near.............................. 29-30, 82-83

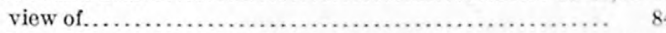

Indian Grave Peak, rocks on and near................... 53, 62

rocks on and near, views of ........................ 78

Indian Queen Consolidated Mining Co.'s mines, deseription of..... 18 rocks at ....................................... 28, $30,70,18$ water supply of ...................................

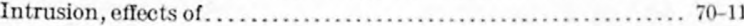
effects of, figure showing .......................... 71

Intrusive rocks, age of ................................. 70 description of ............................................. $11,50-64$ extent of ........................................ $50-51$

intrusion of . . . . . . . . .

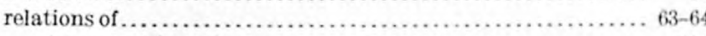
to ore-bearing solutions............................ 136 See also particular intrusive rocks.

Iron, alteration of ................. 143

Iron Springs district, alteration in . . . . . . . . . . . . . . . . . . . . . . .

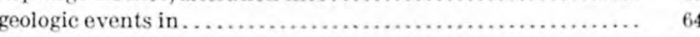

Irving, J. D., and Bancroft, H., cited...................... 152

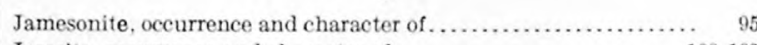

Jarosite, occurrence and character of ..................... 108-109

K.

Kaolinite, occurrence and character of .................... 103

Kemple mine, description of . ........................... 206

Kindle, E. M., cited...................................... work of . . . . . . . . .

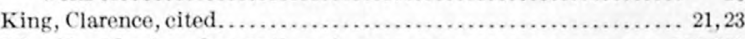

King David mine, description of . . . . . . . . . . . . . . . . . rocks at......................................... 83,185

Water supply of m en war.

Kruse mine, deseription of . ........................... 187

L.

Lady Bryan mine, description of..................... 203-204

ores of ......................................... 204

rocks near................................................. $34,203-204$

Lake sediments, distribution and character of .............. 39-40,44

Larkspur claims, deseription of .......................... 192

Lateral faults, description of ............................ 73

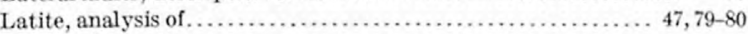
definition of ..................................... 50

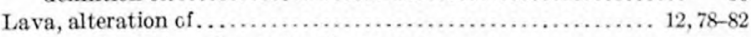

alteration of, analyses showing ..................... $79-80,81$

analyses of ...................................... $46-49$

composition of .................................. 49-50

deposits in ................................... 13, 91, 135

enrichment of ............................... 14

distribution and character of ........................ $45-49$

fissures in ........................................ 74 alteration adjacent to ........................... 131-132 ore deposits in ........................... 131-133, 136 alteration of............................... 144-160 future of ................................. 103 minerals of .............................. 133 Sce also Horn Silver mine.

outpouring of. ...

See also particular lavas.

Lead, alteration of ores of ....................... 14, 143, 171-172

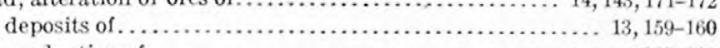

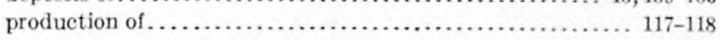


Lead-silver ores, enrichment of.

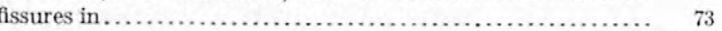
views of.

Linarite..

Lindgren, Waldemar, cited ........ work of......

F. cited.............

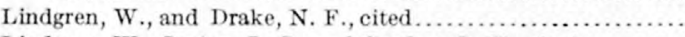

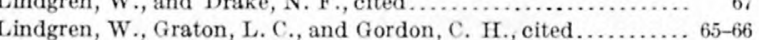

Literature of region ....................................... 16

Loeber Gulch, limestone in, view of ........................ 83 mines in ....................................... 182, 183 rocks in ........................................ 61,83

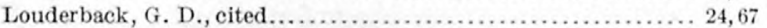

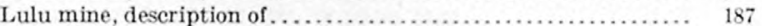

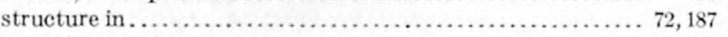

Lydia mine, description of .......................... 206

M.

MeLaughlin, Fred, work of.....................

Magnesite, occurrence and character of ....

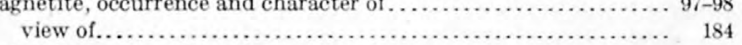

Malachite, occurrence and character of .................... 100

Mammoth mine, description of....................... 205-206

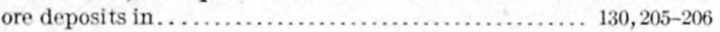

Manganite, occurrence and character of....................... 98

Map, geologic, of region. ............................. In pocket.

Map, index, showing location of mining districts............. 17

Marble Gulch, rocks at $\ldots$

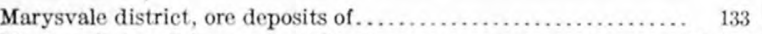

Meadow Lake, Cal., ore deposits at.................... 127-128

Meadow Valley region, Nev., geologic events of ............... 69

Melaconite, occurrence and character of ................... 97

Merwin, H. E., cited .

Metals, migration of ................................ 158-161 See also Metasomatism; Horn Silver mine.

Metamorphism, contact, cause of ......................... 90 See also Metasomatism.

Metasomatism, difference of, in different rocks................. $81-82$ occurrence and character of.......................... 12,74-90 See also Lava; Quartz monzonite; Ores.

Michigan Gold \& Copper Co.'s claims, description of........... 185

Milford, artesian wells at............................. 20,21 artesian wells at, sections of ......................... 40 mines near...................................... 196, 199 smelters at and near.............................. 115,117

Mineralogy of region.............................. 91-110 See also particular minerals; Quartz monzonite; Lava.

Mineral Range, structure of. . . .

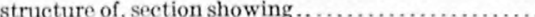

Minerals, alteration of ...................... $75-77,81-82,86,143$ alteration of, analyses showing ...................... 76 See also Metasomatism.

paragenesis of ................................... 121-125 figure showing ............................ 121 See also particular minerals.

Minersville, section near...

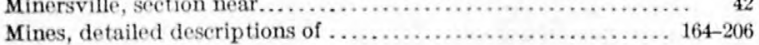
information on, source of .......................... 163 water in.....

Mining, history of ............................................. 110

Mining districts, map showing ........................ In pocket.

Mississippian rocks, distribution and character of............. $35-36$

Modena, climate at.................................... $\quad 19$

Molybdenite, occurrence and character of . . . . . . . . . . . oxidation of . . . . . . . . . relations of, figure showing........................ 126

Molybdenite, veins of, view of.......................... Page.

Monzonite. See Quartz monzonite.

Morehouse Canyon, rocks of ........................... $31-32,63$

Morehouse quartzite, age of.............................. 32,33

deposition of .................................. 32, 33,90

distribution and character of ..................... 29,31-33

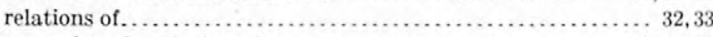

Moscow mine, description of.............................. 201-202

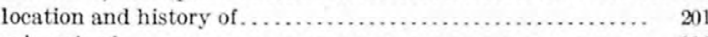

minerals of ............................................. 202

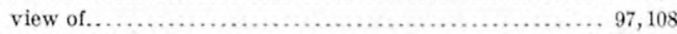

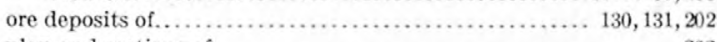

plan and sections of . .............................. 202

rocks of .................................... 88, 201-202

Mowitza mine, description of.......................... 199

Mowitza shale, age of........................................ 35

correlation of ................................... 43

deposition of . . . . . . . . . . . . .

distribution and character of ........................ 29,34

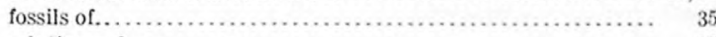

relations of ....................................... 35

Muscovite, occurrence and character of .................... 102

views of ....................................... 97,185

N.

Nevada, geologic events in ............................. $67-69$

Nevada Ready Pay Mining Co.'s mines, deseription of .......... 185

Newhouse, description of................................... 18, 11

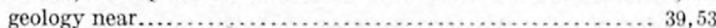

New Mexico, geologic events in........................ $65-66$

New Year's claim, description of . . . . . . . . . . . . . . . . .

Normal faults, description of ........................... $71-73$

figure showing .....................................

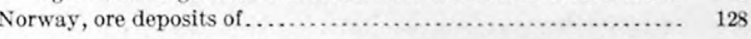

O.

Ogden, section near .................................. 40-41

O K mine, alteration in ................ geology of and near...................... 51,56, 62, 78-79, 189-190 history of . . . . . . . . .

lava from, analyses of . . . . . . . . . . . . .

location of ..................................... 189

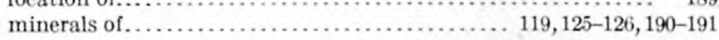

views of............................... 124,140,141

ores of................................ 125-126, 136, 190-191

alteration of . . . . . . . .

stereogram showing........................... 125

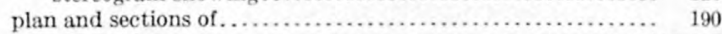

production from ....................................... 116, 118

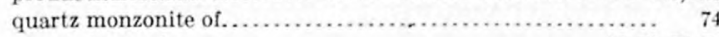

analyses of . . . . . . . . . . . . . . . .

structure in ................................... 125-127

figures showing ............................. 125, 126

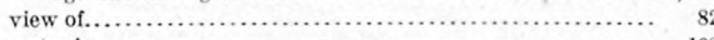

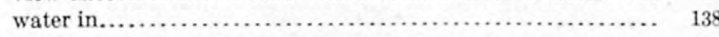

workings of . . . . . . . . .

Old Hickory mine, description of....................... 193-194 ores of..................................... 129-130, 194 plan and sections of ............................. 194

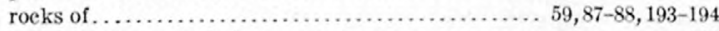

Olivine, occurrence and character of ...................... 101

Opal, occurrence and character of . ........................... 97

Ordovician rocks, distribution and character of .............. 28-32, 43

Ore-bearing solutions. See Solutions, hot.

Ore deposits, classification of ........................ 12-13,119

early development................................. 110-117

enrichment of ..................................... 14-15

formation of ................................. 91,121-126

factors affecting .................................. 118-119

genesis of ........................................ 13-14

relations of ....................................... 118-119 to depth..................................... 160-161

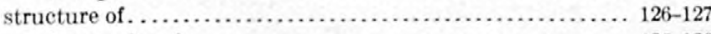

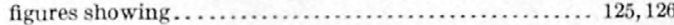

types of ................................ 13-14,118-119 See also deposits in Quartz monzonite; Lava; Sedimentary rocks. 
Page.

Ores, alteration of .

alteration of, bibliography of.

factors in

relation of to erosion .

to mineral character ............................ 139

to physical character ......................... 138-139

to water level............................... 137-138

figure showing ................. 137

genesis of. See also Minerals.

production of . $133-135$

See also Quartz monzonite; particular mines.

Orphan Bay group, deseription of.

Oxidation, zone of, See Horn Silver mine.

\section{P.}

Palmer, Chase, work of. structure in

Peacoek mine, description of

minerals of, view of.

rocks at.

Pearce, Richard, eited ................................ 152-158

Pennsylvanian rocks, distribution and character of ................. $36-37$

Perviousness, relation of, to alteration ................... 138-139

Physiography, discussion of........................... 21-28 See also Structure.

Plagioclase, occurrence and character of ................... 101

Plumbojarosite, occurrence and character of................ 109-110 view of ....

Pneumatolytic alteration, nature of $\ldots \ldots \ldots \ldots \ldots \ldots \ldots \ldots \ldots \ldots \ldots \ldots \ldots \ldots \ldots$

Porphyritic dikes, analysis of........

distribution and character of ...........................60-6

Powell, J. W., eited.................... 23

Powellite, occurrence and character of ..................... 110

Precipitation, records of..

Preuss district, map of

mines of... production of.

Production, records of.

(117

Progressive mine, description of ............................... 204-205

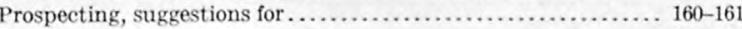

Prospects, future, predictions of ...................... 161-163 predictions of, difficulty of ......................... 161-162

Proustite, occurrence and character of ........................ 96

Purity claim, description of ............................ 188

Pyragyrite, occurrence and character of .................... 96

Pyrite, occurrence and character of .............. 95, 119, 121-122, 126 oxidation of ....................................... 139 views of....................................... 146, 184

Pyrolusite, occurrence and character of ................... 98, 120

$$
\text { Q. }
$$

Quartz, occurrence and character of .............. 96, 120,121-122, 125 views of ..................................... 96,124 Quartz diorite porphyry, relations of ..................... 63

Quartzite Hill, rocks of ............................... $31-32$ Quartzite Mountain, view of.

Quartz latite, analyses of ....................... 47, $79-80$

Quartz monzonite, alteration of ............. 12, 74-78, 81-82, 133-134 alteration of, analyses showing $\ldots \ldots \ldots \ldots \ldots \ldots \ldots \ldots \ldots \ldots \ldots \ldots \ldots \ldots \ldots \ldots, 77$ analyses of ...................................... $55,57,59$

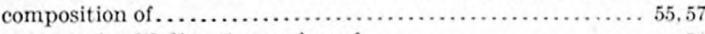

contact of, with limestone, view of .................... 84

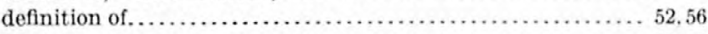

dikes associated with.................................6 63-64

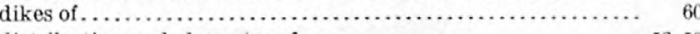

distribution and character of .......................... 52-59

fractures in, alteration near.......................... 74

microscopic features of ............................. $53-55$

ore deposits in, alteration of ....................... 139-142

character of .............................13,119-126

comparison of, with deposits elsewhere............. 127-128 enrichment of .................................. 14 future of .................................... 162 gangue minerals of ............................ 119-126 mineralogy of.

13,119 $\begin{array}{ll}\text { Quartz monzonite, ore of } & \text { Page. }\end{array}$

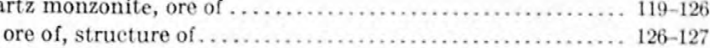
structure of, stereogram showing.................. 125 petrography of ................................. 53,56

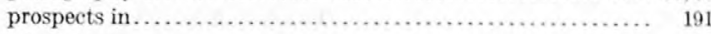

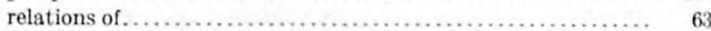
solutions from ................................... 136

water from .................................. 20

Quaternary deposits, distribution and character of ............. 39

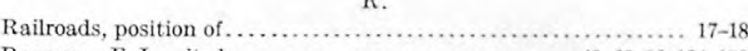
Ransome, F. L., cited ......................... 49, 68, 86, 124, 150

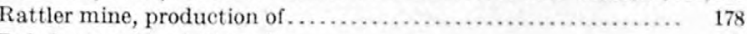
Rebel mine, description of ............................. 196 Reciprocity mine, rocks near................................. rocks near, analyses of ........................... 30,84-85

Red Warrior limestone, age of........................... 34 deposition of.................................... 34 distribution and eharacter of . ...................... 29, 33-34 relations of ....................................... 34

Red Warrior mine, description of . .................... 199-201 ore deposits of ............................... 130, 200-201 plan and sections of ................................ 200 rocks near........................................... 200 view of............................................. 164

Relief, description of ............................... 18-19

Replacement fissure deposits, alteration of ................ 143-160 figure showing ..................................... 130

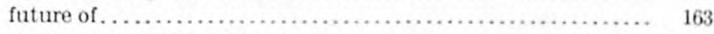
oceurrence and character of ..................13,130-133, 143

Rhodochosite, occurrence and character of ............... 99-100

Rhyolite tuff, distribution and character of ............... 45

Rocky district, alteration in . . . . . . . . . . . . . . . . . $87-88$ copper in $\ldots \ldots \ldots \ldots \ldots \ldots \ldots \ldots \ldots \ldots \ldots \ldots \ldots \ldots \ldots \ldots \ldots \ldots \ldots \ldots \ldots \ldots \ldots, 117$

early history of................................... 117

mines of ..................................... 193-194 production of ................................... 118

Rocky Range, rocks of .......................... 50, 51, 52, 57, 63,70

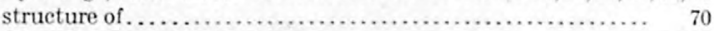

Rutile, occurrence and character of....................... 98

t. Mary's mine, description of ............................. 204 rocks of ........................................... 88,204

San Francisco district, alteration in . . . . . . . . . . . . . . . . . . . . . $82-86$ alteration in, analyses showing ....................... 84, 85 comparison of, with that in other districts . . . . . . . . . . $88-90$

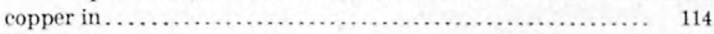
dikes of .......................................... 61 early history of . . . . . . . . . . . map of $\ldots \ldots \ldots \ldots \ldots \ldots \ldots \ldots \ldots \ldots \ldots \ldots \ldots \ldots \ldots, 164$

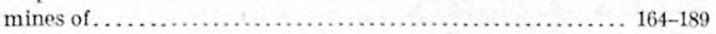
production of ................................. 117 rocks of ....................................... $28-32,62,78$

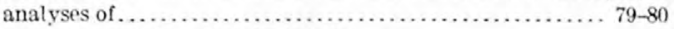

Saา Francisco Mountains, description of ........................ 18

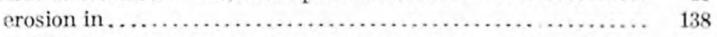

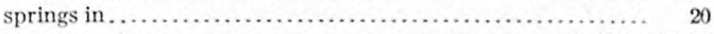
structure of $\ldots \ldots \ldots \ldots \ldots \ldots \ldots \ldots \ldots \ldots \ldots \ldots \ldots \ldots \ldots \ldots \ldots \ldots \ldots \ldots \ldots \ldots \ldots, 25,70,71-73$ section showing ............................... $\quad 26$ stereogram showing .................................... views of....................................... 18 Schaller, W. T., work of ................. 15,93-94, 194-105, 107-108 Scorodite, occurrence and character of ..................... 105 Searchlight district, Nev., age of igneous rocks of .............. 68 Sections, geologic, plate showing .................... In pocket. Sedimentary rocks, age of ........................................ 43 alteration of........................... 12,28,43,82-90, 133-134 See also particular rocks, districts, etc. columnar section of .

description of . . . . . . . . . . . . . ore deposits in................................ 13, 129-131, 136 alteration of ............................. 131, 143-144 figure showing.............................. 129 future of ............................... 162-163 comparison of, with other deposits.................. 131 types of...

See also particular formations. 
Selenides, occurrence and character of.

Sericite, occurrence and character of.

Serpentine, occurrence and character of.

view of

Settlements, history of . . . . . . . . . . . . .

location of.

Shauntie, rocks near

springs near.

Siderite, occurrence and character of.

Silicified reef, views of...

Silurian rocks, distribution and character of .......................

Silver, alteration of ores of $\ldots \ldots \ldots 14,143,145,158,171$ enrichment of ................................ 160 occurrence and character of.................. 92, 144-145, 169, 171

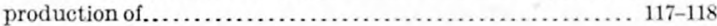

Silver-lead ores, enrichment of ........ 159-160

Skylark mine, description of........................... 191-192 ores of................................. 129-130, 191-192

Skylark Spring, alteration near........................ 86

Smith, G. O., and Tower, G. W., cited .................. 66

Smithsonite, occurrence and character of ..................... 100

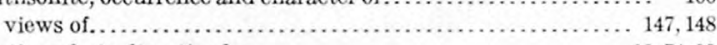

Solutions, hot, alteration by $\ldots \ldots \ldots \ldots \ldots \ldots \ldots \ldots \ldots \ldots \ldots \ldots \ldots \ldots \ldots \ldots \ldots \ldots \ldots, 12,74-90$ nature of .................................. $77-78,133-135$ origin of......................................... 135-136

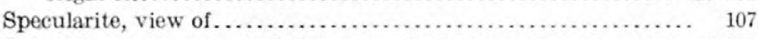

Sphalerite, occurrence and character of ................. 93, 149-150 views of .................................. $1 \times 7,148,149$

Spurr, J. E., cited................................... 23

Squaw Springs, lava from, analysis of .................... 49 location of.

Squaw Springs fault, location of........................ 72

Squaw Springs Pass, rocks at ......................... 28, 45-46

Star district, alteration in............................... 88 early history of ..................................... 114-116

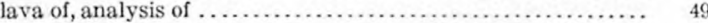

map of .................................................... 194

mines of................................ 115, 116, 194-206

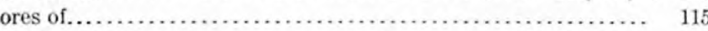

production of........................................ 118

quartzite of .............................. 32-33

quartz monzonite of.............................. $57-59$

analysis of ............................................. 59

Star Range, description of............................. 18-19

dikes of....

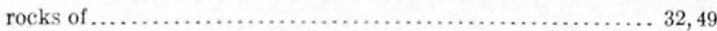

structure of ............................... 25-27, 71,73 section showing...

Steiger, George, analyses by........................... 15, 45,47

Stelzner, A. W., cited................................. 127

Stibnite, occurrence and character of ........................ 92

Stokes, H. N., cited............................... 140-141

Stoping, process of .................................. $70-71$

Stream wash, distribution and character of................ 39-40

Structure, description of....................... 11, 24-28, 70-74 See also Great Basin structure.

Sulphide enrichment. See Horn Silver mine.

Sulphur, alteration of . . . .

Syenite, alteration of, analyses showing ......................... $\quad 81$

\section{T.}

Talisman mine, rocks of..

Talisman quartzite, age of . .

correlation of.

deposition of.

distribution and character of

Temperature, records of.

Tertiary period, igneous rocks of.

Tetrahedrite, occurrence and character of...

Thaumasite, occurrence and character of.

Timber, character of.
Tintic district, geologic age in ............... Page.

Topache limestone, age of .............................. ${ }_{36}^{60}$

correlation of ...

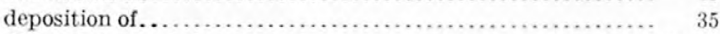

distribution and character of ............................. 29,35

fossils of ............................................ 36

Topache Peak, mines near............................ 204

rocks of .............................. 35

Topography, deseription of.......................... 18-19

Tourmaline, occurrence and character of ............... 102,120,121-122 view of ....................................... 96

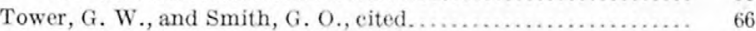

Tremolite, occurrence and character of ................... 101 views of ......................................... 83,185

Triassic rocks, distribution and character of .............. 37-39,44

Ulrich, E, O, cited.

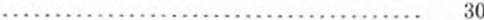
work of ........................................... 15

Uplift, occurrence of.................................. 11

Utah United mine, alteration near..................... $86-87$

V.

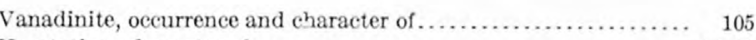

Vegetation, character of ............................... 19-20

Vesuvianite, occurrence and character of ................. 101-102

Vicksburg mine, description of ....................... 115, 206

Vogt, J. H. L., cited .................................. 128

Volcanic rocks. See Effusive rocks.

Von Groddeck, A., cited............................ 127

W.

Wasatch region, rocks of, section of..................... 41

Wasatch Range, uplift in .............................. 24

Wasco mine, description of............................. 116

Washington mine, description of . . . . . . . . . ores of ........................................ 184 views of ...................................... 83,185

rocks near ............................. 30, 83, 85, 183-184

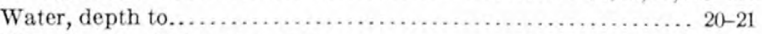

Water level, relation of, to ores........................... 137-138

Water supply, distribution and character of ............. 19, 20-21

Wa Wa Springs, flow from ............................ 20

Wa Wa Range, rocks of $\ldots$

structure of ............................................ 26-27

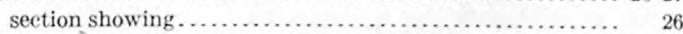

Wa Wa Valley, structure of ............................ 25

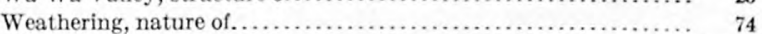

Weed, W. H., cited............................................. $67,150,152$

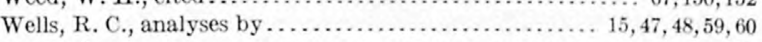

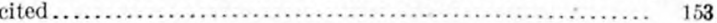

West Spring, water of ................................ 20

White Mountain, mines on............................ 185

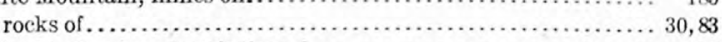

White Rock mine, description of ......................... 196

Wild Bill mine, description of........................ 196-197 ore deposits of...................................... 131,143,197

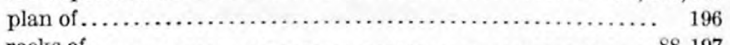
rocks of ....................................... 88,197

Wollastonite, occurrence and character of . . . . . . . . . . . . 101

Wulfenite, occurrence and character of .................. 110

Wurtzite, occurrence and character of ....................... 93-95, 149-150 views of $\ldots \ldots \ldots \ldots \ldots \ldots \ldots \ldots \ldots \ldots \ldots \ldots \ldots \ldots \ldots \ldots \ldots \ldots \ldots \ldots, 141,148$

Y.

Yeatman, Pope, cited........................... 128, 142

$\mathrm{Z}$

Zine, alteration of $\ldots \ldots \ldots \ldots \ldots \ldots \ldots \ldots \ldots \ldots \ldots \ldots \ldots, 14,143-144,152-158,160$ occurrence and character of ..................... 169,170,171 production of ................................... 117-118 sulphides of. See Sphalerite; Wurtzite.

Zircon, occurrence and character of.... 
